\title{
N-Bridged Pincer Iridium Complexes for Highly Efficient Alkane Dehydrogenation and the Relevant Linker Effects
}

Xin Zhang, ${ }^{\dagger}$ Song-Bai Wu, ${ }^{\ddagger}$ Xuebing Leng, ${ }^{\dagger}$ Lung Wa Chung, ${ }^{\ddagger}$ Guixia Liu ${ }^{\dagger, \S}$ and Zheng Huang ${ }^{*}, \dagger, \S, \zeta$

${ }^{\dagger}$ The State Key Laboratory of Organometallic Chemistry, Shanghai Institute of Organic Chemistry, University of Chinese Academy of Sciences, Chinese Academy of Sciences, 345 Lingling Road, Shanghai 200032, China

${ }^{\ddagger}$ Department of Chemistry and Shenzhen Grubbs Institute, Southern University of Science and Technology, Shenzhen 518055, China

${ }^{\S}$ Chang-Kung Chuang Institute, East China Normal University, Shanghai 200062, China

${ }^{\zeta}$ School of Chemistry and Material Sciences, Hangzhou Institute of Advanced Study, University of Chinese Academy of Sciences, 1 Sub-lane Xiangshan, Hangzhou 310024, China

huangzh@sioc.ac.cn 


\section{Table of Contents}

$\begin{array}{ll}\text { I. General materials and methods } & \text { S3 }\end{array}$

II. General procedure for transfer-dehydrogenation of alkane with TBE $\quad$ S3

III. General procedure for acceptorless dehydrogenation of

1,2,3,4-tetrahydronaphthalene $\quad \mathrm{S} 3$

IV. Synthesis of ligands ${ }^{\mathrm{R}} \mathrm{POC}{ }^{\mathrm{R}} \mathrm{NP}$ and ${ }^{\mathrm{R}} \mathrm{PSC}{ }^{\mathrm{Me}} \mathrm{NP} \quad$ S5

$\begin{array}{ll}\text { V. Synthesis of iridium compounds. } & \text { S11 }\end{array}$

$\begin{array}{ll}\text { 1. Synthesis of (pincer)Ir-HCl S11 } & \text { S }\end{array}$

$\begin{array}{lr}\text { 2. Synthesis of (pincer)Ir-CO S14 } & \end{array}$

3. Synthesis of (pincer)Ir-COE S18

$\begin{array}{ll}\text { 4. Synthesis of (pincer)Ir-SMe } & \text { S21 }\end{array}$

$\begin{array}{ll}\text { 5. Synthesis of (pincer)Ir-TBE } & \text { S23 }\end{array}$

$\begin{array}{ll}\text { VI. Additional experiment and spectroscopic data. } & \text { S26 }\end{array}$

1. Studies on the resting state for the COA/TBE TD S26

2. Studies on the equilibrium between (pincer)Ir-COE and $\mathrm{SMe}_{2} \quad$ S27

$\begin{array}{ll}\text { 3. Studies on the thermostability of (pincer)Ir-CO S29 } & \text { SO }\end{array}$

4. Studies on the isomerization of (pincer)Ir-COE and (pincer)Ir-CPE S30

$\begin{array}{ll}\text { VII. References } & \text { S32 }\end{array}$

$\begin{array}{ll}\text { VIII. NMR spectra } & \text { S32 }\end{array}$

$\begin{array}{ll}\text { IX. X-ray crystallographic data } & \text { S97 }\end{array}$

$\begin{array}{lr}\text { X. Computational details } & \text { S114 }\end{array}$

$\begin{array}{ll}\text { XI. Cartesian coordinates of the optimized compounds } & \text { S115 }\end{array}$ 


\section{General materials and methods.}

Unless specified otherwise, all manipulations were carried out in an argon-filled glovebox or under an atmosphere of dry argon using standard Schlenk techniques. $n$-Hexane was purified by distillation over $\mathrm{CaH}_{2}$. Tetrahydrofuran (THF) and toluene were distilled from sodium benzophenone ketyl prior to use. Diethyl ether, dichloromethane, and $n$-pentane were purified by distillation over $\mathrm{LiAlH}_{4}$. Chlorodiisopropylphosphine (96\%) was purchased from Acros and used as received. Cyclooctane (COA) $(98 \%)$, cyclooctene (COE) $(97 \%)$ cycloheptene (CPE) (96\%), tert-butylethylene (TBE) $(98.5 \%), n$-octane (98\%) and 1,2,3,4-tetrahydronaphthalene $(>98 \%)$ were purchased from Alfa Aesar, TCI or Sigma-Aldrich and dried over $\mathrm{LiAlH}_{4}$ overnight under an atmosphere of dry argon, then distilled prior to use and stored in an argon atmosphere glovebox. Unless specified otherwise, all other reagents were purchased from commercial suppliers or synthesized based on reported methods. $[\operatorname{Ir}(\mathrm{COD}) \mathrm{Cl}]_{2}$ was synthesized according to published procedures. ${ }^{1}{ }^{i \mathbf{P r}^{-}} \mathbf{1}-\mathrm{HCl},{ }^{i \mathbf{P r}^{2}} \mathbf{2}-\mathrm{HCl}$ and ${ }^{i \mathbf{P r}^{-}} \mathbf{3}-\mathrm{HCl}$ were prepared by literature procedures. ${ }^{2,3}$

NMR spectra were recorded on Varian $400 \mathrm{MHz}$, Agilent $400 \mathrm{MHz}$ spectrometer, and Bruker 400 spectrometer at $400 \mathrm{MHz} .{ }^{1} \mathrm{H}$ NMR spectra were referenced to residual protio solvent peaks or TMS signal $(0 \mathrm{ppm})$ and ${ }^{13} \mathrm{C}$ NMR spectra were referenced to the solvent resonance. ${ }^{31} \mathrm{P}$ NMR chemical shifts were referenced to an external $\mathrm{H}_{3} \mathrm{PO}_{4}$ standard or a capillary tube containing $\mathrm{PPh}_{3}$ as external standard in toluene. Elemental analyses and high resolution mass spectrometer (HRMS) were performed on the Analytical Laboratory of Shanghai Institute of Organic Chemistry (CAS). GC analysis was acquired on Agilent 7890A gas chromatograph equipped with a flame-ionization detector. GC-MS analysis was performed on Agilent 7890A gas chromatograph coupled to an Agilent 5975C inert mass selective detector.

Crystals were mounted on Bruker APEX-II CCD-based diffractometer or a Bruker D8 Venture diffractometer equipped with an Oxford low-temperature apparatus. Cell parameters were retrieved with SMART, which corrects for Lorentz polarization and decay. Absorption corrections were applied using SADABS. ${ }^{4}$ Space groups were assigned unambiguously by analysis of symmetry and systematic absences determined by XPREP. Using Olex $2,{ }^{5}$ the structures were solved with the SHELXT ${ }^{6}$ structure solution program using Intrinsic Phasing and refined with the SHELXT ${ }^{6}$ refinement package using least squares minimization.

\section{General procedure for transfer dehydrogenation of alkane with TBE}

\section{General procedure for transfer dehydrogenation of COA with TBE}

In an argon-filled glovebox, an oven-dried $5 \mathrm{~mL}$ thick-wall glass tube was charged with pincer Ir complex $(2.0 \mu \mathrm{mol})$ and $\mathrm{NaO} t \mathrm{Bu}(3$ equiv relative to $\mathrm{Ir}, 6.0 \mu \mathrm{mol})$. Then $\mathrm{COA}$ and TBE (3000 equiv each relative to $\mathrm{Ir}, 6.0 \mathrm{mmol}$ ) were added via syringe to the same tube. The tube was sealed by a Teflon plug and heated in preheated oil bath at 200 or $180{ }^{\circ} \mathrm{C}$. At regular interval, the tube was cooled to room temperature and the sample was analyzed by gas chromatography.

\section{General procedure for transfer dehydrogenation of $n$-octane with TBE}

In an argon-filled glovebox, an oven-dried $5 \mathrm{~mL}$ thick-wall glass tube was charged with pincer Ir complex $(2.0 \mu \mathrm{mol})$ and $\mathrm{NaO} t \mathrm{Bu}(3$ equiv relative to pincer Ir, $6.0 \mu \mathrm{mol})$. Then $n$ octane and TBE (3000 equiv each relative to $\mathrm{Ir}, 6.0 \mathrm{mmol}$ ) were added via syringe to the same tube. The tube was sealed by a Teflon plug and heated in preheated oil bath at $200{ }^{\circ} \mathrm{C}$. At regular interval, the tube was cooled to room temperature and the sample was analyzed by gas chromatography.

III. General procedure for acceptorless dehydrogenations of 1,2,3,4tetrahydronaphthalene 


\section{Acceptorless dehydrogenations of 1,2,3,4-tetrahydronaphthalene}

In the argon-atmosphere glovebox, an oven-dried reactor consisting of a 4-mL roundbottom cylindrical flask fused to a water-jacked condenser $(\mathrm{ca} .10 .0 \mathrm{~cm})$ was charged with pincer Ir complex $(7.7 \mu \mathrm{mol})$ and $\mathrm{NaOtBu}(6$ equiv relative to Ir, $46.3 \mu \mathrm{mol})$. Then 1,2,3,4tetrahydronaphthalene (2400 equiv relative to Ir) was added to the same reactor via syringe. The top of the condenser was connected to a two-way piece to permit the loss of $\mathrm{H}_{2}$ gas under a constant argon flow. The solution was refluxed in a sand bath at $250{ }^{\circ} \mathrm{C}$. At regular interval, the tube was cooled to room temperature and the sample was analyzed by gas chromatography.

2. Procedure for trapping $\mathrm{H}_{2}$ formed from the dehydrogenation of 1,2,3,4tetrahydronaphthalene via hydrogenation of diphenylacetylene (Figure S1)

An oven-dried reactor (see Figure S1), which consists of a $4 \mathrm{~mL}$ round-bottom cylindrical vessel as the bottom part and a $4 \mathrm{~mL}$ round-bottom vessel as the top part. The lower vessel is fused to a water-jacketed condenser (ca. $10 \mathrm{~cm}$ in lenght). In an argon-atmosphere glovebox, pincer Ir complex $(7.7 \mu \mathrm{mol})$ and $\mathrm{NaO} t \mathrm{Bu}$ (6 equiv relative to Ir, $46.3 \mu \mathrm{mol})$ and tetrahydronaphthalene (2400 equiv relative to Ir) were added to the lower vessel, and the upper vessel was charged with diphenylacetylene $(2.8 \mathrm{mmol}), \mathrm{Pd} / \mathrm{C}(20 \mathrm{~mol} \%$ relative to diphenylacetylene) and toluene $(2.0 \mathrm{~mL})$. The reactor was sealed by two Teflon plugs. The lower cylindrical flask was fully immersed into a sand bath held at $250{ }^{\circ} \mathrm{C}$, resulting in vigorous reflux of the reaction solution. At regular interval, the lower vessel was cooled to room temperature and the sample from both of the lower and upper vessels were analyzed by gas chromatography.

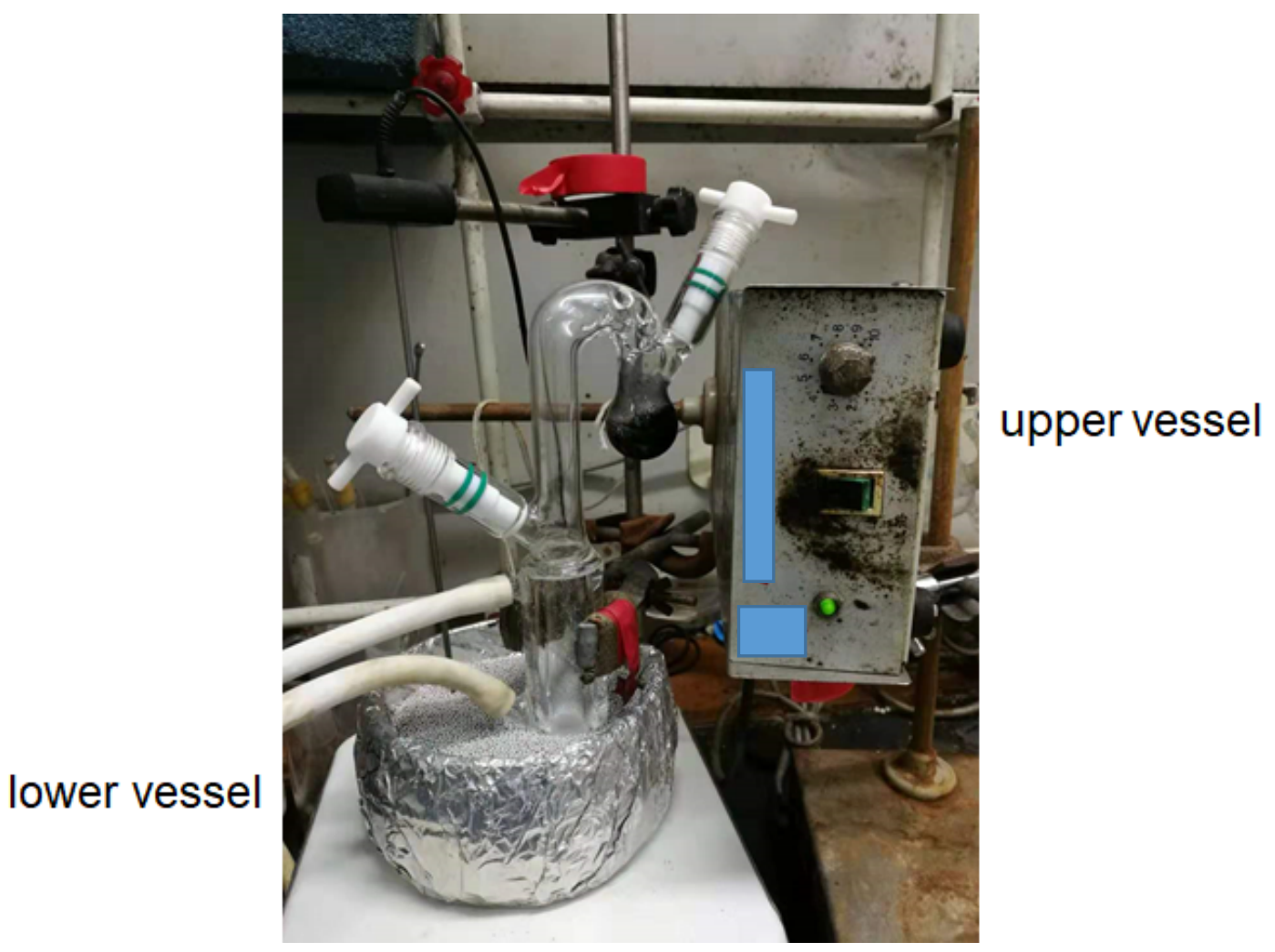

Figure S1. Trapping $\mathrm{H}_{2}$ Formed from the Dehydrogenation of 1,2,3,4-Tetrahydronaphthalene via Hydrogenation of Diphenylacetylene 


\section{Synthesis of ligands ${ }^{\mathrm{R}} \mathrm{POC}{ }^{\mathrm{R}} \mathrm{NP}$ and ${ }^{\mathrm{R}} \mathrm{PSC}^{\mathrm{R}}{ }^{\prime} \mathrm{NP}$}

1. Synthesis of 3-(methylamino)phenol and 3-(ethylamino)phenol.<smiles>CNc1cccc(O)c1</smiles>

3-(Methylamino)phenol was prepared according to a modified literature procedure. ${ }^{7}$ A mixture of 3-aminophenol (36.70 mmol, $4.0 \mathrm{~g})$ and methyl iodide $(36.70 \mathrm{mmol}, 5.1 \mathrm{~g})$ was heated in DMF $(20 \mathrm{~mL})$ in the presence of potassium carbonate $(36.70 \mathrm{mmol}, 5.1 \mathrm{~g})$ at $100^{\circ} \mathrm{C}$ for $2 \mathrm{~h}$. The solvent was removed in vacuo and the resulting residue was purified using flash chromatography $(\mathrm{Hex} / \mathrm{EtOAc}=4 / 1)$. 3-(Methylamino)phenol was isolated as white solid $(3.3$ $\mathrm{g}, 73 \%$ yield). ${ }^{1} \mathrm{H}$ NMR $\left(400 \mathrm{MHz}, \mathrm{CDCl}_{3}\right): \delta 7.03(\mathrm{t}, J=8.0 \mathrm{~Hz}, 1 \mathrm{H}, \mathrm{ArH}), 6.23(\mathrm{~d}, J=8.0 \mathrm{~Hz}$, $2 \mathrm{H}, \mathrm{ArH}), 6.09(\mathrm{~s}, 1 \mathrm{H}, \mathrm{ArH}), 5.20(\mathrm{bs}, 2 \mathrm{H}, \mathrm{NH}$ and $\mathrm{OH}), 2.73\left(\mathrm{~s}, 3 \mathrm{H}, \mathrm{NCH}_{3}\right) ;{ }^{13} \mathrm{C}$ NMR $(101$ $\left.\mathrm{MHz}, \mathrm{CDCl}_{3}\right): \delta 155.8\left(\mathrm{~s}, \mathrm{C}_{\mathrm{Ar}}\right), 150.7\left(\mathrm{~s}, \mathrm{C}_{\mathrm{Ar}}\right), 130.3\left(\mathrm{~s}, \mathrm{C}_{\mathrm{Ar}}\right), 106.0\left(\mathrm{~s}, \mathrm{C}_{\mathrm{Ar}}\right), 105.3\left(\mathrm{~s}, \mathrm{C}_{\mathrm{Ar}}\right), 100.3$ $\left(\mathrm{s}, \mathrm{C}_{\mathrm{Ar}}\right), 31.0(\mathrm{~s}, \mathrm{NMe})$.<smiles>CCNc1cccc(O)c1</smiles>

3-(Ethylamino)phenol was prepared according to a modified literature procedure. ${ }^{7}$ A mixture of 3-aminophenol (36.70 mmol, $4.0 \mathrm{~g}$ ) and ethyl iodide (36.70 mmol, $5.7 \mathrm{~g}$ ) was heated in DMF $(20 \mathrm{~mL})$ in the presence of potassium carbonate $(36.7 \mathrm{mmol}, 5.1 \mathrm{~g})$ at $100^{\circ} \mathrm{C}$ for $2 \mathrm{~h}$. The solvent was removed in vacuo and the resulting residue was purified using flash chromatography $(\mathrm{Hex} / \mathrm{EtOAc}=4 / 1) .3-($ Ethylamino $)$ phenol was isolated as white solid $(4.1 \mathrm{~g}, 81 \%$ yield $) .{ }^{1} \mathrm{H}$ NMR $\left(400 \mathrm{MHz}, \mathrm{CDCl}_{3}\right) \delta 7.02(\mathrm{t}, J=8.0 \mathrm{~Hz}, 1 \mathrm{H}, \mathrm{ArH}), 6.19(\mathrm{ddd}, J=15.3,8.1,2.0 \mathrm{~Hz}, 2 \mathrm{H}$, $\mathrm{ArH}), 6.10(\mathrm{~d}, J=1.9 \mathrm{~Hz}, 1 \mathrm{H}, \mathrm{ArH}), 4.12(\mathrm{~s}, 2 \mathrm{H}, \mathrm{NH}$ and $\mathrm{OH}), 3.35-2.62\left(\mathrm{~m}, 2 \mathrm{H}, \mathrm{NCH}_{2} \mathrm{CH}_{3}\right)$, $1.24\left(\mathrm{td}, J=7.2,1.2 \mathrm{~Hz}, 3 \mathrm{H}, \mathrm{CH}_{3}\right.$ of $\left.\mathrm{NCH}_{2} \mathrm{CH}_{3}\right) .{ }^{13} \mathrm{C} \mathrm{NMR}\left(101 \mathrm{MHz}, \mathrm{CDCl}_{3}\right) \delta 156.8\left(\mathrm{~s}, \mathrm{C}_{\mathrm{Ar}}\right)$, $149.8\left(\mathrm{~s}, \mathrm{C}_{\mathrm{Ar}}\right), 130.2\left(\mathrm{~s}, \mathrm{C}_{\mathrm{Ar}}\right), 106.3\left(\mathrm{~s}, \mathrm{C}_{\mathrm{Ar}}\right), 104.9\left(\mathrm{~s}, \mathrm{C}_{\mathrm{Ar}}\right), 100.3\left(\mathrm{~s}, \mathrm{C}_{\mathrm{Ar}}\right), 38.7\left(\mathrm{~s}, \mathrm{NCH}_{2}\right), 14.7$ ( $\mathrm{s}, \mathrm{CH}_{3}$ of $\mathrm{NCH}_{2} \mathrm{CH}_{3}$ ). HRMS (ESI): calcd for $\mathrm{C}_{8} \mathrm{H}_{12} \mathrm{NO}[\mathrm{M}+\mathrm{H}]^{+} \mathrm{m} / \mathrm{z}$ 138.0919; found, $\mathrm{m} / \mathrm{z}$ 138.0914.

2. Synthesis of 3-(neopentylamino)phenol.<smiles>CC(C)(C)CNc1cccc(O)c1</smiles>

3-(Neopentylamino)phenol was prepared using a modified literature procedures. ${ }^{8}$ In a Schlenk flask equipped with a magnetic stir bar, $\mathrm{Pd} / \mathrm{C}(2.75 \mathrm{mmol}, 293.0 \mathrm{mg})$ and isopropanol $(20 \mathrm{~mL})$ were added. Ammonium formate $(867.0 \mathrm{mg}, 13.75 \mathrm{mmol})$ dissolved in water $(2 \mathrm{~mL})$ was transferred to the same flask. The reaction mixture was stirred for 1 minute to activate $\mathrm{Pd} / \mathrm{C}$. Next, 3-aminophenol (2.75 mmol, $305.0 \mathrm{mg})$ and pivalaldehyde $(2.75 \mathrm{mmol}, 241.0 \mathrm{mg})$ were added and the reaction mixture was stirred at RT. After the reaction was complete according to TLC monitoring, the $\mathrm{Pd} / \mathrm{C}$ catalyst was filtered off through celite and the solvent was removed by rotary evaporation. The reaction mixture was diluted with $\mathrm{CH}_{2} \mathrm{Cl}_{2}$ and washed with brine solution. The organic phase was collected, dried with anhydrous $\mathrm{MgSO}_{4}$, and concentrated by rotary evaporation. The residue was purified by silica flash column chromatography with $\mathrm{PE} / \mathrm{EA}=4 / 1$ as eluent $\left(276.0 \mathrm{mg}, 56 \%\right.$ yield). ${ }^{1} \mathrm{H}$ NMR $\left(400 \mathrm{MHz}, \mathrm{CDCl}_{3}\right) \delta 7.01(\mathrm{td}, J=8.0$, $5.1 \mathrm{~Hz}, 1 \mathrm{H}, \mathrm{ArH}), 6.25-6.19(\mathrm{~m}, 1 \mathrm{H}, \mathrm{ArH}), 6.15(\mathrm{dd}, J=7.9,2.3 \mathrm{~Hz}, 1 \mathrm{H}, \mathrm{ArH}), 6.12(\mathrm{t}, J=$ $2.2 \mathrm{~Hz}, 1 \mathrm{H}, \mathrm{ArH}), 5.00(\mathrm{~s}, 1 \mathrm{H}, \mathrm{OH}), 3.67(\mathrm{~s}, 1 \mathrm{H}, \mathrm{NH}), 2.86\left(\mathrm{~s}, 2 \mathrm{H}, \mathrm{NCH}_{2}\right), 0.98\left(\mathrm{~s}, 9 \mathrm{H}, \mathrm{CH}_{3}\right.$ of $t \mathrm{Bu}){ }^{13} \mathrm{C}$ NMR $\left(101 \mathrm{MHz}, \mathrm{CDCl}_{3}\right) \delta 156.7\left(\mathrm{~s}, \mathrm{C}_{\mathrm{Ar}}\right), 150.7\left(\mathrm{~s}, \mathrm{C}_{\mathrm{Ar}}\right), 130.3\left(\mathrm{~s}, \mathrm{C}_{\mathrm{Ar}}\right), 106.1\left(\mathrm{~s}, \mathrm{C}_{\mathrm{Ar}}\right)$, $104.6\left(\mathrm{~s}, \mathrm{C}_{\mathrm{Ar}}\right), 100.1\left(\mathrm{~s}, \mathrm{C}_{\mathrm{Ar}}\right), 55.9\left(\mathrm{~s}, \mathrm{NCH}_{2}\right), 31.9(\mathrm{~s}, \mathrm{C}$ of $t \mathrm{Bu}), 27.7\left(\mathrm{~s}, \mathrm{CH}_{3}\right.$ of $\left.t \mathrm{Bu}\right)$. HRMS (ESI): calcd for $\mathrm{C}_{11} \mathrm{H}_{17} \mathrm{NO}[\mathrm{M}+\mathrm{H}]^{+} \mathrm{m} / \mathrm{z} 180.1388$; found, $\mathrm{m} / \mathrm{z} 180.1386$.

3. Synthesis of 3-(methylamino)benzenethiol. 
$\overbrace{\mathrm{H}^{\prime}}$

3-(Methylamino)benzenethiol was prepared using a modified literature procedures. ${ }^{9 \mathrm{a}}$ In a Schlenk flask equipped with a magnetic stir bar, formic anhydride was first prepared by addition of formic acid to $3.0 \mathrm{~mL}$ acetic anhydride $(1.5 \mathrm{~mL})$ at $0{ }^{\circ} \mathrm{C}$. The solution was heated for $2 \mathrm{~h}$ at 55-60 ${ }^{\circ} \mathrm{C}$. After cooling to room temperature, anhydrous THF $(3.0 \mathrm{~mL})$ was added. 3,3 'disulfanediyldianiline ${ }^{9 \mathrm{~b}}(12.10 \mathrm{mmol}, 3.0 \mathrm{~g})$ was dissolved in $3.3 \mathrm{~mL}$ THF and dropwise added to the formic anhydride solution at $-20^{\circ} \mathrm{C}$. After $30 \mathrm{~min}$, the acidic fraction was removed under vacuum. The residue was diluted with EtOAc, washed with brine solution. The organic phase was collected, dried with anhydrous $\mathrm{MgSO}_{4}$, and concentrated by rotary evaporation. Without further purification, the residue was dissolved in dry THF, and then $\mathrm{LiAlH}_{4}(1.3 \mathrm{~g}, 32.89 \mathrm{mmol}$, 5 eq.) was added slowly at $0{ }^{\circ} \mathrm{C}$ under argon. The solution was stirred at RT for $30 \mathrm{~min}$, and then the mixture was poured into ice-water and extracted by ether $(3 \times 100 \mathrm{~mL})$, washed with brine solution ( $80 \mathrm{~mL} \times 2$ ), dried over $\mathrm{MgSO}_{4}$ and evaporated to dryness. The residue was immediately purified over silica gel (eluent: $\mathrm{CH}_{2} \mathrm{Cl}_{2} / \mathrm{Hexane}$ : 30/70) to yield 3(methylamino)benzenethiol as yellow oil $\left(1.2 \mathrm{~g}, 36 \%\right.$ yield). ${ }^{1} \mathrm{H}$ NMR $\left(400 \mathrm{MHz}, \mathrm{CDCl}_{3}\right): \delta$ $7.05(\mathrm{t}, J=8.0 \mathrm{~Hz}, 1 \mathrm{H}, \mathrm{ArH}), 6.63-6.61(\mathrm{dd}, J=7.6 \mathrm{~Hz}, J=0.8 \mathrm{~Hz}, \mathrm{H}, \mathrm{ArH}), 6.51(\mathrm{t}, J=2.0$ $\mathrm{Hz}, 1 \mathrm{H}, \mathrm{ArH}), 6.43-6.38(\mathrm{~m}, \mathrm{H}, \mathrm{ArH}), 3.72(\mathrm{bs}, 1 \mathrm{H}, \mathrm{SH}), 3.41(\mathrm{~s}, 1 \mathrm{H}, \mathrm{NH}), 2.81$ (s; 1H, NMe); ${ }^{13} \mathrm{C}$ NMR $\left(101 \mathrm{MHz}, \mathrm{CDCl}_{3}\right): \delta 149.8\left(\mathrm{~s}, \mathrm{C}_{\mathrm{Ar}}\right), 131.5\left(\mathrm{~s}, \mathrm{C}_{\mathrm{Ar}}\right), 129.7\left(\mathrm{~s}, \mathrm{C}_{\mathrm{Ar}}\right), 118.1\left(\mathrm{~s}, \mathrm{C}_{\mathrm{Ar}}\right)$, $112.5\left(\mathrm{~s}, \mathrm{C}_{\mathrm{Ar}}\right), 110.1\left(\mathrm{~s}, \mathrm{C}_{\mathrm{Ar}}\right), 30.6(\mathrm{~s}, \mathrm{NMe})$. HRMS (ESI): calcd for $\mathrm{C}_{7} \mathrm{H}_{10} \mathrm{NS}[\mathrm{M}+\mathrm{H}]^{+} \mathrm{m} / \mathrm{z}$ 140.0534; found, $\mathrm{m} / \mathrm{z} 140.0526$.

4. Synthesis of ligands 6a-g and 7a-b.

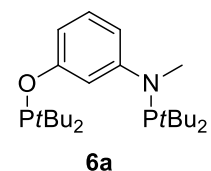

In a Schlenk flask equipped with a magnetic stir bar, $\mathrm{NaH}(11.00 \mathrm{mmol}, 440.0 \mathrm{mg}, 60 \%)$ washed by $n$-pentane was slowly added to a solution of 3-(methylamino)phenol $(5.00 \mathrm{mmol}, 615.0 \mathrm{mg})$ in $50 \mathrm{~mL}$ THF (caution: hydrogen evolution). The mixture was stirred at room temperature for $1 \mathrm{~h}$, then di-tert-butylchlorophosphine $(10.55 \mathrm{mmol}, 1.9 \mathrm{~g})$ was added via syringe. The mixture was stirred at room temperature overnight. After evaporation of the solvent under high vacuum, the residue was dissolved in pentane $(100 \mathrm{~mL})$, and the extract was filtered through a pad of celite. The solvent was evaporated under high vacuum to give product 6a as colorless oil (1.2 $\mathrm{g}, 63 \%$ yield). The ligand was used for synthesis of the Ir complex without further purification. ${ }^{1} \mathrm{H}$ NMR $\left(400 \mathrm{MHz}, \mathrm{C}_{6} \mathrm{D}_{6}\right) \delta 7.57(\mathrm{~s}, 1 \mathrm{H}, \mathrm{ArH}), 7.12(\mathrm{~s}, 2 \mathrm{H}, \mathrm{ArH}), 6.93(\mathrm{dd}, J=6.8,2.1 \mathrm{~Hz}$, $1 \mathrm{H}, \mathrm{ArH}), 2.90(\mathrm{~s}, 3 \mathrm{H}, \mathrm{NMe}), 1.15\left(\mathrm{~d}, J=11.5 \mathrm{~Hz}, 18 \mathrm{H}, \mathrm{CH}_{3}\right.$ of $\left.t \mathrm{Bu}\right), 1.08(\mathrm{~d}, J=12.2 \mathrm{~Hz}, 18 \mathrm{H}$, $\mathrm{CH}_{3}$ of $\left.t \mathrm{Bu}\right) .{ }^{31} \mathrm{P}$ NMR $\left(162 \mathrm{MHz}, \mathrm{C}_{6} \mathrm{D}_{6}\right) \delta 151.3(\mathrm{~s}), 85.6(\mathrm{~s}) .{ }^{13} \mathrm{C} \mathrm{NMR}\left(101 \mathrm{MHz}, \mathrm{C}_{6} \mathrm{D}_{6}\right) \delta$ $160.9\left(\mathrm{dd}, J=9.5,2.0 \mathrm{~Hz}, \mathrm{C}_{\mathrm{Ar}}\right), 155.3\left(\mathrm{~d}, J=24.0 \mathrm{~Hz}, \mathrm{C}_{\mathrm{Ar}}\right), 129.4\left(\mathrm{~d}, J=1.9 \mathrm{~Hz}, \mathrm{C}_{\mathrm{Ar}}\right), 110.2$ $\left(\mathrm{d}, J=19.9 \mathrm{~Hz}, \mathrm{C}_{\mathrm{Ar}}\right), 108.9\left(\mathrm{dd}, J=11.5,1.6 \mathrm{~Hz}, \mathrm{C}_{\mathrm{Ar}}\right), 107.1\left(\mathrm{dd}, J=19.8,10.7 \mathrm{~Hz}, \mathrm{C}_{\mathrm{Ar}}\right), 38.5$ $(\mathrm{d}, J=8.8 \mathrm{~Hz}, \mathrm{NMe}), 36.4(\mathrm{~s}, \mathrm{C}$ of $t \mathrm{Bu}), 36.1(\mathrm{~s}, \mathrm{C}$ of $t \mathrm{Bu}), 35.9(\mathrm{~s}, \mathrm{C}$ of $t \mathrm{Bu}), 35.6(\mathrm{~s}, \mathrm{C}$ of $t \mathrm{Bu}$ ), $30.0\left(\mathrm{~d}, J=17.3 \mathrm{~Hz}, \mathrm{CH}_{3}\right.$ of $t \mathrm{Bu}$ ), $27.7\left(\mathrm{~d}, J=15.7 \mathrm{~Hz}, \mathrm{CH}_{3}\right.$ of $t \mathrm{Bu}$ ).; HRMS (DART): calcd for $\mathrm{C}_{23} \mathrm{H}_{44} \mathrm{NOP}_{2}[\mathrm{M}+\mathrm{H}]^{+} \mathrm{m} / \mathrm{z} 412.2898$; found, $\mathrm{m} / \mathrm{z} 412.2888$.

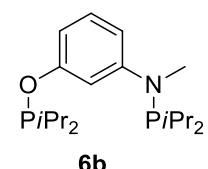

Ligand 6b. In a Schlenk flask equipped with a magnetic stir bar, NaH $(5.50 \mathrm{mmol}, 220.0 \mathrm{mg}$, $60 \%$ ) washed by $n$-pentane was slowly added to a solution of 3-(methylamino)phenol (5.00 $\mathrm{mmol}, 615.0 \mathrm{mg}$ ) in $50 \mathrm{~mL}$ THF (caution: hydrogen evolution). The mixture was stirred at room temperature for $1 \mathrm{~h}$, then chlorodiisopropylphosphine $(5.30 \mathrm{mmol}, 806.0 \mathrm{mg}$ ) was added via syringe. The mixture was stirred at room temperature overnight. After evaporation of the solvent under high vacuum, the residue was dissolved in pentane $(50 \mathrm{~mL}) . n$-Butyllithium $(5.25$ 
mmol, $2.1 \mathrm{~mL}, 2.5 \mathrm{M}$ in hexane) was added to the mixture under argon at $-78{ }^{\circ} \mathrm{C}$ followed by 3 $\mathrm{h}$ of stirring. White solids precipitated from the solution. After that, the solution of chlorodiisopropylphosphine $(5.30 \mathrm{mmol}, 806.0 \mathrm{mg})$ in $2 \mathrm{~mL}$ THF was added dropwise. Then the reaction mixture was slowly warmed to room temperature and stirred overnight. After evaporation of the solvent under vacuum, the residue was extracted with pentane $(100 \mathrm{~mL})$ and the extract was filtered through a pad of celite. After the removal of pentane under vacuum, the flask was heated to $60{ }^{\circ} \mathrm{C}$ for $6 \mathrm{~h}$ under high to remove the unreacted chlorodiisopropylphosphine, furnishing $6 \mathbf{b}$ as light yellow oil (1.0 g, 59\% yield). ${ }^{1} \mathrm{H}$ NMR (400 $\left.\mathrm{MHz}, \mathrm{C}_{6} \mathrm{D}_{6}\right) \delta 7.49-7.45(\mathrm{~m}, 1 \mathrm{H}, \mathrm{ArH}), 7.13(\mathrm{t}, J=8.3 \mathrm{~Hz}, 1 \mathrm{H}, \mathrm{ArH}), 7.07-7.02(\mathrm{~m}, 1 \mathrm{H}$, ArH), 6.90 (d, $J=7.9 \mathrm{~Hz}, 1 \mathrm{H}, \mathrm{ArH}), 2.64(\mathrm{~d}, J=1.1 \mathrm{~Hz}, 3 \mathrm{H}, \mathrm{NMe}), 1.80(\mathrm{td}, J=7.1,2.8 \mathrm{~Hz}$, $2 \mathrm{H}, \mathrm{CH}$ of $i \mathrm{Pr}), 1.71(\mathrm{td}, J=7.0,3.3 \mathrm{~Hz}, 2 \mathrm{H}, \mathrm{CH}$ of $i \mathrm{Pr}), 1.20\left(\mathrm{~d}, J=7.0 \mathrm{~Hz}, 3 \mathrm{H}, \mathrm{CH}_{3}\right.$ of $\left.i \operatorname{Pr}\right)$, $1.18\left(\mathrm{~d}, J=7.0 \mathrm{~Hz}, 3 \mathrm{H}, \mathrm{CH}_{3}\right.$ of $\left.i \operatorname{Pr}\right), 1.04\left(\mathrm{~d}, J=7.2 \mathrm{~Hz}, 3 \mathrm{H}, \mathrm{CH}_{3}\right.$ of $\left.i \mathrm{Pr}\right), 1.00(\mathrm{~d}, J=7.0 \mathrm{~Hz}$, $6 \mathrm{H}, \mathrm{CH}_{3}$ of $i \mathrm{Pr}$ ), $0.96\left(\mathrm{~d}, J=6.9 \mathrm{~Hz}, 3 \mathrm{H}, \mathrm{CH}_{3}\right.$ of $\left.i \mathrm{Pr}\right), 0.92$ (d, $J=7.0 \mathrm{~Hz}, 3 \mathrm{H}, \mathrm{CH}_{3}$ of $i \mathrm{Pr}$ ), 0.89 $\left(\mathrm{d}, J=7.0 \mathrm{~Hz}, 3 \mathrm{H}, \mathrm{CH}_{3}\right.$ of $\left.i \mathrm{Pr}\right) .{ }^{31} \mathrm{P}$ NMR $\left(162 \mathrm{MHz}, \mathrm{C}_{6} \mathrm{D}_{6}\right): \delta 144.8(\mathrm{~s}), \delta 71.1(\mathrm{~s}) ;{ }^{13} \mathrm{C}$ NMR $\left(101 \mathrm{MHz}, \mathrm{C}_{6} \mathrm{D}_{6}\right) \delta 160.2\left(\mathrm{~d}, J=10.3 \mathrm{~Hz}, \mathrm{C}_{\mathrm{Ar}}\right), 154.3\left(\mathrm{~d}, J=21.0 \mathrm{~Hz}, \mathrm{C}_{\mathrm{Ar}}\right), 129.2\left(\mathrm{~s}, \mathrm{C}_{\mathrm{Ar}}\right), 109.9$ $\left(\mathrm{d}, J=17.3 \mathrm{~Hz}, \mathrm{C}_{\mathrm{Ar}}\right), 108.7\left(\mathrm{~d}, J=10.6 \mathrm{~Hz}, \mathrm{C}_{\mathrm{Ar}}\right), 106.9\left(\mathrm{dd}, J=17.6,10.6 \mathrm{~Hz}, \mathrm{C}_{\mathrm{Ar}}\right), 33.9(\mathrm{~d}, J$ $=7.2 \mathrm{~Hz}, \mathrm{NMe}), 28.6$ (d, $J=18.5 \mathrm{~Hz}, \mathrm{CH}$ of $i \operatorname{Pr}), 26.6$ (d, $J=16.5 \mathrm{~Hz}, \mathrm{CH}$ of $i \operatorname{Pr}), 19.5\left(\mathrm{~s}, \mathrm{CH}_{3}\right.$ of $i \mathrm{Pr}$ ), 19.4 (d, $J=1.1 \mathrm{~Hz}, \mathrm{CH}_{3}$ of $i \mathrm{Pr}$ ), 19.1 (s, $\mathrm{CH}_{3}$ of $i \mathrm{Pr}$ ), 17.7 (d, $J=20.7 \mathrm{~Hz}, \mathrm{CH}_{3}$ of $i \operatorname{Pr}$ ), $17.0\left(\mathrm{~d}, J=8.7 \mathrm{~Hz}, \mathrm{CH}_{3}\right.$ of $i \mathrm{Pr}$ ). HRMS (DART): calcd for $\mathrm{C}_{19} \mathrm{H}_{36} \mathrm{NOP}_{2}[\mathrm{M}+\mathrm{H}]^{+} \mathrm{m} / \mathrm{z} 356.2272$; found, $\mathrm{m} / \mathrm{z} 356.2265$.

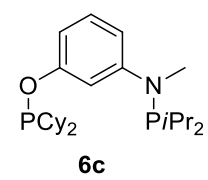

Ligand 6c. In a Schlenk flask equipped with a magnetic stir bar, NaH $(5.50 \mathrm{mmol}, 220.0 \mathrm{mg}$, $60 \%$ ) washed by $n$-pentane was slowly added to a solution of 3-(methylamino)phenol (5.00 $\mathrm{mmol}, 615.0 \mathrm{mg}$ ) in $50 \mathrm{~mL}$ THF (caution: hydrogen evolution). The mixture was stirred at room temperature for $1 \mathrm{~h}$, then chlorodicyclohexylphosphine $(5.30 \mathrm{mmol}, 1.2 \mathrm{~g})$ was added via syringe. The mixture was stirred at room temperature overnight. After evaporation of the solvent under high vacuum, the residue was dissolved in pentane $(50 \mathrm{~mL}) . n$-Butyllithium $(2.1$ $\mathrm{mL}, 2.5 \mathrm{M}$ in hexane, $5.25 \mathrm{mmol}$ ) was added to the mixture under argon at $-78{ }^{\circ} \mathrm{C}$ followed by $3 \mathrm{~h}$ of stirring. White solids precipitated from the solution. After that, a solution of chlorodiisopropylphosphine $(5.30 \mathrm{mmol}, 806.0 \mathrm{mg})$ in $2 \mathrm{~mL}$ THF was added dropwise. Then the solution was slowly warmed to room temperature and stirred overnight. After evaporation of the solvent under vacuum, the residue was extracted with pentane $(100 \mathrm{~mL})$ and the extract was filtered through a pad of celite. After the removal of pentane under vacuum, the flask was heated to $60{ }^{\circ} \mathrm{C}$ for $6 \mathrm{~h}$ under high to remove the unreacted chlorodiisopropylphosphine, furnishing $6 \mathbf{c}$ as light yellow oil (1.4 g, 64\% yield). ${ }^{1} \mathrm{H} \mathrm{NMR}\left(400 \mathrm{MHz}, \mathrm{C}_{6} \mathrm{D}_{6}\right) \delta 7.49-7.45$ (m, 1H, ArH), $7.17-7.10(\mathrm{~m}, 1 \mathrm{H}, \mathrm{ArH}), 7.08-7.01(\mathrm{~m}, 1 \mathrm{H}, \mathrm{ArH}), 6.93(\mathrm{~d}, J=7.9 \mathrm{~Hz}, 1 \mathrm{H}$, ArH), 2.63 (s, 3H, NMe), $2.02(\mathrm{~d}, J=13.0 \mathrm{~Hz}, 2 \mathrm{H}, \mathrm{CH}$ of Cy), $1.76(\mathrm{t}, J=3.1 \mathrm{~Hz}, 2 \mathrm{H}, \mathrm{CH}$ of $i \mathrm{Pr}), 1.74-1.69\left(\mathrm{~m}, 4 \mathrm{H}, \mathrm{CH}_{2}\right.$ of $\left.\mathrm{Cy}\right), 1.68\left(\mathrm{t}, J=3.4 \mathrm{~Hz}, 2 \mathrm{H}, \mathrm{CH}_{2}\right.$ of $\left.\mathrm{Cy}\right), 1.64-1.62(\mathrm{~m}, 2 \mathrm{H}$, $\mathrm{CH}_{2}$ of $\mathrm{Cy}$ ), $1.58-1.51$ (m, $4 \mathrm{H}, \mathrm{CH}_{2}$ of $\mathrm{Cy}$ ), $1.42-1.29\left(\mathrm{~m}, 4 \mathrm{H}, \mathrm{CH}_{2}\right.$ of Cy), 1.15 (tdt, $J=$ 11.0, 5.6, $3.0 \mathrm{~Hz}, 3 \mathrm{H}, \mathrm{CH}_{3}$ of $\left.i \mathrm{Pr}\right), 0.98\left(\mathrm{~d}, J=6.9 \mathrm{~Hz}, 3 \mathrm{H}, \mathrm{CH}_{3}\right.$ of $\left.i \mathrm{Pr}\right), 0.94(\mathrm{~d}, J=6.9 \mathrm{~Hz}, 3 \mathrm{H}$, $\mathrm{CH}_{3}$ of $\left.i \mathrm{Pr}\right), 0.91\left(\mathrm{~d}, J=7.0 \mathrm{~Hz}, 3 \mathrm{H}, \mathrm{CH}_{3}\right.$ of $\left.i \mathrm{Pr}\right), 0.88\left(\mathrm{~d}, J=7.0 \mathrm{~Hz}, 3 \mathrm{H}, \mathrm{CH}_{3}\right.$ of $\left.i \operatorname{Pr}\right) .{ }^{31} \mathrm{P}$ NMR $\left(162 \mathrm{MHz}, \mathrm{C}_{6} \mathrm{D}_{6}\right): \delta 139.0(\mathrm{~s}), \delta 80.9(\mathrm{~s}) ;{ }^{13} \mathrm{C}$ NMR $\left(101 \mathrm{MHz}, \mathrm{C}_{6} \mathrm{D}_{6}\right) \delta 160.5(\mathrm{~d}, J=9.2 \mathrm{~Hz}$, $\left.\mathrm{C}_{\mathrm{Ar}}\right), 154.3\left(\mathrm{~d}, J=21.0 \mathrm{~Hz}, \mathrm{C}_{\mathrm{Ar}}\right), 129.2\left(\mathrm{~s}, \mathrm{C}_{\mathrm{Ar}}\right), 109.7\left(\mathrm{~d}, J=17.9 \mathrm{~Hz}, \mathrm{C}_{\mathrm{Ar}}\right), 108.5(\mathrm{~d}, J=11.2$ $\left.\mathrm{Hz}, \mathrm{C}_{\mathrm{Ar}}\right), 106.7\left(\mathrm{dd}, J=17.4,10.9 \mathrm{~Hz}, \mathrm{C}_{\mathrm{Ar}}\right), 38.2(\mathrm{~d}, J=18.6 \mathrm{~Hz}, \mathrm{NMe}), 28.10(\mathrm{~d}, J=18.8 \mathrm{~Hz}$, CH of $i \operatorname{Pr}$ ), $27.1-26.9$ (m, CH of $i \operatorname{Pr}), 26.78$ (d, $J=4.9 \mathrm{~Hz}, \mathrm{CH}$ of Cy), 26.7 (d, $J=5.8 \mathrm{~Hz}$, $\mathrm{CH}$ of $\mathrm{Cy}$ ), 26.5 (s, $\mathrm{CH}_{2}$ of Cy), 26.4 (s, $\mathrm{CH}_{2}$ of $\mathrm{Cy}$ ), 19.4 (s, $\mathrm{CH}_{3}$ of $\left.i \mathrm{Pr}\right), 19.3$ (s, $\mathrm{CH}_{3}$ of $i \mathrm{Pr}$ ), 19.1 (s, $\mathrm{CH}_{3}$ of $i \mathrm{Pr}$ ). HRMS (DART): calcd for $\mathrm{C}_{25} \mathrm{H}_{44} \mathrm{NOP}_{2}[\mathrm{M}+\mathrm{H}]^{+} \mathrm{m} / \mathrm{z}$ 436.2898; found, $\mathrm{m} / \mathrm{z} 436.2892$. 


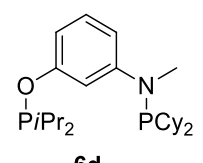

$6 d$

Ligand 6d. In a Schlenk flask equipped with a magnetic stir bar, $\mathrm{NaH}(5.50 \mathrm{mmol}, 220.0 \mathrm{mg}$, $60 \%$ ) washed by $n$-pentane was slowly added to a solution of 3-(methylamino)phenol (5.00 $\mathrm{mmol}, 615.0 \mathrm{mg}$ ) in $50 \mathrm{~mL}$ THF (caution: hydrogen evolution). The mixture was stirred at room temperature for $1 \mathrm{~h}$, then chlorodiisopropylphosphine $(5.30 \mathrm{mmol}, 806.0 \mathrm{mg})$ was added via syringe. The mixture was stirred at room temperature overnight. After evaporation of the solvent under high vacuum, the residue was dissolved in pentane $(50 \mathrm{~mL}) . n$-Butyllithium $(2.1$ $\mathrm{mL}, 2.5 \mathrm{M}$ in hexane, $5.25 \mathrm{mmol}$ ) was added to the mixture under argon at $-78{ }^{\circ} \mathrm{C}$ followed by $3 \mathrm{~h}$ of stirring. White solids precipitated from the solution. After that, a solution of chlorodicyclohexylphosphine $(5.30 \mathrm{mmol}, 1.2 \mathrm{~g})$ in $2 \mathrm{~mL}$ THF was added dropwise. Then the solution was slowly warmed to room temperature and stirred overnight. After evaporation of the solvent under vacuum, the residue was extracted with pentane $(100 \mathrm{~mL})$ and the extract was filtered through a pad of celite. After the removal of pentane under vacuum, the flask was heated to $60{ }^{\circ} \mathrm{C}$ for $6 \mathrm{~h}$ under high to remove the unreacted chlorodicyclohexylphosphine, furnishing 6d as light yellow oil (1.7 g, 73\% yield). ${ }^{1} \mathrm{H}$ NMR $\left(400 \mathrm{MHz}, \mathrm{C}_{6} \mathrm{D}_{6}\right) \delta 7.42(\mathrm{p}, J=2.4 \mathrm{~Hz}, 1 \mathrm{H}$, $\mathrm{ArH}), 7.13(\mathrm{t}, J=8.1 \mathrm{~Hz}, 1 \mathrm{H}, \mathrm{ArH}), 7.03(\mathrm{dt}, J=8.4,2.7 \mathrm{~Hz}, 1 \mathrm{H}, \mathrm{ArH}), 6.86(\mathrm{dd}, J=8.1,2.3$ $\mathrm{Hz}, 1 \mathrm{H}, \mathrm{ArH}), 2.69$ (d, $J=1.5 \mathrm{~Hz}, 3 \mathrm{H}, \mathrm{NMe}), 1.80(\mathrm{pd}, J=7.1,2.7 \mathrm{~Hz}, 4 \mathrm{H}, \mathrm{CH}$ of $i \operatorname{Pr}$ and Cy), $1.73-1.65\left(\mathrm{~m}, 8 \mathrm{H}, \mathrm{CH}_{2}\right.$ of $\left.\mathrm{Cy}\right), 1.64-1.54\left(\mathrm{~m}, 8 \mathrm{H}, \mathrm{CH}_{2}\right.$ of $\left.\mathrm{Cy}\right), 1.31-1.22\left(\mathrm{~m}, 4 \mathrm{H}, \mathrm{CH}_{2}\right.$ of Cy), $1.20\left(\mathrm{~d}, J=7.0 \mathrm{~Hz}, 3 \mathrm{H}, \mathrm{CH}_{3}\right.$ of $\left.i \operatorname{Pr}\right), 1.17\left(\mathrm{~d}, J=7.0 \mathrm{~Hz}, 3 \mathrm{H}, \mathrm{CH}_{3}\right.$ of $\left.i \operatorname{Pr}\right), 1.04(\mathrm{~d}, J=7.2$ $\mathrm{Hz}, 3 \mathrm{H}, \mathrm{CH}_{3}$ of $\left.i \mathrm{Pr}\right), 1.00\left(\mathrm{~d}, J=7.3 \mathrm{~Hz}, 3 \mathrm{H}, \mathrm{CH}_{3}\right.$ of $\left.i \mathrm{Pr}\right) .{ }^{31} \mathrm{P} \mathrm{NMR}\left(162 \mathrm{MHz}, \mathrm{C}_{6} \mathrm{D}_{6}\right) \delta 144.6$ (s), $62.6(\mathrm{~s}) .{ }^{13} \mathrm{C}$ NMR $\left(101 \mathrm{MHz}, \mathrm{C}_{6} \mathrm{D}_{6}\right) \delta 160.2\left(\mathrm{dd}, J=8.8,1.7 \mathrm{~Hz}, \mathrm{C}_{\mathrm{Ar}}\right), 154.4(\mathrm{~d}, J=20.8$ $\left.\mathrm{Hz}, \mathrm{C}_{\mathrm{Ar}}\right), 129.1\left(\mathrm{~s}, \mathrm{C}_{\mathrm{Ar}}\right), 109.8\left(\mathrm{~d}, J=17.9 \mathrm{~Hz}, \mathrm{C}_{\mathrm{Ar}}\right), 108.4\left(\mathrm{~d}, J=11.8 \mathrm{~Hz}, \mathrm{C}_{\mathrm{Ar}}\right), 36.8(\mathrm{~d}, J=$ $17.3 \mathrm{~Hz}, \mathrm{Nme}$ ), 29.8 (d, $J=23.9 \mathrm{~Hz}, \mathrm{CH}$ of $i \mathrm{Pr}), 29.1$ (d, $J=8.7 \mathrm{~Hz}, \mathrm{CH}$ of Cy), 28.4 (d, $J=$ $18.5 \mathrm{~Hz}, \mathrm{CH}$ of $i \mathrm{Pr}$ ), 26.9 (d, $J=7.9 \mathrm{~Hz}, \mathrm{CH}$ of $\mathrm{Cy}$ ), 26.7 (d, $J=13.3 \mathrm{~Hz}, \mathrm{CH}_{2}$ of Cy), 26.5 (s, $\mathrm{CH}_{2}$ of Cy), 17.7 (d, $J=20.8 \mathrm{~Hz}, \mathrm{CH}_{3}$ of $i \mathrm{Pr}$ ), 17.0 (d, $J=8.8 \mathrm{~Hz}, \mathrm{CH}_{3}$ of $i \operatorname{Pr}$ ). HRMS (DART): calcd for $\mathrm{C}_{25} \mathrm{H}_{44} \mathrm{NOP}_{2}[\mathrm{M}+\mathrm{H}]^{+} \mathrm{m} / \mathrm{z} 436.2898$; found, $\mathrm{m} / \mathrm{z} 436.2886$.

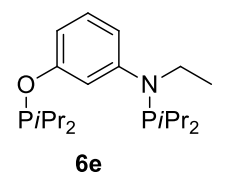

Ligand 6e. In a Schlenk flask equipped with a magnetic stir bar, NaH $(5.50 \mathrm{mmol}, 220.0 \mathrm{mg}$, $60 \%$ ) washed by $n$-pentane was slowly added to a solution of 3 -(ethylamino)phenol $(5.00 \mathrm{mmol}$, $685.0 \mathrm{mg}$ ) in $50 \mathrm{~mL}$ THF (caution: hydrogen evolution). The mixture was stirred at room temperature for $1 \mathrm{~h}$, then chlorodiisopropylphosphine $(5.30 \mathrm{mmol}, 806.0 \mathrm{mg})$ was added via syringe. The mixture was stirred at room temperature overnight. After evaporation of the solvent under high vacuum, the residue was dissolved in pentane $(50 \mathrm{~mL}) . n$-Butyllithium (2.1 $\mathrm{mL}, 2.5 \mathrm{M}$ in hexane, $5.25 \mathrm{mmol}$ ) was added to the mixture under argon at $-78^{\circ} \mathrm{C}$ followed by $3 \mathrm{~h}$ of stirring. White solids precipitated from the solution. After that, the solution of chlorodiisopropylphosphine (5.30 mmol, $806.0 \mathrm{mg}$ ) in $2 \mathrm{~mL}$ THF was added dropwise. Then the reaction mixture was slowly warmed to room temperature and stirred overnight. After evaporation of the solvent under vacuum, the residue was extracted with pentane $(100 \mathrm{~mL})$ and the extract was filtered through a pad of celite. After the removal of pentane under vacuum, the flask was heated to $60{ }^{\circ} \mathrm{C}$ for $6 \mathrm{~h}$ under high to remove the unreacted chlorodiisopropylphosphine, furnishing 6e as light yellow oil (1.2 g, 63\% yield). ${ }^{1} \mathrm{H}$ NMR (400 $\left.\mathrm{MHz} \mathrm{CDCl}_{3}\right) \delta 7.07(\mathrm{t}, J=8.1 \mathrm{~Hz}, 1 \mathrm{H}, \mathrm{ArH}), 6.89(\mathrm{~s}, 1 \mathrm{H}, \mathrm{ArH}), 6.83(\mathrm{~d}, J=8.1 \mathrm{~Hz}, 1 \mathrm{H}, \mathrm{ArH})$, $6.56(\mathrm{~d}, J=7.9 \mathrm{~Hz}, 1 \mathrm{H}, \mathrm{ArH}), 3.58-3.41\left(\mathrm{~m}, 2 \mathrm{H}, \mathrm{NCH}_{2}\right), 2.11(\mathrm{dt}, J=6.7,3.4 \mathrm{~Hz}, 2 \mathrm{H}, \mathrm{CH}$ of $i \operatorname{Pr}), 1.99-1.79(\mathrm{~m}, 2 \mathrm{H}, \mathrm{CH}$ of $i \mathrm{Pr}), 1.27$ (dt, $J=15.1,7.6 \mathrm{~Hz}, 3 \mathrm{H}, \mathrm{CH}_{3}$ of $\left.\mathrm{NCH}_{2} \mathrm{CH}_{3}\right), 1.18$ (dd, $J=10.4,6.9 \mathrm{~Hz}, 6 \mathrm{H}, \mathrm{CH}_{3}$ of $i \mathrm{Pr}$ ), $1.13\left(\mathrm{dd}, J=6.8,3.2 \mathrm{~Hz}, 6 \mathrm{H}, \mathrm{CH}_{3}\right.$ of $i \operatorname{Pr}$ ), $1.11-1.04$ (m, $12 \mathrm{H}, \mathrm{CH}_{3}$ of $\left.i \mathrm{Pr}\right) . ;{ }^{31} \mathrm{P} \mathrm{NMR}\left(162 \mathrm{MHz}, \mathrm{CDCl}_{3}\right) \delta 147.6(\mathrm{~s}), 80.7(\mathrm{~s}) . ;{ }^{13} \mathrm{C} \mathrm{NMR}(101 \mathrm{MHz}$, $\left.\mathrm{CDCl}_{3}\right) \delta 159.8\left(\mathrm{~d}, J=8.5 \mathrm{~Hz}, \mathrm{C}_{\mathrm{Ar}}\right), 151.4\left(\mathrm{~d}, J=16.3 \mathrm{~Hz}, \mathrm{C}_{\mathrm{Ar}}\right), 128.9\left(\mathrm{~s}, \mathrm{C}_{\mathrm{Ar}}\right), 112.9(\mathrm{~d}, J=$ $\left.14.7 \mathrm{~Hz}, \mathrm{C}_{\mathrm{Ar}}\right), 109.2\left(\mathrm{t}, J=10.7 \mathrm{~Hz}, \mathrm{C}_{\mathrm{Ar}}\right), 42.9\left(\mathrm{~s}, \mathrm{NCH}_{2}\right), 28.4(\mathrm{~d}, J=17.6 \mathrm{~Hz}, \mathrm{CH}$ of $i \operatorname{Pr}), 26.8$ 
$(\mathrm{d}, J=16.5 \mathrm{~Hz}, \mathrm{CH}$ of $i \operatorname{Pr}), 19.8\left(\mathrm{~d}, J=11.3 \mathrm{~Hz}, \mathrm{CH}_{3}\right.$ of $\left.i \operatorname{Pr}\right), 19.6\left(\mathrm{~d}, J=25.3 \mathrm{~Hz}, \mathrm{CH}_{3}\right.$ of $\left.i \operatorname{Pr}\right)$, 17.9 (d, $J=20.2 \mathrm{~Hz}, \mathrm{CH}_{3}$ of $\left.i \operatorname{Pr}\right), 17.1$ (d, $J=8.5 \mathrm{~Hz}, \mathrm{CH}_{3}$ of $\left.i \operatorname{Pr}\right), 14.1\left(\mathrm{~s}, \mathrm{CH}_{3}\right.$ of $\mathrm{NCH}_{2} \mathrm{CH}_{3}$ ); HRMS (DART): calcd for $\mathrm{C}_{25} \mathrm{H}_{44} \mathrm{NSP}_{2}[\mathrm{M}+\mathrm{H}]^{+} \mathrm{m} / \mathrm{z} 370.2429$; found, $\mathrm{m} / \mathrm{z} 370.2423$.

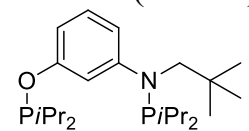

$6 f$

Ligand 6f. In a Schlenk flask equipped with a magnetic stir bar, NaH (5.50 mmol, $220.0 \mathrm{mg}$, $60 \%)$ washed by $n$-pentane was slowly added to a solution of 3-(neopentylamino)phenol (5.0 $\mathrm{mmol}, 895.0 \mathrm{mg}$ ) in $50 \mathrm{~mL}$ THF (caution: hydrogen evolution). The mixture was stirred at room temperature for $1 \mathrm{~h}$, then chlorodiisopropylphosphine $(5.30 \mathrm{mmol}, 806.0 \mathrm{mg})$ was added via syringe. The mixture was stirred at room temperature overnight. After evaporation of the solvent under high vacuum, the residue was dissolved in pentane $(50 \mathrm{~mL}) . n$-Butyllithium $(2.1$ $\mathrm{mL}, 2.5 \mathrm{M}$ in hexane, $5.25 \mathrm{mmol}$ ) was added to the mixture under argon at $-78{ }^{\circ} \mathrm{C}$ followed by $3 \mathrm{~h}$ of stirring. White solids precipitated from the solution. After that, the solution of chlorodiisopropylphosphine $(5.30 \mathrm{mmol}, 806.0 \mathrm{mg})$ in $2 \mathrm{~mL}$ THF was added dropwise. Then the reaction mixture was slowly warmed to room temperature and stirred overnight. After evaporation of the solvent under vacuum, the residue was extracted with pentane $(30 \mathrm{~mL}$ x 2$)$ and the extract was filtered through a pad of celite. After the removal of pentane under vacuum, the flask was heated to $60{ }^{\circ} \mathrm{C}$ for $6 \mathrm{~h}$ under high to remove the unreacted chlorodiisopropylphosphine, furnishing $\mathbf{6 f}$ as colorless oil (1.2 g, 56\% yield). ${ }^{1} \mathrm{H}$ NMR (400 $\left.\mathrm{MHz}, \mathrm{C}_{6} \mathrm{D}_{6}\right) \delta 7.33(\mathrm{q}, J=2.4 \mathrm{~Hz}, 1 \mathrm{H}, \mathrm{ArH}), 7.02(\mathrm{t}, J=8.1 \mathrm{~Hz}, 1 \mathrm{H}, \mathrm{ArH}), 6.93(\mathrm{~d}, J=8.2 \mathrm{~Hz}$, $1 \mathrm{H}, \mathrm{ArH}), 6.81(\mathrm{dd}, J=8.3,2.1 \mathrm{~Hz}, 1 \mathrm{H}, \mathrm{ArH}), 3.57\left(\mathrm{~d}, J=9.4 \mathrm{~Hz}, 2 \mathrm{H}, \mathrm{NCH}_{2}\right), 2.02(\mathrm{p}, J=7.1$ $\mathrm{Hz}, 2 \mathrm{H}, \mathrm{CH}$ of $i \operatorname{Pr}$ ), 1.77 (ddd, $J=10.0,7.1,3.5 \mathrm{~Hz}, 2 \mathrm{H}, \mathrm{CH}$ of $i \operatorname{Pr}), 1.21(\mathrm{~d}, J=7.0 \mathrm{~Hz}, 3 \mathrm{H}$, $\mathrm{CH}_{3}$ of $\left.i \mathrm{Pr}\right), 1.18\left(\mathrm{dd}, J=7.0,1.6 \mathrm{~Hz}, 6 \mathrm{H}, \mathrm{CH}_{3}\right.$ of $\left.i \operatorname{Pr}\right), 1.15\left(\mathrm{~d}, J=6.9 \mathrm{~Hz}, 3 \mathrm{H}, \mathrm{CH}_{3}\right.$ of $\left.i \operatorname{Pr}\right)$, $1.04\left(\mathrm{~d}, J=7.0 \mathrm{~Hz}, 3 \mathrm{H}, \mathrm{CH}_{3}\right.$ of $\left.i \mathrm{Pr}\right), 1.01$ (dd, $J=7.1,2.4 \mathrm{~Hz}, 6 \mathrm{H}, \mathrm{CH}_{3}$ of $\left.i \operatorname{Pr}\right), 0.97(\mathrm{~d}, J=7.3$ $\mathrm{Hz}, 3 \mathrm{H}, \mathrm{CH}_{3}$ of $\left.i \mathrm{Pr}\right), 0.91\left(\mathrm{~s}, 9 \mathrm{H}, \mathrm{CH}_{3}\right.$ of $\left.t \mathrm{Bu}\right) .{ }^{31} \mathrm{P} \mathrm{NMR}\left(162 \mathrm{MHz}, \mathrm{C}_{6} \mathrm{D}_{6}\right): \delta 147.2(\mathrm{~s}), 96.2(\mathrm{~s})$. ${ }^{13} \mathrm{C}$ NMR $\left(101 \mathrm{MHz}, \mathrm{C}_{6} \mathrm{D}_{6}\right) \delta 159.0\left(\mathrm{~d}, J=8.9 \mathrm{~Hz}, \mathrm{C}_{\mathrm{Ar}}\right), 151.5\left(\mathrm{~d}, J=4.5 \mathrm{~Hz}, \mathrm{C}_{\mathrm{Ar}}\right), 128.1(\mathrm{~s}$, $\left.\mathrm{C}_{\mathrm{Ar}}\right), 117.4\left(\mathrm{dd}, J=2.4,1.2 \mathrm{~Hz}, \mathrm{C}_{\mathrm{Ar}}\right), 114.5\left(\mathrm{dd}, J=12.3,2.1 \mathrm{~Hz}, \mathrm{C}_{\mathrm{Ar}}\right), 112.1(\mathrm{~d}, J=9.4 \mathrm{~Hz}$, $\left.\mathrm{C}_{\mathrm{Ar}}\right), 54.6\left(\mathrm{~s}, \mathrm{NCH}_{2}\right), 34.2\left(\mathrm{~d}, J=3.4 \mathrm{~Hz}, \mathrm{C}\right.$ of $\left.\mathrm{NCH}_{2} t \mathrm{Bu}\right), 27.9\left(\mathrm{~d}, J=1.0 \mathrm{~Hz}, \mathrm{CH}_{3}\right.$ of $\left.\mathrm{NCH}_{2} t \mathrm{Bu}\right)$, $27.5\left(\mathrm{~d}, J=4.6 \mathrm{~Hz}, \mathrm{CH}_{3}\right.$ of $\left.\mathrm{NCH}_{2} t \mathrm{Bu}\right), 27.3(\mathrm{~d}, J=4.7 \mathrm{~Hz}, \mathrm{CH}$ of $i \mathrm{Pr}), 27.1$ (s, $\mathrm{CH}$ of $\left.i \operatorname{Pr}\right), 26.9$ (s, CH of $i \mathrm{Pr}$ ), 26.4 (s, CH of $i \mathrm{Pr}), 19.0\left(\mathrm{~d}, J=13.5 \mathrm{~Hz}, \mathrm{CH}_{3}\right.$ of $\left.i \mathrm{Pr}\right), 18.1$ (d, $J=21.6 \mathrm{~Hz}, \mathrm{CH}_{3}$ of $i \operatorname{Pr}$ ), 16.8 (d, $J=20.7 \mathrm{~Hz}, \mathrm{CH}_{3}$ of $i \operatorname{Pr}$ ), 16.0 (d, $J=8.7 \mathrm{~Hz}, \mathrm{CH}_{3}$ of $i \operatorname{Pr}$ ). HRMS (DART): calcd for $\mathrm{C}_{23} \mathrm{H}_{43} \mathrm{NOP}_{2}[\mathrm{M}+\mathrm{H}]^{+} \mathrm{m} / \mathrm{z}$ 412.2898; found, $\mathrm{m} / \mathrm{z} 412.2887$.

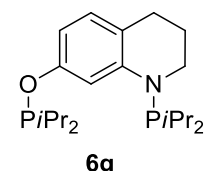

Ligand 6g. In a Schlenk flask equipped with a magnetic stir bar, NaH $(5.50 \mathrm{mmol}, 220.0 \mathrm{mg}$, $60 \%$ ) washed by $n$-pentane was slowly added to a solution of 1,2,3,4-tetrahydroquinolin-7-ol $(5.00 \mathrm{mmol}, 745.0 \mathrm{mg})$ in $50 \mathrm{~mL}$ THF (caution: hydrogen evolution). The mixture was stirred at room temperature for $1 \mathrm{~h}$, then chlorodiisopropylphosphine $(5.30 \mathrm{mmol}, 806.0 \mathrm{mg})$ was added via syringe. The mixture was stirred at room temperature overnight. After evaporation of the solvent under high vacuum, the residue was dissolved in pentane $(50 \mathrm{~mL}) . n$-Butyllithium $\left(2.1 \mathrm{~mL}, 2.5 \mathrm{M}\right.$ in hexane, $5.25 \mathrm{mmol}$ ) was added to the mixture under argon at $-78{ }^{\circ} \mathrm{C}$ followed by $3 \mathrm{~h}$ of stirring. White solids precipitated from the solution. After that, the solution of chlorodiisopropylphosphine $(5.30 \mathrm{mmol}, 806.0 \mathrm{mg})$ in $2 \mathrm{~mL}$ THF was added dropwise. Then the reaction mixture was slowly warmed to room temperature and stirred overnight. After evaporation of the solvent under vacuum, the residue was extracted with pentane $(2 \times 30 \mathrm{~mL})$ and the extract was filtered through a pad of celite. After the removal of pentane under vacuum, the flask was heated to $60{ }^{\circ} \mathrm{C}$ for $6 \mathrm{~h}$ under high to remove the unreacted chlorodiisopropylphosphine, furnishing $\mathbf{6 g}$ as light yellow oil (1.0 g, 51\% yield). ${ }^{1} \mathrm{H}$ NMR (400 $\left.\mathrm{MHz}, \mathrm{C}_{6} \mathrm{D}_{6}\right) \delta 8.03(\mathrm{~s}, 1 \mathrm{H}, \mathrm{ArH}), 6.80(\mathrm{~d}, J=8.2 \mathrm{~Hz}, 1 \mathrm{H}, \mathrm{ArH}), 6.72(\mathrm{~d}, J=8.1 \mathrm{~Hz}, 1 \mathrm{H}, \operatorname{ArH})$, 3.00 (s, 2H, $\mathrm{NCH}_{2}$ ), 2.54 (t, $J=6.4 \mathrm{~Hz}, 2 \mathrm{H}, \mathrm{ArCH}_{2}$ ), 1.78 (dtd, $J=14.1,7.1,2.7 \mathrm{~Hz}, 4 \mathrm{H}, \mathrm{CH}$ 
of $i \mathrm{Pr}$ ), 1.59 (dt, $\left.J=11.7,6.3 \mathrm{~Hz}, 2 \mathrm{H}, \mathrm{NCH}_{2} \mathrm{CH}_{2}\right), 1.19\left(\mathrm{~d}, J=7.0 \mathrm{~Hz}, 3 \mathrm{H}, \mathrm{CH}_{3}\right.$ of $\left.t \mathrm{Bu}\right), 1.16$ $\left(\mathrm{d}, J=7.0 \mathrm{~Hz}, 3 \mathrm{H}, \mathrm{CH}_{3}\right.$ of $\left.t \mathrm{Bu}\right), 0.99$ (ddd, $J=23.1,13.7,7.1 \mathrm{~Hz}, 18 \mathrm{H}, \mathrm{CH}_{3}$ of $\left.t \mathrm{Bu}\right){ }^{31} \mathrm{P}$ NMR $\left(162 \mathrm{MHz}, \mathrm{C}_{6} \mathrm{D}_{6}\right) \delta 145.40(\mathrm{~s}, 1 \mathrm{P}), 63.07(\mathrm{~s}, 1 \mathrm{P}) .{ }^{13} \mathrm{C} \mathrm{NMR}\left(101 \mathrm{MHz}, \mathrm{C}_{6} \mathrm{D}_{6}\right) \delta 158.2(\mathrm{~d}, J=7.0$ $\left.\mathrm{Hz}, \mathrm{C}_{\mathrm{Ar}}\right), 130.1\left(\mathrm{~s}, \mathrm{C}_{\mathrm{Ar}}\right), 117.0\left(\mathrm{~s}, \mathrm{C}_{\mathrm{Ar}}\right), 108.5\left(\mathrm{~s}, \mathrm{C}_{\mathrm{Ar}}\right), 107.6\left(\mathrm{~d}, J=10.9 \mathrm{~Hz}, \mathrm{C}_{\mathrm{Ar}}\right), 107.3(\mathrm{~d}, J=$ $\left.10.9 \mathrm{~Hz}, \mathrm{C}_{\mathrm{Ar}}\right),{ }^{13} \mathrm{C} \mathrm{NMR}\left(101 \mathrm{MHz}, \mathrm{C}_{6} \mathrm{D}_{6}\right) \delta 44.4\left(\mathrm{~s}, \mathrm{NCH}_{2}\right), 28.3\left(\mathrm{~d}, J=18.7 \mathrm{~Hz}, \mathrm{ArCH}_{2}\right), 27.5$ $\left(\mathrm{s}, \mathrm{NCH}_{2} \mathrm{CH}_{2}\right), 25.6(\mathrm{~d}, J=16.3 \mathrm{~Hz}, \mathrm{CH}$ of $i \operatorname{Pr}), 23.1$ (s, $\mathrm{CH}_{3}$ of $\left.i \mathrm{Pr}\right), 19.5\left(\mathrm{~d}, J=11.1 \mathrm{~Hz}, \mathrm{CH}_{3}\right.$ of $i \operatorname{Pr}$ ), 17.7 (d, $J=20.8 \mathrm{~Hz}, \mathrm{CH}_{3}$ of $i \operatorname{Pr}$ ), 16.9 (d, $J=8.8 \mathrm{~Hz}, \mathrm{CH}_{3}$ of $i \operatorname{Pr}$ ). HRMS (DART): calcd for $\mathrm{C}_{21} \mathrm{H}_{37} \mathrm{NOP}_{2}[\mathrm{M}+\mathrm{H}]^{+} 382.2429$; found, $\mathrm{m} / \mathrm{z} 382.2423$.

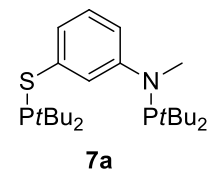

Ligand 7a. In a Schlenk flask equipped with a magnetic stir bar, $\mathrm{NaH}(11.00 \mathrm{mmol}, 440.0 \mathrm{mg}$, $60 \%$ ) washed by $n$-pentane was slowly added to a solution of 3-(methylamino)benzenethiol $(5.00 \mathrm{mmol}, 695.0 \mathrm{mg})$ in $50 \mathrm{~mL}$ THF (caution: hydrogen evolution). The mixture was stirred at room temperature for $1 \mathrm{~h}$, then di-tert-butylchlorophosphine $(10.56 \mathrm{mmol}, 1.9 \mathrm{~g})$ was added via syringe. The mixture was stirred at room temperature overnight. After evaporation of the solvent under high vacuum, the residue was dissolved in pentane $(100 \mathrm{~mL})$, and the extract was filtered through a pad of celite. The solvent was evaporated under high vacuum to give product 7a as colorless oil (1.1 g, 53\% yield). The ligand was used for synthesis of the Ir complex without further purification. ${ }^{1} \mathrm{H}$ NMR $\left(400 \mathrm{MHz}, \mathrm{C}_{6} \mathrm{D}_{6}\right) \delta 7.96(\mathrm{~s}, 1 \mathrm{H}, \mathrm{ArH}), 7.36(\mathrm{~d}, J=7.5 \mathrm{~Hz}$, $1 \mathrm{H}, \mathrm{ArH}), 7.34-7.28(\mathrm{~m}, 1 \mathrm{H}, \mathrm{ArH}), 7.11(\mathrm{t}, J=8.0 \mathrm{~Hz}, 1 \mathrm{H}, \mathrm{ArH}), 2.91$ (s, 3H, NMe), 1.29 (d, $J=11.9 \mathrm{~Hz}, 18 \mathrm{H}, \mathrm{CH}_{3}$ of $\left.t \mathrm{Bu}\right), 1.10\left(\mathrm{~d}, J=12.3 \mathrm{~Hz}, 18 \mathrm{H}, \mathrm{CH}_{3}\right.$ of $\left.t \mathrm{Bu}\right) .{ }^{31} \mathrm{P} \mathrm{NMR}(162 \mathrm{MHz}$, $\left.\mathrm{C}_{6} \mathrm{D}_{6}\right) \delta 85.2(\mathrm{~s}), 80.9(\mathrm{~s}) .{ }^{13} \mathrm{C}$ NMR $\left(101 \mathrm{MHz}, \mathrm{C}_{6} \mathrm{D}_{6}\right) \delta 154.2\left(\mathrm{~d}, J=23.6 \mathrm{~Hz}, \mathrm{C}_{\mathrm{Ar}}\right), 138.6-$ $137.3\left(\mathrm{~m}, \mathrm{C}_{\mathrm{Ar}}\right), 129.0\left(\mathrm{~d}, J=1.9 \mathrm{~Hz}, \mathrm{C}_{\mathrm{Ar}}\right), 121.4\left(\mathrm{dd}, J=9.3,1.8 \mathrm{~Hz}, \mathrm{C}_{\mathrm{Ar}}\right), 119.2(\mathrm{dd}, J=18.9$, $\left.8.4 \mathrm{~Hz}, \mathrm{C}_{\mathrm{Ar}}\right), 114.7\left(\mathrm{~d}, J=20.6 \mathrm{~Hz}, \mathrm{C}_{\mathrm{Ar}}\right), 38.4(\mathrm{~d}, J=8.7 \mathrm{~Hz}, \mathrm{NMe}), 36.2(\mathrm{~d}, J=29.7 \mathrm{~Hz}, \mathrm{C}$ of $t \mathrm{Bu}), 35.3(\mathrm{~d}, J=30.8 \mathrm{~Hz}, \mathrm{C}$ of $t \mathrm{Bu}), 30.1\left(\mathrm{~s}, \mathrm{CH}_{3}\right.$ of $\left.t \mathrm{Bu}\right), 30.0\left(\mathrm{~s}, \mathrm{CH}_{3}\right.$ of $\left.t \mathrm{Bu}\right), 29.9\left(\mathrm{~s}, \mathrm{CH}_{3}\right.$ of $t \mathrm{Bu}$ ), $29.8\left(\mathrm{~s}, \mathrm{CH}_{3}\right.$ of $t \mathrm{Bu}$ ). HRMS (DART): calcd for $\mathrm{C}_{23} \mathrm{H}_{44} \mathrm{NSP}_{2}[\mathrm{M}+\mathrm{H}]^{+} \mathrm{m} / \mathrm{z}$ 428.2670; found, $\mathrm{m} / \mathrm{z} 428.2661$.

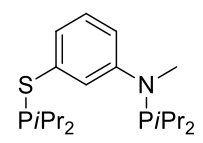

$7 b$

Ligand 7b. In a Schlenk flask equipped with a magnetic stir bar, $\mathrm{NaH}(5.50 \mathrm{mmol}, 0.2, \mathrm{~g} 60 \%)$ washed by $n$-pentane was slowly added to a solution of 3-(methylamino)benzenethiol (5.0 $\mathrm{mmol}, 695.0 \mathrm{mg}$ ) in $50 \mathrm{~mL}$ THF (caution: hydrogen evolution). The mixture was stirred at room temperature for $1 \mathrm{~h}$, then chlorodiisopropylphosphine $(5.30 \mathrm{mmol}, 806.0 \mathrm{mg})$ was added via syringe. The mixture was stirred at room temperature overnight. After evaporation of the solvent under high vacuum, the residue was dissolved in pentane $(50 \mathrm{~mL}) . n$-Butyllithium $(2.1$ $\mathrm{mL}, 2.5 \mathrm{M}$ in hexane, $5.25 \mathrm{mmol}$ ) was added to the mixture under argon at $-78{ }^{\circ} \mathrm{C}$ followed by $3 \mathrm{~h}$ of stirring. White solids precipitated from the solution. After that, the solution of chlorodiisopropylphosphine $(5.30 \mathrm{mmol}, 806.0 \mathrm{mg}$ ) in $2 \mathrm{~mL}$ THF was added dropwise. Then the reaction mixture was slowly warmed to room temperature and stirred overnight. After evaporation of the solvent under vacuum, the residue was extracted with pentane $(2 \times 30 \mathrm{~mL})$ and the extract was filtered through a pad of celite. After the removal of pentane under vacuum, the flask was heated to $60{ }^{\circ} \mathrm{C}$ for $6 \mathrm{~h}$ under high to remove the unreacted chlorodiisopropylphosphine, furnishing $7 \mathbf{b}$ as light yellow oil (1.3 g, 71\% yield). ${ }^{1} \mathrm{H}$ NMR (400 $\left.\mathrm{MHz}, \mathrm{C}_{6} \mathrm{D}_{6}\right) \delta 7.82(\mathrm{t}, J=2.5 \mathrm{~Hz}, 1 \mathrm{H}, \mathrm{ArH}), 7.27(\mathrm{dt}, J=7.6,1.3 \mathrm{~Hz}, 1 \mathrm{H}, \mathrm{ArH}), 7.19(\mathrm{dt}, J=$ $8.4,2.9 \mathrm{~Hz}, 1 \mathrm{H}, \mathrm{ArH}), 7.06(\mathrm{t}, J=8.0 \mathrm{~Hz}, 1 \mathrm{H}, \mathrm{ArH}), 2.61(\mathrm{~s}, 3 \mathrm{H}, \mathrm{NMe}), 1.87$ (pd, $J=6.9,5.0$ $\mathrm{Hz}, 2 \mathrm{H}, \mathrm{CH}$ of $i \mathrm{Pr}), 1.71(\mathrm{pd}, J=7.0,3.4 \mathrm{~Hz}, 2 \mathrm{H}, \mathrm{CH}$ of $i \mathrm{Pr}), 1.22\left(\mathrm{~d}, J=6.9 \mathrm{~Hz}, 3 \mathrm{H}, \mathrm{CH}_{3}\right.$ of $i \operatorname{Pr}), 1.20\left(\mathrm{~d}, J=6.9 \mathrm{~Hz}, 3 \mathrm{H}, \mathrm{CH}_{3}\right.$ of $\left.i \operatorname{Pr}\right), 1.11\left(\mathrm{~d}, J=7.1 \mathrm{~Hz}, 3 \mathrm{H}, \mathrm{CH}_{3}\right.$ of $\left.i \operatorname{Pr}\right), 1.07(\mathrm{~d}, J=7.1$ $\mathrm{Hz}, 3 \mathrm{H}, \mathrm{CH}_{3}$ of $\left.i \mathrm{Pr}\right), 0.99$ (d, $J=6.9 \mathrm{~Hz}, 3 \mathrm{H}, \mathrm{CH}_{3}$ of $\left.i \mathrm{Pr}\right), 0.95\left(\mathrm{~d}, J=6.9 \mathrm{~Hz}, 3 \mathrm{H}, \mathrm{CH}_{3}\right.$ of $i \operatorname{Pr}$ ), $0.89\left(\mathrm{~d}, J=7.0 \mathrm{~Hz}, 3 \mathrm{H}, \mathrm{CH}_{3}\right.$ of $\left.i \mathrm{Pr}\right), 0.86\left(\mathrm{~d}, J=7.0 \mathrm{~Hz}, 3 \mathrm{H}, \mathrm{CH}_{3}\right.$ of $\left.i \mathrm{Pr}\right) .{ }^{31} \mathrm{P}$ NMR $(162 \mathrm{MHz}$, 
$\left.\mathrm{C}_{6} \mathrm{D}_{6}\right): \delta 80.5(\mathrm{~s}), \delta 71.7(\mathrm{~s}) ;{ }^{13} \mathrm{C} \mathrm{NMR}\left(101 \mathrm{MHz}, \mathrm{C}_{6} \mathrm{D}_{6}\right): \delta 153.6\left(\mathrm{~d}, J=20.5 \mathrm{~Hz}, \mathrm{C}_{\mathrm{Ar}}\right), 137.3$ $\left(\mathrm{dd}, J=14.2,1.4 \mathrm{~Hz}, \mathrm{C}_{\mathrm{Ar}}\right), 129.2\left(\mathrm{~d}, J=1.5 \mathrm{~Hz}, \mathrm{C}_{\mathrm{Ar}}\right), 121.8\left(\mathrm{dd}, J=8.3,1.6 \mathrm{~Hz}, \mathrm{C}_{\mathrm{Ar}}\right), 119.4$ (dd, $J=16.7,8.7 \mathrm{~Hz}, \mathrm{C}_{\mathrm{Ar}}$ ), 114.7 (dd, $\left.J=18.0,1.3 \mathrm{~Hz}, \mathrm{C}_{\mathrm{Ar}}\right), 34.1$ (d, $\left.J=6.9 \mathrm{~Hz}, \mathrm{NMe}\right), 26.9$ (d, $J=16.5 \mathrm{~Hz}, \mathrm{CH}$ of $i \mathrm{Pr}$ ), 26.1 (d, $J=21.4 \mathrm{~Hz}, \mathrm{CH}$ of $i \mathrm{Pr}$ ), 19.9 (s, $\mathrm{CH}_{3}$ of $\left.i \mathrm{Pr}\right), 19.7$ (d, $J=$ $3.9 \mathrm{~Hz}, \mathrm{CH}_{3}$ of $i \operatorname{Pr}$ ), 19.7 (s, $\mathrm{CH}_{3}$ of $i \operatorname{Pr}$ ), 19.4 (s, $\mathrm{CH}_{3}$ of $i \operatorname{Pr}$ ), 18.9 (d, $J=8.4 \mathrm{~Hz}, \mathrm{CH}_{3}$ of $i \operatorname{Pr}$ ).; HRMS (DART): calcd for $\mathrm{C}_{19} \mathrm{H}_{35} \mathrm{NSP}_{2}[\mathrm{M}+\mathrm{H}]^{+} \mathrm{m} / \mathrm{z} 372.2044$; found, $\mathrm{m} / \mathrm{z} 372.2038$.

\section{Synthesis of iridium compounds}

1. Synthesis of (pincer)- $\mathrm{IrHCl}^{3,10}$<smiles>CN1c2cccc3c2[In](C)[C@]31Cl</smiles>

4a-HCI

4a-HCl. A rubber septum-capped Schlenk flask was charged with $\mathbf{6 a}(0.76 \mathrm{mmol}, 312.0 \mathrm{mg})$ and $[\operatorname{Ir}(\mathrm{COD}) \mathrm{Cl}]_{2}(0.35 \mathrm{mmol}, 236.0 \mathrm{mg})$. Toluene $(10 \mathrm{~mL})$ was added via syringe, and the solution was stirred in an oil bath at $150{ }^{\circ} \mathrm{C}$ for $2 \mathrm{~h}$. The reaction mixture was then cooled to room temperature and volatiles were then removed under high vacuum. The residue was washed with pentane $(15 \mathrm{~mL} \mathrm{x} 3)$ and dried under vacuum to give $4 \mathbf{a}-\mathrm{HCl}(0.35 \mathrm{mmol}, 226.0$ $\mathrm{mg}, 51 \%$ yield) as wine-red solid. ${ }^{1} \mathrm{H}$ NMR $\left(400 \mathrm{MHz}, \mathrm{CDCl}_{3}\right): \delta 6.83$ (bs, $\left.1 \mathrm{H}, \mathrm{ArH}\right), 6.50(\mathrm{bs}$, $1 \mathrm{H}, \mathrm{ArH}), 6.05$ (bs, 1H, ArH), 3.19 (s, 3H, NMe), 1.38 (s, 36H, $\left.\mathrm{CH}_{3}\right),-42.2(\mathrm{t}, J=12.0 \mathrm{~Hz}, \mathrm{IrH})$; ${ }^{31} \mathrm{P}$ NMR $\left(162 \mathrm{MHz}, \mathrm{CDCl}_{3}\right): \delta 172.2(\mathrm{dd}, J=356.4 \mathrm{~Hz}, J=11.3 \mathrm{~Hz}), \delta 124.3(\mathrm{dd}, J=356.4$ $\mathrm{Hz}, J=11.3 \mathrm{~Hz}) ;{ }^{13} \mathrm{C}$ NMR $\left(101 \mathrm{MHz}, \mathrm{CDCl}_{3}\right) \delta 167.2\left(\mathrm{t}, J=6.0 \mathrm{~Hz}, \mathrm{C}_{\mathrm{Ar}}\right), 160.6(\mathrm{dd}, J=18.2$, $\left.5.0 \mathrm{~Hz}, \mathrm{C}_{\mathrm{Ar}}\right), 124.8\left(\mathrm{~s}, \mathrm{C}_{\mathrm{Ar}}\right), 103.2\left(\mathrm{~d}, J=11.4 \mathrm{~Hz}, \mathrm{C}_{\mathrm{Ar}}\right), 102.2\left(\mathrm{~d}, J=10.3 \mathrm{~Hz}, \mathrm{C}_{\mathrm{Ar}}\right), 45.3(\mathrm{dd}, J$ $=17.5,3.7 \mathrm{~Hz}, \mathrm{NMe}), 42.8(\mathrm{dd}, J=18.7,5.1 \mathrm{~Hz}, \mathrm{C}$ of $t \mathrm{Bu}), 40.2(\mathrm{dd}, J=18.0,3.4 \mathrm{~Hz}, \mathrm{C}$ of $t \mathrm{Bu}), 39.4(\mathrm{dd}, J=20.9,5.3 \mathrm{~Hz}, \mathrm{C}$ of $t \mathrm{Bu}), 37.5(\mathrm{dd}, J=4.6,1.9 \mathrm{~Hz}, \mathrm{C}$ of $t \mathrm{Bu}), 30.5-29.9(\mathrm{~m}$, $\mathrm{CH}_{3}$ of $\left.t \mathrm{Bu}\right), 29.1\left(\mathrm{~d}, J=4.6 \mathrm{~Hz}, \mathrm{CH}_{3}\right.$ of $\left.t \mathrm{Bu}\right), 27.9\left(\mathrm{~d}, J=4.9 \mathrm{~Hz}, \mathrm{CH}_{3}\right.$ of $\left.t \mathrm{Bu}\right), 27.7(\mathrm{~d}, J=4.4$ $\mathrm{Hz}, \mathrm{CH}_{3}$ of $t \mathrm{Bu}$ ). Anal. Calcd for $\mathrm{C}_{23} \mathrm{H}_{43} \mathrm{ClIrNOP}_{2}$ : C, 43.22; H, 6.78; N, 2.19; Found: C, 43.00; $\mathrm{H}, 6.59 ; \mathrm{N}, 1.87$.

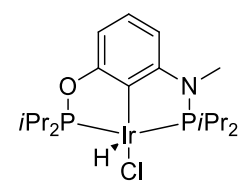

4b-HCl

4b-HCl. A rubber septum-capped Schlenk flask was charged with $\mathbf{6 b}(0.62 \mathrm{mmol}, 220.0 \mathrm{mg})$ and $[\operatorname{Ir}(\mathrm{COD}) \mathrm{Cl}]_{2}(0.30 \mathrm{mmol}, 200.0 \mathrm{mg})$. Toluene $(10 \mathrm{~mL})$ was added via syringe, and the solution was stirred in an oil bath at $150{ }^{\circ} \mathrm{C}$ for $2 \mathrm{~h}$. The reaction mixture was then cooled to room temperature and volatiles were then removed under high vacuum. The residue was washed with pentane $(30 \mathrm{~mL} \times 3)$ and filtered through celite, and solvent was removed in vacuo, resulting in formation of deep purple solids. The residue was purified by column chromatography on neutral alumina (eluent: hexane/THF $=90 / 10$ ), furnishing $\mathbf{4 b}-\mathrm{HCl}$ as deep wine-red solid $\left(0.34 \mathrm{mmol}, 196.0 \mathrm{mg}, 56 \%\right.$ yield). ${ }^{1} \mathrm{H}$ NMR $\left(400 \mathrm{MHz}, \mathrm{CDCl}_{3}\right) 6.84$ (t, $J=7.9$ $\mathrm{Hz}, 1 \mathrm{H}, \mathrm{ArH}), 6.43(\mathrm{~d}, J=7.8 \mathrm{~Hz}, 1 \mathrm{H}, \mathrm{ArH}), 6.04(\mathrm{~d}, J=7.9 \mathrm{~Hz}, 1 \mathrm{H}, \mathrm{ArH}), 2.99(\mathrm{~d}, J=5.1 \mathrm{~Hz}$, $3 \mathrm{H}, \mathrm{NMe}$ ), $2.90-2.77$ (m, 3H, CH of $i \mathrm{Pr}$ ), $2.70-2.57$ (m, $1 \mathrm{H}, \mathrm{CH}$ of $i \operatorname{Pr}$ ), 1.29 (ddd, $J=27.7$, $15.6,7.0 \mathrm{~Hz}, 15 \mathrm{H}, \mathrm{CH}_{3}$ of $i \mathrm{Pr}$ ), $1.16\left(\mathrm{dt}, J=14.7,7.2 \mathrm{~Hz}, 6 \mathrm{H}, \mathrm{CH}_{3}\right.$ of $i \mathrm{Pr}$ ), 1.03 (dd, $J=16.2$, $6.8 \mathrm{~Hz}, 3 \mathrm{H}, \mathrm{CH}_{3}$ of $\left.i \mathrm{Pr}\right)-37.88(\mathrm{~s}, 1 \mathrm{H}, \mathrm{IrH}) .{ }^{31} \mathrm{P} \mathrm{NMR}\left(162 \mathrm{MHz}, \mathrm{CDCl}_{3}\right) \delta 171.0(\mathrm{~d}, J=361.4$ $\mathrm{Hz}, 1 \mathrm{P}), 116.0(\mathrm{~d}, J=361.7 \mathrm{~Hz}, 1 \mathrm{P}) .{ }^{13} \mathrm{C} \mathrm{NMR}\left(101 \mathrm{MHz}, \mathrm{CDCl}_{3}\right) 165.4\left(\mathrm{t}, J=6.3 \mathrm{~Hz}, \mathrm{C}_{\mathrm{Ar}}\right)$, $158.6\left(\mathrm{dd}, J=19.2,5.3 \mathrm{~Hz}, \mathrm{C}_{\mathrm{Ar}}\right), 124.8\left(\mathrm{~s}, \mathrm{C}_{\mathrm{Ar}}\right), 111.7\left(\mathrm{~s}, \mathrm{C}_{\mathrm{Ar}}\right), 103.3\left(\mathrm{~d}, J=11.4 \mathrm{~Hz}, \mathrm{C}_{\mathrm{Ar}}\right), 102.1$ $\left(\mathrm{d}, J=10.7 \mathrm{~Hz}, \mathrm{C}_{\mathrm{Ar}}\right), 33.4(\mathrm{~d}, J=2.2 \mathrm{~Hz}, \mathrm{NMe}), 31.1$ (dd, $J=25.0,5.1 \mathrm{~Hz}, \mathrm{CH}$ of $\left.i \operatorname{Pr}\right), 30.4$ (dd, $J=23.7,3.3 \mathrm{~Hz}, \mathrm{CH}$ of $i \mathrm{Pr}$ ), $29.0(\mathrm{dd}, J=29.3,4.9 \mathrm{~Hz}, \mathrm{CH}$ of $i \operatorname{Pr}$ ), $25.9(\mathrm{~d}, J=29.7 \mathrm{~Hz}$, $\mathrm{CH}$ of $i \mathrm{Pr}$ ), 18.8 (s, $\mathrm{CH}_{3}$ of $i \mathrm{Pr}$ ), 18.3 (s, $\mathrm{CH}_{3}$ of $\left.i \operatorname{Pr}\right), 17.9$ (s, $\mathrm{CH}_{3}$ of $\left.i \mathrm{Pr}\right), 17.5$ (s, $\mathrm{CH}_{3}$ of $i \operatorname{Pr}$ ), 
$17.1\left(\mathrm{~d}, J=3.4 \mathrm{~Hz}, \mathrm{CH}_{3}\right.$ of $\left.i \operatorname{Pr}\right), 17.0\left(\mathrm{~d}, J=8.1 \mathrm{~Hz}, \mathrm{CH}_{3}\right.$ of $\left.i \operatorname{Pr}\right), 16.8\left(\mathrm{~s}, \mathrm{CH}_{3}\right.$ of $\left.i \operatorname{Pr}\right)$.Anal. Calcd for $\mathrm{C}_{19} \mathrm{H}_{35} \mathrm{ClIINOP}_{2}$ : C, 39.14; H, 6.05; N, 2.40; Found: C, 38.97; H, 6.29; N, 2.09.

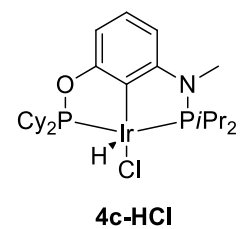

4c-HCl. A rubber septum-capped Schlenk flask was charged with $\mathbf{6 c}(0.64 \mathrm{mmol}, 278.0 \mathrm{mg})$ and $[\operatorname{Ir}(\mathrm{COD}) \mathrm{Cl}]_{2}(0.36 \mathrm{mmol}, 243.0 \mathrm{mg})$. Toluene $(10 \mathrm{~mL})$ was added via syringe, and the solution was stirred in an oil bath at $150{ }^{\circ} \mathrm{C}$ for $2 \mathrm{~h}$. The reaction mixture was then cooled to room temperature and volatiles were then removed under high vacuum. The residue was washed with pentane $(30 \mathrm{~mL} \times 3)$ and filtered through celite, and solvent was removed in vacuo, resulting in formation of deep purple solids. The residue was purified by column chromatography on neutral alumina (eluent: hexane/THF $=90 / 10$ ), furnishing $\mathbf{4 c}-\mathrm{HCl}$ as deep wine-red solid (0.37 mmol, $243.0 \mathrm{mg}, 51 \%$ yield). ${ }^{1} \mathrm{H}$ NMR $\left(400 \mathrm{MHz}, \mathrm{C}_{6} \mathrm{D}_{6}\right) \delta 6.99(\mathrm{~s}, 1 \mathrm{H}$, ArH), 6.81 (s, 1H, ArH), $6.14-5.92(\mathrm{~m}, 1 \mathrm{H}, \mathrm{ArH}), 2.97-2.65$ (m, 2H, CH of Cy), 2.47 (s, 3H, $\mathrm{NMe}$ ), $2.40-2.25(\mathrm{~m}, 2 \mathrm{H}, \mathrm{CH}$ of $i \mathrm{Pr}), 2.10-1.83\left(\mathrm{~m}, 4 \mathrm{H}, \mathrm{CH}_{2}\right.$ of $\left.\mathrm{Cy}\right), 1.55$ (q, $J=32.9,25.8$ $\mathrm{Hz}, 6 \mathrm{H}, \mathrm{CH}_{2}$ of $\left.\mathrm{Cy}\right), 1.26-1.12\left(\mathrm{~m}, 4 \mathrm{H}, \mathrm{CH}_{2}\right.$ of $\left.\mathrm{Cy}\right), 1.12-0.88\left(\mathrm{~m}, 6 \mathrm{H}, \mathrm{CH}_{2}\right.$ of $\left.\mathrm{Cy}\right),-37.06$ $(\mathrm{d}, J=16.1 \mathrm{~Hz}, 1 \mathrm{H}, \mathrm{IrH}) .{ }^{31} \mathrm{P}$ NMR $\left(162 \mathrm{MHz}, \mathrm{C}_{6} \mathrm{D}_{6}\right) \delta 164.8(\mathrm{~d}, J=366.1 \mathrm{~Hz}), 116.6(\mathrm{~d}, J=$ $366.3 \mathrm{~Hz}) .{ }^{13} \mathrm{C}$ NMR $\left(101 \mathrm{MHz}, \mathrm{C}_{6} \mathrm{D}_{6}\right) \delta 165.6\left(\mathrm{t}, J=6.2 \mathrm{~Hz}, \mathrm{C}_{\mathrm{Ar}}\right), 158.5(\mathrm{dd}, J=19.2,5.3 \mathrm{~Hz}$, $\left.\mathrm{C}_{\mathrm{Ar}}\right), 124.8\left(\mathrm{~s}, \mathrm{C}_{\mathrm{Ar}}\right), 111.6\left(\mathrm{~s}, \mathrm{C}_{\mathrm{Ar}}\right), 103.7\left(\mathrm{~d}, J=11.4 \mathrm{~Hz}, \mathrm{C}_{\mathrm{Ar}}\right), 102.4\left(\mathrm{~d}, J=10.6 \mathrm{~Hz}, \mathrm{C}_{\mathrm{Ar}}\right), 40.8$ (dd, $J=25.1,4.7 \mathrm{~Hz}, \mathrm{NMe}$ ), 38.2 (dd, $J=29.0,4.4 \mathrm{~Hz}, \mathrm{CH}$ of Cy), 32.7 (s, CH of Cy), 30.12 (d, $J=23.5 \mathrm{~Hz}, \mathrm{CH}$ of $i \mathrm{Pr}$ ), 27.4 (s, $\mathrm{CH}_{2}$ of Cy), 27.1 (d, $J=6.0 \mathrm{~Hz}, \mathrm{CH}_{2}$ of Cy), 26.7 (d, $J=$ $8.2 \mathrm{~Hz}, \mathrm{CH}_{2}$ of $\mathrm{Cy}$ ), 26.5 (d, $J=5.9 \mathrm{~Hz}, \mathrm{CH}_{2}$ of $\mathrm{Cy}$ ), $26.2\left(\mathrm{~s}, \mathrm{CH}_{2}\right.$ of $\left.\mathrm{Cy}\right), 26.1(\mathrm{~d}, J=5.0 \mathrm{~Hz}$, $\mathrm{CH}_{2}$ of $\mathrm{Cy}$ ), $25.9-25.7$ (m, $\mathrm{CH}_{2}$ of $\mathrm{Cy}$ ), 18.2, (s, $\mathrm{CH}_{3}$ of $\left.i \mathrm{Pr}\right), 18.0$ (s, $\mathrm{CH}_{3}$ of $\left.i \mathrm{Pr}\right), 17.8(\mathrm{~d}, J=$ $9.5 \mathrm{~Hz}, \mathrm{CH}_{3}$ of $\left.i \mathrm{Pr}\right), 17.6$ (d, $J=3.6 \mathrm{~Hz}, \mathrm{CH}_{3}$ of $i \mathrm{Pr}$ ). Anal. Calcd for $\mathrm{C}_{25} \mathrm{H}_{43} \mathrm{ClIrNOP}_{2}$ : C, 45.27; H, 6.53; N, 2.11; Found: C, 45.65; H, 6.61; N, 2.12.

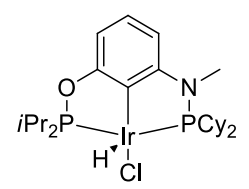

4d-HCl

4d-HCl. A rubber septum-capped Schlenk flask was charged with $\mathbf{6 d}(0.69 \mathrm{mmol}, 300.0 \mathrm{mg})$ and $[\operatorname{Ir}(\mathrm{COD}) \mathrm{Cl}]_{2}(0.33 \mathrm{mmol}, 220.0 \mathrm{mg})$. Toluene $(10 \mathrm{~mL})$ was added via syringe, and the solution was stirred in an oil bath at $150{ }^{\circ} \mathrm{C}$ for $2 \mathrm{~h}$. The reaction mixture was then cooled to room temperature and volatiles were then removed under high vacuum. The residue was washed with pentane $(30 \mathrm{~mL} \times 3)$ and filtered through celite, and solvent was removed in vacuo, resulting in formation of deep purple solids. The residue was purified by column chromatography on neutral alumina (eluent: hexane/THF $=90 / 10$ ), furnishing $\mathbf{4 d}-\mathrm{HCl}$ as deep wine-red solid (0.28 mmol, $188.0 \mathrm{mg}, 43 \%$ yield). ${ }^{1} \mathrm{H}$ NMR $\left(400 \mathrm{MHz}, \mathrm{C}_{6} \mathrm{D}_{6}\right) \delta 7.00$ (t, $J=8.2$ $\mathrm{Hz}, 1 \mathrm{H}, \mathrm{ArH}), 6.79$ (d, $J=8.0 \mathrm{~Hz}, 1 \mathrm{H}, \mathrm{ArH}), 6.05(\mathrm{~d}, J=7.8 \mathrm{~Hz}, 1 \mathrm{H}, \mathrm{ArH}), 2.80$ (t, $J=12.0$ $\mathrm{Hz}, 1 \mathrm{H}, \mathrm{CH}$ of Cy), 2.68 (dt, $J=14.3,6.6 \mathrm{~Hz}, 1 \mathrm{H}, \mathrm{CH}$ of $\mathrm{Cy}$ ), 2.52 (d, $J=5.4 \mathrm{~Hz}, 3 \mathrm{H}, \mathrm{NMe}$ ), $2.37-2.25(\mathrm{~m}, 2 \mathrm{H}, \mathrm{CH}$ of $i \mathrm{Pr}), 2.02-1.94\left(\mathrm{~m}, 2 \mathrm{H}, \mathrm{CH}_{2}\right.$ of $\left.\mathrm{Cy}\right), 1.90-1.82\left(\mathrm{~m}, 2 \mathrm{H}, \mathrm{CH}_{2}\right.$ of $\mathrm{Cy}), 1.75-1.66\left(\mathrm{~s}, 4 \mathrm{H}, \mathrm{CH}_{2}\right.$ of $\left.\mathrm{Cy}\right), 1.66-1.58\left(\mathrm{~m}, 4 \mathrm{H}, \mathrm{CH}_{2}\right.$ of $\left.\mathrm{Cy}\right), 1.55-1.49\left(\mathrm{~m}, 4 \mathrm{H}, \mathrm{CH}_{2}\right.$ of Cy), $1.45-1.40\left(\mathrm{~m}, 4 \mathrm{H}, \mathrm{CH}_{2}\right.$ of $\left.\mathrm{Cy}\right), 1.28\left(\mathrm{~d}, J=7.5 \mathrm{~Hz}, 3 \mathrm{H}, \mathrm{CH}_{3}\right.$ of $\left.i \mathrm{Pr}\right), 1.12(\mathrm{~d}, J=2.9$ $\mathrm{Hz}, 3 \mathrm{H}, \mathrm{CH}_{3}$ of $\left.i \mathrm{Pr}\right), 1.04\left(\mathrm{~d}, J=6.9 \mathrm{~Hz}, 3 \mathrm{H}, \mathrm{CH}_{3}\right.$ of $\left.i \operatorname{Pr}\right), 0.88\left(\mathrm{~d}, J=6.3 \mathrm{~Hz}, 3 \mathrm{H}, \mathrm{CH}_{3}\right.$ of $\left.i \operatorname{Pr}\right)$, $-36.99(\mathrm{t}, J=13.5 \mathrm{~Hz}, 1 \mathrm{H}, \mathrm{IrH}){ }^{31} \mathrm{P}$ NMR $\left(162 \mathrm{MHz}, \mathrm{C}_{6} \mathrm{D}_{6}\right) \delta 171.6(\mathrm{dd}, J=367.2,12.3 \mathrm{~Hz})$, $109.1(\mathrm{dd}, J=366.9,11.5 \mathrm{~Hz}) .{ }^{13} \mathrm{C} \mathrm{NMR}\left(101 \mathrm{MHz}, \mathrm{C}_{6} \mathrm{D}_{6}\right) \delta 165.5\left(\mathrm{t}, J=6.3 \mathrm{~Hz}, \mathrm{C}_{\mathrm{Ar}}\right), 158.5$ $\left(\mathrm{dd}, J=19.4,5.3 \mathrm{~Hz}, \mathrm{C}_{\mathrm{Ar}}\right), 124.8\left(\mathrm{~S}, \mathrm{C}_{\mathrm{Ar}}\right), 111.4\left(\mathrm{~s}, \mathrm{C}_{\mathrm{Ar}}\right), 103.6\left(\mathrm{~d}, J=11.4 \mathrm{~Hz}, \mathrm{C}_{\mathrm{Ar}}\right), 102.6(\mathrm{~d}$, $J=11.2 \mathrm{~Hz}, \mathrm{C}_{\mathrm{Ar}}$ ), 40.3 (dd, $\left.J=23.6,3.5 \mathrm{~Hz}, \mathrm{NMe}\right), 35.0$ (dd, $J=29.3,2.9 \mathrm{~Hz}, \mathrm{CH}$ of Cy), 30.9 (dd, $J=24.9,5.2 \mathrm{~Hz}, \mathrm{CH}$ of Cy), $29.1(\mathrm{dd}, J=28.8,5.1 \mathrm{~Hz}, \mathrm{CH}$ of $i \mathrm{Pr}), 28.5-28.3\left(\mathrm{~m}, \mathrm{CH}_{2}\right.$ of Cy), 28.0 (s, $\mathrm{CH}_{2}$ of Cy), 27.9 (d, $J=3.2 \mathrm{~Hz}, \mathrm{CH}_{2}$ of Cy), $27.2\left(\mathrm{~d}, J=9.0 \mathrm{~Hz}, \mathrm{CH}_{2}\right.$ of Cy), 26.8 
(d, $J=13.6 \mathrm{~Hz}, \mathrm{CH}_{2}$ of Cy), $26.5\left(\mathrm{~d}, J=3.7 \mathrm{~Hz}, \mathrm{CH}_{2}\right.$ of $\mathrm{Cy}$ ), $26.4\left(\mathrm{~s}, \mathrm{CH}_{2}\right.$ of $\left.\mathrm{Cy}\right), 26.1$ (, $\mathrm{CH}_{2}$ of Cy), 25.9 (s, $\mathrm{CH}_{2}$ of $\mathrm{Cy}$ ), 17.3 ( $\mathrm{s}, \mathrm{CH}_{3}$ of $\left.i \mathrm{Pr}\right), 17.0-16.7$ (m, $\mathrm{CH}_{3}$ of $\left.i \mathrm{Pr}\right), 16.5$ (t, $J=2.2$ $\mathrm{Hz}, \mathrm{CH}_{3}$ of $i \mathrm{Pr}$ ). Anal. Calcd for $\mathrm{C}_{25} \mathrm{H}_{43} \mathrm{ClIrNOP}_{2}$ : C, 45.27; H, 6.53; N, 2.11; Found: C, 45.76; $\mathrm{H}, 6.82 ; \mathrm{N}, 1.71$.

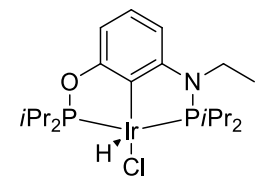

$4 \mathrm{e}-\mathrm{HCl}$

4d-HCl. A rubber septum-capped Schlenk flask was charged with $6 \mathrm{e}(1.08 \mathrm{mmol}, 400.0 \mathrm{mg})$ and $\left[\operatorname{Ir}(\mathrm{COD}) \mathrm{Cl}_{2}(0.52 \mathrm{mmol}, 350.0 \mathrm{mg})\right.$. Toluene $(15 \mathrm{~mL})$ was added via syringe, and the solution was stirred in an oil bath at $150{ }^{\circ} \mathrm{C}$ for $2 \mathrm{~h}$. The reaction mixture was then cooled to room temperature and volatiles were then removed under high vacuum. The residue was washed with pentane $(30 \mathrm{~mL} \times 3)$ and filtered through celite, and solvent was removed in vacuo, resulting in formation of deep purple solids. The residue was purified by column chromatography on neutral alumina (eluent: hexane/THF $=90 / 10$ ), furnishing $4 \mathbf{e}-\mathrm{HCl}$ as deep wine-red solid (0.62 mmol, $371.0 \mathrm{mg}, 61 \%$ yield). ${ }^{1} \mathrm{H} \mathrm{NMR}\left(400 \mathrm{MHz}, \mathrm{C}_{6} \mathrm{D}_{6}\right) \delta 6.94$ (t, $J=8.0$ $\mathrm{Hz}, 1 \mathrm{H}, \mathrm{ArH}), 6.75(\mathrm{~d}, J=7.9 \mathrm{~Hz}, 1 \mathrm{H}, \mathrm{ArH}), 6.05(\mathrm{~d}, J=7.9 \mathrm{~Hz}, 1 \mathrm{H}, \mathrm{ArH}), 3.10-2.98(\mathrm{~m}, 1 \mathrm{H}$, $\mathrm{NCH}_{2}$ ), $2.96-2.78$ (m, 2H, CH of $\left.i \mathrm{Pr}\right), 2.73-2.62(\mathrm{~m}, 1 \mathrm{H}, \mathrm{CH}$ of $i \mathrm{Pr}), 2.36-2.27(\mathrm{~m}, 1 \mathrm{H}, \mathrm{CH}$ of $i \mathrm{Pr}$ ), 2.24 (dd, $\left.J=13.5,6.8 \mathrm{~Hz}, 1 \mathrm{H}, \mathrm{NCH}_{2}\right), 1.30\left(\mathrm{dd}, J=7.0,4.3 \mathrm{~Hz}, 3 \mathrm{H}, \mathrm{CH}_{3}\right.$ of $\left.\mathrm{NCH}_{2} \mathrm{CH}_{3}\right)$, $1.27-1.20\left(\mathrm{~m}, 6 \mathrm{H}, \mathrm{CH}_{3}\right.$ of $\left.i \mathrm{Pr}\right), 1.17-1.08\left(\mathrm{~m}, 6 \mathrm{H}, \mathrm{CH}_{3}\right.$ of $\left.i \mathrm{Pr}\right), 1.06-0.95\left(\mathrm{~m}, 9 \mathrm{H}, \mathrm{CH}_{3}\right.$ of $i \operatorname{Pr}), 0.86\left(\mathrm{t}, J=16.1 \mathrm{~Hz}, 3 \mathrm{H}, \mathrm{CH}_{3}\right.$ of $\left.i \operatorname{Pr}\right),-37.20(\mathrm{t}, J=13.5 \mathrm{~Hz}, 1 \mathrm{H}, \mathrm{IrH}) .{ }^{31} \mathrm{P}$ NMR $(162 \mathrm{MHz}$, $\left.\mathrm{C}_{6} \mathrm{D}_{6}\right) \delta 172.2(\mathrm{dd}, \mathrm{J}=365.2,9.7 \mathrm{~Hz}), 118.7(\mathrm{dd}, \mathrm{J}=365.2,9.7 \mathrm{~Hz}) .{ }^{13} \mathrm{C} \mathrm{NMR}\left(101 \mathrm{MHz}, \mathrm{C}_{6} \mathrm{D}_{6}\right)$ $\delta 165.9\left(\mathrm{~s}, \mathrm{C}_{\mathrm{Ar}}\right), 157.1\left(\mathrm{dd}, J=19.6,5.3 \mathrm{~Hz}, \mathrm{C}_{\mathrm{Ar}}\right), 127.6\left(\mathrm{~s}, \mathrm{C}_{\mathrm{Ar}}\right), 124.7\left(\mathrm{~s}, \mathrm{C}_{\mathrm{Ar}}\right), 111.4\left(\mathrm{~s}, \mathrm{C}_{\mathrm{Ar}}\right)$, $103.4\left(\mathrm{t}, J=12.4 \mathrm{~Hz}, \mathrm{C}_{\mathrm{Ar}}\right), 40.6\left(\mathrm{~s}, \mathrm{NCH}_{2}\right), 31.0(\mathrm{dd}, J=24.9,5.2 \mathrm{~Hz}, \mathrm{CH}$ of $i \mathrm{Pr}), 30.30-29.76$ (m, CH of $i \operatorname{Pr}$ ), 28.9 (dd, $J=28.9,5.0 \mathrm{~Hz}, \mathrm{CH}$ of $i \operatorname{Pr}$ ), 26.1 (d, $J=28.7 \mathrm{~Hz}, \mathrm{CH}$ of $i \operatorname{Pr}$ ), 18.4 (s, $\left.\mathrm{NCH}_{2} \mathrm{CH}_{3}\right), 18.2\left(\mathrm{~d}, J=9.0 \mathrm{~Hz}, \mathrm{CH}_{3}\right.$ of $\left.i \mathrm{Pr}\right), 18.0\left(\mathrm{~s}, \mathrm{CH}_{3}\right.$ of $\left.i \operatorname{Pr}\right), 17.4\left(\mathrm{~d}, J=3.9 \mathrm{~Hz}, \mathrm{CH}_{3}\right.$ of $i \operatorname{Pr}$ ), 17.3 (s, $\mathrm{CH}_{3}$ of $i \mathrm{Pr}$ ), 16.8 (d, $J=3.7 \mathrm{~Hz}, \mathrm{CH}_{3}$ of $i \operatorname{Pr}$ ), 16.4 (s, $\mathrm{CH}_{3}$ of $i \operatorname{Pr}$ ). Anal. Calcd for $\mathrm{C}_{20} \mathrm{H}_{37} \mathrm{ClIrNOP}_{2}$ : C, 40.23; H, 6.25; N, 2.35; Found: C, 39.99; H, 6.62; N, 2.13.

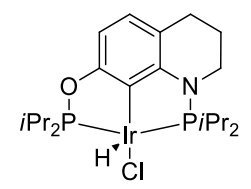

4g-HCl

4g-HCl. A rubber septum-capped Schlenk flask was charged with $\mathbf{6 g}(1.05 \mathrm{mmol}, 400.0 \mathrm{mg})$ and $[\operatorname{Ir}(\mathrm{COD}) \mathrm{Cl}]_{2}(0.51 \mathrm{mmol}, 340.0 \mathrm{mg})$. Toluene $(15 \mathrm{~mL})$ was added via syringe, and the solution was stirred in an oil bath at $150{ }^{\circ} \mathrm{C}$ for $2 \mathrm{~h}$. The reaction mixture was then cooled to room temperature and volatiles were then removed under high vacuum. The residue was washed with pentane $(30 \mathrm{~mL} \mathrm{x} 3)$ and filtered through celite, and solvent was removed in vacuo, resulting in formation of deep purple solids. The residue was purified by column chromatography on neutral alumina (eluent: hexane/THF $=90 / 10$ ), furnishing $\mathbf{4 g}$ - $\mathrm{HCl}$ as deep wine-red solid (0.65 mmol, $396.0 \mathrm{mg}, 65 \%$ yield). ${ }^{1} \mathrm{H}$ NMR $\left(400 \mathrm{MHz}, \mathrm{CDCl}_{3}\right) \delta 6.53(\mathrm{~d}, J=$ $7.9 \mathrm{~Hz}, 1 \mathrm{H}, \mathrm{ArH}), 6.33$ (d, $J=7.9 \mathrm{~Hz}, 1 \mathrm{H}, \mathrm{ArH}), 3.55-3.31$ (m, 2H, $\left.\mathrm{NCH}_{2}\right), 2.98$ (dd, $J=20.1$, $\left.13.1 \mathrm{~Hz}, 1 \mathrm{H}, \mathrm{ArCH}_{2}\right), 2.95-2.75(\mathrm{~m}, 2 \mathrm{H}, \mathrm{CH}$ of $i \mathrm{Pr}), 2.73-2.65(\mathrm{~m}, 2 \mathrm{H}, \mathrm{CH}$ of $i \mathrm{Pr}), 2.64-$ $2.58\left(\mathrm{~m}, 1 \mathrm{H}, \mathrm{ArCH}_{2}\right) 1.90\left(\mathrm{dd}, J=17.2,13.9 \mathrm{~Hz}, 2 \mathrm{H}, \mathrm{NCH}_{2} \mathrm{CH}_{2}\right), 1.39-1.21\left(\mathrm{~m}, 18 \mathrm{H}, \mathrm{CH}_{3}\right.$ of $i \operatorname{Pr}), 1.23-1.02\left(\mathrm{~m}, 6 \mathrm{H}, \mathrm{CH}_{3}\right.$ of $\left.i \operatorname{Pr}\right),-38.21(\mathrm{t}, J=13.7 \mathrm{~Hz}, 1 \mathrm{H}, \mathrm{IrH}) .{ }^{31} \mathrm{P}$ NMR $(162 \mathrm{MHz}$, $\left.\mathrm{CDCl}_{3}\right) \delta 170.7(\mathrm{dd}, J=360.2,11.8 \mathrm{~Hz}), 113.1(\mathrm{dd}, J=360.3,11.3 \mathrm{~Hz}) \cdot{ }^{13} \mathrm{C}$ NMR $(101 \mathrm{MHz}$, $\left.\mathrm{CDCl}_{3}\right) \delta 164.1\left(\mathrm{~s}, \mathrm{C}_{\mathrm{Ar}}\right), 153.6\left(\mathrm{~d}, J=18.2 \mathrm{~Hz}, \mathrm{C}_{\mathrm{Ar}}\right), 113.8\left(\mathrm{~d}, J=10.0 \mathrm{~Hz}, \mathrm{C}_{\mathrm{Ar}}\right), 111.2\left(\mathrm{~s}, \mathrm{C}_{\mathrm{Ar}}\right)$, $102.3\left(\mathrm{~d}, J=11.4 \mathrm{~Hz}, \mathrm{C}_{\mathrm{Ar}}\right), 45.5\left(\mathrm{~s}, \mathrm{NCH}_{2}\right), 31.1$ (dd, $J=25.0,5.1 \mathrm{~Hz}, \mathrm{CH}$ of $\left.i \mathrm{Pr}\right), 29.8$ (d, $J=$ $26.8 \mathrm{~Hz}, \mathrm{CH}$ of $i \mathrm{Pr}$ ), 29.0 (dd, $J=29.3,4.9 \mathrm{~Hz}, \mathrm{CH}$ of $i \mathrm{Pr}), 26.1\left(\mathrm{~s}, \mathrm{ArCH}_{2}\right), 25.4(\mathrm{~d}, J=30.1$ $\mathrm{Hz}, \mathrm{NCH}_{2} \mathrm{CH}_{2}$ ), 23.16 (s, $\mathrm{CH}_{3}$ of $\left.i \mathrm{Pr}\right), 18.9$ (s, $\mathrm{CH}_{3}$ of $\left.i \operatorname{Pr}\right), 18.5$ (s, $\mathrm{CH}_{3}$ of $\left.i \operatorname{Pr}\right), 18.0-17.8$ (m, $\mathrm{CH}_{3}$ of $i \mathrm{Pr}$ ), 17.7 (s, $\mathrm{CH}_{3}$ of $i \mathrm{Pr}$ ), $17.5\left(\mathrm{~s}, \mathrm{CH}_{3}\right.$ of $\left.i \mathrm{Pr}\right), 17.2$ (d, $J=3.7 \mathrm{~Hz}, \mathrm{CH}_{3}$ of $\left.i \mathrm{Pr}\right), 17.0$ (d, $J=8.1 \mathrm{~Hz}, \mathrm{CH}_{3}$ of $i \mathrm{Pr}$ ), 16.8 (s, $\mathrm{CH}_{3}$ of $i \mathrm{Pr}$ ). Anal. Calcd for $\mathrm{C}_{21} \mathrm{H}_{37} \mathrm{ClIrNOP}_{2}: \mathrm{C}, 41.41 ; \mathrm{H}$, 
6.12; N, 2.30; Found: C, 41.47; H, 6.11; N, 1.93.

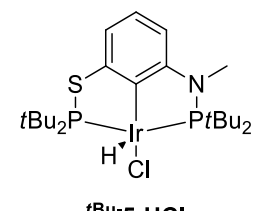

tBu-5-HCl

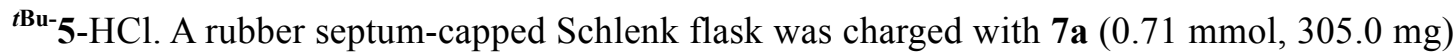
and $[\operatorname{Ir}(\mathrm{COD}) \mathrm{Cl}]_{2}(0.33 \mathrm{mmol}, 223.0 \mathrm{mg})$. Toluene $(10 \mathrm{~mL})$ was added via syringe, and the solution was stirred in an oil bath at $150{ }^{\circ} \mathrm{C}$ for $2 \mathrm{~h}$. The reaction mixture was then cooled to room temperature and volatiles were then removed under high vacuum. The residue was washed with pentane $(15 \mathrm{~mL} \times 3)$ and dried under vacuum to give ${ }^{{ }^{\mathbf{B} u} \mathbf{5}} \mathbf{5}-\mathrm{HCl}(0.49 \mathrm{mmol}, 319.0$ $\mathrm{mg}, 72 \%$ yield) as red solid. ${ }^{1} \mathrm{H}$ NMR $\left(400 \mathrm{MHz}, \mathrm{CDCl}_{3}\right): \delta 6.95(\mathrm{~d}, J=8.0 \mathrm{~Hz}, 1 \mathrm{H}, \mathrm{ArH}), 6.80$ $(\mathrm{t}, J=8.0 \mathrm{~Hz}, 1 \mathrm{H}, \mathrm{ArH}), 6.07(\mathrm{~d}, J=8.0 \mathrm{~Hz}, 1 \mathrm{H}, \mathrm{ArH}), 3.15(\mathrm{~s}, 3 \mathrm{H}, \mathrm{NMe}), 1.65-1.35(\mathrm{~m}, 36 \mathrm{H}$, $\mathrm{CH}_{3}$ of $\left.i \mathrm{Pr}\right),-42.4(\mathrm{t}, J=12.0 \mathrm{~Hz}, \mathrm{IrH}) ;{ }^{31} \mathrm{P}$ NMR $\left(162 \mathrm{MHz}, \mathrm{CDCl}_{3}\right): \delta 115.7(\mathrm{dd}, J=350.7 \mathrm{~Hz}$, $J=8.1 \mathrm{~Hz}), \delta 106.0(\mathrm{dd}, J=355.0 \mathrm{~Hz}, J=8.1 \mathrm{~Hz}) ;{ }^{13} \mathrm{C} \mathrm{NMR}\left(101 \mathrm{MHz}, \mathrm{CDCl}_{3}\right) \delta 160.9(\mathrm{dd}$, $\left.J=18.1,5.0 \mathrm{~Hz}, \mathrm{C}_{\mathrm{Ar}}\right), 153.4\left(\mathrm{dd}, J=10.7,6.7 \mathrm{~Hz}, \mathrm{C}_{\mathrm{Ar}}\right), 128.8\left(\mathrm{~d}, J=81.4 \mathrm{~Hz}, \mathrm{C}_{\mathrm{Ar}}\right), 124.1(\mathrm{~s}$, $\left.\mathrm{C}_{\mathrm{Ar}}\right), 114.0\left(\mathrm{~d}, J=10.6 \mathrm{~Hz}, \mathrm{C}_{\mathrm{Ar}}\right), 104.7\left(\mathrm{~d}, J=10.8 \mathrm{~Hz}, \mathrm{C}_{\mathrm{Ar}}\right), 45.8(\mathrm{dd}, J=20.0,3.8 \mathrm{~Hz}, \mathrm{NMe})$, $42.4(\mathrm{dd}, J=10.3,3.2 \mathrm{~Hz}, \mathrm{C}$ of $t \mathrm{Bu}), 40.5(\mathrm{dd}, J=20.2,3.7 \mathrm{~Hz}, \mathrm{C}$ of $t \mathrm{Bu}), 39.5(\mathrm{dd}, J=13.0$, $2.8 \mathrm{~Hz}, \mathrm{C}$ of $t \mathrm{Bu}), 38.5(\mathrm{dd}, J=4.3,2.3 \mathrm{~Hz}, \mathrm{C}$ of $t \mathrm{Bu}), 30.4\left(\mathrm{dd}, J=4.4,0.9 \mathrm{~Hz}, \mathrm{CH}_{3}\right.$ of $\left.t \mathrm{Bu}\right)$, $30.0\left(\mathrm{dd}, J=4.4,0.9 \mathrm{~Hz}, \mathrm{CH}_{3}\right.$ of $\left.t \mathrm{Bu}\right), 29.7\left(\mathrm{dd}, J=4.1,1.0 \mathrm{~Hz}, \mathrm{CH}_{3}\right.$ of $\left.t \mathrm{Bu}\right), 29.3(\mathrm{~d}, J=3.6$ $\mathrm{Hz}, \mathrm{CH}_{3}$ of $t \mathrm{Bu}$ ). Anal. Calcd for $\mathrm{C}_{23} \mathrm{H}_{43} \mathrm{ClIrNSP}_{2}$ : C, 42.16; H, 6.61; N, 2.14; Found: C, 41.85; $\mathrm{H}, 6.43 ; \mathrm{N}, 1.73$.

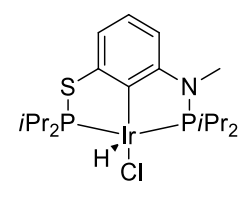

$$
\text { iPr-5-HCI }
$$

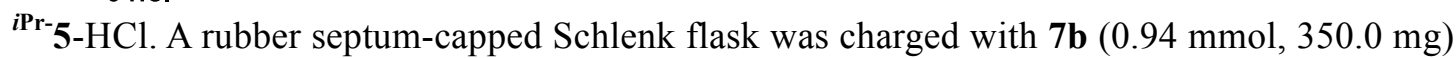
and $\left[\operatorname{Ir}(\mathrm{COD}) \mathrm{Cl}_{2}(0.45 \mathrm{mmol}, 300.0 \mathrm{mg})\right.$. Toluene $(10 \mathrm{~mL})$ was added via syringe, and the solution was stirred in an oil bath at $150{ }^{\circ} \mathrm{C}$ for $2.5 \mathrm{~h}$. The reaction mixture was then cooled to room temperature and volatiles were then removed under high vacuum. The residue was washed with pentane $(15 \mathrm{~mL} \times 3)$ and dried under vacuum to give ${ }^{i \mathbf{P r}-5}-\mathrm{HCl}(0.45 \mathrm{mmol}, 270.0$ $\mathrm{mg}$, yield $50 \%)$ as lavender solid. ${ }^{1} \mathrm{H}$ NMR $\left(400 \mathrm{MHz}, \mathrm{C}_{6} \mathrm{D}_{6}\right) \delta 7.16(\mathrm{~s}, 1 \mathrm{H}, \mathrm{ArH}), 6.88(\mathrm{~s}, 1 \mathrm{H}$, $\mathrm{ArH}), 5.96(\mathrm{~s}, 1 \mathrm{H}, \mathrm{ArH}), 2.40$ (s, 3H, NMe), 0.85-1.55 (m, 24H, CH3), $-36.45(\mathrm{~s}, 1 \mathrm{H}, \mathrm{IrH}) .{ }^{31} \mathrm{P}$ NMR $\left(162 \mathrm{MHz}, \mathrm{C}_{6} \mathrm{D}_{6}\right) \delta 110.8(\mathrm{~d}, J=367.2 \mathrm{~Hz}), 99.4(\mathrm{~d}, J=365.3 \mathrm{~Hz}) .{ }^{13} \mathrm{C}$ NMR $(101 \mathrm{MHz}$, $\left.\mathrm{C}_{6} \mathrm{D}_{6}\right) \delta 158.7\left(\mathrm{~d}, J=13.8 \mathrm{~Hz}, \mathrm{C}_{\mathrm{Ar}}\right), 151.2\left(\mathrm{~s}, \mathrm{C}_{\mathrm{Ar}}\right), 126.6\left(\mathrm{~s}, \mathrm{C}_{\mathrm{Ar}}\right), 123.9\left(\mathrm{~s}, \mathrm{C}_{\mathrm{Ar}}\right), 114.8(\mathrm{~d}, J=$ $\left.11.2 \mathrm{~Hz}, \mathrm{C}_{\mathrm{Ar}}\right), 104.8\left(\mathrm{~d}, J=11.1 \mathrm{~Hz}, \mathrm{C}_{\mathrm{Ar}}\right), 33.4(\mathrm{~s}, \mathrm{NMe}), 29.1(\mathrm{~d}, J=25.5 \mathrm{~Hz}, \mathrm{CH}$ of $i \operatorname{Pr}), 28.2$ $(\mathrm{d}, J=22.8 \mathrm{~Hz}, \mathrm{CH}$ of $i \operatorname{Pr}), 27.2(\mathrm{~d}, J=19.0 \mathrm{~Hz}, \mathrm{CH}$ of $i \operatorname{Pr}), 25.0(\mathrm{~d}, J=32.1 \mathrm{~Hz}, \mathrm{CH}$ of $i \operatorname{Pr})$, 22.7 ( s, $\mathrm{CH}_{3}$ of $i \mathrm{Pr}$ ), 19.1 (d, $J=2.4 \mathrm{~Hz}, \mathrm{CH}_{3}$ of $i \mathrm{Pr}$ ), 18.3 (dd, $J=8.4,4.7 \mathrm{~Hz}, \mathrm{CH}_{3}$ of $i \operatorname{Pr}$ ), 17.9 (s, $\mathrm{CH}_{3}$ of $\left.i \mathrm{Pr}\right), 17.83-17.69\left(\mathrm{~m}, \mathrm{CH}_{3}\right.$ of $\left.i \mathrm{Pr}\right), 17.3\left(\mathrm{~s}, \mathrm{CH}_{3}\right.$ of $\left.i \operatorname{Pr}\right)$. Anal. Calcd for $\mathrm{C}_{19} \mathrm{H}_{35} \mathrm{ClIINSP}_{2}$ : C, 38.09; H, 5.89; N, 2.34; Found: C, 38.37; H, 5.94; N, 2.06.

2. Synthesis of (pincer)Ir-CO

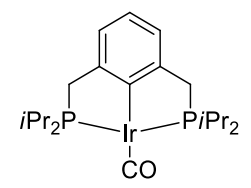

iPr-1-CO

${ }^{i{ }^{i} r}$ 1-CO. ${ }^{i \mathbf{P r}}{ }^{1} \mathbf{1}-\mathrm{HCl}(0.21 \mathrm{mmol}, 120.0 \mathrm{mg})$ and toluene $(8 \mathrm{~mL})$ were added to a $50 \mathrm{~mL}$ Schlenk flask equipped with a magnetic stir bar. tert-Butylene $(0.63 \mathrm{mmol}, 53.0 \mathrm{mg})$ was added via a syringe, followed by the addition of $\mathrm{NaO} t \mathrm{Bu}(0.32 \mathrm{mmol}, 30.7 \mathrm{mg})$. The solution was stirred 
for $2 \mathrm{~h}$ at RT, then the flask was brought out of glovebox, degassed and charged with $1 \mathrm{~atm}$ of $\mathrm{CO}$. The solution was stirred for $5 \mathrm{~h}$ at RT, producing a yellow solution. The solvent was removed in vacuo, and the residue was washed with pentane $(10 \mathrm{~mL} \times 3)$ and filtered through celite. The solvent was removed in vacuo to for yellow solids, which were then dissolved in a minimum amount of diethyl ether. The solution was placed in a $-32{ }^{\circ} \mathrm{C}$ freezer overnight, resulting in the precipitation of yellow solids. Decanting the supernatant and drying the residue in vacuo provided $105.0 \mathrm{mg}{ }^{i{ }^{2}-1}$-CO as yellow solids $(0.19 \mathrm{mmol}, 90 \%$ yield $)$. Single crystals suitable for X-ray analysis were obtained from the diethyl ether solution at RT. ${ }^{1} \mathrm{H}$ NMR (400 $\left.\mathrm{MHz}, \mathrm{C}_{6} \mathrm{D}_{6}\right) \delta 7.31(\mathrm{~d}, J=7.5 \mathrm{~Hz}, 2 \mathrm{H}, \mathrm{ArH}), 7.20(\mathrm{~d}, J=7.5 \mathrm{~Hz}, 1 \mathrm{H}, \mathrm{ArH}), 3.25(\mathrm{t}, J=4.1 \mathrm{~Hz}$, $4 \mathrm{H}, \mathrm{ArCH}_{2}$ ), 2.05 (ddd, $J=10.1,6.7,3.0 \mathrm{~Hz}, 4 \mathrm{H}, \mathrm{CH}$ of $i \mathrm{Pr}$ ) 1.23 (q, $J=7.6 \mathrm{~Hz}, 12 \mathrm{H}, \mathrm{CH}_{3}$ of $i \operatorname{Pr}), 0.97$ (q, $J=7.1 \mathrm{~Hz}, 12 \mathrm{H}, \mathrm{CH}_{3}$ of $\left.i \mathrm{Pr}\right) .{ }^{31} \mathrm{P} \mathrm{NMR}\left(162 \mathrm{MHz}, \mathrm{C}_{6} \mathrm{D}_{6}\right) \delta 67.7(\mathrm{~s}) .{ }^{13} \mathrm{C} \mathrm{NMR}(101$ $\left.\mathrm{MHz}, \mathrm{C}_{6} \mathrm{D}_{6}\right) \delta 196.4(\mathrm{~s}, \mathrm{CO}), 181.4\left(\mathrm{~s}, \mathrm{C}_{\mathrm{Ar}}\right), 154.4\left(\mathrm{~s}, \mathrm{C}_{\mathrm{Ar}}\right), 125.7\left(\mathrm{~s}, \mathrm{C}_{\mathrm{Ar}}\right), 120.4\left(\mathrm{~s}, \mathrm{C}_{\mathrm{Ar}}\right), 38.3$ ( $\left.\mathrm{s}, \mathrm{ArCH}_{2}\right), 26.4(\mathrm{t}, J=14.5 \mathrm{~Hz}, \mathrm{CH}$ of $i \mathrm{Pr}), 19.30\left(\mathrm{t}, J=2.3 \mathrm{~Hz}, \mathrm{CH}_{3}\right.$ of $\left.i \mathrm{Pr}\right), 18.5\left(\mathrm{~s}, \mathrm{CH}_{3}\right.$ of $i \mathrm{Pr}$ ). Anal. Calcd for $\mathrm{C}_{21} \mathrm{H}_{35} \mathrm{IrOP}{ }_{2}$ : C, 45.23; H, 6.33; Found: C, 45.40; H, 6.58. IR (solid, $v_{\mathrm{CO}}$ ): $1921.71 \mathrm{~cm}^{-1}$.

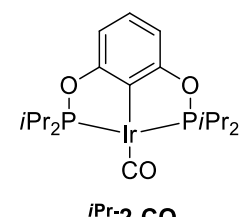

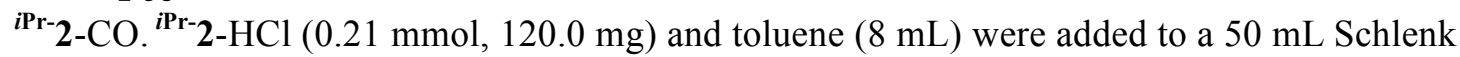
flask equipped with a magnetic stir bar. tert-Butylene $(0.63 \mathrm{mmol}, 53.0 \mathrm{mg})$ was added via a syringe, followed by the addition of $\mathrm{NaO} t \mathrm{Bu}(0.32 \mathrm{mmol}, 30.7 \mathrm{mg})$. The solution was stirred for $2 \mathrm{~h}$ at RT, then the flask was brought out of glovebox, degassed and charged with $1 \mathrm{~atm}$ of $\mathrm{CO}$. The solution was stirred for $5 \mathrm{~h}$ at RT, producing a yellow solution. The solvent was removed in vacuo, and the residue was washed with pentane $(10 \mathrm{~mL} \times 3)$ and filtered through celite. The solvent was removed in vacuo to for yellow solids, which were then dissolved in a minimum amount of diethyl ether. The solution was placed in a $-32{ }^{\circ} \mathrm{C}$ freezer overnight, resulting in the precipitation of yellow solids. Decanting the supernatant and drying the residue in vacuo provided $109.0 \mathrm{mg}{ }^{i P r}-2-\mathrm{CO}$ as yellow solids $(0.20 \mathrm{mmol}, 93 \%$ yield $)$. Single crystals suitable for X-ray analysis were obtained from the diethyl ether solution at RT. ${ }^{1} \mathrm{H}$ NMR (400 $\left.\mathrm{MHz}, \mathrm{C}_{6} \mathrm{D}_{6}\right) \delta 6.97-6.80(\mathrm{~m}, 3 \mathrm{H}, \mathrm{ArH}), 2.25-2.03(\mathrm{~m}, 4 \mathrm{H}, \mathrm{CH}$ of $i \mathrm{Pr}), 1.22-1.02(\mathrm{~m}, 24 \mathrm{H}$, $\mathrm{CH}_{3}$ of $\left.i \mathrm{Pr}\right) .{ }^{31} \mathrm{P}$ NMR $\left(162 \mathrm{MHz}, \mathrm{C}_{6} \mathrm{D}_{6}\right) \delta 190.0(\mathrm{~s}) .{ }^{13} \mathrm{C}$ NMR $\left(101 \mathrm{MHz}, \mathrm{C}_{6} \mathrm{D}_{6}\right) \delta 198.2(\mathrm{t}, J=$ $4.7 \mathrm{~Hz}, \mathrm{CO}), 169.0\left(\mathrm{t}, J=8.7 \mathrm{~Hz}, \mathrm{C}_{\mathrm{Ar}}\right), 148.5\left(\mathrm{t}, J=8.7 \mathrm{~Hz}, \mathrm{C}_{\mathrm{Ar}}\right), 129.5\left(\mathrm{~s}, \mathrm{C}_{\mathrm{Ar}}\right), 104.1(\mathrm{t}, J=$ $\left.6.1 \mathrm{~Hz}, \mathrm{C}_{\mathrm{Ar}}\right), 31.4(\mathrm{t}, J=16.2 \mathrm{~Hz}, \mathrm{CH}$ of $i \mathrm{Pr}), 18.2\left(\mathrm{t}, J=3.6 \mathrm{~Hz}, \mathrm{CH}_{3}\right.$ of $\left.i \operatorname{Pr}\right), 17.3\left(\mathrm{~s}, \mathrm{CH}_{3}\right.$ of $i \mathrm{Pr}$ ). Anal. Calcd for $\mathrm{C}_{19} \mathrm{H}_{32} \mathrm{IrO}_{3} \mathrm{P}_{2}$ : C, 40.56; H, 5.73; Found: C, 41.05; H,5.82. IR (solid, $v_{\mathrm{CO}}$ ): $1937.26 \mathrm{~cm}^{-1}$.

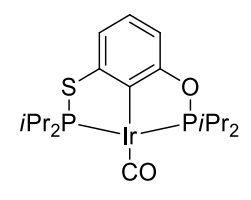

iPr-3-CO

${ }^{i P r}$-3-CO. ${ }^{{ }^{\mathbf{P r} r}-3}-\mathrm{HCl}(0.21 \mathrm{mmol}, 120.0 \mathrm{mg})$ and toluene $(8 \mathrm{~mL})$ were added to a $50 \mathrm{~mL}$ Schlenk flask equipped with a magnetic stir bar. tert-Butylene $(0.63 \mathrm{mmol}, 53.0 \mathrm{mg})$ was added via a syringe, followed by the addition of $\mathrm{NaO} t \mathrm{Bu}(0.32 \mathrm{mmol}, 30.7 \mathrm{mg})$. The solution was stirred for $2 \mathrm{~h}$ at RT, then the flask was brought out of glovebox, degassed and charged with $1 \mathrm{~atm}$ of $\mathrm{CO}$. The solution was stirred for $5 \mathrm{~h}$ at RT, producing a yellow solution. The solvent was removed in vacuo, and the residue was washed with pentane $(10 \mathrm{~mL} \times 3)$ and filtered through celite. The solvent was removed in vacuo to for yellow solids, which were then dissolved in a minimum amount of diethyl ether. The solution was placed in a $-32{ }^{\circ} \mathrm{C}$ freezer overnight, resulting in the precipitation of yellow solids. Decanting the supernatant and drying the residue in vacuo provided $105.0 \mathrm{mg}{ }^{i P r}-3-\mathrm{CO}$ as yellow solids $(0.18 \mathrm{mmol}, 91 \%$ yield $)$. Single crystals 
suitable for X-ray analysis were obtained from the diethyl ether solution at RT. ${ }^{1} \mathrm{H}$ NMR (400 $\left.\mathrm{MHz}, \mathrm{C}_{6} \mathrm{D}_{6}\right) \delta 7.19(\mathrm{dd}, J=7.6,1.0 \mathrm{~Hz}, 1 \mathrm{H}, \mathrm{ArH}), 6.81(\mathrm{dd}, J=7.9,1.1 \mathrm{~Hz}, 1 \mathrm{H}, \mathrm{ArH}), 6.74$ (t, $J=7.8 \mathrm{~Hz}, 1 \mathrm{H}, \mathrm{ArH}), 2.25-2.16(\mathrm{~m}, 2 \mathrm{H}, \mathrm{CH}$ of $i \mathrm{Pr}), 2.12-2.02(\mathrm{~m}, 2 \mathrm{H}, \mathrm{CH}$ of $i \operatorname{Pr}), 1.21$ (d, $J=7.0 \mathrm{~Hz}, 3 \mathrm{H}, \mathrm{CH}_{3}$ of $\left.i \mathrm{Pr}\right), 1.17\left(\mathrm{~d}, J=7.0 \mathrm{~Hz}, 3 \mathrm{H}, \mathrm{CH}_{3}\right.$ of $\left.i \mathrm{Pr}\right), 1.12\left(\mathrm{~d}, J=6.8 \mathrm{~Hz}, 3 \mathrm{H}, \mathrm{CH}_{3}\right.$ of $i \operatorname{Pr}), 1.09$ (d, $J=1.7 \mathrm{~Hz}, 3 \mathrm{H}, \mathrm{CH}_{3}$ of $\left.i \operatorname{Pr}\right), 1.09-0.99\left(\mathrm{~m}, 12 \mathrm{H}, \mathrm{CH}_{3}\right.$ of $\left.i \operatorname{Pr}\right) .{ }^{31} \mathrm{P}$ NMR $(162$ $\left.\mathrm{MHz}, \mathrm{C}_{6} \mathrm{D}_{6}\right) \delta 180.8(\mathrm{~d}, J=314.1 \mathrm{~Hz}), 107.6(\mathrm{~d}, J=314.1 \mathrm{~Hz}) .{ }^{13} \mathrm{C} \mathrm{NMR}\left(101 \mathrm{MHz}, \mathrm{C}_{6} \mathrm{D}_{6}\right) \delta$ $194.8(\mathrm{t}, J=6.4 \mathrm{~Hz}, \mathrm{CO}), 168.7\left(\mathrm{t}, J=8.7 \mathrm{~Hz}, \mathrm{C}_{\mathrm{Ar}}\right), 167.4\left(\mathrm{t}, J=7.5 \mathrm{~Hz}, \mathrm{C}_{\mathrm{Ar}}\right), 157.8$ (dd, $J=$ 14.0, 9.4 Hz, $\left.\mathrm{C}_{\mathrm{Ar}}\right), 128.2\left(\mathrm{~s}, \mathrm{C}_{\mathrm{Ar}}\right), 115.1\left(\mathrm{~d}, J=12.3 \mathrm{~Hz}, \mathrm{C}_{\mathrm{Ar}}\right), 106.8\left(\mathrm{~d}, J=13.5 \mathrm{~Hz}, \mathrm{C}_{\mathrm{Ar}}\right), 31.6$ (s, CH of $i \operatorname{Pr}$ ), $31.2(\mathrm{dd}, J=31.3,3.1 \mathrm{~Hz}, \mathrm{CH}$ of $i \operatorname{Pr}), 30.1$ (d, $J=23.1 \mathrm{~Hz}, \mathrm{CH}$ of $i \mathrm{Pr}$ ), 22.7 (s, $\mathrm{CH}_{3}$ of $\left.i \operatorname{Pr}\right), 19.0\left(\mathrm{~d}, J=5.6 \mathrm{~Hz}, \mathrm{CH}_{3}\right.$ of $\left.i \operatorname{Pr}\right), 18.2\left(\mathrm{~d}, J=1.5 \mathrm{~Hz}, \mathrm{CH}_{3}\right.$ of $\left.i \operatorname{Pr}\right), 18.0(\mathrm{~d}, J=6.3$ $\mathrm{Hz}, \mathrm{CH}_{3}$ of $i \mathrm{Pr}$ ), 17.1 (s, $\mathrm{CH}_{3}$ of $i \mathrm{Pr}$ ), 14.00 (s, $\mathrm{CH}_{3}$ of $i \mathrm{Pr}$ ). Anal. Calcd for $\mathrm{C}_{19} \mathrm{H}_{32} \mathrm{IrO}_{2} \mathrm{P}_{2} \mathrm{~S}: \mathrm{C}$, 39.43; H, 5.57; Found: C, 39.99; H,5.85. IR (solid $v_{\mathrm{CO}}$ ): $1938.98 \mathrm{~cm}^{-1}$.

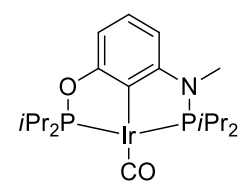

4b-CO

4b-CO. $4 \mathbf{b}-\mathrm{HCl}(0.21 \mathrm{mmol}, 120.0 \mathrm{mg})$ and toluene $(8 \mathrm{~mL})$ were added to a $50 \mathrm{~mL}$ Schlenk flask equipped with a magnetic stir bar. tert-Butylene $(0.63 \mathrm{mmol}, 53.0 \mathrm{mg})$ was added via a syringe, followed by the addition of $\mathrm{NaO} t \mathrm{Bu}(0.32 \mathrm{mmol}, 30.7 \mathrm{mg})$. The solution was stirred for $2 \mathrm{~h}$ at RT, then the flask was brought out of glovebox, degassed and charged with $1 \mathrm{~atm}$ of $\mathrm{CO}$. The solution was stirred for $5 \mathrm{~h}$ at RT, producing a yellow solution. The solvent was removed in vacuo, and the residue was washed with pentane $(10 \mathrm{~mL} \times 3)$ and filtered through celite. The solvent was removed in vacuo to for yellow solids, which were then dissolved in a minimum amount of diethyl ether. The solution was placed in a $-32{ }^{\circ} \mathrm{C}$ freezer overnight, resulting in the precipitation of yellow solids. Decanting the supernatant and drying the residue in vacuo provided $107.0 \mathrm{mg}{ }^{i \mathbf{P r}-} \mathbf{4 b}-\mathrm{CO}$ as yellow solids $(0.19 \mathrm{mmol}, 91 \%$ yield $)$. Single crystals suitable for X-ray analysis were obtained from the diethyl ether solution at RT. ${ }^{1} \mathrm{H}$ NMR (400 $\left.\mathrm{MHz}, \mathrm{C}_{6} \mathrm{D}_{6}\right) \delta 7.08-7.01(\mathrm{~m}, 1 \mathrm{H}, \mathrm{ArH}), 6.90(\mathrm{~d}, J=7.9 \mathrm{~Hz}, 1 \mathrm{H}, \mathrm{ArH}), 6.12(\mathrm{~d}, J=7.8 \mathrm{~Hz}, 1 \mathrm{H}$, $\mathrm{ArH}), 2.46$ (d, $J=5.4 \mathrm{~Hz}, 3 \mathrm{H}, \mathrm{NMe}), 2.24-2.15(\mathrm{~m}, 2 \mathrm{H}, \mathrm{CH}$ of $i \mathrm{Pr}), 2.13-2.00(\mathrm{~m}, 2 \mathrm{H}, \mathrm{CH}$ of $i \operatorname{Pr}), 1.24$ (d, $J=6.9 \mathrm{~Hz}, 3 \mathrm{H}, \mathrm{CH}_{3}$ of $\left.i \operatorname{Pr}\right), 1.20$ (d, $J=2.4 \mathrm{~Hz}, 3 \mathrm{H}, \mathrm{CH}_{3}$ of $\left.i \operatorname{Pr}\right), 1.18$ (d, $J=2.6$ $\mathrm{Hz}, 3 \mathrm{H}, \mathrm{CH}_{3}$ of $\left.i \mathrm{Pr}\right), 1.17-1.11\left(\mathrm{~m}, 9 \mathrm{H}, \mathrm{CH}_{3}\right.$ of $\left.i \mathrm{Pr}\right), 0.90\left(\mathrm{dd}, J=14.9,7.0 \mathrm{~Hz}, 6 \mathrm{H}, \mathrm{CH}_{3}\right.$ of $i \mathrm{Pr}) .{ }^{31} \mathrm{P}$ NMR $\left(162 \mathrm{MHz}, \mathrm{C}_{6} \mathrm{D}_{6}\right) \delta 188.1(\mathrm{~d}, J=306.3 \mathrm{~Hz}, 1 \mathrm{P}), 134.2(\mathrm{~d}, J=306.3 \mathrm{~Hz}, 1 \mathrm{P}) .{ }^{13} \mathrm{C}$ NMR (101 MHz, $\left.\mathrm{C}_{6} \mathrm{D}_{6}\right) \delta 198.9-198.2(\mathrm{~m}, \mathrm{CO}), 169.1\left(\mathrm{dd}, J=10.3,7.0 \mathrm{~Hz}, \mathrm{C}_{\mathrm{Ar}}\right), 162.0(\mathrm{dd}$, $\left.J=23.8,5.9 \mathrm{~Hz}, \mathrm{C}_{\mathrm{Ar}}\right), 146.5\left(\mathrm{t}, J=8.1 \mathrm{~Hz}, \mathrm{C}_{\mathrm{Ar}}\right), 128.9\left(\mathrm{~s}, \mathrm{C}_{\mathrm{Ar}}\right), 102.5\left(\mathrm{~d}, J=13.2 \mathrm{~Hz}, \mathrm{C}_{\mathrm{Ar}}\right)$, $101.4\left(\mathrm{~d}, J=12.2 \mathrm{~Hz}, \mathrm{C}_{\mathrm{Ar}}\right), 32.1(\mathrm{dd}, J=3.8,1.4 \mathrm{~Hz}, \mathrm{NMe}), 31.5(\mathrm{~d}, J=3.1 \mathrm{~Hz}, \mathrm{CH}$ of $i \operatorname{Pr})$, 31.2 (d, $J=3.1 \mathrm{~Hz}, \mathrm{CH}$ of $i \operatorname{Pr}), 29.7(\mathrm{~d}, J=1.7 \mathrm{~Hz}, \mathrm{CH}$ of $i \operatorname{Pr}), 29.4(\mathrm{~d}, J=1.7 \mathrm{~Hz}, \mathrm{CH}$ of $i \operatorname{Pr}$ ), 19.8 (d, $J=8.2 \mathrm{~Hz}, \mathrm{CH}_{3}$ of $i \mathrm{Pr}$ ), $18.6\left(\mathrm{~s}, \mathrm{CH}_{3}\right.$ of $\left.i \operatorname{Pr}\right), 18.2$ (d, $J=6.9 \mathrm{~Hz}, \mathrm{CH}_{3}$ of $i \operatorname{Pr}$ ), 17.3 (s, $\mathrm{CH}_{3}$ of $i \mathrm{Pr}$ ). Anal. Calcd for $\mathrm{C}_{20} \mathrm{H}_{35} \mathrm{IrNO}_{2} \mathrm{P}_{2}: \mathrm{C}, 41.73 ; \mathrm{H}, 6.13 ; \mathrm{N}, 2.43$; Found: $\mathrm{C}, 41.75 ; \mathrm{H}$, 5.90; N, 2.44. IR (solid $v_{\mathrm{CO}}$ ): $1925.33 \mathrm{~cm}^{-1}$.

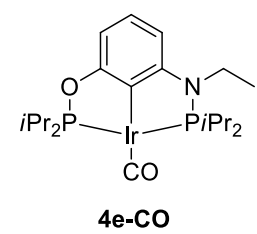

4e-CO. $4 \mathbf{e}-\mathrm{HCl}(0.20 \mathrm{mmol}, 120.0 \mathrm{mg})$ and toluene $(8 \mathrm{~mL})$ were added to a $50 \mathrm{~mL}$ Schlenk flask equipped with a magnetic stir bar. tert-Butylene $(0.60 \mathrm{mmol}, 50.0 \mathrm{mg})$ was added via a syringe, followed by the addition of $\mathrm{NaO} t \mathrm{Bu}(0.30 \mathrm{mmol}, 29.0 \mathrm{mg})$. The solution was stirred for $2 \mathrm{~h}$ at RT, then the flask was brought out of glovebox, degassed and charged with $1 \mathrm{~atm}$ of $\mathrm{CO}$. The solution was stirred for $5 \mathrm{~h}$ at RT, producing a yellow solution. The solvent was removed in vacuo, and the residue was washed with pentane $(10 \mathrm{~mL} \times 3)$ and filtered through celite. The solvent was removed in vacuo to for yellow solids, which were then dissolved in a minimum amount of diethyl ether. The solution was placed in a $-32{ }^{\circ} \mathrm{C}$ freezer overnight, 
resulting in the precipitation of yellow solids. Decanting the supernatant and drying the residue in vacuo provided $112.0 \mathrm{mg}^{i \mathbf{P r}-} \mathbf{4 e - C O}$ as yellow solids $(0.19 \mathrm{mmol}, 95 \%$ yield $)$. Single crystals suitable for X-ray analysis were obtained from the diethyl ether solution at RT. ${ }^{1} \mathrm{H}$ NMR (400 $\left.\mathrm{MHz}, \mathrm{C}_{6} \mathrm{D}_{6}\right) \delta 7.01(\mathrm{t}, J=7.9 \mathrm{~Hz}, 1 \mathrm{H}, \mathrm{ArH}), 6.88(\mathrm{~d}, J=7.9 \mathrm{~Hz}, 1 \mathrm{H}, \mathrm{ArH}), 6.17(\mathrm{~d}, J=7.9 \mathrm{~Hz}$, $1 \mathrm{H}, \mathrm{ArH}), 2.99$ (p, $\left.J=6.9 \mathrm{~Hz}, 2 \mathrm{H}, \mathrm{NCH}_{2}\right), 2.25-2.14(\mathrm{~m}, 2 \mathrm{H}, \mathrm{CH}$ of $i \mathrm{Pr}), 2.15-2.02$ (m, $2 \mathrm{H}$, $\mathrm{CH}$ of $i \operatorname{Pr}), 1.26\left(\mathrm{~d}, J=6.9 \mathrm{~Hz}, 3 \mathrm{H}, \mathrm{CH}_{3}\right.$ of $\left.\mathrm{NCH}_{2} \mathrm{CH}_{3}\right), 1.22\left(\mathrm{~d}, J=6.9 \mathrm{~Hz}, 3 \mathrm{H}, \mathrm{CH}_{3}\right.$ of $\left.i \mathrm{Pr}\right)$, $1.19\left(\mathrm{~d}, J=7.2 \mathrm{~Hz}, 3 \mathrm{H}, \mathrm{CH}_{3}\right.$ of $\left.i \mathrm{Pr}\right), 1.14\left(\mathrm{q}, J=7.2 \mathrm{~Hz}, 9 \mathrm{H}, \mathrm{CH}_{3}\right.$ of $\left.i \operatorname{Pr}\right), 0.98$ (dd, $J=15.4$, $7.1 \mathrm{~Hz}, 9 \mathrm{H}, \mathrm{CH}_{3}$ of $\left.i \mathrm{Pr}\right){ }^{31} \mathrm{P}$ NMR $\left(162 \mathrm{MHz}, \mathrm{C}_{6} \mathrm{D}_{6}\right) \delta 188.1(\mathrm{~d}, J=305.7 \mathrm{~Hz}), 135.7(\mathrm{~d}, J=$ 305.7 Hz). ${ }^{13} \mathrm{C}$ NMR $\left(101 \mathrm{MHz}, \mathrm{C}_{6} \mathrm{D}_{6}\right) \delta 198.7(\mathrm{t}, J=5.1 \mathrm{~Hz}, \mathrm{CO}), 169.4(\mathrm{dd}, J=10.3,7.0 \mathrm{~Hz}$, $\left.\mathrm{C}_{\mathrm{Ar}}\right), 160.8\left(\mathrm{dd}, J=24.1,5.8 \mathrm{~Hz}, \mathrm{C}_{\mathrm{Ar}}\right), 146.8\left(\mathrm{t}, J=8.1 \mathrm{~Hz}, \mathrm{C}_{\mathrm{Ar}}\right), 128.8\left(\mathrm{~s}, \mathrm{C}_{\mathrm{Ar}}\right), 102.2(\mathrm{dd}, J=$ $\left.13.0,6.7 \mathrm{~Hz}, \mathrm{C}_{\mathrm{Ar}}\right), 40.4\left(\mathrm{~d}, J=3.1 \mathrm{~Hz}, \mathrm{NCH}_{2}\right), 31.4(\mathrm{dd}, J=30.0,3.0 \mathrm{~Hz}, \mathrm{CH}$ of $i \operatorname{Pr}), 29.7(\mathrm{dd}$, $J=28.9,1.5 \mathrm{~Hz}, \mathrm{CH}$ of $i \mathrm{Pr}), 19.9\left(\mathrm{~d}, J=7.9 \mathrm{~Hz}, \mathrm{CH}_{3}\right.$ of $\left.\mathrm{NCH}_{2} \mathrm{CH}_{3}\right), 19.0\left(\mathrm{~s}, \mathrm{CH}_{3}\right.$ of $\left.i \mathrm{Pr}\right), 18.3$ $\left(\mathrm{d}, J=7.0 \mathrm{~Hz}, \mathrm{CH}_{3}\right.$ of $\left.i \operatorname{Pr}\right), 17.4\left(\mathrm{~s}, \mathrm{CH}_{3}\right.$ of $\left.i \operatorname{Pr}\right), 13.4\left(\mathrm{~s}, \mathrm{CH}_{3}\right.$ of $\left.i \operatorname{Pr}\right)$. Anal. Calcd for $\mathrm{C}_{20} \mathrm{H}_{35} \mathrm{IrNO}_{2} \mathrm{P}_{2}: \mathrm{C}, 42.77 ; \mathrm{H}, 6.32 ; \mathrm{N}, 2.38$; Found: $\mathrm{C}, 42.65 ; \mathrm{H}, 6.05 ; \mathrm{N}, 2.36$. IR (solid, $v_{\mathrm{CO}}$ ): $1922.08 \mathrm{~cm}^{-1}$.

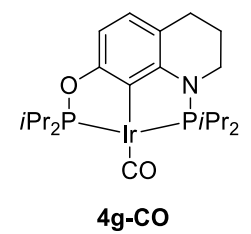

4g-CO. $4 \mathrm{~g}-\mathrm{HCl}(0.20 \mathrm{mmol}, 120.0 \mathrm{mg})$ and toluene $(8 \mathrm{~mL})$ were added to a $50 \mathrm{~mL}$ Schlenk flask equipped with a magnetic stir bar. tert-Butylene $(0.6 \mathrm{mmol}, 50.0 \mathrm{mg})$ was added via a syringe, followed by the addition of $\mathrm{NaO} t \mathrm{Bu}(0.29 \mathrm{mmol}, 28.0 \mathrm{mg})$. The solution was stirred for $2 \mathrm{~h}$ at RT, then the flask was brought out of glovebox, degassed and charged with $1 \mathrm{~atm}$ of $\mathrm{CO}$. The solution was stirred for $5 \mathrm{~h}$ at RT, producing a yellow solution. The solvent was removed in vacuo, and the residue was washed with pentane $(10 \mathrm{~mL} \times 3)$ and filtered through celite. The solvent was removed in vacuo to for yellow solids, which were then dissolved in a minimum amount of diethyl ether. The solution was placed in a $-32{ }^{\circ} \mathrm{C}$ freezer overnight, resulting in the precipitation of yellow solids. Decanting the supernatant and drying the residue

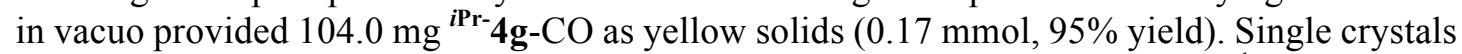
suitable for X-ray analysis were obtained from the diethyl ether solution at RT. ${ }^{1} \mathrm{H}$ NMR (400 $\left.\mathrm{MHz}, \mathrm{C}_{6} \mathrm{D}_{6}\right) \delta 6.81(\mathrm{~d}, J=8.0 \mathrm{~Hz}, 1 \mathrm{H}, \mathrm{ArH}), 6.69(\mathrm{~d}, J=8.0 \mathrm{~Hz}, 1 \mathrm{H}, \mathrm{ArH}), 2.86(\mathrm{td}, J=5.5$, $\left.2.5 \mathrm{~Hz}, 2 \mathrm{H}, \mathrm{NCH}_{2}\right), 2.50\left(\mathrm{t}, J=6.2 \mathrm{~Hz}, 2 \mathrm{H}, \mathrm{ArCH}_{2}\right), 2.31-2.16(\mathrm{~m}, 2 \mathrm{H}, \mathrm{CH}$ of $i \mathrm{Pr}), 2.17-$ $2.03(\mathrm{~m}, 2 \mathrm{H}, \mathrm{CH}$, of $i \mathrm{Pr}), 1.60-1.50\left(\mathrm{~m}, 2 \mathrm{H}, \mathrm{NCH}_{2} \mathrm{CH}_{2}\right), 1.27\left(\mathrm{~d}, J=6.9 \mathrm{~Hz}, 3 \mathrm{H}, \mathrm{CH}_{3}\right.$ of $\left.i \mathrm{Pr}\right)$, $1.23\left(\mathrm{~d}, J=7.0 \mathrm{~Hz}, 3 \mathrm{H}, \mathrm{CH}_{3}\right.$ of $\left.i \mathrm{Pr}\right), 1.21\left(\mathrm{~d}, J=7.2 \mathrm{~Hz}, 3 \mathrm{H}, \mathrm{CH}_{3}\right.$ of $\left.i \mathrm{Pr}\right), 1.16$ (dd, $J=14.4$, $7.1 \mathrm{~Hz}, 9 \mathrm{H}, \mathrm{CH}_{3}$ of $\left.i \operatorname{Pr}\right), 0.99\left(\mathrm{~d}, J=7.0 \mathrm{~Hz}, 3 \mathrm{H}, \mathrm{CH}_{3}\right.$ of $\left.i \mathrm{Pr}\right), 0.95\left(\mathrm{~d}, J=7.0 \mathrm{~Hz}, 3 \mathrm{H}, \mathrm{CH}_{3}\right.$ of $i$ Pr). ${ }^{31}$ P NMR (162 MHz, $\left.\mathrm{C}_{6} \mathrm{D}_{6}\right) \delta 187.3(\mathrm{~d}, J=306.6 \mathrm{~Hz}), 130.5(\mathrm{~d}, J=306.6 \mathrm{~Hz}) .{ }^{13} \mathrm{C}$ NMR $\left(101 \mathrm{MHz}, \mathrm{C}_{6} \mathrm{D}_{6}\right) \delta 200.7-197.9(\mathrm{~m}, \mathrm{CO}), 167.9\left(\mathrm{dd}, J=10.3,6.9 \mathrm{~Hz}, \mathrm{C}_{\mathrm{Ar}}\right), 156.8(\mathrm{dd}, J=$ $\left.22.7,6.0 \mathrm{~Hz}, \mathrm{C}_{\mathrm{Ar}}\right), 146.3\left(\mathrm{t}, J=8.1 \mathrm{~Hz}, \mathrm{C}_{\mathrm{Ar}}\right), 128.9\left(\mathrm{~s}, \mathrm{C}_{\mathrm{Ar}}\right), 112.71\left(\mathrm{~d}, J=11.4 \mathrm{~Hz}, \mathrm{C}_{\mathrm{Ar}}\right), 101.6$ $\left(\mathrm{d}, J=13.3 \mathrm{~Hz}, \mathrm{C}_{\mathrm{Ar}}\right), 44.7\left(\mathrm{~d}, J=4.6 \mathrm{~Hz}, \mathrm{NCH}_{2}\right), 31.3$ (dd, $\left.J=30.1,3.1 \mathrm{~Hz}, \mathrm{ArCH}_{2}\right), 28.9$ (dd, $J=29.3,1.6 \mathrm{~Hz}, \mathrm{CH}$ of $i \mathrm{Pr}), 26.5\left(\mathrm{~s}, \mathrm{NCH}_{2} \mathrm{CH}_{2}\right), 23.4\left(\mathrm{~d}, J=2.0 \mathrm{~Hz}, \mathrm{CH}_{3}\right.$ of $\left.i \mathrm{Pr}\right), 19.7(\mathrm{~d}, J=$ $7.8 \mathrm{~Hz}, \mathrm{CH}_{3}$ of $i \mathrm{Pr}$ ), 18.9 (s, $\mathrm{CH}_{3}$ of $i \mathrm{Pr}$ ), 18.3 (d, $J=7.0 \mathrm{~Hz}, \mathrm{CH}_{3}$ of $i \mathrm{Pr}$ ), 17.3 (s, $\mathrm{CH}_{3}$ of $i \operatorname{Pr}$ ). Anal. Calcd for $\mathrm{C}_{22} \mathrm{H}_{37} \mathrm{IrNO}_{2} \mathrm{P}_{2}: \mathrm{C}, 43.91 ; \mathrm{H}, 6.20 ; \mathrm{N}, 2.33$; Found: $\mathrm{C}, 44.21 ; \mathrm{H}, 6.04 ; \mathrm{N}, 2.29$. IR (solid, $v_{\mathrm{CO}}$ ): $1923.64 \mathrm{~cm}^{-1}$.

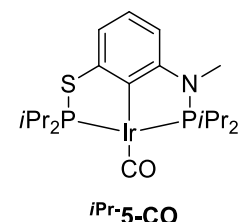

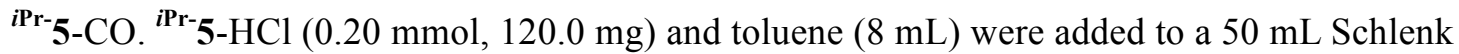
flask equipped with a magnetic stir bar. tert-Butylene $(0.6 \mathrm{mmol}, 50.0 \mathrm{mg})$ was added via a syringe, followed by the addition of $\mathrm{NaO} t \mathrm{Bu}(0.30 \mathrm{mmol}, 29.0 \mathrm{mg})$. The solution was stirred for $2 \mathrm{~h}$ at RT, then the flask was brought out of glovebox, degassed and charged with $1 \mathrm{~atm}$ of 
$\mathrm{CO}$. The solution was stirred for $5 \mathrm{~h}$ at RT, producing a yellow solution. The solvent was removed in vacuo, and the residue was washed with pentane $(10 \mathrm{~mL} \times 3)$ and filtered through celite. The solvent was removed in vacuo to for yellow solids, which were then dissolved in a minimum amount of diethyl ether. The solution was placed in a $-32{ }^{\circ} \mathrm{C}$ freezer overnight, resulting in the precipitation of yellow solids. Decanting the supernatant and drying the residue in vacuo provided $117.0 \mathrm{mg}{ }^{i P r}-\mathbf{5}-\mathrm{CO}$ as yellow solids $(0.17 \mathrm{mmol}, 99 \%$ yield $)$. Single crystals suitable for X-ray analysis were obtained from the diethyl ether solution at RT. ${ }^{1} \mathrm{H}$ NMR (400 $\left.\mathrm{MHz}, \mathrm{C}_{6} \mathrm{D}_{6}\right) \delta 7.31(\mathrm{t}, J=13.2 \mathrm{~Hz}, 1 \mathrm{H}, \mathrm{ArH}), 7.02-6.82(\mathrm{~m}, 1 \mathrm{H}, \mathrm{ArH}), 6.10(\mathrm{t}, J=12.6 \mathrm{~Hz}$, $1 \mathrm{H}, \mathrm{ArH}), 2.38$ (dd, $J=11.7,5.4 \mathrm{~Hz}, 3 \mathrm{H}, \mathrm{NMe}), 2.36-2.28$ (m, $2 \mathrm{H}, \mathrm{CH}$ of $i \mathrm{Pr}), 2.14-2.04$ (m, $2 \mathrm{H}, \mathrm{CH}$ of $i \mathrm{Pr}), 1.31$ (d, $J=7.0 \mathrm{~Hz}, 3 \mathrm{H}, \mathrm{CH}_{3}$ of $\left.i \mathrm{Pr}\right), 1.26\left(\mathrm{~d}, J=7.1 \mathrm{~Hz}, 3 \mathrm{H}, \mathrm{CH}_{3}\right.$ of $\left.i \operatorname{Pr}\right), 1.21$ $\left(\mathrm{t}, J=7.0 \mathrm{~Hz}, 6 \mathrm{H}, \mathrm{CH}_{3}\right.$ of $\left.i \mathrm{Pr}\right), 1.18\left(\mathrm{~d}, J=5.4 \mathrm{~Hz}, 3 \mathrm{H}, \mathrm{CH}_{3}\right.$ of $\left.i \operatorname{Pr}\right), 1.16(\mathrm{~d}, J=5.2 \mathrm{~Hz}, 3 \mathrm{H}$, $\mathrm{CH}_{3}$ of $\left.i \mathrm{Pr}\right), 0.91\left(\mathrm{~d}, J=7.0 \mathrm{~Hz}, 3 \mathrm{H}, \mathrm{CH}_{3}\right.$ of $\left.i \mathrm{Pr}\right), 0.87\left(\mathrm{t}, J=6.2 \mathrm{~Hz}, 3 \mathrm{H}, \mathrm{CH}_{3}\right.$ of $\left.i \operatorname{Pr}\right) .{ }^{31} \mathrm{P}$ NMR $\left(162 \mathrm{MHz}, \mathrm{C}_{6} \mathrm{D}_{6}\right) \delta 127.8(\mathrm{~d}, J=311.0 \mathrm{~Hz}, 1 \mathrm{P}), 108.0(\mathrm{~d}, J=311.0 \mathrm{~Hz}, 1 \mathrm{P}) .{ }^{13} \mathrm{C}$ NMR $(101$ $\left.\mathrm{MHz}, \mathrm{C}_{6} \mathrm{D}_{6}\right) \delta 195.4(\mathrm{t}, J=6.9 \mathrm{~Hz}, \mathrm{CO}), 166.7\left(\mathrm{t}, J=7.3 \mathrm{~Hz}, \mathrm{C}_{\mathrm{Ar}}\right), 162.4(\mathrm{dd}, J=23.3,6.3 \mathrm{~Hz}$, $\left.\mathrm{C}_{\mathrm{Ar}}\right), 158.4\left(\mathrm{dd}, J=15.6,8.3 \mathrm{~Hz}, \mathrm{C}_{\mathrm{Ar}}\right), 127.4\left(\mathrm{~s}, \mathrm{C}_{\mathrm{Ar}}\right), 113.0\left(\mathrm{~d}, J=12.7 \mathrm{~Hz}, \mathrm{C}_{\mathrm{Ar}}\right), 103.8(\mathrm{~d}, J=$ $\left.12.6 \mathrm{~Hz}, \mathrm{C}_{\mathrm{Ar}}\right), 32.9(\mathrm{~d}, J=2.0 \mathrm{~Hz}, \mathrm{NMe}), 30.1(\mathrm{~d}, J=23.8 \mathrm{~Hz}, \mathrm{CH}$ of $i \operatorname{Pr}), 29.5$ (dd, $J=31.0$, $1.8 \mathrm{~Hz}, \mathrm{CH}$ of $i \operatorname{Pr}$ ), 19.6 (d, $J=7.1 \mathrm{~Hz}, \mathrm{CH}_{3}$ of $\left.i \operatorname{Pr}\right), 19.1$ (d, $J=5.4 \mathrm{~Hz}, \mathrm{CH}_{3}$ of $i \operatorname{Pr}$ ), 18.6 (s, $\mathrm{CH}_{3}$ of $i \mathrm{Pr}$ ), 18.3 (s, $\mathrm{CH}_{3}$ of $i$ Pr). Anal. Calcd for $\mathrm{C}_{20} \mathrm{H}_{34} \mathrm{IrNOP}{ }_{2} \mathrm{~S}: \mathrm{C}, 40.66 ; \mathrm{H}, 5.80 ; \mathrm{N}, 2.37$; Found: C, 41.12; H, 6.17; N, 1.94. IR (solid, $v_{\mathrm{CO}}$ ): $1932.65 \mathrm{~cm}^{-1}$.

\section{Synthesis of (pincer)Ir-COE ${ }^{11}$}

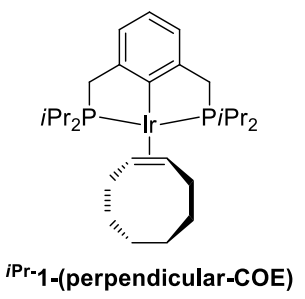

${ }^{i P^{P}-1}$-(perpendicular-COE). ${ }^{i \mathbf{P r}-1}$ - $\mathrm{HCl}(0.18 \mathrm{mmol}, 100.0 \mathrm{mg})$ and toluene $(8 \mathrm{~mL})$ were added to a $50 \mathrm{~mL}$ Schlenk flask equipped with a magnetic stir bar. COE $(0.54 \mathrm{mmol}, 60.0 \mathrm{mg})$ was added, followed by the addition of $\mathrm{NaO} t \mathrm{Bu}(0.29 \mathrm{mmol}, 25.0 \mathrm{mg})$. The solution was stirred at RT for $5 \mathrm{~h}$. Then the solvent of the deep khaki solution was removed in vacuo, and the residue was washed with pentane $(10 \mathrm{ml} \times 3)$ and filtered through celite. The solvent was removed in vacuo to form deep khaki solids. The resulting solids were dissolved using a minimum amount of pentane and the solution was placed in a $-32{ }^{\circ} \mathrm{C}$ freezer overnight, resulting in precipitation of solids. Decanting the supernatant and drying the residue in vacuo provided ${ }^{\mathrm{iPr}-} 73 \mathrm{mg}$ of 1(perpendicular-COE) as deep khaki solids ( $0.11 \mathrm{mmol}, 63 \%$ yield). ${ }^{1} \mathrm{H}$ NMR (400 MHz, $\left.\mathrm{C}_{6} \mathrm{D}_{6}\right)$ $\delta 7.36(\mathrm{~d}, J=7.4 \mathrm{~Hz}, 2 \mathrm{H}, \mathrm{ArH}), 7.24(\mathrm{t}, J=7.4 \mathrm{~Hz}, 1 \mathrm{H}, \mathrm{ArH}), 3.79(\mathrm{~d}, J=9.2 \mathrm{~Hz}, 2 \mathrm{H}, \mathrm{CH}=\mathrm{CH})$, $3.13\left(\mathrm{t}, J=3.8 \mathrm{~Hz}, 4 \mathrm{H}, \mathrm{ArCH}_{2}\right), 2.51\left(\mathrm{dd}, J=12.5,3.6 \mathrm{~Hz}, 2 \mathrm{H}, \mathrm{CH}=\mathrm{CH}-\mathrm{CH}_{2}\right), 2.05(\mathrm{dt}, J=$ 14.5, $5.9 \mathrm{~Hz}, 4 \mathrm{H}, \mathrm{CH}$ of $i \mathrm{Pr}), 1.94-1.84\left(\mathrm{~m}, 4 \mathrm{H}, \mathrm{CH}_{2}\right.$ of $\left.\mathrm{COE}\right), 1.79(\mathrm{dd}, J=13.1,3.1 \mathrm{~Hz}, 2 \mathrm{H}$, $\left.\mathrm{CH}=\mathrm{CH}-\mathrm{CH}_{2}\right), 1.56\left(\mathrm{q}, J=10.2 \mathrm{~Hz}, 4 \mathrm{H}, \mathrm{CH}_{2}\right.$ of $\left.\mathrm{COE}\right), 1.15\left(\mathrm{q}, J=6.9 \mathrm{~Hz}, 12 \mathrm{H}, \mathrm{CH}_{3}\right.$ of $\left.i \mathrm{Pr}\right)$, $0.93\left(\mathrm{q}, J=6.5 \mathrm{~Hz}, 12 \mathrm{H}, \mathrm{CH}_{3}\right.$ of $\left.i \mathrm{Pr}\right) .{ }^{31} \mathrm{P}$ NMR $\left(162 \mathrm{MHz}, \mathrm{C}_{6} \mathrm{D}_{6}\right) \delta 44.3(\mathrm{~s}) .{ }^{13} \mathrm{C}$ NMR $(101$ $\left.\mathrm{MHz}, \mathrm{C}_{6} \mathrm{D}_{6}\right) \delta 176.4\left(\mathrm{~s}, \mathrm{C}_{\mathrm{Ar}}\right), 152.6\left(\mathrm{t}, J=9.6 \mathrm{~Hz}, \mathrm{C}_{\mathrm{Ar}}\right), 130.0\left(\mathrm{~s}, \mathrm{C}_{\mathrm{Ar}}\right), 125.4\left(\mathrm{~s}, \mathrm{C}_{\mathrm{Ar}}\right), 119.7(\mathrm{t}$, $\left.J=8.1 \mathrm{~Hz}, \mathrm{C}_{\mathrm{Ar}}\right), 57.6(\mathrm{~s}, \mathrm{CH}=\mathrm{CH}), 39.6(\mathrm{t}, J=15.2 \mathrm{~Hz}, \mathrm{CH}$ of $i \mathrm{Pr}), 34.3\left(\mathrm{~s}, \mathrm{CH}=\mathrm{CH}-\mathrm{CH}_{2}\right), 32.9$ (s, $\mathrm{CH}_{2}$ of COE ), 27.0 (s, $\mathrm{CH}_{2}$ of COE), 25.3 (t, $\left.J=11.7 \mathrm{~Hz}, \mathrm{ArCH}_{2}\right), 19.4\left(\mathrm{~s}, \mathrm{CH}_{3}\right.$ of $i \mathrm{Pr}$ ), 18.3 $\left(\mathrm{CH}_{3}\right.$ of $i \mathrm{Pr}$ ). Anal. Calcd for $\mathrm{C}_{28} \mathrm{H}_{49} \mathrm{IrP}_{2}$ : C, 52.56; H, 7.72; Found: C, 52.17; H,7.35.

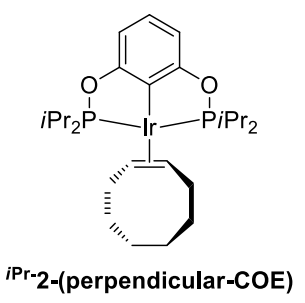




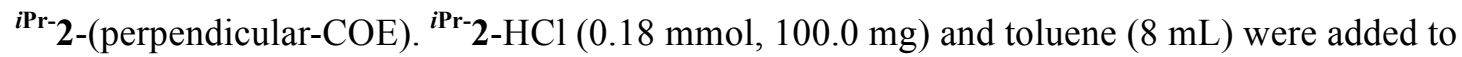
a $50 \mathrm{~mL}$ Schlenk flask equipped with a magnetic stir bar. COE $(0.54 \mathrm{mmol}, 60.0 \mathrm{mg})$ was added, followed by the addition of $\mathrm{NaO} t \mathrm{Bu}(0.29 \mathrm{mmol}, 28.0 \mathrm{mg})$. The solution was stirred at RT for $5 \mathrm{~h}$. Then the solvent of the red solution was removed in vacuo, and the residue was washed with pentane $(10 \mathrm{~mL} \times 3)$ and filtered through celite. The solvent was removed in vacuo to form red solids. The residue was dissolved using a minimum amount of pentane, and the solution was placed in a $-32{ }^{\circ} \mathrm{C}$ freezer overnight, resulting in precipitation of solids. Decanting the supernatant and drying the residue in vacuo provided $111.0 \mathrm{mg}$ of ${ }^{i \mathbf{P r}-2}$-(perpendicular-COE) as red solids $(0.17 \mathrm{mmol}, 96 \%$ yield $)$. Single crystal suitable for X-ray analysis were obtained from the solution of diethyl ether at $-32{ }^{\circ} \mathrm{C} .{ }^{1} \mathrm{H}$ NMR $\left(400 \mathrm{MHz}, \mathrm{C}_{6} \mathrm{D}_{6}\right) \delta 7.04$ (t, $J=7.8 \mathrm{~Hz}$, $1 \mathrm{H}, \mathrm{ArH}), 6.95(\mathrm{~d}, J=7.8 \mathrm{~Hz}, 2 \mathrm{H}, \mathrm{ArH}), 3.98(\mathrm{~d}, J=8.5 \mathrm{~Hz}, 2 \mathrm{H}, \mathrm{CH}=\mathrm{CH}), 2.44(\mathrm{~d}, J=12.8$ $\left.\mathrm{Hz}, 2 \mathrm{H}, \mathrm{CH}=\mathrm{CH}-\mathrm{CH}_{2}\right), 2.22(\mathrm{p}, J=7.1 \mathrm{~Hz}, 4 \mathrm{H}, \mathrm{CH}$ of $i \mathrm{Pr}), 1.84-1.74\left(\mathrm{~m}, 4 \mathrm{H}, \mathrm{CH}_{2}\right.$ of COE$)$, $1.69\left(\mathrm{~d}, J=3.6 \mathrm{~Hz}, 2 \mathrm{H}, \mathrm{CH}=\mathrm{CH}-\mathrm{CH}_{2}\right), 1.54-1.43\left(\mathrm{~m}, 4 \mathrm{H}, \mathrm{CH}_{2}\right.$ of $\left.\mathrm{COE}\right), 1.13(\mathrm{dq}, J=15.3$, 7.9, 7.4 Hz, 24H, $\mathrm{CH}_{3}$ of $\left.i \mathrm{Pr}\right) .{ }^{31} \mathrm{P}$ NMR $\left(162 \mathrm{MHz}, \mathrm{C}_{6} \mathrm{D}_{6}\right) \delta 173.6 .{ }^{13} \mathrm{C} \mathrm{NMR}\left(101 \mathrm{MHz}, \mathrm{C}_{6} \mathrm{D}_{6}\right)$ $\delta 168.0\left(\mathrm{t}, J=8.1 \mathrm{~Hz}, \mathrm{C}_{\mathrm{Ar}}\right), 145.3\left(\mathrm{t}, J=7.4 \mathrm{~Hz}, \mathrm{C}_{\mathrm{Ar}}\right), 128.5\left(\mathrm{~s}, \mathrm{C}_{\mathrm{Ar}}\right), 103.1\left(\mathrm{t}, J=5.9 \mathrm{~Hz}, \mathrm{C}_{\mathrm{Ar}}\right)$, $62.0(\mathrm{~s}, \mathrm{CH}=\mathrm{CH}), 34.5\left(\mathrm{~s}, \mathrm{CH}_{2}\right.$ of $\left.\mathrm{COE}\right), 33.1\left(\mathrm{~s}, \mathrm{CH}_{2}\right.$ of COE), $30.2(\mathrm{t}, J=14.2 \mathrm{~Hz}, \mathrm{CH}$ of $i \mathrm{Pr})$, 26.7 (s, $\mathrm{CH}_{2}$ of $\mathrm{COE}$ ), 17.6 (t, $J=2.9 \mathrm{~Hz}, \mathrm{CH}_{3}$ of $i \mathrm{Pr}$ ), 16.7 (s, $\mathrm{CH}_{3}$ of $i \mathrm{Pr}$ ). Anal. Calcd for $\mathrm{C}_{26} \mathrm{H}_{45} \mathrm{IrO}_{2} \mathrm{P}_{2}$ : C, 48.51; H, 7.05; Found: C, 48.55; H,6.77.

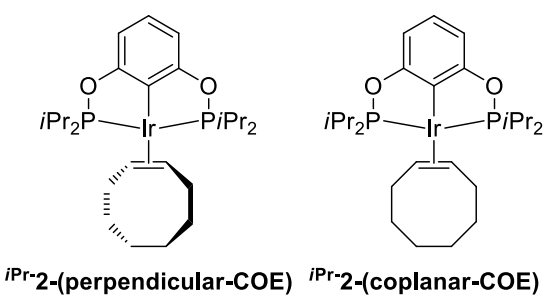

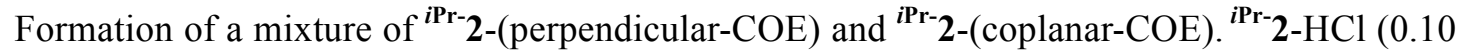
$\mathrm{mmol}, 60.0 \mathrm{mg}$ ), cyclooctene (COE, $0.55 \mathrm{mmol}, 60.0 \mathrm{mg}$ ) and cyclooctane $(\mathrm{COA}, 3 \mathrm{~mL})$ were added to a $5 \mathrm{~mL}$ thick-wall glass tube, followed by the addition of $\mathrm{NaO} t \mathrm{Bu}(0.17 \mathrm{mmol}, 16.0$ $\mathrm{mg}$ ). The tube was sealed by a Teflon plug and brought out of glovebox and heated in a preheated oil bath at $200{ }^{\circ} \mathrm{C}$ for $2 \mathrm{~h}$. After that, the solvent was removed in vacuo, and the residue was washed with pentane $(10 \mathrm{~mL} \times 3)$ and filtered through celite, and solvent was removed in vacuo, resulting in formation of red solids. $(76.1 \mu \mathrm{mol}, 49.0 \mathrm{mg}) .{ }^{1} \mathrm{H}$ and ${ }^{31} \mathrm{P}$ NMR analysis revealed the formation of an 80/20 mixture of ${ }^{i P r}-2$-(perpendicular-COE) (80\%) and ${ }^{i \mathbf{P r}-}$ 2-(coplanar-COE) (20\%). NMR data of ${ }^{\text {iPr-2}}$-(coplanar-COE): ${ }^{1} \mathrm{H}$ NMR $\left(400 \mathrm{MHz}, \mathrm{C}_{6} \mathrm{D}_{6}\right) \delta 7.05$ $(\mathrm{s}, 1 \mathrm{H}, \mathrm{ArH}), 6.99(\mathrm{~d}, J=1.3 \mathrm{~Hz}, 2 \mathrm{H}, \mathrm{ArH}), 3.77-3.68(\mathrm{~m}, 2 \mathrm{H}, \mathrm{CH}=\mathrm{CH}), 2.48-2.39(\mathrm{~m}, 2 \mathrm{H}$, $\left.\mathrm{CH}=\mathrm{CH}-\mathrm{CH}_{2}\right), 2.34(\mathrm{~d}, J=15.4 \mathrm{~Hz}, 2 \mathrm{H}, \mathrm{CH}$ of $i \mathrm{Pr}), 2.13-2.08(\mathrm{~m}, 2 \mathrm{H}, \mathrm{CH}$ of $i \operatorname{Pr}), 2.01(\mathrm{~d}, J$ $\left.=14.0 \mathrm{~Hz}, 2 \mathrm{H}, \mathrm{CH}=\mathrm{CH}-\mathrm{CH}_{2}\right), 1.54-1.58\left(\mathrm{~m}, 4 \mathrm{H}, \mathrm{CH}_{2}\right.$ of $\left.\mathrm{COE}\right), 1.33-1.40\left(\mathrm{~m}, 4 \mathrm{H}, \mathrm{CH}_{2}\right.$ of COE), 1.28 (q, $J=7.7,7.2 \mathrm{~Hz}, 12 \mathrm{H}, \mathrm{CH}_{3}$ of $\left.i \mathrm{Pr}\right), 1.12-1.05\left(\mathrm{~m}, 12 \mathrm{H}, \mathrm{CH}_{3}\right.$ of $\left.i \mathrm{Pr}\right) .{ }^{31} \mathrm{P} \mathrm{NMR}$ $\left(162 \mathrm{MHz}, \mathrm{C}_{6} \mathrm{D}_{6}\right) \delta 178.4 .{ }^{13} \mathrm{C}$ NMR $\left(151 \mathrm{MHz}, \mathrm{C}_{6} \mathrm{D}_{6}\right) \delta 167.1\left(\mathrm{t}, J=9.1 \mathrm{~Hz}, \mathrm{C}_{\mathrm{Ar}}\right), 143.9(\mathrm{t}, J=$ $\left.8.8 \mathrm{~Hz}, \mathrm{C}_{\mathrm{Ar}}\right), 126.8\left(\mathrm{~s}, \mathrm{C}_{\mathrm{Ar}}\right), 103.7-103.6\left(\mathrm{~m}, \mathrm{C}_{\mathrm{Ar}}\right), 54.9(\mathrm{~s}, \mathrm{CH}=\mathrm{CH}), 38.5\left(\mathrm{~s}, \mathrm{CH}=\mathrm{CH}-\mathrm{CH}_{2}\right)$, 36.8 (s, $\mathrm{CH}_{2}$ of COE), 31.2 (t, $J=14.7 \mathrm{~Hz}, \mathrm{CH}$ of $i \mathrm{Pr}$ ), 29.9 (d, $J=3.5 \mathrm{~Hz}, \mathrm{CH}_{2}$ of COE), 18.1 (d, $J=1.5 \mathrm{~Hz}, \mathrm{CH}_{3}$ of $i \operatorname{Pr}$ ), 17.3 (s, $\mathrm{CH}_{3}$ of $i \operatorname{Pr}$ ), 16.7 (s, $\mathrm{CH}_{3}$ of $i \operatorname{Pr}$ ).

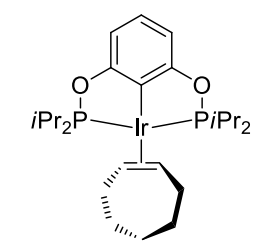

iPr-2-(perpendicular-CPE)

${ }^{i P r}$-2-(perpendicular-CPE) ${ }^{i P r}$-2-HCl $(0.18 \mathrm{mmol}, 100.0 \mathrm{mg})$ and toluene $(8 \mathrm{~mL})$ were added to a $50 \mathrm{~mL}$ Schlenk flask equipped with a magnetic stir bar. Cycloheptene (CPE) (0.54 mmol, 52.0 $\mathrm{mg}$ ) was added via a syringe, followed by the addition of $\mathrm{NaO} t \mathrm{Bu}(0.26 \mathrm{mmol}, 25.0 \mathrm{mg})$. The solution was stirred for at RT $5 \mathrm{~h}$. Then the solvent of the deep red solution was removed in vacuo, and the residue was washed with pentane $(10 \mathrm{~mL}$ x 3$)$ and filtered through celite. The 
solvent was removed in vacuo to form yellow solids. The resulting solid was dissolved using a minimum amount of pentane and the solution was placed in a $-32{ }^{\circ} \mathrm{C}$ freezer overnight, resulting in the precipitation of solids. Decanting the supernatant and drying the residue in vacuo provided $104.0 \mathrm{mg}$ of ${ }^{i \mathbf{P r}-2}$-(perpendicular-CPE) as yellow solids $\left(0.17 \mathrm{mmol}, 92 \%\right.$ yield). ${ }^{1} \mathrm{H}$ NMR (400 MHz, $\left.\mathrm{C}_{6} \mathrm{D}_{6}\right) \delta 7.07-7.00(\mathrm{~m}, 1 \mathrm{H}, \mathrm{ArH}), 6.96$ (d, $\left.J=7.6 \mathrm{~Hz}, 2 \mathrm{H}, \mathrm{ArH}\right), 3.99$ (t, $J=$ $4.9 \mathrm{~Hz}, 2 \mathrm{H}, \mathrm{CH}=\mathrm{CH}), 2.40-2.32\left(\mathrm{~m}, 2 \mathrm{H}, \mathrm{CH}=\mathrm{CH}-\mathrm{CH}_{2}\right), 2.27(\mathrm{p}, J=7.1 \mathrm{~Hz}, 4 \mathrm{H}, \mathrm{CH}$ of $i \operatorname{Pr})$, $2.03\left(\mathrm{~d}, J=12.9 \mathrm{~Hz}, 2 \mathrm{H}, \mathrm{CH}_{2}\right.$ of cycloheptene), $1.84\left(\mathrm{dt}, J=11.9,5.7 \mathrm{~Hz}, 4 \mathrm{H}, \mathrm{CH}_{2}\right.$ of cycloheptene), 1.47 (dd, $\left.J=9.3,6.2 \mathrm{~Hz}, 2 \mathrm{H}, \mathrm{CH}=\mathrm{CH}-\mathrm{CH}_{2}\right), 1.37$ (d, $J=12.7 \mathrm{~Hz}, 4 \mathrm{H}, \mathrm{CH}_{2}$ of cycloheptene), $1.18-1.08\left(\mathrm{~m}, 24 \mathrm{H}, \mathrm{CH}_{3}\right.$ of cycloheptene) ${ }^{31} \mathrm{P}$ NMR $\left(162 \mathrm{MHz}, \mathrm{C}_{6} \mathrm{D}_{6}\right) \delta 175.7$ (s). ${ }^{13} \mathrm{C}$ NMR $\left(101 \mathrm{MHz}, \mathrm{C}_{6} \mathrm{D}_{6}\right) \delta 167.2\left(\mathrm{t}, J=8.7 \mathrm{~Hz}, \mathrm{C}_{\mathrm{Ar}}\right), 142.8\left(\mathrm{t}, J=8.3 \mathrm{~Hz}, \mathrm{C}_{\mathrm{Ar}}\right), 127.2(\mathrm{~s}$, $\left.\mathrm{C}_{\mathrm{Ar}}\right), 103.3\left(\mathrm{t}, J=6.1 \mathrm{~Hz}, \mathrm{C}_{\mathrm{Ar}}\right), 60.0(\mathrm{~s}, \mathrm{CH}=\mathrm{CH}), 35.1\left(\mathrm{~d}, J=2.4 \mathrm{~Hz}, \mathrm{CH}_{2}\right.$ of cycloheptene), 33.2 (s, $\mathrm{CH}_{2}$ of cycloheptene), 30.3 (t, $J=14.5 \mathrm{~Hz}, \mathrm{CH}$ of $i \mathrm{Pr}$ ), 29.9 (s, $\mathrm{CH}_{2}$ of cycloheptene), 17.9 (t, $J=2.9 \mathrm{~Hz}, \mathrm{CH}_{3}$ of $\left.i \mathrm{Pr}\right), 16.9$ (s, $\mathrm{CH}_{3}$ of $i \mathrm{Pr}$ ). Anal. Calcd for $\mathrm{C}_{25} \mathrm{H}_{43} \mathrm{IrO}_{2} \mathrm{P}_{2}: \mathrm{C}, 47.68 ; \mathrm{H}$, 6.88; Found: C, 46.99; H,6.94.

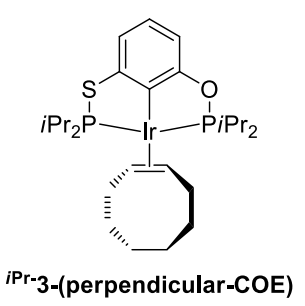

${ }^{i P r}$-3-(perpendicular-COE). ${ }^{i \mathbf{P r}-3}$ - $\mathrm{HCl}(0.17 \mathrm{mmol}, 100.0 \mathrm{mg})$ and toluene $(8 \mathrm{~mL})$ were added to a $50 \mathrm{~mL}$ Schlenk flask equipped with a magnetic stir bar. COE $(0.51 \mathrm{mmol}, 56.0 \mathrm{mg})$ was added, followed by the addition of $\mathrm{NaO} t \mathrm{Bu}(0.26 \mathrm{mmol}, 25.0 \mathrm{mg})$. The solution was stirred at RT for $5 \mathrm{~h}$. Then the solvent of the deep red solution was removed in vacuo, and the residue was washed with pentane $(10 \mathrm{~mL} \times 3)$ and filtered through celite. The solvent was removed in vacuo to form deep red solids. The residue was dissolved using a minimum amount of pentane, and the solution was placed in a $-32{ }^{\circ} \mathrm{C}$ freezer overnight, resulting in precipitation of solids. Decanting the supernatant and drying the residue in vacuo provided $92.0 \mathrm{mg}$ of ${ }^{i \mathrm{Pr}^{-}}$(perpendicular-COE) as deep red solids ( $0.14 \mathrm{mmol}, 83 \%$ yield). ${ }^{1} \mathrm{H}$ NMR $\left(400 \mathrm{MHz}, \mathrm{C}_{6} \mathrm{D}_{6}\right) \delta$ $7.37(\mathrm{~d}, J=7.5 \mathrm{~Hz}, 1 \mathrm{H}, \mathrm{ArH}), 6.98(\mathrm{~d}, J=7.8 \mathrm{~Hz}, 1 \mathrm{H}, \mathrm{ArH}), 6.91(\mathrm{t}, J=7.6 \mathrm{~Hz}, 1 \mathrm{H}, \mathrm{ArH}), 3.79$ $(\mathrm{q}, J=4.8 \mathrm{~Hz}, 2 \mathrm{H}, \mathrm{CH}=\mathrm{CH}), 2.39\left(\mathrm{~d}, J=12.8 \mathrm{~Hz}, 2 \mathrm{H}, \mathrm{CH}=\mathrm{CH}-\mathrm{CH}_{2}\right), 2.35-2.27(\mathrm{~m}, 2 \mathrm{H}, \mathrm{CH}$ of $i \mathrm{Pr}), 2.22-2.11(\mathrm{~m}, 2 \mathrm{H}, \mathrm{CH}$ of $i \mathrm{Pr}), 1.75\left(\mathrm{~d}, J=9.7 \mathrm{~Hz}, 2 \mathrm{H}, \mathrm{CH}=\mathrm{CH}-\mathrm{CH}_{2}\right), 1.67(\mathrm{t}, J=11.1$ $\mathrm{Hz}, 4 \mathrm{H}, \mathrm{CH}_{2}$ of COE), $1.45\left(\mathrm{dp}, J=14.2,8.2,7.7 \mathrm{~Hz}, 4 \mathrm{H}, \mathrm{CH}_{2}\right.$ of COE), 1.18 (dt, $J=12.1,5.3$ $\mathrm{Hz}, 24 \mathrm{H}, \mathrm{CH}_{3}$ of $\left.i \mathrm{Pr}\right) .{ }^{31} \mathrm{P}$ NMR $\left(162 \mathrm{MHz}, \mathrm{C}_{6} \mathrm{D}_{6}\right) \delta 166.3(\mathrm{~d}, J=375.7 \mathrm{~Hz}), 89.9(\mathrm{~d}, J=375.6$ $\mathrm{Hz}) .{ }^{13} \mathrm{C}$ NMR $\left(101 \mathrm{MHz}, \mathrm{C}_{6} \mathrm{D}_{6}\right) \delta 167.8\left(\mathrm{dd}, J=8.5,6.7 \mathrm{~Hz}, \mathrm{C}_{\mathrm{Ar}}\right), 163.7\left(\mathrm{~s}, \mathrm{C}_{\mathrm{Ar}}\right), 156.1(\mathrm{dd}, J$ $\left.=13.9,7.7 \mathrm{~Hz}, \mathrm{C}_{\mathrm{Ar}}\right), 114.0\left(\mathrm{~d}, J=11.8 \mathrm{~Hz}, \mathrm{C}_{\mathrm{Ar}}\right), 106.1\left(\mathrm{~d}, J=12.5 \mathrm{~Hz}, \mathrm{C}_{\mathrm{Ar}}\right), 60.3(\mathrm{~s}, \mathrm{CH}=\mathrm{CH})$, $34.55-34.30$ (m, $\mathrm{CH}_{2}$ of COE), 32.8 (s, $\mathrm{CH}_{2}$ of COE), 31.20 (dd, $J=24.2,5.4 \mathrm{~Hz}, \mathrm{CH}$ of $i \mathrm{Pr}$ ), 28.7 (d, $J=18.0 \mathrm{~Hz}, \mathrm{CH}_{2}$ of COE), 26.8 (s, $\mathrm{CH}_{2}$ of COE), 18.6 (d, $J=5.1 \mathrm{~Hz}, \mathrm{CH}_{3}$ of $i \mathrm{Pr}$ ), 18.0 (s, $\mathrm{CH}_{3}$ of $i \mathrm{Pr}$ ), 16.7 (s, $\mathrm{CH}_{3}$ of $i \mathrm{Pr}$ ). Anal. Calcd for $\mathrm{C}_{26} \mathrm{H}_{45} \mathrm{IrOP}_{2} \mathrm{~S}$ : C, 47.32; H, 6.87; Found: C, 47.47; H,6.98.

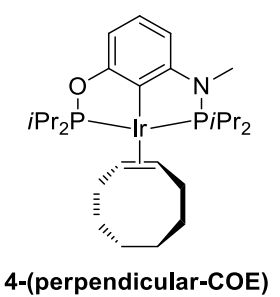

4b-(perpendicular-COE). $4 \mathbf{b}-\mathrm{HCl}(0.17 \mathrm{mmol}, 100.0 \mathrm{mg})$ and toluene $(8 \mathrm{~mL})$ were added to a $50 \mathrm{~mL}$ Schlenk flask equipped with a magnetic stir bar. COE $(0.51 \mathrm{mmol}, 56.0 \mathrm{mg})$ was added, followed by the addition of $\mathrm{NaO} t \mathrm{Bu}(0.26 \mathrm{mmol}, 25.0 \mathrm{mg})$. The solution was stirred at RT for $5 \mathrm{~h}$. Then the solvent of the deep red solution was removed in vacuo, and the residue was washed with pentane $(10 \mathrm{~mL} \times 3)$ and filtered through celite. The solvent was removed in vacuo 
to form deep red solids. The residue was dissolved using a minimum amount of pentane, and the solution was placed in a $-32{ }^{\circ} \mathrm{C}$ freezer overnight, resulting in precipitation of solids. Decanting the supernatant and drying the residue in vacuo provided $99.0 \mathrm{mg}$ of $\mathbf{4 b} \mathbf{b}$ (perpendicular-COE) as deep red solids $\left(0.15 \mathrm{mmol}, 89 \%\right.$ yield). ${ }^{1} \mathrm{H}$ NMR $\left(400 \mathrm{MHz}, \mathrm{C}_{6} \mathrm{D}_{6}\right) \delta$ $7.19(\mathrm{~d}, J=8.3 \mathrm{~Hz}, 1 \mathrm{H}, \mathrm{ArH}), 7.05(\mathrm{~d}, J=7.8 \mathrm{~Hz}, 1 \mathrm{H}, \mathrm{ArH}), 6.18(\mathrm{~d}, J=7.7 \mathrm{~Hz}, 1 \mathrm{H}, \operatorname{ArH})$, $3.92-3.80(\mathrm{~m}, 2 \mathrm{H}, \mathrm{CH}=\mathrm{CH}), 2.54(\mathrm{~d}, J=5.1 \mathrm{~Hz}, 3 \mathrm{H}, \mathrm{NMe}), 2.46(\mathrm{dt}, J=13.1,3.4 \mathrm{~Hz}, 2 \mathrm{H}$, $\left.\mathrm{CH}=\mathrm{CH}-\mathrm{CH}_{2}\right), 2.38-2.31(\mathrm{~m}, 2 \mathrm{H}, \mathrm{CH}$ of $i \mathrm{Pr}), 2.26$ (tt, $J=6.8,3.1 \mathrm{~Hz}, 2 \mathrm{H}, \mathrm{CH}$ of $\left.i \operatorname{Pr}\right), 1.87-$ $1.77\left(\mathrm{~m}, 4 \mathrm{H}, \mathrm{CH}_{2}\right.$ of $\left.\mathrm{COE}\right), 1.76-1.65\left(\mathrm{~m}, 2 \mathrm{H}, \mathrm{CH}=\mathrm{CH}_{-} \mathrm{CH}_{2}\right), 1.52(\mathrm{tt}, J=12.8,5.0 \mathrm{~Hz}, 4 \mathrm{H}$, $\mathrm{CH}_{2}$ of $\mathrm{COE}$ ), $1.27-1.18\left(\mathrm{~m}, 12 \mathrm{H}, \mathrm{CH}_{3}\right.$ of $\left.i \operatorname{Pr}\right), 1.11\left(\mathrm{dd}, J=15.3,7.1 \mathrm{~Hz}, 6 \mathrm{H}, \mathrm{CH}_{3}\right.$ of $i \mathrm{Pr}$ ), $0.95\left(\mathrm{dd}, J=13.1,7.1 \mathrm{~Hz}, 6 \mathrm{H}, \mathrm{CH}_{3}\right.$ of $\left.i \mathrm{Pr}\right) .{ }^{31} \mathrm{P}$ NMR $\left(162 \mathrm{MHz}, \mathrm{C}_{6} \mathrm{D}_{6}\right) \delta 174.4(\mathrm{~d}, J=363.7$ $\mathrm{Hz}), 108.8(\mathrm{~d}, J=363.7 \mathrm{~Hz}) .{ }^{13} \mathrm{C}$ NMR $\left(101 \mathrm{MHz}, \mathrm{C}_{6} \mathrm{D}_{6}\right) \delta 166.8\left(\mathrm{dd}, J=9.8,5.4 \mathrm{~Hz}, \mathrm{C}_{\mathrm{Ar}}\right)$, $160.5\left(\mathrm{dd}, J=23.5,5.4 \mathrm{~Hz}, \mathrm{C}_{\mathrm{Ar}}\right), 143.0\left(\mathrm{t}, J=7.0 \mathrm{~Hz}, \mathrm{C}_{\mathrm{Ar}}\right), 127.5\left(\mathrm{~s}, \mathrm{C}_{\mathrm{Ar}}\right), 101.1(\mathrm{~d}, J=12.2$ $\left.\mathrm{Hz}, \mathrm{C}_{\mathrm{Ar}}\right), 100.0\left(\mathrm{~d}, J=12.3 \mathrm{~Hz}, \mathrm{C}_{\mathrm{Ar}}\right), 59.3(\mathrm{~s}, \mathrm{CH}=\mathrm{CH}), 33.9(\mathrm{dd}, J=4.4,1.4 \mathrm{~Hz}, \mathrm{NMe}), 32.4$ (s, $\mathrm{CH}_{2}$ of COE), 32.1 (dd, $J=5.0,1.3 \mathrm{~Hz}, \mathrm{CH}_{2}$ of COE), 30.4 (dd, $J=22.7,5.4 \mathrm{~Hz}, \mathrm{CH}$ of $i \operatorname{Pr}$ ), 26.2 (d, $J=2.9 \mathrm{~Hz}, \mathrm{CH}_{2}$ of COE), 26.0 (s, $\mathrm{CH}_{2}$ of COE), 25.9 (d, $J=2.9 \mathrm{~Hz}, \mathrm{CH}_{2}$ of COE), $17.7\left(\mathrm{~d}, J=5.9 \mathrm{~Hz}, \mathrm{CH}_{3}\right.$ of $\left.i \operatorname{Pr}\right), 17.1\left(\mathrm{~d}, J=1.5 \mathrm{~Hz}, \mathrm{CH}_{3}\right.$ of $\left.i \mathrm{Pr}\right), 16.6\left(\mathrm{~d}, J=5.5 \mathrm{~Hz}, \mathrm{CH}_{3}\right.$ of $i \operatorname{Pr}), 16.0\left(\mathrm{~d}, J=1.5 \mathrm{~Hz}, \mathrm{CH}_{3}\right.$ of $i \mathrm{Pr}$ ). Anal. Calcd for $\mathrm{C}_{27} \mathrm{H}_{48} \mathrm{IrNOP}_{2}: \mathrm{C}, 49.37 ; \mathrm{H}, 7.37 ; \mathrm{N}, 2.13$; Found: C, 48.95; H,7.35; N, 2.11.

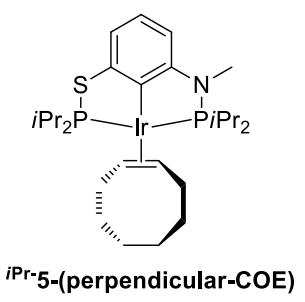

${ }^{i P r}$-5-(perpendicular-COE). ${ }^{i P r}$-5-HCl $(0.17 \mathrm{mmol}, 100.0 \mathrm{mg})$ and toluene $(8 \mathrm{~mL})$ were added to a $50 \mathrm{~mL}$ Schlenk flask equipped with a magnetic stir bar. COE $(0.51 \mathrm{mmol}, 56.0 \mathrm{mg})$ was added, followed by the addition of $\mathrm{NaO} t \mathrm{Bu}(0.26 \mathrm{mmol}, 25.0 \mathrm{mg})$. The solution was stirred at RT for $5 \mathrm{~h}$. Then the solvent of the deep red solution was removed in vacuo, and the residue was washed with pentane $(10 \mathrm{~mL} \times 3)$ and filtered through celite. The solvent was removed in vacuo to form light black solids $(90.0 \mu \mathrm{mol}, 59.0 \mathrm{mg}, 52 \%$ yield $)$. This COE adduct is not stable, render the further purification difficult. ${ }^{1} \mathrm{H}$ NMR $\left(400 \mathrm{MHz}, \mathrm{C}_{6} \mathrm{D}_{6}\right) \delta 7.55(\mathrm{~d}, J=7.7 \mathrm{~Hz}, 1 \mathrm{H}$, ArH), 7.05 (t, $J=7.7 \mathrm{~Hz}, 1 \mathrm{H}, \mathrm{ArH}), 6.16(\mathrm{~d}, J=7.9 \mathrm{~Hz}, 1 \mathrm{H}, \mathrm{ArH}), 3.65$ (q, $J=4.5 \mathrm{~Hz}, 2 \mathrm{H}$, $\mathrm{CH}=\mathrm{CH}), 2.46(\mathrm{~d}, J=5.0 \mathrm{~Hz}, 3 \mathrm{H}, \mathrm{NMe}), 2.37(\mathrm{~m}, 4 \mathrm{H}, \mathrm{CH}$ of $i \mathrm{Pr}), 2.25(\mathrm{ddq}, J=10.4,6.8,3.5$ $\left.\mathrm{Hz}, 2 \mathrm{H}, \mathrm{CH}=\mathrm{CH}-\mathrm{CH}_{2}\right), 2.06\left(\mathrm{q}, J=6.5 \mathrm{~Hz}, 2 \mathrm{H}, \mathrm{CH}=\mathrm{CH}-\mathrm{CH}_{2}\right), 1.82-1.65\left(\mathrm{~m}, 4 \mathrm{H}, \mathrm{CH}_{2}\right.$ of COE), $1.48-1.42\left(\mathrm{~m}, 4 \mathrm{H}, \mathrm{CH}_{2}\right.$ of COE), $1.34-1.25\left(\mathrm{~m}, 12 \mathrm{H}, \mathrm{CH}_{3}\right.$ of $\left.i \mathrm{Pr}\right), 1.15-1.09(\mathrm{~m}, 6 \mathrm{H}$, $\mathrm{CH}_{3}$ of $\left.i \mathrm{Pr}\right), 0.93\left(\mathrm{dd}, J=13.1,7.1 \mathrm{~Hz}, 6 \mathrm{H}, \mathrm{CH}_{3}\right.$ of $\left.i \mathrm{Pr}\right) .{ }^{31} \mathrm{P} \mathrm{NMR}\left(162 \mathrm{MHz}, \mathrm{C}_{6} \mathrm{D}_{6}\right) \delta 103.8(\mathrm{~d}$, $J=378.8 \mathrm{~Hz}), 93.9(\mathrm{~d}, J=378.5 \mathrm{~Hz}) .{ }^{13} \mathrm{C}$ NMR $\left(101 \mathrm{MHz}, \mathrm{C}_{6} \mathrm{D}_{6}\right) \delta 162.8\left(\mathrm{t}, J=6.3 \mathrm{~Hz}, \mathrm{C}_{\mathrm{Ar}}\right)$, $161.7\left(\mathrm{~d}, J=28.0 \mathrm{~Hz}, \mathrm{C}_{\mathrm{Ar}}\right), 156.6-155.9\left(\mathrm{~m}, \mathrm{C}_{\mathrm{Ar}}\right), 127.0\left(\mathrm{~s}, \mathrm{C}_{\mathrm{Ar}}\right), 111.9\left(\mathrm{~d}, J=10.8 \mathrm{~Hz}, \mathrm{C}_{\mathrm{Ar}}\right)$, $103.5\left(\mathrm{~d}, J=12.0 \mathrm{~Hz}, \mathrm{C}_{\mathrm{Ar}}\right), 57.4(\mathrm{~s}, \mathrm{CH}=\mathrm{CH}), 33.7(\mathrm{~d}, J=3.6 \mathrm{~Hz}, \mathrm{NMe}), 33.4(\mathrm{t}, J=2.6 \mathrm{~Hz}$, $\mathrm{CH}$ of $i \mathrm{Pr}$ ), 32.7 (s, $\mathrm{CH}_{2}$ of $\mathrm{COE}$ ), 31.0 (s, $\mathrm{CH}_{2}$ of $\left.\mathrm{COE}\right), 26.8$ (s, $\mathrm{CH}_{2}$ of $\left.\mathrm{COE}\right), 26.6\left(\mathrm{~s}, \mathrm{CH}_{2}\right.$ of COE), 20.1 (d, $J=5.7 \mathrm{~Hz}, \mathrm{CH}_{3}$ of $i \operatorname{Pr}$ ), 18.5 (s, $\mathrm{CH}_{3}$ of $i \operatorname{Pr}$ ), 17.9 (s, $\mathrm{CH}_{3}$ of $i \operatorname{Pr}$ ).

4. Synthesis of (pincer)Ir-SMe 2

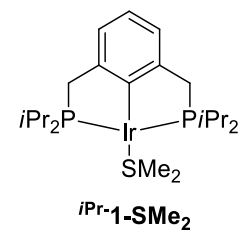

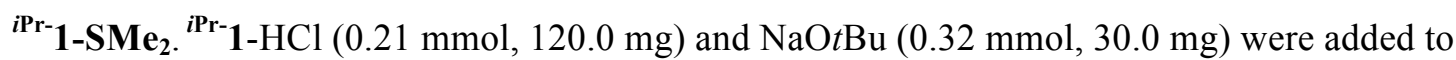
a $50 \mathrm{~mL}$ Schlenk flask equipped with a magnetic stir bar. The flask was sealed and brought out of the glovebox. $\mathrm{SMe}_{2}(0.63 \mathrm{mmol}, 39.0 \mathrm{mg})$ was then added via a syringe, followed by the 
addition of toluene $(10 \mathrm{~mL})$. The reaction was stirred for $4 \mathrm{~h}$ at $60{ }^{\circ} \mathrm{C}$, producing a red solution. The solvent was removed in vacuo, and the residue was washed with pentane $(10 \mathrm{~mL} \times 3)$ and filtered through celite. The volatiles were removed in vacuo to form red solids. The resulting solids were dissolved using a minimum amount of $n$-pentane and the solution was placed in a $32{ }^{\circ} \mathrm{C}$ freezer overnight, resulting in precipitation of red solids. Decanting the supernatant and

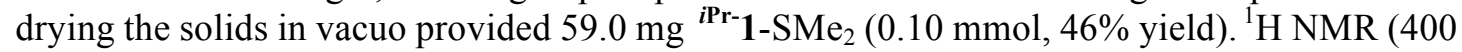
$\left.\mathrm{MHz}, \mathrm{C}_{6} \mathrm{D}_{6}\right) \delta 7.29$ (d, $\left.J=7.3 \mathrm{~Hz}, 2 \mathrm{H}, \mathrm{ArH}\right), 7.20(\mathrm{~d}, J=7.2 \mathrm{~Hz}, 1 \mathrm{H}, \mathrm{ArH}), 2.97$ (t, $J=3.9 \mathrm{~Hz}$, $\left.4 \mathrm{H}, \mathrm{ArCH}_{2}\right), 2.28\left(\mathrm{~s}, 6 \mathrm{H}, \mathrm{SMe}_{2}\right), 1.97(\mathrm{dtd}, J=9.6,6.9,4.6 \mathrm{~Hz}, 4 \mathrm{H}, \mathrm{CH}$ of $i \operatorname{Pr}), 1.19$ (q, $J=7.3$ $\mathrm{Hz}, 12 \mathrm{H}, \mathrm{CH}_{3}$ of $\left.i \operatorname{Pr}\right), 1.01$ (q, $J=6.5 \mathrm{~Hz}, 12 \mathrm{H}, \mathrm{CH}_{3}$ of $\left.i \operatorname{Pr}\right) .{ }^{31} \mathrm{P} \mathrm{NMR}\left(162 \mathrm{MHz}, \mathrm{C}_{6} \mathrm{D}_{6}\right) \delta 56.2$ (s). ${ }^{13} \mathrm{C}$ NMR $\left(101 \mathrm{MHz}, \mathrm{C}_{6} \mathrm{D}_{6}\right) \delta 167.8\left(\mathrm{~d}, J=3.2 \mathrm{~Hz}, \mathrm{C}_{\mathrm{Ar}}\right), 150.7\left(\mathrm{t}, J=11.1 \mathrm{~Hz}, \mathrm{C}_{\mathrm{Ar}}\right), 121.7$ $\left(\mathrm{s}, \mathrm{C}_{\mathrm{Ar}}\right), 120.0\left(\mathrm{t}, J=8.5 \mathrm{~Hz}, \mathrm{C}_{\mathrm{Ar}}\right), 37.7(\mathrm{t}, J=15.0 \mathrm{~Hz}, \mathrm{CH}$ of $i \mathrm{Pr}), 28.9\left(\mathrm{~d}, J=3.3 \mathrm{~Hz}, \mathrm{CH}_{3}\right.$ of $\mathrm{SMe}_{2}$ ), 26.0 (t, $\left.J=12.6 \mathrm{~Hz}, \mathrm{ArCH}_{2}\right), 19.4$ ( $\mathrm{s} \mathrm{CH}_{3}$ of $i \mathrm{Pr}$ ), 18.3 (s, $\mathrm{CH}_{3}$ of $i \mathrm{Pr}$ ). Anal. Calcd for $\mathrm{C}_{22} \mathrm{H}_{41} \mathrm{IrP}_{2} \mathrm{~S}$ : C, 44.65; H, 6.98; Found: C, 44.32; H,7.22.

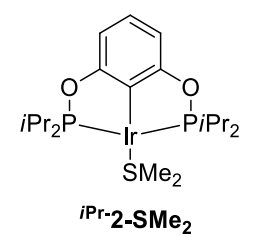

${ }^{i \mathbf{P r}-2}-\mathrm{SMe}_{2} .{ }^{i \mathbf{P r}} \mathbf{2}-\mathrm{HCl}(0.21 \mathrm{mmol}, 120.0 \mathrm{mg})$ and $\mathrm{NaO} t \mathrm{Bu}(0.32 \mathrm{mmol}, 30.0 \mathrm{mg})$ were added to a $50 \mathrm{~mL}$ Schlenk flask equipped with a magnetic stir bar. The flask was sealed and brought out of the glovebox. $\mathrm{SMe}_{2}(0.63 \mathrm{mmol}, 39.0 \mathrm{mg})$ was then added via a syringe, followed by the addition of toluene $(10 \mathrm{~mL})$. The reaction was stirred for $4 \mathrm{~h}$ at $60{ }^{\circ} \mathrm{C}$, producing a red solution. The solvent was removed in vacuo, and the residue was washed with pentane $(10 \mathrm{~mL} \times 3)$ and filtered through celite. The volatiles were removed in vacuo to form red solids. The resulting solids were dissolved using a minimum amount of $n$-pentane and the solution was placed in a $32{ }^{\circ} \mathrm{C}$ freezer overnight, resulting in precipitation of red solids. Decanting the supernatant and drying the solids in vacuo provided $109.0 \mathrm{mg}{ }^{i P r}-2-\mathrm{SMe}_{2}(0.18 \mathrm{mmol}, 87 \%$ yield $)$. Single crystals suitable for X-ray analysis were obtained from the solution of diethyl ether at $-32{ }^{\circ} \mathrm{C}$. ${ }^{1} \mathrm{H}$ NMR (400 MHz, $\left.\mathrm{C}_{6} \mathrm{D}_{6}\right) \delta 6.99(\mathrm{t}, J=7.7 \mathrm{~Hz}, 1 \mathrm{H}, \mathrm{ArH}), 6.89(\mathrm{~d}, J=7.7 \mathrm{~Hz}, 2 \mathrm{H}, \mathrm{ArH}), 2.21$ (s, 6H, $\mathrm{SMe}_{2}$ ), $2.16-2.09$ (m, 4H, CH of $\left.i \operatorname{Pr}\right), 1.24$ (q, $J=6.5 \mathrm{~Hz}, 12 \mathrm{H}, \mathrm{CH}_{3}$ of $\left.i \operatorname{Pr}\right), 1.15$ (q, $J$ $=8.0 \mathrm{~Hz}, 12 \mathrm{H}, \mathrm{CH}_{3}$ of $\left.i \mathrm{Pr}\right){ }^{31} \mathrm{P}$ NMR $\left(162 \mathrm{MHz}, \mathrm{C}_{6} \mathrm{D}_{6}\right) \delta 176.1(\mathrm{~s}) .{ }^{13} \mathrm{C} \mathrm{NMR}\left(101 \mathrm{MHz}, \mathrm{C}_{6} \mathrm{D}_{6}\right)$ $\delta 166.4\left(\mathrm{t}, J=9.1 \mathrm{~Hz}, \mathrm{C}_{\mathrm{Ar}}\right), 136.8\left(\mathrm{t}, J=7.9 \mathrm{~Hz}, \mathrm{C}_{\mathrm{Ar}}\right), 123.5\left(\mathrm{~s}, \mathrm{C}_{\mathrm{Ar}}\right), 103.4\left(\mathrm{t}, J=6.2 \mathrm{~Hz}, \mathrm{C}_{\mathrm{Ar}}\right)$, 31.5 (t, $J=14.9 \mathrm{~Hz}, \mathrm{CH}$ of $i \operatorname{Pr}), 30.6$ (t, $J=3.4 \mathrm{~Hz}, \mathrm{CH}_{3}$ of $\mathrm{SMe}_{2}$ ), 18.1 (t, $J=3.9 \mathrm{~Hz}, \mathrm{CH}_{3}$ of $i \operatorname{Pr}$ ), 17.1 (s, $\mathrm{CH}_{3}$ of $i \mathrm{Pr}$ ). Anal. Calcd for $\mathrm{C}_{20} \mathrm{H}_{37} \mathrm{IrO}_{2} \mathrm{P}_{2} \mathrm{~S}$ : C, 40.32; H, 6.26; Found: C, 40.19; H,6.31.

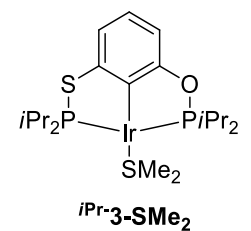

${ }^{i \mathbf{P r}}$-3-SMe ${ }_{2}{ }^{i \mathbf{P r}} \mathbf{3}-\mathrm{HCl}(0.20 \mathrm{mmol}, 120.0 \mathrm{mg})$ and $\mathrm{NaO} t \mathrm{Bu}(0.3 \mathrm{mmol}, 29.0 \mathrm{mg})$ were added to a $50 \mathrm{~mL}$ Schlenk flask equipped with a magnetic stir bar. The flask was sealed and brought out of the glovebox. $\mathrm{SMe}_{2}(0.63 \mathrm{mmol}, 39.0 \mathrm{mg})$ was then added via a syringe, followed by the addition of toluene $(10 \mathrm{~mL})$. The reaction was stirred for $4 \mathrm{~h}$ at $60{ }^{\circ} \mathrm{C}$, producing a red solution. The solvent was removed in vacuo, and the residue was washed with pentane $(10 \mathrm{~mL} \times 3)$ and filtered through celite. The volatiles were removed in vacuo to form red solids. The resulting solids were dissolved using a minimum amount of $n$-pentane and the solution was placed in a $32{ }^{\circ} \mathrm{C}$ freezer overnight, resulting in precipitation of red solids. Decanting the supernatant and drying the solids in vacuo provided $87.0 \mathrm{mg}{ }^{\text {iPr- }} 3-\mathrm{SMe}_{2}(0.14 \mathrm{mmol}, 71 \%$ yield $) .{ }^{1} \mathrm{H}$ NMR (400 $\left.\mathrm{MHz}, \mathrm{C}_{6} \mathrm{D}_{6}\right) \delta 7.35(\mathrm{dd}, J=5.6,3.2 \mathrm{~Hz}, 1 \mathrm{H}, \mathrm{ArH}), 6.95-6.82(\mathrm{~m}, 2 \mathrm{H}, \mathrm{ArH}), 2.31-2.25(\mathrm{~m}$, $2 \mathrm{H}, \mathrm{CH}$ of $i \operatorname{Pr}), 2.12\left(\mathrm{~s}, 6 \mathrm{H}, \mathrm{SMe}_{2}\right), 2.10-2.05(\mathrm{~m}, 2 \mathrm{H}, \mathrm{CH}$ of $i \operatorname{Pr}), 1.30(\mathrm{~d}, J=2.9 \mathrm{~Hz}, 3 \mathrm{H}$, 
$\mathrm{CH}_{3}$ of $\left.i \operatorname{Pr}\right), 1.29\left(\mathrm{~d}, J=2.8 \mathrm{~Hz}, 3 \mathrm{H}, \mathrm{CH}_{3}\right.$ of $\left.i \mathrm{Pr}\right), 1.24\left(\mathrm{~d}, J=5.1 \mathrm{~Hz}, 3 \mathrm{H}, \mathrm{CH}_{3}\right.$ of $\left.i \operatorname{Pr}\right), 1.21(\mathrm{~d}$, $J=6.9 \mathrm{~Hz}, 3 \mathrm{H}, \mathrm{CH}_{3}$ of $\left.i \mathrm{Pr}\right), 1.15\left(\mathrm{~d}, J=7.3 \mathrm{~Hz}, 3 \mathrm{H}, \mathrm{CH}_{3}\right.$ of $\left.i \operatorname{Pr}\right), 1.11\left(\mathrm{~d}, J=7.2 \mathrm{~Hz}, 3 \mathrm{H}, \mathrm{CH}_{3}\right.$ of $i \mathrm{Pr}) .{ }^{31} \mathrm{P}$ NMR $\left(162 \mathrm{MHz}, \mathrm{C}_{6} \mathrm{D}_{6}\right) \delta 167.6(\mathrm{~d}, J=366.8 \mathrm{~Hz}), 96.3(\mathrm{~d}, J=366.7 \mathrm{~Hz}) .{ }^{13} \mathrm{C}$ NMR $\left(101 \mathrm{MHz}, \mathrm{C}_{6} \mathrm{D}_{6}\right) \delta 166.4\left(\mathrm{dd}, J=10.0,8.3 \mathrm{~Hz}, \mathrm{C}_{\mathrm{Ar}}\right), 154.1\left(\mathrm{t}, J=6.4 \mathrm{~Hz}, \mathrm{C}_{\mathrm{Ar}}\right), 152.6(\mathrm{dd}, J=$ $\left.15.3,8.6 \mathrm{~Hz}, \mathrm{C}_{\mathrm{Ar}}\right), 123.7\left(\mathrm{~s}, \mathrm{C}_{\mathrm{Ar}}\right), 115.0\left(\mathrm{~d}, J=12.1 \mathrm{~Hz}, \mathrm{C}_{\mathrm{Ar}}\right), 106.0\left(\mathrm{~d}, J=13.3 \mathrm{~Hz}, \mathrm{C}_{\mathrm{Ar}}\right), 31.5$ (dd, $J=27.0,4.3 \mathrm{~Hz}, \mathrm{CH}$ of $i \mathrm{Pr}$ ), 30.2 (dd, $J=19.3,1.9 \mathrm{~Hz}, \mathrm{CH}$ of $i \mathrm{Pr}$ ), 28.6 (t, $J=3.0 \mathrm{~Hz}$, $\mathrm{CH}_{3}$ of $\mathrm{SMe}_{2}$ ), 19.3 (d, $J=6.4 \mathrm{~Hz}, \mathrm{CH}_{3}$ of $\left.i \mathrm{Pr}\right), 18.50-17.94\left(\mathrm{~m}, \mathrm{CH}_{3}\right.$ of $\left.i \mathrm{Pr}\right), 17.1\left(\mathrm{~s}, \mathrm{CH}_{3}\right.$ of $i$ Pr). Anal. Calcd for $\mathrm{C}_{20} \mathrm{H}_{37} \mathrm{IrOP}_{2} \mathrm{~S}_{2}$ : C, 39.26; H, 6.10; Found: C, 39.23; H,6.47.

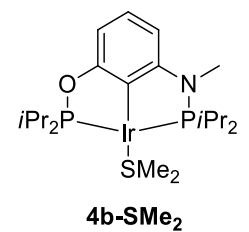

4b-SMe $2.4 \mathbf{b}-\mathrm{HCl}(0.20 \mathrm{mmol}, 120.0 \mathrm{mg})$ and $\mathrm{NaO} t \mathrm{Bu}(0.3 \mathrm{mmol}, 29.0 \mathrm{mg})$ were added to a $50 \mathrm{~mL}$ Schlenk flask equipped with a magnetic stir bar. The flask was sealed and brought out of the glovebox. $\mathrm{SMe}_{2}(0.63 \mathrm{mmol}, 39.0 \mathrm{mg})$ was then added via a syringe, followed by the addition of toluene $(10 \mathrm{~mL})$. The reaction was stirred for $4 \mathrm{~h}$ at $60{ }^{\circ} \mathrm{C}$, producing a red solution. The solvent was removed in vacuo, and the residue was washed with pentane $(10 \mathrm{~mL} \times 3)$ and filtered through celite. The volatiles were removed in vacuo to form red solids. The resulting solids were dissolved using a minimum amount of $n$-pentane and the solution was placed in a $32{ }^{\circ} \mathrm{C}$ freezer overnight, resulting in precipitation of red solids. Decanting the supernatant and drying the solids in vacuo provided $99.0 \mathrm{mg} \mathbf{4 b}-\mathrm{SMe}_{2}\left(0.16 \mathrm{mmol}, 81 \%\right.$ yield). ${ }^{1} \mathrm{H}$ NMR (400 $\left.\mathrm{MHz}, \mathrm{C}_{6} \mathrm{D}_{6}\right) \delta 7.11$ (t, $\left.J=7.8 \mathrm{~Hz}, 1 \mathrm{H}, \mathrm{ArH}\right), 6.94(\mathrm{~d}, J=7.8 \mathrm{~Hz}, 1 \mathrm{H}, \mathrm{ArH}), 6.15$ (d, $J=7.8 \mathrm{~Hz}$, $1 \mathrm{H}, \mathrm{ArH}), 2.66(\mathrm{~d}, J=5.2 \mathrm{~Hz}, 3 \mathrm{H}, \mathrm{NMe}), 2.34-2.28(\mathrm{~m}, 2 \mathrm{H}, \mathrm{CH}$ of $i \operatorname{Pr}), 2.24$ (s, 6H, $\mathrm{SMe}_{2}$ ), $2.18-2.08(\mathrm{~m}, 2 \mathrm{H}, \mathrm{CH}$ of $i \mathrm{Pr}), 1.30-1.21\left(\mathrm{~m}, 12 \mathrm{H}, \mathrm{CH}_{3}\right.$ of $\left.i \mathrm{Pr}\right), 1.18\left(\mathrm{~d}, J=7.3 \mathrm{~Hz}, 3 \mathrm{H}, \mathrm{CH}_{3}\right.$ of $i \operatorname{Pr}), 1.14\left(\mathrm{~d}, J=7.2 \mathrm{~Hz}, 3 \mathrm{H}, \mathrm{CH}_{3}\right.$ of $\left.i \mathrm{Pr}\right), 1.08\left(\mathrm{~d}, J=7.0 \mathrm{~Hz}, 3 \mathrm{H}, \mathrm{CH}_{3}\right.$ of $\left.i \operatorname{Pr}\right), 1.05(\mathrm{~d}, J=$ $7.0 \mathrm{~Hz}, 3 \mathrm{H}, \mathrm{CH}_{3}$ of $\left.i \mathrm{Pr}\right) .{ }^{31} \mathrm{P}$ NMR $\left(162 \mathrm{MHz}, \mathrm{C}_{6} \mathrm{D}_{6}\right) \delta 175.8(\mathrm{~d}, J=355.5 \mathrm{~Hz}), 115.0(\mathrm{~d}, J=$ $355.2 \mathrm{~Hz}) .{ }^{13} \mathrm{C}$ NMR $\left(101 \mathrm{MHz}, \mathrm{C}_{6} \mathrm{D}_{6}\right) \delta 165.9\left(\mathrm{dd}, J=11.2,6.5 \mathrm{~Hz}, \mathrm{C}_{\mathrm{Ar}}\right), 160.0(\mathrm{dd}, J=24.6$, $\left.5.9 \mathrm{~Hz}, \mathrm{C}_{\mathrm{Ar}}\right), 135.1\left(\mathrm{t}, J=7.1 \mathrm{~Hz}, \mathrm{C}_{\mathrm{Ar}}\right), 123.7\left(\mathrm{~s}, \mathrm{C}_{\mathrm{Ar}}\right), 102.2\left(\mathrm{~d}, J=12.8 \mathrm{~Hz}, \mathrm{C}_{\mathrm{Ar}}\right), 100.9(\mathrm{dd}, J$ $\left.=12.5,7.3 \mathrm{~Hz}, \mathrm{C}_{\mathrm{Ar}}\right), 33.1$ (t, $J=4.4 \mathrm{~Hz}, \mathrm{CH}_{3}$ of $\left.\mathrm{SMe}_{2}\right), 32.3-31.6(\mathrm{~m}, \mathrm{CH}$ of $i \mathrm{Pr}), 29.8-29.5$ (m, $\mathrm{CH}$ of $\mathrm{CH}_{3}$ ), 29.2 (d, $\left.J=24.1 \mathrm{~Hz}, \mathrm{NMe}\right), 18.8$ (dd, $J=7.8,2.1 \mathrm{~Hz}, \mathrm{CH}_{3}$ of $i \mathrm{Pr}$ ), 18.6 (s, $\mathrm{CH}_{3}$ of $i \mathrm{Pr}$ ), $17.4\left(\mathrm{~s}, \mathrm{CH}_{3}\right.$ of $i \mathrm{Pr}$ ). Anal. Calcd for $\mathrm{C}_{21} \mathrm{H}_{40} \mathrm{IrNOP}_{2} \mathrm{~S}$ : C, 41.43; H, 6.62; N, 2.30; Found: C, 41.41; H,6.69; N, 2.44.

5. Synthesis of (pincer)Ir-TBE ${ }^{11}$

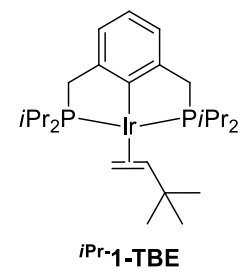

Formation of (pincer)Ir-TBE in situ. A J. Young NMR tube was charged with ${ }^{i P r}$ - $1-\mathrm{HCl}(18.0$ $\mu \mathrm{mol}, 10.0 \mathrm{mg}), \mathrm{NaO} t \mathrm{Bu}(19.8 \mu \mathrm{mol}, 1.9 \mathrm{mg})$, tert-butylethylene $(19.8 \mu \mathrm{mol}, 3.0 \mu \mathrm{L})$ and $\mathrm{C}_{6} \mathrm{D}_{6}$ $(0.4 \mathrm{~mL})$. The tube was shocked by hand at RT. ${ }^{1} \mathrm{H}$ and ${ }^{31} \mathrm{P}$ NMR spectroscopy revealed the formation of ${ }^{i{ }^{2}-1}$-TBE $(80 \%)$. The same procedure was used for synthesis and characterization of $^{i \mathbf{P r}-3-T B E}$ and $\mathbf{4 b}$-TBE. With the exception of ${ }^{i P r}-2-T B E$, we did not isolate the TBE adducts. Attempts to isolate ${ }^{i \mathbf{P r}^{-}} \mathbf{1}-\mathrm{TBE}$ failed, presumably due to facile TBE dissociation from the $14 \mathrm{e}$ (pincer)Ir fragment. However, NMR data of the TBE adducts provided useful information for the purpose of reference. ${ }^{i{ }^{P r}-1}$-TBE: ${ }^{1} \mathrm{H}$ NMR $\left(400 \mathrm{MHz}, \mathrm{C}_{6} \mathrm{D}_{6}\right) \delta 7.35(\mathrm{t}, J=7.0 \mathrm{~Hz}, 2 \mathrm{H}, \mathrm{ArH})$, $7.24(\mathrm{t}, J=7.8 \mathrm{~Hz}, 1 \mathrm{H}, \mathrm{ArH}), 3.81$ (ddt, $J=9.9,4.9,2.1 \mathrm{~Hz}, 1 \mathrm{H}, \mathrm{TBE}), 3.16-3.12(\mathrm{~m}, 1 \mathrm{H}$, TBE), $3.10\left(\mathrm{t}, J=4.1 \mathrm{~Hz}, 4 \mathrm{H}, \mathrm{ArCH}_{2}\right), 2.97(\mathrm{~d}, J=7.7 \mathrm{~Hz}, 1 \mathrm{H}, \mathrm{TBE}), 2.31-2.19(\mathrm{~m}, 2 \mathrm{H}, \mathrm{CH}$ of $i \mathrm{Pr}$ ), $1.96-1.86$ (m, $2 \mathrm{H}, \mathrm{CH}$ of $i \operatorname{Pr}), 1.24$ (q, $J=7.2 \mathrm{~Hz}, 6 \mathrm{H}, \mathrm{CH}_{3}$ of $\left.i \operatorname{Pr}\right), 1.10$ (s, 9H, $\mathrm{CH}_{3}$ of $t \mathrm{Bu}), 0.95\left(\mathrm{dt}, J=14.4,6.8 \mathrm{~Hz}, 12 \mathrm{H}, \mathrm{CH}_{3}\right.$ of $\left.i \mathrm{Pr}\right), 0.85\left(\mathrm{q}, J=6.5 \mathrm{~Hz}, 6 \mathrm{H}, \mathrm{CH}_{3}\right.$ of $\left.i \operatorname{Pr}\right){ }^{31} \mathrm{P}$ 
$\operatorname{NMR}\left(162 \mathrm{MHz}, \mathrm{C}_{6} \mathrm{D}_{6}\right) \delta 49.1(\mathrm{~s}) .{ }^{13} \mathrm{C}$ NMR $\left(101 \mathrm{MHz}, \mathrm{C}_{6} \mathrm{D}_{6}\right) \delta 175.6\left(\mathrm{~s}, \mathrm{C}_{\mathrm{Ar}}\right), 151.4(\mathrm{t}, J=$ $\left.11.0 \mathrm{~Hz}, \mathrm{C}_{\mathrm{Ar}}\right), 127.3\left(\mathrm{~s}, \mathrm{C}_{\mathrm{Ar}}\right), 123.8\left(\mathrm{~s}, \mathrm{C}_{\mathrm{Ar}}\right), 119.4\left(\mathrm{t}, J=8.6 \mathrm{~Hz}, \mathrm{C}_{\mathrm{Ar}}\right), 53.9(\mathrm{~s}, \mathrm{TBE}), 39.0(\mathrm{~s}$, TBE), $38.0(\mathrm{t}, J=15.1 \mathrm{~Hz}, \mathrm{CH}$ of $i \mathrm{Pr}), 35.2(\mathrm{~s}, \mathrm{C}$ of $t \mathrm{Bu}), 30.4\left(\mathrm{~s}, \mathrm{CH}_{3}\right.$ of TBE), $25.4(\mathrm{t}, J=$ $12.5 \mathrm{~Hz}, \mathrm{ArCH}_{2}$ ), 24.0 (t, $J=13.4 \mathrm{~Hz}, \mathrm{ArCH}_{2}$ ), 18.2 (s, $\mathrm{CH}_{3}$ of $\left.i \operatorname{Pr}\right), 17.9$ (s, $\mathrm{CH}_{3}$ of $\left.i \operatorname{Pr}\right), 17.4$ (s, $\mathrm{CH}_{3}$ of $i \mathrm{Pr}$ ), 17.1 (s, $\mathrm{CH}_{3}$ of $i \mathrm{Pr}$ ).

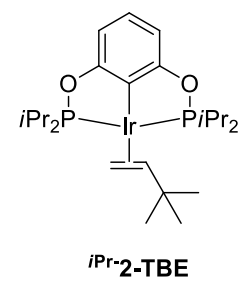

${ }^{i P r}$-2-TBE. ${ }^{i \text { Pr- }}$ 2- $\mathrm{HCl}(0.18 \mathrm{mmol}, 100.0 \mathrm{mg})$ and toluene $(8 \mathrm{~mL})$ were added to a $50 \mathrm{~mL}$ Schlenk flask equipped with a magnetic stir bar. tert-Butylethylene (TBE) $(0.54 \mathrm{mmol}, 45.0 \mathrm{mg})$ was added via syringe, followed by the addition of $\mathrm{NaO} t \mathrm{Bu}(0.29 \mathrm{mmol}, 28.0 \mathrm{mg})$. The reaction was stirred for $30 \mathrm{~min}$ at RT, producing a red solution. The solvent was removed in vacuo, and the residue was washed with pentane $(10 \mathrm{~mL} \times 3)$ and filtered through celite. The volatiles were then removed in vacuo, resulting in formation of red solids. The resulting solid was dissolved in a minimum of pentane and placed in a $-32{ }^{\circ} \mathrm{C}$ freezer overnight, resulting in precipitation of solids. Decanting the supernatant and drying the solids in vacuo provided $63.0 \mathrm{mg}$ of ${ }^{i \operatorname{Pr}-2}$-TBE

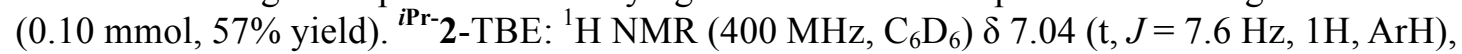
$6.94(\mathrm{~d}, J=7.9 \mathrm{~Hz}, 2 \mathrm{H}, \mathrm{ArH}), 4.27(\mathrm{~d}, J=9.3 \mathrm{~Hz}, 1 \mathrm{H}, \mathrm{TBE}), 3.70(\mathrm{dt}, J=11.6,5.6 \mathrm{~Hz}, 1 \mathrm{H}$, TBE), 2.94 (d, $J=8.6 \mathrm{~Hz}, 1 \mathrm{H}, \mathrm{TBE}), 2.57$ (p, $J=7.3 \mathrm{~Hz}, 2 \mathrm{H}, \mathrm{CH}$ of $i \operatorname{Pr}), 2.32(\mathrm{p}, J=7.3 \mathrm{~Hz}$, $2 \mathrm{H}, \mathrm{CH}$ of $i \mathrm{Pr}$ ), $1.28-1.16\left(\mathrm{~m}, 12 \mathrm{H}, \mathrm{CH}_{3}\right.$ of $\left.i \mathrm{Pr}\right), 1.13$ (s, 9H, $\mathrm{CH}_{3}$ of TBE), $1.09-0.91$ (m, $12 \mathrm{H}, \mathrm{CH}_{3}$ of $\left.i \mathrm{Pr}\right) .{ }^{31} \mathrm{P}$ NMR $\left(162 \mathrm{MHz}, \mathrm{C}_{6} \mathrm{D}_{6}\right) \delta 173.0 .{ }^{13} \mathrm{C}$ NMR $\left(101 \mathrm{MHz}, \mathrm{C}_{6} \mathrm{D}_{6}\right) \delta 167.4(\mathrm{t}, J$ $\left.=8.6 \mathrm{~Hz}, \mathrm{C}_{\mathrm{Ar}}\right), 143.5\left(\mathrm{t}, J=8.4 \mathrm{~Hz}, \mathrm{C}_{\mathrm{Ar}}\right), 103.4\left(\mathrm{t}, J=6.1 \mathrm{~Hz}, \mathrm{C}_{\mathrm{Ar}}\right), 67.8(\mathrm{~s}, \mathrm{TBE}), 38.1(\mathrm{~s}, \mathrm{TBE})$, 34.0 (s, TBE), 30.8 (d, $J=14.3 \mathrm{~Hz}, \mathrm{CH}$ of $i \mathrm{Pr}), 30.6$ (s, $\mathrm{CH}_{3}$ of TBE), $18.0\left(\mathrm{~s}, \mathrm{CH}_{3}\right.$ of $\left.i \mathrm{Pr}\right), 16.9$ (s, $\mathrm{CH}_{3}$ of $i \mathrm{Pr}$ ). Anal. Calcd for $\mathrm{C}_{24} \mathrm{H}_{43} \mathrm{IrO}_{2} \mathrm{P}_{2}$ : C, 46.66; H, 7.02; Found: C, 46.11; H, 7.12.

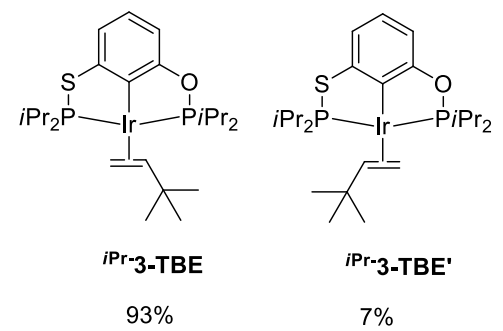

Formation of ${ }^{i \mathrm{Pr}-} \mathbf{3}-\mathrm{TBE}$ in situ. A J. Young NMR tube was charged with ${ }^{i \mathrm{Pr}-\mathbf{3}-\mathrm{HCl}}(17.1 \mu \mathrm{mol}$, $10.0 \mathrm{mg}), \mathrm{NaO} t \mathrm{Bu}(19.8 \mu \mathrm{mol}, 1.9 \mathrm{mg})$, tert-butylethylene $(18.8 \mu \mathrm{mol}, 2.5 \mu \mathrm{L})$ and $\mathrm{C}_{6} \mathrm{D}_{6}(0.4$ $\mathrm{mL})$. The tube was shocked by hand at RT. ${ }^{1} \mathrm{H}$ and ${ }^{31} \mathrm{P}$ NMR spectroscopy revealed the formation of two isomers ${ }^{i \mathbf{P r}} \mathbf{3}$-TBE (93\%) and ${ }^{{ }^{i P r}-3}$-TBE' $(7 \%)$ due to the asymmetric nature of the pincer ligand. ${ }^{i \text { Pr- } 3-T B E: ~}{ }^{1} \mathrm{H}$ NMR $\left(400 \mathrm{MHz}, \mathrm{C}_{6} \mathrm{D}_{6}\right) \delta 7.40(\mathrm{~d}, J=7.4 \mathrm{~Hz}, 1 \mathrm{H}, \mathrm{ArH}), 6.97(\mathrm{~d}$, $J=7.7 \mathrm{~Hz}, 1 \mathrm{H}, \mathrm{ArH}), 6.91(\mathrm{t}, J=7.7 \mathrm{~Hz}, 1 \mathrm{H}, \mathrm{ArH}), 3.86(\mathrm{dtq}, J=10.0,5.0,2.6,2.1 \mathrm{~Hz}, 1 \mathrm{H}$, TBE), 3.14 (dt, $J=10.1,6.1 \mathrm{~Hz}, 1 \mathrm{H}, \mathrm{TBE}), 2.75(\mathrm{~d}, J=7.6 \mathrm{~Hz}, 1 \mathrm{H}, \mathrm{TBE}), 2.58-2.47(\mathrm{~m}, 1 \mathrm{H}$, CH of $i \mathrm{Pr}), 2.44-2.35(\mathrm{~m}, 1 \mathrm{H}, \mathrm{CH}$ of $i \mathrm{Pr}), 2.30-2.21(\mathrm{~m}, 1 \mathrm{H}, \mathrm{CH}$ of $i \mathrm{Pr}), 2.18-2.08(\mathrm{~m}, 1 \mathrm{H}$, $\mathrm{CH}$ of $i \mathrm{Pr}), 1.34\left(\mathrm{dd}, J=16.6,7.0 \mathrm{~Hz}, 6 \mathrm{H}, \mathrm{CH}_{3}\right.$ of $\left.i \mathrm{Pr}\right), 1.23\left(\mathrm{dd}, J=7.3,4.0 \mathrm{~Hz}, 3 \mathrm{H}, \mathrm{CH}_{3}\right.$ of $i \operatorname{Pr}), 1.21-1.18\left(\mathrm{~m}, 3 \mathrm{H}, \mathrm{CH}_{3}\right.$ of $\left.i \mathrm{Pr}\right), 1.12\left(\mathrm{~d}, J=6.8 \mathrm{~Hz}, 3 \mathrm{H}, \mathrm{CH}_{3}\right.$ of $\left.i \mathrm{Pr}\right), 1.06\left(\mathrm{~s}, 9 \mathrm{H}, \mathrm{CH}_{3}\right.$ of $t \mathrm{Bu}), 1.00\left(\mathrm{dd}, J=10.4,3.3 \mathrm{~Hz}, 3 \mathrm{H}, \mathrm{CH}_{3}\right.$ of $\left.i \mathrm{Pr}\right), 0.95\left(\mathrm{~d}, J=2.9 \mathrm{~Hz}, 3 \mathrm{H}, \mathrm{CH}_{3}\right.$ of $\left.i \mathrm{Pr}\right), 0.90(\mathrm{~d}$, $J=7.6 \mathrm{~Hz}, 3 \mathrm{H}, \mathrm{CH}_{3}$ of $\left.i \mathrm{Pr}\right) .{ }^{31} \mathrm{P} \mathrm{NMR}\left(162 \mathrm{MHz}, \mathrm{C}_{6} \mathrm{D}_{6}\right) \delta 166.9(\mathrm{~d}, J=349.9 \mathrm{~Hz}), 95.5(\mathrm{~d}, J=$ $349.9 \mathrm{~Hz}) .{ }^{13} \mathrm{C}$ NMR $\left(101 \mathrm{MHz}, \mathrm{C}_{6} \mathrm{D}_{6}\right) \delta 167.2\left(\mathrm{dd}, J=9.9,7.9 \mathrm{~Hz}, \mathrm{C}_{\mathrm{Ar}}\right), 162.6(\mathrm{t}, J=7.2 \mathrm{~Hz}$, $\left.\mathrm{C}_{\mathrm{Ar}}\right), 155.0\left(\mathrm{dd}, J=15.1,7.9 \mathrm{~Hz}, \mathrm{C}_{\mathrm{Ar}}\right), 126.6\left(\mathrm{~s}, \mathrm{C}_{\mathrm{Ar}}\right), 114.6\left(\mathrm{~d}, J=12.2 \mathrm{~Hz}, \mathrm{C}_{\mathrm{Ar}}\right), 106.3(\mathrm{~d}, J=$ $\left.13.5 \mathrm{~Hz}, \mathrm{C}_{\mathrm{Ar}}\right), 56.4(\mathrm{~s}, \mathrm{TBE}), 40.2(\mathrm{~s}, \mathrm{TBE}), 38.5(\mathrm{~s}, \mathrm{TBE}), 35.5$ (s, TBE), $31.0(\mathrm{~s}, \mathrm{TBE}), 30.7$ (dd, $J=27.9,3.3 \mathrm{~Hz}, \mathrm{CH}$ of $i \operatorname{Pr}$ ), 30.1 (d, $J=19.6 \mathrm{~Hz}, \mathrm{CH}$ of $i \operatorname{Pr}$ ), 29.7 (dd, $J=27.7,5.5 \mathrm{~Hz}$, 
CH of $i \mathrm{Pr}$ ), 28.9 (dd, $J=19.4,3.0 \mathrm{~Hz}, \mathrm{CH}$ of $i \mathrm{Pr}$ ), 22.5 (s, $\mathrm{CH}_{3}$ of $i \mathrm{Pr}$ ), 19.0 (d, $J=5.0 \mathrm{~Hz}, \mathrm{CH}_{3}$ of $i \operatorname{Pr}), 18.3$ (d, $J=4.2 \mathrm{~Hz}, \mathrm{CH}_{3}$ of $\left.i \operatorname{Pr}\right), 17.9\left(\mathrm{~d}, J=2.2 \mathrm{~Hz}, \mathrm{CH}_{3}\right.$ of $\left.i \operatorname{Pr}\right), 17.7$ (d, $J=5.1 \mathrm{~Hz}$, $\mathrm{CH}_{3}$ of $i \mathrm{Pr}$ ), 17.0 (s, $\mathrm{CH}_{3}$ of $\left.i \mathrm{Pr}\right), 16.8-16.3\left(\mathrm{~m}, \mathrm{CH}_{3}\right.$ of $\left.i \mathrm{Pr}\right)$.

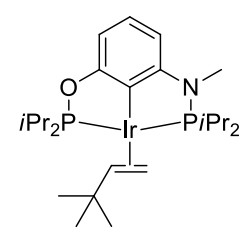

4b-TBE

$91 \%$

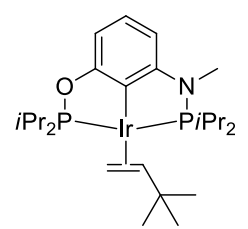

4b-TBE'

$9 \%$

Formation of $\mathbf{4 b}-\mathbf{T B E}$ in situ. A J. Young NMR tube was charged with $\mathbf{4 b}-\mathrm{HCl}(17.2 \mu \mathrm{mol}$, $10 \mathrm{mg}), \mathrm{NaO} t \mathrm{Bu}(19.8 \mu \mathrm{mol}, 1.9 \mathrm{mg})$, tert-butylethylene $(18.8 \mu \mathrm{mol}, 2.5 \mu \mathrm{L})$ and $\mathrm{C}_{6} \mathrm{D}_{6}(0.4$ $\mathrm{mL})$. The tube was shocked by hand at RT. ${ }^{1} \mathrm{H}$ and ${ }^{31} \mathrm{P}$ NMR spectroscopy revealed the formation of two isomers $4 \mathbf{b}$-TBE (91\%) and 4b-TBE' (9\%) due to the asymmetric nature of the pincer ligand. 4b-TBE: ${ }^{1} \mathrm{H}$ NMR $\left(400 \mathrm{MHz}, \mathrm{C}_{6} \mathrm{D}_{6}\right) \delta 7.19(\mathrm{~d}, J=8.5 \mathrm{~Hz}, 1 \mathrm{H}, \mathrm{ArH}), 7.02(\mathrm{~d}, J=$ $8.0 \mathrm{~Hz}, 1 \mathrm{H}, \mathrm{ArH}), 6.18(\mathrm{~d}, J=7.8 \mathrm{~Hz}, 1 \mathrm{H}, \mathrm{ArH}), 4.13$ (q, $J=9.1 \mathrm{~Hz}, 1 \mathrm{H}, \mathrm{TBE}), 3.68(\mathrm{t}, J=$ $10.1 \mathrm{~Hz}, 1 \mathrm{H}, \mathrm{TBE}), 3.04(\mathrm{~d}, J=8.6 \mathrm{~Hz}, 1 \mathrm{H}, \mathrm{TBE}), 2.88-2.78$ (m, 1H, CH of $i \mathrm{Pr}), 2.71-2.64$ (m, $1 \mathrm{H}, \mathrm{CH}$ of $i \mathrm{Pr}), 2.56$ (d, $J=5.1 \mathrm{~Hz}, 3 \mathrm{H}, \mathrm{NMe}), 2.40-2.20(\mathrm{~m}, 2 \mathrm{H}, \mathrm{CH}$ of $i \operatorname{Pr}), 1.25(\mathrm{~d}, J$ $=18.8 \mathrm{~Hz}, 12 \mathrm{H}, \mathrm{CH}_{3}$ of $\left.i \operatorname{Pr}\right), 1.18\left(\mathrm{~s}, 9 \mathrm{H}, \mathrm{CH}_{3}\right.$ of $\left.t \mathrm{Bu}\right), 1.05\left(\mathrm{~s}, 12 \mathrm{H}, \mathrm{CH}_{3}\right.$ of $\left.i \mathrm{Pr}\right) .{ }^{31} \mathrm{P} \mathrm{NMR}(162$ $\left.\mathrm{MHz}, \mathrm{C}_{6} \mathrm{D}_{6}\right) \delta 172.0(\mathrm{~d}, J=349.0 \mathrm{~Hz}), 107.4(\mathrm{~d}, J=349.0 \mathrm{~Hz}){ }^{13} \mathrm{C}$ NMR $\left(101 \mathrm{MHz}, \mathrm{C}_{6} \mathrm{D}_{6}\right) \delta$ 167.1 (dd, $\left.J=10.6,6.0 \mathrm{~Hz}, \mathrm{C}_{\mathrm{Ar}}\right), 161.0\left(\mathrm{~d}, J=23.2 \mathrm{~Hz}, \mathrm{C}_{\mathrm{Ar}}\right), 142.5\left(\mathrm{~s}, \mathrm{C}_{\mathrm{Ar}}\right), 126.5\left(\mathrm{~s}, \mathrm{C}_{\mathrm{Ar}}\right)$, $102.0\left(\mathrm{~d}, J=12.8 \mathrm{~Hz}, \mathrm{C}_{\mathrm{Ar}}\right), 100.9\left(\mathrm{~d}, J=12.1 \mathrm{~Hz}, \mathrm{C}_{\mathrm{Ar}}\right), 67.6(\mathrm{~s}, \mathrm{TBE}), 37.5(\mathrm{~s}, \mathrm{TBE}), 33.7$ (s, $\mathrm{C}$ of $t \mathrm{Bu}), 33.0(\mathrm{~d}, J=4.9 \mathrm{~Hz}, \mathrm{CH}$ of $i \mathrm{Pr}), 30.7(\mathrm{~d}, J=3.0 \mathrm{~Hz}, \mathrm{NMe}), 30.5\left(\mathrm{~s}, \mathrm{CH}_{3}\right.$ of $\left.t \mathrm{Bu}\right), 22.7$ (d, $J=11.5 \mathrm{~Hz}, \mathrm{CH}_{3}$ of $\left.i \operatorname{Pr}\right), 17.9$ (d, $J=25.9 \mathrm{~Hz}, \mathrm{CH}_{3}$ of $i \operatorname{Pr}$ ). 
VI. Additional experiment and spectroscopic data.

1. Studies on the resting state for the COA/TBE TD.

A J. Young NMR tubes was charged with ${ }^{i \mathbf{P r}-1}-\mathrm{HCl}(17.7 \mu \mathrm{mol}, 10.0 \mathrm{mg}), \mathrm{NaO} t \mathrm{Bu}(1.5$ equiv relative to $\left.{ }^{i \mathbf{P r}-1} \mathbf{- H C l} 26.5 \mu \mathrm{mol}, 2.5 \mathrm{mg}\right)$, cyclooctane $(0.25 \mathrm{~mL})$, TBE $(0.25 \mathrm{~mL})$, and a capillary containing an external standard solution. The NMR tube was sealed and brought out of glovebox. The NMR tube was gently shocked by hand at RT. After that, the sample was placed into a $200{ }^{\circ} \mathrm{C}$ oil bath. The sample was monitored periodically by ${ }^{31} \mathrm{P}$ NMR spectroscopy.

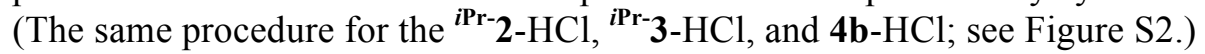

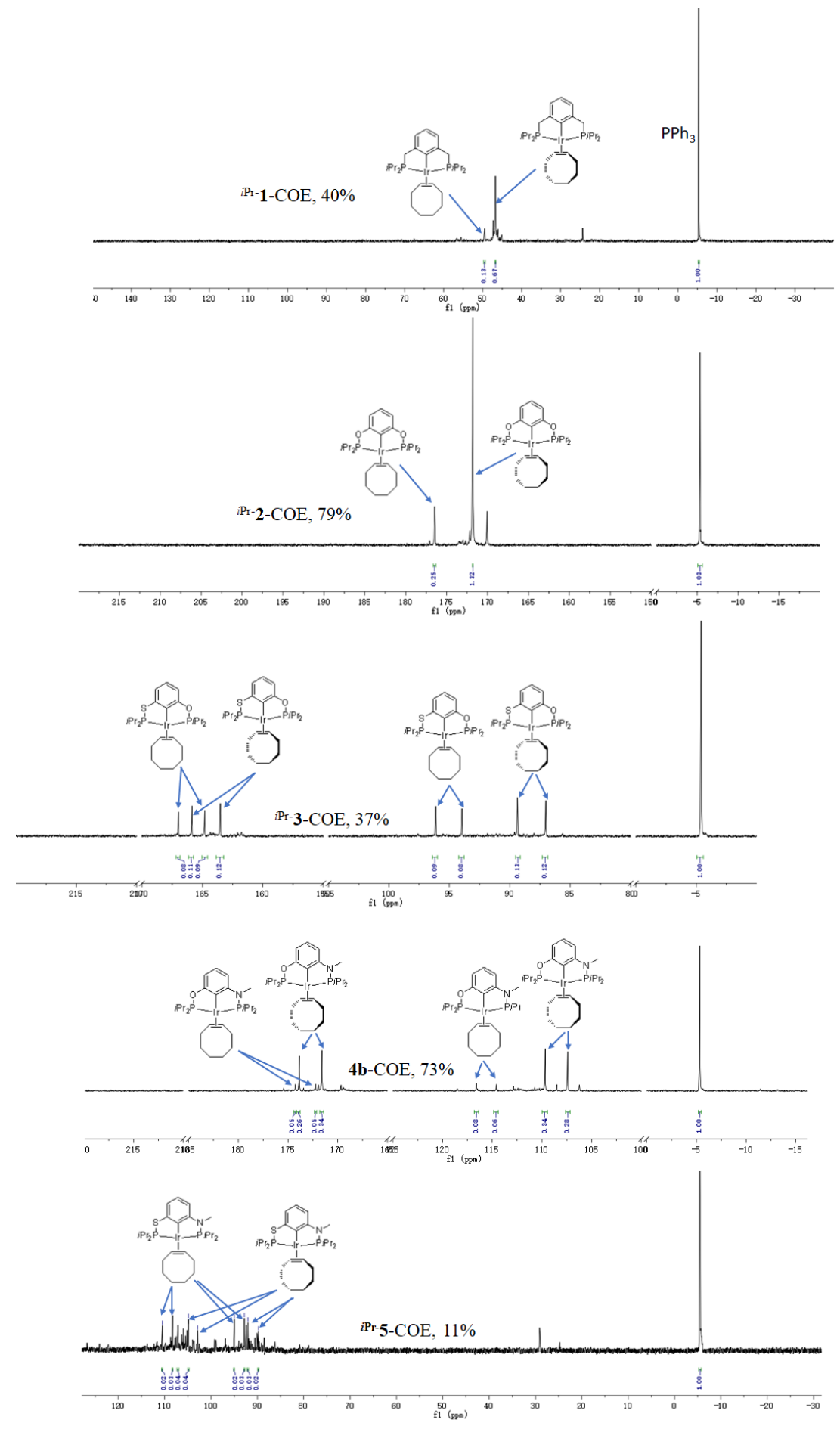

Figure S2. Studies on the resting state for the COA/TBE TD 
2. Studies on the equilibrium between (pincer) Ir-COE and $\mathrm{Me}_{2} \mathrm{~S}$.

A J. Young NMR tubes was charged with ${ }^{i \mathbf{P r}} \mathbf{1}-\mathrm{COE}(8.8 \mu \mathrm{mol}, 5.7 \mathrm{mg})$, cyclooctene (400 equiv relative to $\left.{ }^{i \mathbf{P r}-1}-\mathrm{COE}\right), \mathrm{Me}_{2} \mathrm{~S}$ (4 equiv relative to $\left.{ }^{i \mathbf{P r}}{ }^{-1}-\mathrm{COE}\right), \mathrm{C}_{6} \mathrm{D}_{6}(0.2 \mathrm{~mL}$ ), and a capillary containing an external standard solution. The NMR tube was sealed with a Teflon plug and brought out of glovebox. After that, the sample was placed into a $55^{\circ} \mathrm{C}$ oil bath. The sample was monitored by ${ }^{31} \mathrm{P}$ NMR spectroscopy. (The same procedure, but with different amounts of $\mathrm{COE}$, was used for the studies of ${ }^{i \mathbf{P r}-2}-\mathrm{COE},{ }^{i \mathbf{P r}} \mathbf{3}-\mathrm{COE}$, and $\mathbf{4 b}-\mathrm{COE}$; see Figure S3.)
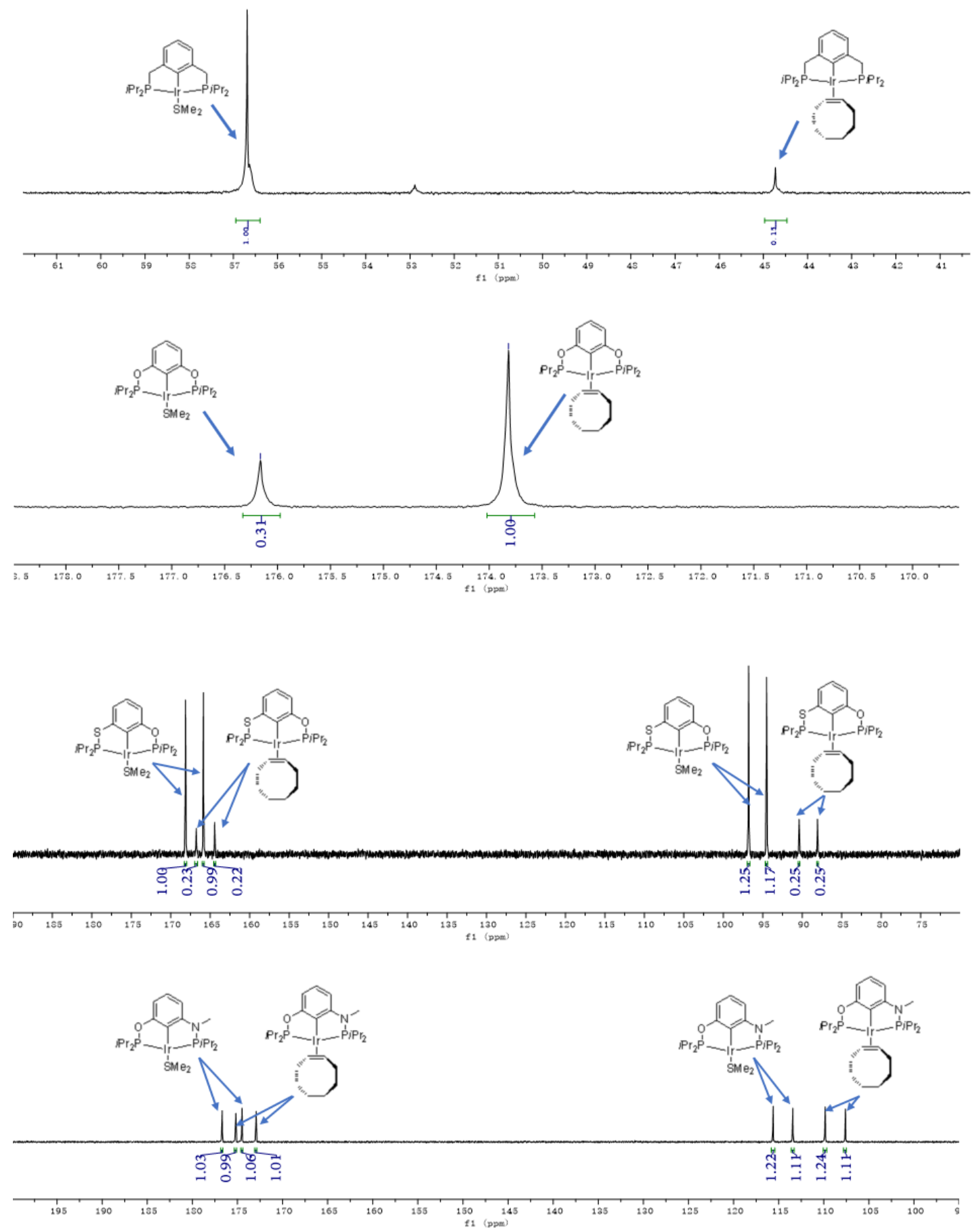

Figure S3. Studies on the equilibrium between (pincer)Ir-COE and $\mathrm{Me}_{2} \mathrm{~S}$. 
When we treated ${ }^{i P r}$-5- $\mathrm{HCl}(8.8 \mu \mathrm{mol}, 5.3 \mathrm{mg})$ with $\mathrm{NaO} t \mathrm{Bu}(9.4 \mu \mathrm{mol}, 0.9 \mathrm{mg}), \mathrm{COE}(0.9$ mmol, $99.0 \mathrm{mg})$ in $\mathrm{C}_{6} \mathrm{D}_{6}(0.4 \mathrm{~mL}),{ }^{31} \mathrm{P}$ NMR spectroscopy showed the formation of an unidentified species in addition to ${ }^{i \mathbf{P r}-5}$-(COE), suggesting the ${ }^{i \mathrm{Pr}^{-}} \mathbf{5}-(\mathrm{COE})$ is unstable under the reaction conditions. Because of its low stability, we were unable to measure the equilibrium constant for the exchange of Ir-bound COE with $\mathrm{Me}_{2} \mathrm{~S}$ (Figure S4).

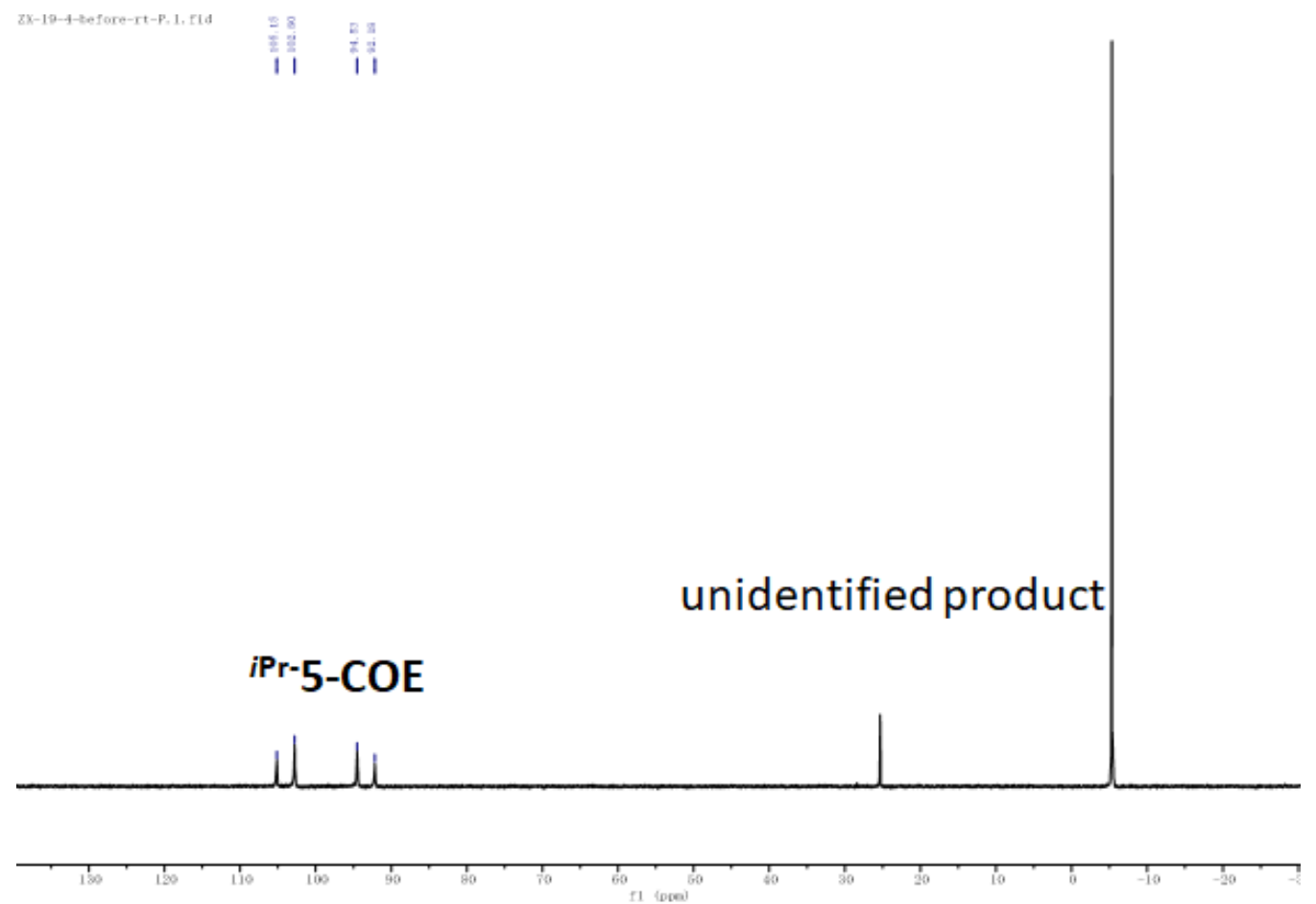

Figure S4. ${ }^{31} \mathrm{P}$ NMR spectrum of the reaction of ${ }^{i \mathrm{Pr}-5}-\mathrm{HCl}, \mathrm{NaO} t \mathrm{Bu}$, and $\mathrm{COE}$ in $\mathrm{C}_{6} \mathrm{D}_{6}$. 
3. Studies on the thermostability of (pincer)Ir-COE.

A J. Young NMR tubes was charged with ${ }^{i P r}$ - $1-H C l(17.7 \mu \mathrm{mol}, 10.0 \mathrm{mg}), \mathrm{NaO} t \mathrm{Bu}(19.8$ $\mu \mathrm{mol}, 1.9 \mathrm{mg})$, cyclooctene $(0.34 \mathrm{mmol}, 37.0 \mathrm{mg})$, cyclooctane $(0.4 \mathrm{~mL})$, and a capillary containing an external standard solution. The NMR tube was sealed and brought out of glovebox. The NMR tube was gently shocked by hand at RT condition. Analysis via ${ }^{31} \mathrm{P}$ NME spectroscopy revealed quantitative formation of ${ }^{i \mathbf{P r}-1}$-COE. After that, the sample was placed into a $200{ }^{\circ} \mathrm{C}$ oil bath. The sample was monitored by ${ }^{31} \mathrm{P}$ NMR spectroscopy. (The same procedure was used for ${ }^{i \mathbf{P r}-2}-\mathrm{HCl},{ }^{i \mathbf{P r}} \mathbf{3}-\mathrm{HCl}, \mathbf{4} \mathbf{b}-\mathrm{HCl}$, and ${ }^{i{ }^{i P r}-} \mathbf{5}-\mathrm{HCl}$; see Figure $\mathrm{S} 5$ and results in Table S1.)
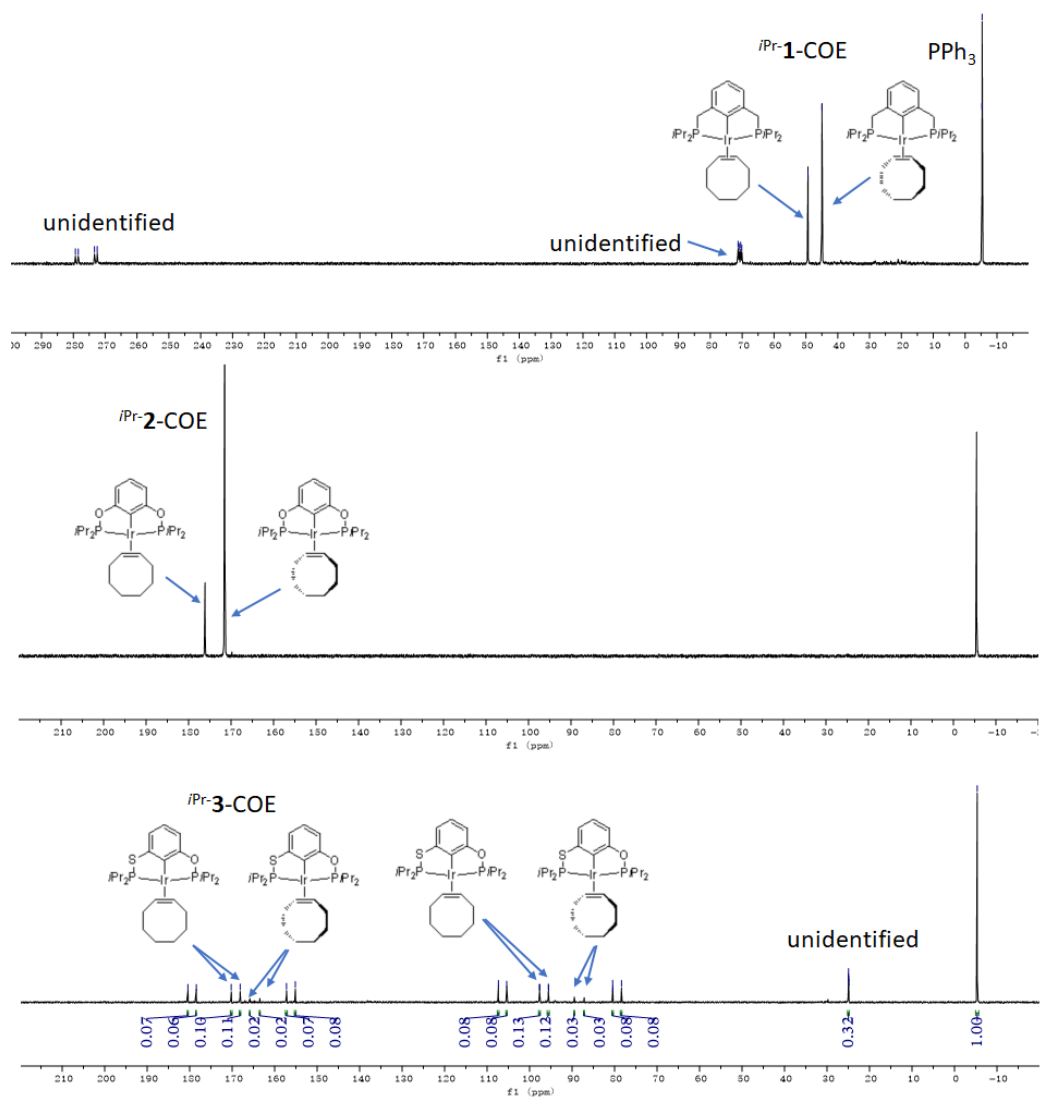

4b-COE
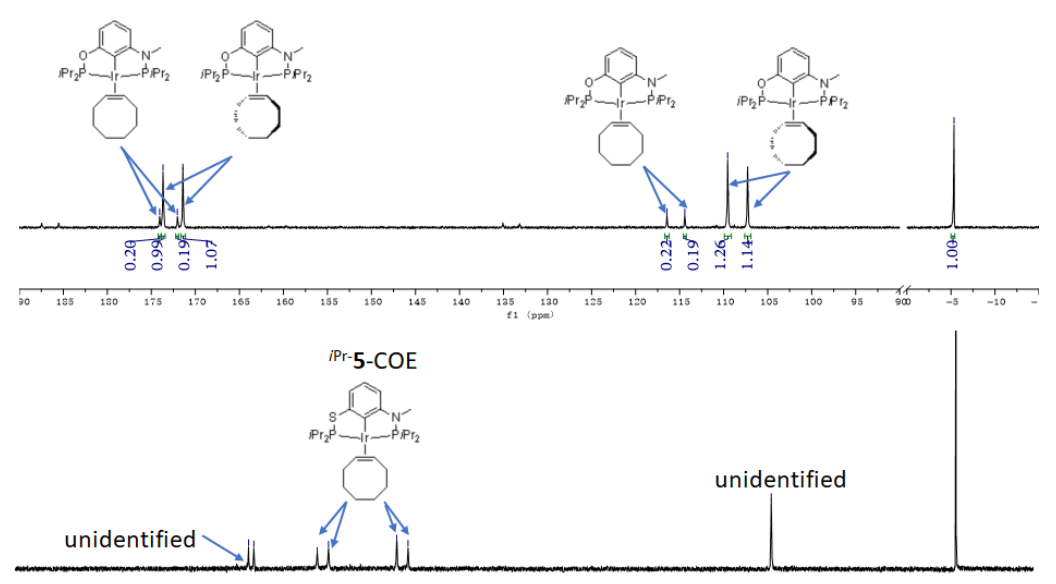

Figure S5. Studies on the thermostability of (pincer)Ir-COE. 
Table S1. Percentages on the iridium species formed by thermolysis of (pincer)Ir-COE.

\begin{tabular}{|c|c|c|c|c|c|c|c|c|c|c|c|c|c|c|c|c|c|}
\hline \multirow{2}{*}{ entry $^{a}$} & \multirow{2}{*}{$\mathrm{T} /{ }^{\circ} \mathrm{C}$} & \multirow{2}{*}{$\mathrm{t} / \mathrm{min}$} & \multicolumn{3}{|c|}{ iPr-2-COE / mM } & \multicolumn{3}{|c|}{$4 \mathrm{~b}-\mathrm{COE} / \mathrm{mM}$} & \multicolumn{3}{|c|}{ iPr-3-COE / mM } & \multicolumn{3}{|c|}{${ }^{i P r}-5-C O E / m M$} & \multicolumn{3}{|c|}{${ }^{i P r}-1-C O E / m M$} \\
\hline & & & perp. & cop. & un. & perp. & cop. & un. & perp. & cop. & un. & perp. & cop. & un. & perp. & . cop. & un. \\
\hline 1 & rt. & 30 & 40.0 & 0.0 & 0.0 & 40.0 & 0.0 & 0.0 & 40.0 & 0.0 & 0.0 & 20.0 & 0.0 & 0.0 & 40.0 & 0.0 & 0.0 \\
\hline 2 & 200 & 5 & 33.0 & 7.0 & 0.0 & 31.0 & 9.0 & 0.0 & 2.0 & 12.0 & 9.0 & 0.0 & 8.0 & 8.0 & 10.0 & 5.0 & 11.0 \\
\hline 3 & 200 & 20 & 27.0 & 7.0 & 0.0 & 28.0 & 6.0 & 0.0 & 0.0 & 7.0 & 17.0 & 0.0 & 0.0 & 15.0 & 2.0 & 7.0 & 20.0 \\
\hline
\end{tabular}

4. Studies on the isomerization of (pincer)Ir-COE and (pincer)Ir-CPE.

A J. Young NMR tube was charged with ${ }^{i P r} \mathbf{2}-\mathrm{HCl}(11.9 \mu \mathrm{mol}, 6.8 \mathrm{mg}), \mathrm{NaO} t \mathrm{Bu}(18.7$ umol, $1.8 \mathrm{mg})$, cycloheptene $(0.21 \mathrm{mmol}, 20.0 \mathrm{mg})$, cycloheptane $(0.4 \mathrm{~mL})$ and a capillary containing external standard solution. The NMR tube was gently shocked by hand at RT. After that, the sample was monitored by ${ }^{31} \mathrm{P}$ NMR spectroscopy (Figure S6).
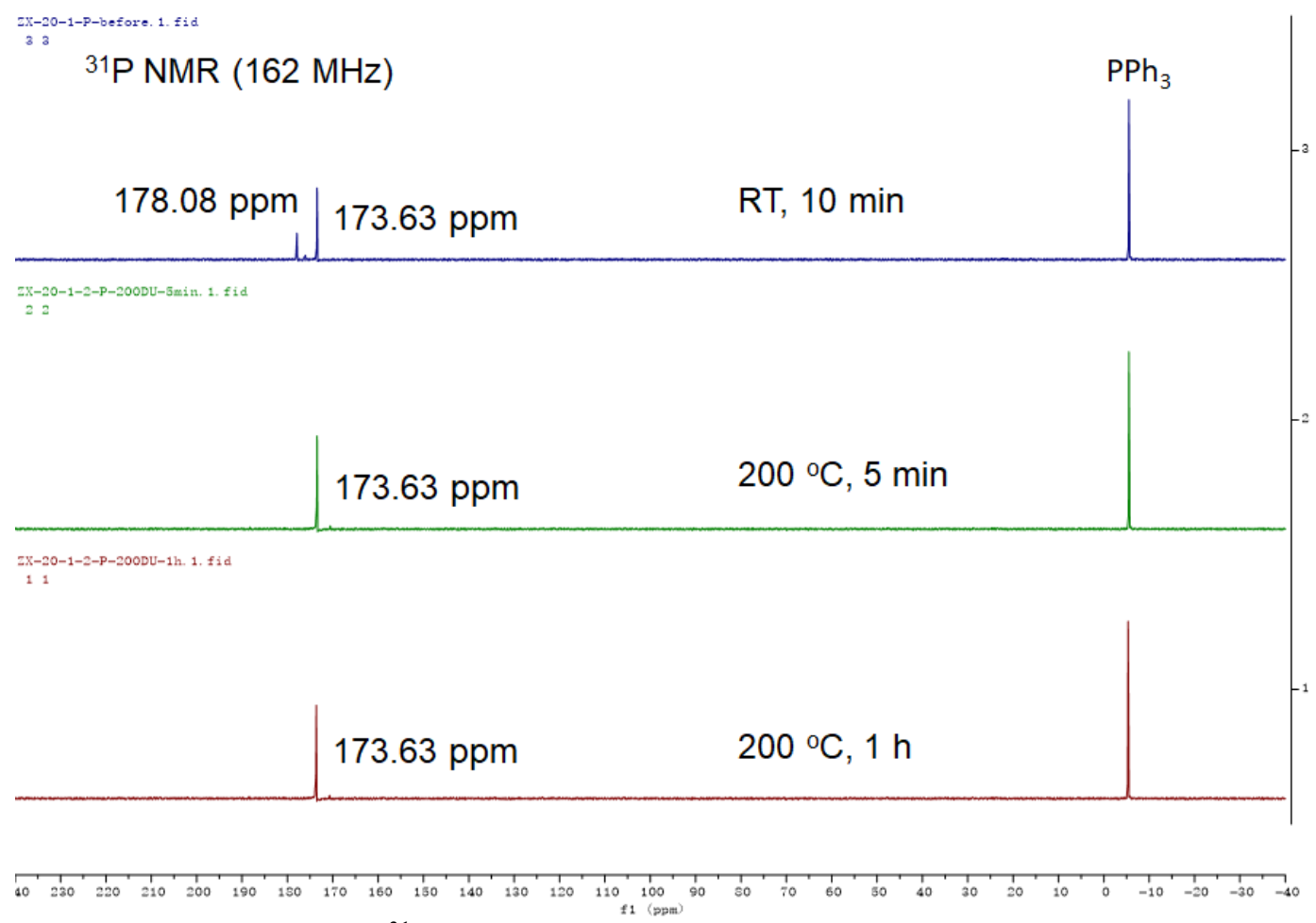

Figure S6. Monitored by ${ }^{31} \mathrm{P}$ NMR (162 MHz) in cycloheptene. 
A J. Young NMR tube was charged with ${ }^{i P r}-2-\mathrm{HCl}(17.5 \mu \mathrm{mol}, 10.0 \mathrm{mg}), \mathrm{NaO} t \mathrm{Bu}(26.0$ $\mu \mathrm{mol}, 2.5 \mathrm{mg})$, cyclooctene $(0.33 \mathrm{mmol}, 36.0 \mathrm{mg})$, cyclooctane $(0.4 \mathrm{~mL})$, and a capillary containing and external standard solution. The tube was shocked gently. After that, the tube was monitored by ${ }^{31} \mathrm{P}$ NMR spectroscopy under different conditions (Figure S7).

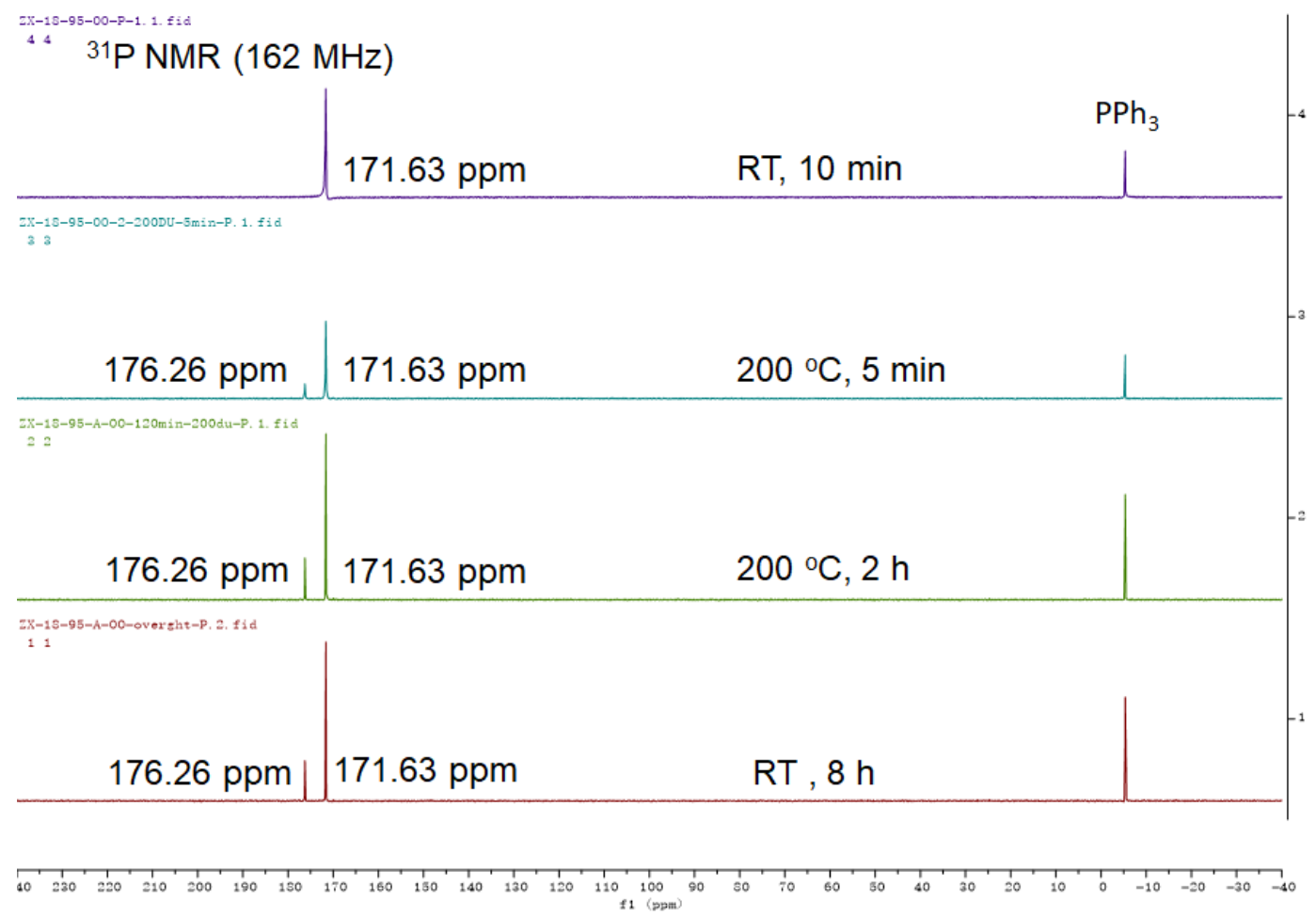

Figure S7. Monitored by ${ }^{31} \mathrm{P}$ NMR (162 MHz) in cyclooctane.

Table S2. Comparison of the key bond distances and angles of 5-coordinate, $t \mathrm{Bu}$-substituted Ir(III) hydrido chloride complexes.

\begin{tabular}{lllll}
\hline$t$ Bu-5-HCl & tBu-3-HCl & $t$ Bu-1-HCl & 4a-HCl & $t$ Bu-2-HCl \\
\hline $\mathrm{S}-\mathrm{P}=2.070(3)$ & $\mathrm{S}-\mathrm{P}=2.123(3)$ & $\mathrm{C}-\mathrm{P}=1.888(5)$ & $\mathrm{N}-\mathrm{P}=1.707(2)$ & $\mathrm{O}-\mathrm{P}=1.662(3)$ \\
$\mathrm{C}_{\mathrm{Ar}}-\mathrm{S}=1.711(7)$ & $\mathrm{C}_{\mathrm{Ar}-\mathrm{S}=1.772(7)}$ & $\mathrm{C}_{\mathrm{Ar}}-\mathrm{C}=1.509(8)$ & $\mathrm{C}_{\mathrm{Ar}}-\mathrm{N}=1.408(4)$ & $\mathrm{C}$ Ar $-\mathrm{O}=1.399(5)$
\end{tabular}

$P(1)-\operatorname{Ir} 1-P(2)=170.39(5) \quad P(1)-\operatorname{Ir} 1-P(2)=168.32(3) \quad P(1)-\operatorname{Ir} 1-P(2)=164.27(4) \quad P(1)-\operatorname{Ir} 1-P(2)=161.87(3) \quad P(1)-\operatorname{Ir} 1-P(2)=160.06(4)$ 


\section{References}

1. Herde, J. L.; Lambert, J. C.; Senoff, C. V.; Cushing, M. A. Cyclooctene and 1,5-Cyclooctadiene Complexes of Iridium (I). Inorg. Synth. 1974, 15, 18.

2. Mucha, N. T.; Waterman, R. Iridium Pincer Catalysts for Silane Dehydrocoupling: Ligand effects on Selectivity and Activity. Organometallics 2015, 34, 3865-3872.

3. Yao, W.; Zhang, Y.; Jia, X.; Huang, Z. Selective Catalytic Transfer Dehydrogenation of Alkanes and Heterocycles by an Iridium Pincer Complex. Angew. Chem., Int. Ed. 2014, 53, 1390-1394.

4. Sheldrick, G. M. SADABS: Program for Empirical Absorption Correction of Area Detector Data; University of Gottingen: Germany, 1996.

5. Dolomanov, O.V., Bourhis, L.J., Gildea, R.J, Howard, J.A.K. \& Puschmann, H. OLEX2: A Complete Structure Solution, Refinement and Analysis Program. J. Appl. Cryst. 2009, 42, 339-341.

6. Sheldrick, G. M. SHELXT-Integrated Space-Group and Crystal-Structure Determination. Acta Cryst. 2015, A71, 3-8.

7. Tsai, C. S.; Liu, P. Y.; Wong, C. H. Development of Trifunctional Probes for Glycoproteomic Analysis. Chem. Commun. 2010, 46, 5575-5577.

8. Eunyoung. Byun.; Bomi. Hong.; Hakjune. Rhee.;One-Pot reductive Mono-N-alkylation of Aniline and Nitroarene Derivatives Using Aldehydes. J. Org. Chem. 2007, 25, 9815-9817.

9. (a) Abdessamad, E. A.; Frederic, S.; Mohamed; Marianne, S.; Didier, D.; Claude, F. J.; Ludger, J. Shiga ToxinMediated Retrograde Delivery of a Topoisomerase I Inhibitor Prodrug. Angew. Chem. Int. Ed. 2007, 46, 6469-6472. (b) Puig-de-la-Bellacasa, R.; Teixidó, J. Diverse combinatorial design, synthesis and in vitro evaluation of new HEPT analogues as potential non-nucleoside HIV-1 reverse transcription inhibitors. Eur. J. Med. Chem. 2012, 54, 159-174. 10. Göttker-Schnetmann, I.; White, P. S.; Brookhart, M. Iridium Bis(phosphinite) p-XPCP Pincer Complexes: Highly Active Catalysts for the Transfer Dehydrogenation of Alkanes. J. Am. Chem. Soc. 2004, 126, 1804-1811. 11. Press, L. P.; Kosanovich, A. J.; McCulloch, B. J.; Ozerov, O. V. High-Turnover Aromatic C-H Borylation Catalyzed by POCOP-Type Pincer Complexes of Iridium. J. Am. Chem. Soc. 2016, 138, 9487-9497.

\section{NMR spectra}

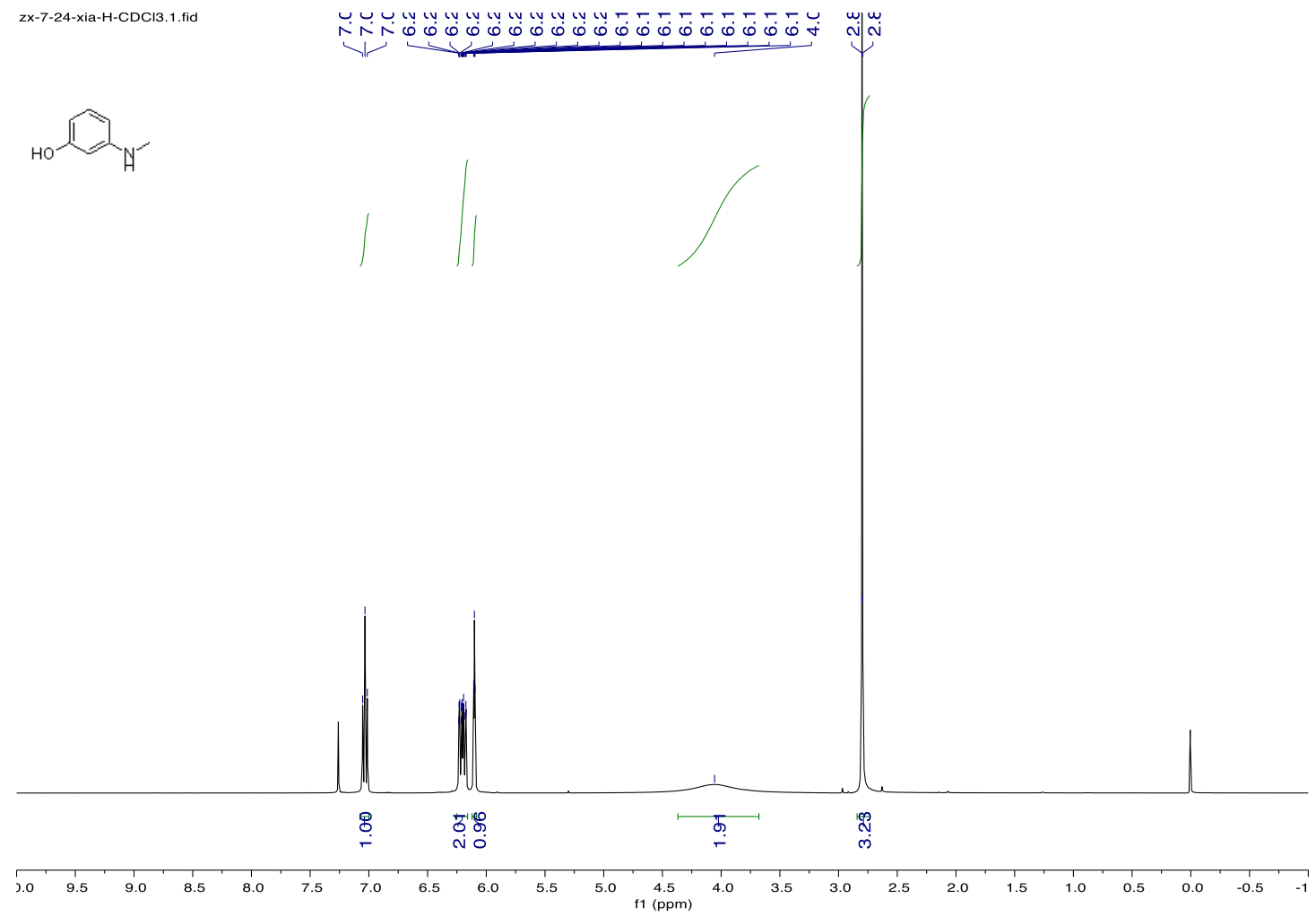

Figure S8. ${ }^{1} \mathrm{H}$ NMR of 3-(methylamino)phenol in $\mathrm{CDCl}_{3}$. 
Ho

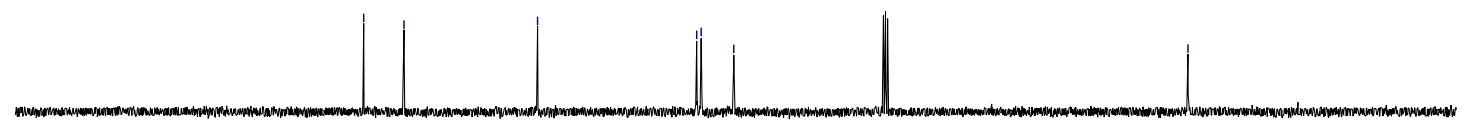

Figure S9. ${ }^{13} \mathrm{C}$ NMR of 3-(methylamino)phenol in $\mathrm{CDCl}_{3}$.

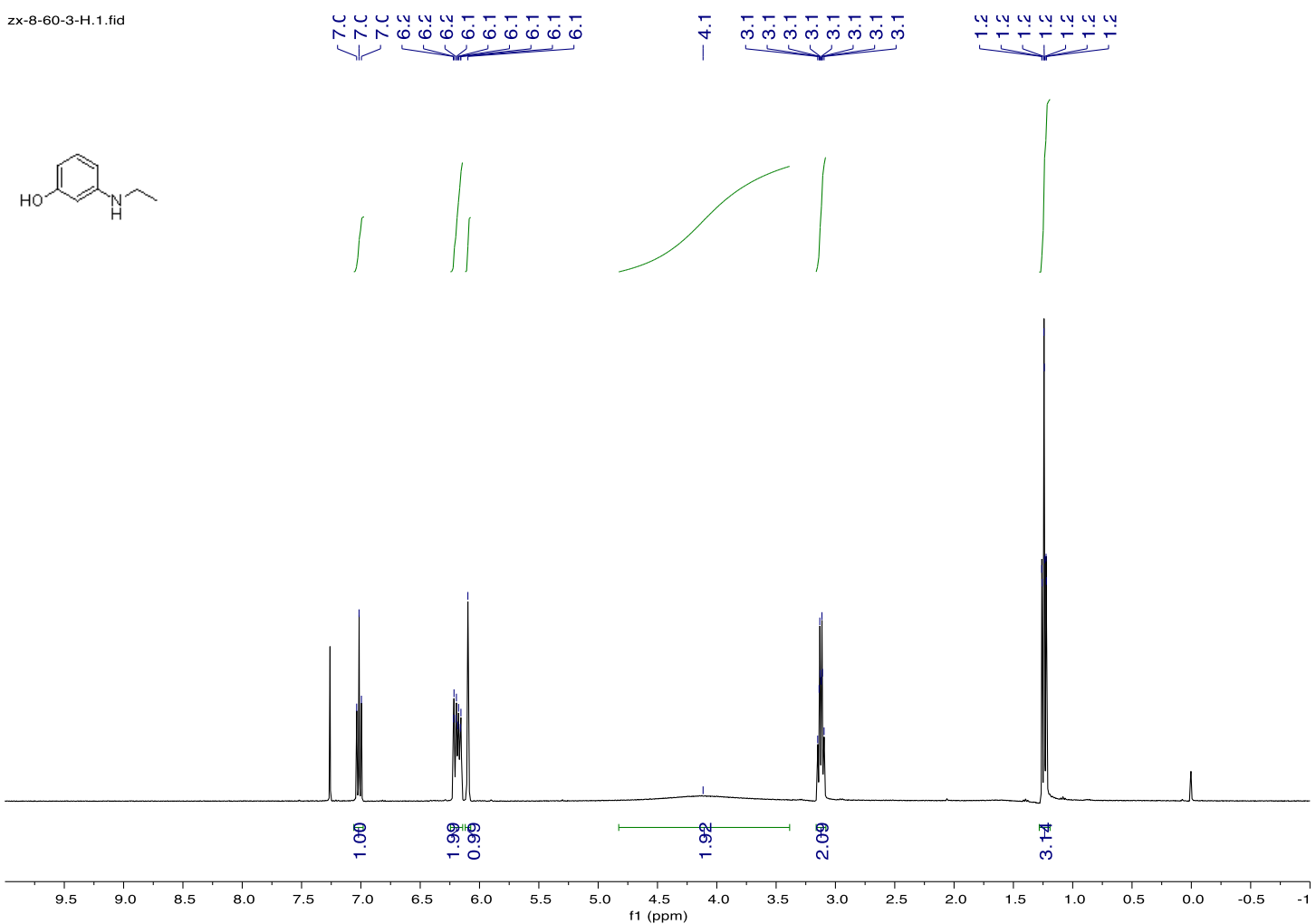

Figure S10. ${ }^{1} \mathrm{H}$ NMR of 3-(ethylamino)phenol in $\mathrm{CDCl}_{3}$. 
Ho
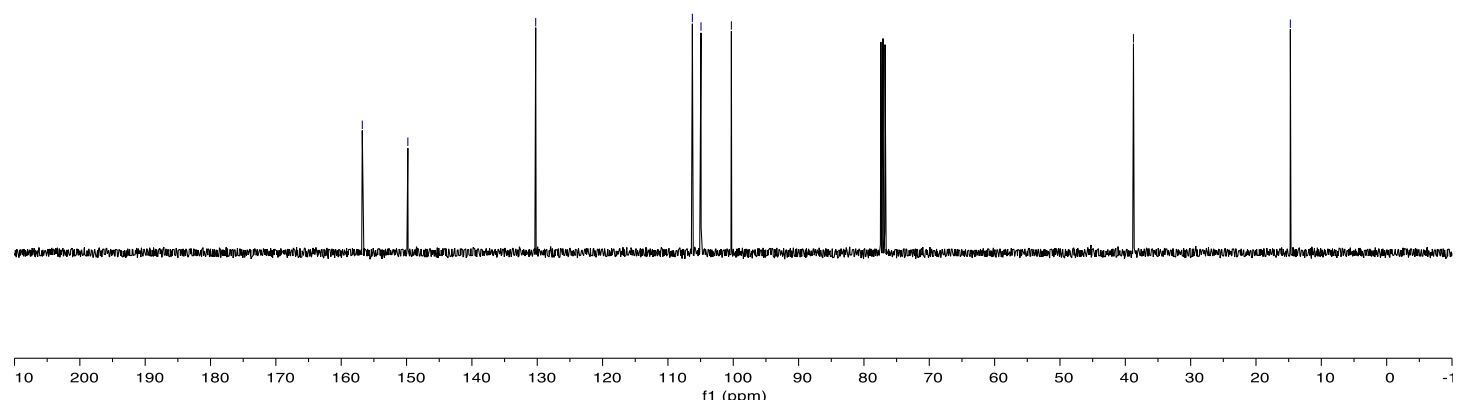

Figure S11. ${ }^{13} \mathrm{C}$ NMR of 3-(ethylamino)phenol in $\mathrm{CDCl}_{3}$.<smiles></smiles>

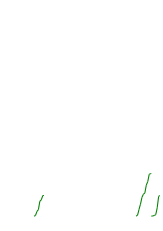

H
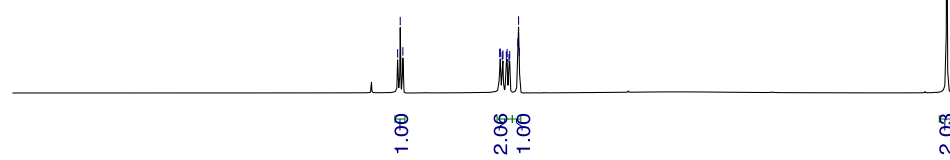

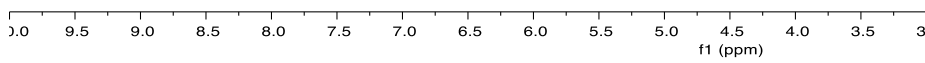

Figure S12. ${ }^{1} \mathrm{H}$ NMR of 3-(neopentylamino)phenol in $\mathrm{CDCl}_{3}$. 


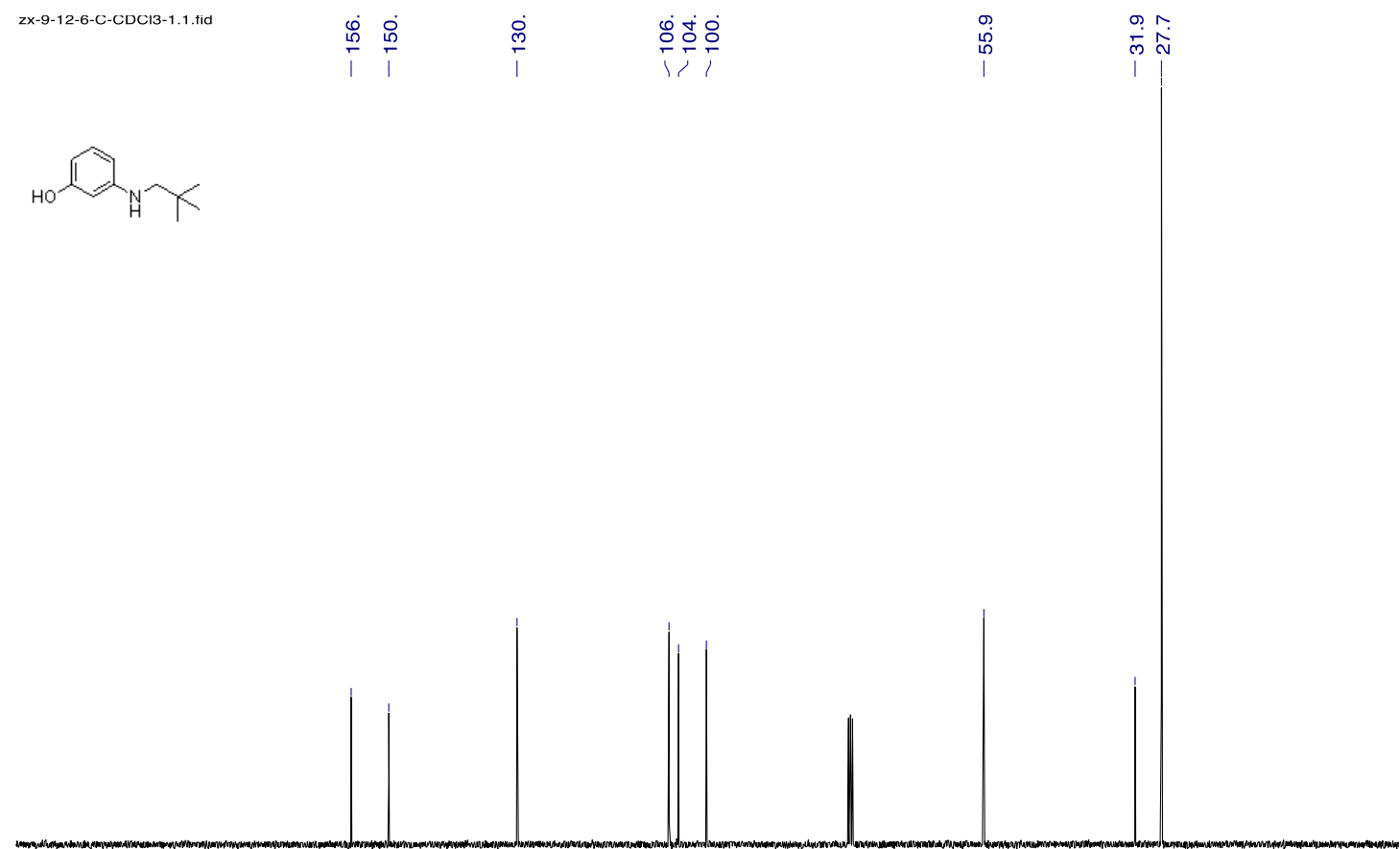

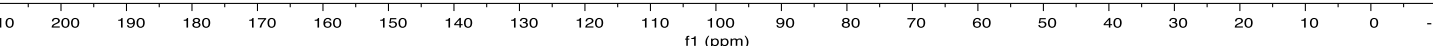

Figure S13. ${ }^{13} \mathrm{C}$ NMR of 3-(neopentylamino)phenol in $\mathrm{CDCl}_{3}$.

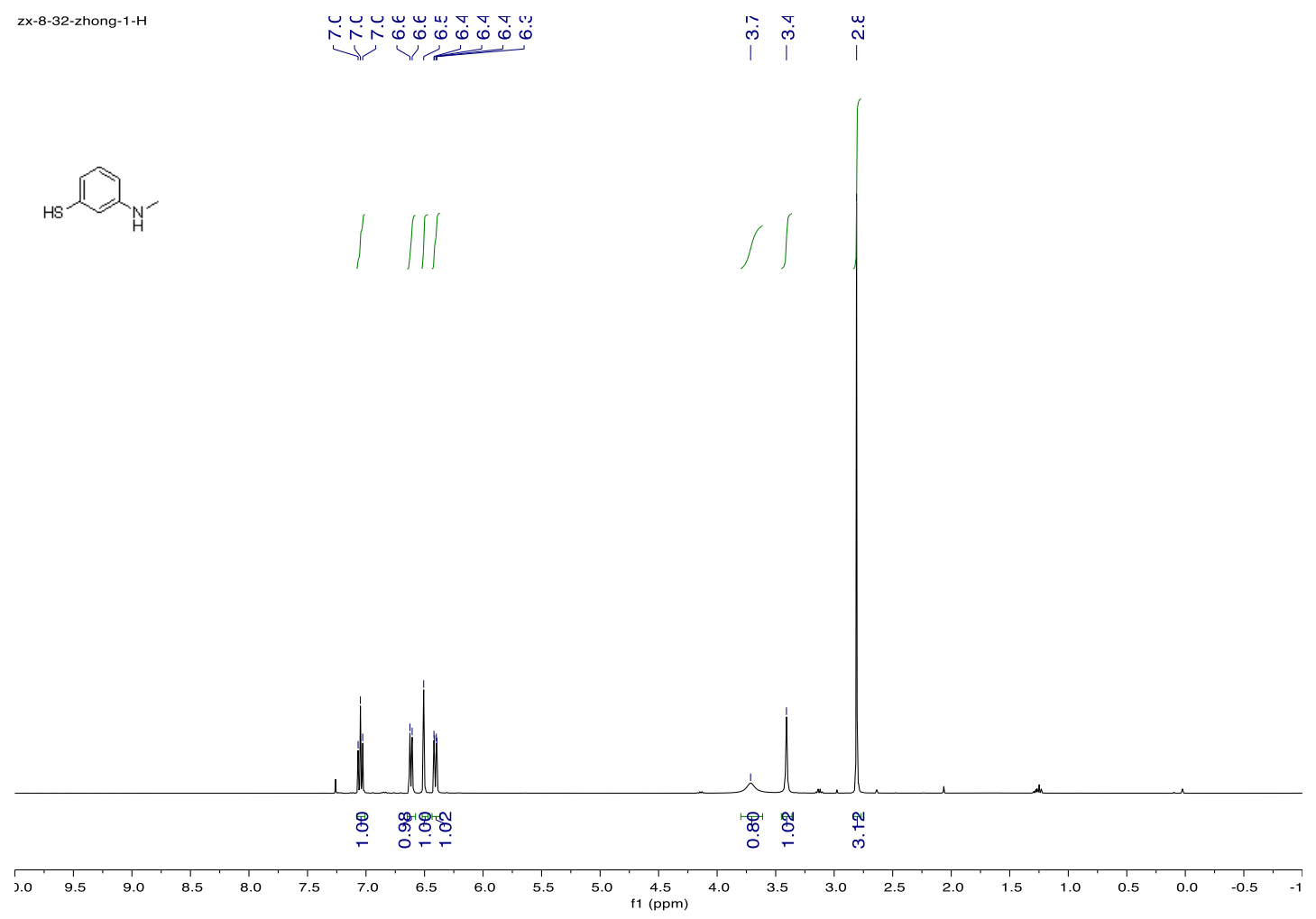

Figure S14. ${ }^{1} \mathrm{H}$ NMR of 3-(methylamino)benzenethiol in $\mathrm{CDCl}_{3}$. 
HS

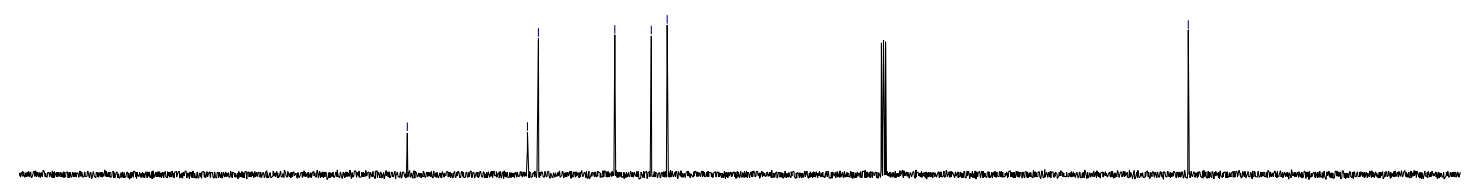

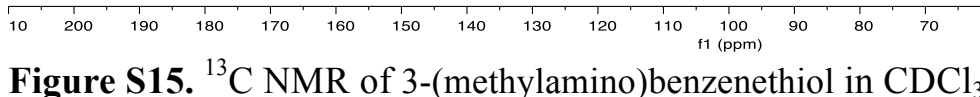
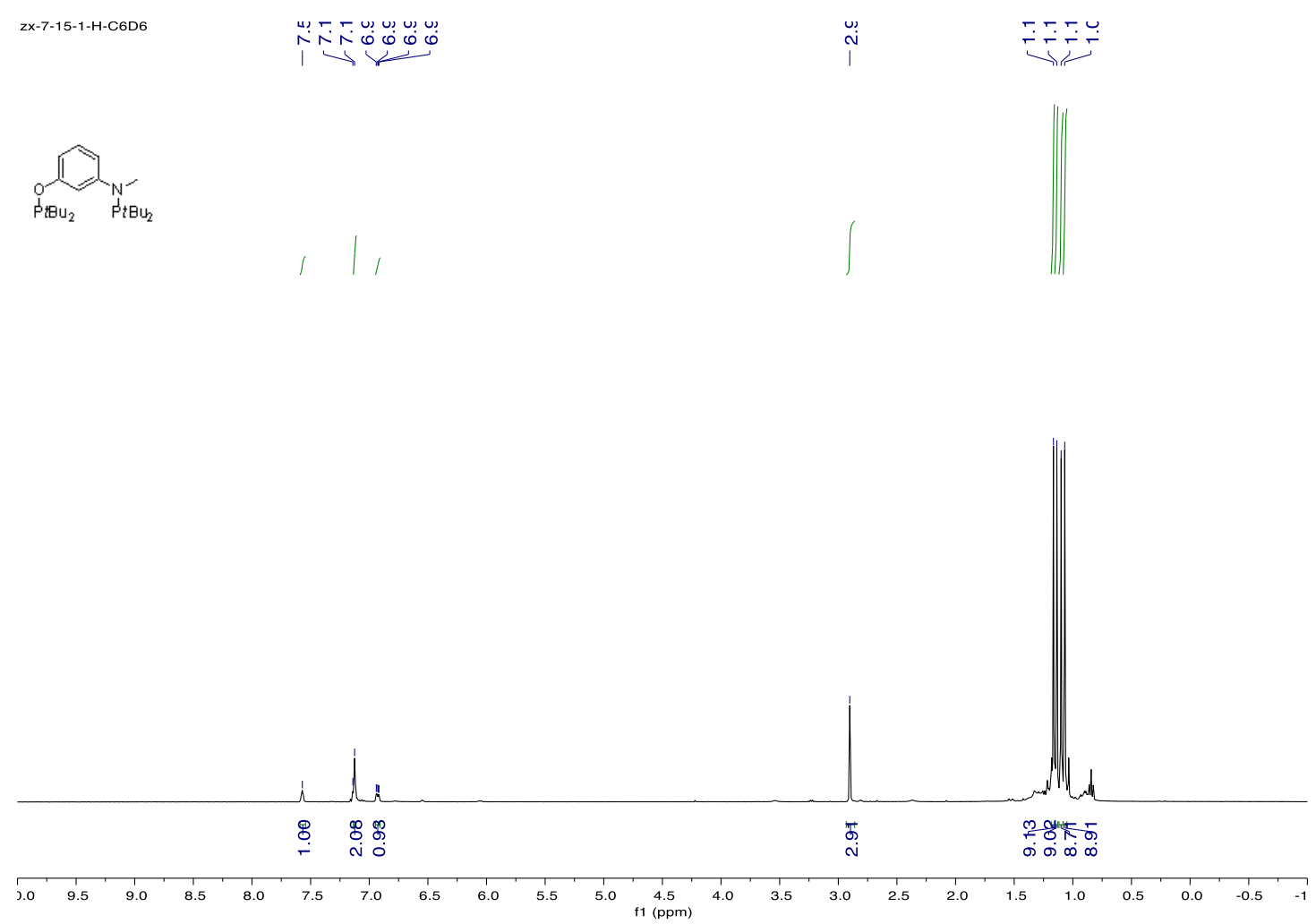

Figure S16. ${ }^{1} \mathrm{H}$ NMR of $\mathbf{6 a}$ in $\mathrm{C}_{6} \mathrm{D}_{6}$ 

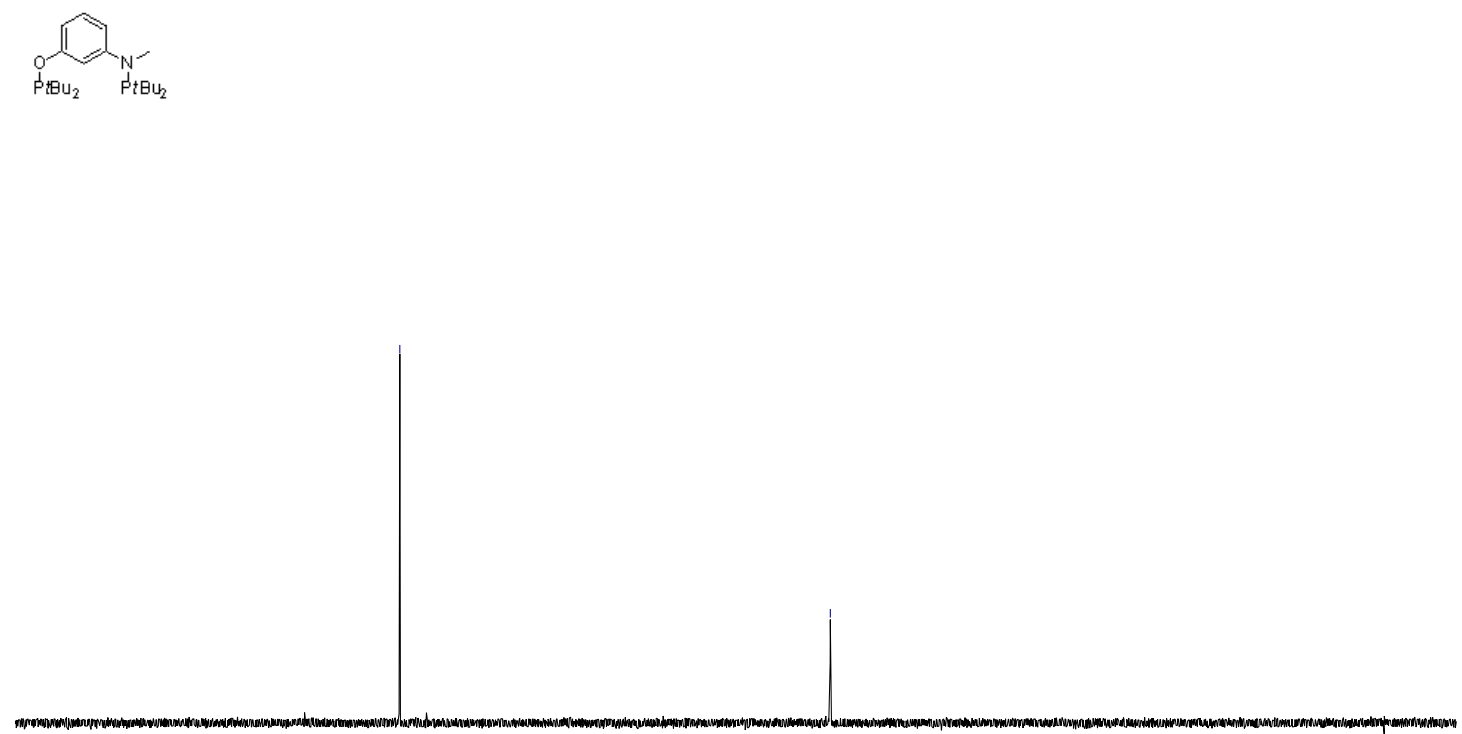

Figure S17. ${ }^{31} \mathrm{P}$ NMR of $6 \mathbf{a}$ in $\mathrm{C}_{6} \mathrm{D}_{6}$

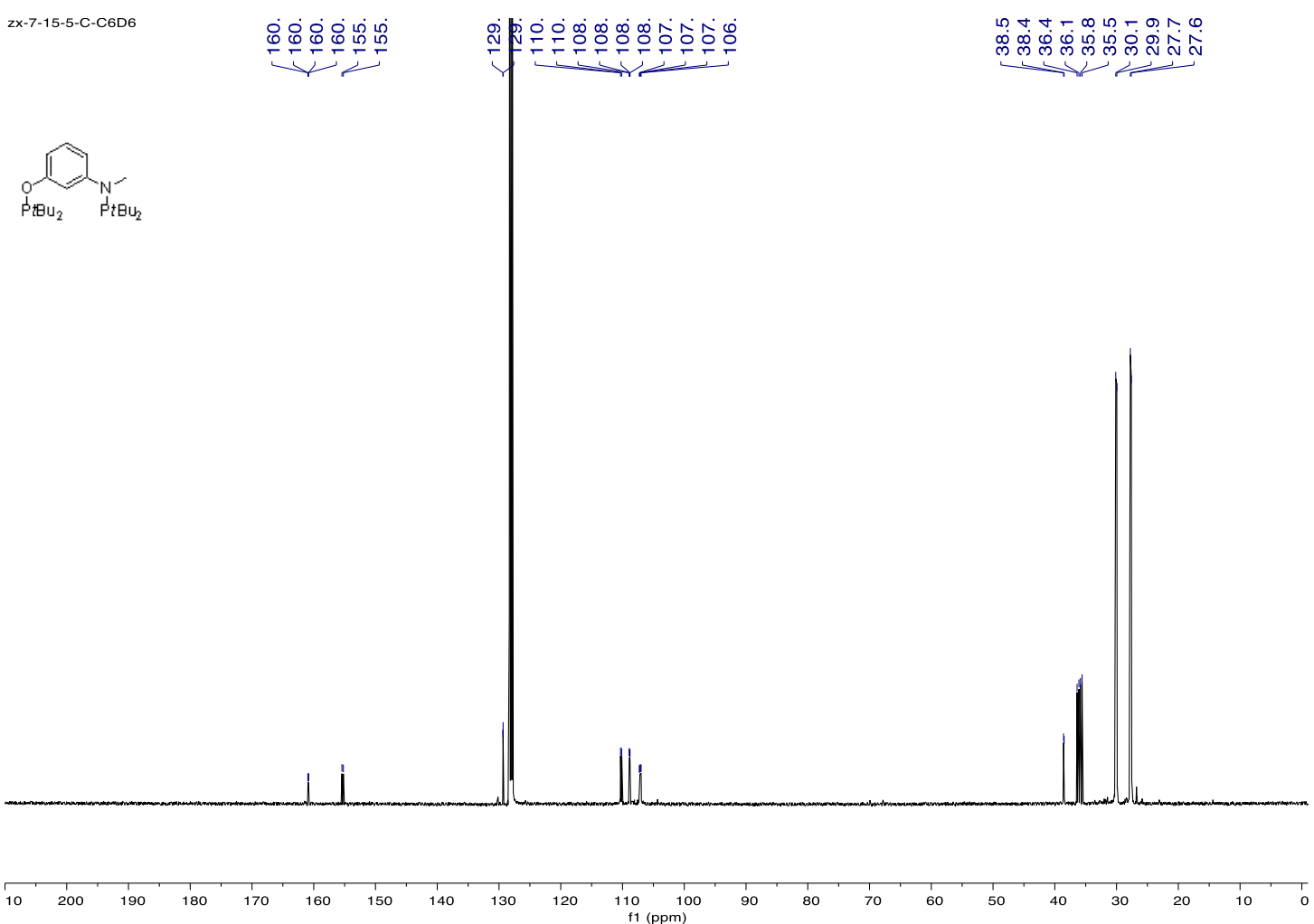

Figure S18. ${ }^{13} \mathrm{C}$ NMR of 6a in $\mathrm{C}_{6} \mathrm{D}_{6}$. 


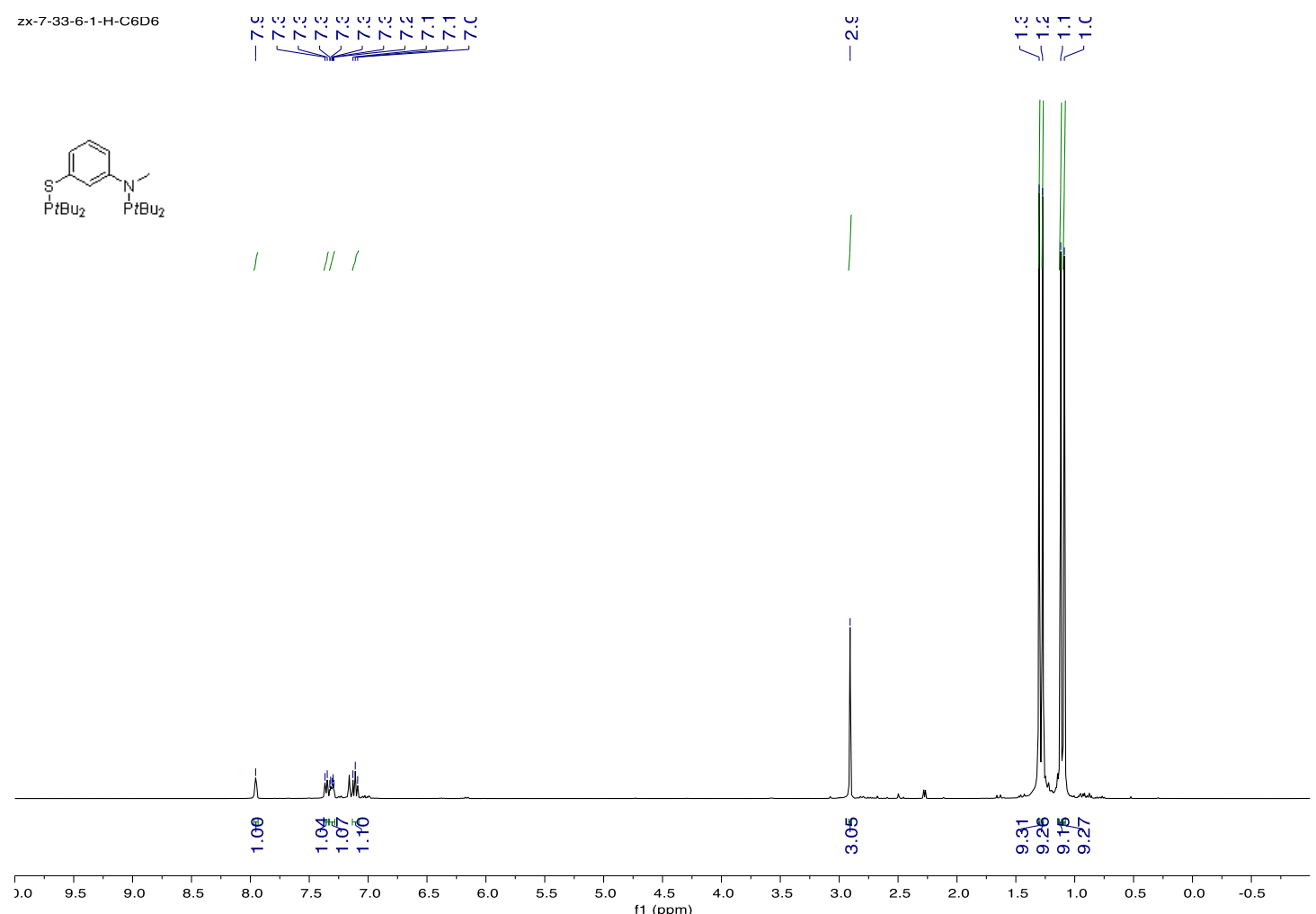

Figure S19. ${ }^{1} \mathrm{H}$ NMR of $7 \mathbf{a}$ in $\mathrm{C}_{6} \mathrm{D}_{6}$.
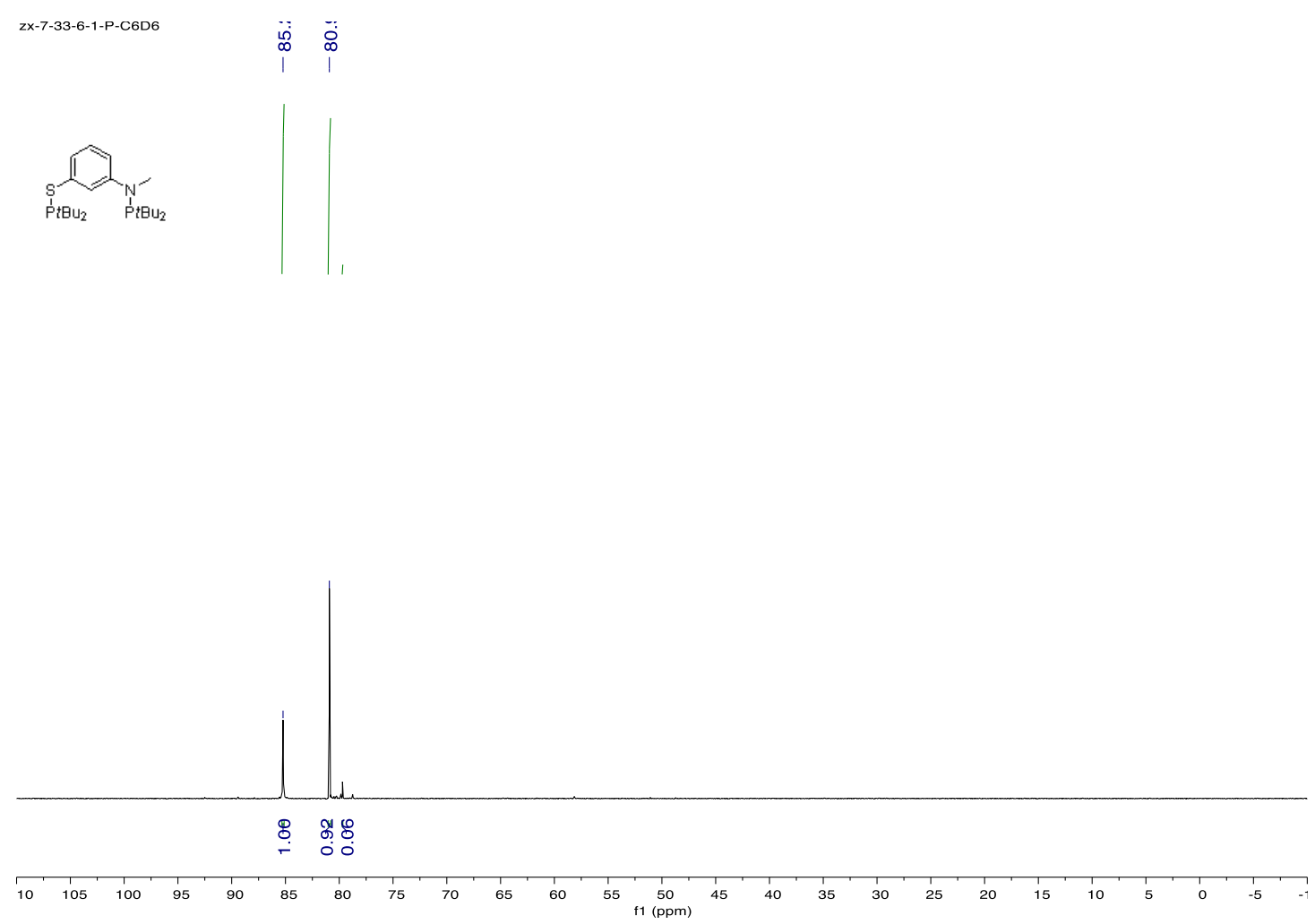

Figure S20. ${ }^{31} \mathrm{P}$ NMR of 7a in $\mathrm{C}_{6} \mathrm{D}_{6}$. 


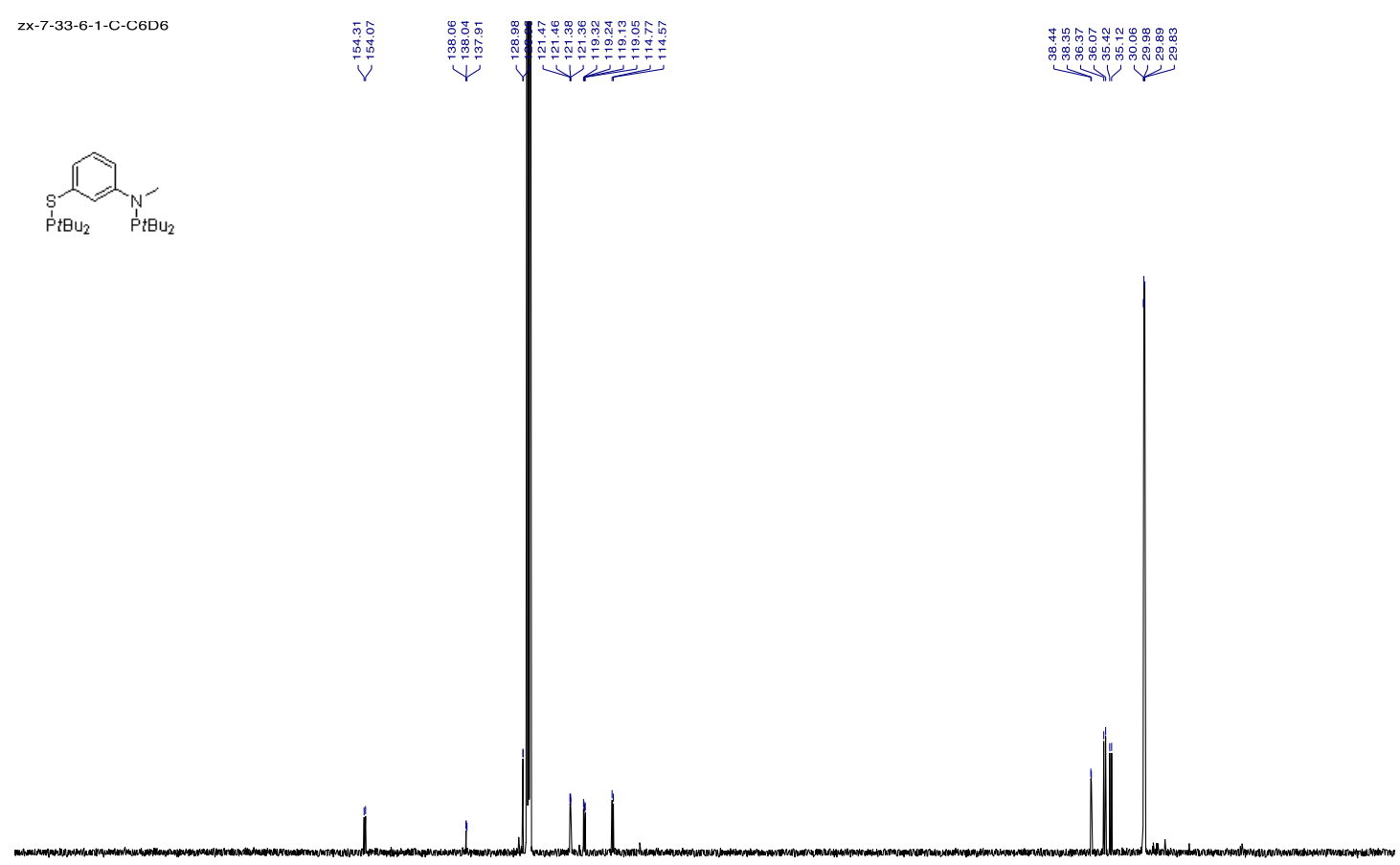

Figure S21. ${ }^{13} \mathrm{C}$ NMR of $7 \mathbf{a}$ in $\mathrm{C}_{6} \mathrm{D}_{6}$

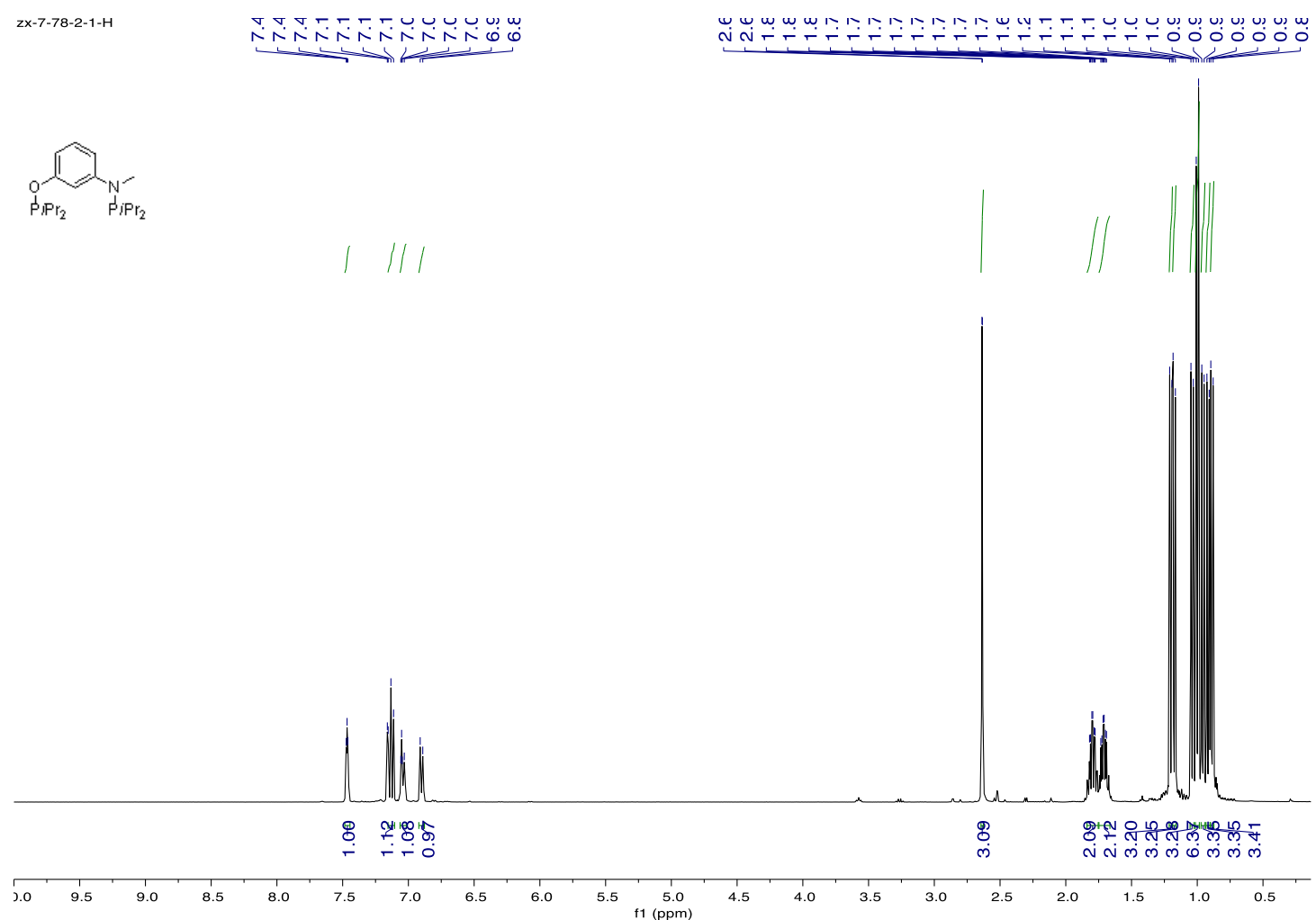

Figure S22. ${ }^{1} \mathrm{H}$ NMR of $\mathbf{6 b}$ in $\mathrm{C}_{6} \mathrm{D}_{6}$. 


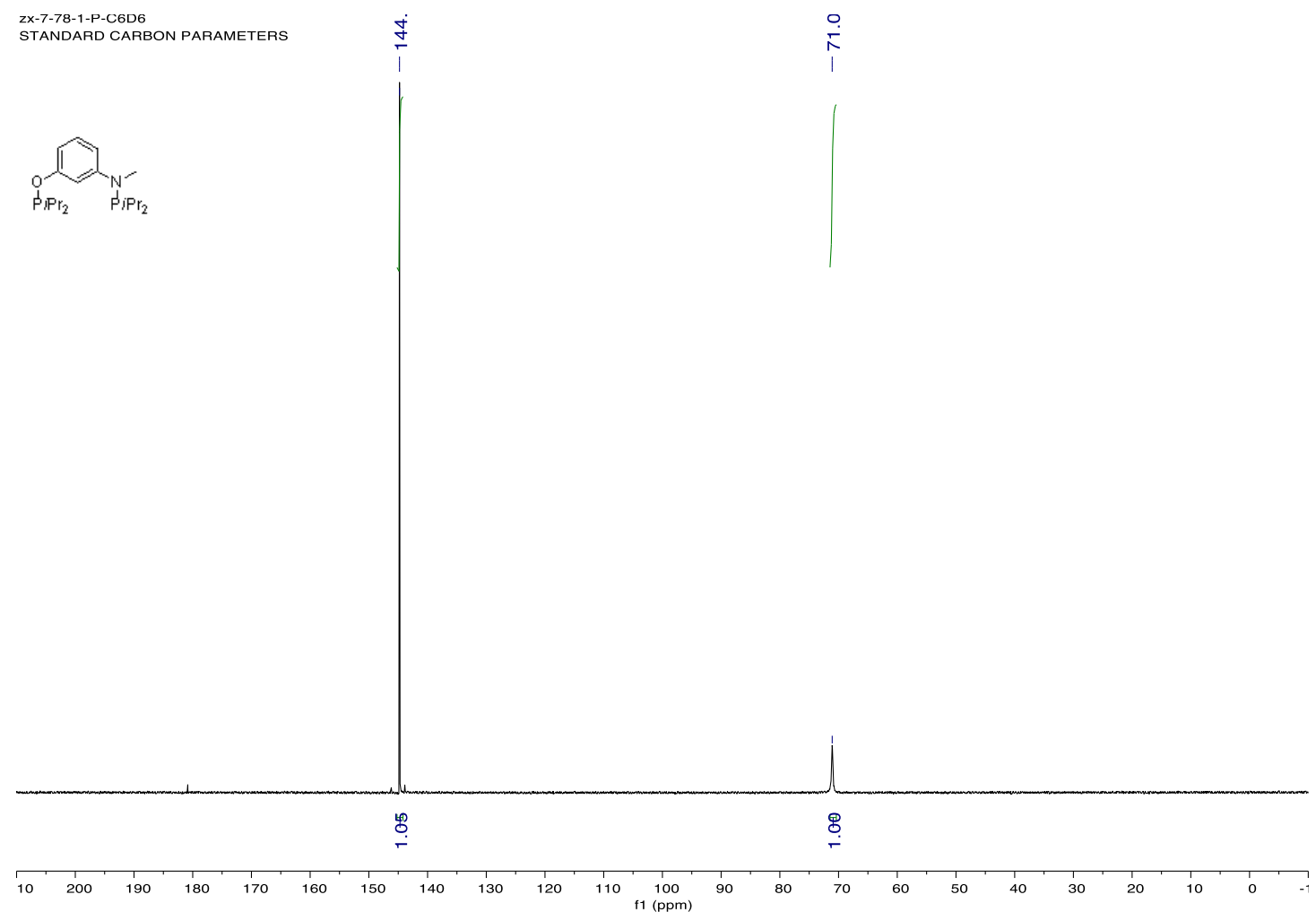

Figure S23. ${ }^{31} \mathrm{P}$ NMR of $\mathbf{6 b}$ in $\mathrm{C}_{6} \mathrm{D}_{6}$.

\begin{tabular}{|c|c|c|}
\hline zx-7-78-1-C-C6D6 & 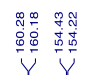 & 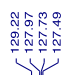 \\
\hline
\end{tabular}

V V V V

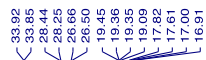

$\overbrace{\substack{\mathrm{P}_{2} r_{2} \\ \mathrm{PiPr}_{2}}}$
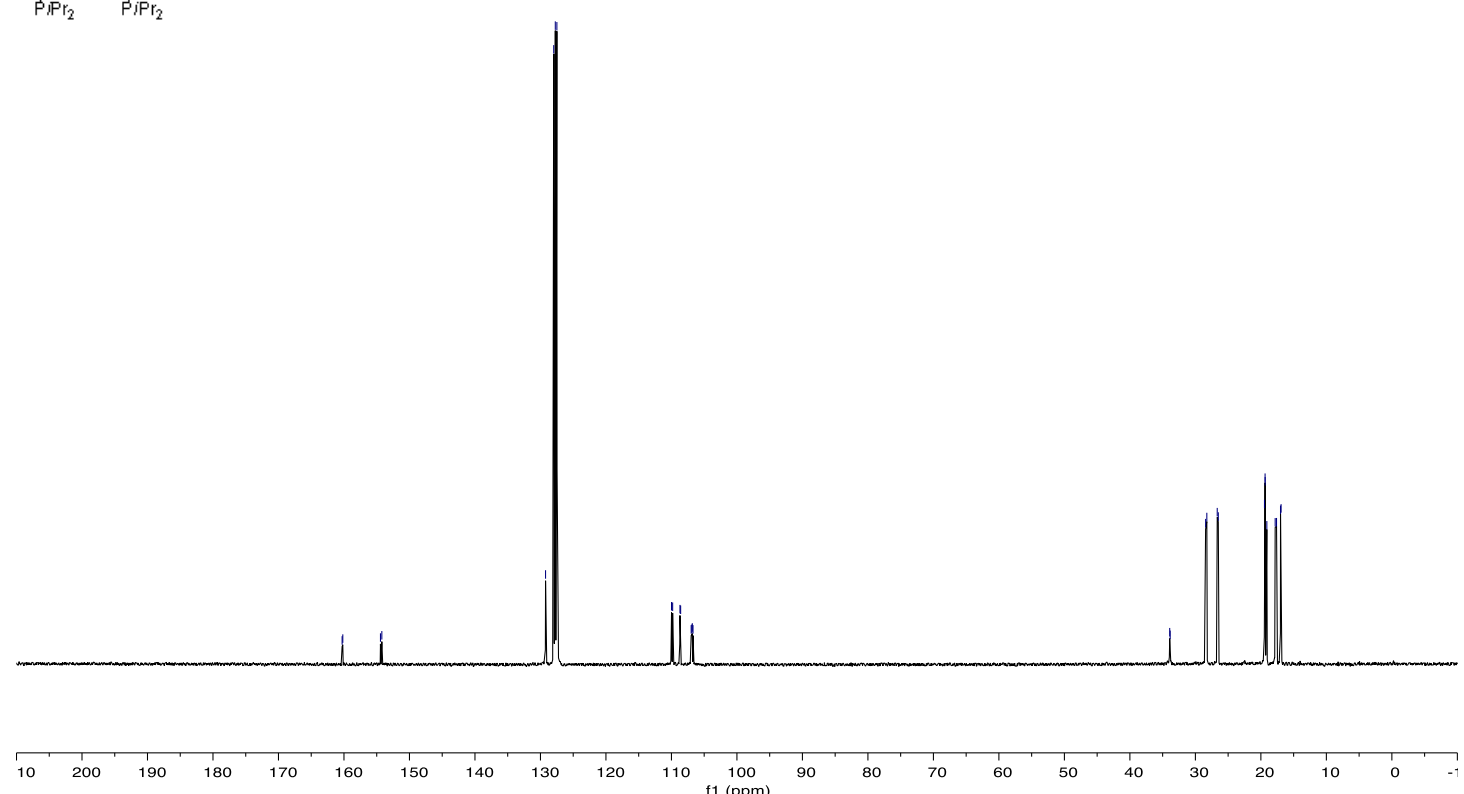

Figure S24. ${ }^{13} \mathrm{C}$ NMR of $6 \mathbf{b}$ in $\mathrm{C}_{6} \mathrm{D}_{6}$ 
<smiles>C[PbH2]Oc1cccc(N(C)[PbH2])c1</smiles>
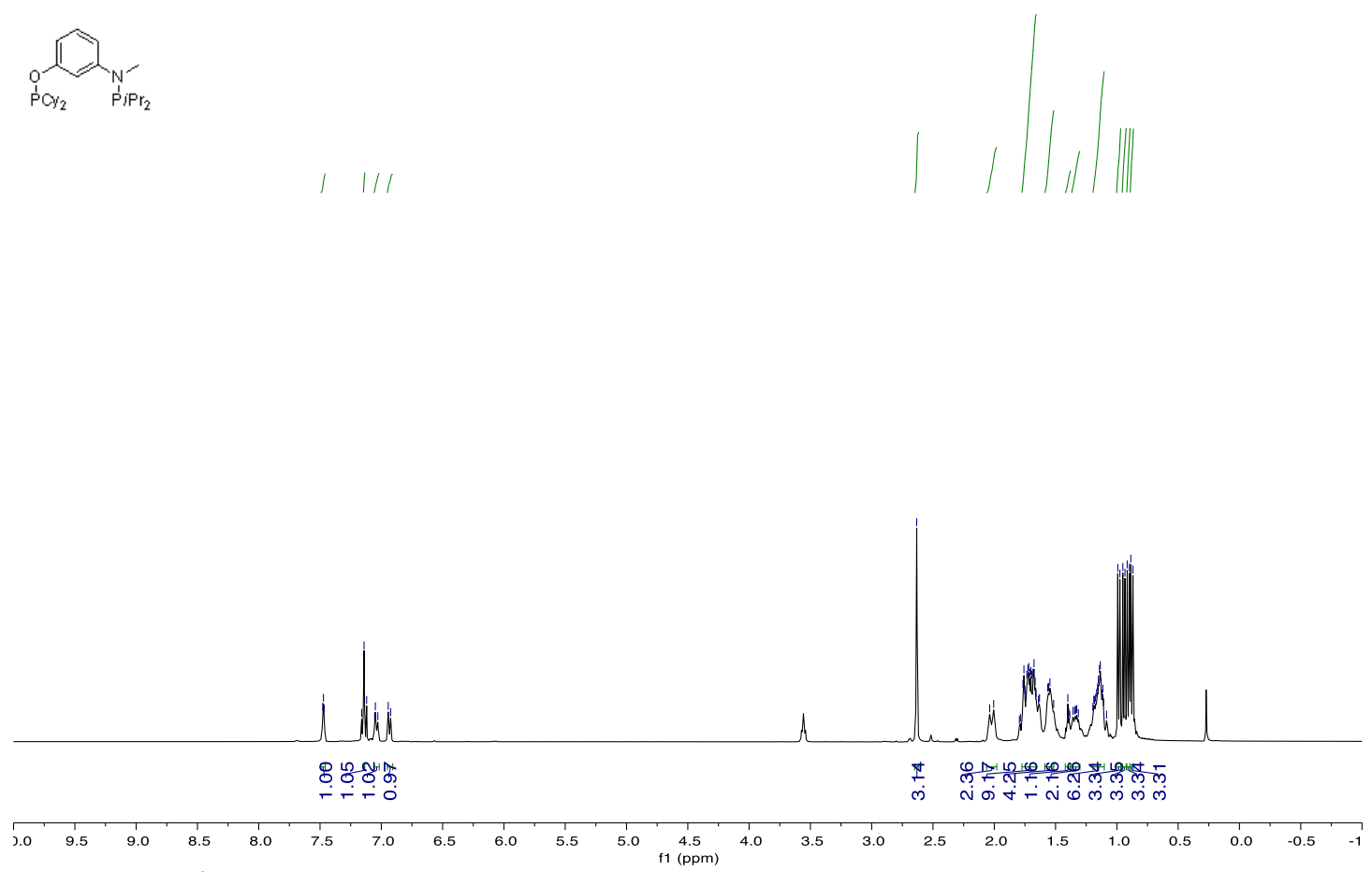

Figure S25. ${ }^{1} \mathrm{H}$ NMR of $\mathbf{6 c}$ in $\mathrm{C}_{6} \mathrm{D}_{6}$.

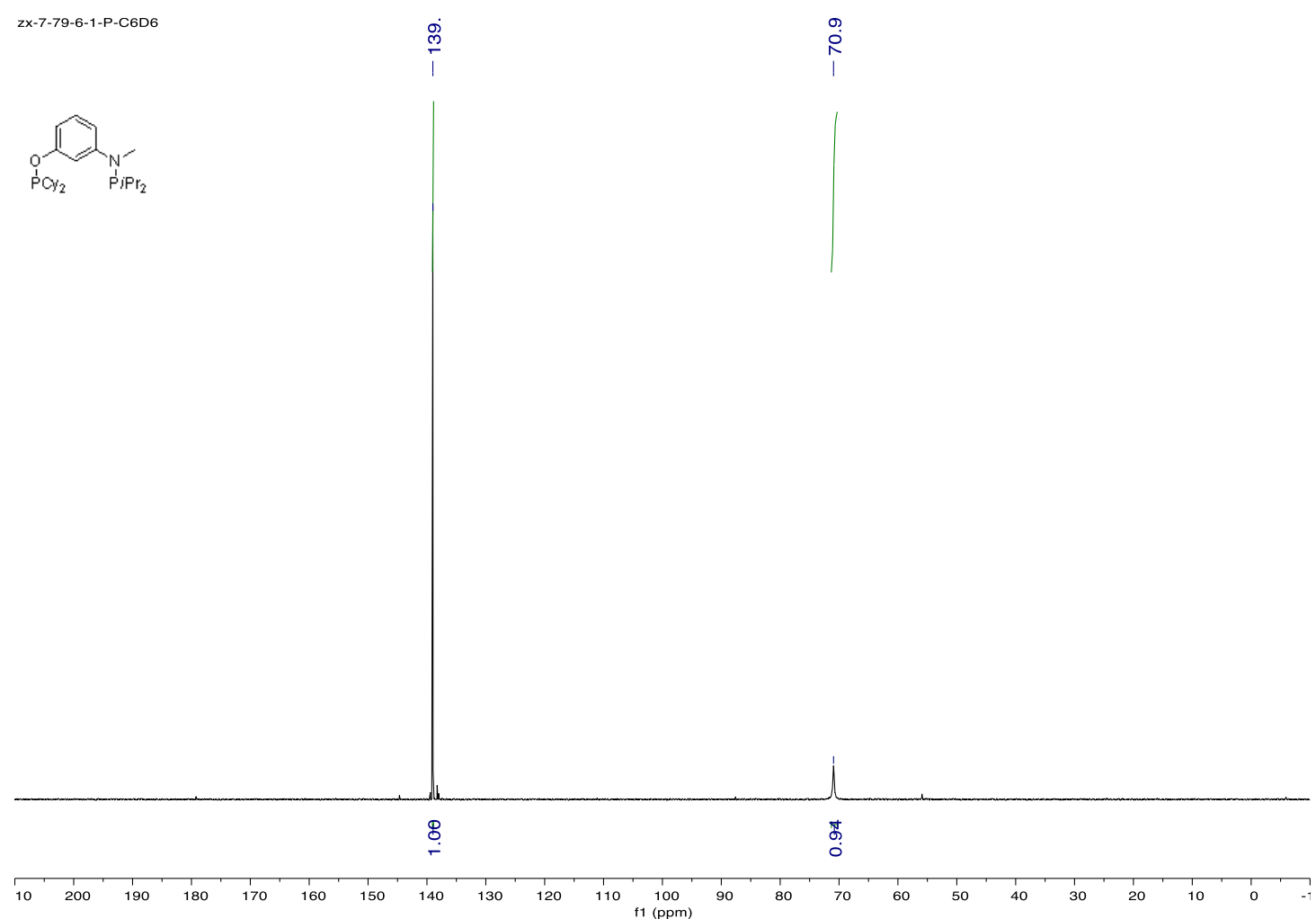

Figure S26. ${ }^{31} \mathrm{P}$ NMR of $6 \mathbf{c}$ in $\mathrm{C}_{6} \mathrm{D}_{6}$. 
<smiles>CN(C)c1cccc(Oc2ccccc2)c1</smiles>

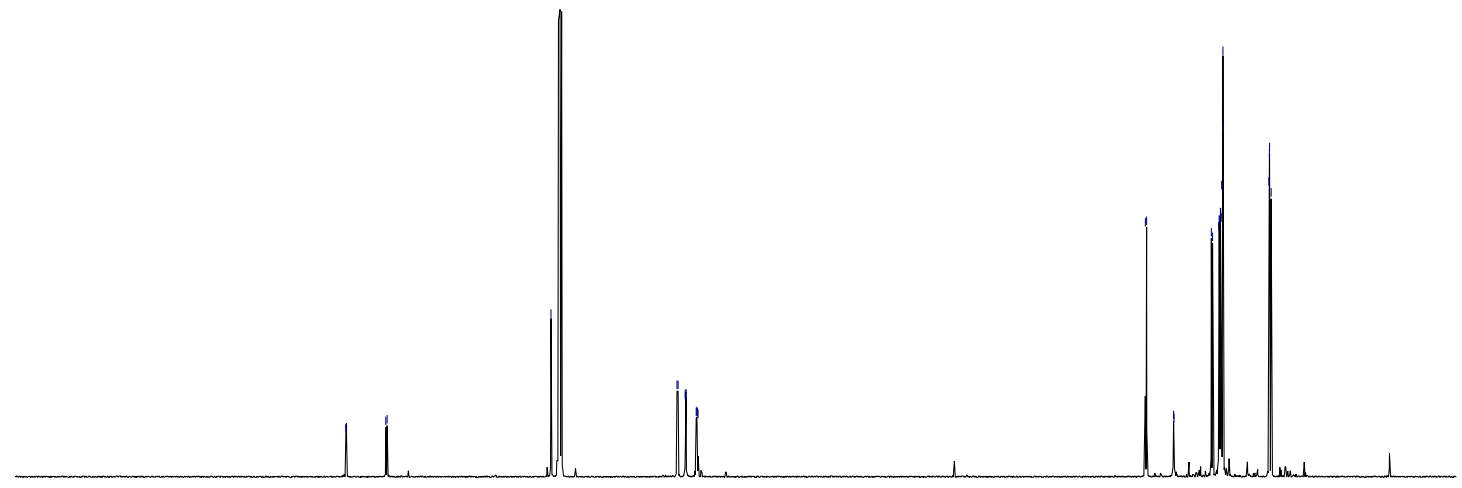

Figure S27. ${ }^{13} \mathrm{C}$ NMR of $\mathbf{6 c}$ in $\mathrm{C}_{6} \mathrm{D}_{6}$

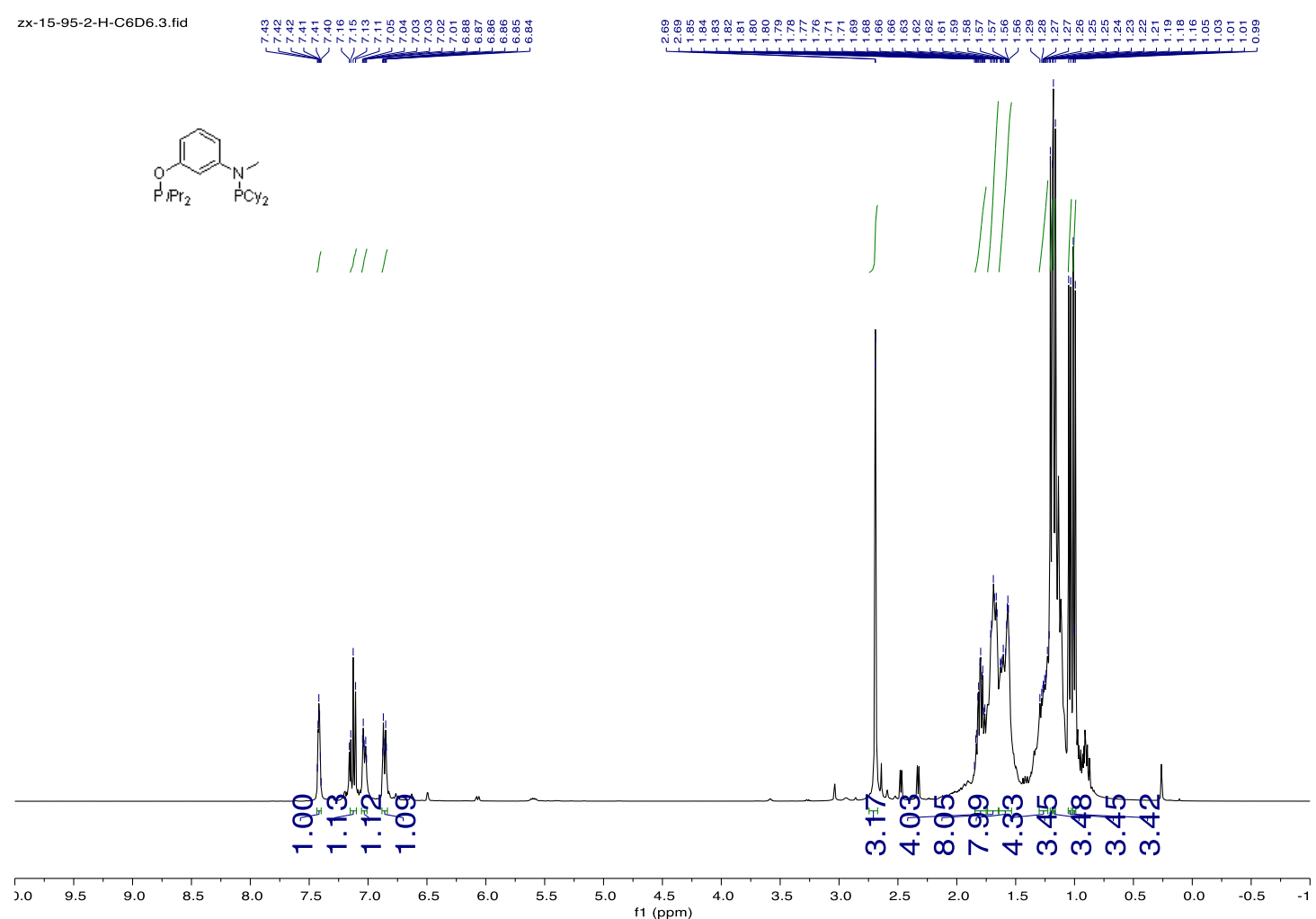

Figure S28. ${ }^{1} \mathrm{H}$ NMR of $\mathbf{6 d}$ in $\mathrm{C}_{6} \mathrm{D}_{6}$. 


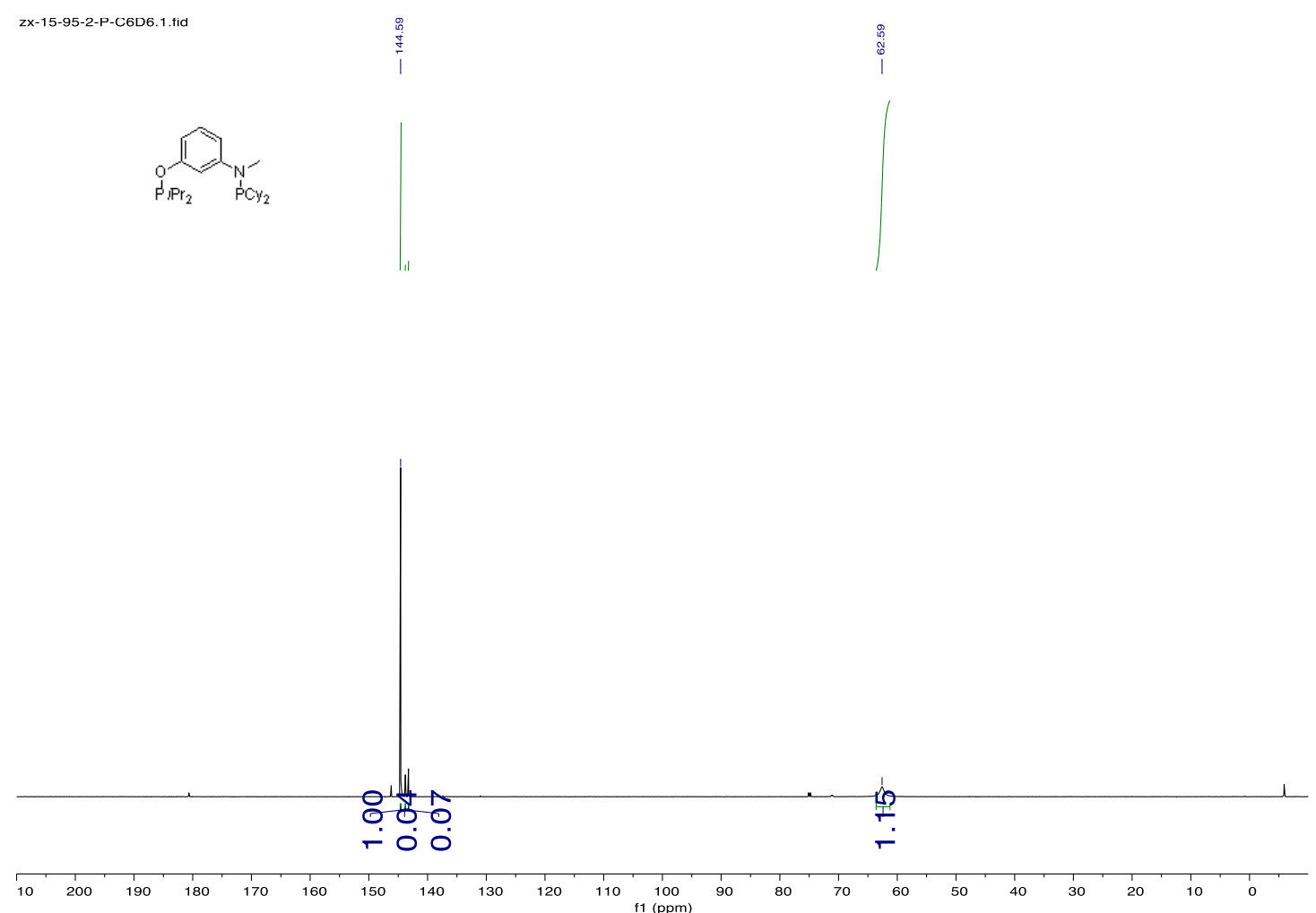

Figure S29 ${ }^{31} \mathrm{P}$ NMR of $\mathbf{6 d}$ in $\mathrm{C}_{6} \mathrm{D}_{6}$.
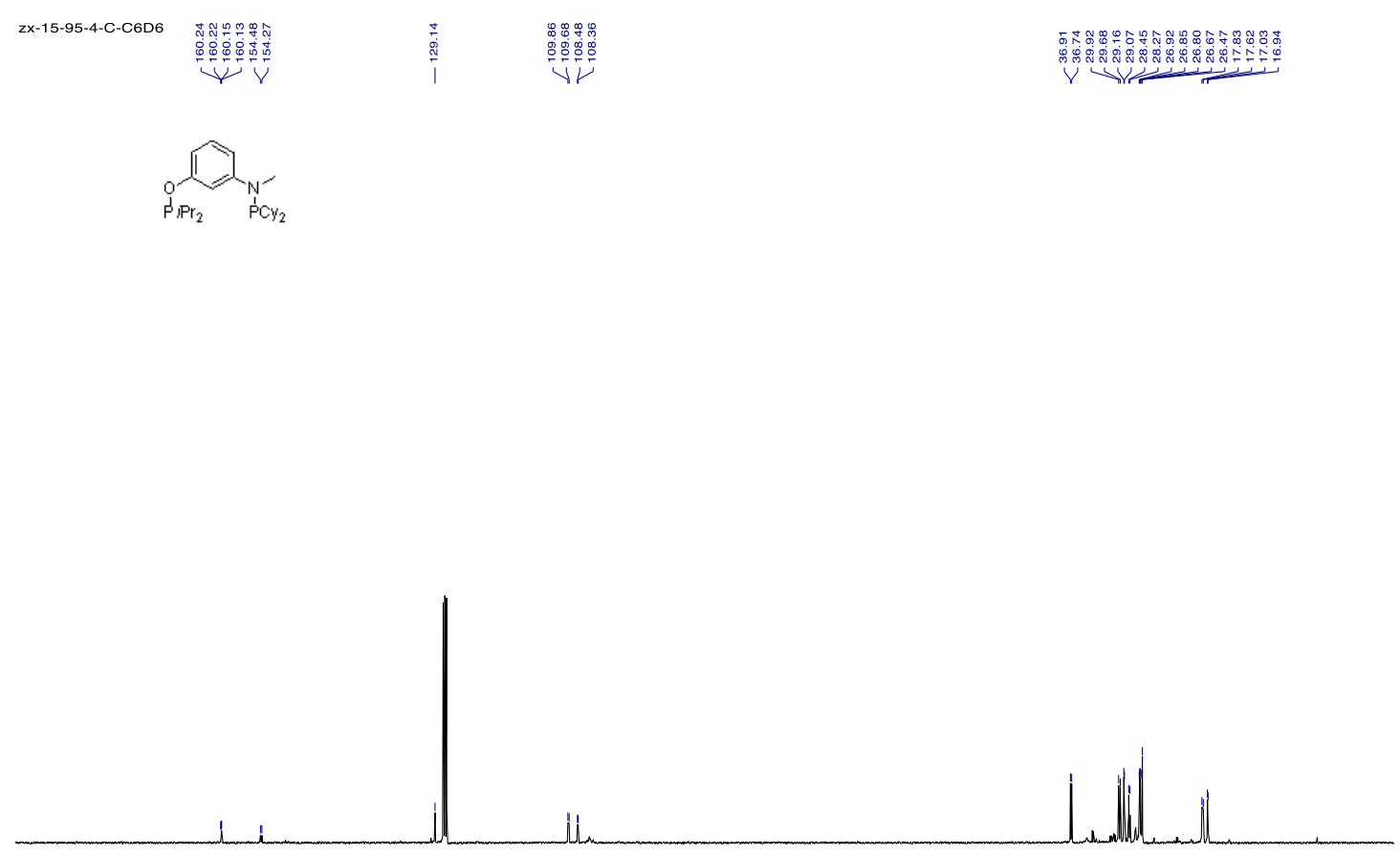

Figure S30 ${ }^{13} \mathrm{C}$ NMR of $6 \mathbf{d}$ in $\mathrm{C}_{6} \mathrm{D}_{6}$. 


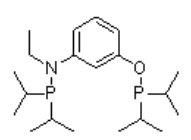

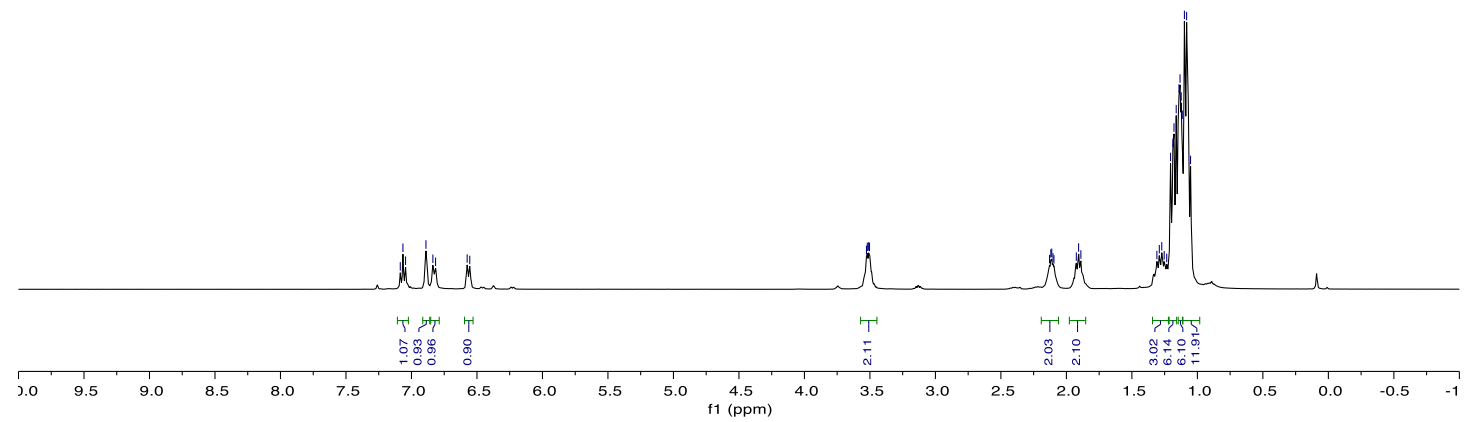

Figure S31 ${ }^{1} \mathrm{H}$ NMR of $6 \mathbf{e}$ in $\mathrm{CDCl}_{3}$.

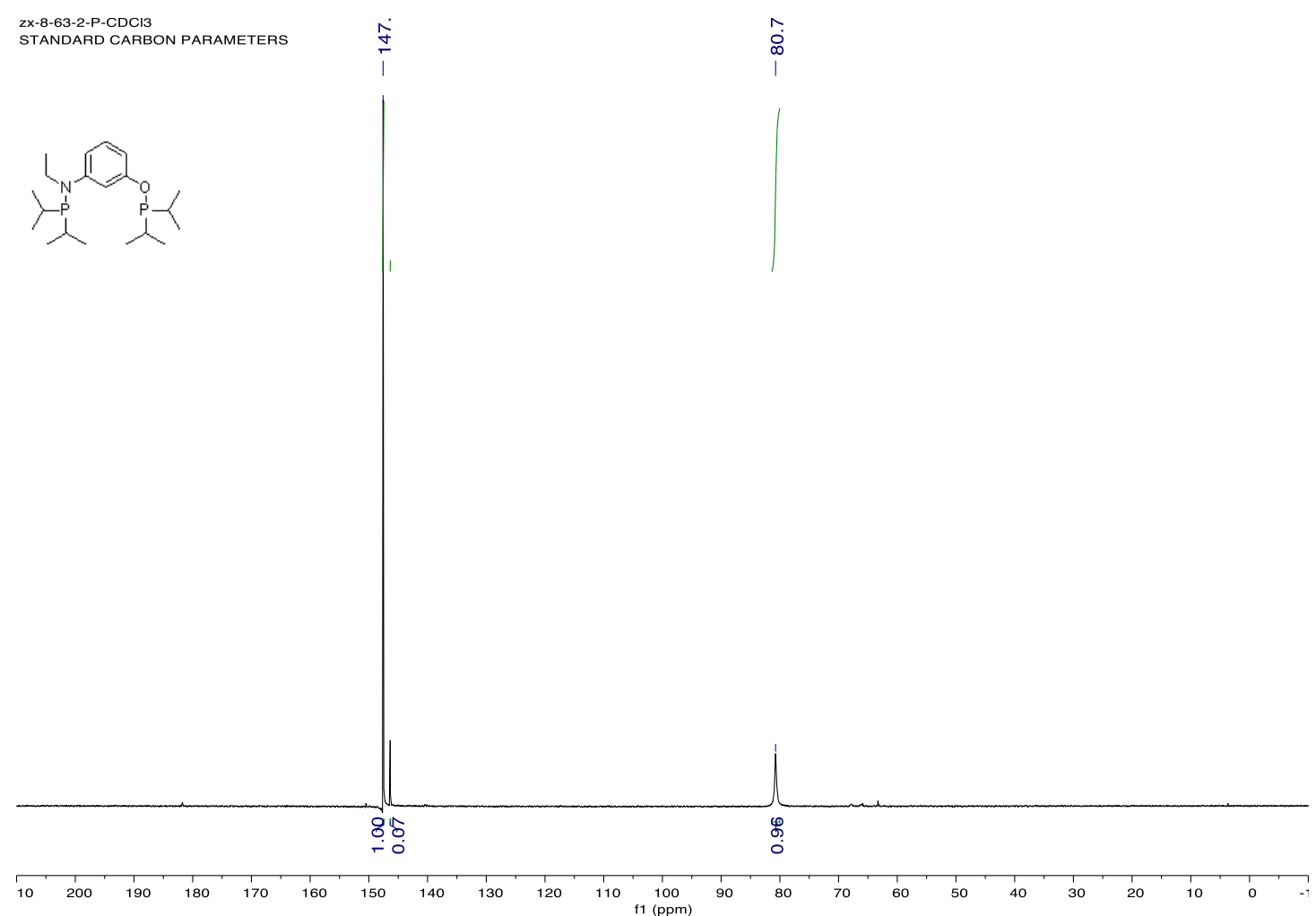

Figure $\mathrm{S32}^{31} \mathrm{P}$ NMR of $6 \mathrm{e}$ in $\mathrm{CDCl}_{3}$. 


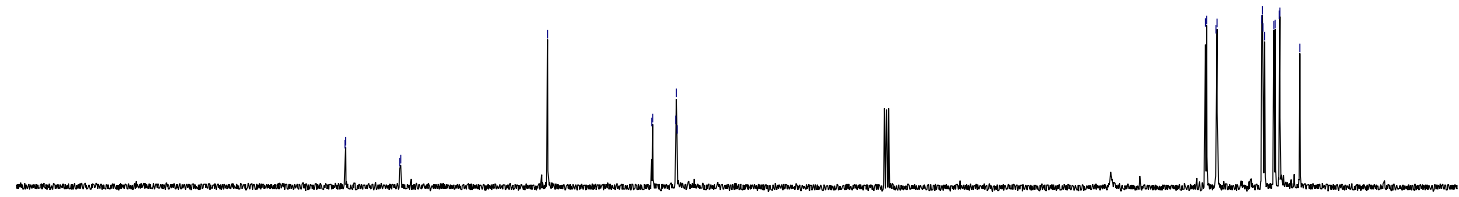

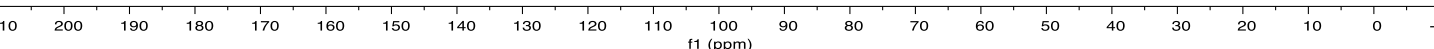

Figure S33. ${ }^{13} \mathrm{C}$ NMR of $6 \mathbf{e}$ in $\mathrm{CDCl}_{3}$

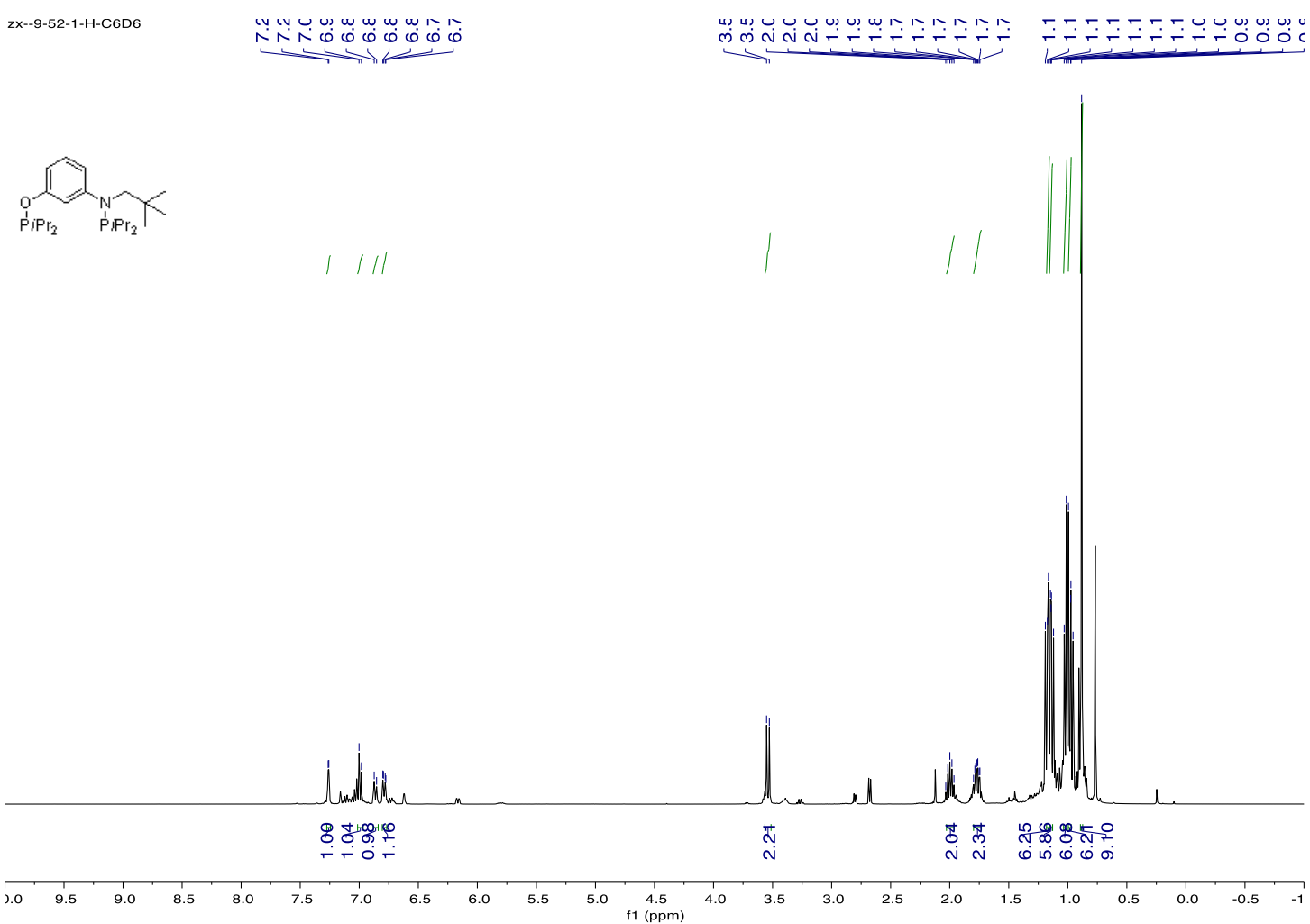

Figure S34. ${ }^{1} \mathrm{H}$ NMR of $6 \mathbf{f}$ in $\mathrm{C}_{6} \mathrm{D}_{6}$. 


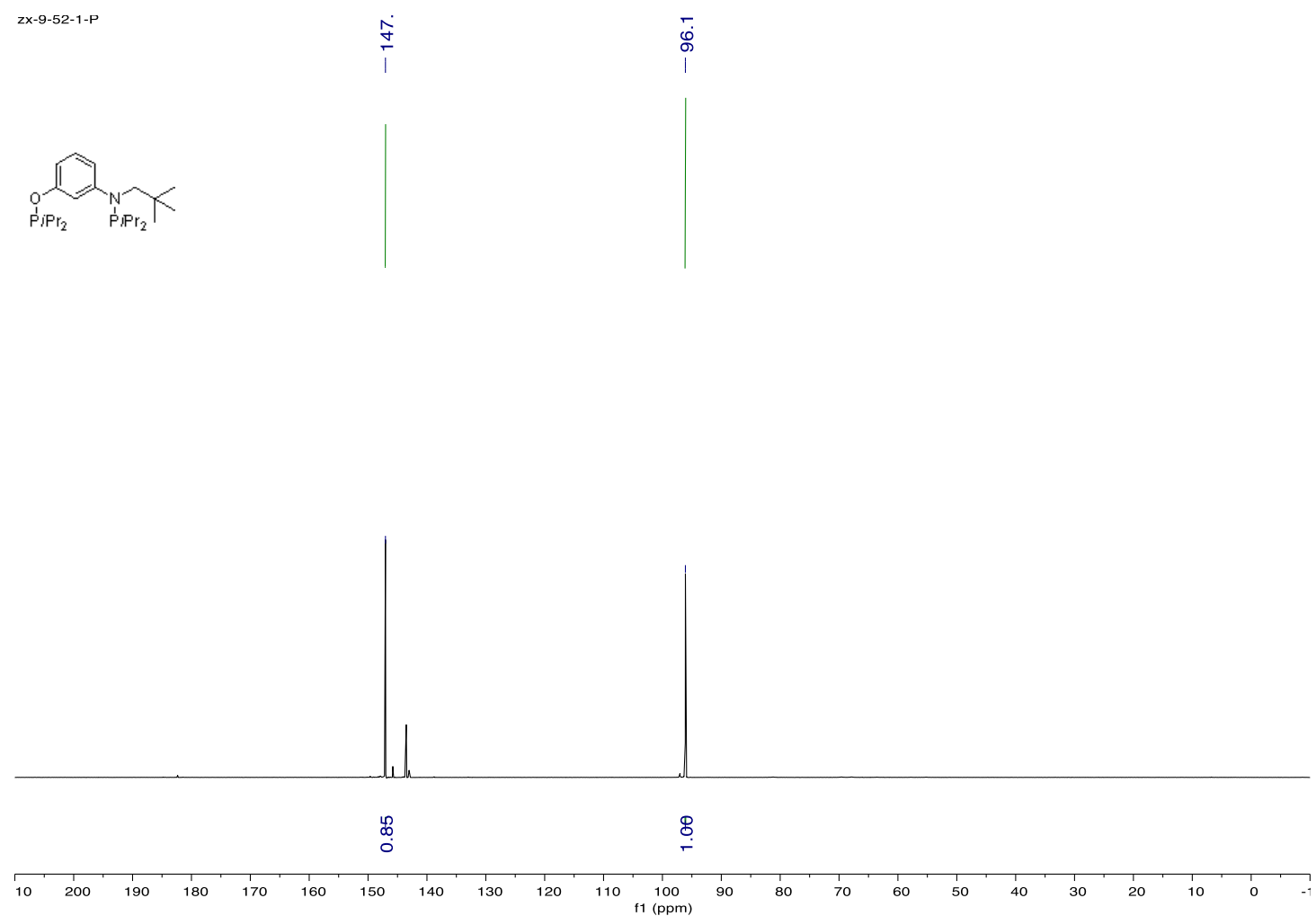

Figure S35. ${ }^{31} \mathrm{P}$ NMR of $\mathbf{6} \mathbf{f}$ in $\mathrm{C}_{6} \mathrm{D}_{6}$.

ZX-16-3-2-C-C6D6.1.fid V V V

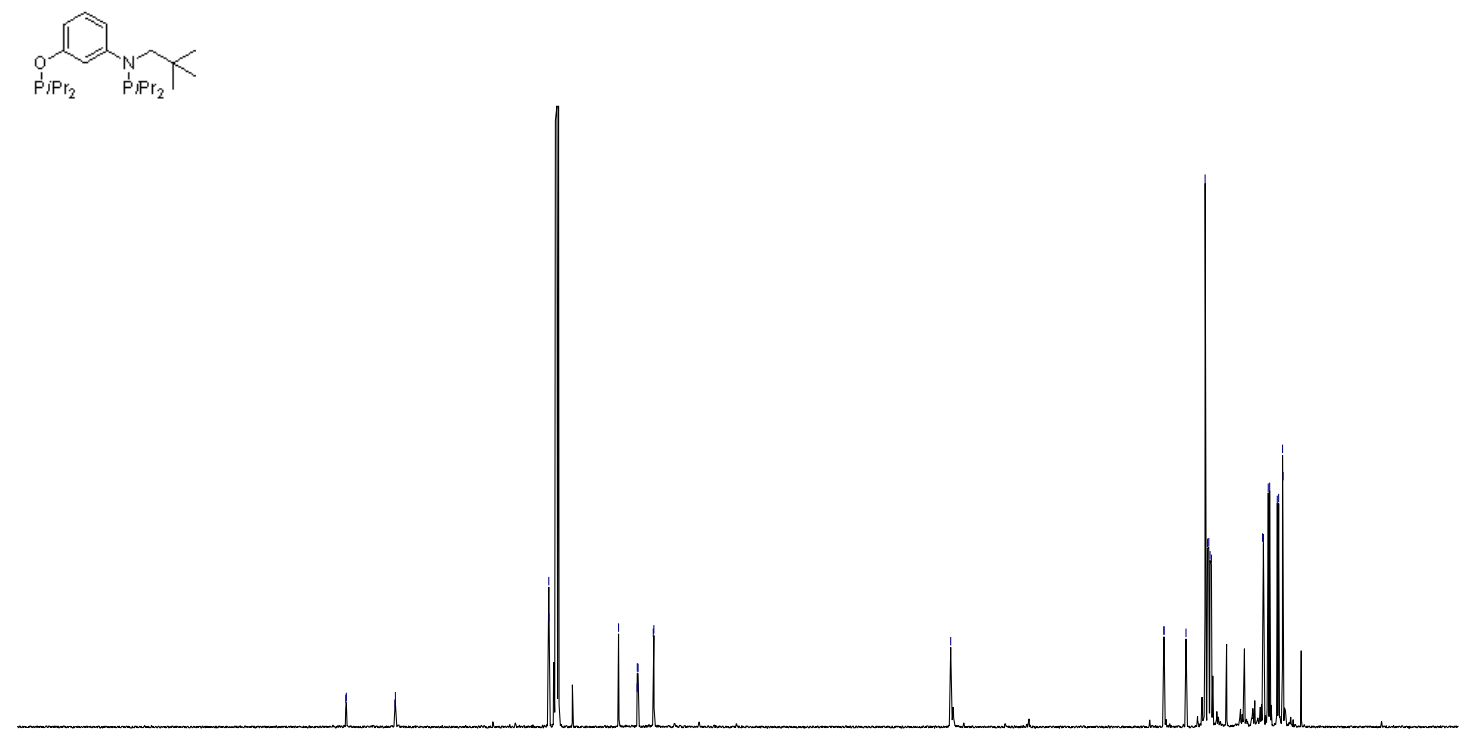

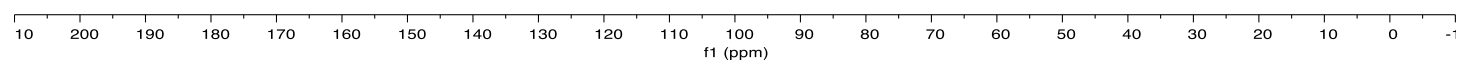

Figure S36. ${ }^{13} \mathrm{C}$ NMR of 6 f in $\mathrm{C}_{6} \mathrm{D}_{6}$. 


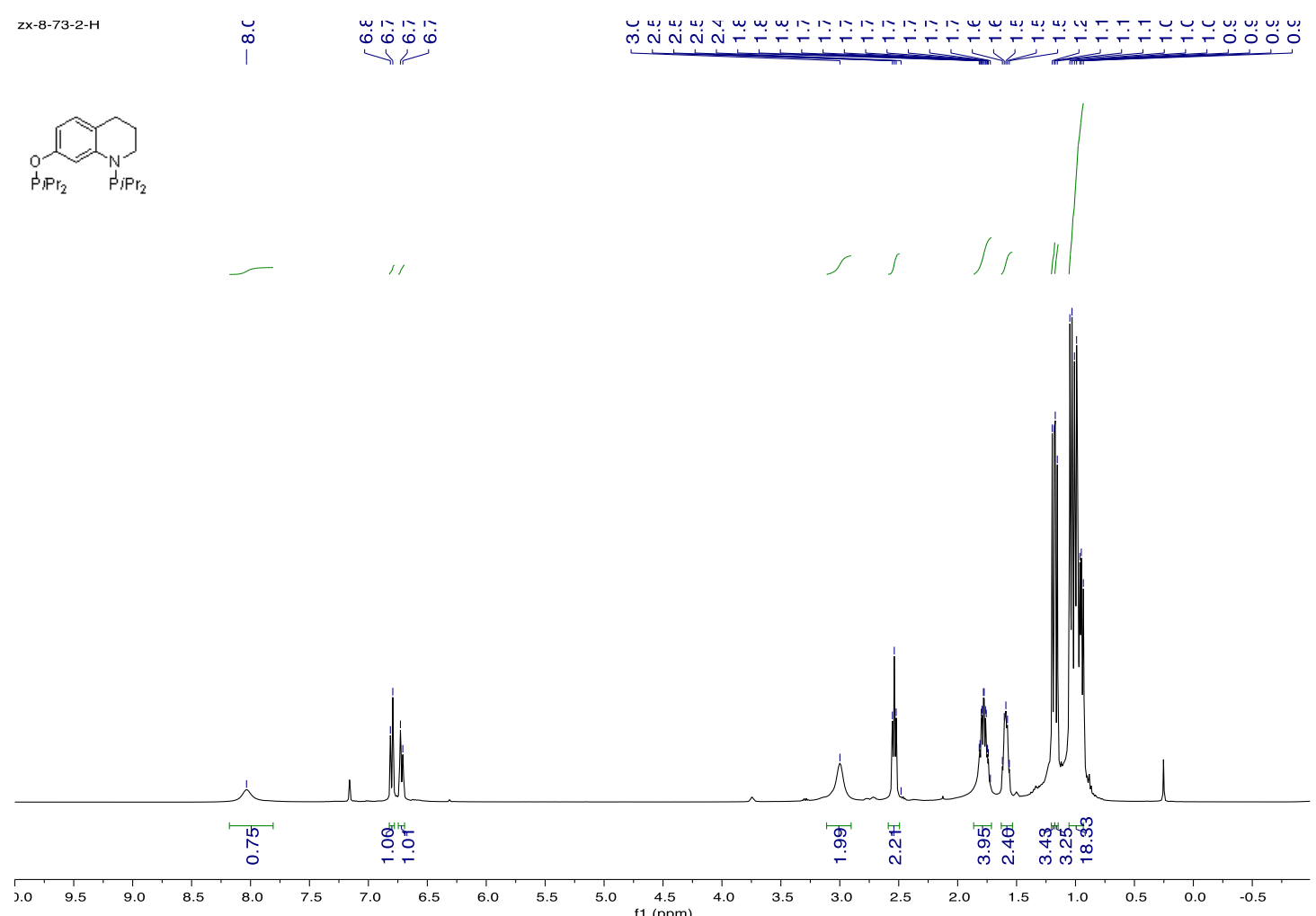

Figure S37. ${ }^{1} \mathrm{H}$ NMR of $6 \mathrm{~g}$ in $\mathrm{C}_{6} \mathrm{D}_{6}$.
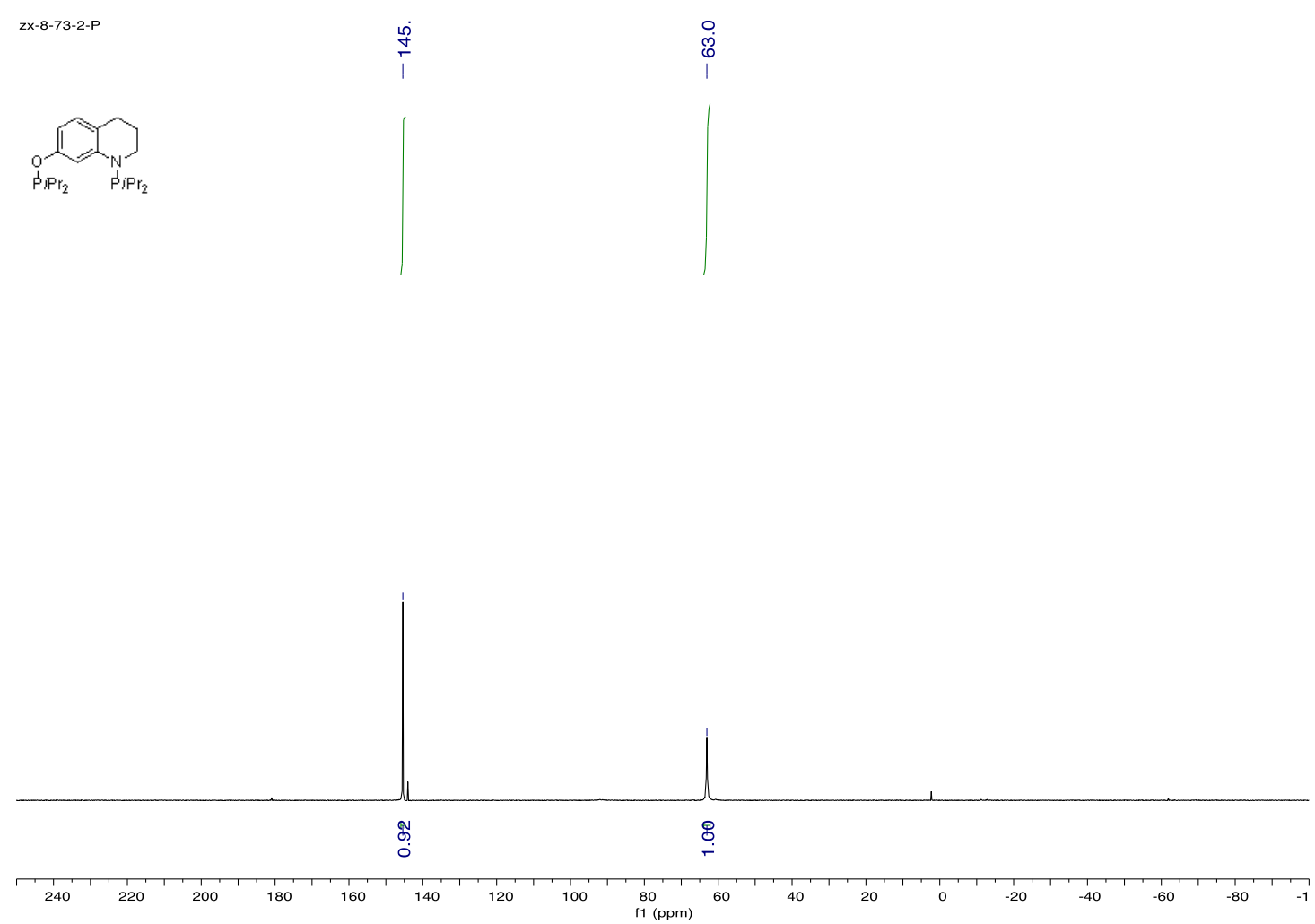

Figure S38. ${ }^{31} \mathrm{P}$ NMR of $\mathbf{6 g}$ in $\mathrm{C}_{6} \mathrm{D}_{6}$. 
PIPr2

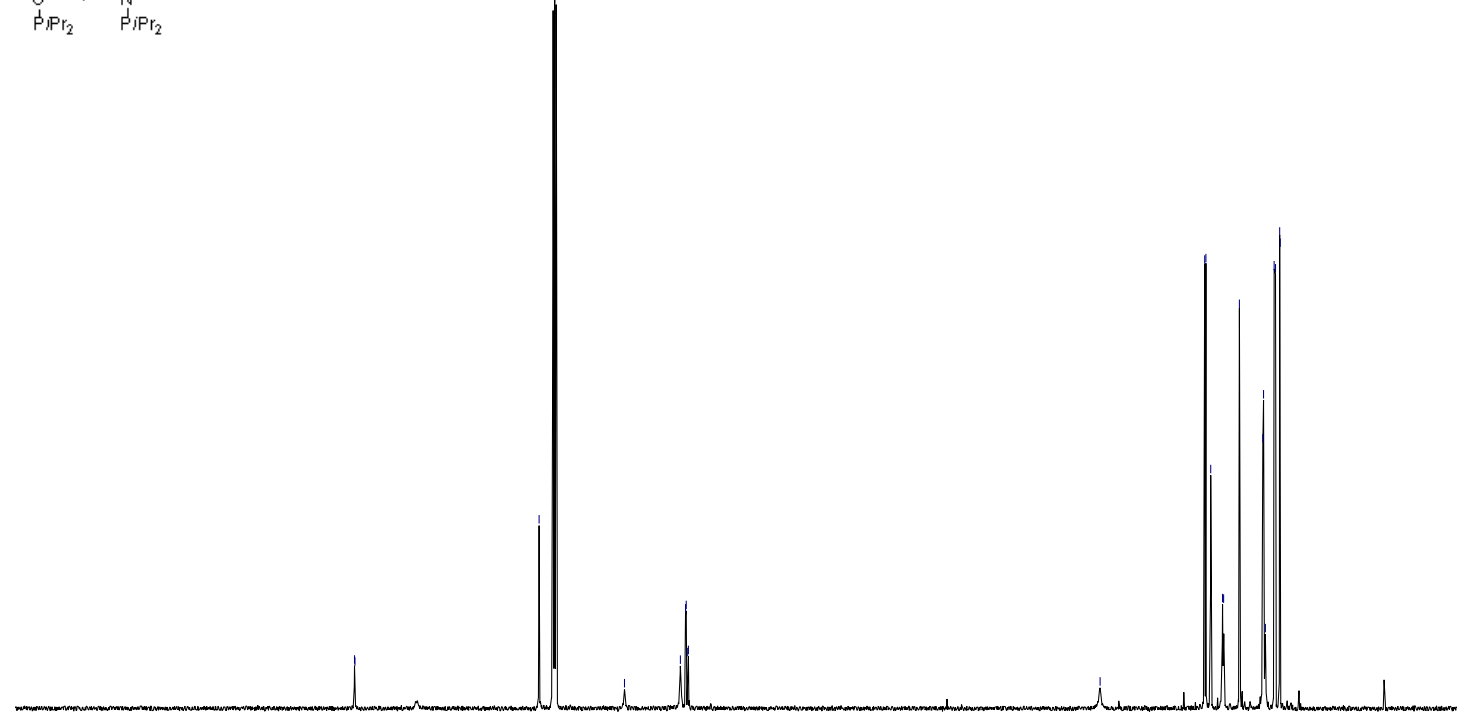

$\begin{array}{lllllllll}10 & 200 & 190 & 180 & 170 & 160 & 150 & 140 & 130\end{array}$ $\mathrm{D}_{6}$.

Figure S39. ${ }^{13} \mathrm{C}$ NMR of $6 \mathbf{g}$ in $\mathrm{C}_{6} \mathrm{D}_{6}$.

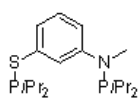
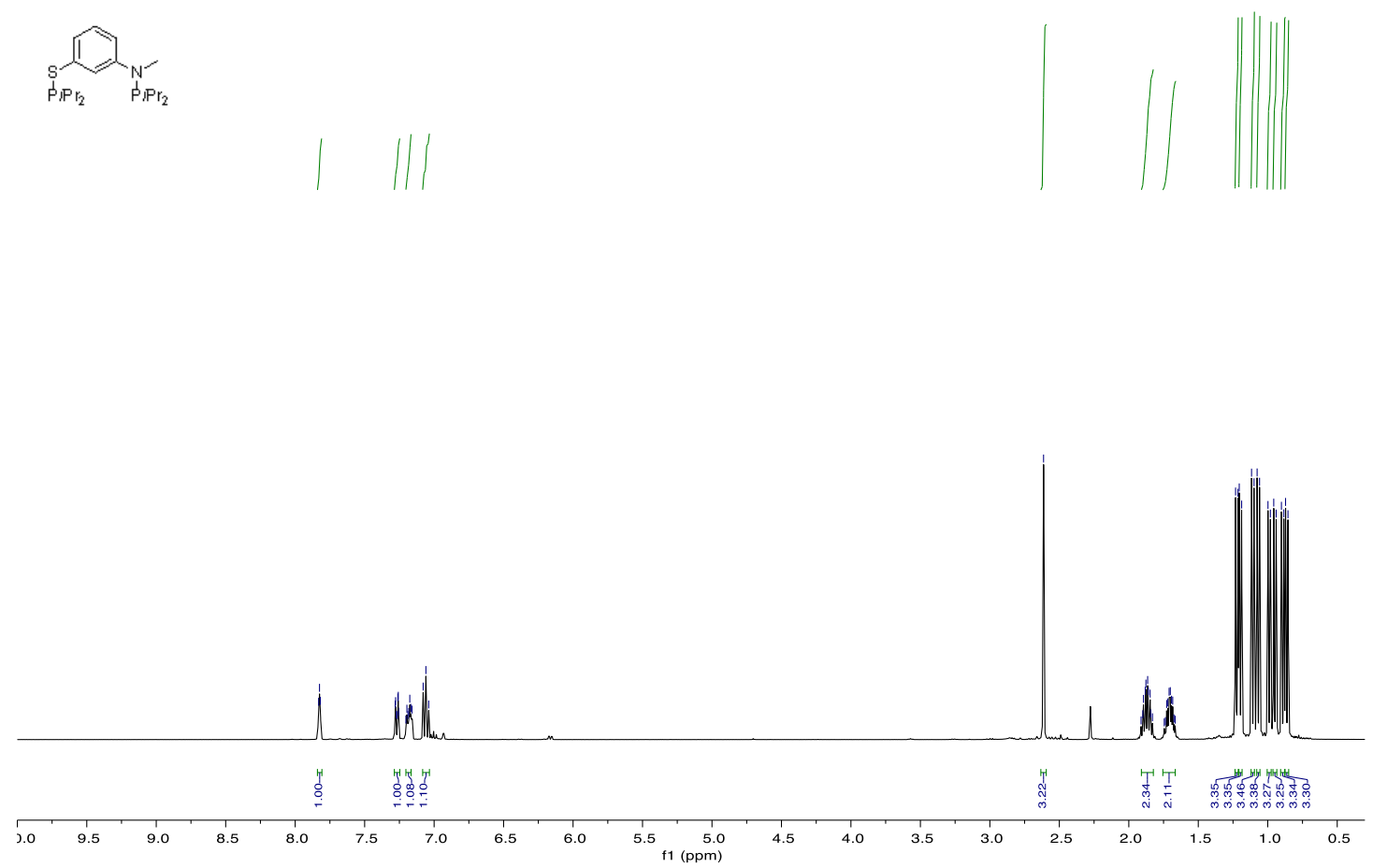

Figure S40. ${ }^{1} \mathrm{H}$ NMR of $7 \mathbf{b}$ in $\mathrm{C}_{6} \mathrm{D}_{6}$. 


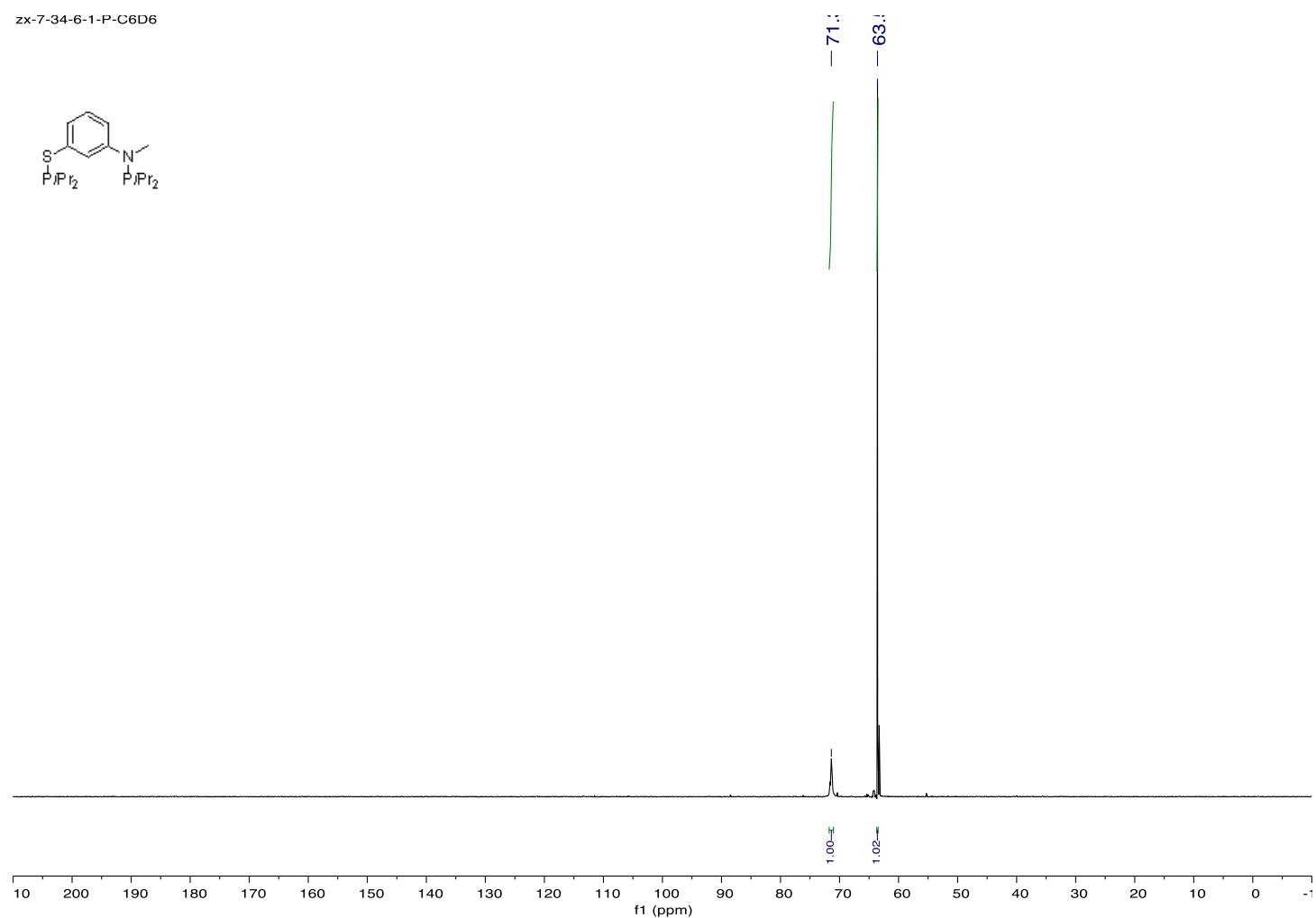

Figure S41. ${ }^{31} \mathrm{P}$ NMR of $7 \mathbf{b}$ in $\mathrm{C}_{6} \mathrm{D}_{6}$.

2x-7-34-6-1-C-C6D6

番兽

- 0 \%

ले

$\overbrace{\mathrm{P}_{\mathrm{Pr}}}$

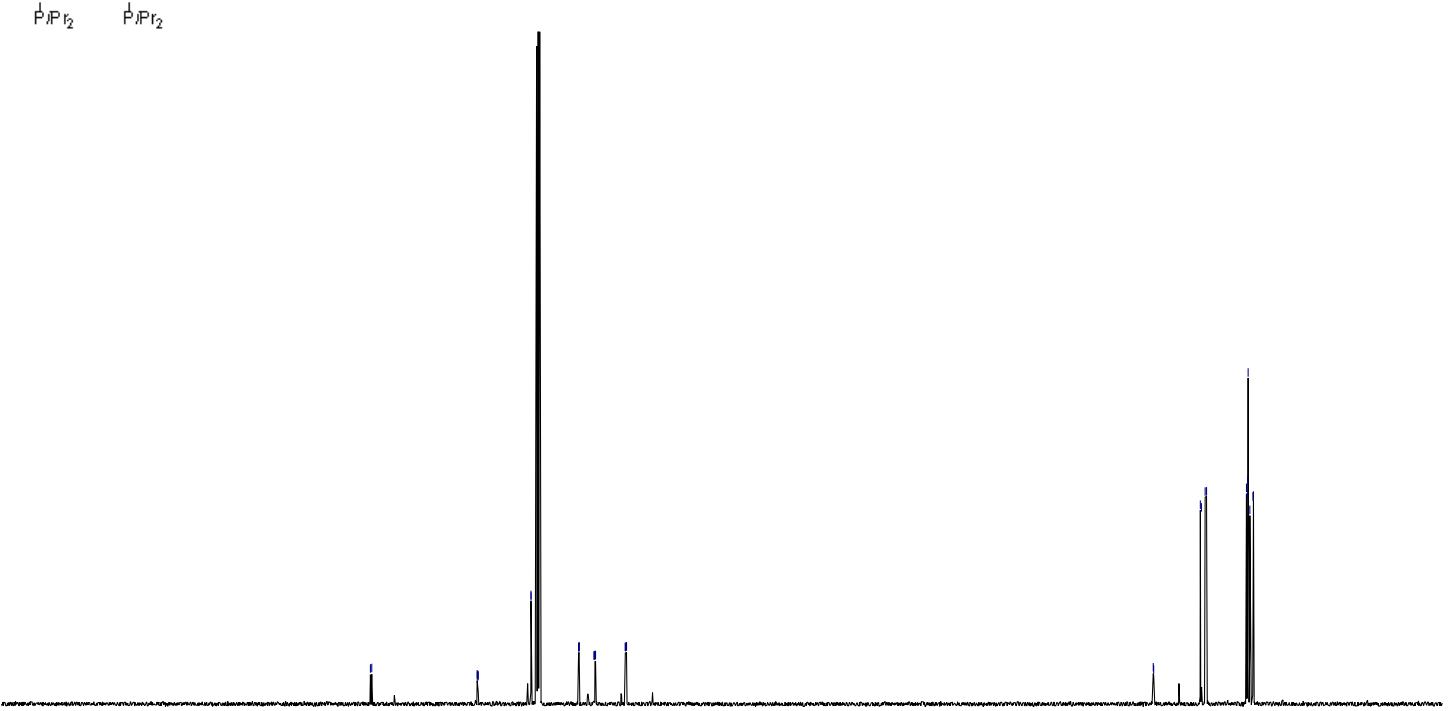

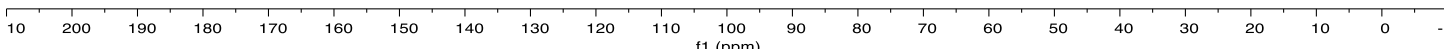

Figure $\mathbf{S 4 2} .{ }^{13} \mathrm{C}$ NMR of $7 \mathbf{b}$ in $\mathrm{C}_{6} \mathrm{D}_{6}$ 


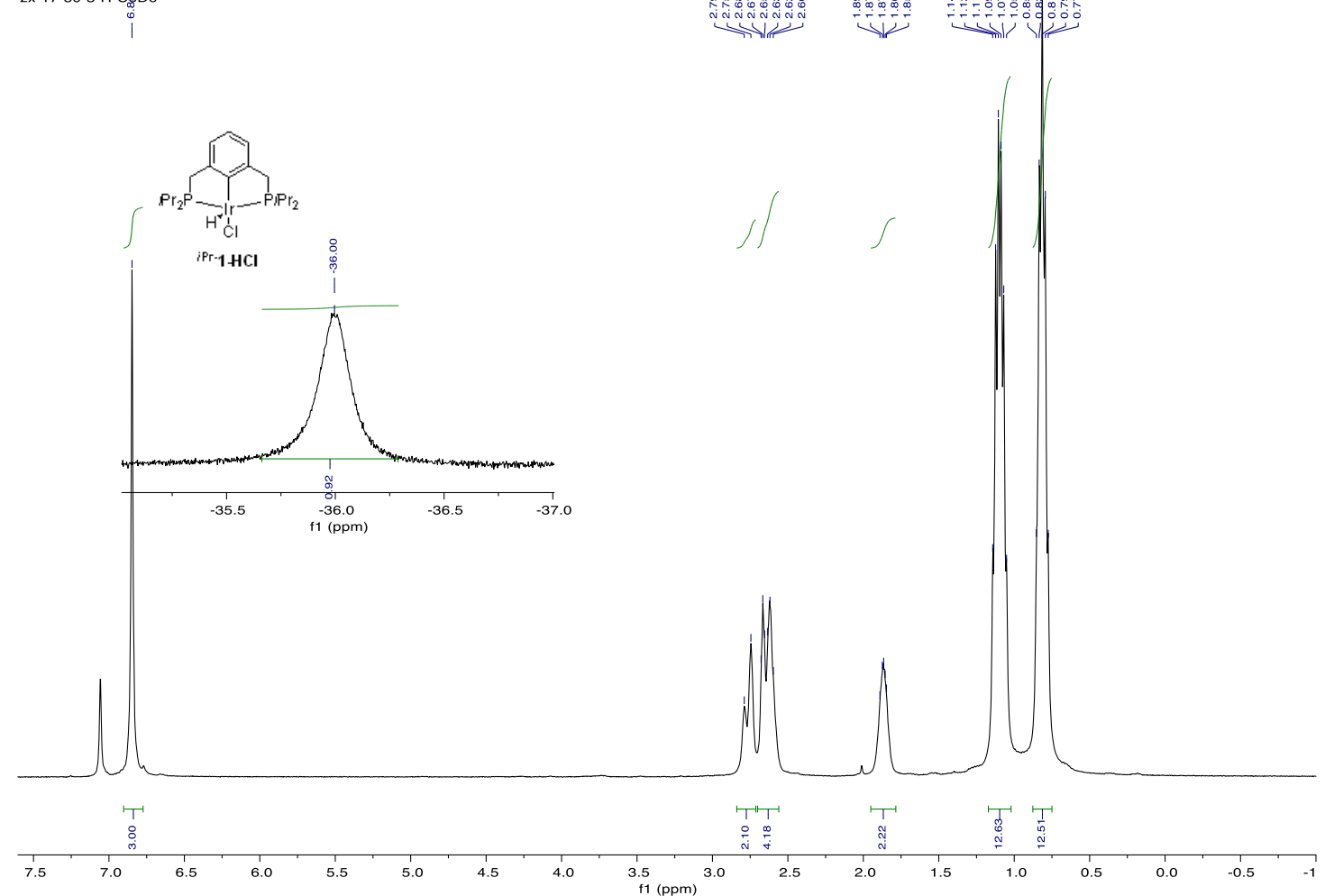

Figure S43. ${ }^{1} \mathrm{H}$ NMR of ${ }^{i \mathrm{Pr}_{-}} \mathbf{1 - H C l}$ in $\mathrm{C}_{6} \mathrm{D}_{6}$

zx-17-30-3-p

STANDARD CARBON PARAMETERS

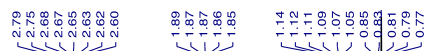

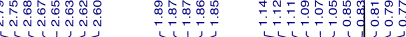
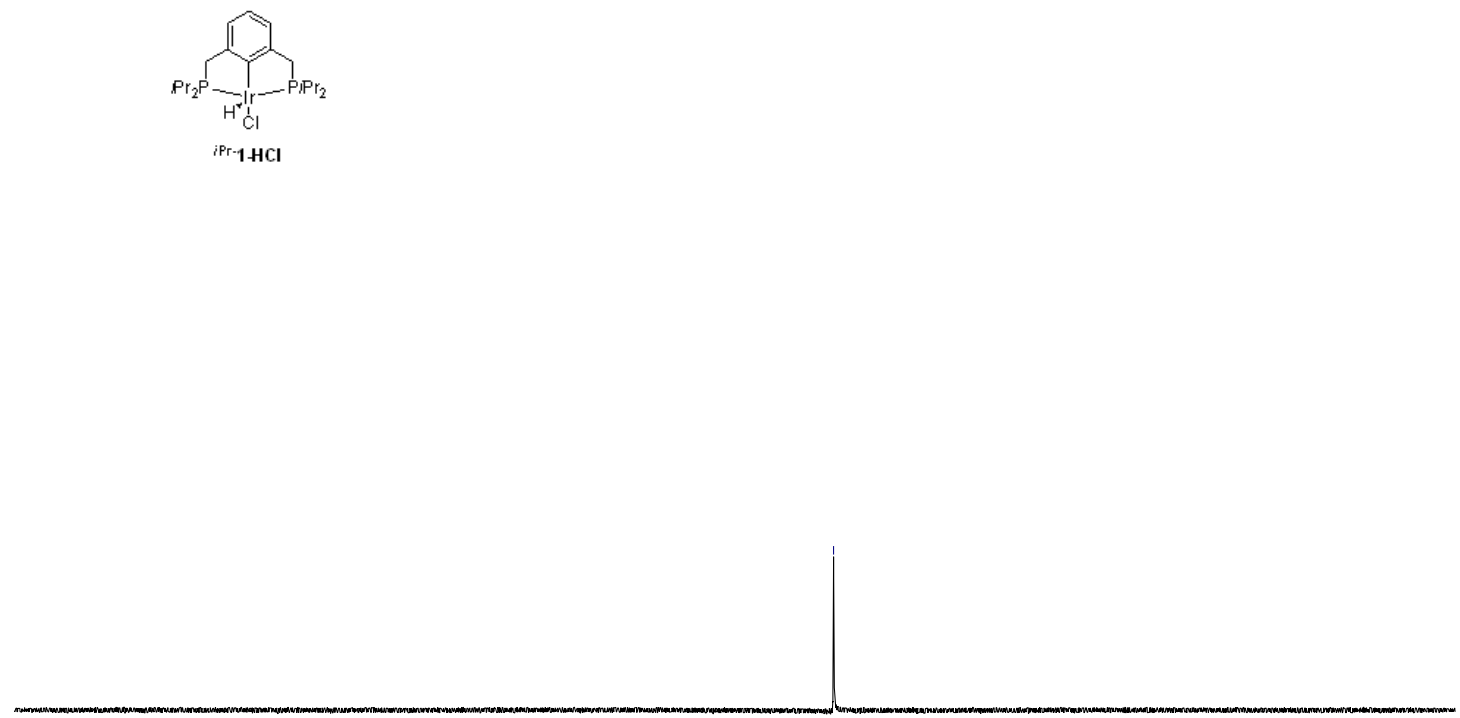

$\begin{array}{lllllllllllllllllllllllllllllllllllll}380 & 360 & 340 & 320 & 300 & 280 & 260 & 240 & 220 & 200 & 180 & 160 & 140 & 120 & 1 & 100 & 80 & 60 & 40 & 20 & 0 & -20 & -40 & -60 & -80 & -100 & -120 & -140 & -160 & -180\end{array}$ Figure S44. ${ }^{31} \mathrm{P}$ NMR of ${ }^{i \mathrm{Pr}_{-}} \mathbf{1}-\mathrm{HCl}$ in $\mathrm{C}_{6} \mathrm{D}_{6}$. 


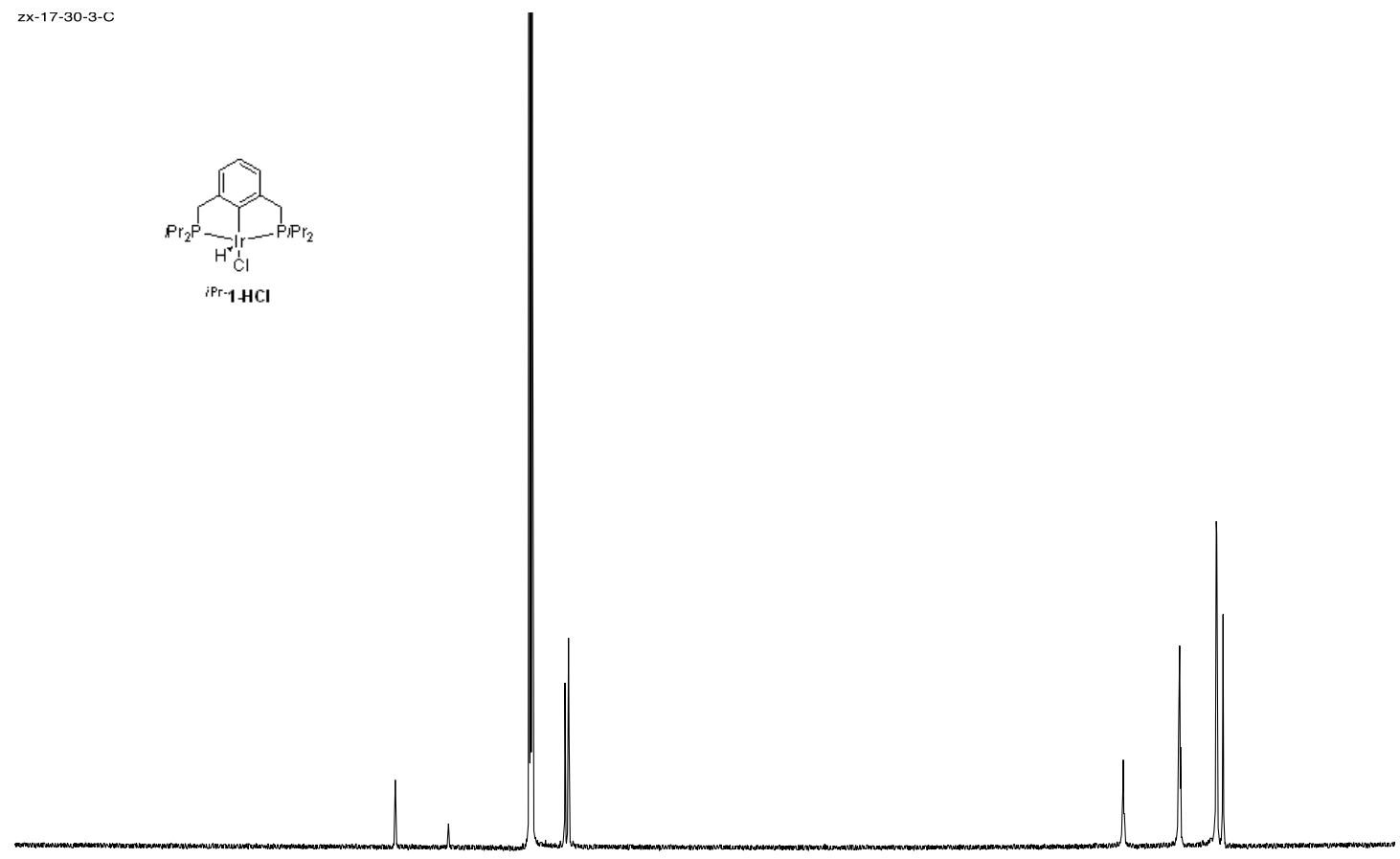

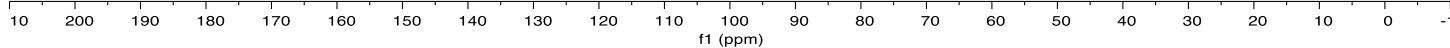

Figure S45. ${ }^{13} \mathrm{C}$ NMR of ${ }^{i \mathrm{Pr}-1}-\mathrm{HCl}$ in $\mathrm{C}_{6} \mathrm{D}_{6}$

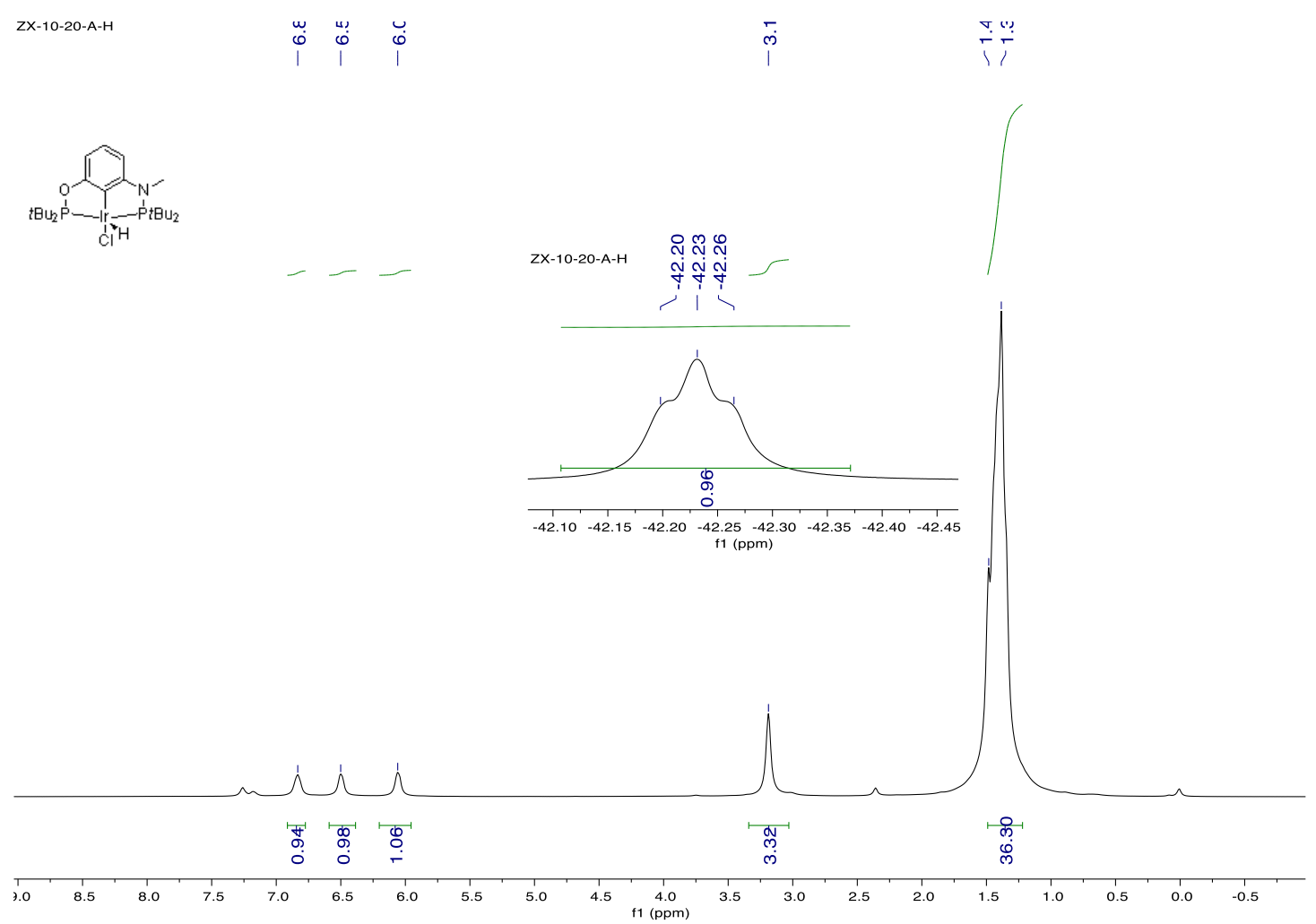

Figure S46. ${ }^{1} \mathrm{H} \mathrm{NMR}$ of $4 \mathrm{a}-\mathrm{HCl}$ in $\mathrm{CDCl}_{3}$. 

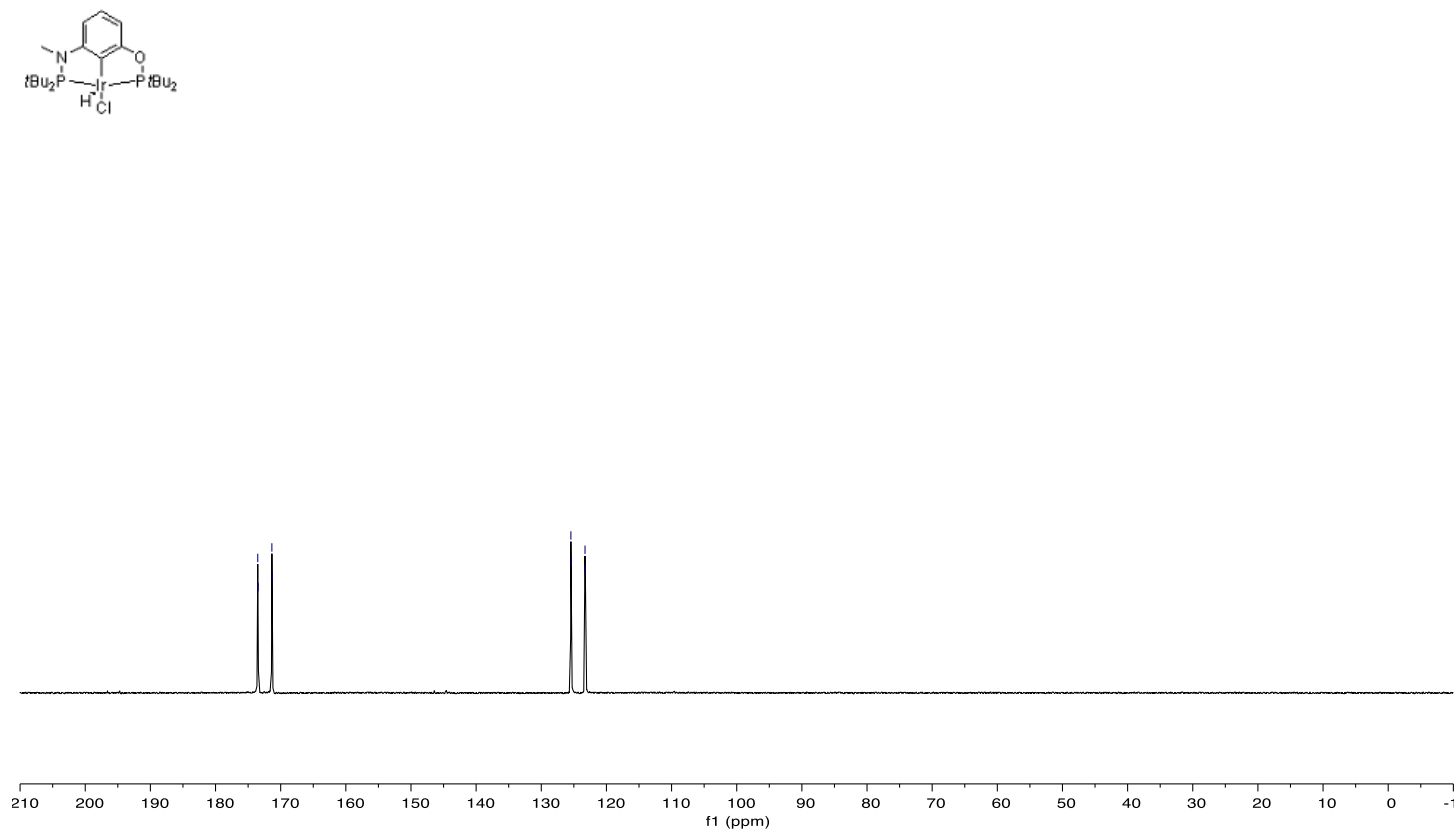

Figure S47. ${ }^{31} \mathrm{P} \mathrm{NMR}$ of $4 \mathrm{a}-\mathrm{HCl}$ in $\mathrm{C}_{6} \mathrm{D}_{6}$ ZX-10-20-A-C-CDCl3

ล்

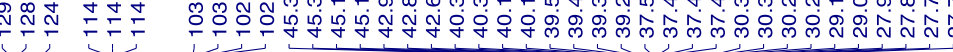
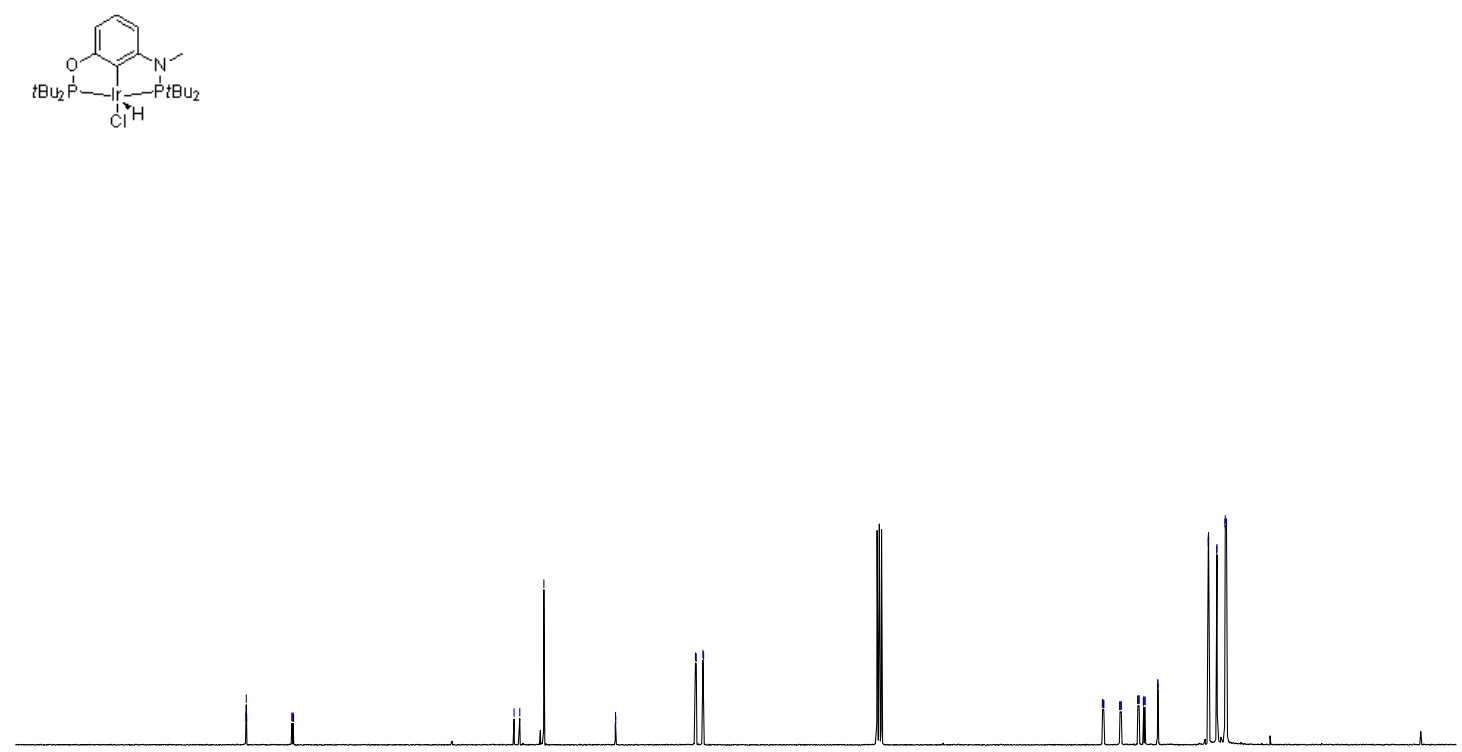

oo $\quad 190 \quad 180 \quad 170 \quad 160 \quad 150 \quad 140 \quad 130 \quad 120 \quad 110$

Figure S48. ${ }^{13} \mathrm{C}$ NMR of $4 \mathbf{a}-\mathrm{HCl}$ in $\mathrm{CDCl}_{3}$. 

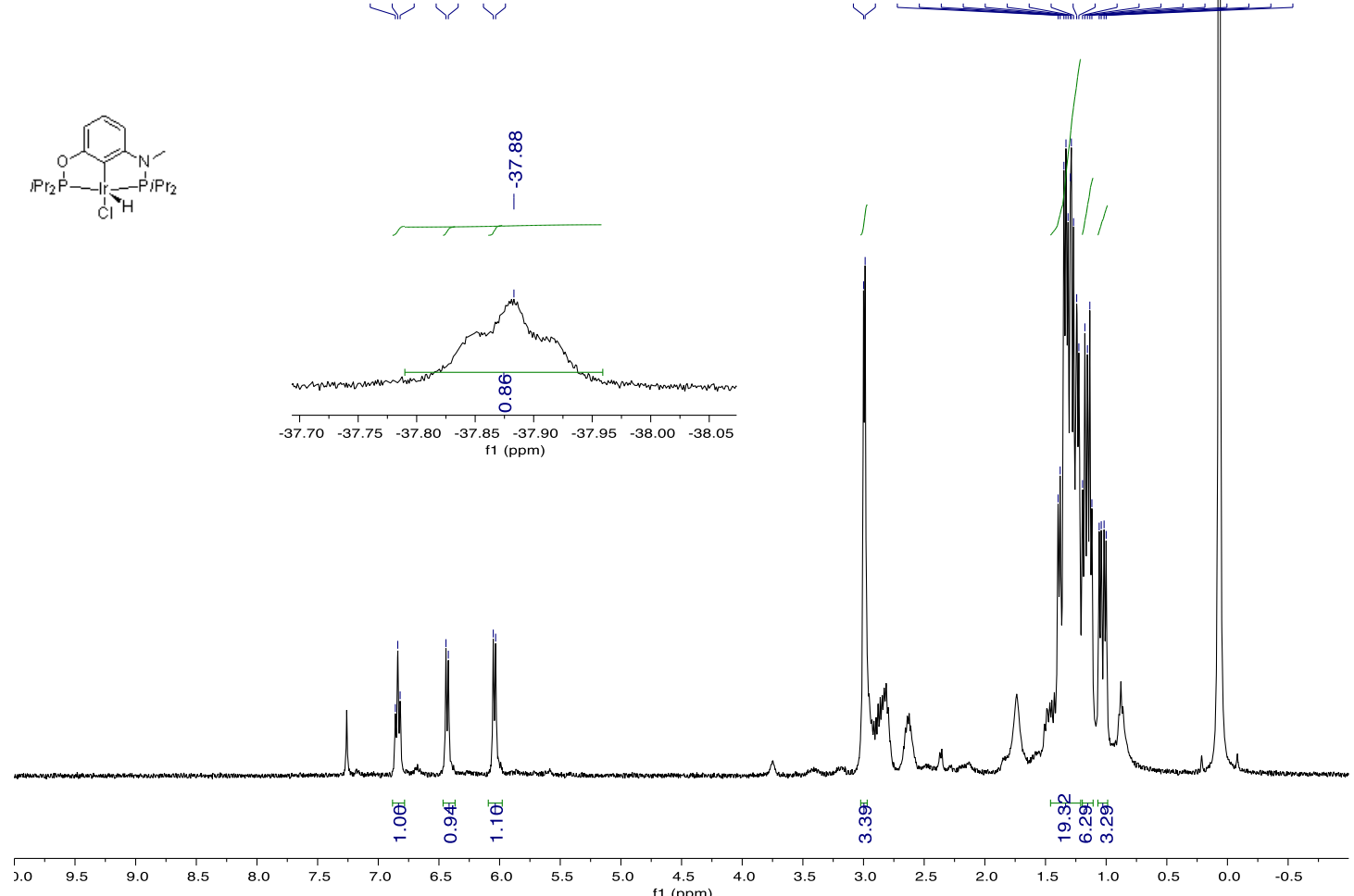

Figure S49. ${ }^{1} \mathrm{H} \mathrm{NMR}$ of $\mathbf{4 b}-\mathrm{HCl}$ in $\mathrm{CDCl}_{3}$.

$-\mathrm{x}-7-92-6-1-\mathrm{P}-\mathrm{CDC} / 3$

TANDARD CARBON PARAMETERS
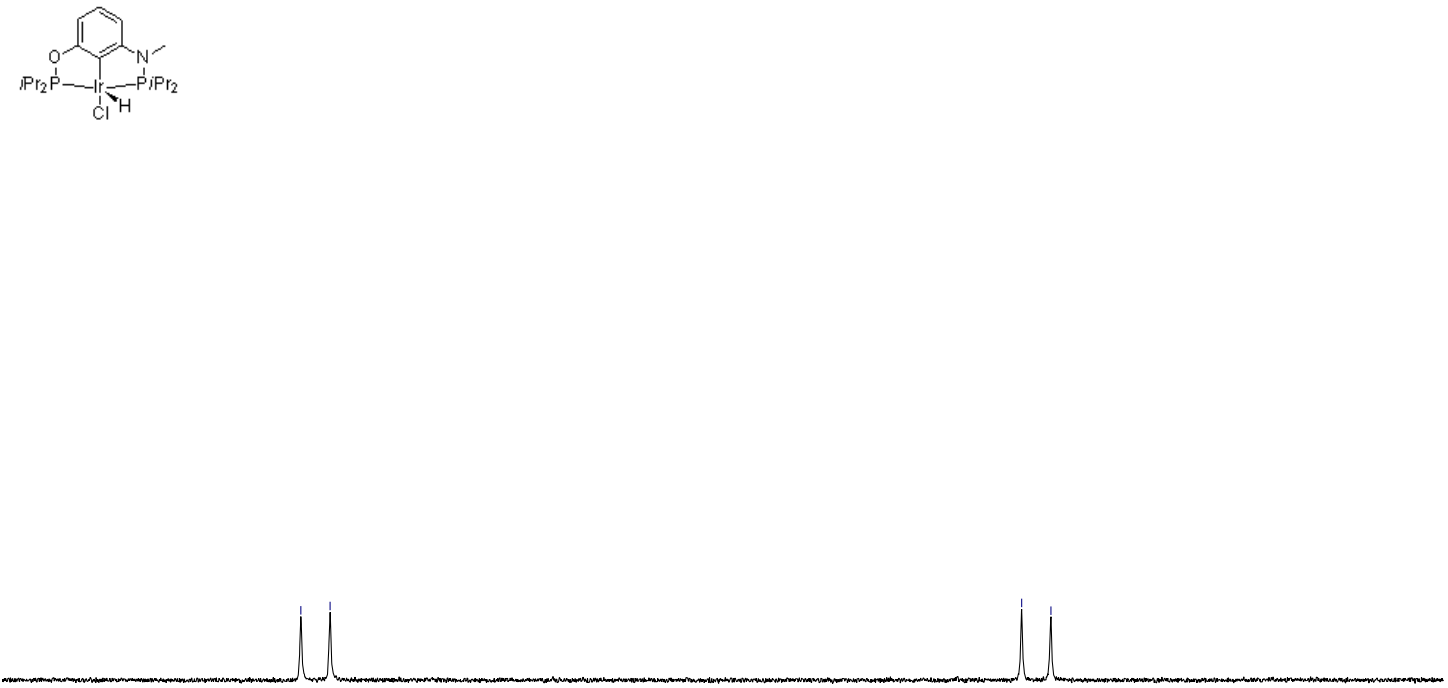

igure S50. ${ }^{31} \mathrm{P} \mathrm{NMR}$ of $\mathbf{4 b}-\mathrm{HCl}$ in $\mathrm{CDCl}_{3}$. 

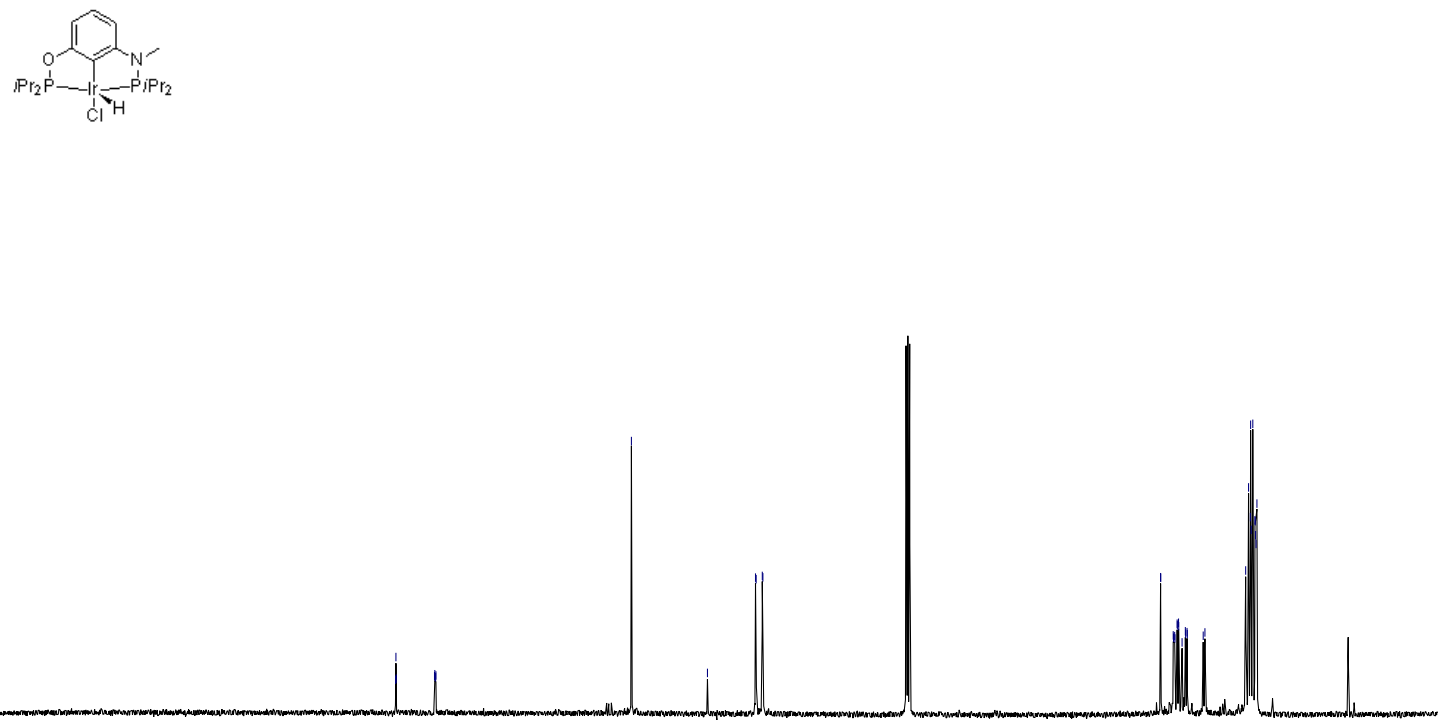

Figure S51. ${ }^{13} \mathrm{C} \mathrm{NMR}$ of $\mathbf{4 b}-\mathrm{HCl}$ in $\mathrm{CDCl}_{3}$

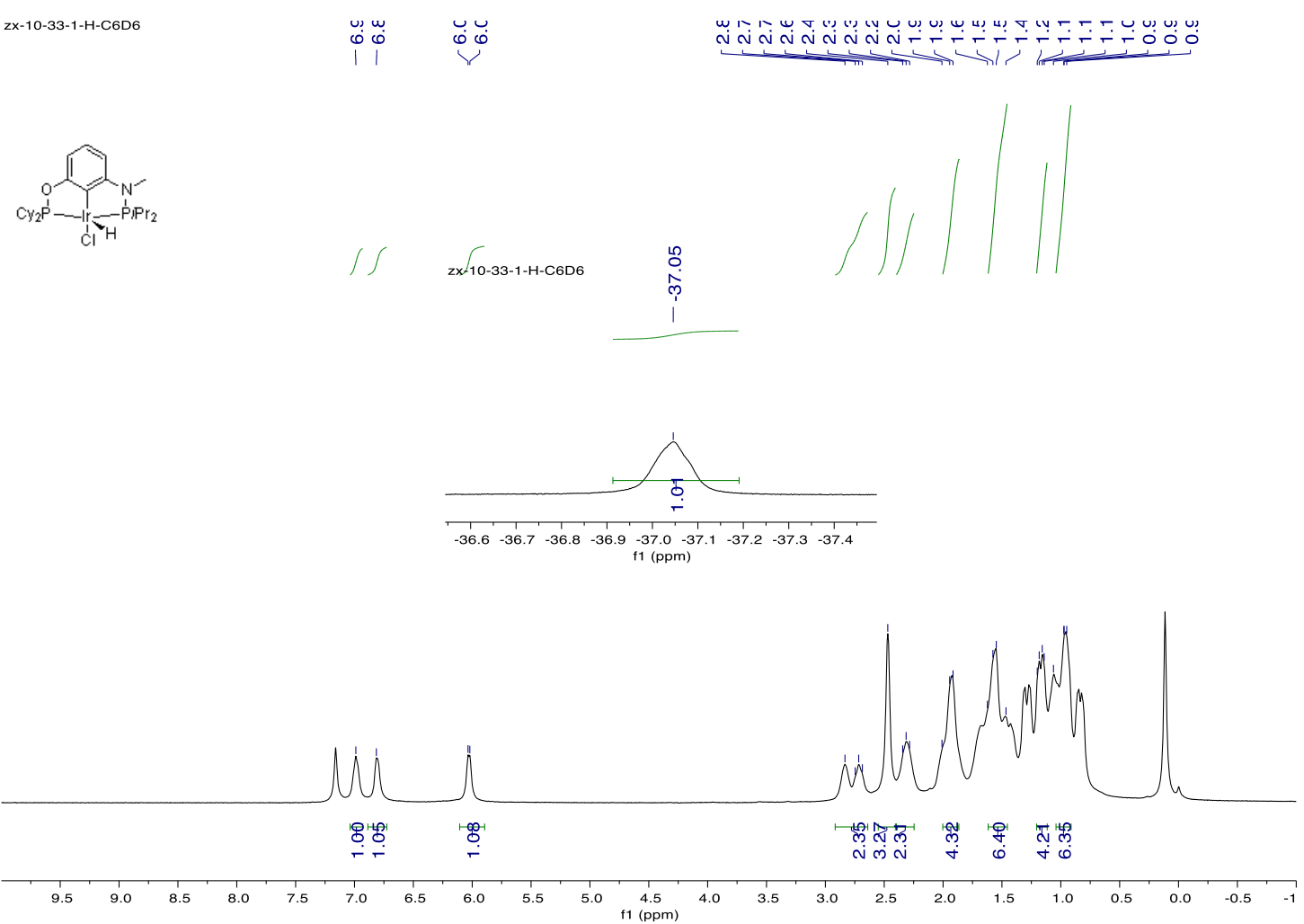

Figure S52. ${ }^{1} \mathrm{H}$ NMR of $4 c-H C l$ in $\mathrm{C}_{6} \mathrm{D}_{6}$. 

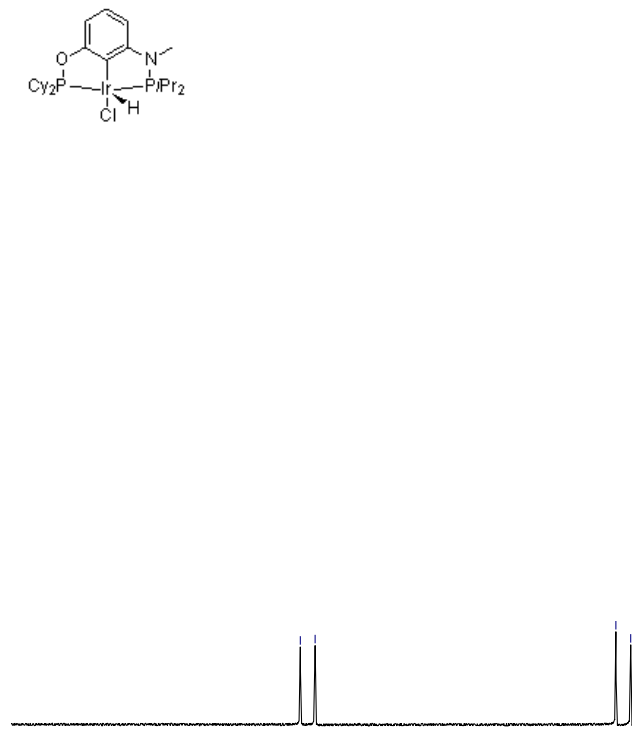

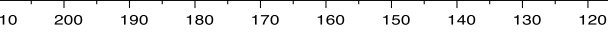
$10 \begin{gathered}100 \\ \mathrm{f} 1(\mathrm{ppm})\end{gathered}$

Figure S53. ${ }^{31} \mathrm{P}$ NMR of $4 \mathrm{c}-\mathrm{HCl}$ in $\mathrm{C}_{6} \mathrm{D}_{6}$

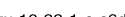

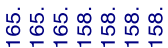

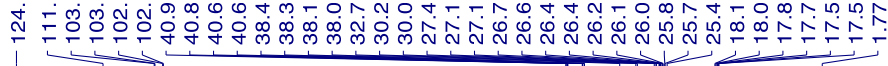

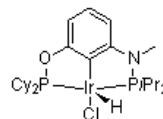
工

CI

Figure S54. ${ }^{13} \mathrm{C}$ NMR of $4 c-H C l$ in $\mathrm{C}_{6} \mathrm{D}_{6}$. 

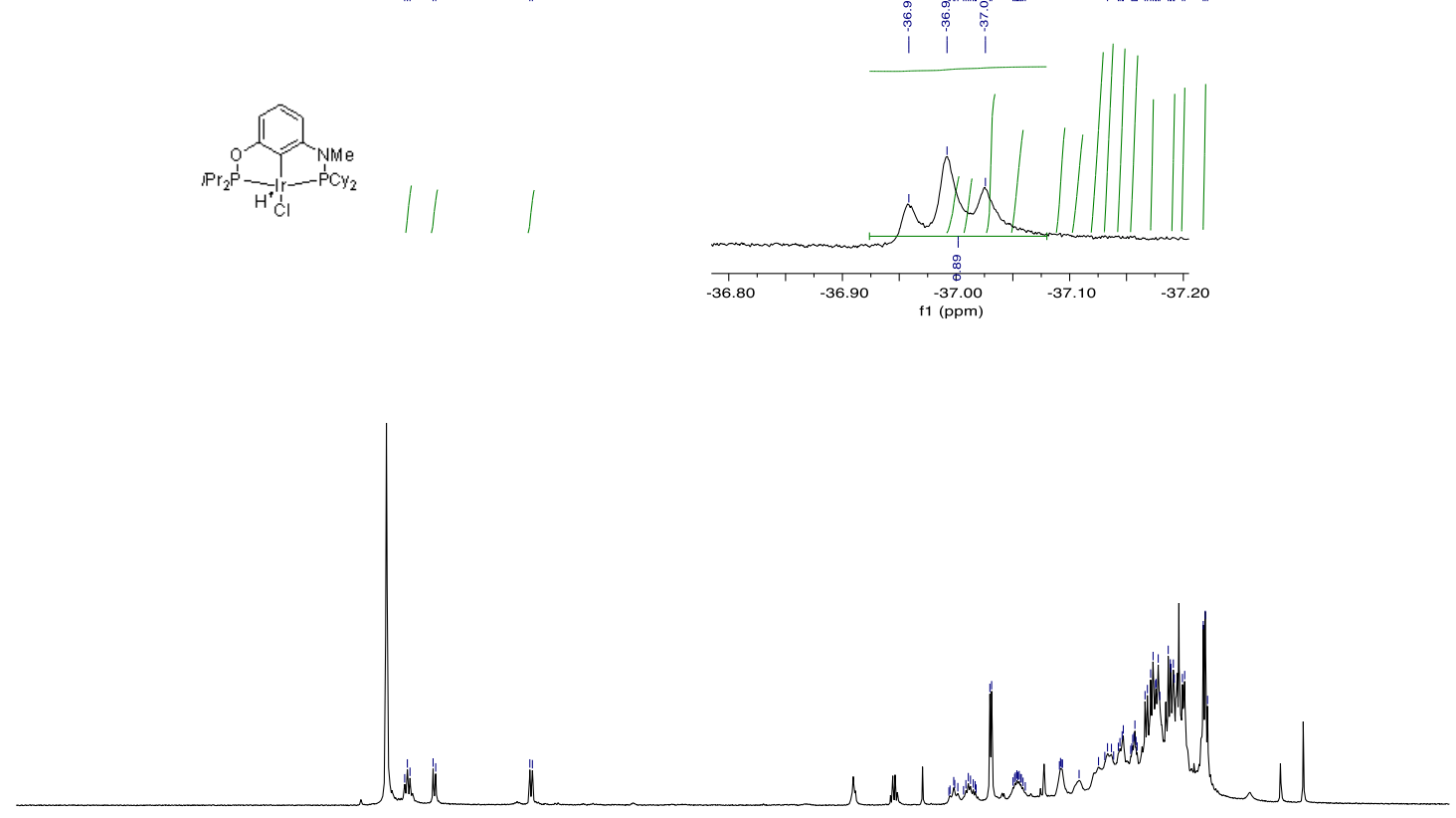

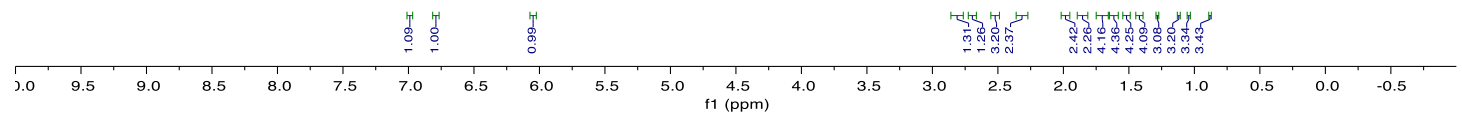

Figure S55. ${ }^{1} \mathrm{H}$ NMR of $4 d-H C l$ in $\mathrm{C}_{6} \mathrm{D}_{6}$.
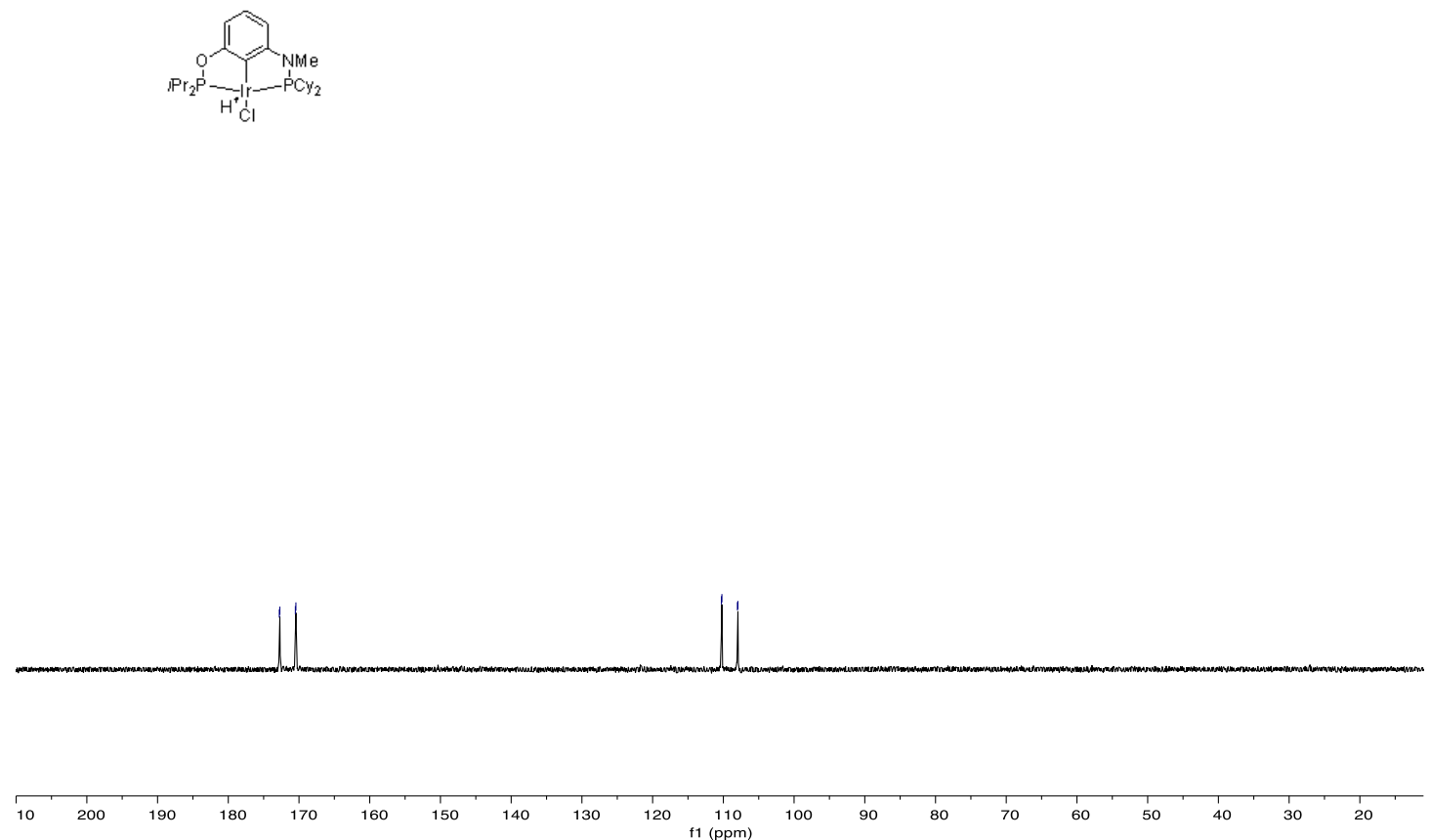

Figure S56. ${ }^{31} \mathrm{P}$ NMR of $4 d-H C l$ in $\mathrm{C}_{6} \mathrm{D}_{6}$. 


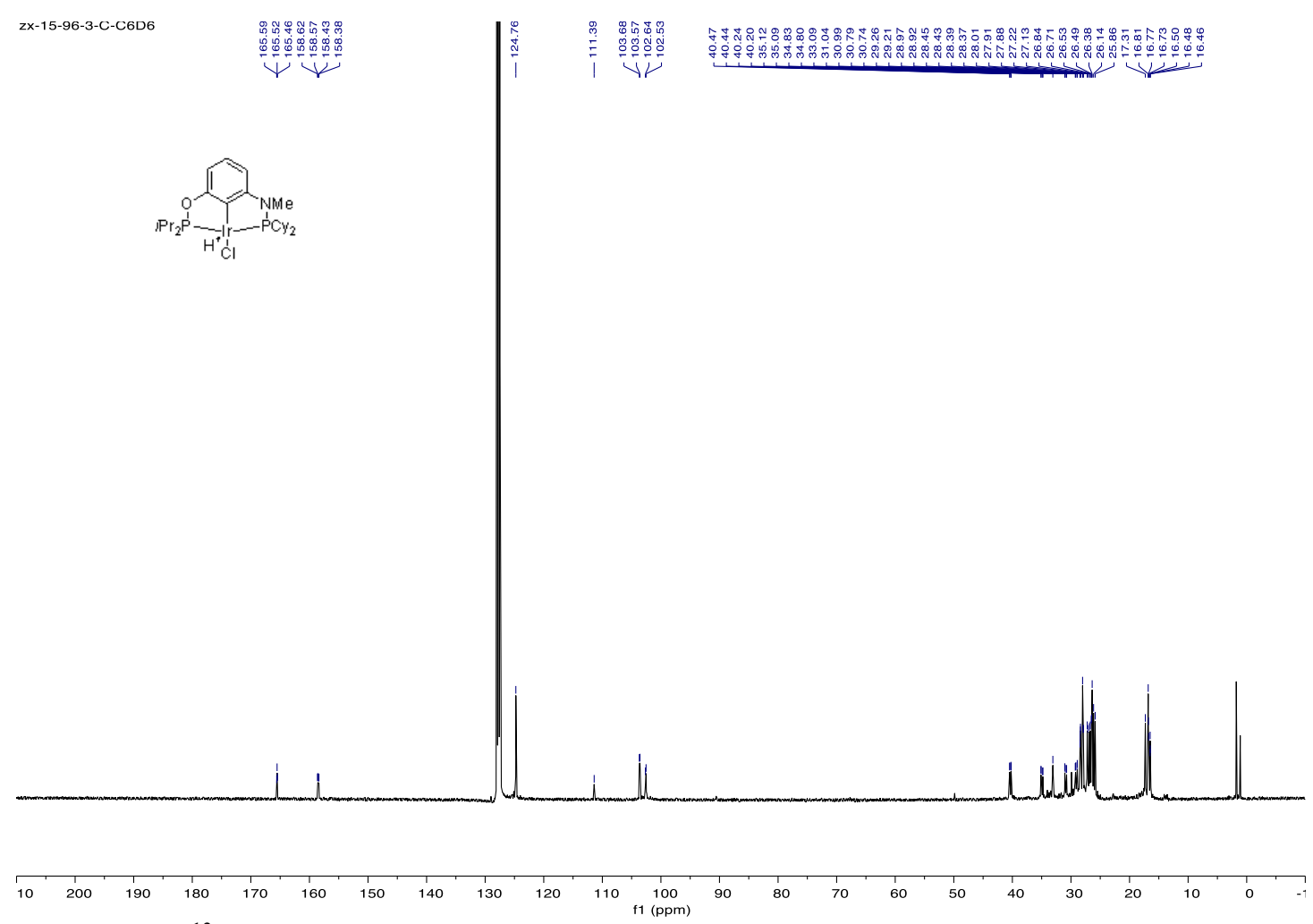

Figure S57. ${ }^{13} \mathrm{C}$ NMR of $4 d-H C l$ in $\mathrm{C}_{6} \mathrm{D}_{6}$.

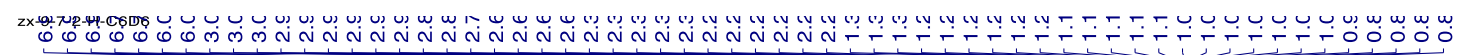
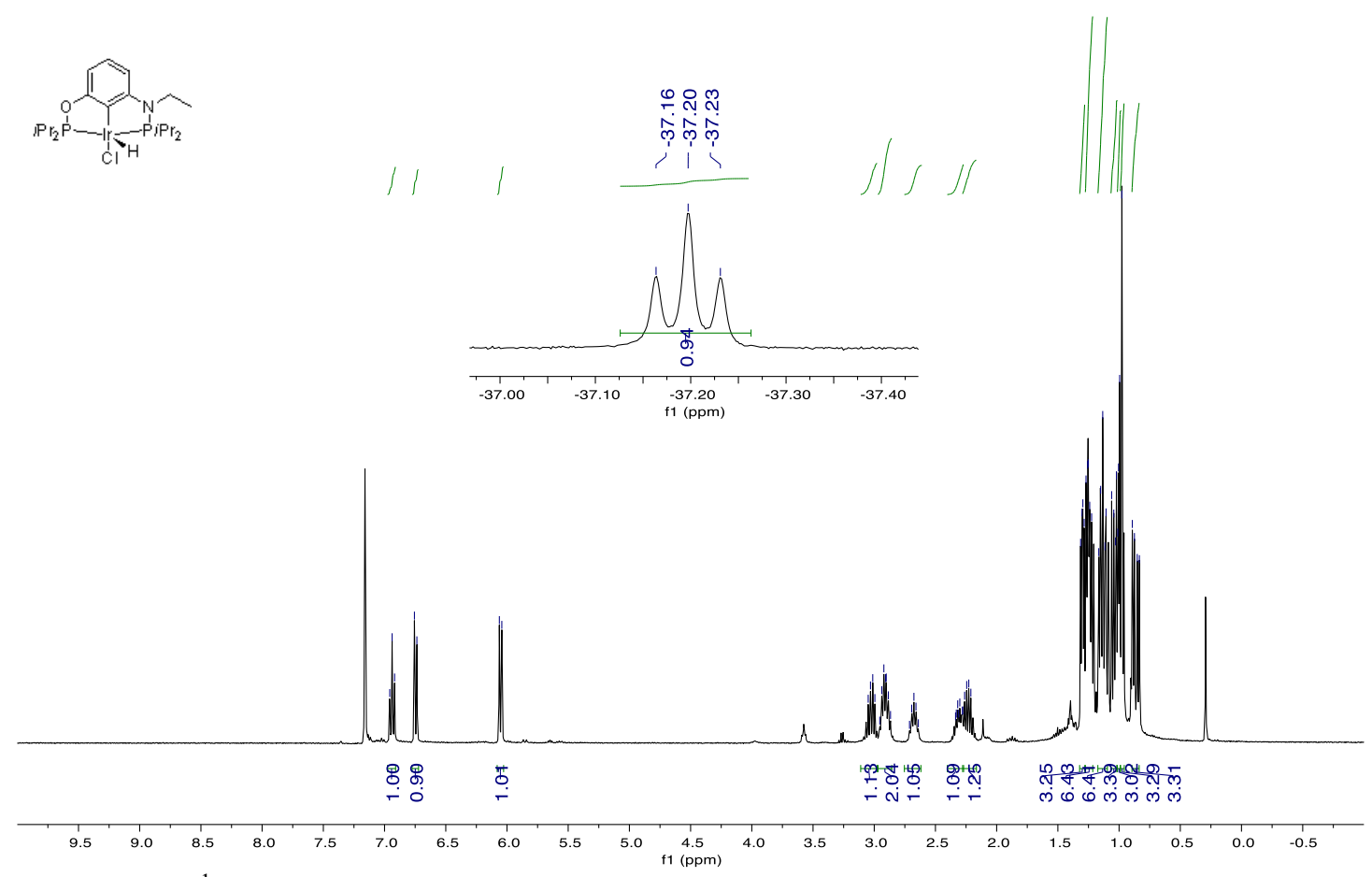

Figure S58. ${ }^{1} \mathrm{H}$ NMR of $4 e-H C l$ in $\mathrm{C}_{6} \mathrm{D}_{6}$. 

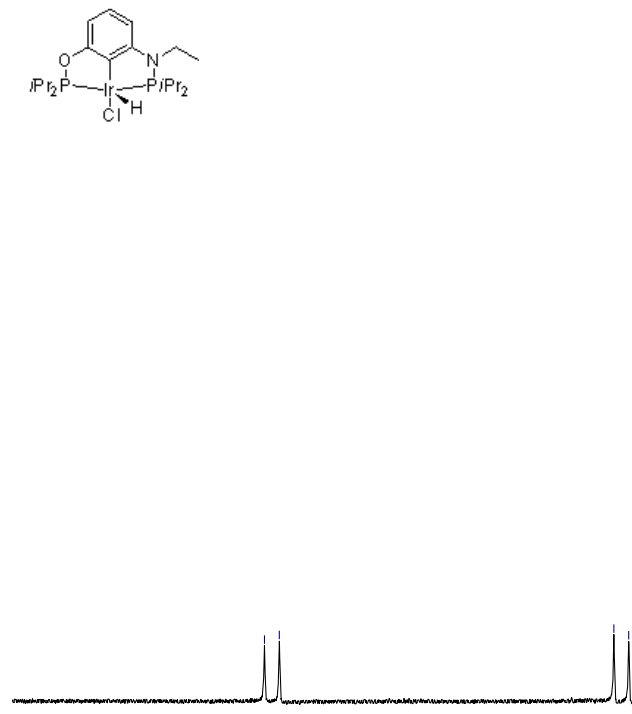

Figure S59. ${ }^{31} \mathrm{P} \mathrm{NMR}$ of $4 \mathrm{e}-\mathrm{HCl}$ in $\mathrm{C}_{6} \mathrm{D}_{6}$

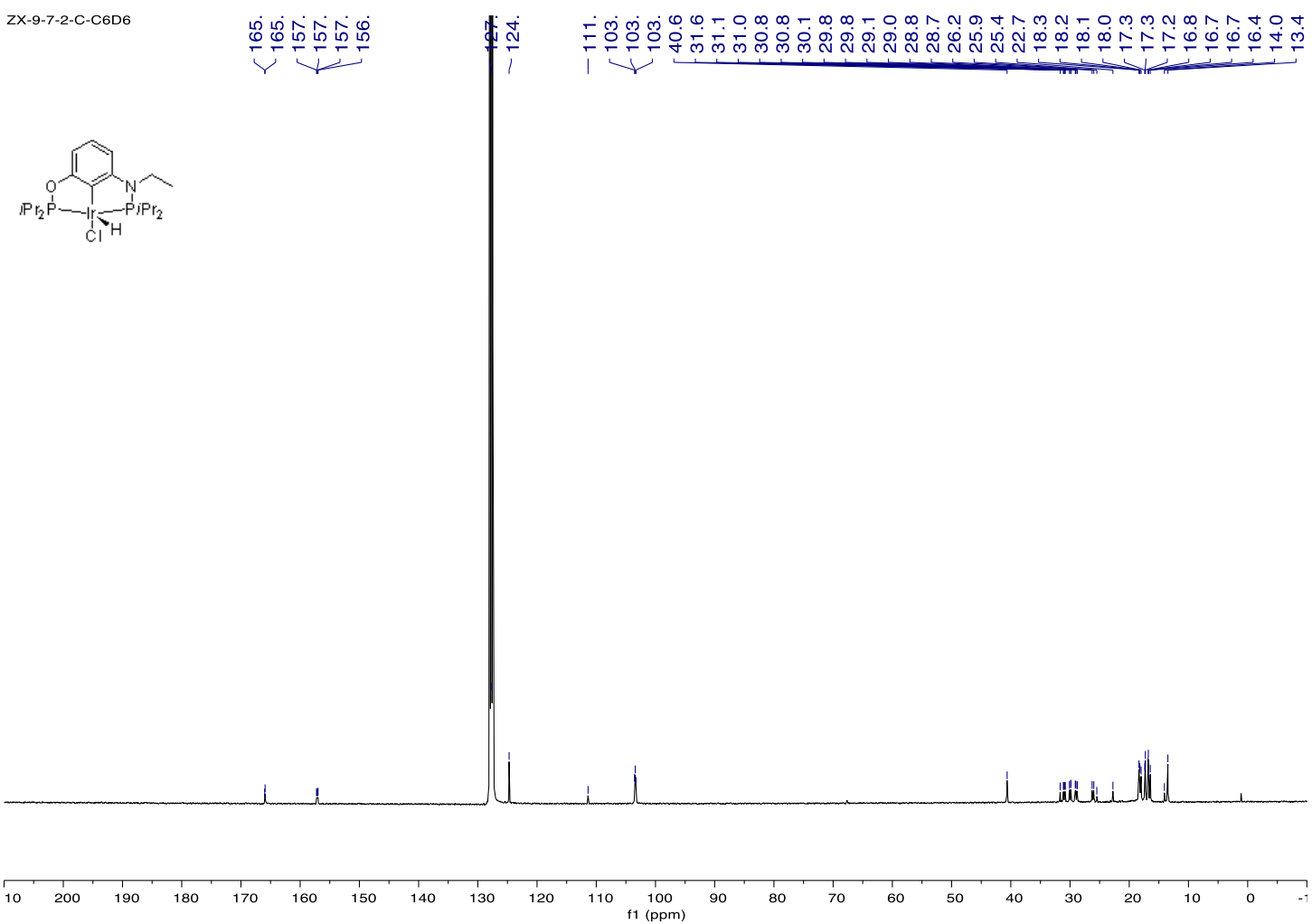

Figure S60. ${ }^{13} \mathrm{C}$ NMR of $4 \mathrm{e}-\mathrm{HCl}$ in $\mathrm{C}_{6} \mathrm{D}_{6}$. 

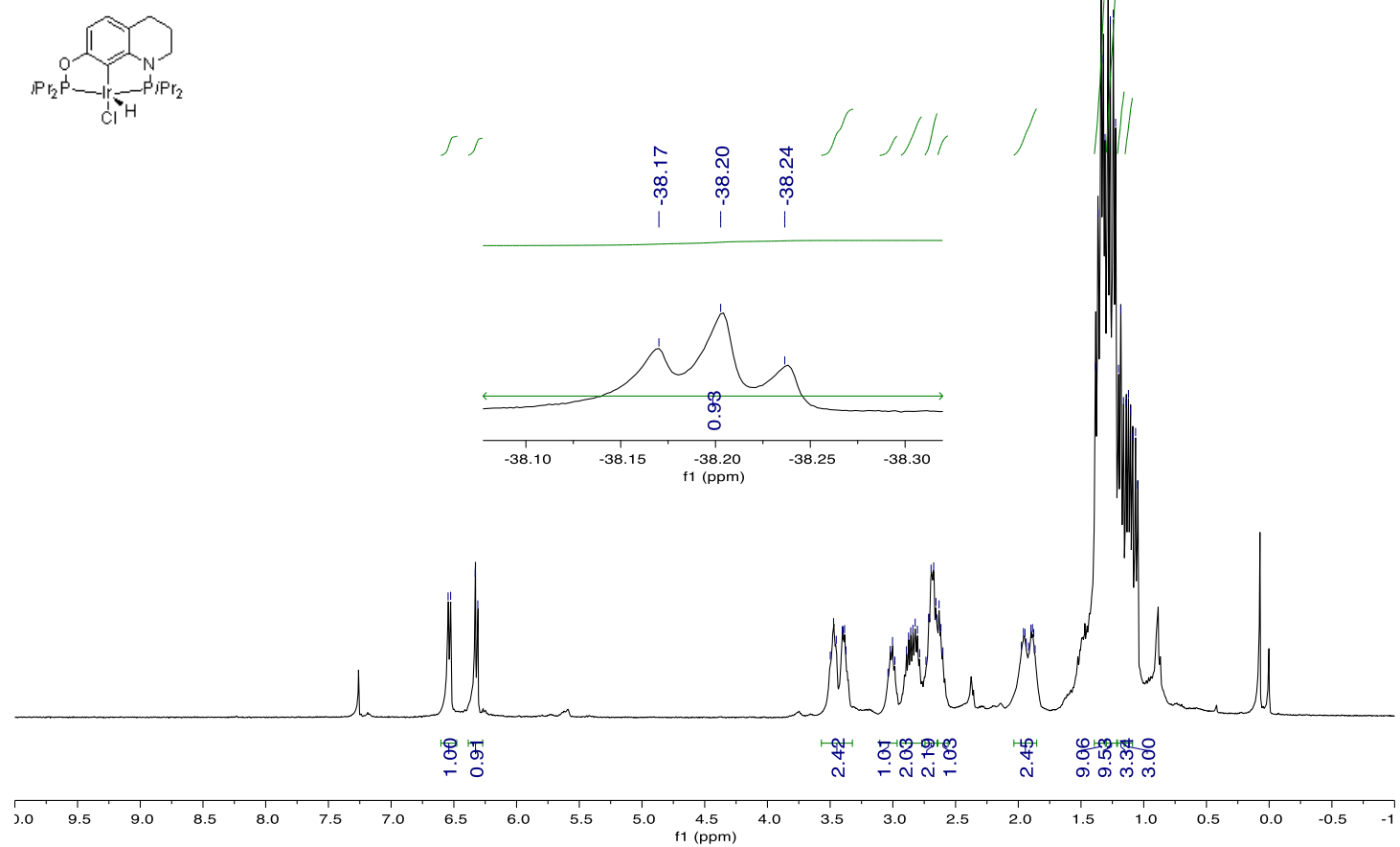

Figure $\mathbf{S 6 1}{ }^{1} \mathrm{H}$ NMR of $\mathbf{4 g}-\mathrm{HCl}$ in $\mathrm{CDCl}_{3}$.

8X-8-75-3-P-CDCI3

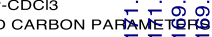

4

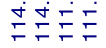
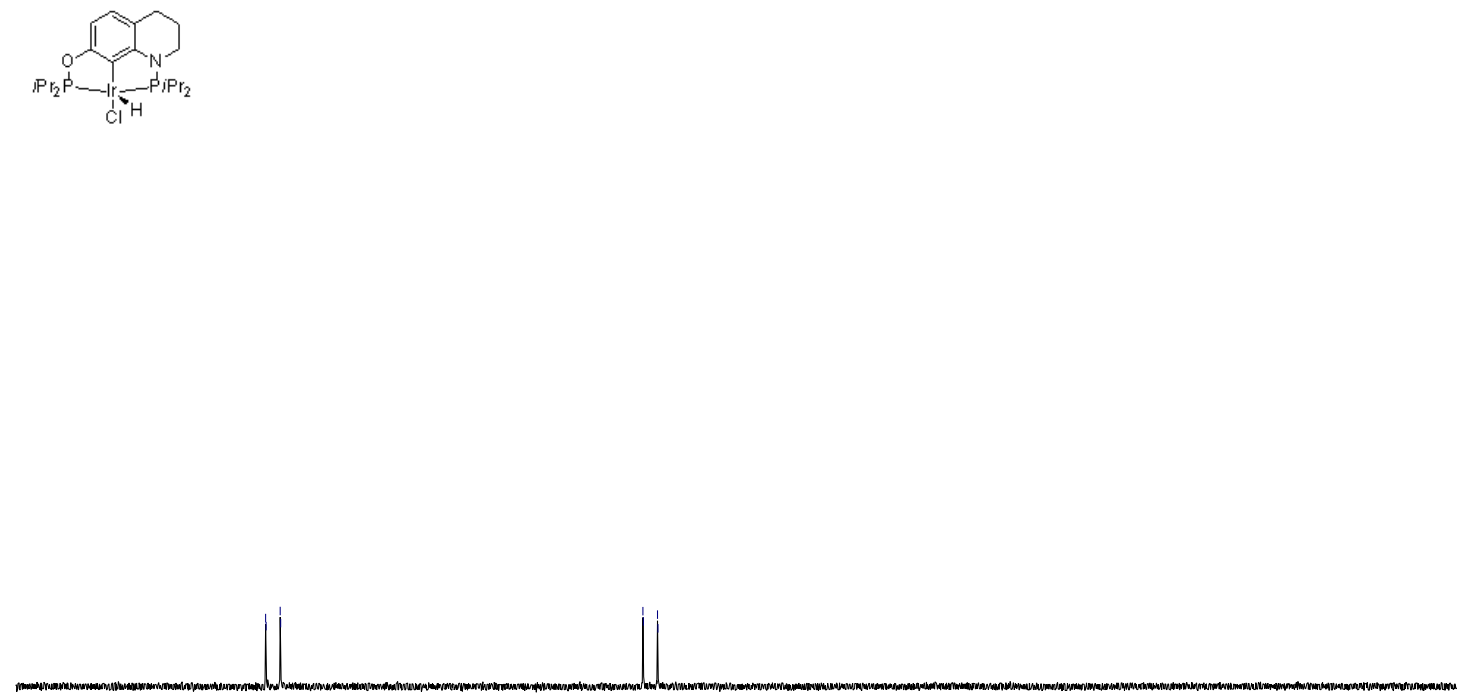

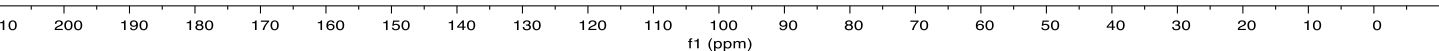

Figure $\mathbf{S 6 2}{ }^{31} \mathrm{P}$ NMR of $\mathbf{4 g}-\mathrm{HCl}$ in $\mathrm{CDCl}_{3}$. 

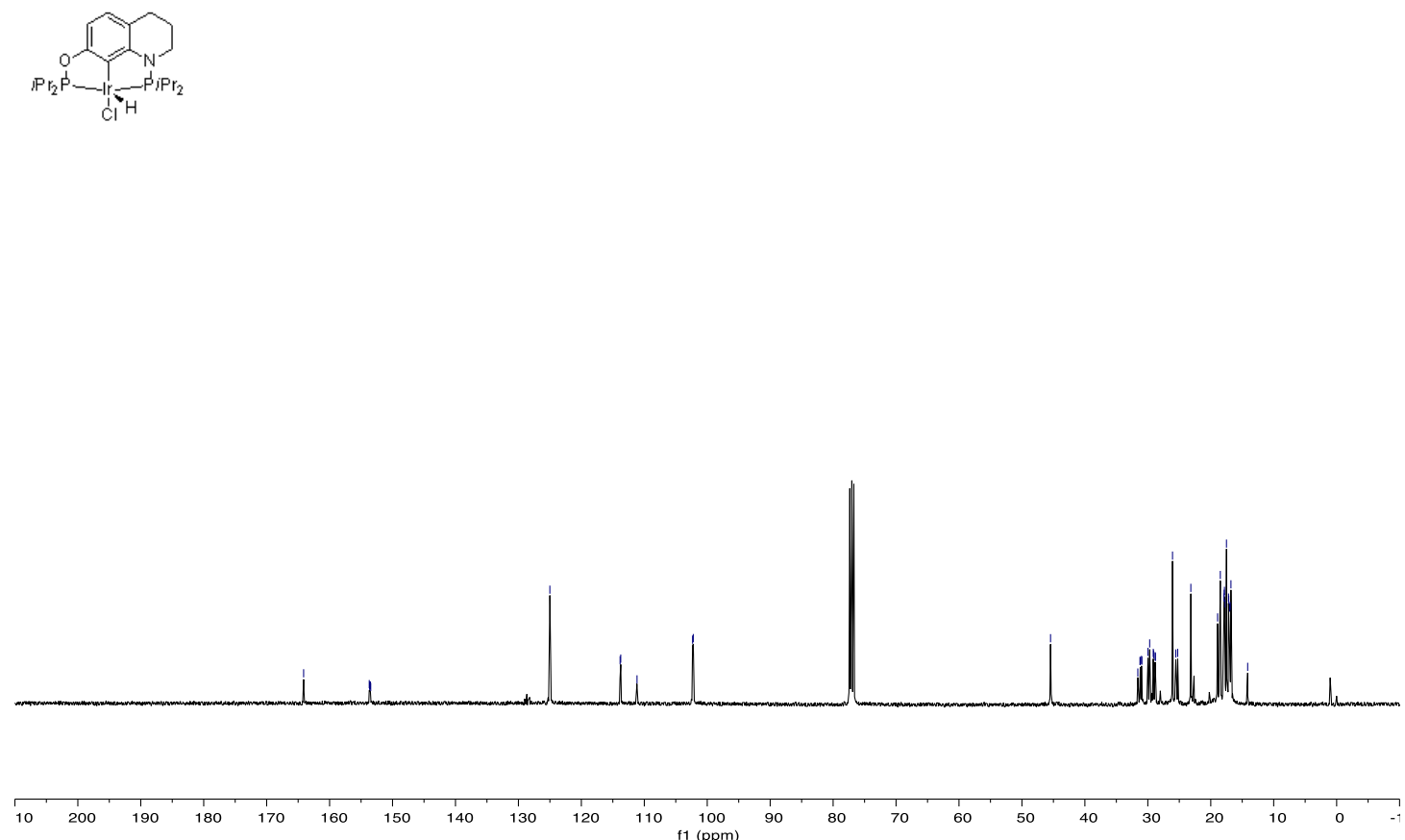

Figure $\mathrm{S}^{63}{ }^{13} \mathrm{C} \mathrm{NMR}$ of $\mathbf{4 g}-\mathrm{HCl}$ in $\mathrm{CDCl}_{3}$

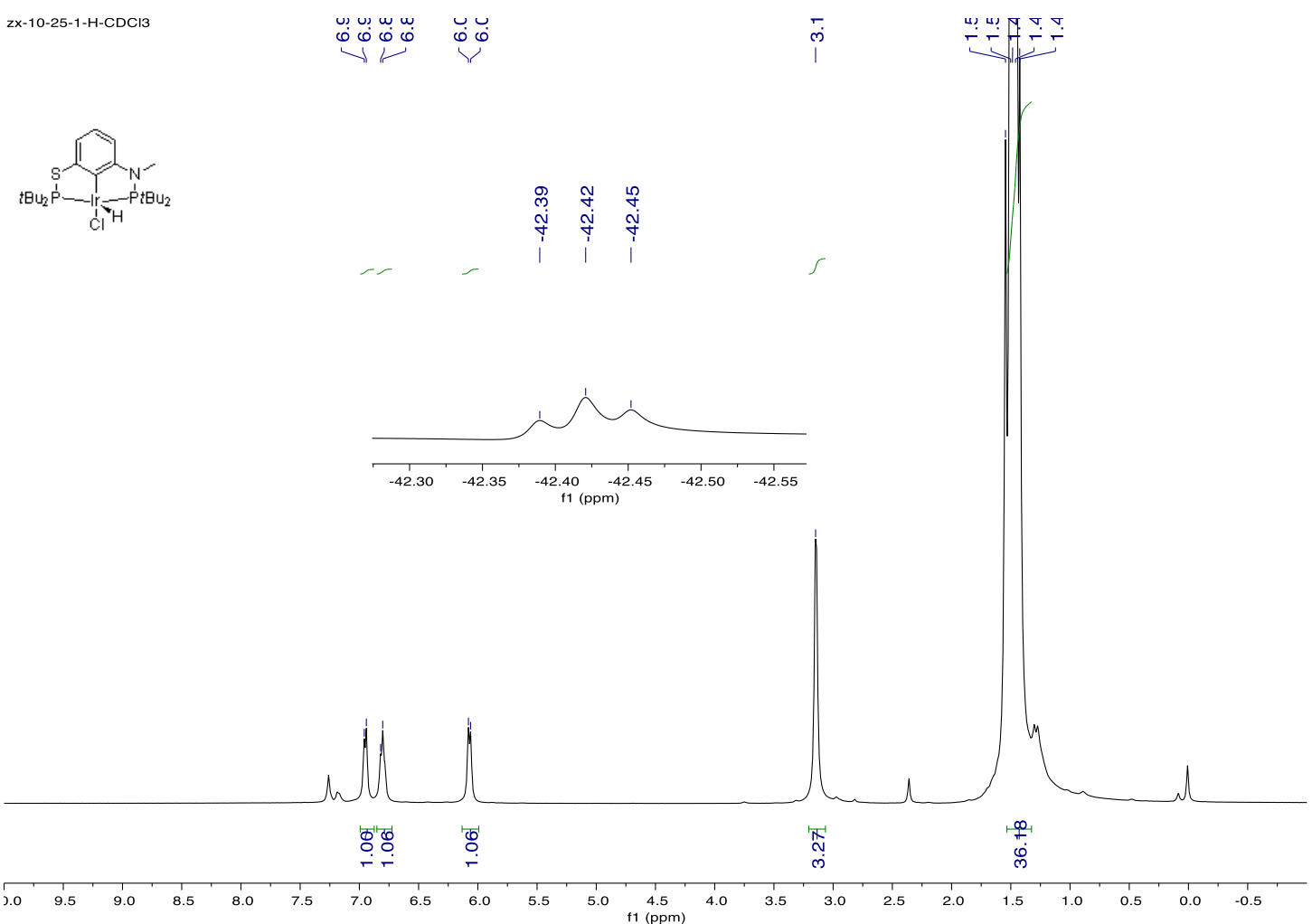

Figure $\mathbf{S 6 4}{ }^{1} \mathrm{H}$ NMR of ${ }^{t \mathrm{Bu}}-5-\mathrm{HCl}$ in $\mathrm{CDCl}_{3}$. 

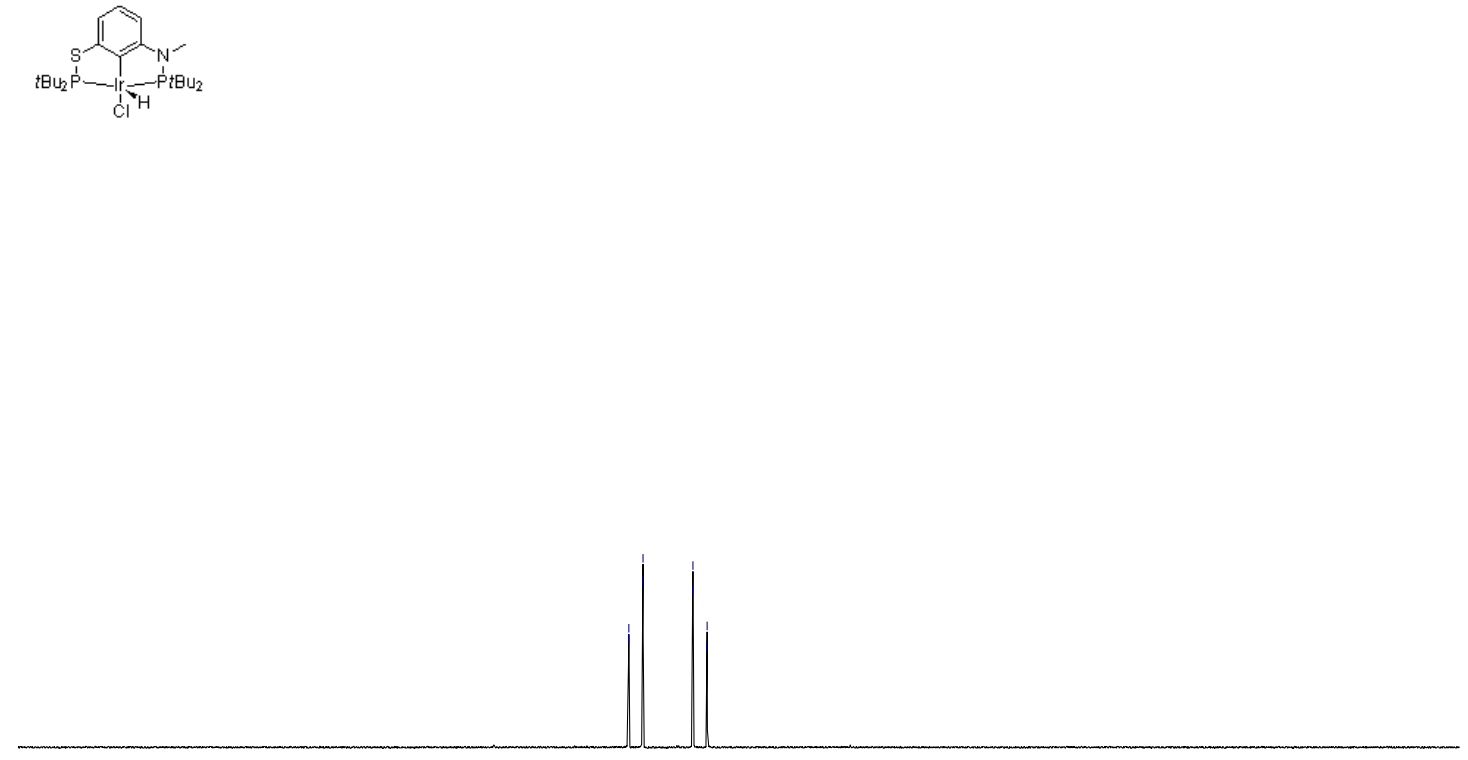

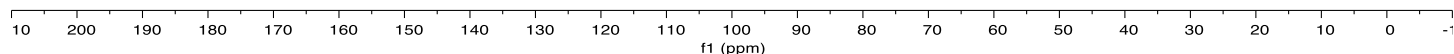

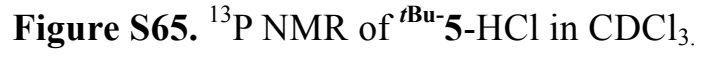

$\mathrm{zx}-10-25-1-\mathrm{C}-\mathrm{CDCl}$

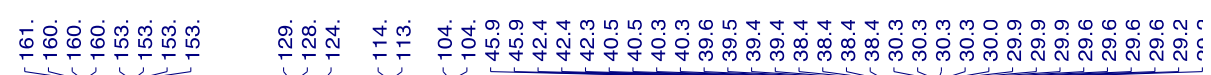

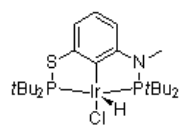

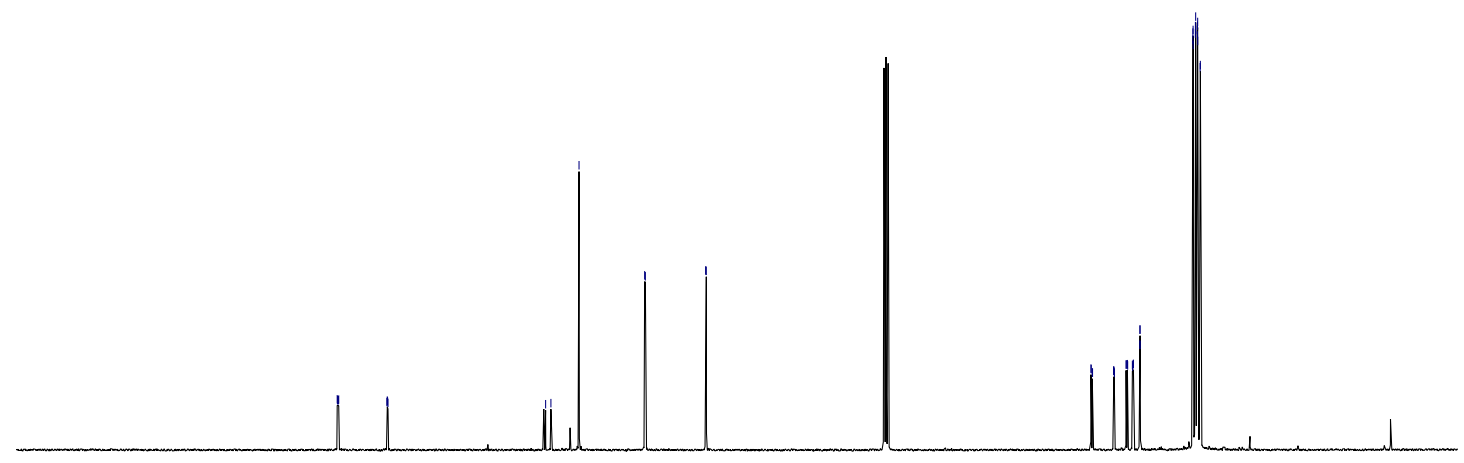

$\begin{array}{llllllllllll}10 & 200 & 190 & 180 & 170 & 160 & 150 & 140 & 130 & 120 & 110 & 1 \\ \mathrm{f} 1 & 100 \\ (\mathrm{ppm})\end{array}$

Figure S66. ${ }^{13} \mathrm{C}$ NMR of ${ }^{\mathrm{tBu}-} 5-\mathrm{HCl}$ in $\mathrm{CDCl}_{3}$. 

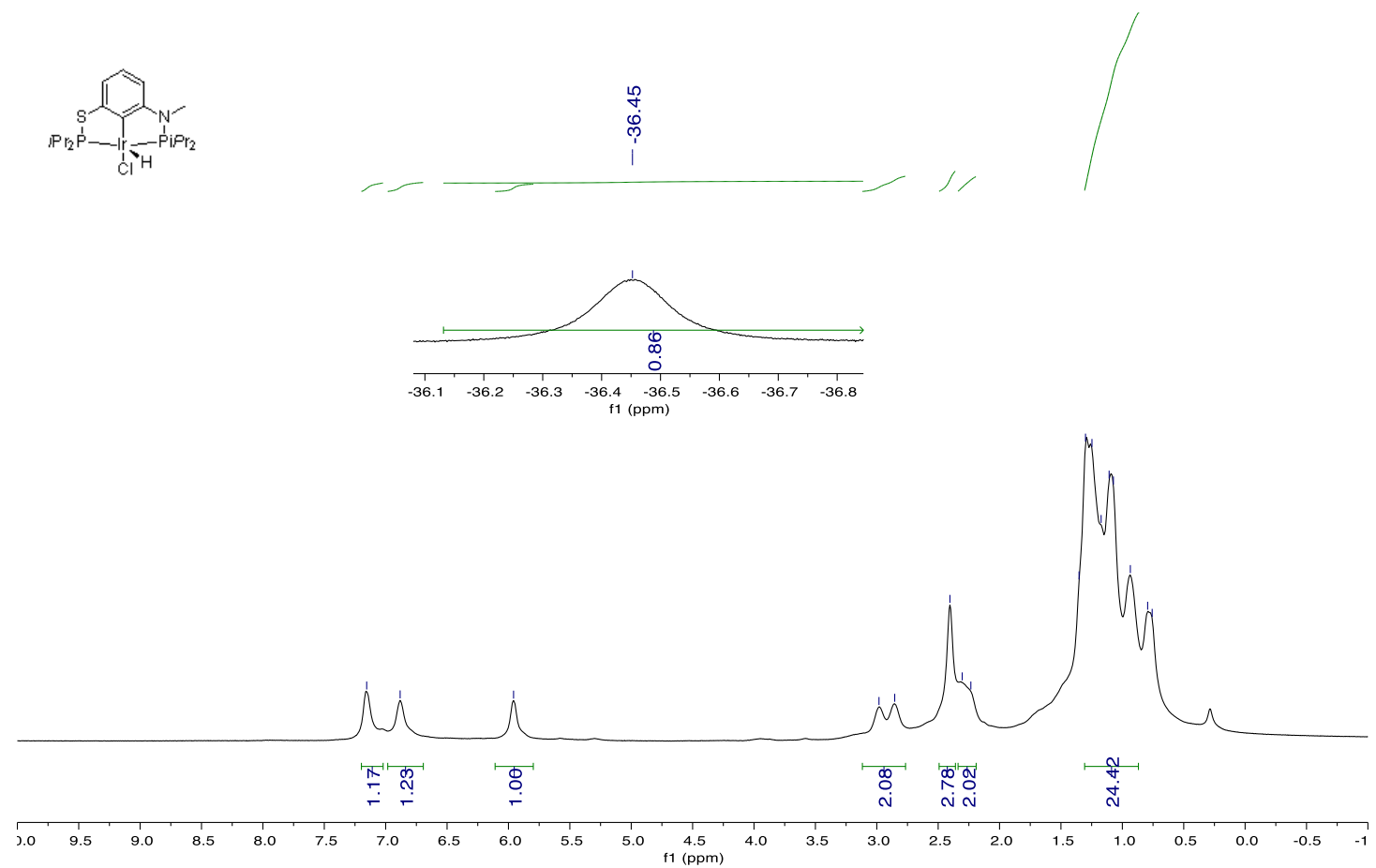

Figure S67. ${ }^{1} \mathrm{H}$ NMR of ${ }^{i \mathrm{Pr}-} 5-\mathrm{HCl}$ in $\mathrm{C}_{6} \mathrm{D}_{6}$.

$\mathrm{Zx}-10-22-\mathrm{A}-1-\mathrm{P}-\mathrm{C} 6 \mathrm{D} 6$

TANDARD CARBON PARAMETERS
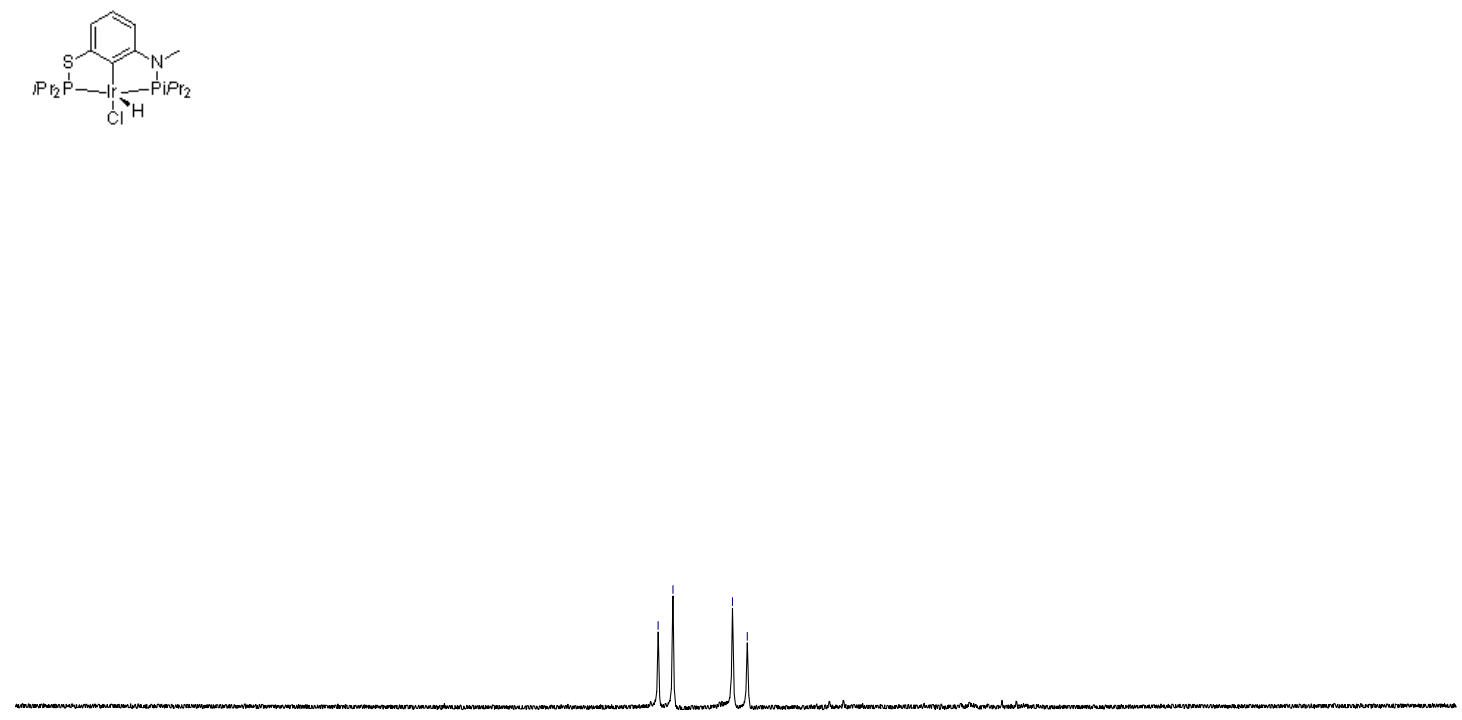

Figure S68. ${ }^{31} \mathrm{P}$ NMR of ${ }^{i \mathrm{Pr}-} 5-\mathrm{HCl}$ in $\mathrm{C}_{6} \mathrm{D}_{6}$. 


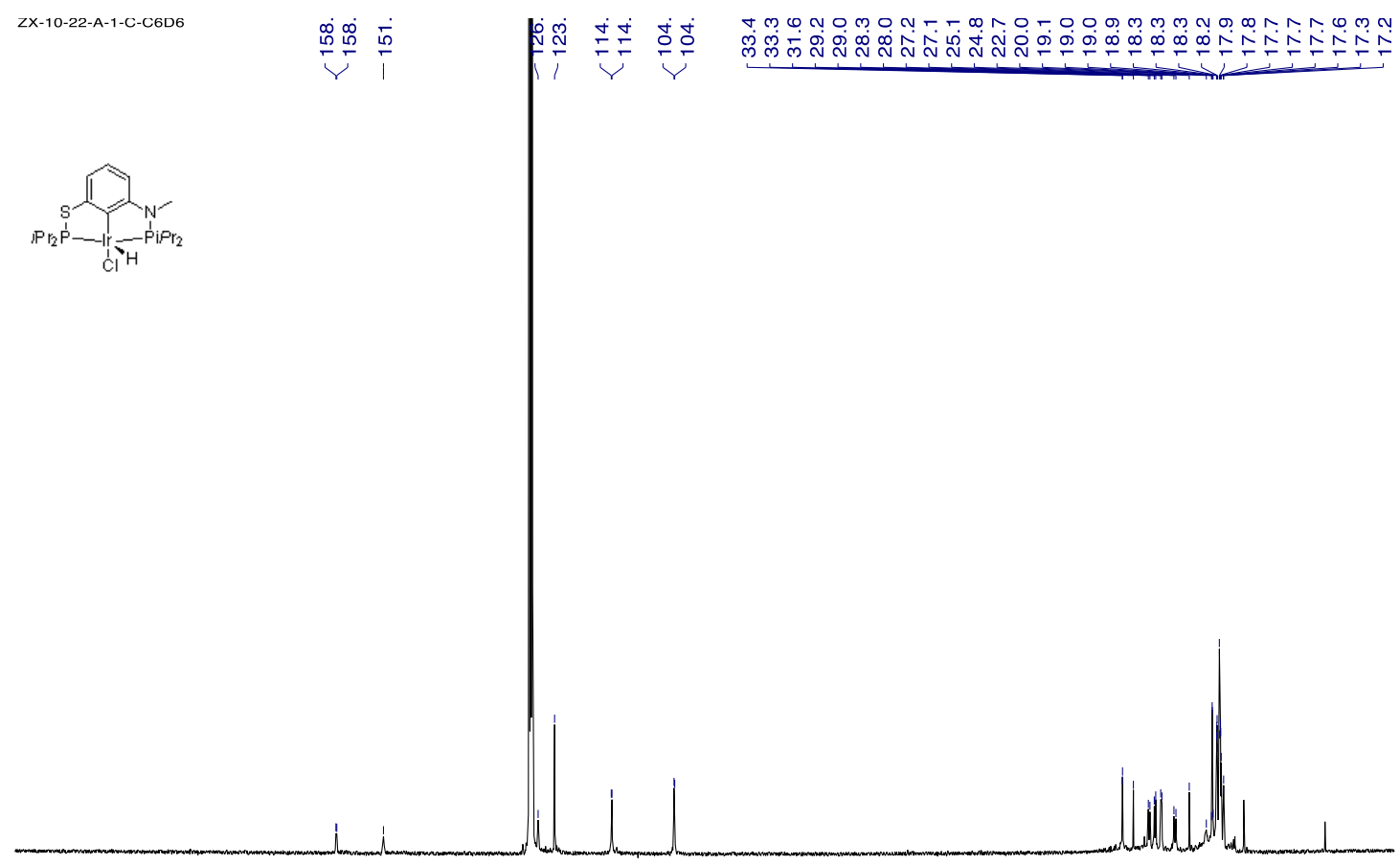

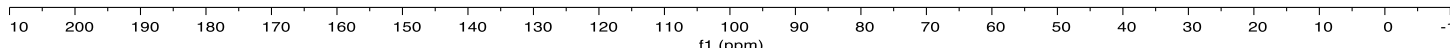

Figure S69. ${ }^{13} \mathrm{C}$ NMR of ${ }^{i \mathrm{Pr}-} 5-\mathrm{HCl}$ in $\mathrm{C}_{6} \mathrm{D}_{6}$.

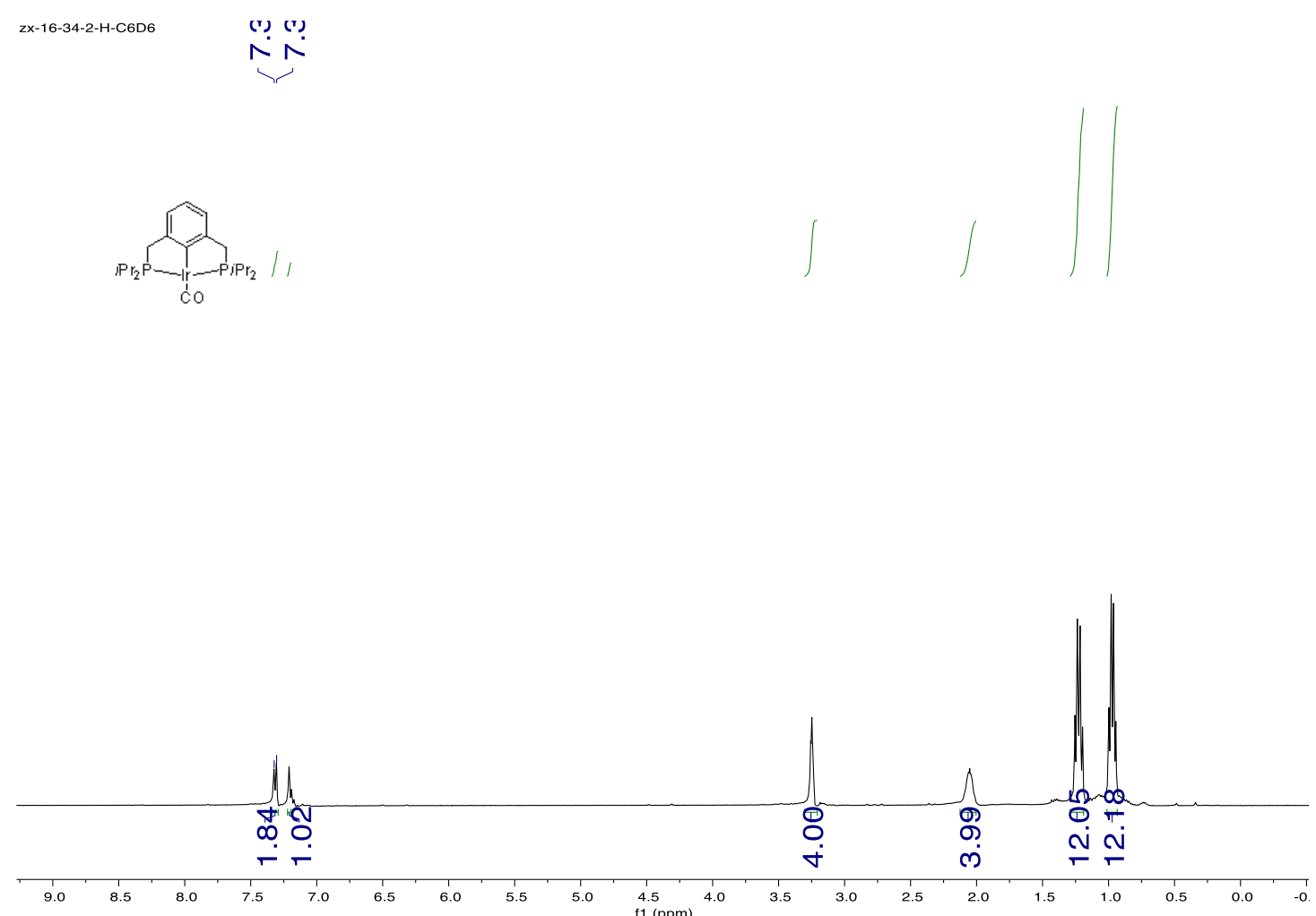

Figure S70. ${ }^{1} \mathrm{H}$ NMR of ${ }^{i \mathrm{Pr}_{-}} 1-\mathrm{CO}$ in $\mathrm{C}_{6} \mathrm{D}_{6}$. 

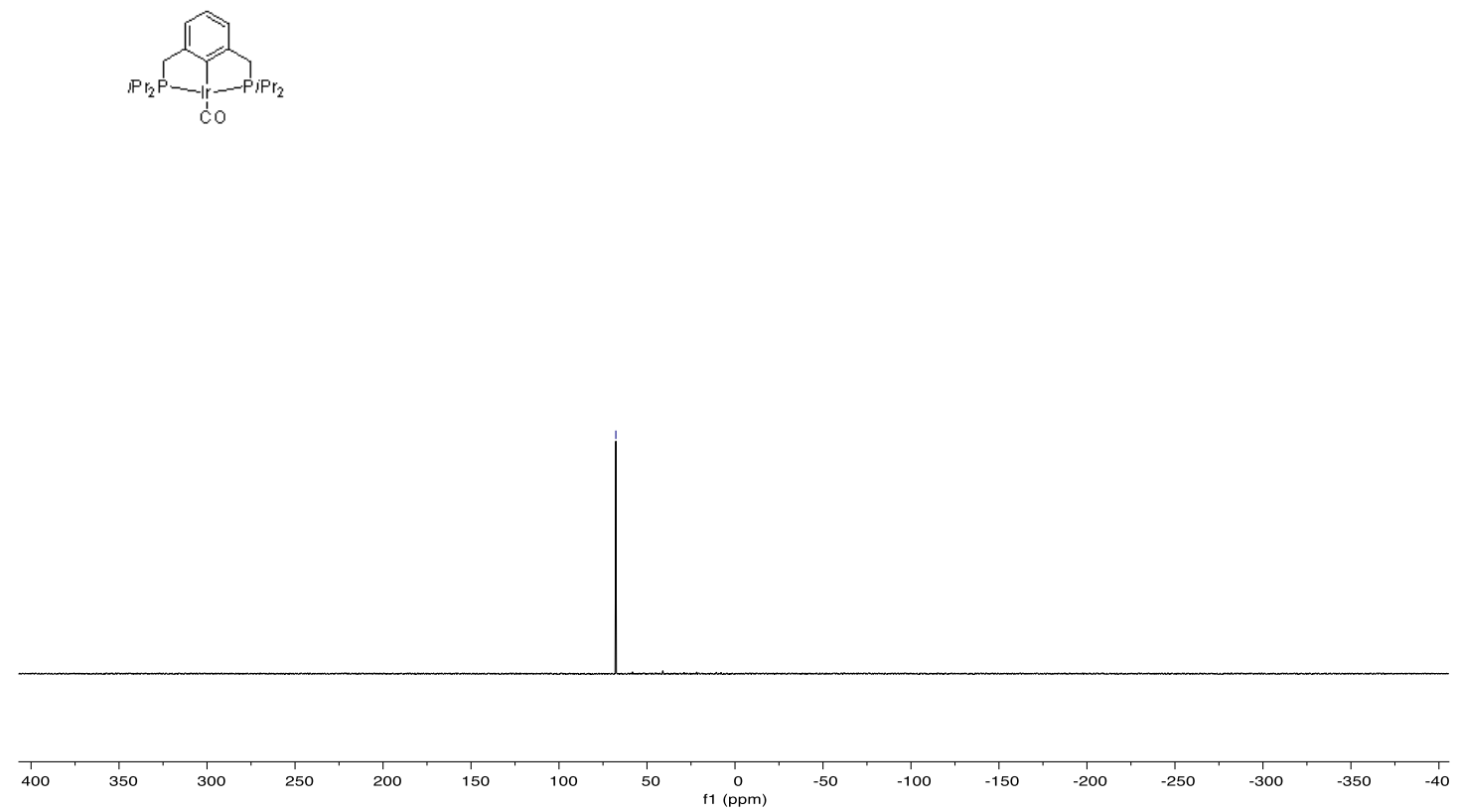

Figure S71. ${ }^{31} \mathrm{P}$ NMR of ${ }^{i{ }^{i r}-1}-\mathrm{CO}$ in $\mathrm{C}_{6} \mathrm{D}_{6}$.

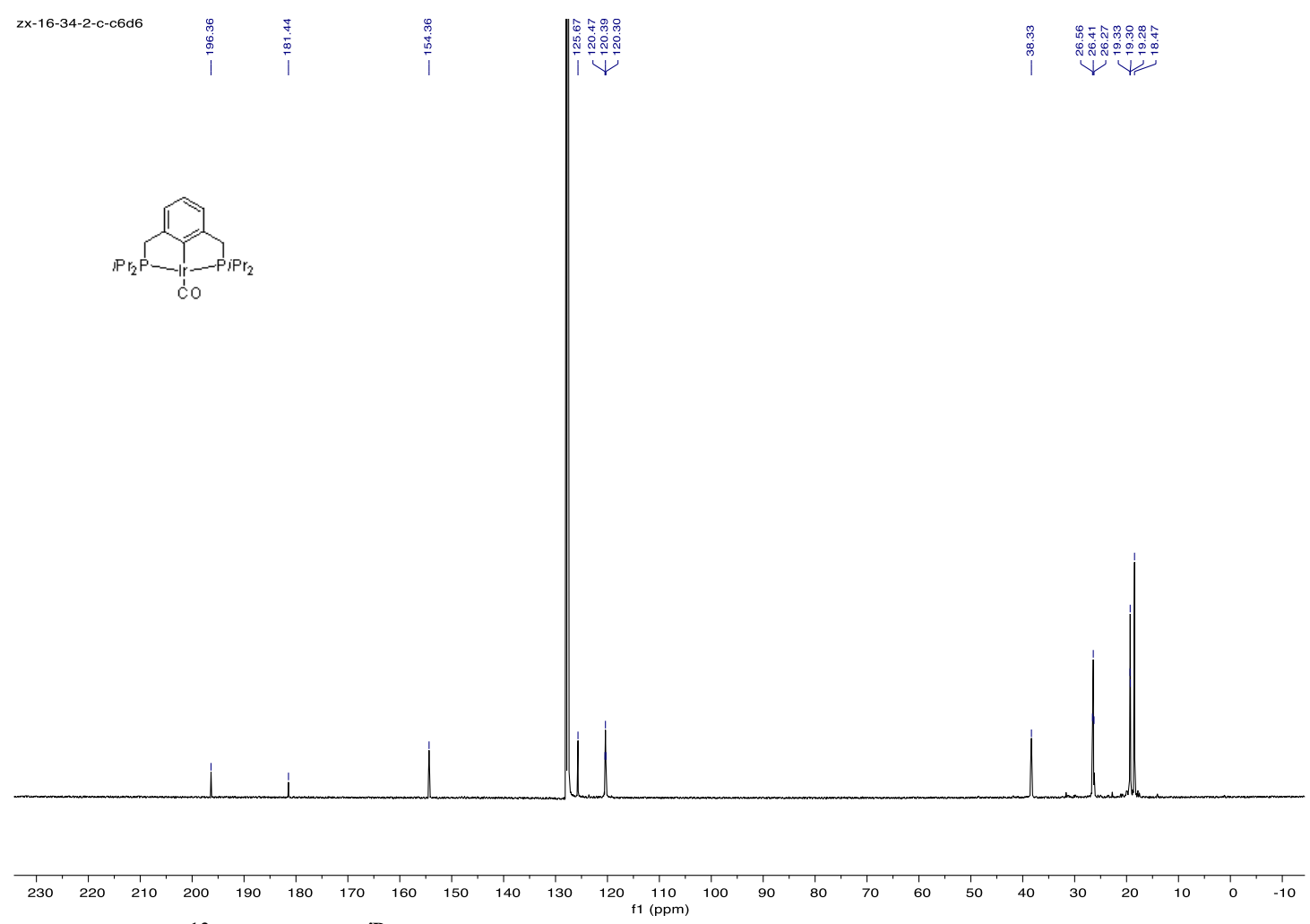

Figure S72. ${ }^{13} \mathrm{C}$ NMR of ${ }^{i P^{2}-1-C O}$ in $\mathrm{C}_{6} \mathrm{D}_{6}$. 

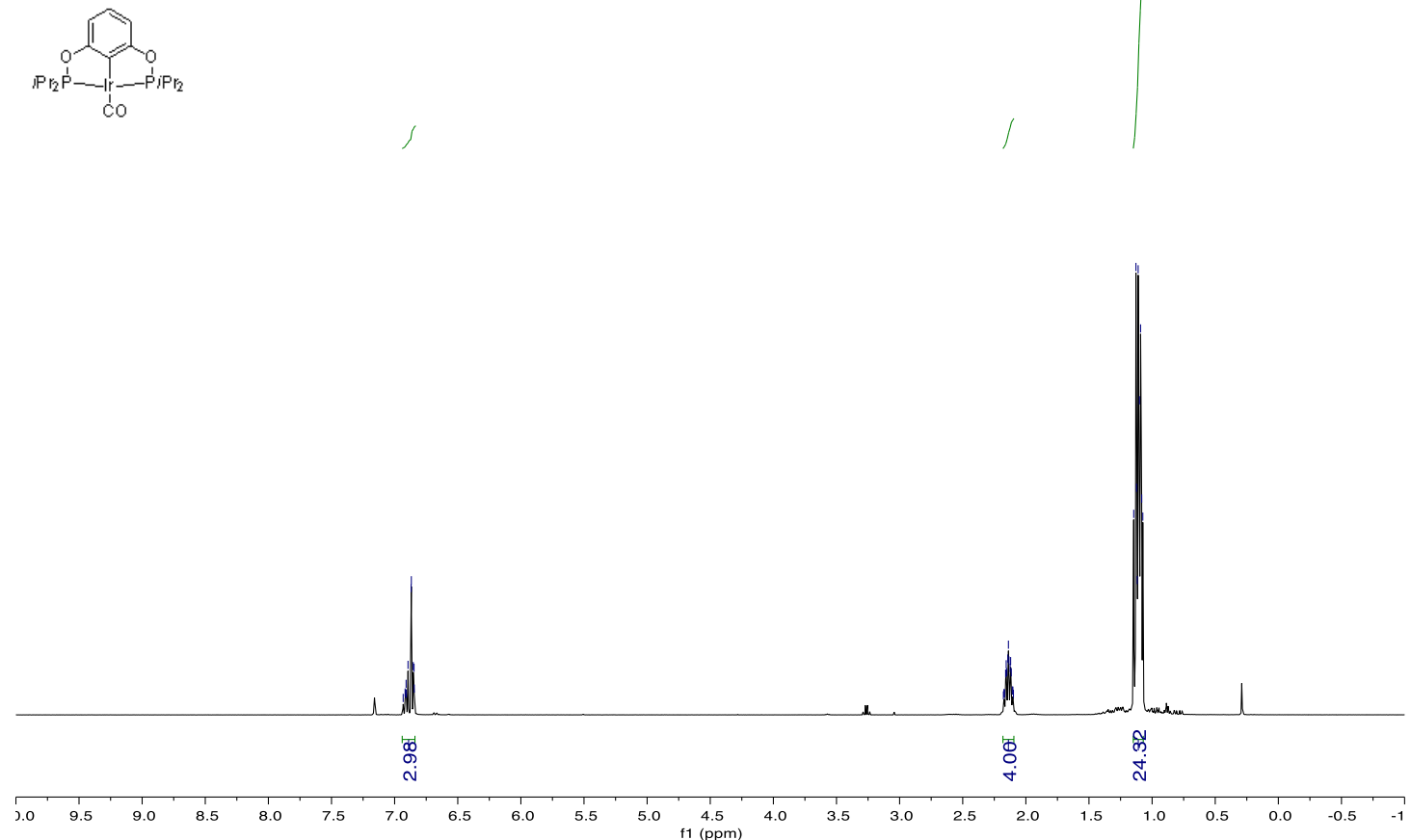

Figure S73. ${ }^{1} \mathrm{H}$ NMR of ${ }^{i \mathrm{Pr}-2}-\mathrm{CO}$ in $\mathrm{C}_{6} \mathrm{D}_{6}$.

2x-13-2-2-P-C6Be

PARAMETERS

$$
\text { i }
$$
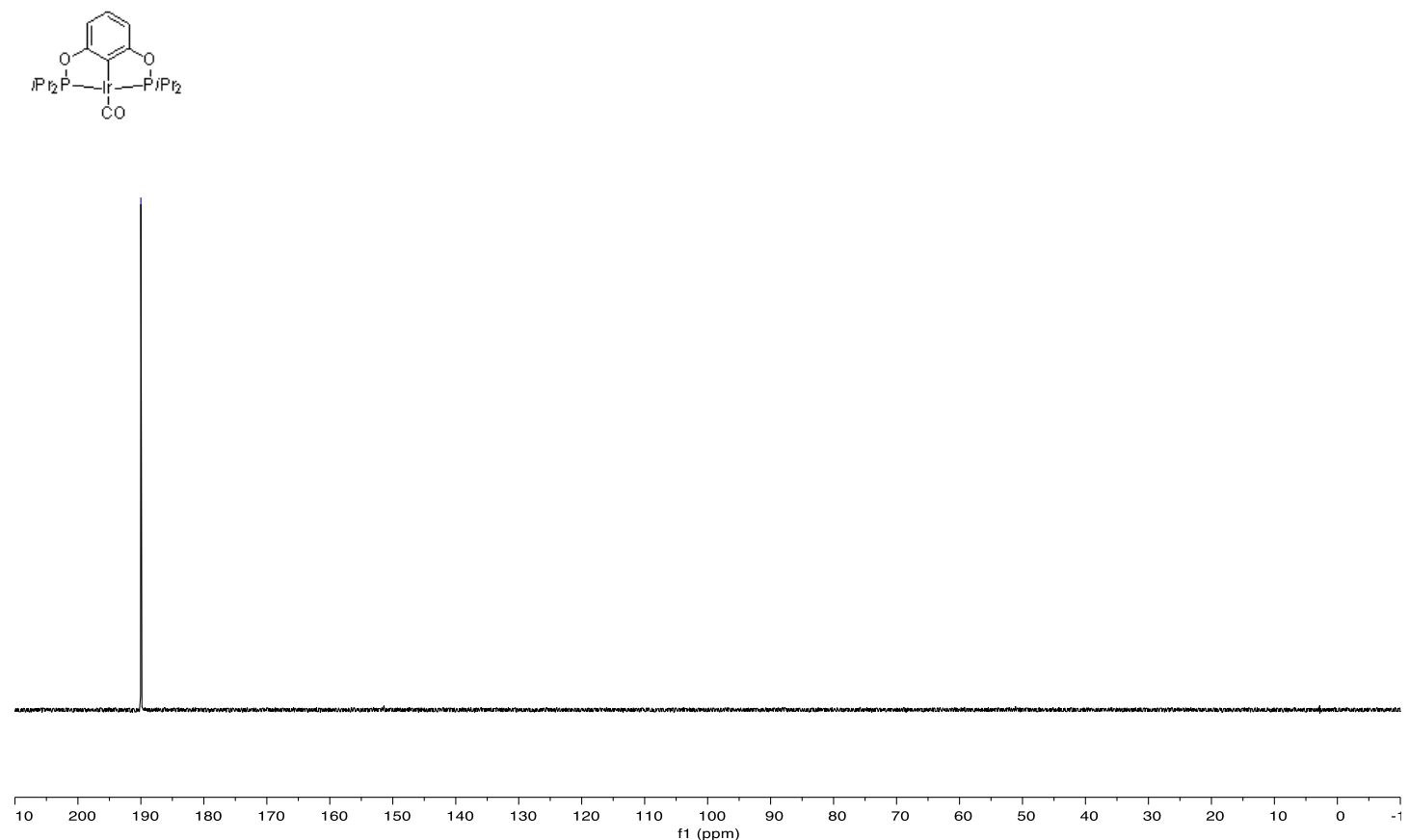

Figure S74. ${ }^{31} \mathrm{P}$ NMR of ${ }^{i \mathrm{Pr}-2}-\mathrm{CO}$ in $\mathrm{C}_{6} \mathrm{D}_{6}$. 


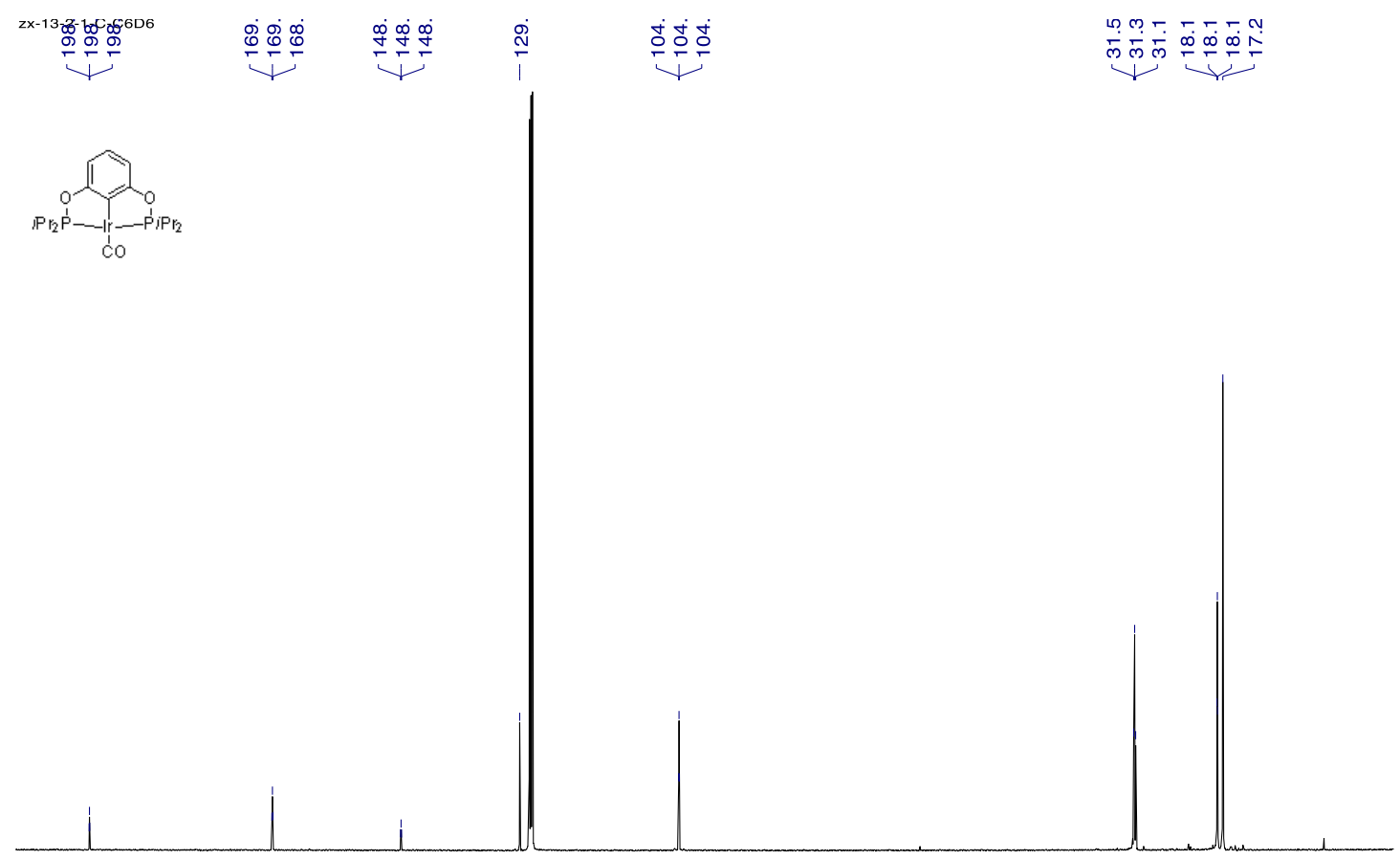

Figure S75. ${ }^{13} \mathrm{C}$ NMR of ${ }^{i P r}-2-C O$ in $\mathrm{C}_{6} \mathrm{D}_{6}$.

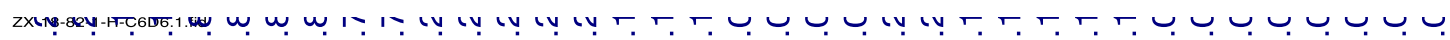
N $N$ N
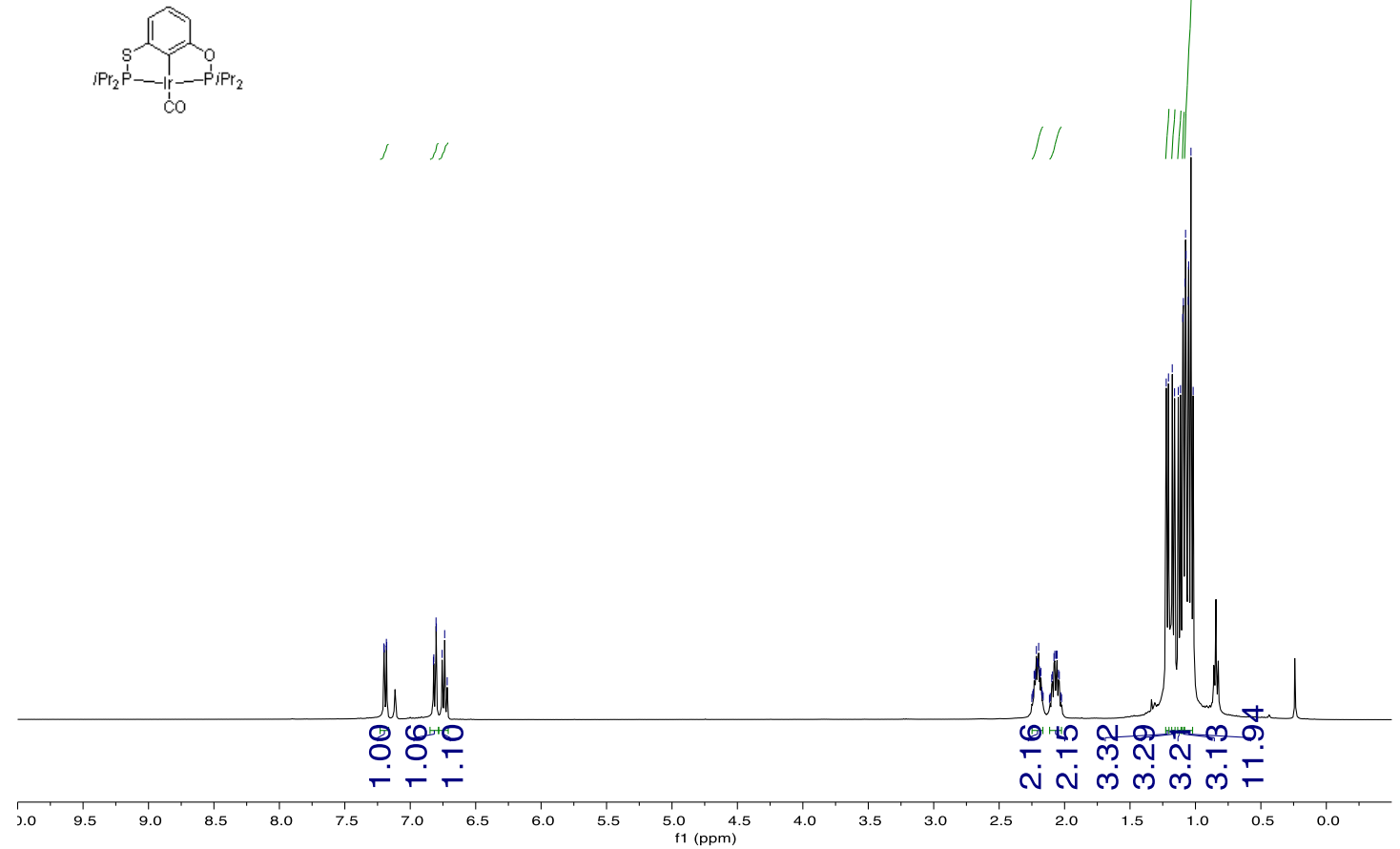

Figure S76. ${ }^{1} \mathrm{H}$ NMR of ${ }^{i P r}-3-\mathrm{CO}$ in $\mathrm{CDCl}_{3}$. 

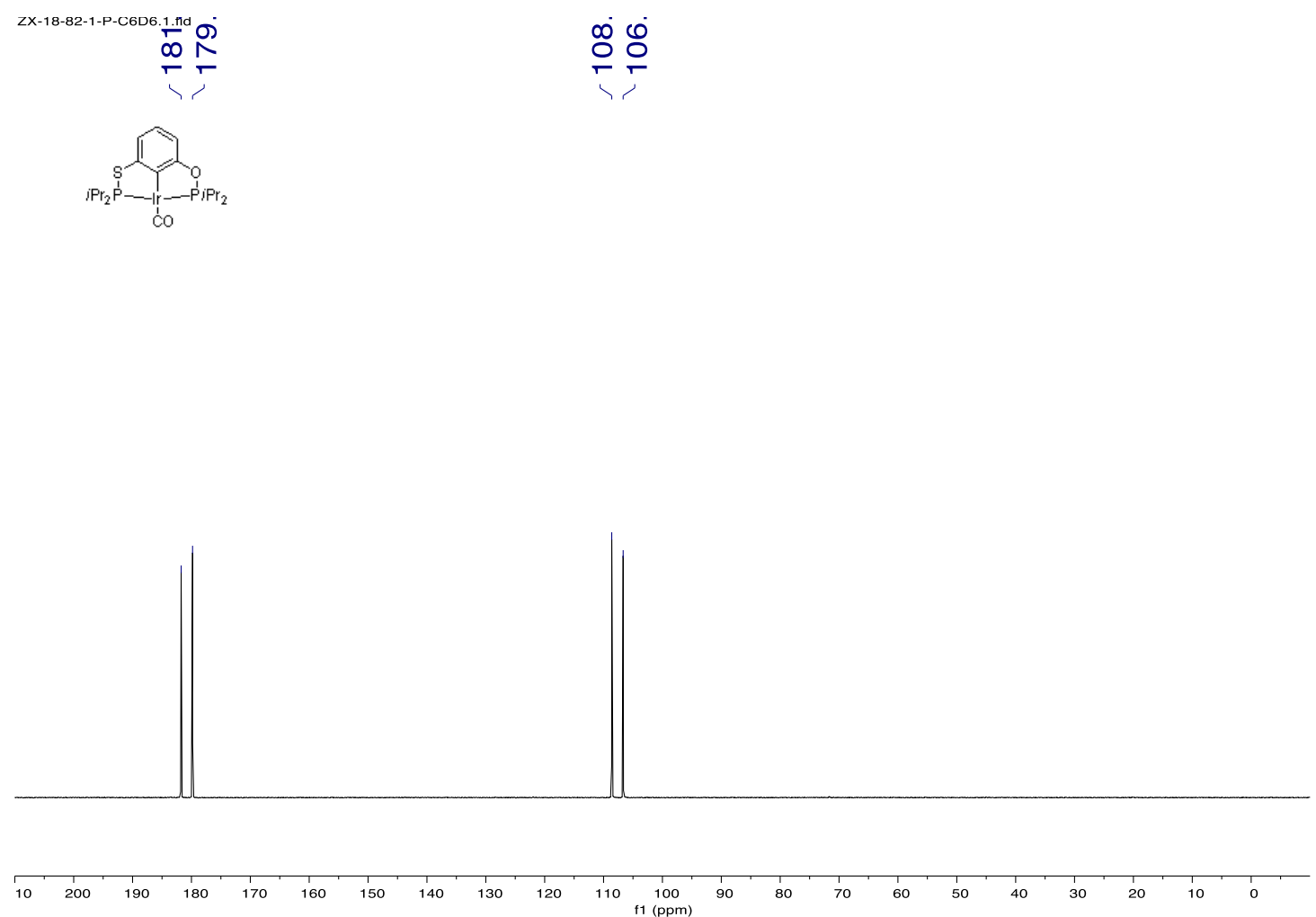

Figure S77. ${ }^{31} \mathrm{P} \mathrm{NMR}$ of ${ }^{i \mathrm{Pr}-3}-\mathrm{CO}$ in $\mathrm{CDCl}_{3}$
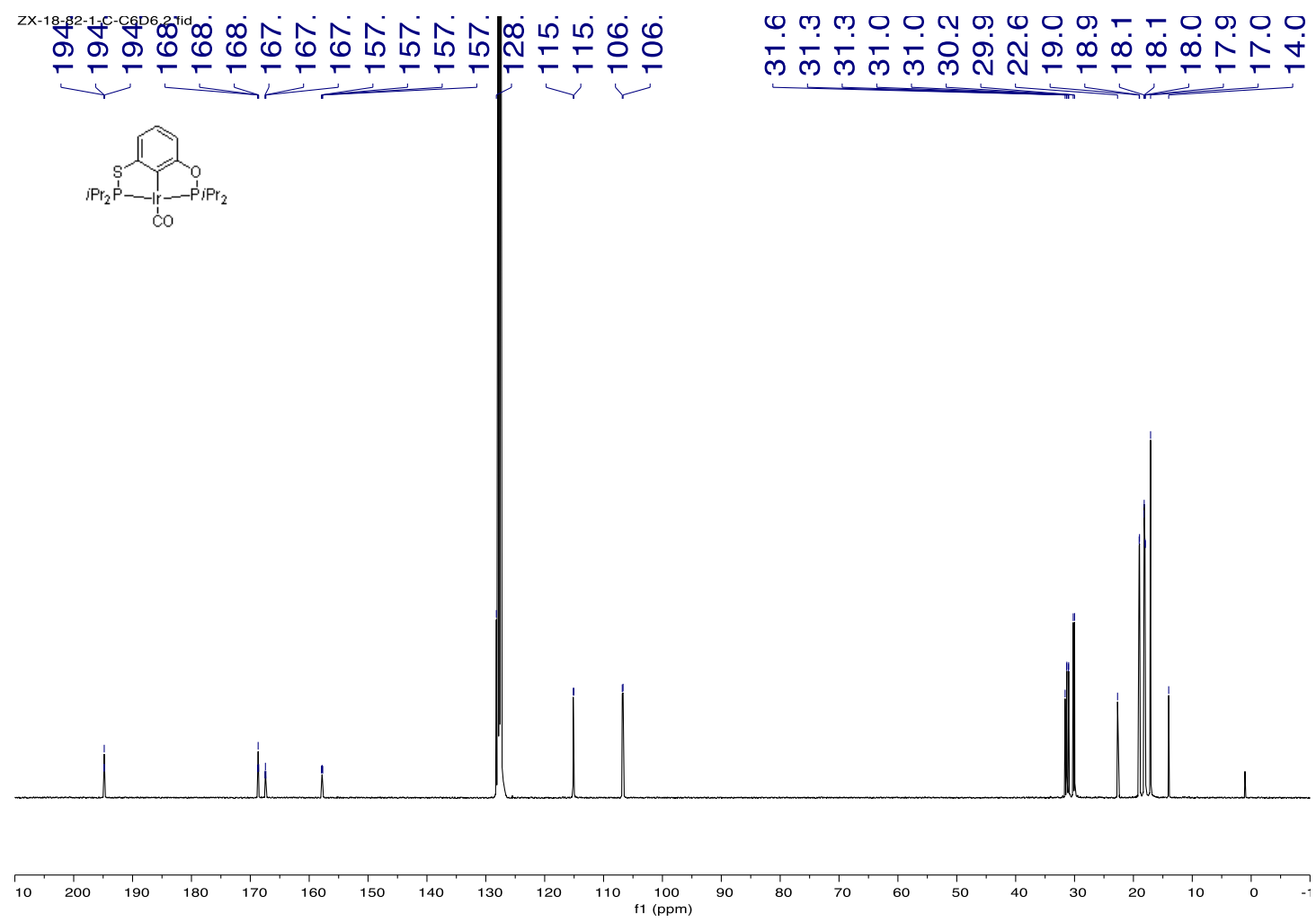

Figure S78. ${ }^{13} \mathrm{C}$ NMR of ${ }^{i \mathrm{Pr}-3}-\mathrm{CO}$ in $\mathrm{CDCl}_{3}$. 

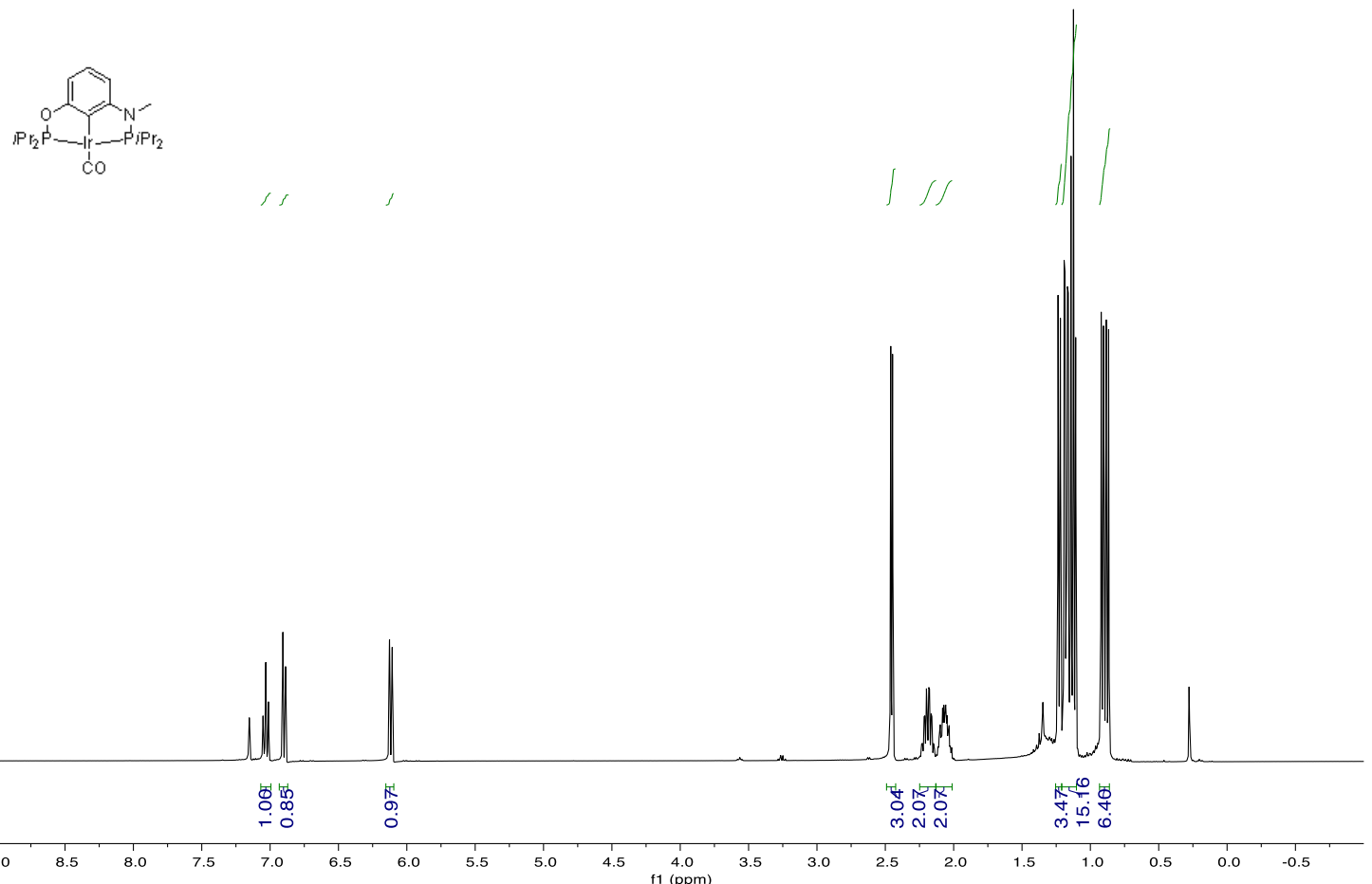

Figure S79. ${ }^{1} \mathrm{H}$ NMR of $\mathbf{4 b}-\mathrm{CO}$ in $\mathrm{C}_{6} \mathrm{D}_{6}$.
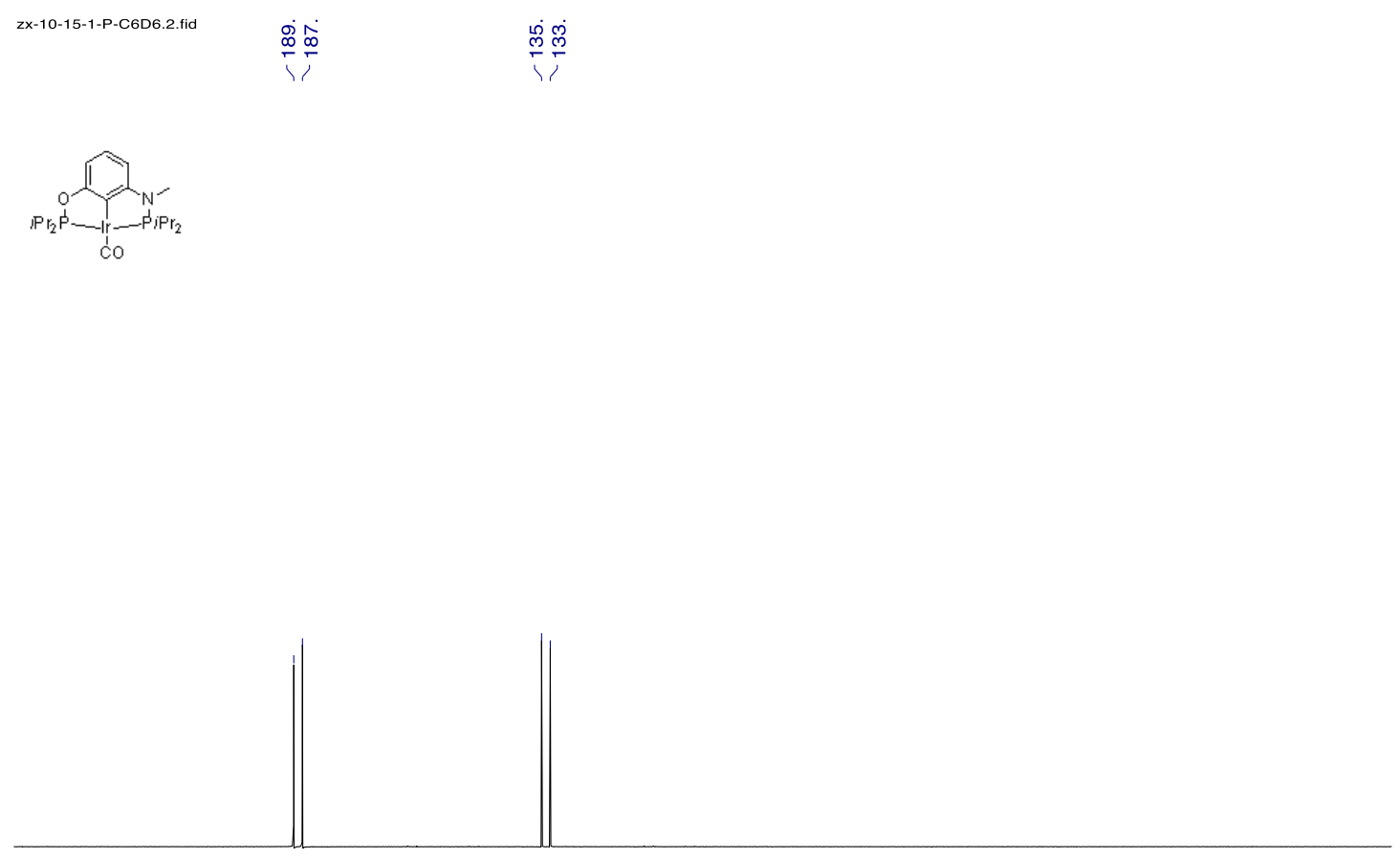

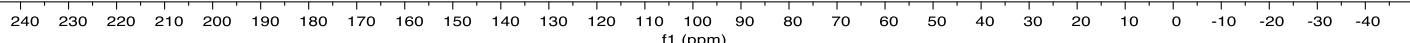

Figure S80. ${ }^{31} \mathrm{P}$ NMR of $\mathbf{4 b}-\mathrm{CO}$ in $\mathrm{C}_{6} \mathrm{D}_{6}$. 


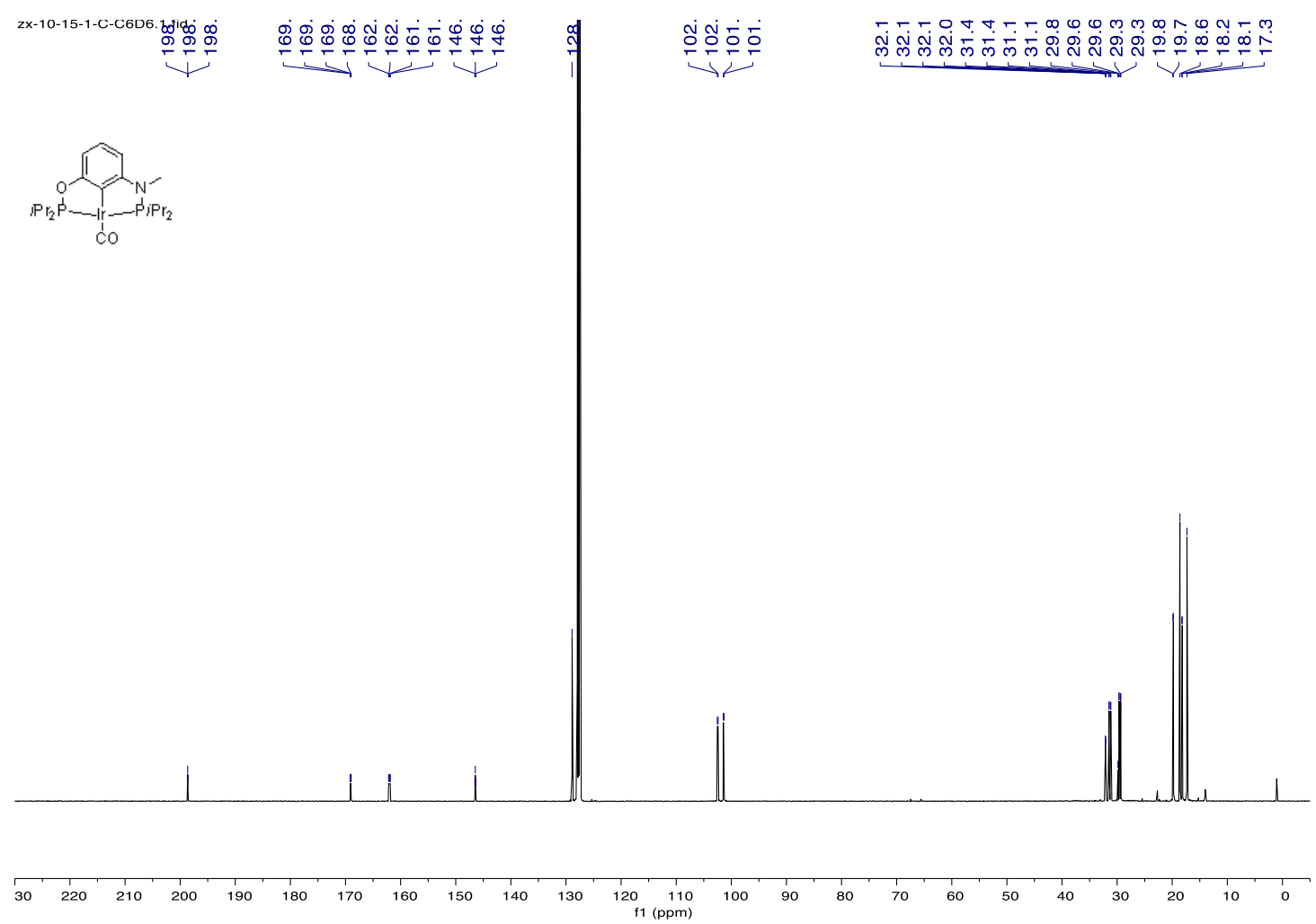

Figure S81. ${ }^{13} \mathrm{C}$ NMR of $\mathbf{4 b}-\mathrm{CO}$ in $\mathrm{C}_{6} \mathrm{D}_{6}$.

$\mathrm{zx}-10-16-1-\mathrm{H}-\mathrm{C} 6 \mathrm{D} 6-1$

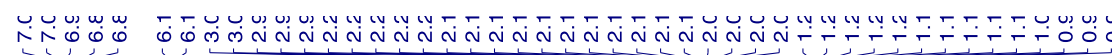
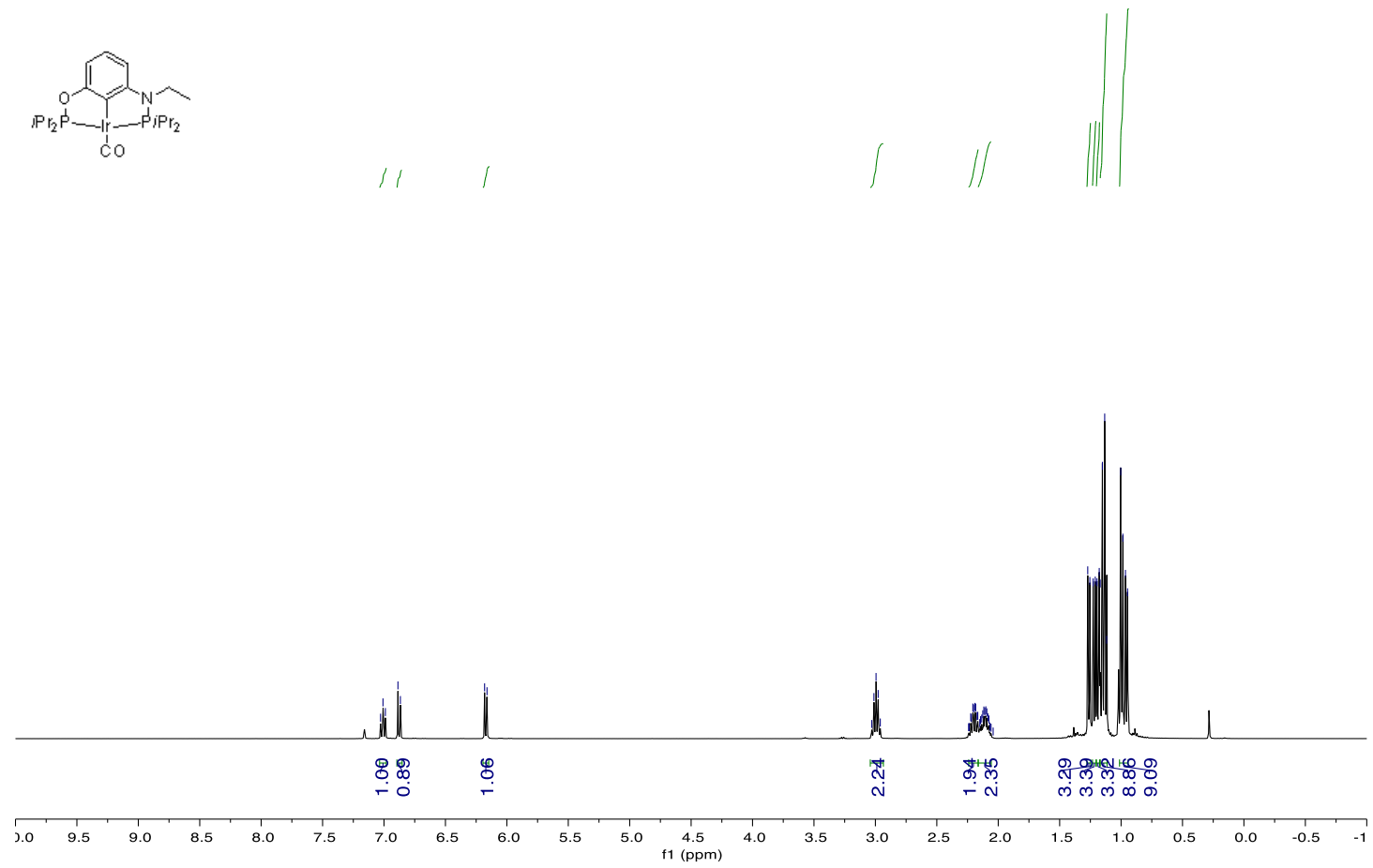

Figure S82. ${ }^{1} \mathrm{H}$ NMR of $4 \mathrm{e}-\mathrm{CO}$ in $\mathrm{C}_{6} \mathrm{D}_{6}$. 

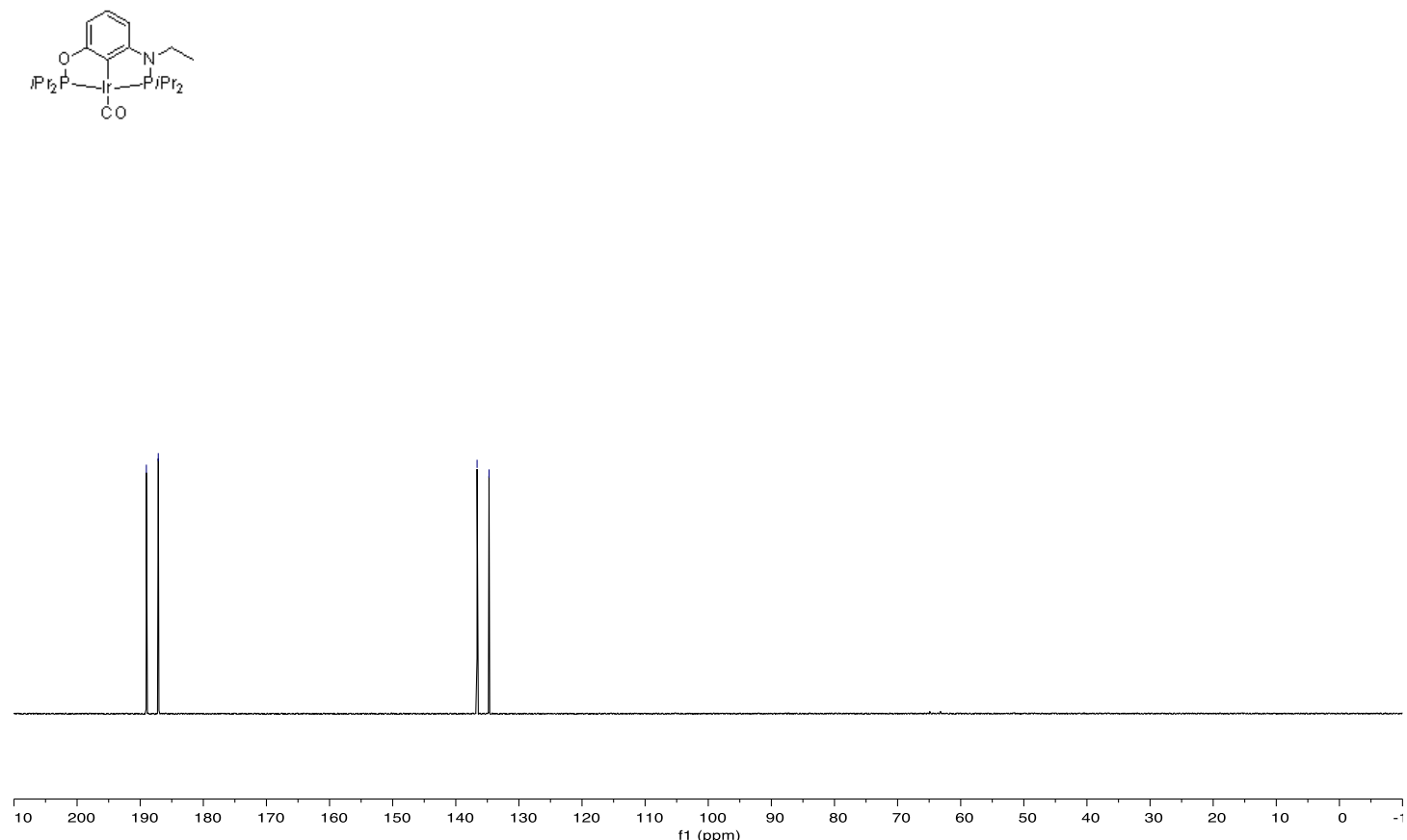

$10 \begin{gathered}100 \\ \mathrm{f} 1(\mathrm{ppm})\end{gathered}$

Figure S83. ${ }^{31} \mathrm{P}$ NMR of $4 \mathrm{e}-\mathrm{CO}$ in $\mathrm{C}_{6} \mathrm{D}_{6}$.

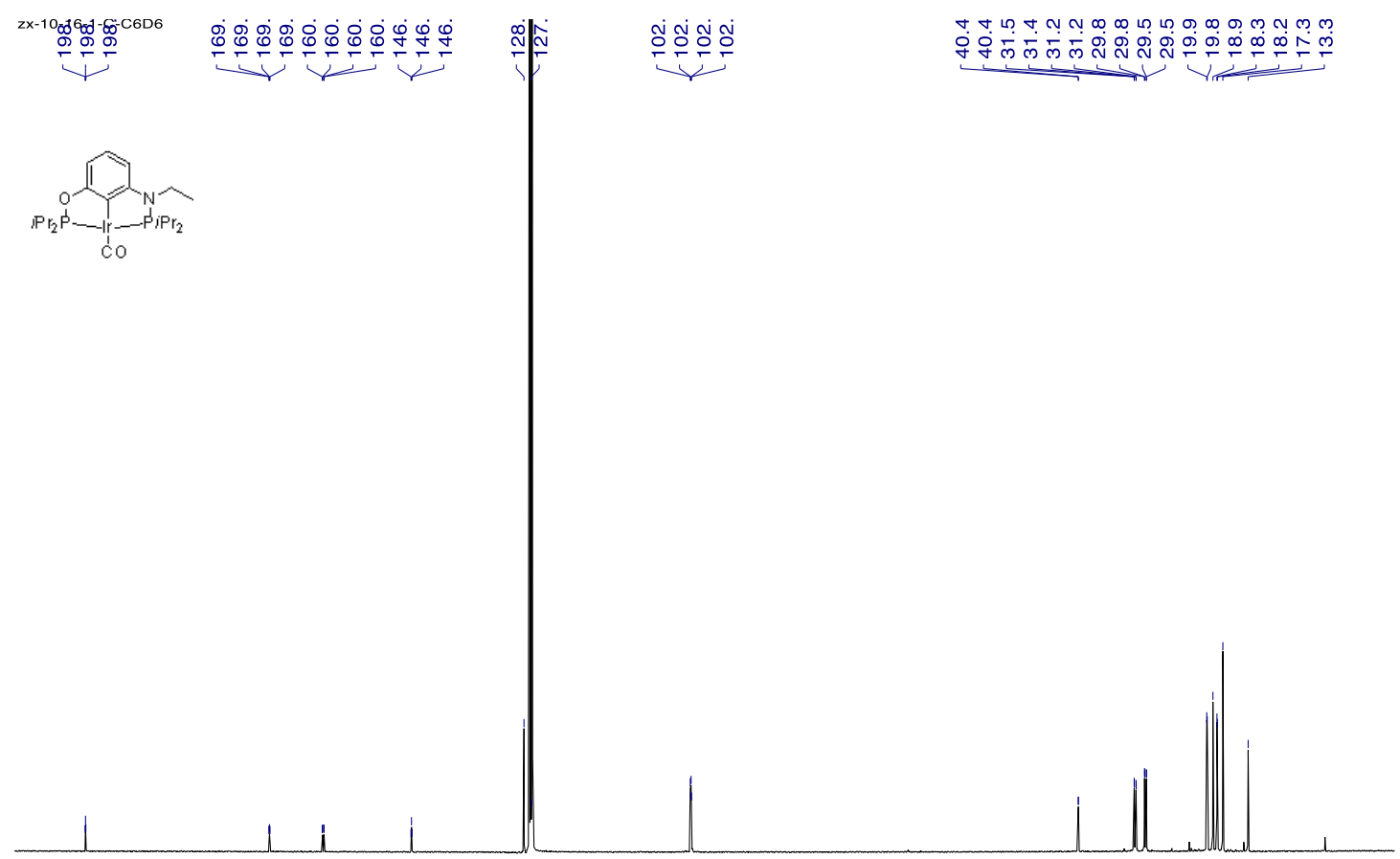

$\begin{array}{llllllllll}10 & 200 & 190 & 180 & 170 & 160 & 150 & 140 & 130 & 120\end{array}$

Figure S84. ${ }^{13} \mathrm{C}$ NMR of $4 \mathrm{e}-\mathrm{CO}$ in $\mathrm{C}_{6} \mathrm{D}_{6}$. 

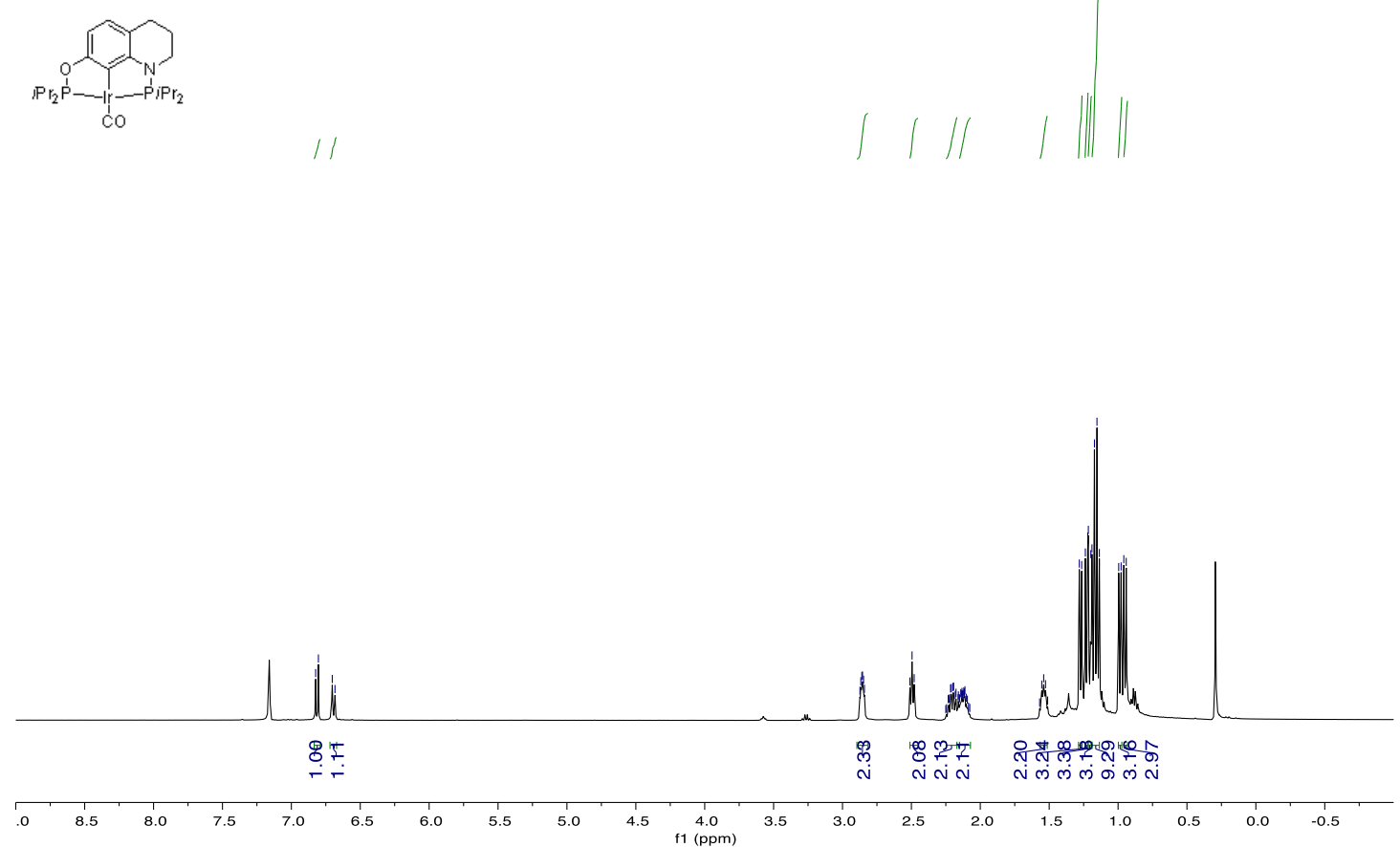

Figure S85. ${ }^{1} \mathrm{H}$ NMR of $\mathbf{4 g}-\mathrm{CO}$ in $\mathrm{C}_{6} \mathrm{D}_{6}$.
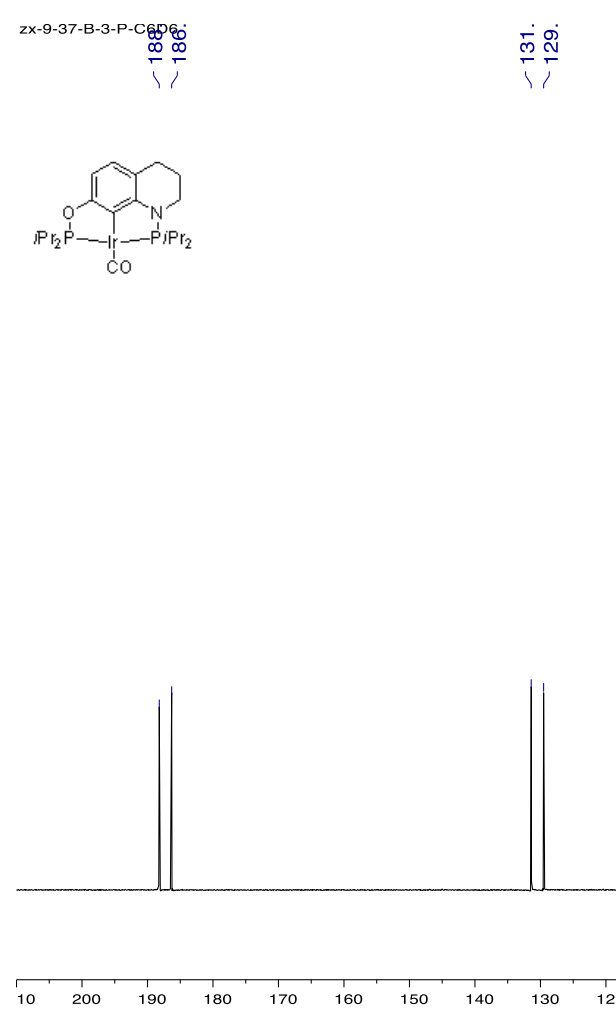

Figure S86. ${ }^{31} \mathrm{P}$ NMR of $4 \mathrm{~g}-\mathrm{CO}$ in $\mathrm{C}_{6} \mathrm{D}_{6}$. 


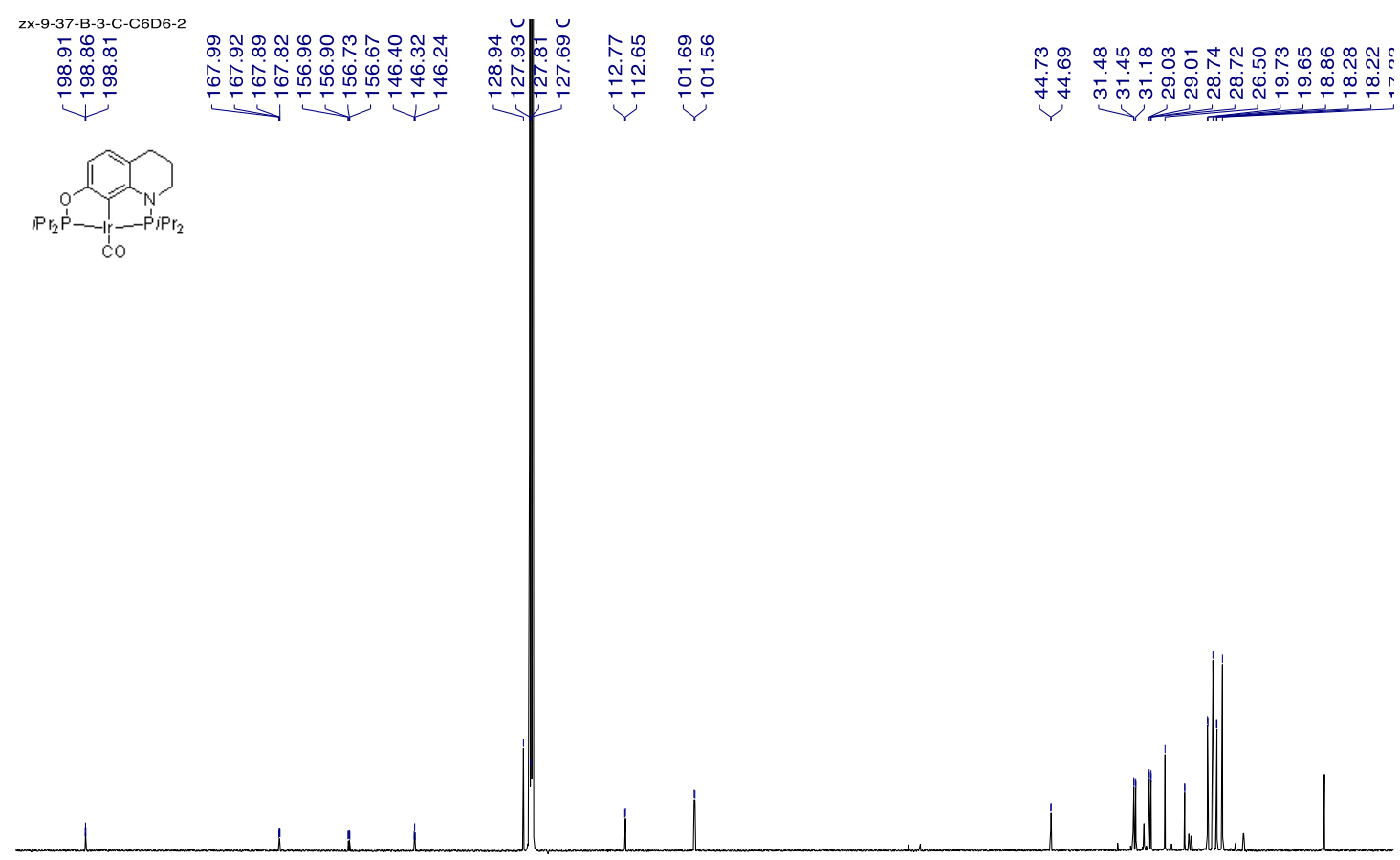

Figure S87. ${ }^{13} \mathrm{C}$ NMR of $4 \mathrm{~g}-\mathrm{CO}$ in $\mathrm{C}_{6} \mathrm{D}_{6}$.
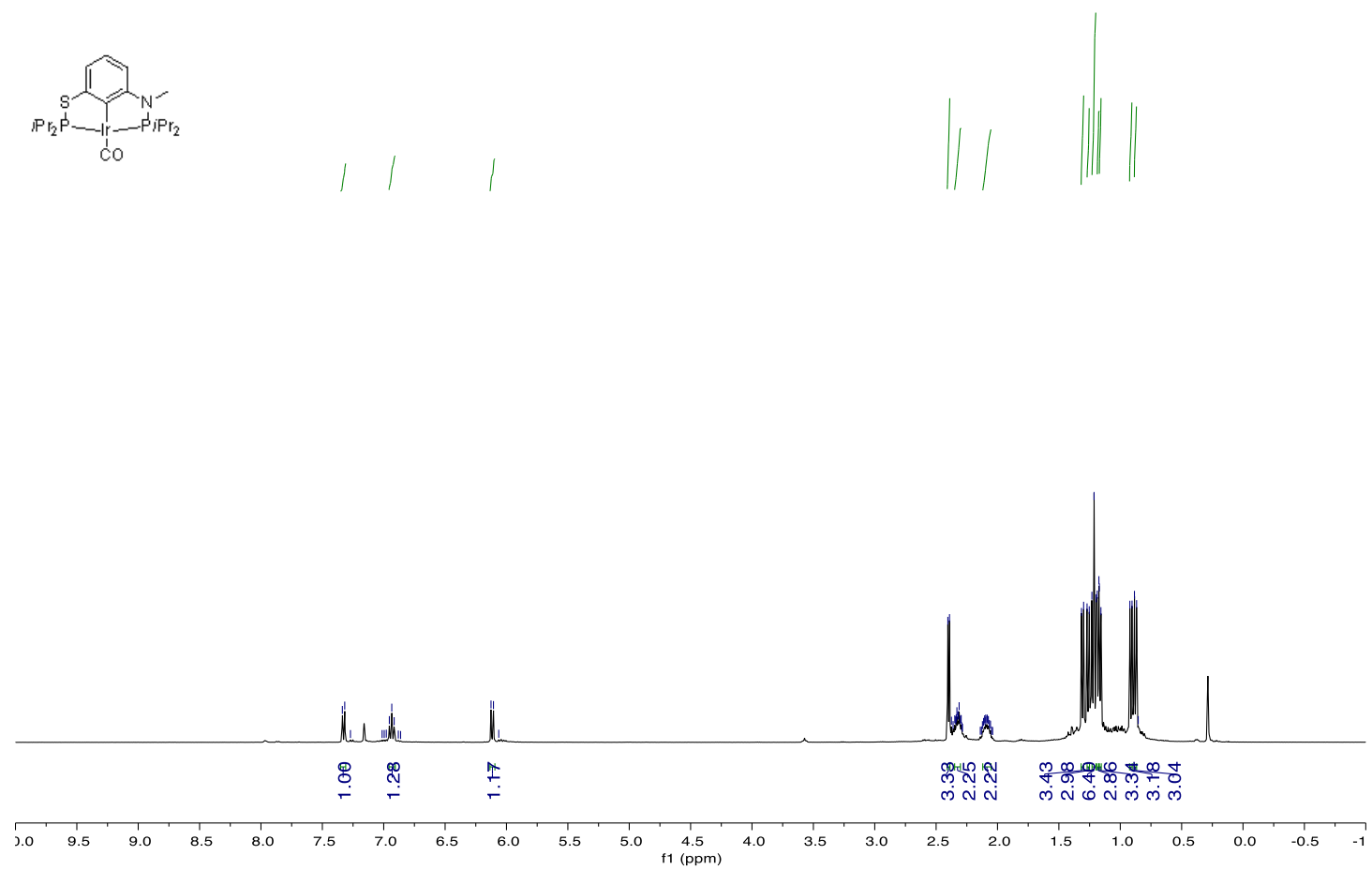

Figure S88. ${ }^{1} \mathrm{H}$ NMR of ${ }^{i \mathrm{Pr}-}$ 5-CO in $\mathrm{C}_{6} \mathrm{D}_{6}$. 

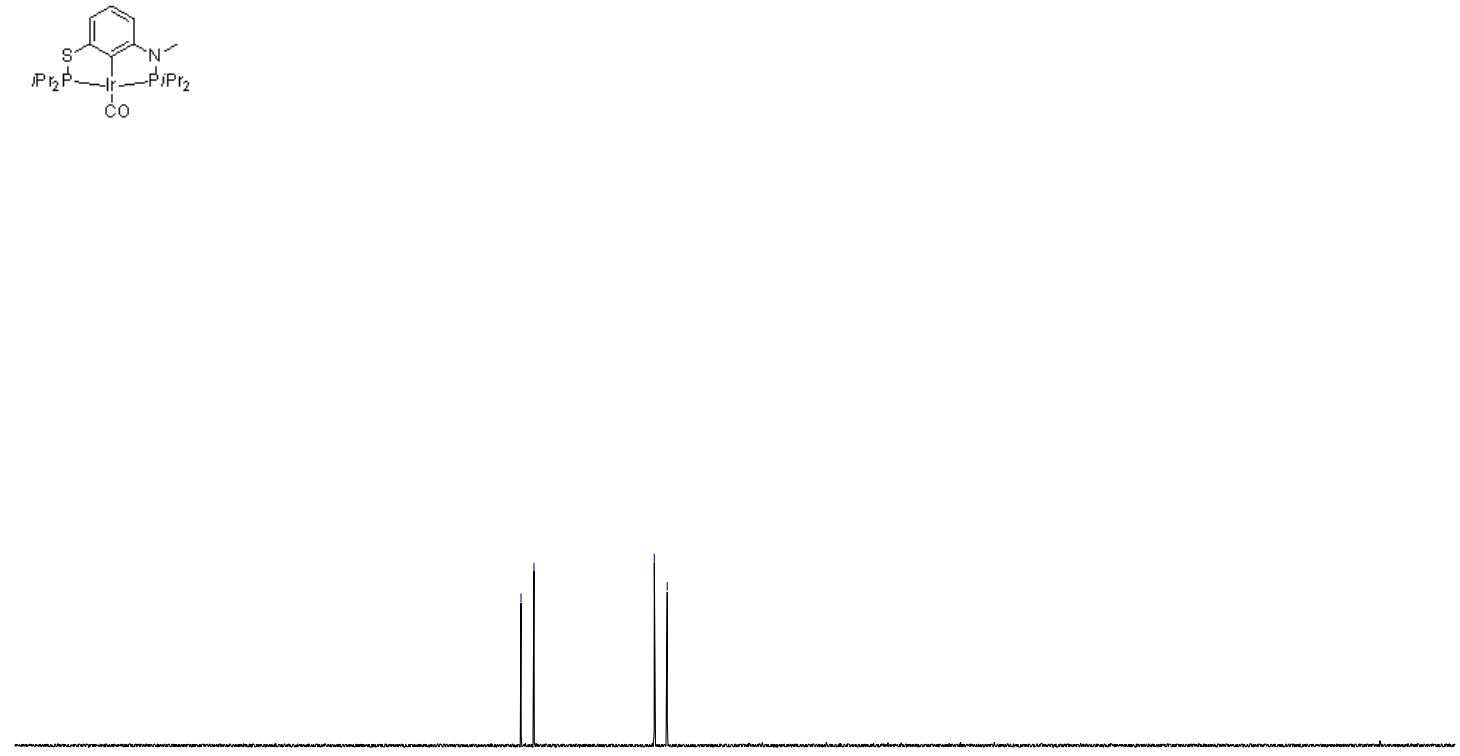

Figure S89. ${ }^{31} \mathrm{P}$ NMR of ${ }^{i \mathrm{Pr}-5}-\mathrm{CO}$ in $\mathrm{C}_{6} \mathrm{D}_{6}$.

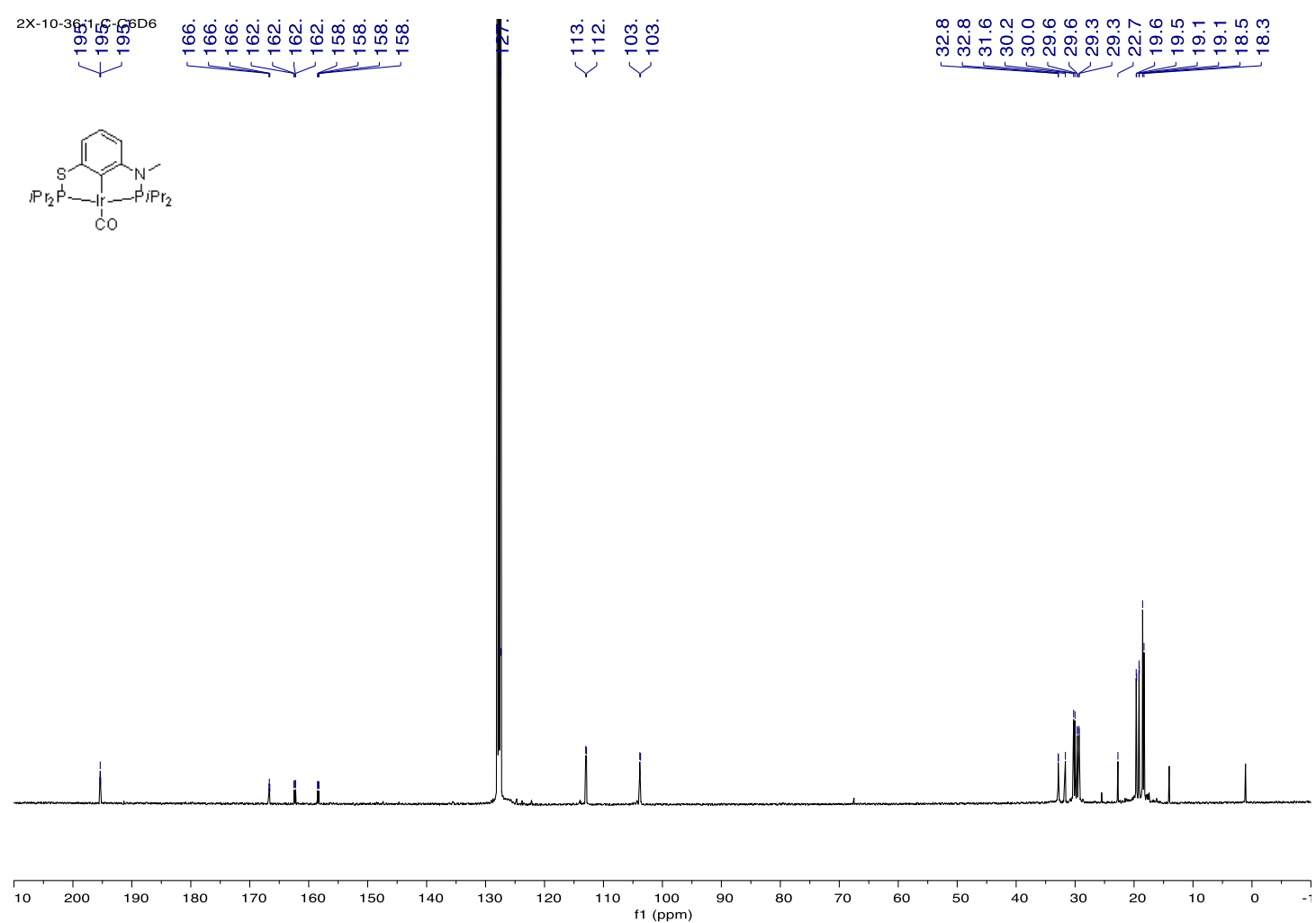

Figure S90. ${ }^{13} \mathrm{C}$ NMR of ${ }^{i P r}-5-C O$ in $\mathrm{C}_{6} \mathrm{D}_{6}$. 
ベN

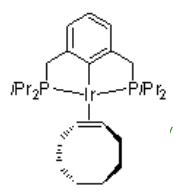

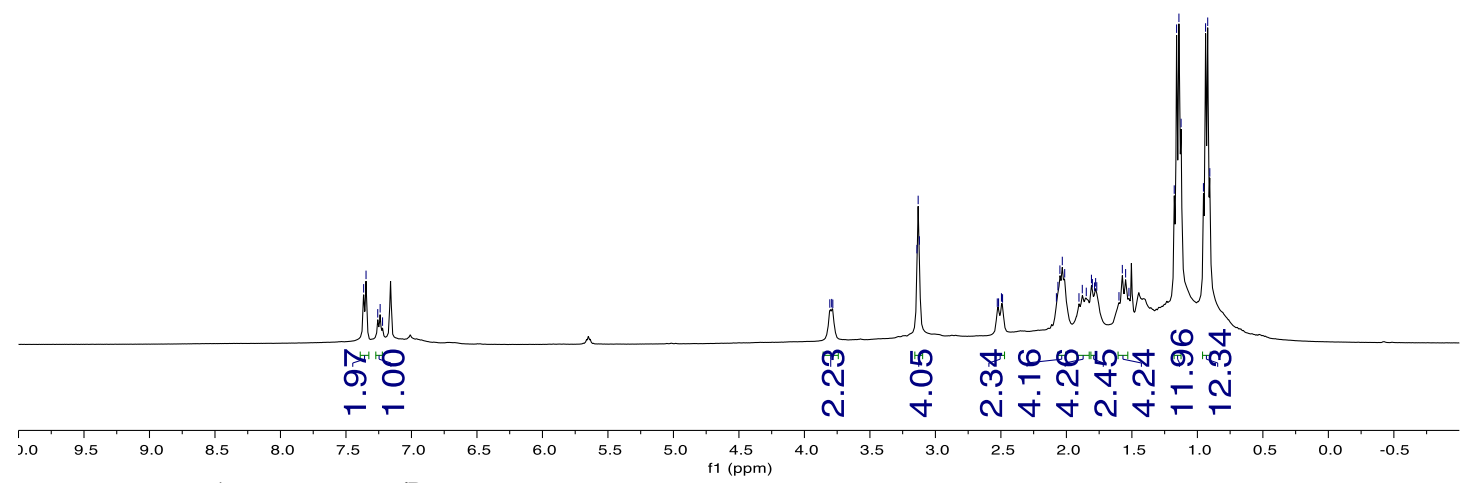

Figure S91. ${ }^{1} \mathrm{H}$ NMR of ${ }^{i{ }^{2}-1}$-(perpendicular-COE) in $\mathrm{C}_{6} \mathrm{D}_{6}$.

ZX-20-18-1-P-C6D6.1.fid

$\stackrel{+}{\dot{J}}$
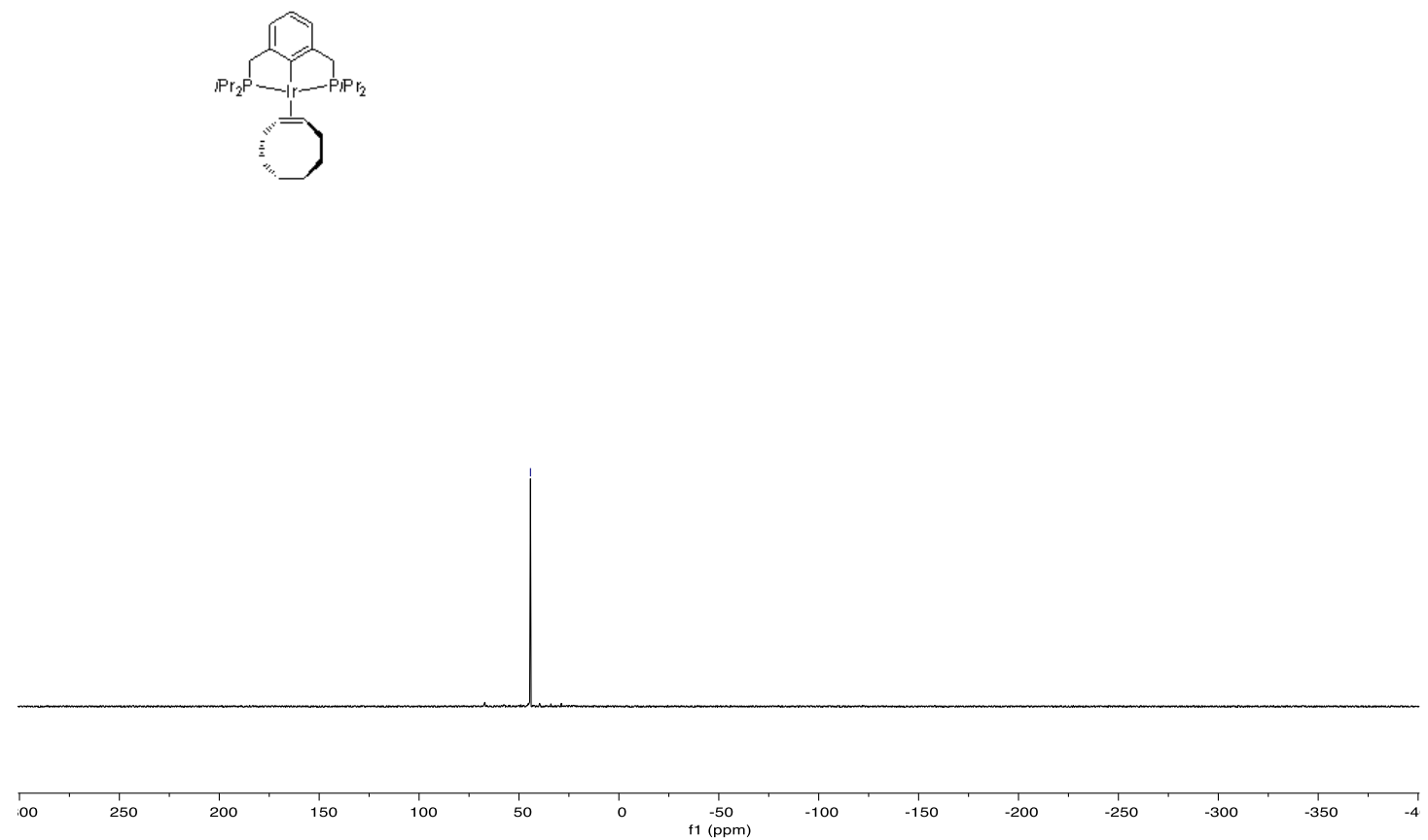

Figure S92. ${ }^{31} \mathrm{P}$ NMR of ${ }^{i{ }^{i r}-1}$-(perpendicular-COE) in $\mathrm{C}_{6} \mathrm{D}_{6}$. 


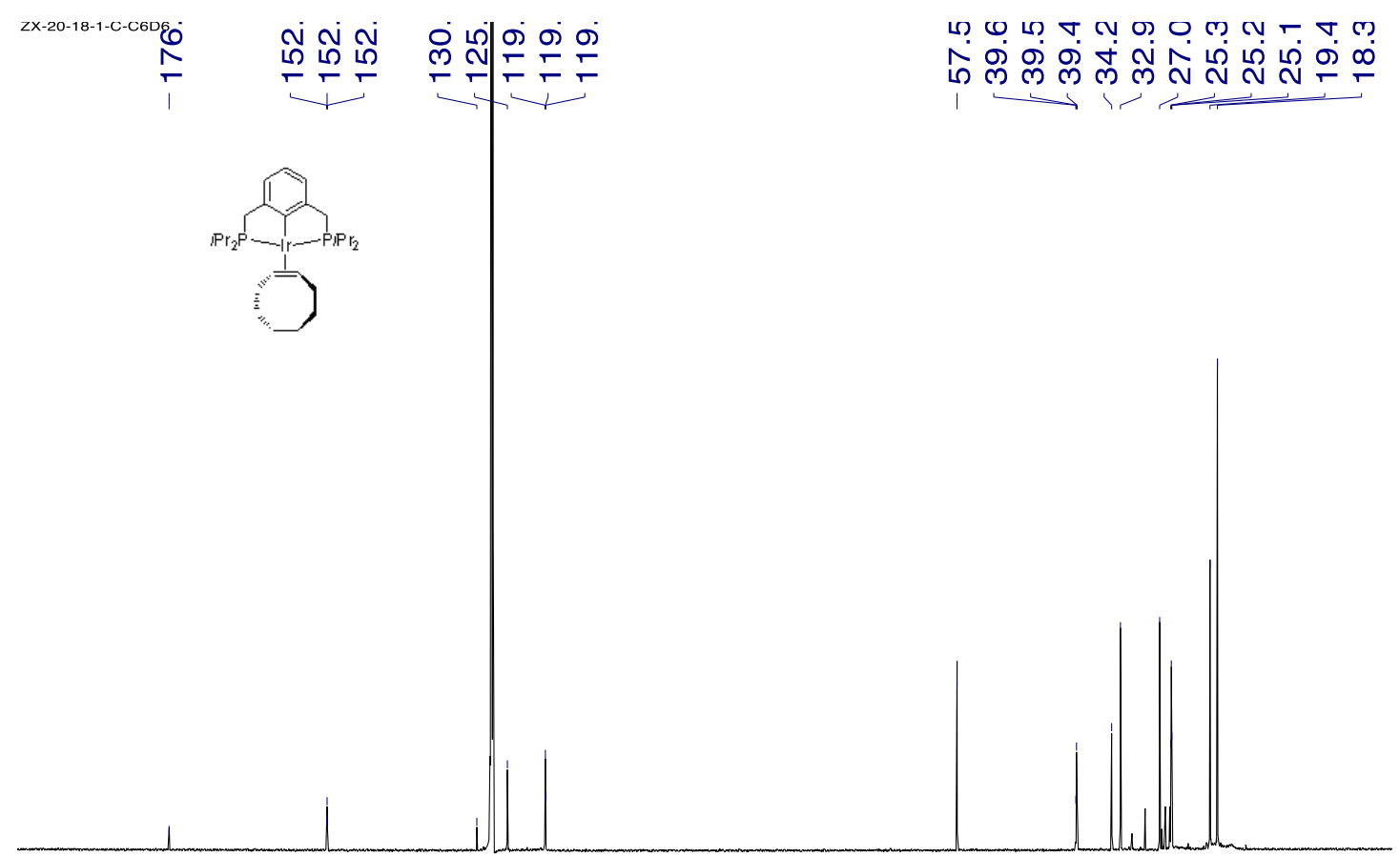

Figure S93. ${ }^{13} \mathrm{C}$ NMR of ${ }^{i{ }^{2}-1}$-(perpendicular-COE) in $\mathrm{C}_{6} \mathrm{D}_{6}$.

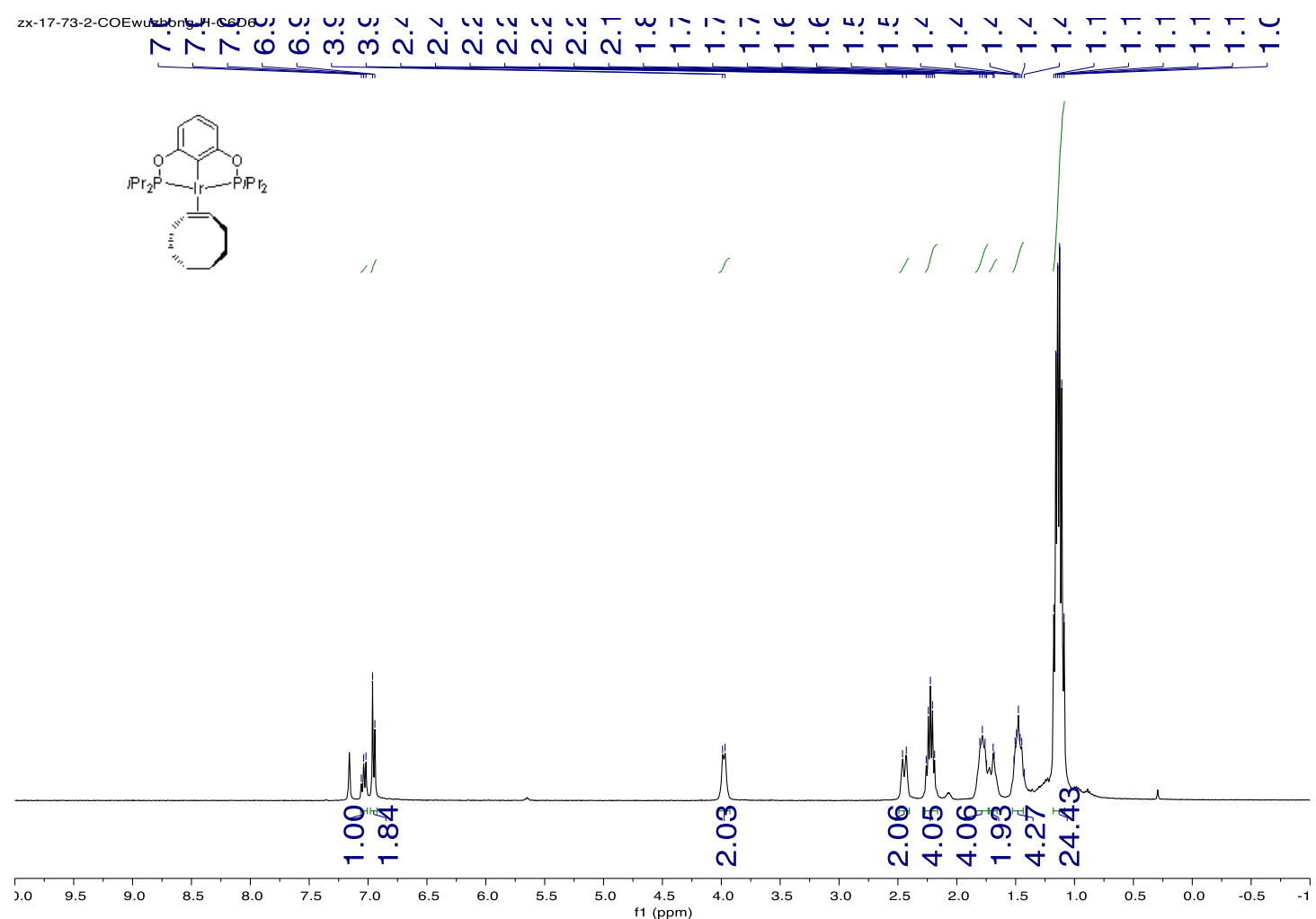

Figure S94. ${ }^{1} \mathrm{H}$ NMR of ${ }^{i P r}-2$-(perpendicular-COE) in $\mathrm{C}_{6} \mathrm{D}_{6}$. 


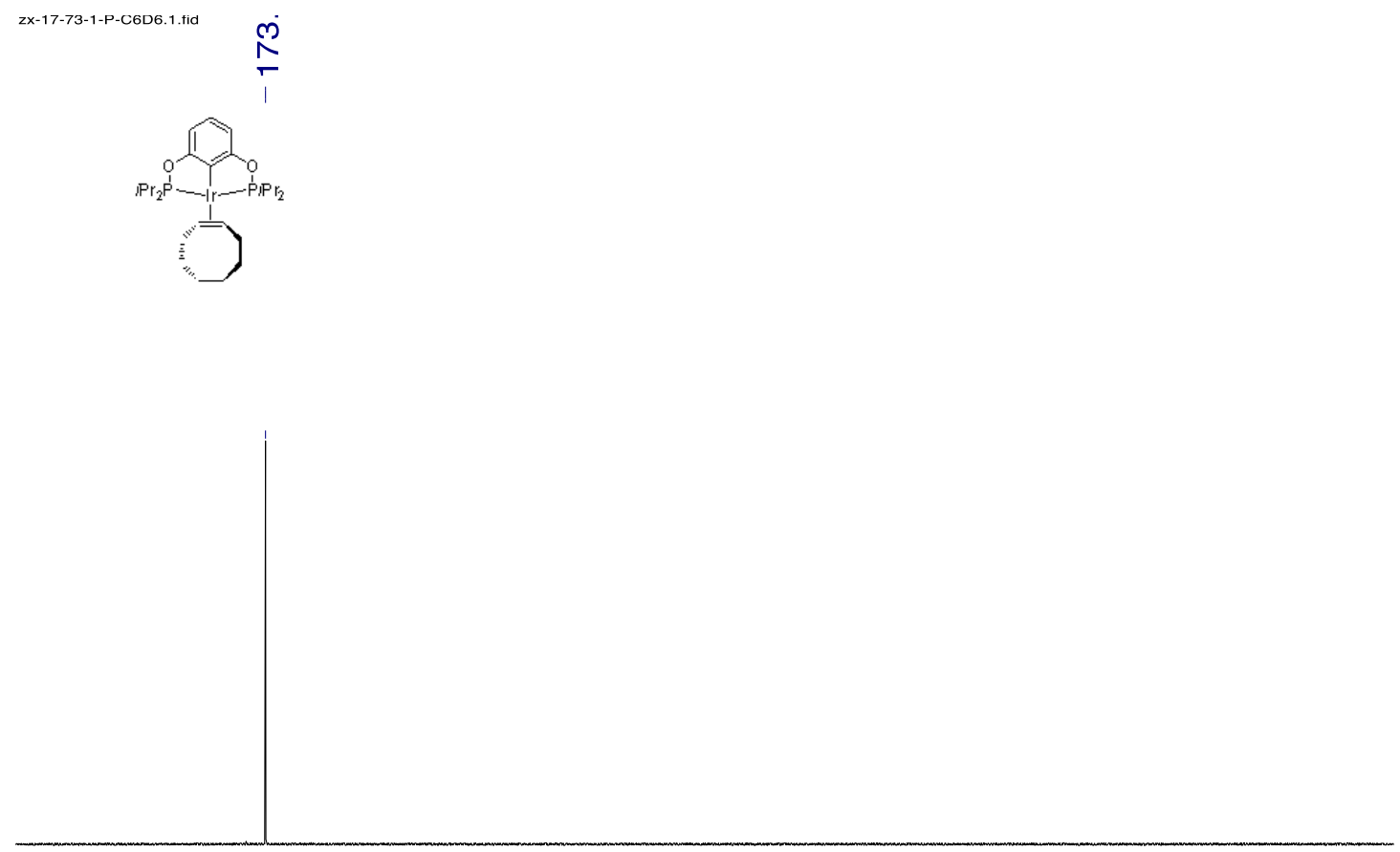

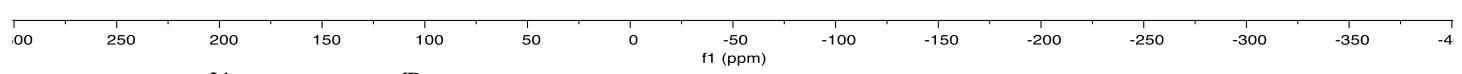

Figure S95. ${ }^{31} \mathrm{P}$ NMR of ${ }^{i \mathrm{Pr}-2}$-(perpendicular-COE) in $\mathrm{C}_{6} \mathrm{D}_{6}$.

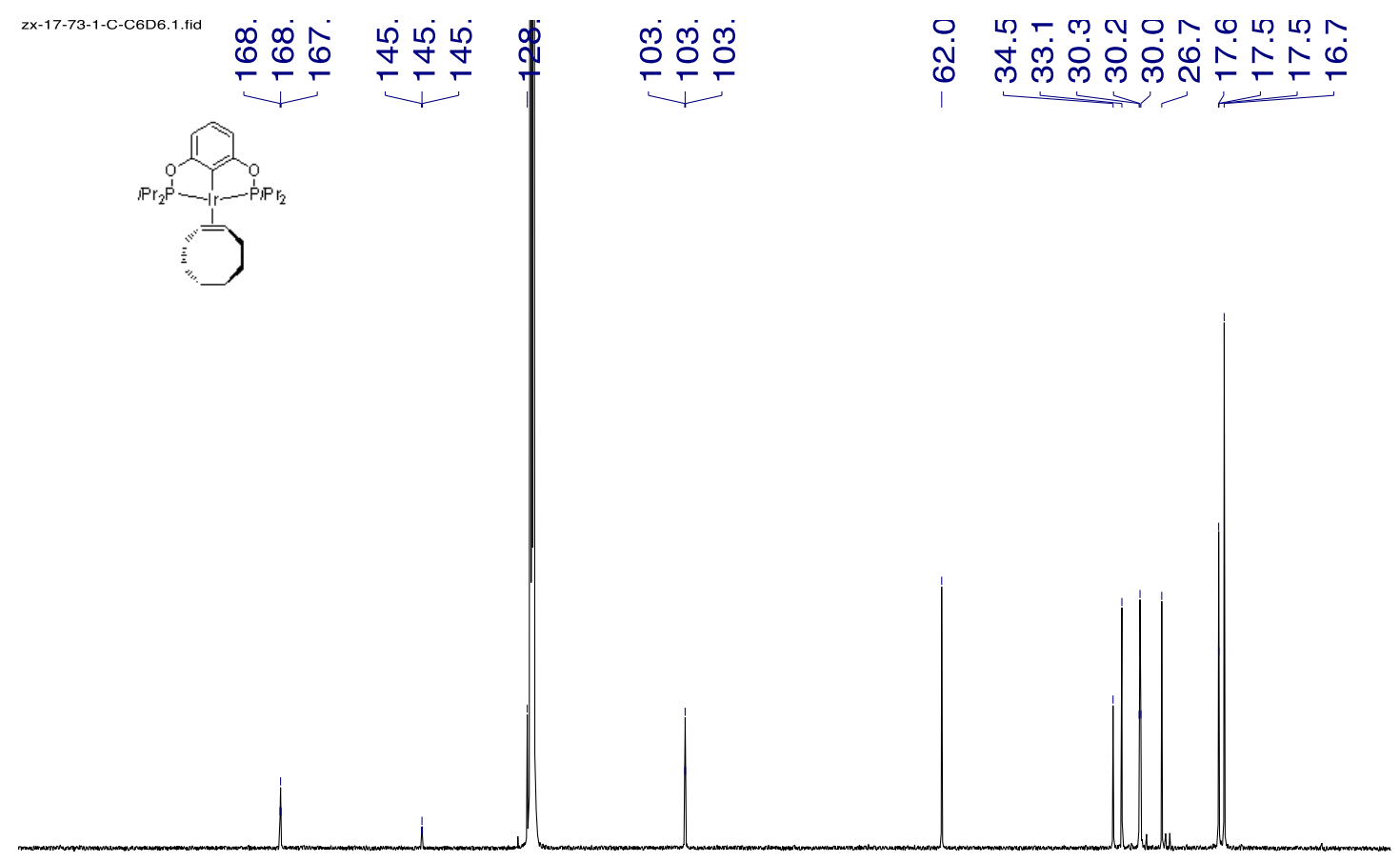

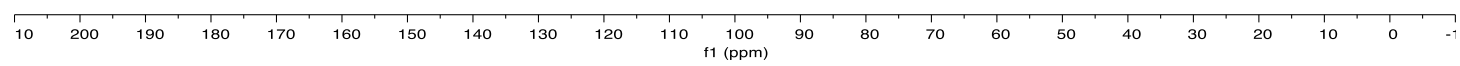

Figure S96. ${ }^{13} \mathrm{C}$ NMR of ${ }^{i P r-2}$-(perpendicular-COE) in $\mathrm{C}_{6} \mathrm{D}_{6}$. 
N
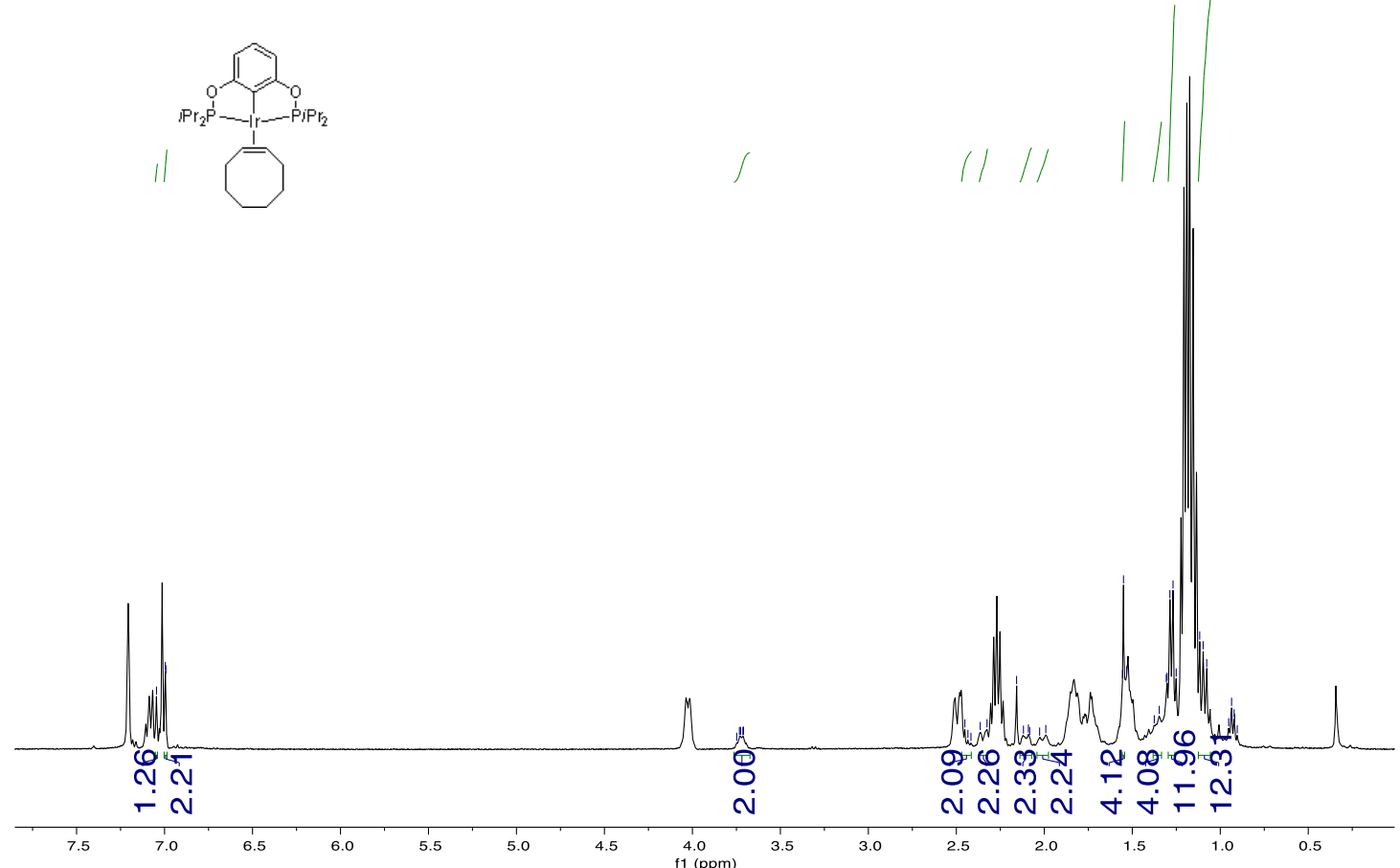

Figure S97. ${ }^{1} \mathrm{H}$ NMR of ${ }^{i P r}$ 2-(coplanar-COE) in $\mathrm{C}_{6} \mathrm{D}_{6}$.

ZX-19-46-1-P-C6D6.1. fid
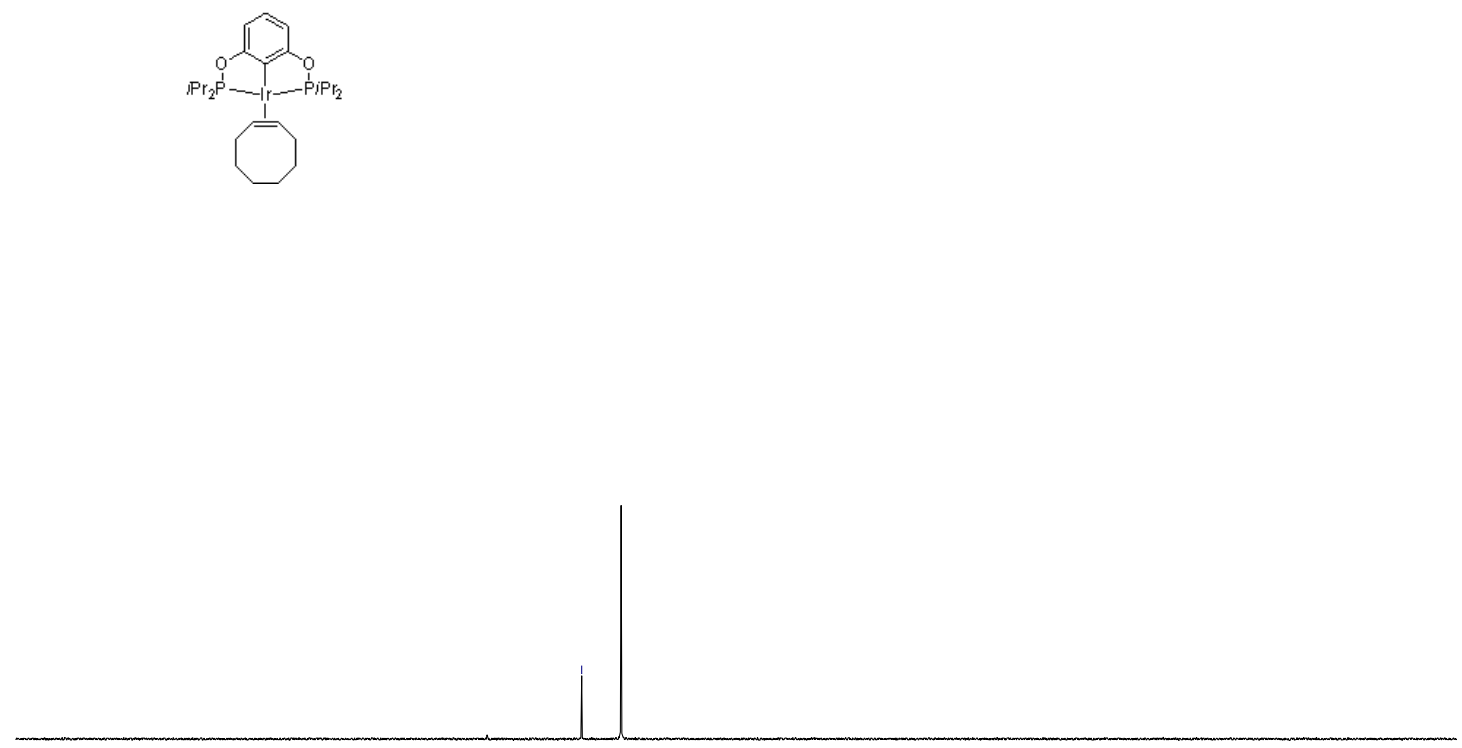

$\begin{array}{llllllllll}240 & 230 & 220 & 210 & 200 & 190 & 180 & 170 & \begin{array}{ll}160 \\ \mathrm{f} 1(\mathrm{ppm})\end{array} & 150 \\ & & & & & & & \end{array}$ 


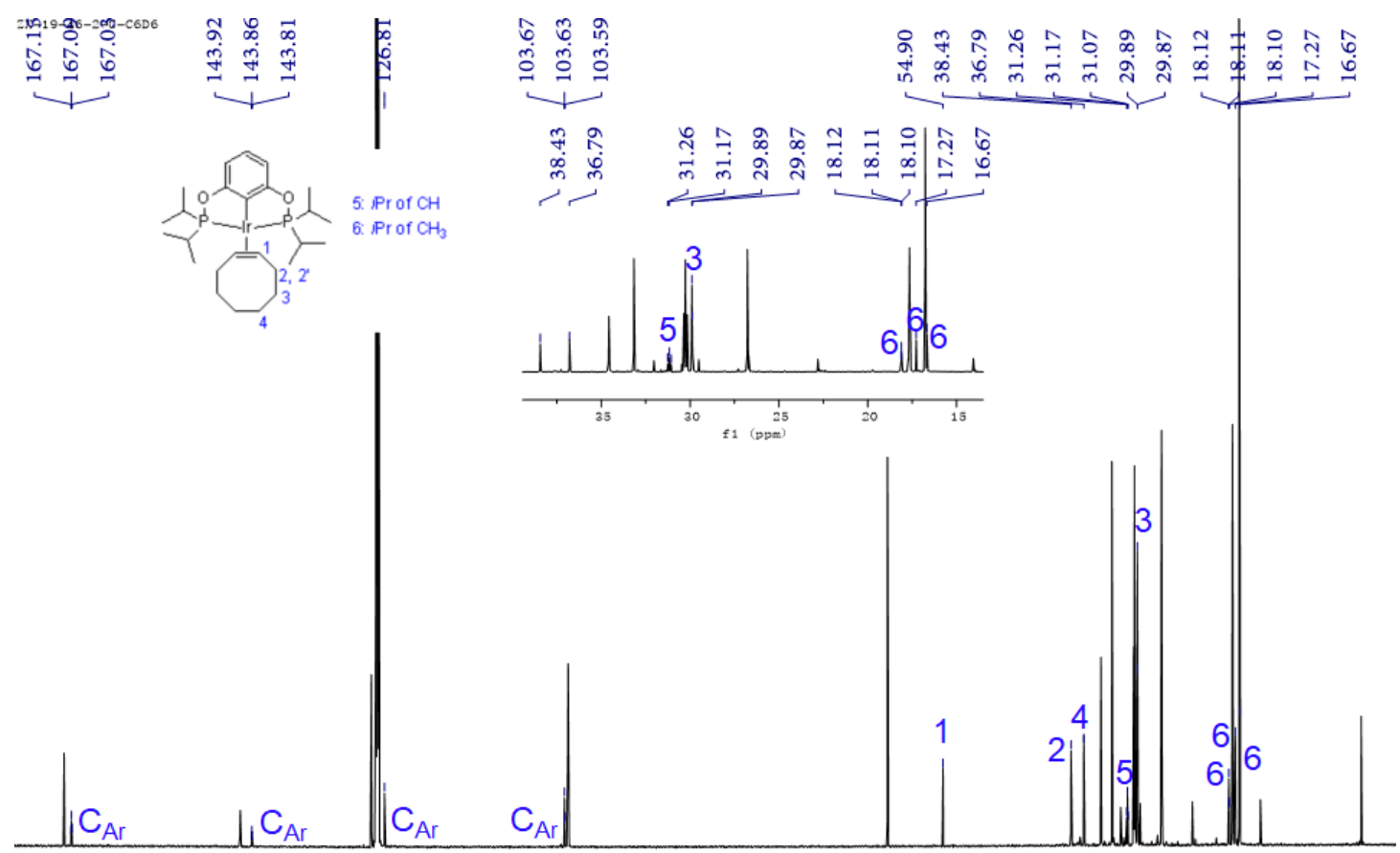

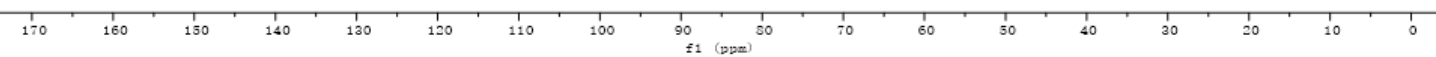

Figure S99. ${ }^{13} \mathrm{C}$ NMR of ${ }^{i P r}-2-\left(\right.$ coplanar-COE) in $\mathrm{C}_{6} \mathrm{D}_{6}$.

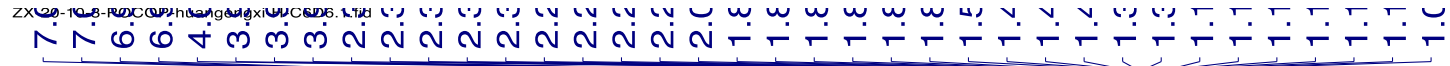

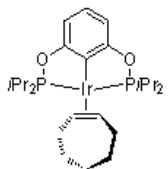

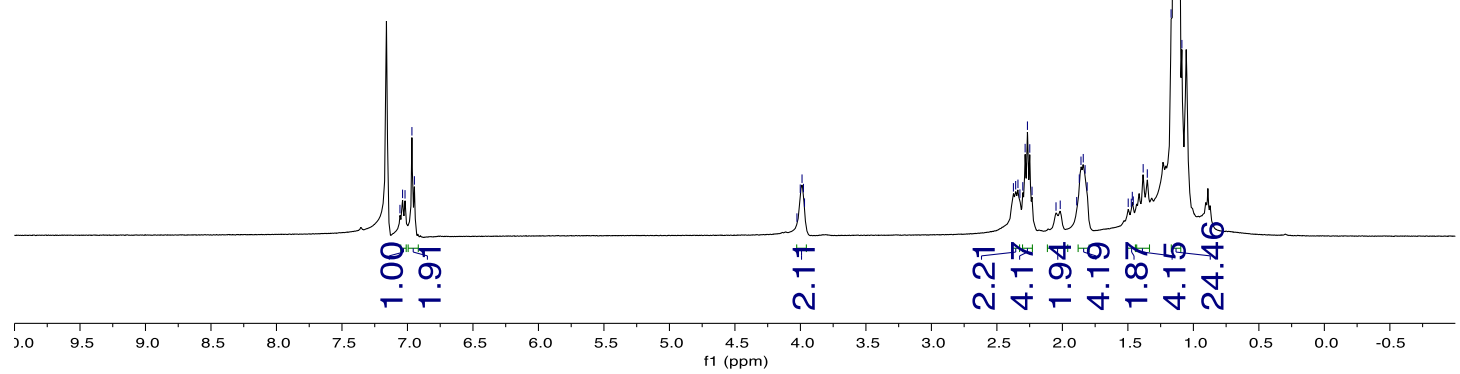

Figure S100. ${ }^{1} \mathrm{H}$ NMR of ${ }^{i P r}-2$-(perpendicular-CPE) in $\mathrm{C}_{6} \mathrm{D}_{6}$. 

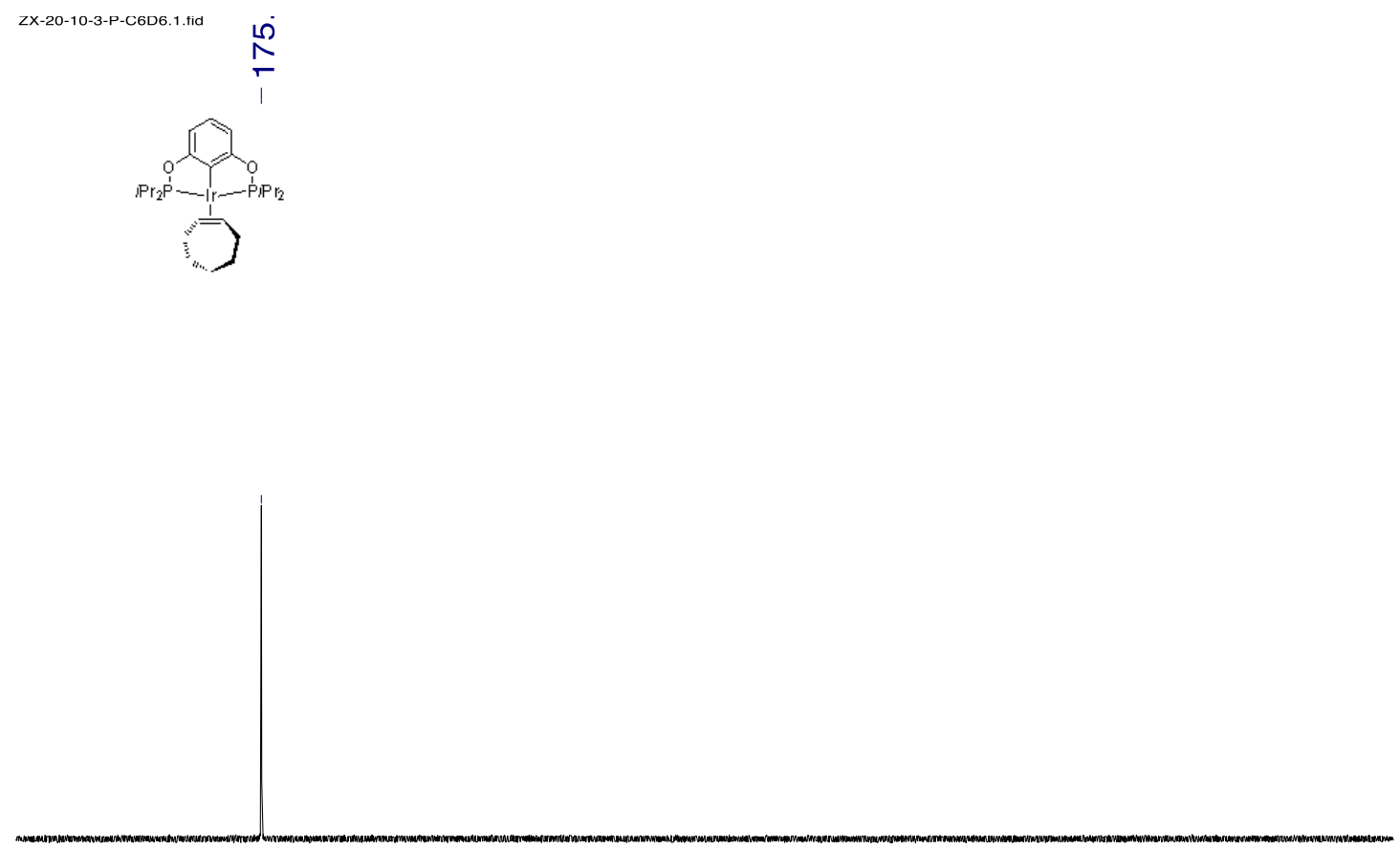

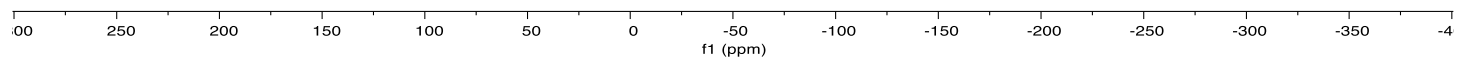

Figure S101. ${ }^{31} \mathrm{P}$ NMR of ${ }^{i P r}-2$-(perpendicular-CPE) in $\mathrm{C}_{6} \mathrm{D}_{6}$.

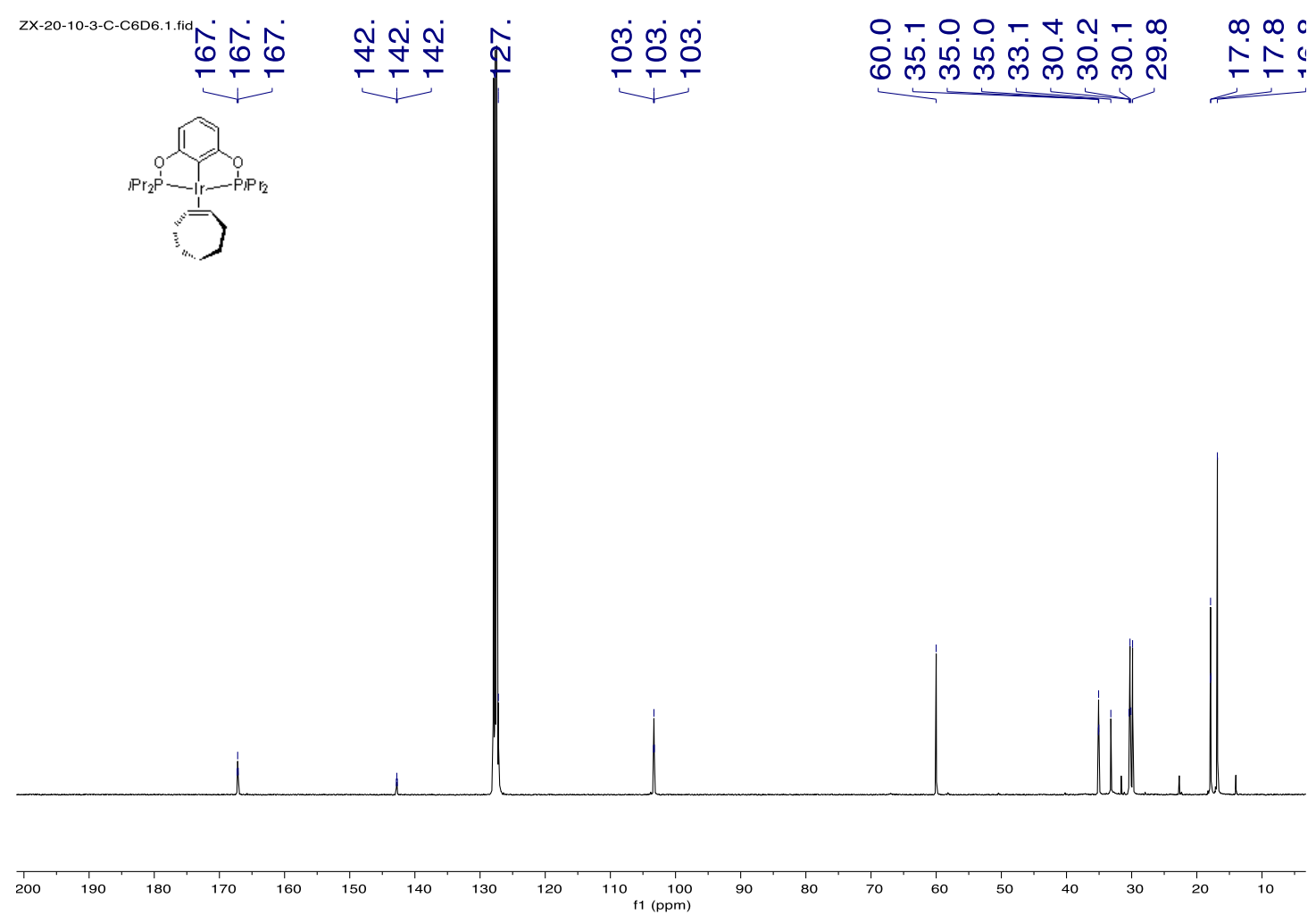

Figure S102. ${ }^{13} \mathrm{C}$ NMR of ${ }^{i P r}-2$-(perpendicular-CPE) in $\mathrm{C}_{6} \mathrm{D}_{6}$. 


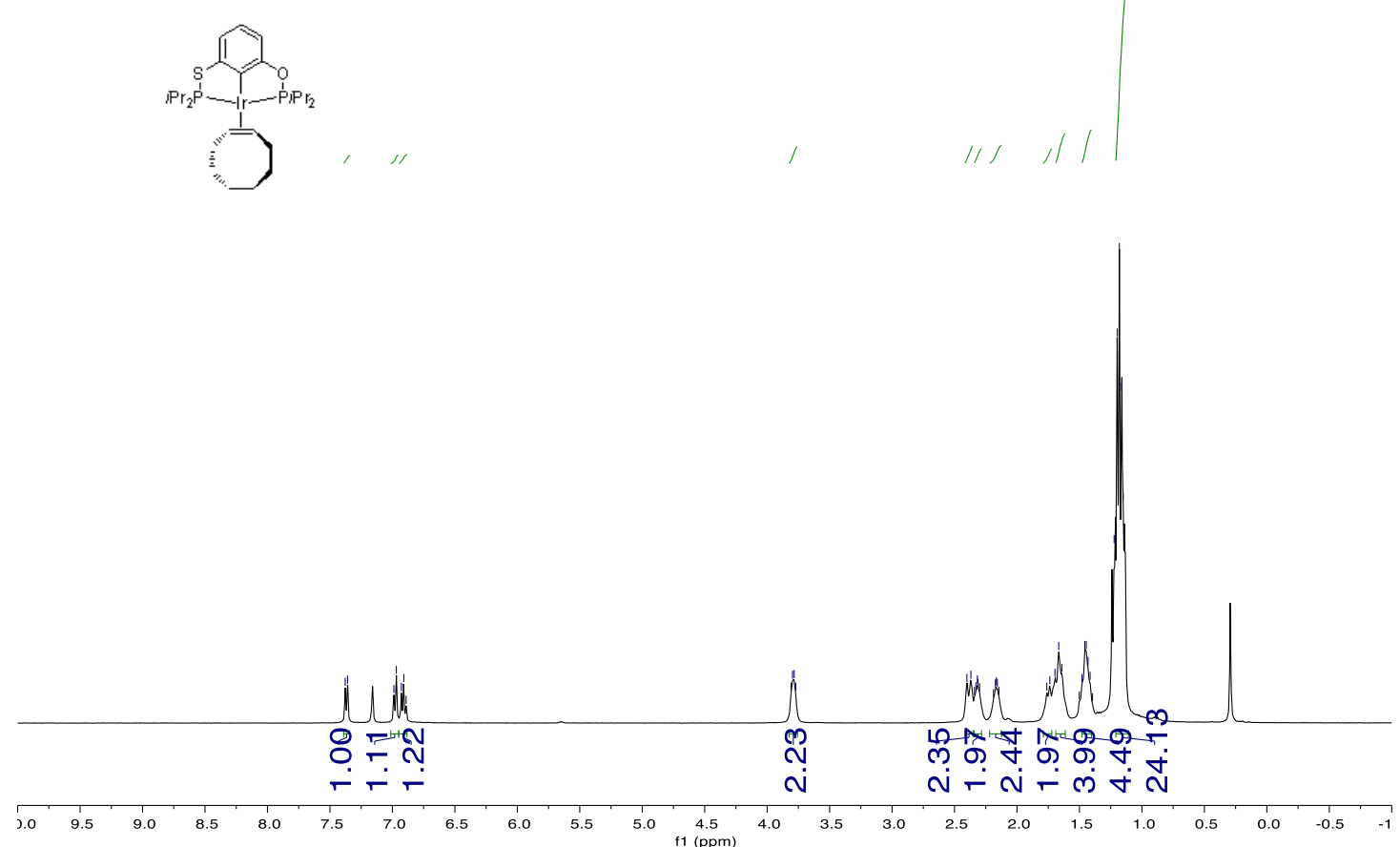

Figure S103. ${ }^{1} \mathrm{H}$ NMR of ${ }^{i \mathrm{Pr}-3}$-(perpendicular-COE) in $\mathrm{C}_{6} \mathrm{D}_{6}$.

ZX-17-72-1-P-C6D6

6D6

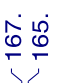

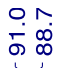

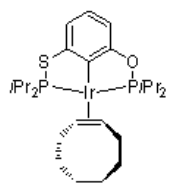

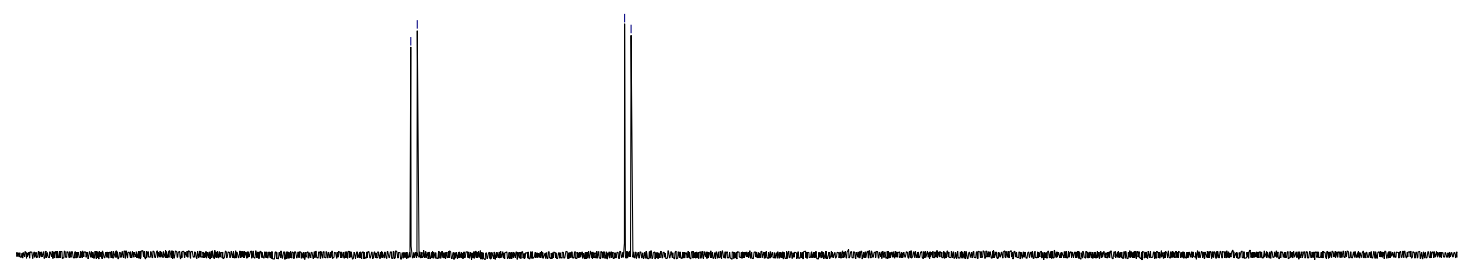

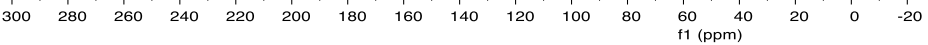

Figure S104. ${ }^{31} \mathrm{P}$ NMR of ${ }^{i \mathrm{Pr}-}$ 3-(perpendicular-COE) in $\mathrm{C}_{6} \mathrm{D}_{6}$. 


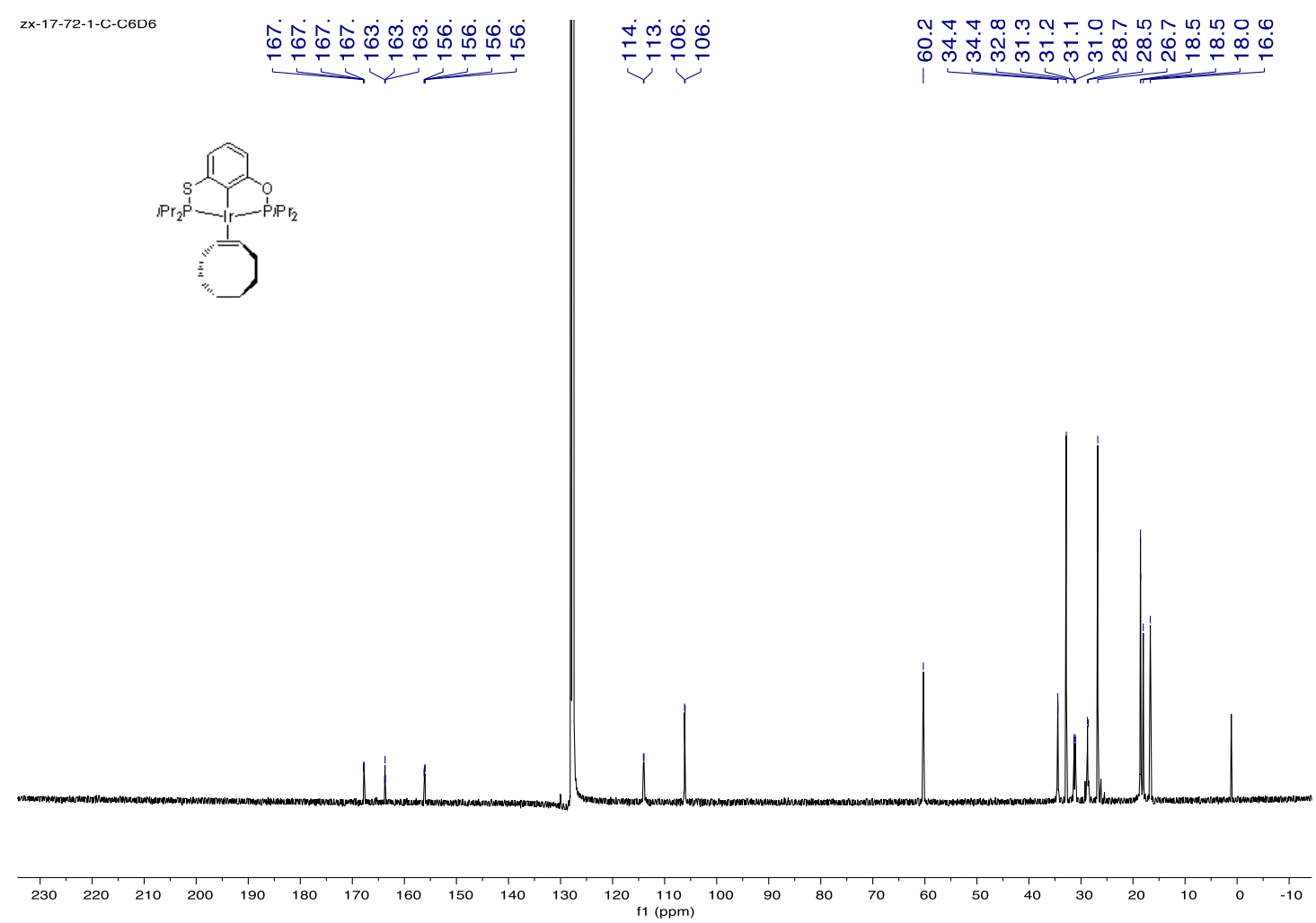

Figure S105. ${ }^{13} \mathrm{C}$ NMR of ${ }^{i P r-3}$-(perpendicular-COE) in $\mathrm{C}_{6} \mathrm{D}_{6}$.

ז N
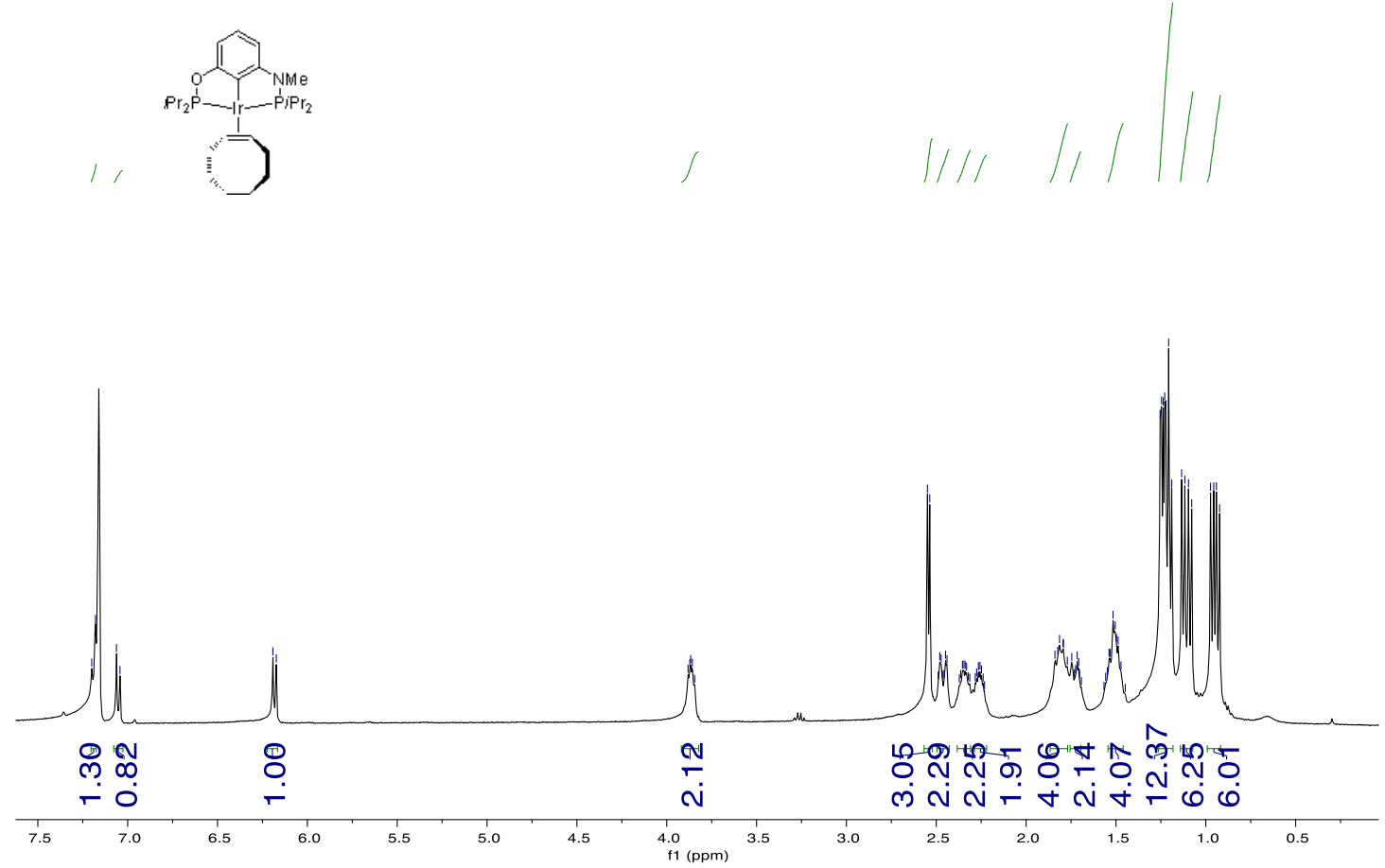

Figure S106. ${ }^{1} \mathrm{H}$ NMR of $\mathbf{4 b}$-(perpendicular-COE) in $\mathrm{C}_{6} \mathrm{D}_{6}$. 

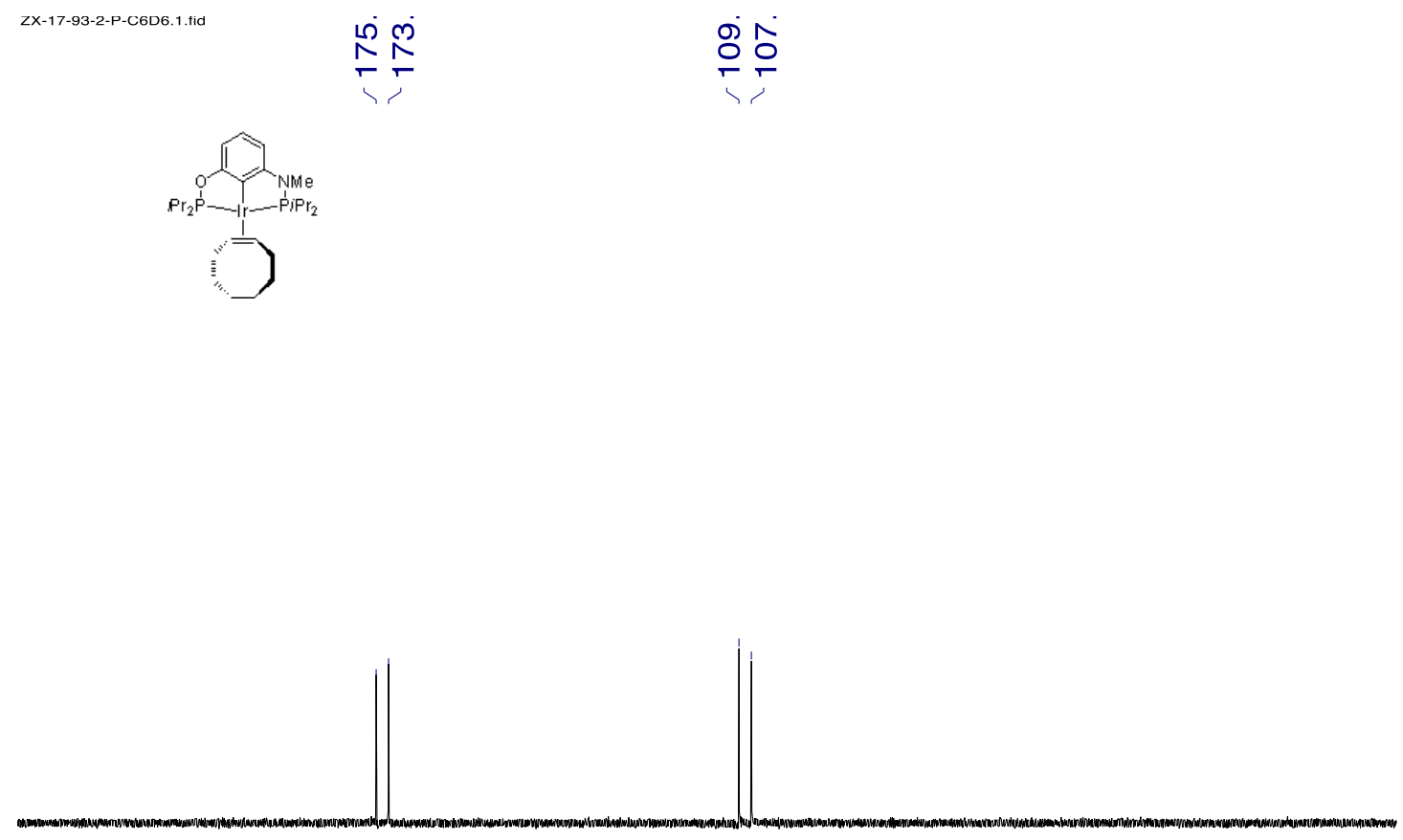

Figure S107. ${ }^{31} \mathrm{P}$ NMR of $\mathbf{4 b}$-(perpendicular-COE) in $\mathrm{C}_{6} \mathrm{D}_{6}$.

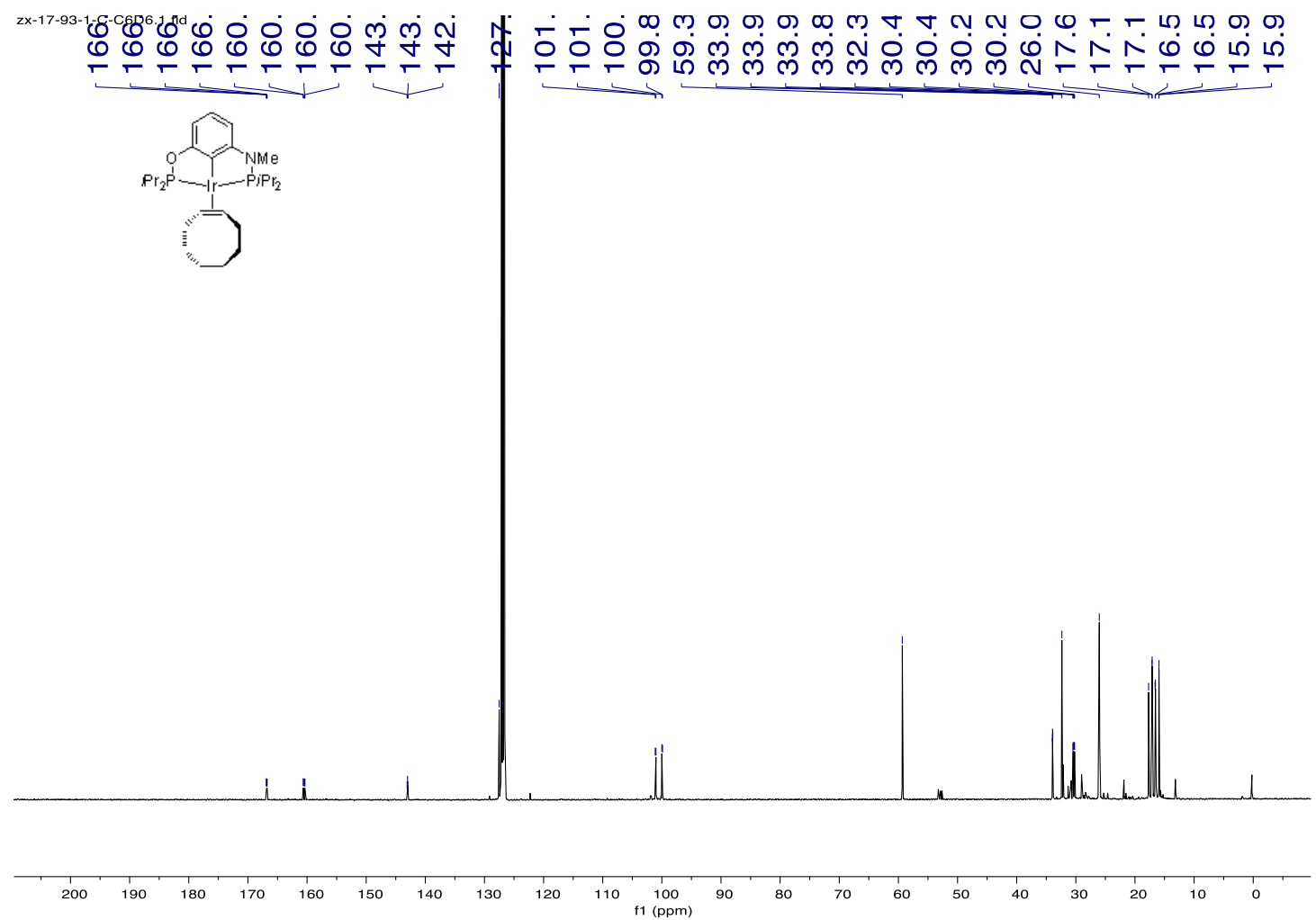

Figure S108. ${ }^{13} \mathrm{C}$ NMR of $\mathbf{4 b}$-(perpendicular-COE) in $\mathrm{C}_{6} \mathrm{D}_{6}$. 


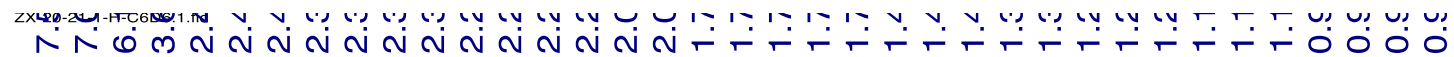

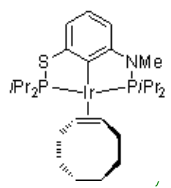

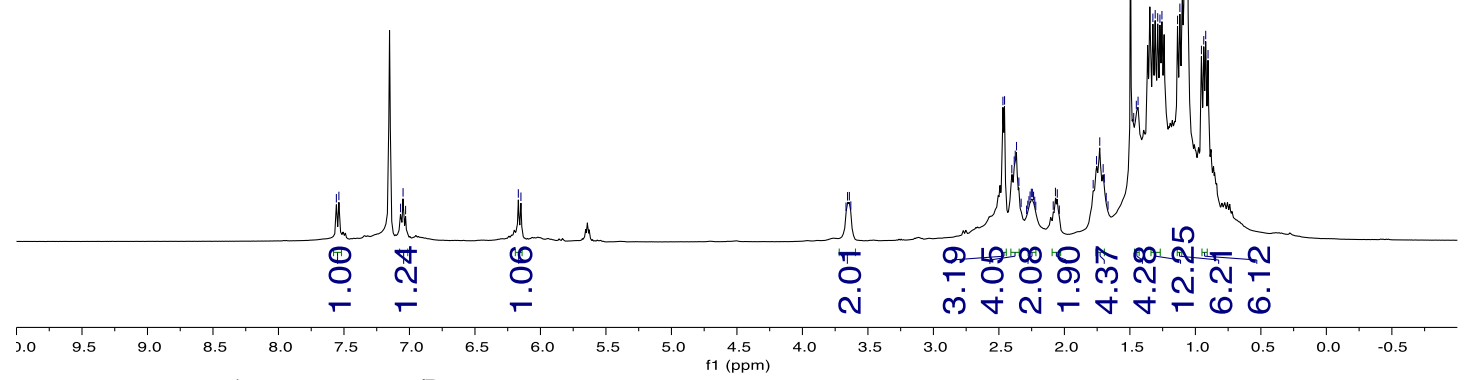

Figure S109. ${ }^{1} \mathrm{H}$ NMR of ${ }^{i \mathrm{Pr}-5}$-(perpendicular-COE) (impure) in $\mathrm{C}_{6} \mathrm{D}_{6}$.

ZX-20-21-1-P-C6D6.1.fid

ปั

ริ드응
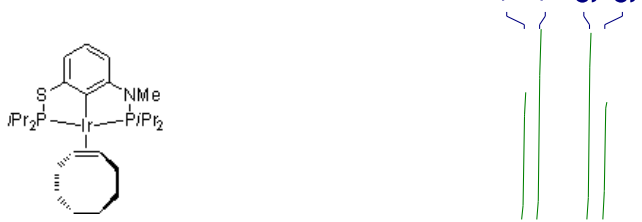

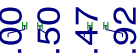

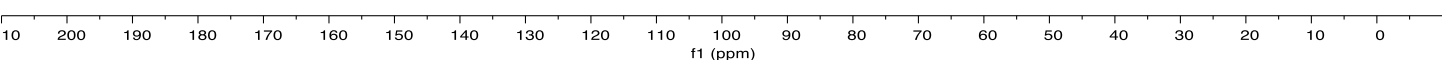

Figure S110. ${ }^{31} \mathrm{P}$ NMR of ${ }^{i \mathrm{Pr}-5}$-(perpendicular-COE) (impure) in $\mathrm{C}_{6} \mathrm{D}_{6}$. 


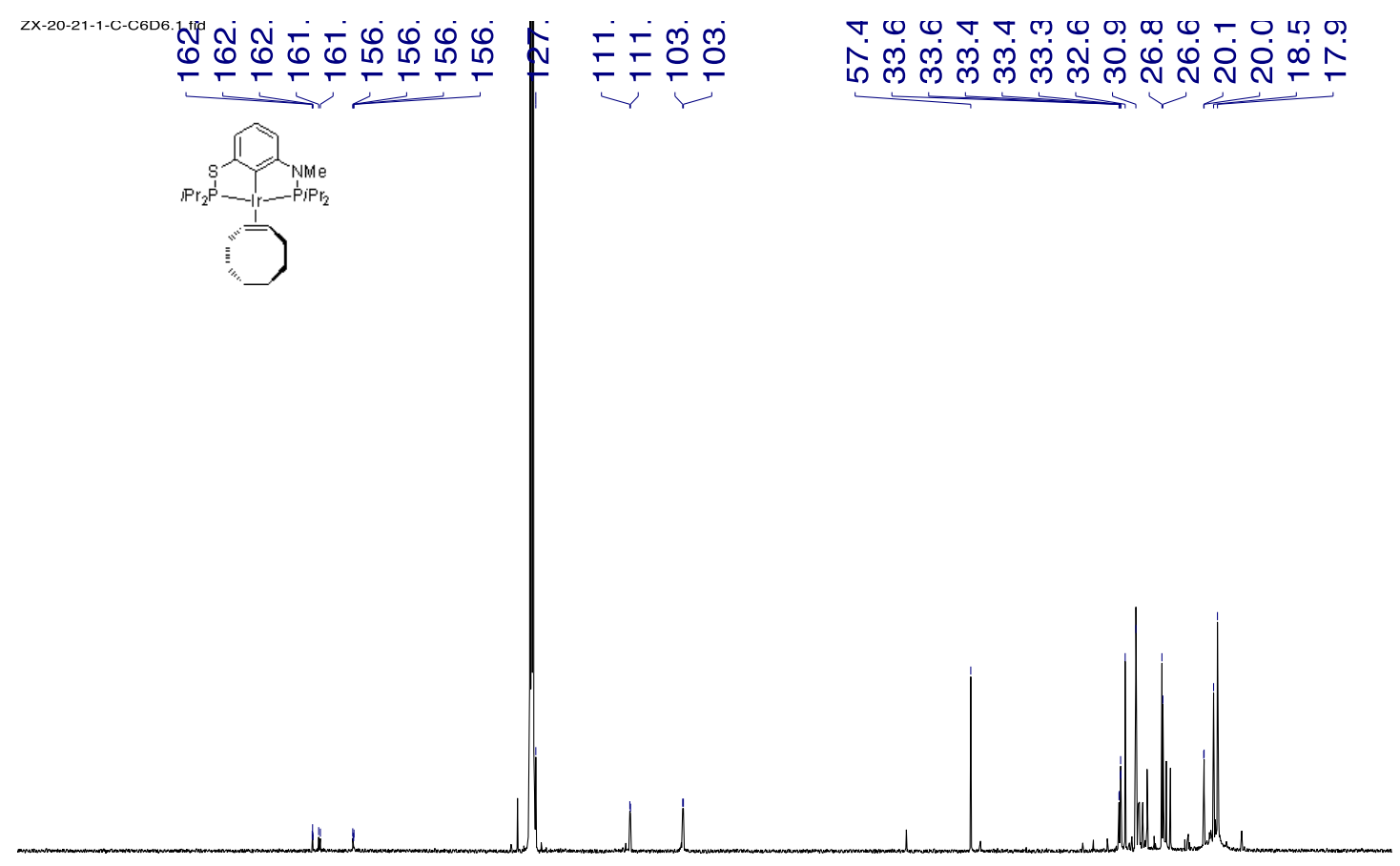

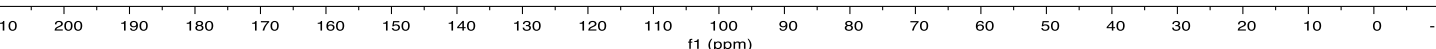

Figure S111. ${ }^{13} \mathrm{C}$ NMR of ${ }^{i P r}-5$-(perpendicular-COE) (impure) in $\mathrm{C}_{6} \mathrm{D}_{6}$.

ZX-20-27-1-H-C6D6.1.fid

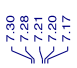

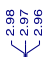

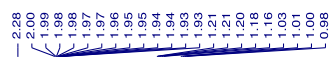
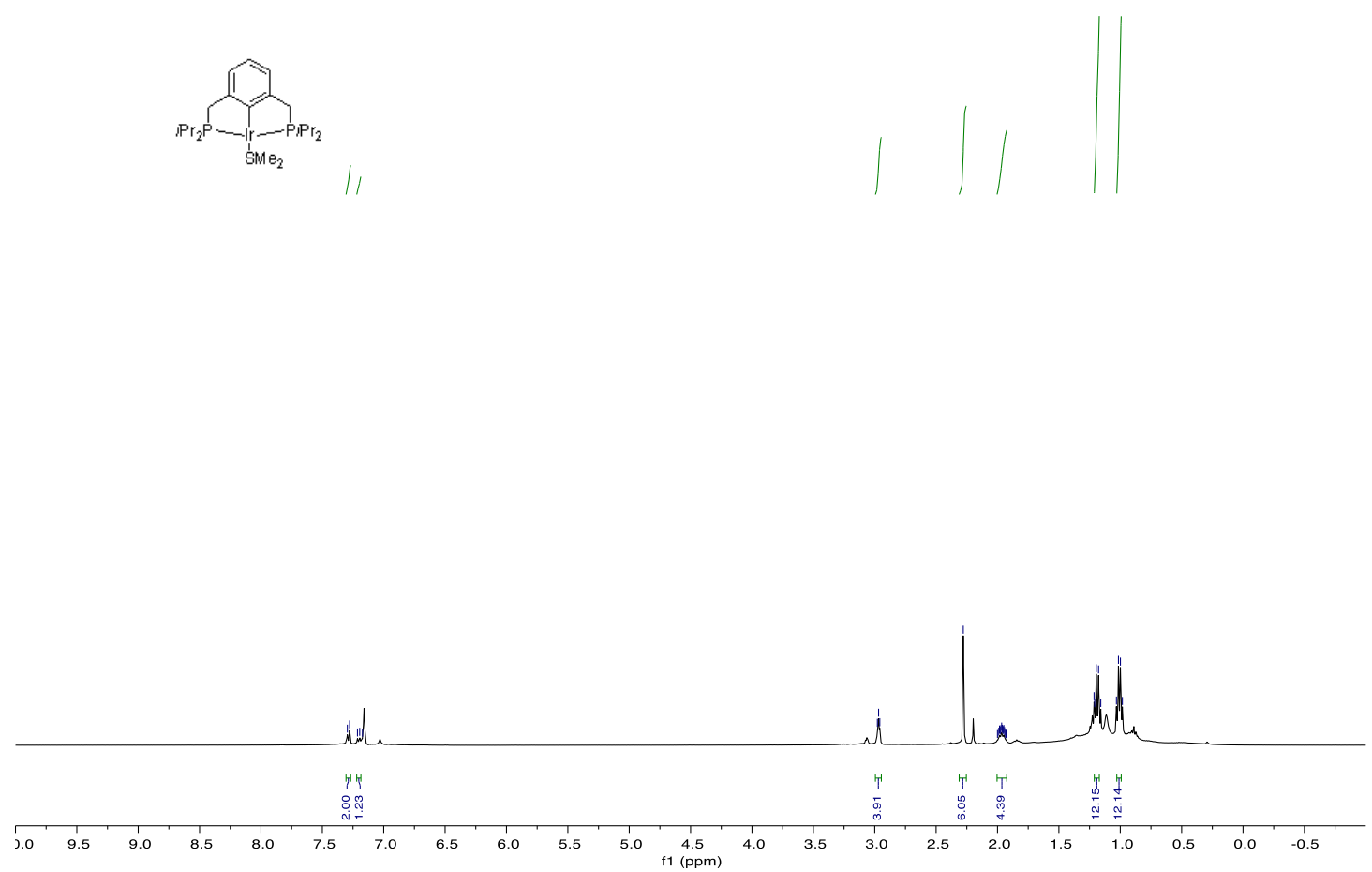

Figure S112. ${ }^{1} \mathrm{H}$ NMR of ${ }^{i{ }^{2}-1}-\mathrm{SMe}_{2}$ in $\mathrm{C}_{6} \mathrm{D}_{6}$. 

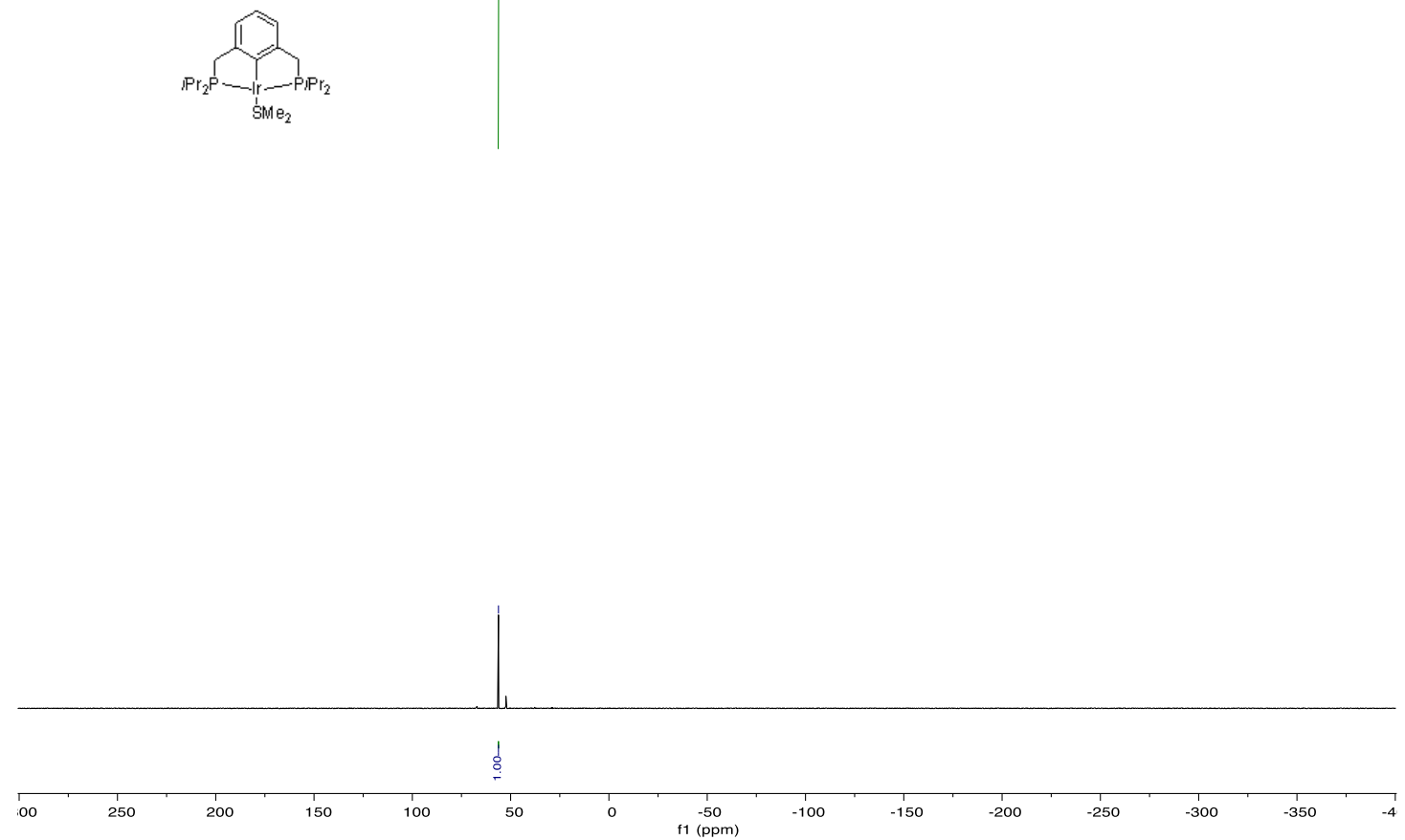

Figure S113. ${ }^{31} \mathrm{P}$ NMR of ${ }^{i{ }^{2}-1}-\mathrm{SMe}_{2}$ in $\mathrm{C}_{6} \mathrm{D}_{6}$.
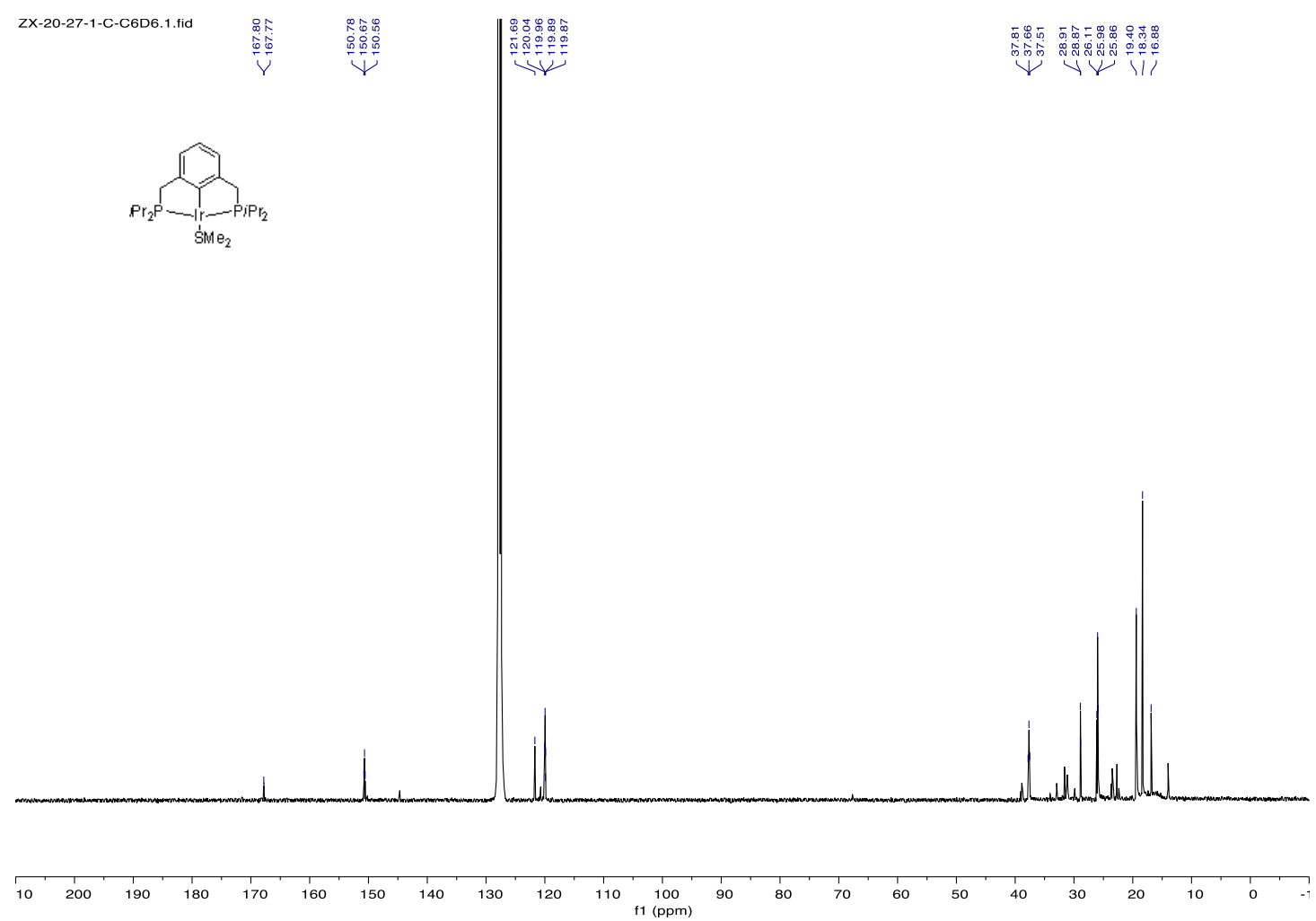

Figure S114. ${ }^{13} \mathrm{C}$ NMR of ${ }^{i \mathrm{Pr}-1}-\mathrm{SMe}_{2}$ in $\mathrm{C}_{6} \mathrm{D}_{6}$. 


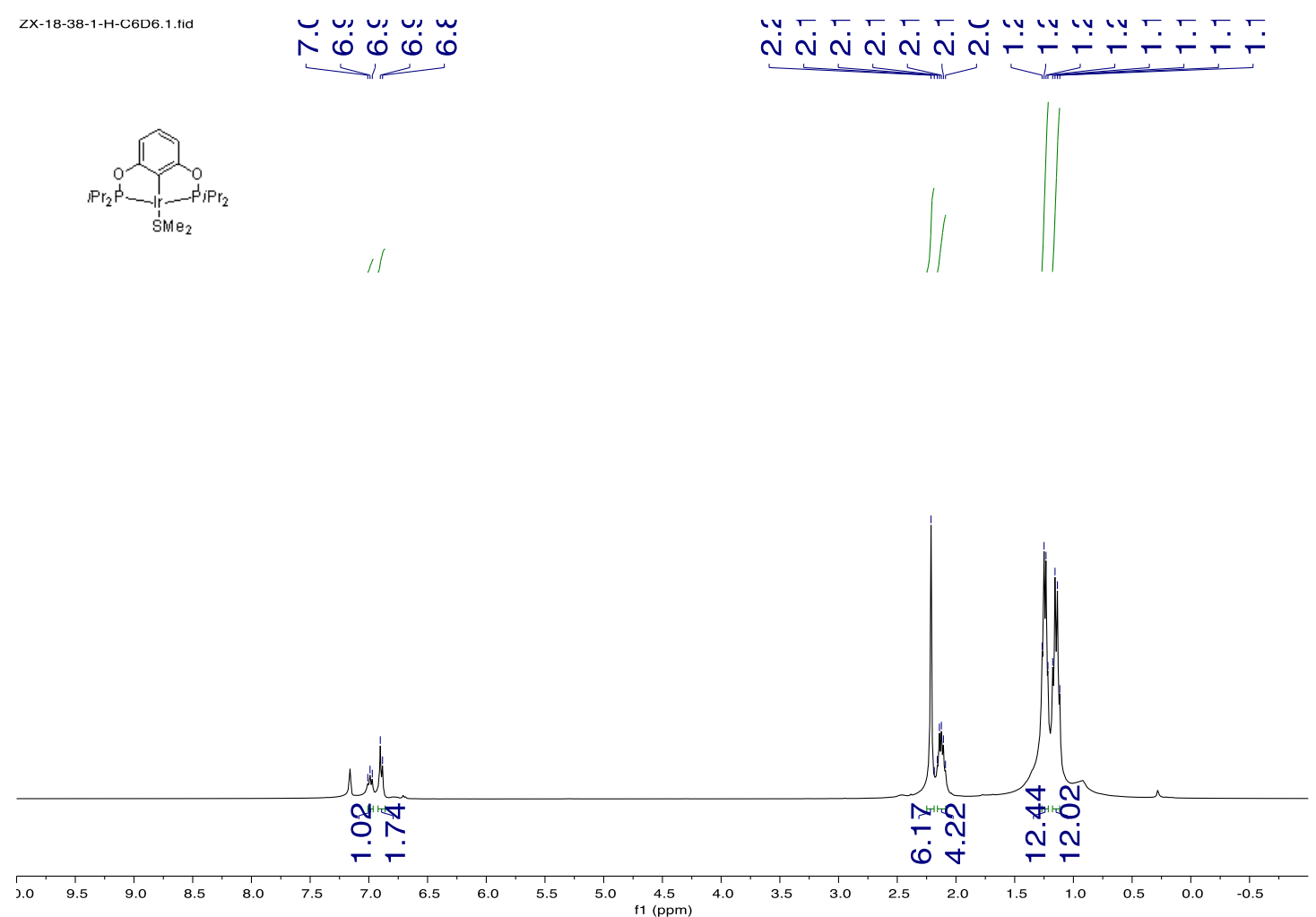

Figure S115. ${ }^{1} \mathrm{H}$ NMR of ${ }^{i \mathrm{Pr}-2}-\mathrm{SMe}_{2}$ in $\mathrm{C}_{6} \mathrm{D}_{6}$.
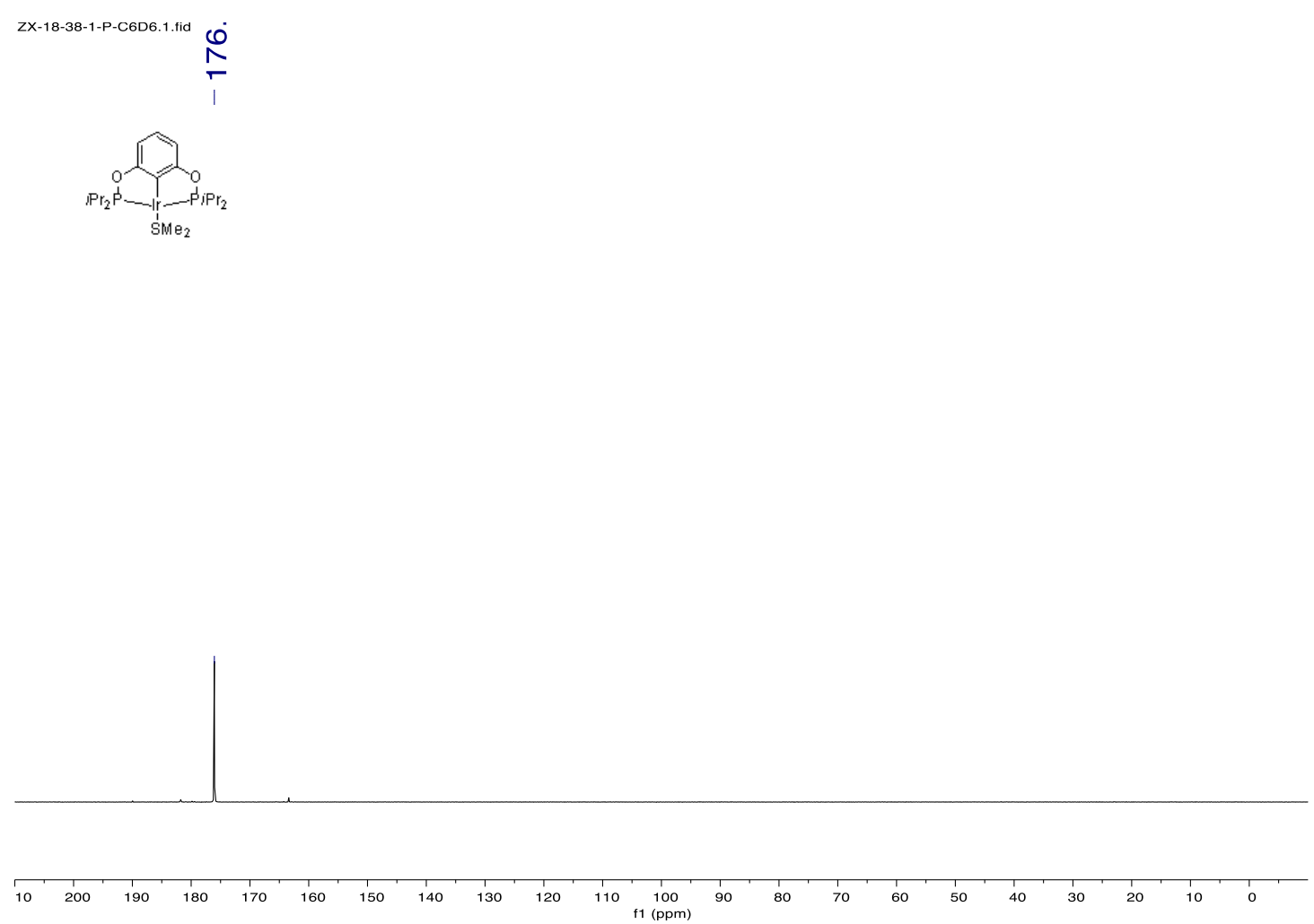

Figure S116. ${ }^{31} \mathrm{P}$ NMR of ${ }^{i \mathrm{Pr}-2}-\mathrm{SMe}_{2}$ in $\mathrm{C}_{6} \mathrm{D}_{6}$. 


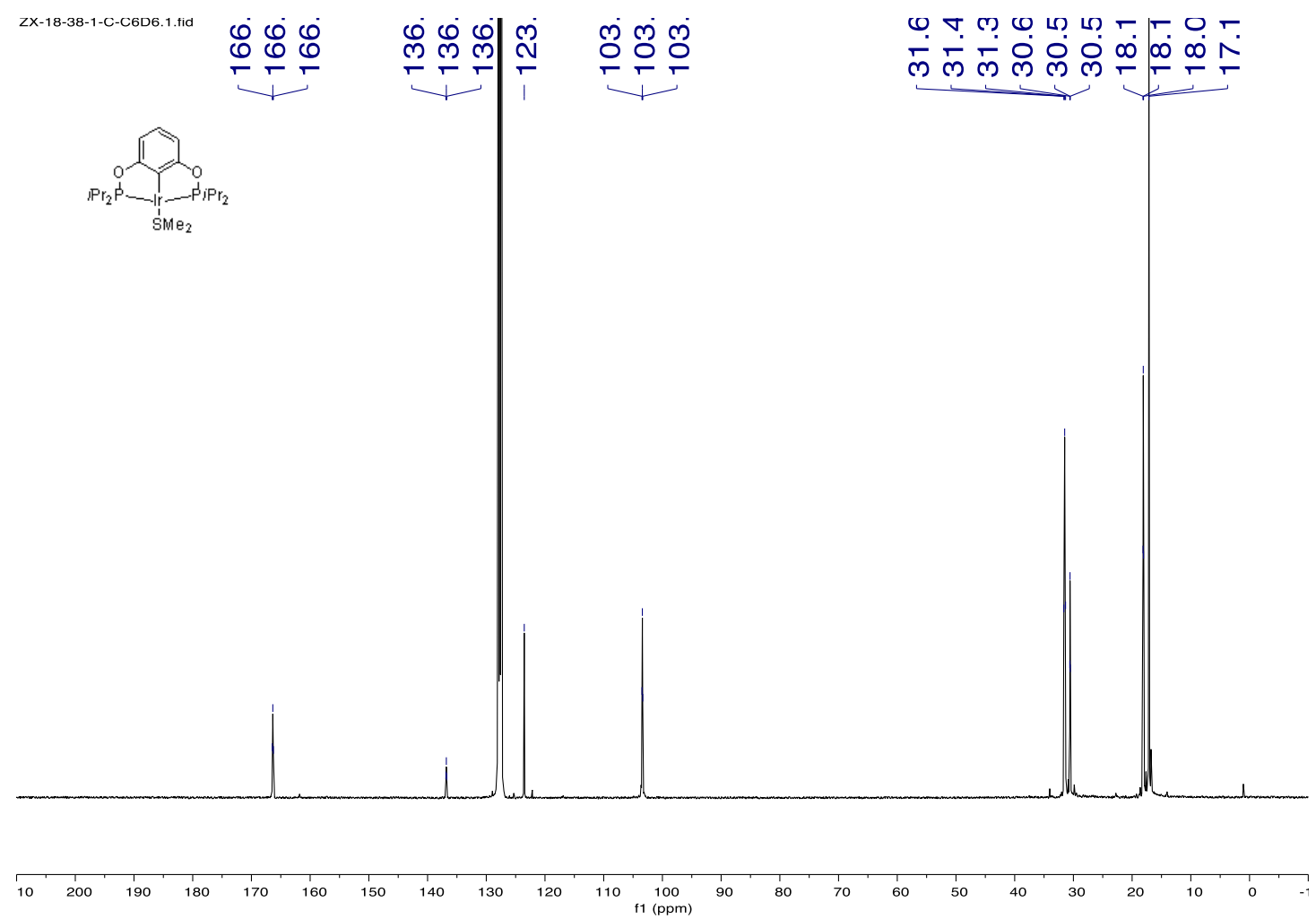

Figure S117. ${ }^{13} \mathrm{C}$ NMR of ${ }^{i \mathrm{Pr}-2}-\mathrm{SMe}_{2}$ in $\mathrm{C}_{6} \mathrm{D}_{6}$.

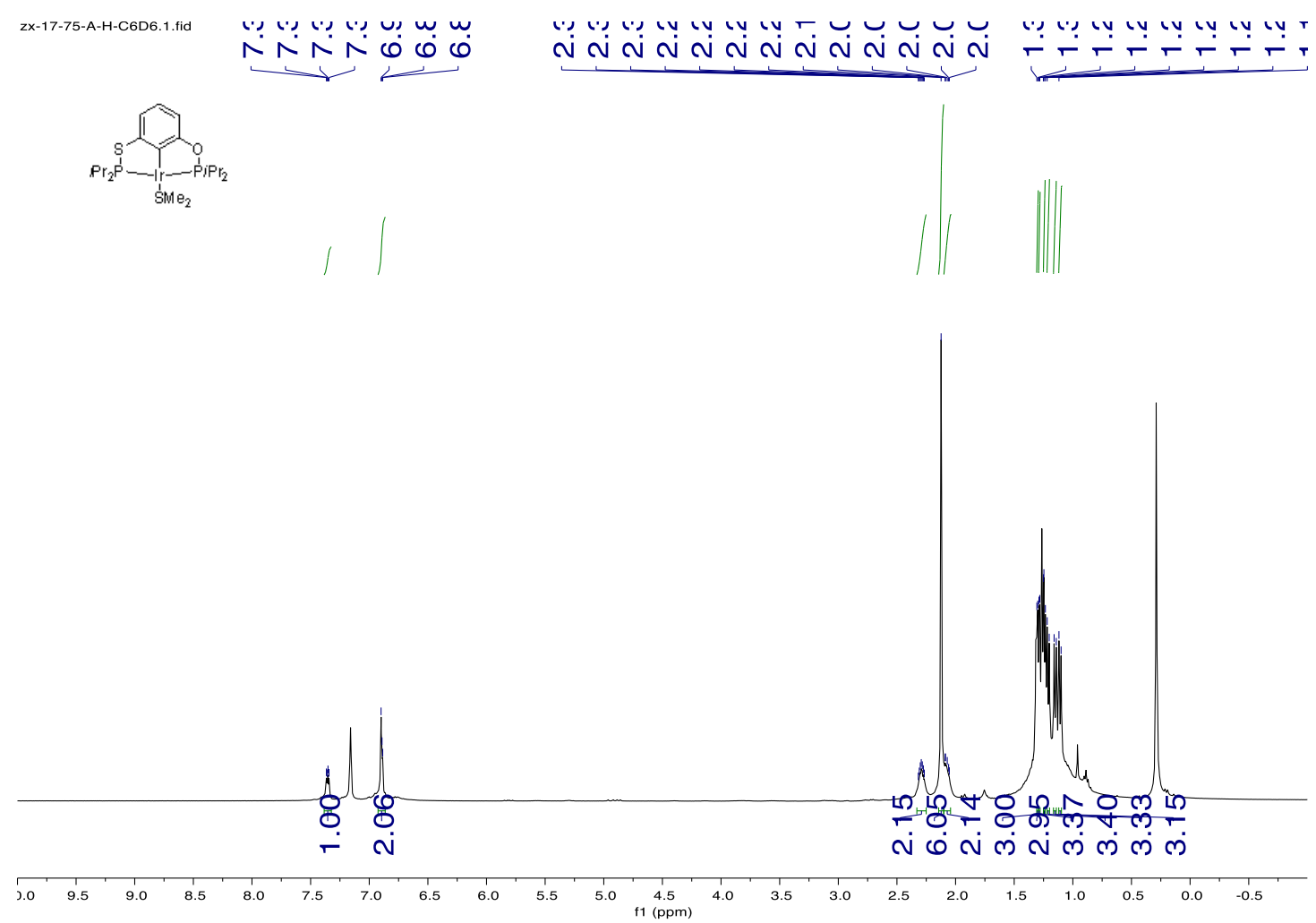

Figure S118. ${ }^{1} \mathrm{H}$ NMR of ${ }^{i P r}-3-S e_{2}$ in $\mathrm{C}_{6} \mathrm{D}_{6}$. 

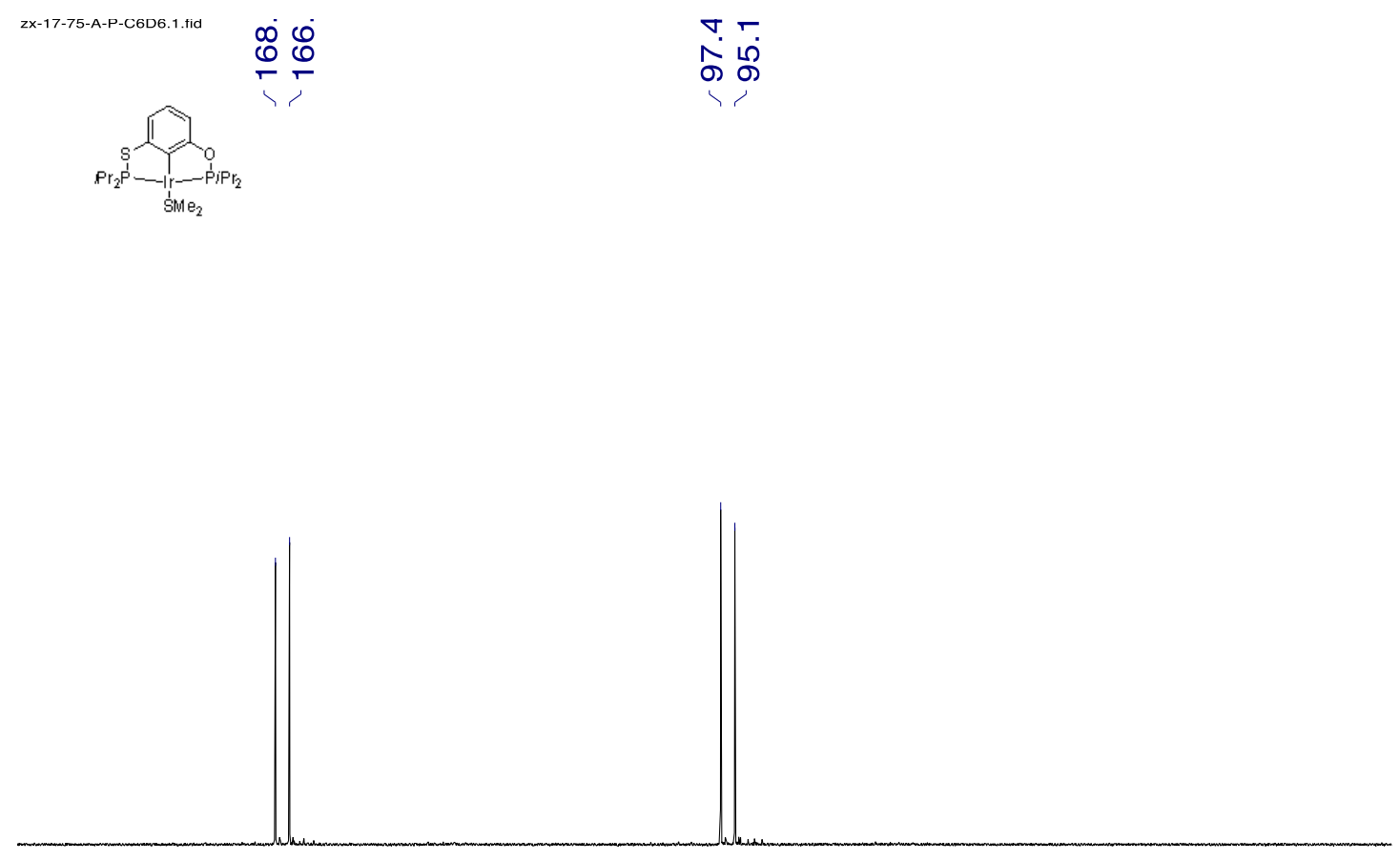

Figure S119. ${ }^{31} \mathrm{H}$ NMR of ${ }^{i \mathrm{Pr}-3}-\mathrm{SMe}_{2}$ in $\mathrm{C}_{6} \mathrm{D}_{6}$.

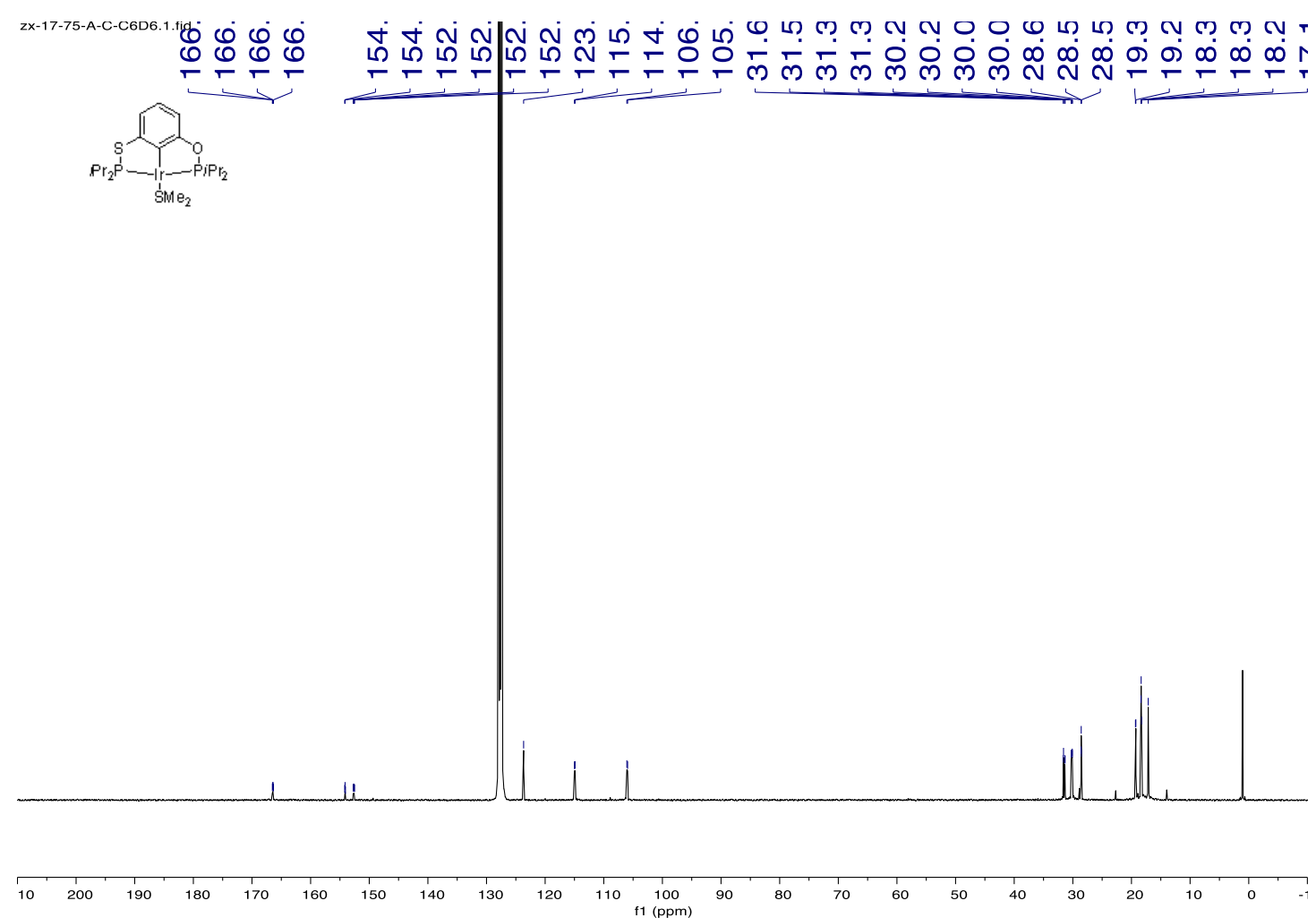

Figure S120. ${ }^{13} \mathrm{C}$ NMR of ${ }^{i \mathrm{Pr}-} 3-\mathrm{SMe}_{2}$ in $\mathrm{C}_{6} \mathrm{D}_{6}$. 


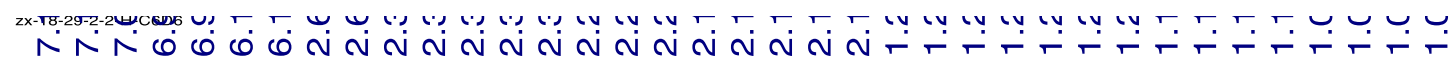
S

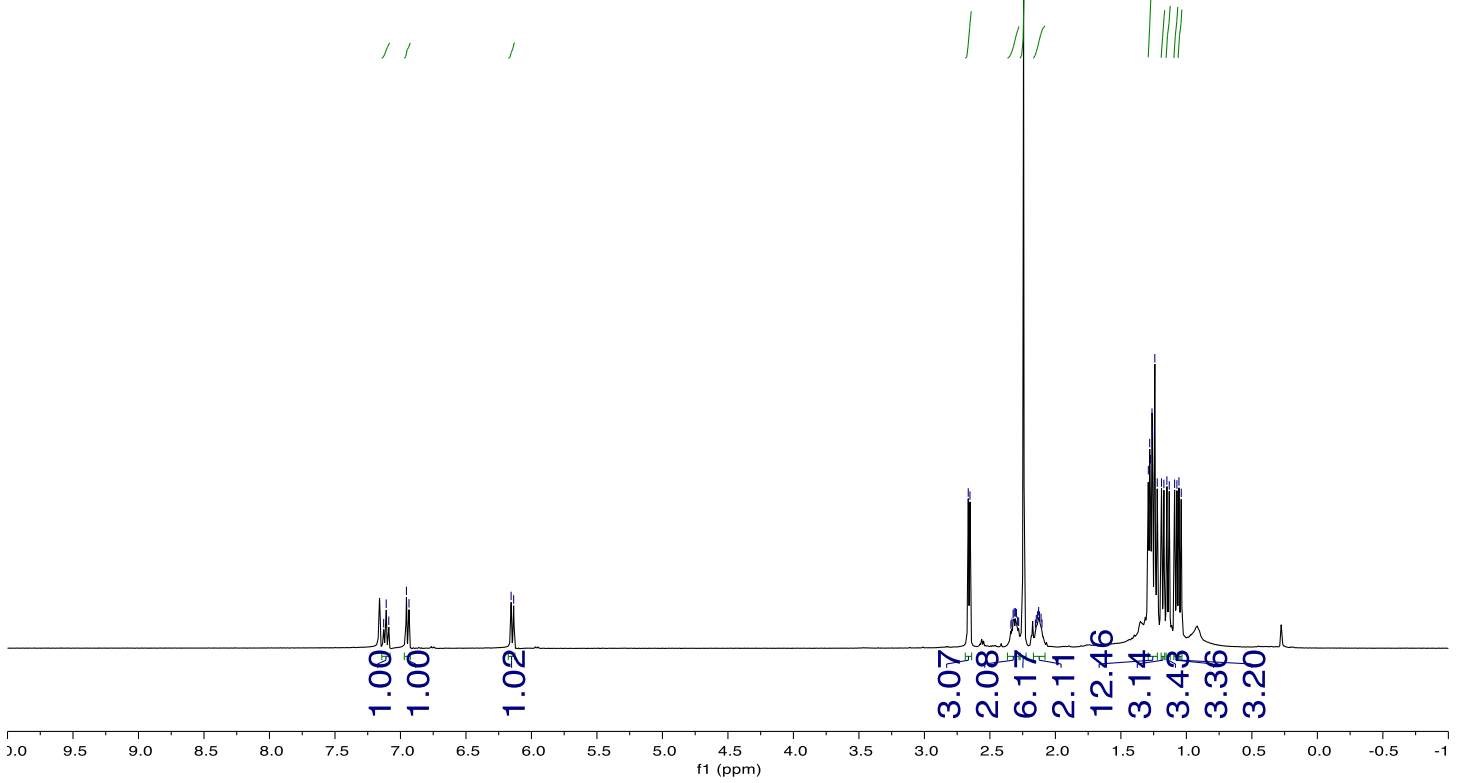

Figure S121. ${ }^{1} \mathrm{H}$ NMR of $4 \mathbf{b}-\mathrm{SMe}_{2}$ in $\mathrm{C}_{6} \mathrm{D}_{6}$.
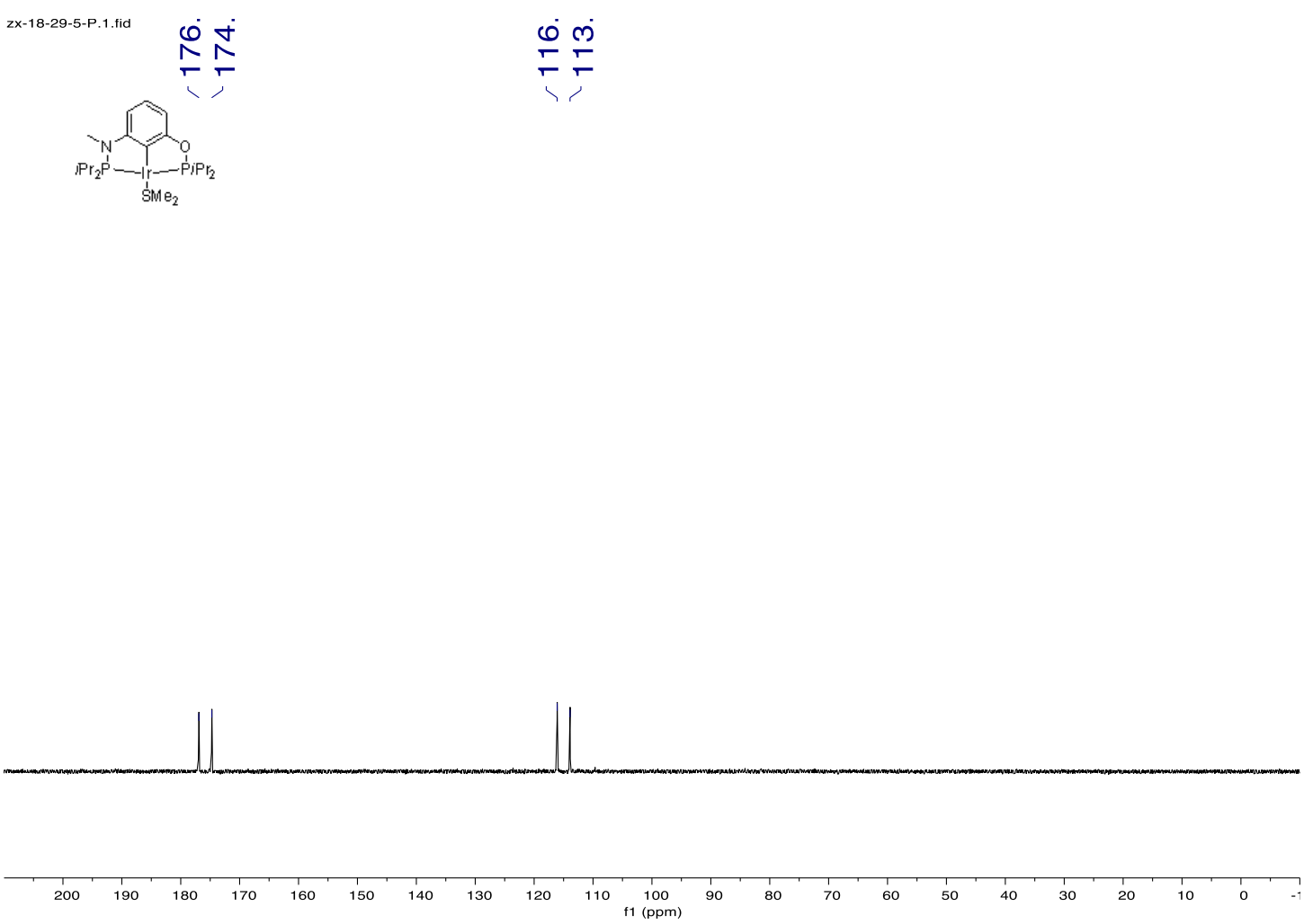

Figure S122. ${ }^{31} \mathrm{P}$ NMR of $4 \mathbf{b}-\mathrm{SMe}_{2}$ in $\mathrm{C}_{6} \mathrm{D}_{6}$. 


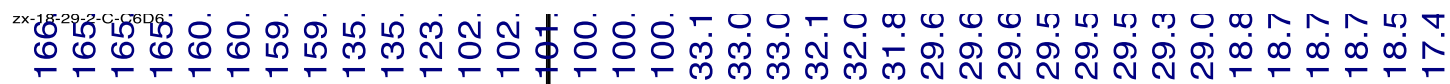
(c)

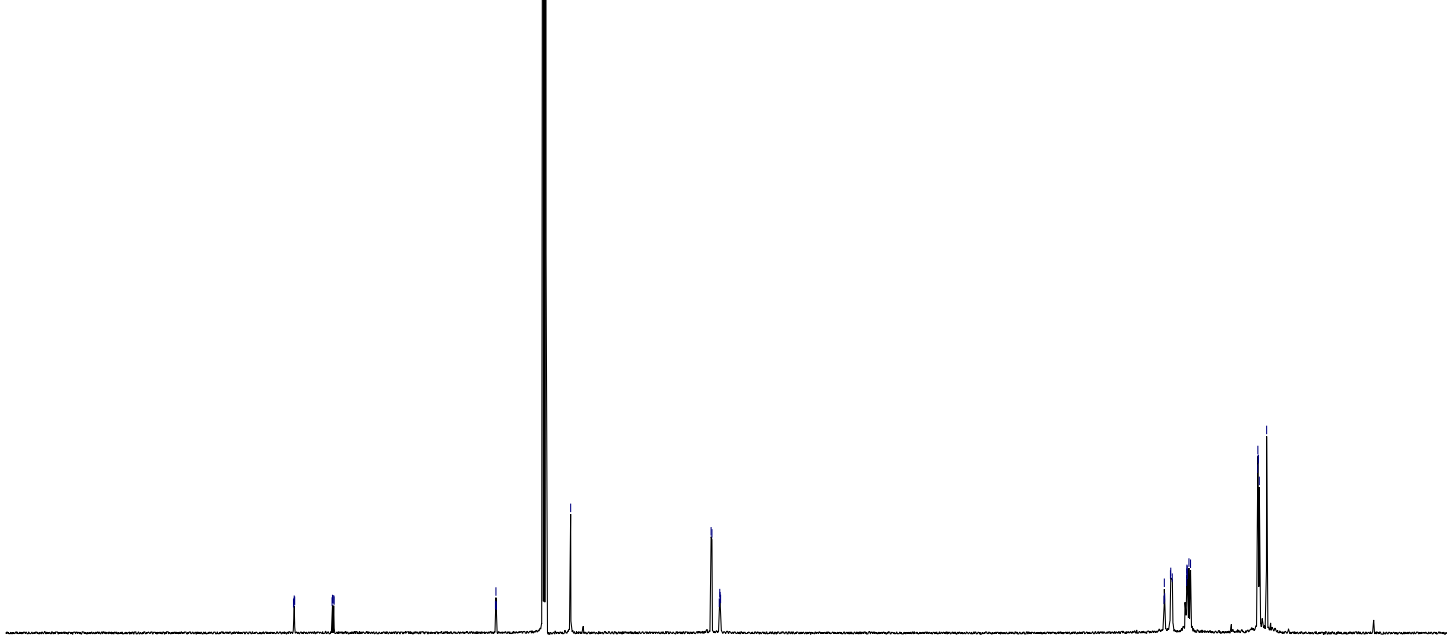

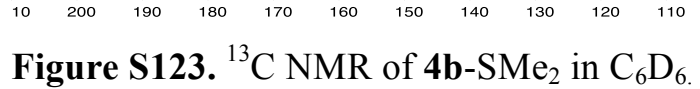

ZX-20-29-1-H-C6D6.1.fid

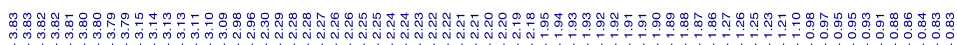
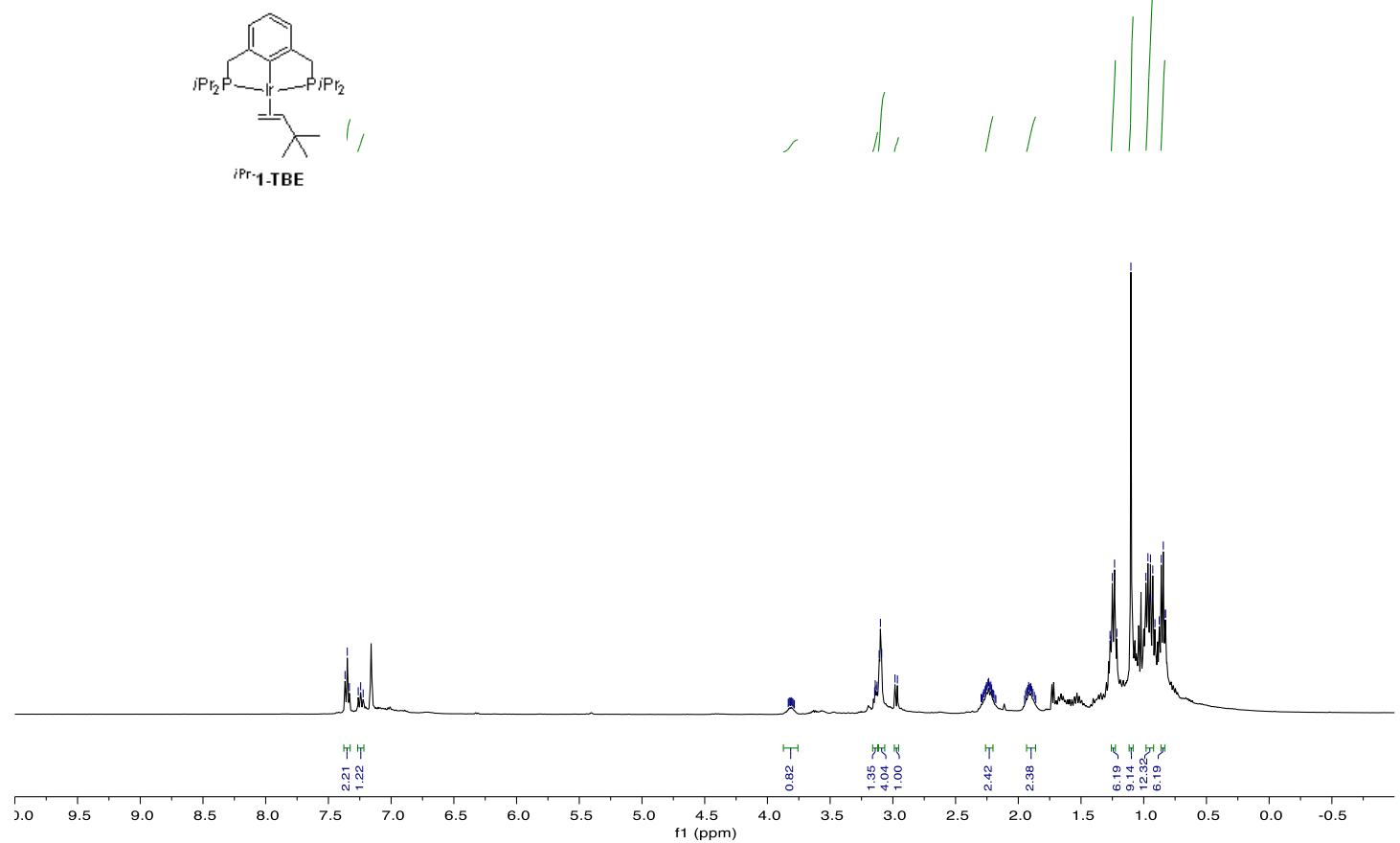

Figure S124. ${ }^{1} \mathrm{H}$ NMR of ${ }^{i \mathrm{Pr}-1}-\mathrm{TBE}$ in $\mathrm{C}_{6} \mathrm{D}_{6}$. 

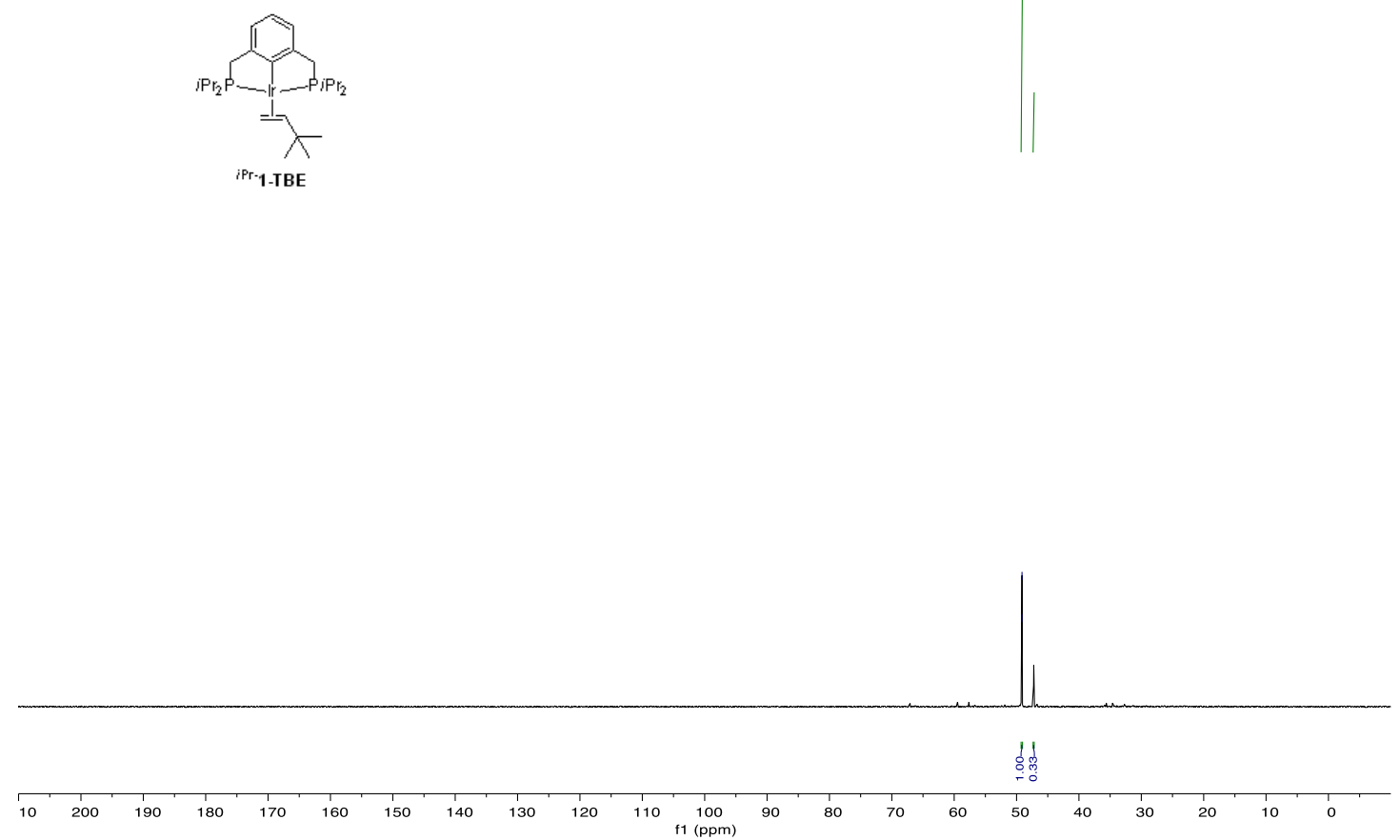

Figure S125. ${ }^{31} \mathrm{P}$ NMR of ${ }^{i \mathrm{Pr}-1}$-TBE in $\mathrm{C}_{6} \mathrm{D}_{6}$, showing small amounts of impurities.

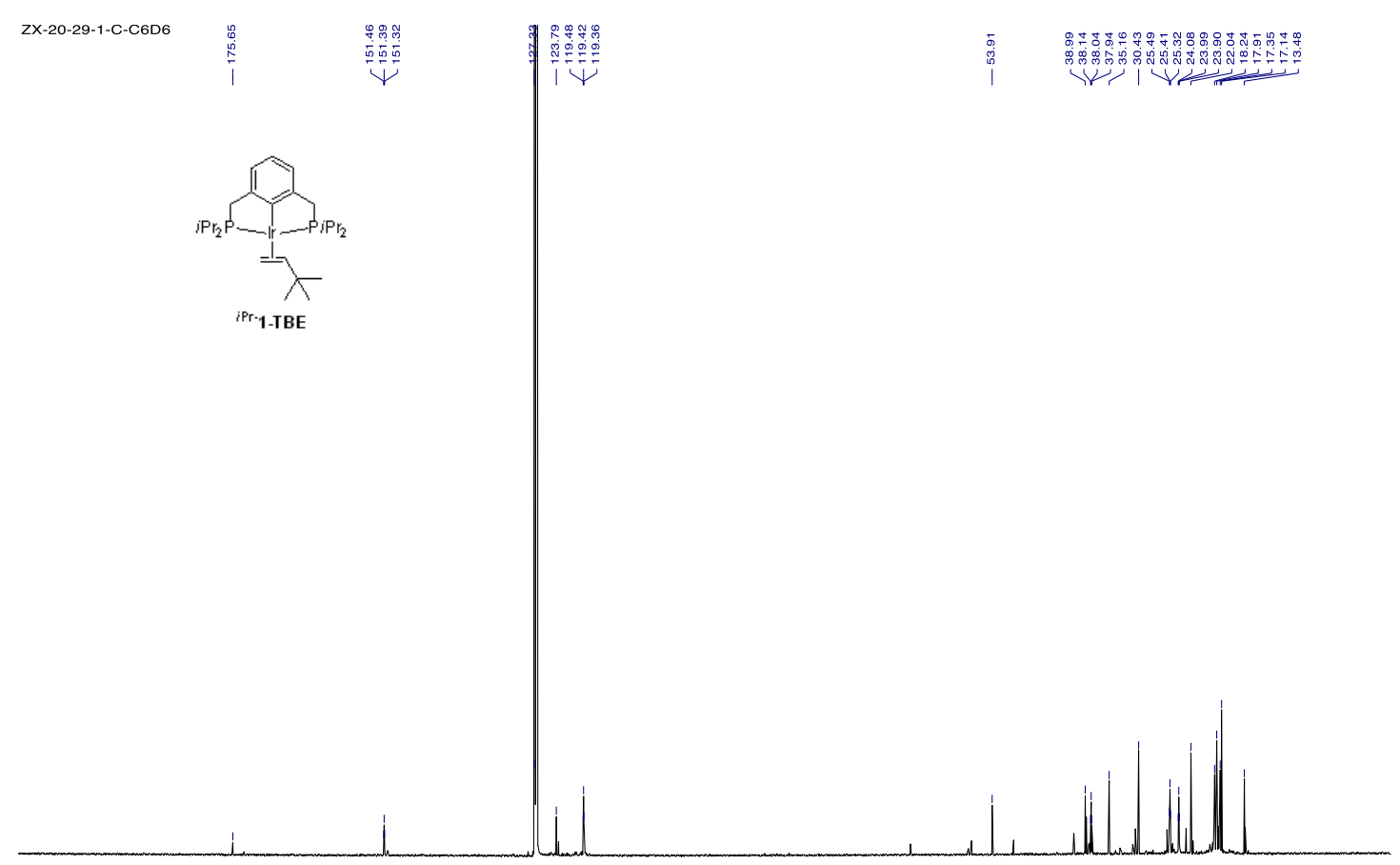

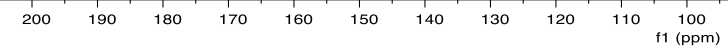

Figure S126. ${ }^{13} \mathrm{C}$ NMR of ${ }^{i \mathrm{Pr}-} \mathbf{1}-\mathrm{TBE}$ in $\mathrm{C}_{6} \mathrm{D}_{6}$. 


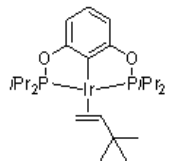

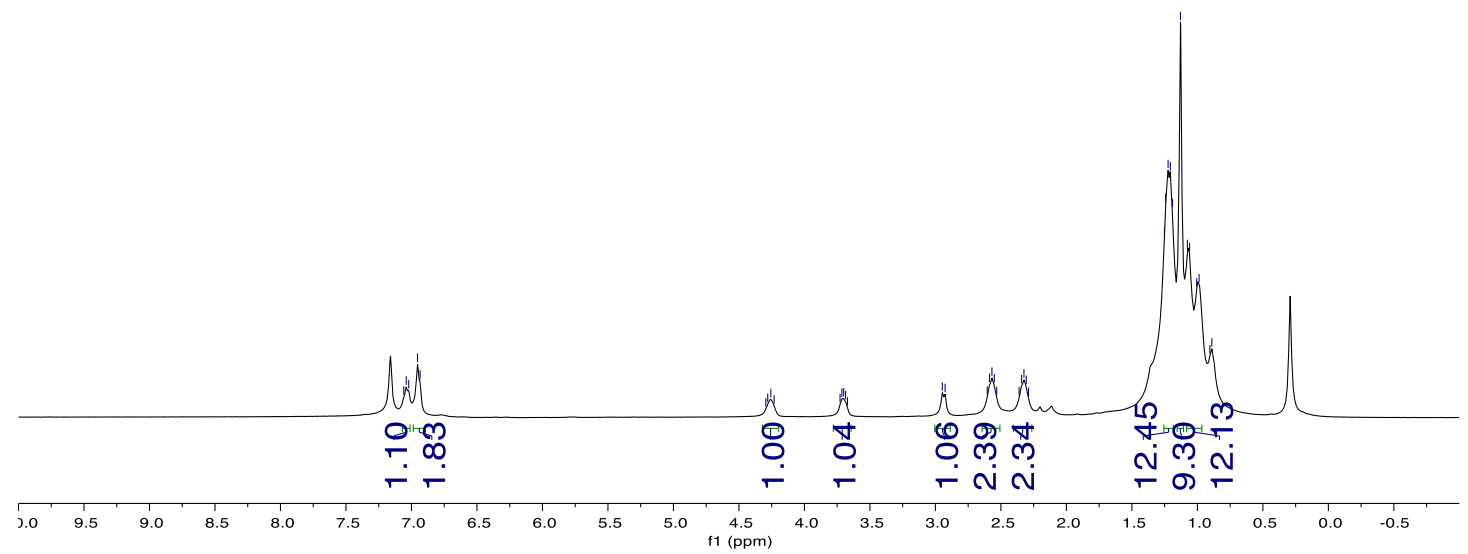

Figure S127. ${ }^{1} \mathrm{H}$ NMR of ${ }^{i \mathrm{Pr}-2}-\mathrm{TBE}$ in $\mathrm{C}_{6} \mathrm{D}_{6}$.

ZX-19-93-1-P-C6D6.1.fid
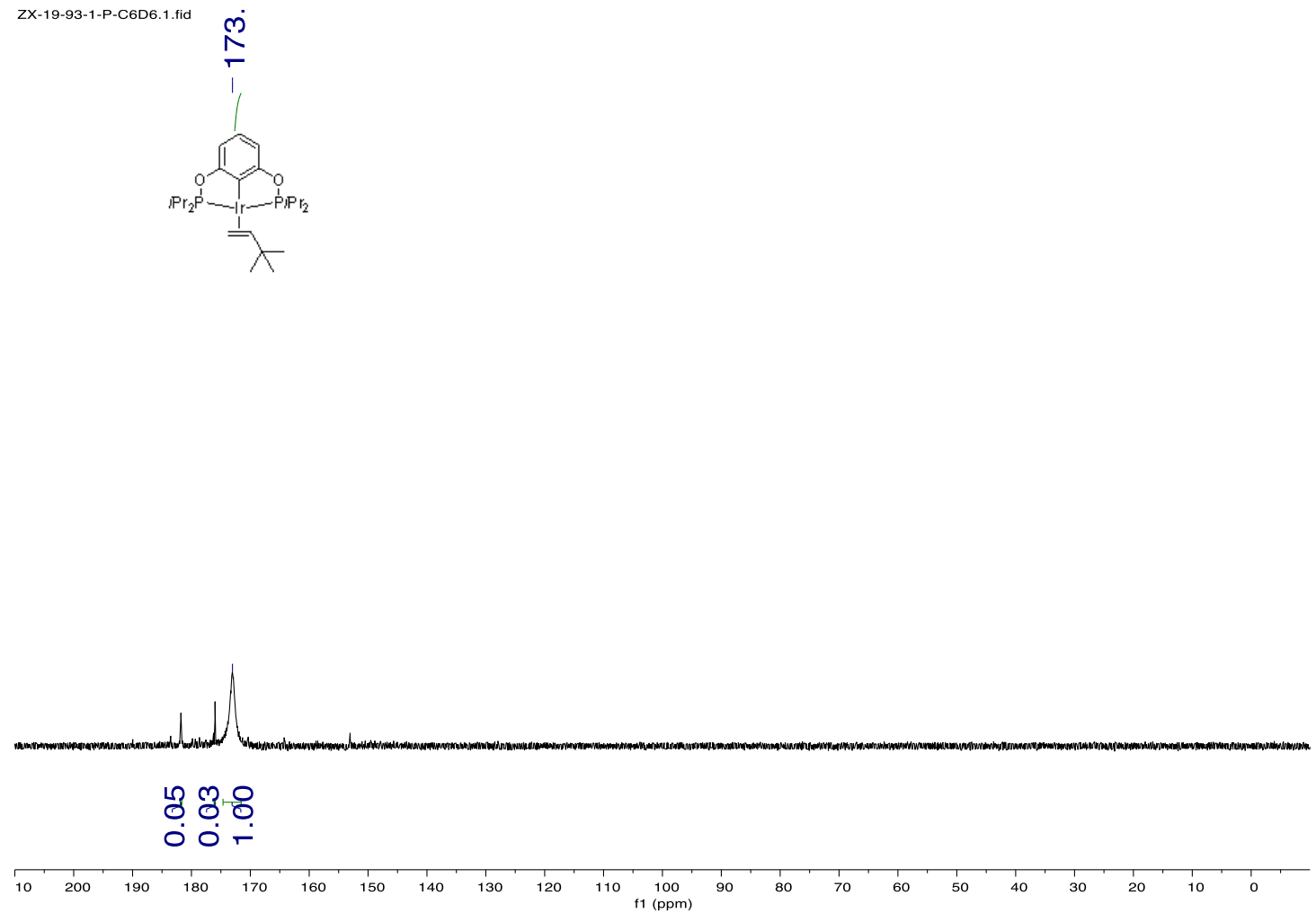

Figure S128. ${ }^{31} \mathrm{P}$ NMR of ${ }^{i \mathrm{Pr}-2}$-TBE in $\mathrm{C}_{6} \mathrm{D}_{6}$, showing small amounts of impurities. 


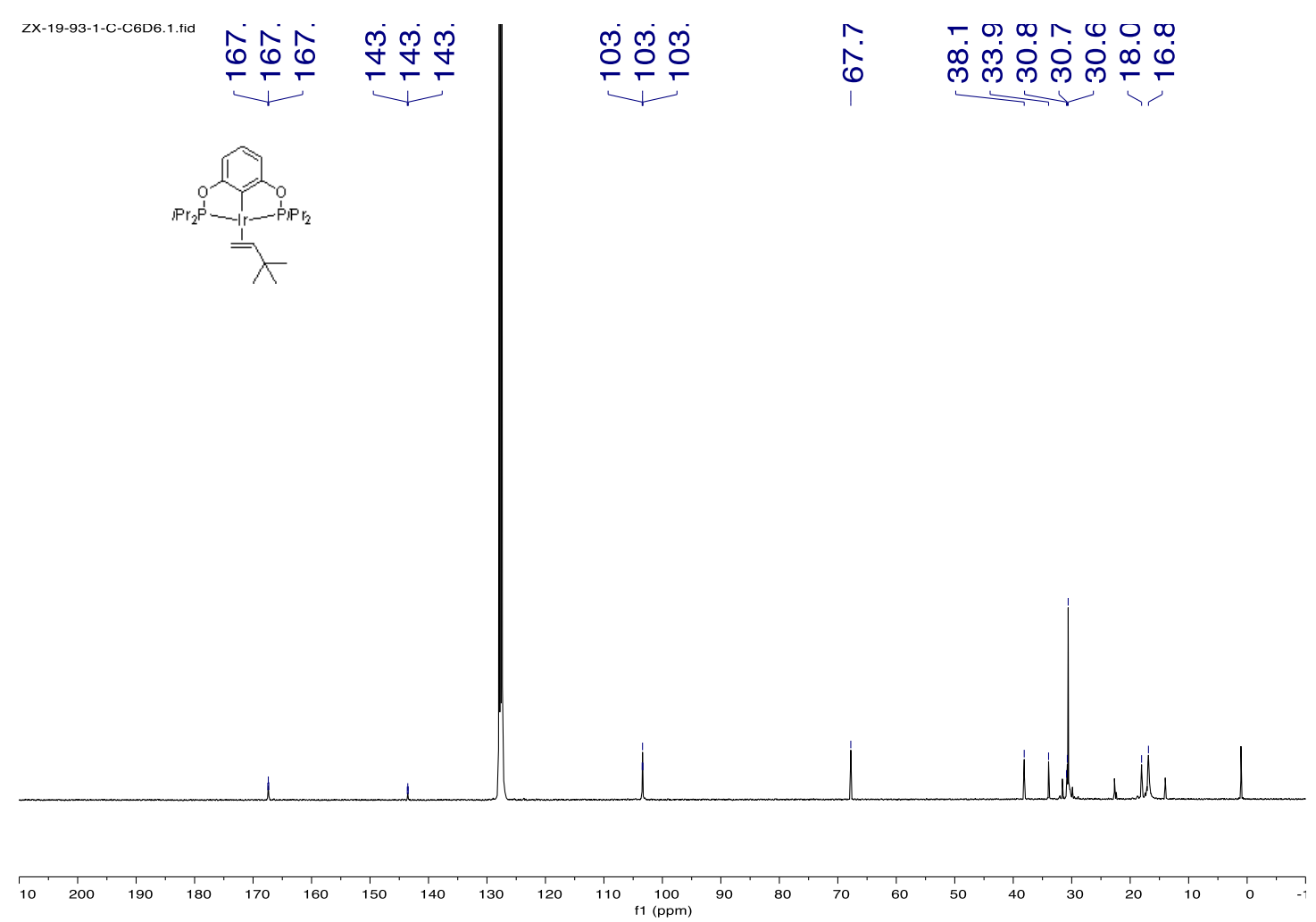

Figure S129. ${ }^{13} \mathrm{C}$ NMR of ${ }^{i P r}-2-\mathrm{TBE}$ in $\mathrm{C}_{6} \mathrm{D}_{6}$.

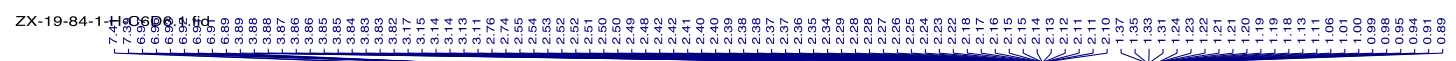
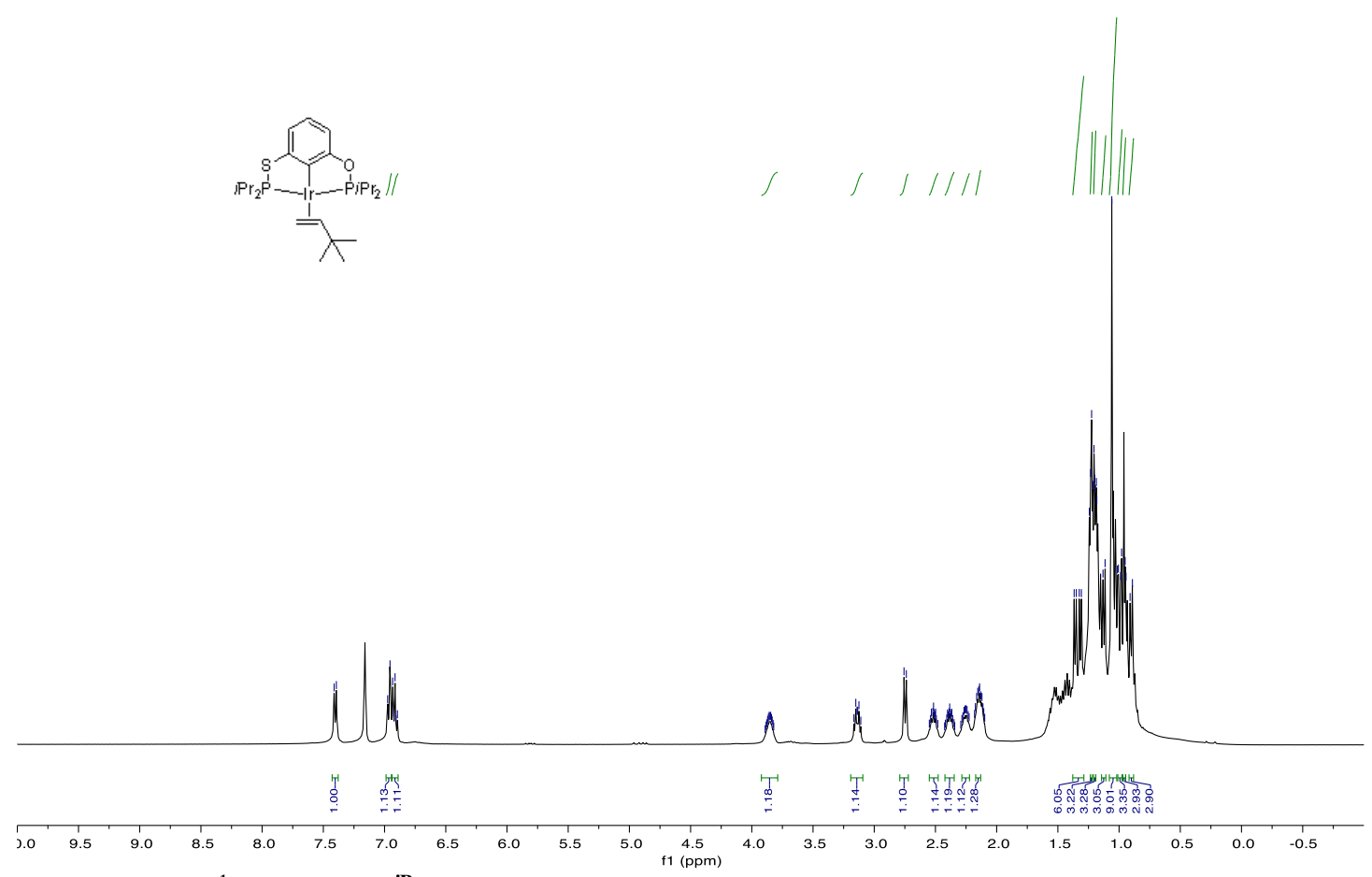

Figure S130. ${ }^{1} \mathrm{H}$ NMR of ${ }^{i \mathrm{Pr}-} 3$-TBE in $\mathrm{C}_{6} \mathrm{D}_{6}$. 


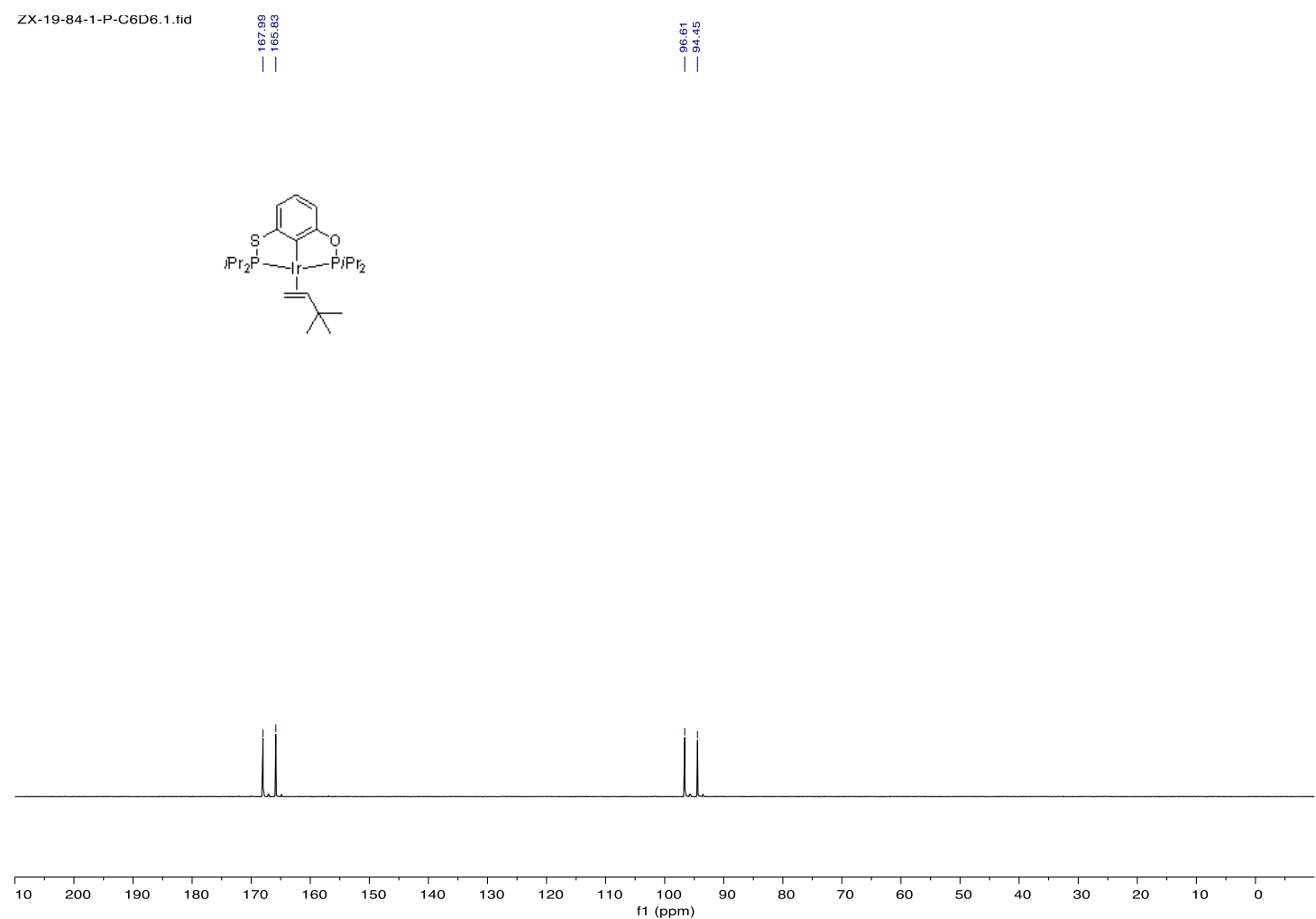

Figure S131. ${ }^{31} \mathrm{P}$ NMR of ${ }^{i \mathrm{Pr}-} 3-\mathrm{TBE}$ in $\mathrm{C}_{6} \mathrm{D}_{6}$, showing the presence of two conformers due to the asymmetric nature of the pincer.

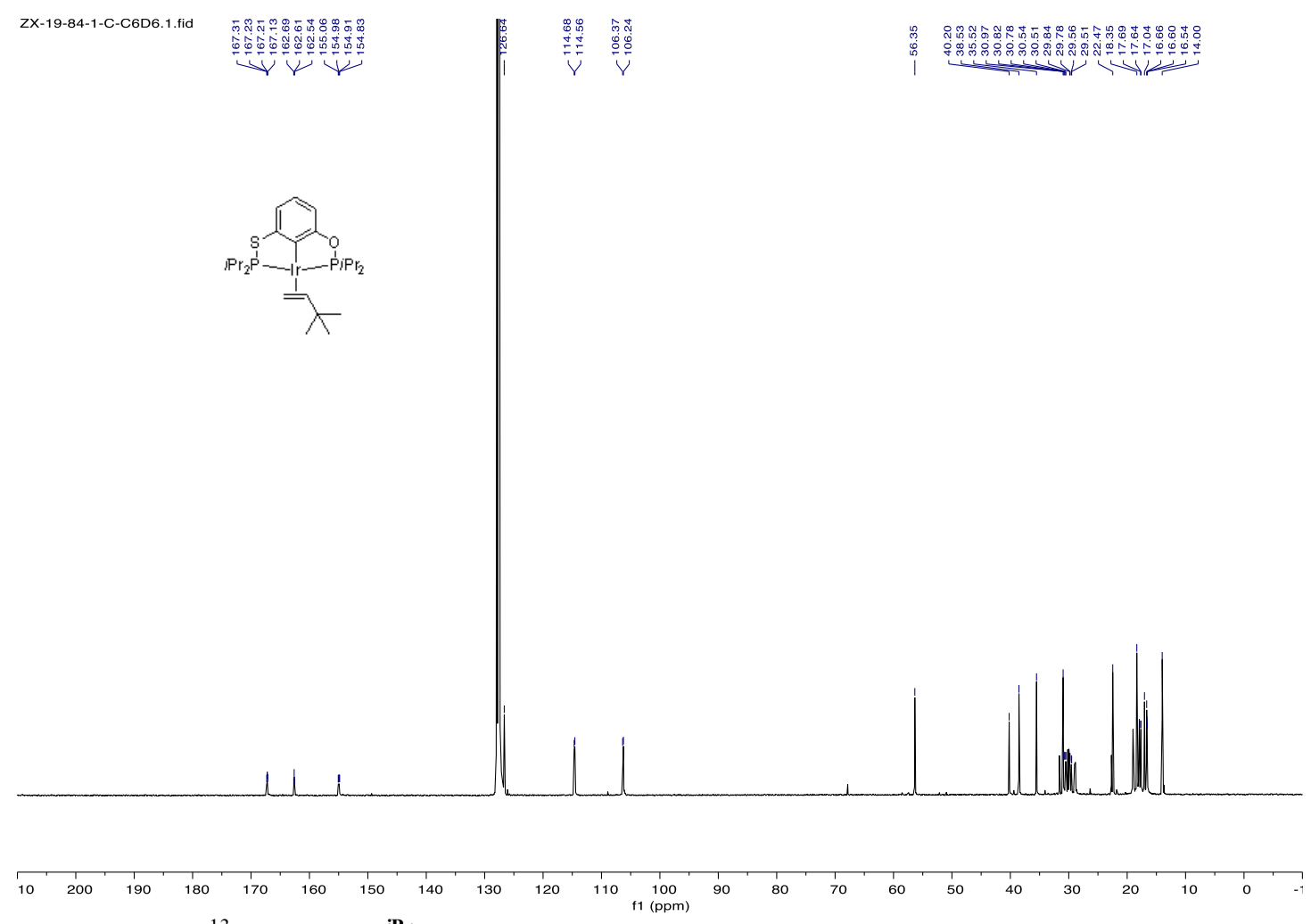

Figure S132. ${ }^{13} \mathrm{C}$ NMR of ${ }^{\text {iPr- }}$ - $-\mathrm{TBE}$ in $\mathrm{C}_{6} \mathrm{D}_{6}$. 


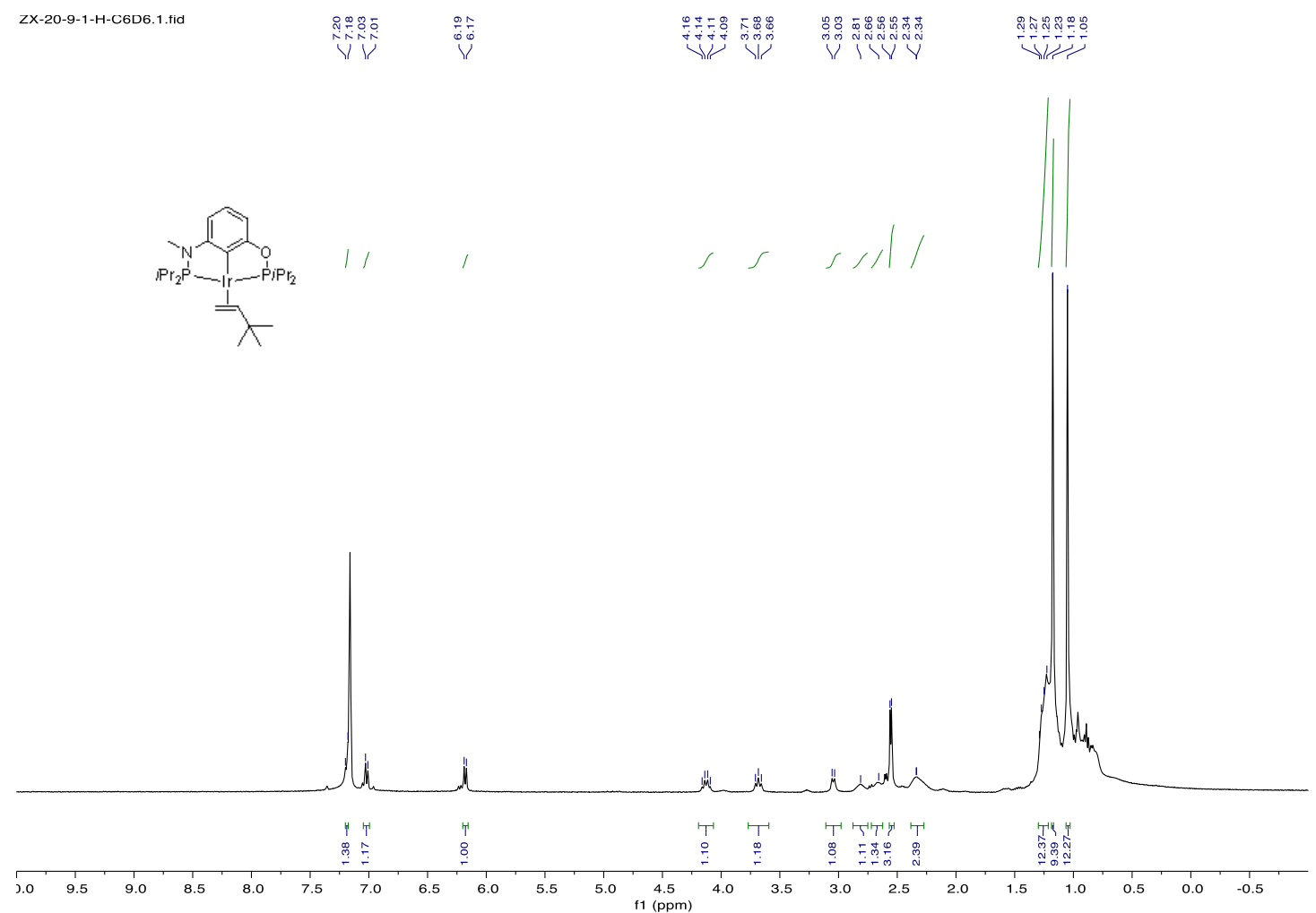

Figure S133. ${ }^{1} \mathrm{H}$ NMR of $4 \mathbf{b}-\mathrm{TBE}$ in $\mathrm{C}_{6} \mathrm{D}_{6}$.

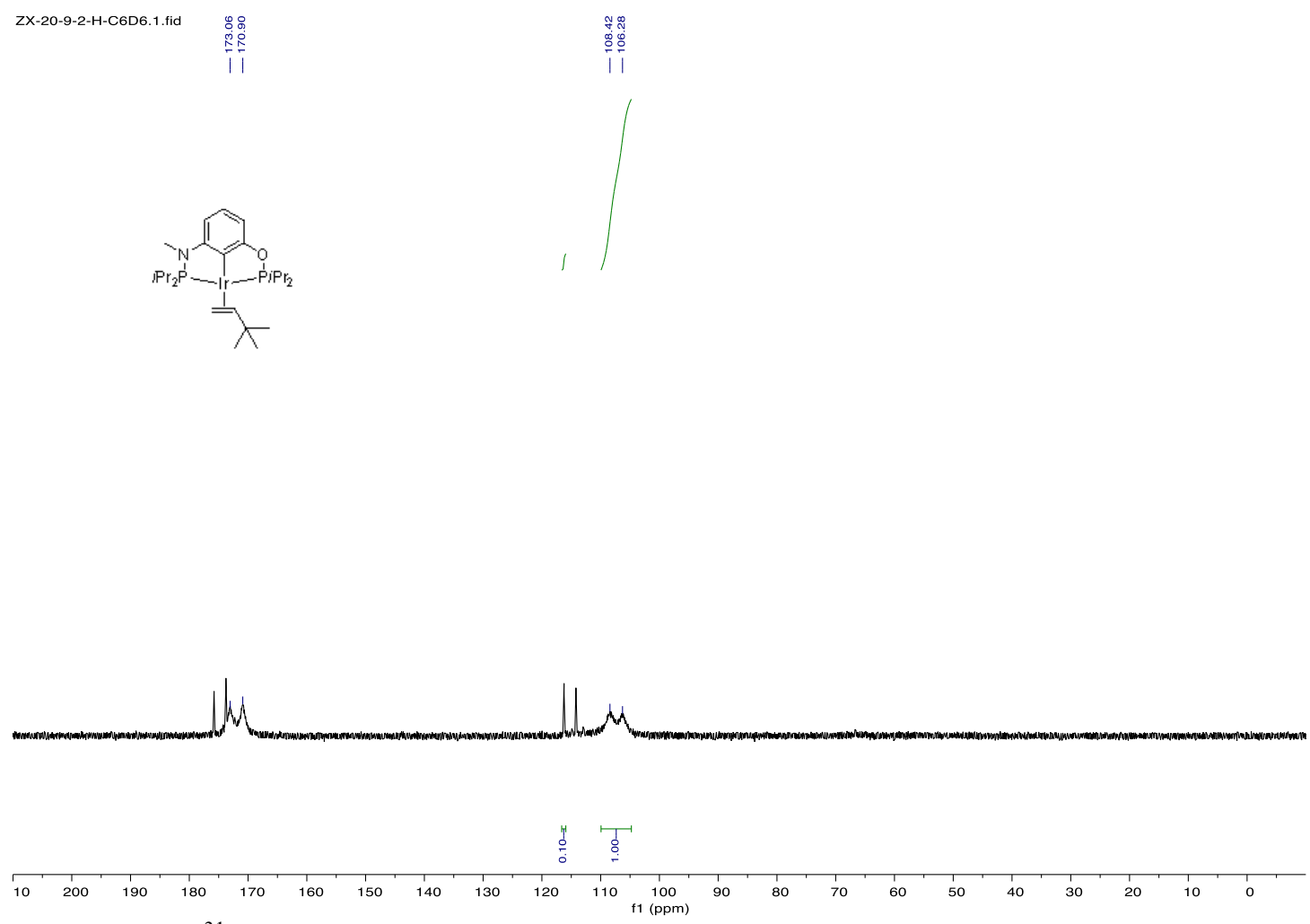

Figure S134. ${ }^{31} \mathrm{P}$ NMR of $4 \mathbf{b}-\mathrm{TBE}$ in $\mathrm{C}_{6} \mathrm{D}_{6}$, showing the presence of two conformers due to the asymmetric nature of the pincer. 


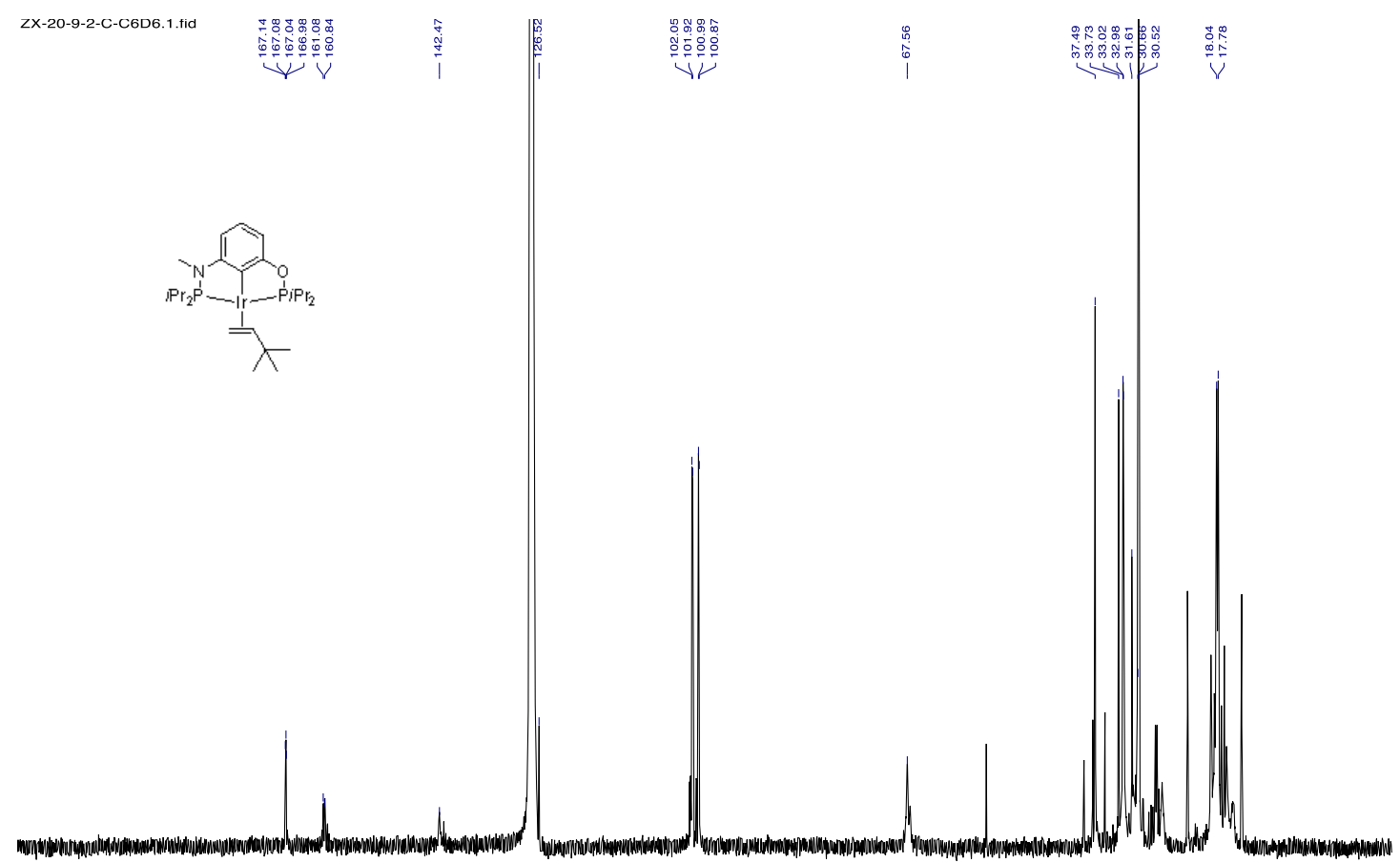

Figure S135. ${ }^{13} \mathrm{C}$ NMR of $\mathbf{4 b}$-TBE in $\mathrm{C}_{6} \mathrm{D}_{6}$ 


\section{X-ray crystallographic data}

Note that all of the structures have been collected on a Gallium Metal-Jet source. Crystals ${ }^{i \mathrm{Pr}-1}$ $\mathrm{CO}$ and ${ }^{i \mathrm{Pr}-2}-\mathrm{SMe}_{2}$ were air sensitive and twinning at low temperature. It was difficult to obtain good reflection data. We also obtained reflections at low temperature, but twinning crystal data could not be separated to be a good enough multi-domain twin to solve the structure. Fortunately, the structure of crystals was not twinning at room temperature and could be determined. It is common to restrain some atoms to make the model more suitable to refine the structures. The large residual electron density peaks appear probably due to poor crystal data or inadequate absorption corrections of iridium. Twin law of crystal i ${ }^{i \mathrm{r}-} 2-\mathrm{SMe}_{2}$ was determined by program Platon. The structures with possible twinning $\left(\mathbf{4 e}-\mathrm{CO},{ }^{\mathrm{iPr}-} \mathbf{5}-\mathrm{CO}\right.$ and $\left.{ }^{\mathrm{iPr}-2}-\mathrm{SMe}_{2}\right)$ were also treated with the program cell_now to determine unit cell with several domains, but failed in integrating and scaling process. As a result, dozens of bad reflections were omitted to obtain a good refinement. 
1. Crystal structures and crystallographic data for complexes $\mathbf{4 a - H C l}$ and ${ }^{t \mathbf{B u}-5-H C l}$.

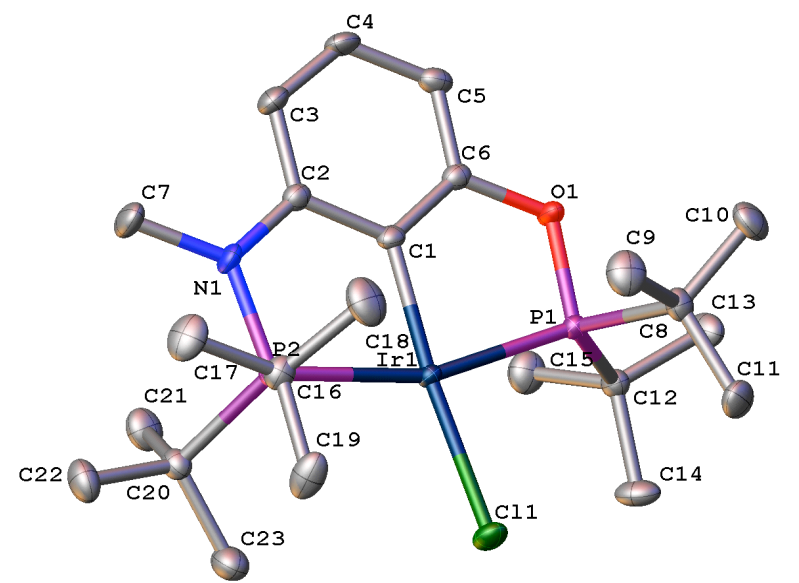

Figure S136. Crystal structure for $\mathbf{4 a - H C l}$.

Table S3. Selected bond length and bond angles for $\mathbf{4 a - H C l}$.

\begin{tabular}{|c|c|c|c|}
\hline Selected bond length & Distance $(\AA)$ & Selected Bond Angles & $(\mathrm{deg})$ \\
\hline $\operatorname{Ir}(1)-\mathrm{P}(1)$ & $2.2842(7)$ & $\mathrm{P}(1)-\operatorname{Ir}(1)-\mathrm{P}(2)$ & $161.87(3)$ \\
\hline $\operatorname{Ir}(1)-\mathrm{P}(2)$ & $2.3196(7)$ & $\mathrm{C}(1)-\operatorname{Ir}(1)-\mathrm{Cl}(1)$ & $174.31(8)$ \\
\hline $\operatorname{Ir}(1)-\mathrm{C}(1)$ & $2.012(3)$ & $\mathrm{C}(1)-\operatorname{Ir}(1)-\mathrm{P}(1)$ & $80.68(9)$ \\
\hline $\mathrm{P}(1)-\mathrm{O}(1)$ & $1.648(2)$ & $\mathrm{C}(1)-\operatorname{Ir}(1)-\mathrm{P}(2)$ & $81.42(9)$ \\
\hline $\mathrm{P}(2)-\mathrm{N}(1)$ & $1.707(2)$ & & \\
\hline
\end{tabular}

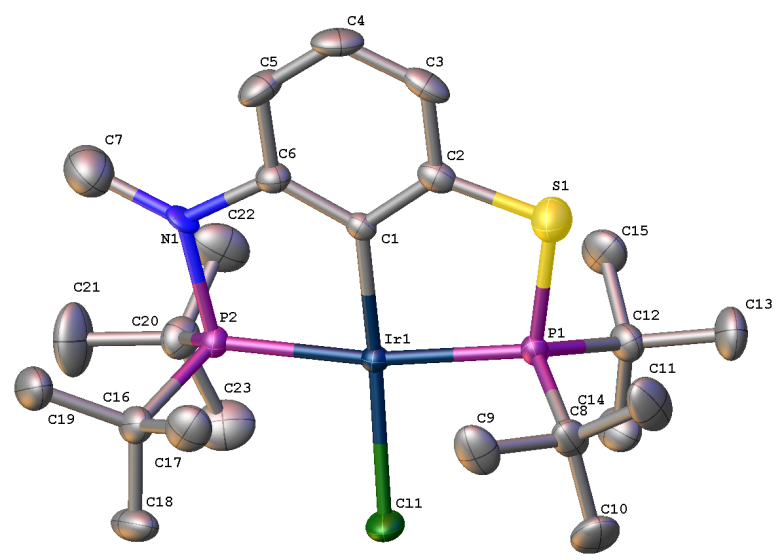

Figure S137. Crystal structure for ${ }^{\mathrm{tBu}-} \mathbf{5}-\mathrm{HCl}$.

Table S4. Selected bond length and bond angles for ${ }^{t \mathrm{Bu}} \mathbf{5}-\mathrm{HCl}$.

\begin{tabular}{|c|c|c|c|}
\hline Selected bond length & Distance $(\AA)$ & Selected Bond Angles & $(\mathrm{deg})$ \\
\hline $\operatorname{Ir}(1)-\mathrm{P}(1)$ & $2.3102(11)$ & $\mathrm{P}(2)-\operatorname{Ir}(1)-\mathrm{P}(1)$ & $170.45(4)$ \\
\hline $\operatorname{Ir}(1)-\mathrm{P}(2)$ & $2.2994(11)$ & $\mathrm{C}(1)-\operatorname{Ir}(1)-\mathrm{Cl}(1)$ & $170.4(2)$ \\
\hline $\operatorname{Ir}(1)-\mathrm{C}(1)$ & $2.026(4)$ & $\mathrm{C}(1)-\operatorname{Ir}(1)-\mathrm{P}(1)$ & $86.26(12)$ \\
\hline $\mathrm{S}(1)-\mathrm{P}(1)$ & $2.098(3)$ & $\mathrm{C}(1)-\operatorname{Ir}(1)-\mathrm{P}(2)$ & $84.20(12)$ \\
\hline $\mathrm{P}(2)-\mathrm{N}(1)$ & $1.695(11)$ & & \\
\hline
\end{tabular}




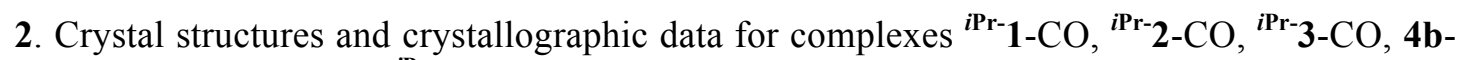

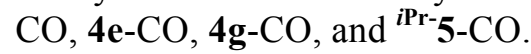

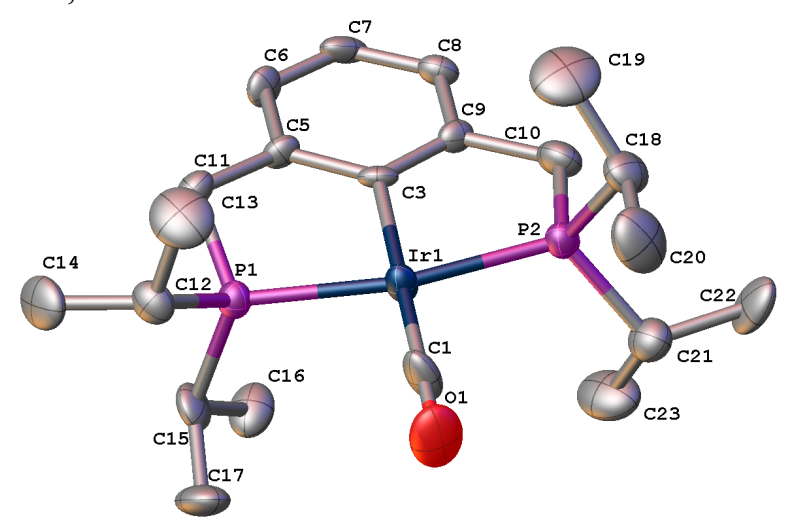

Figure S138. Crystal structure for ${ }^{i \mathrm{Pr}-1}-\mathrm{CO}$.

Table S5. Selected bond length and bond angles for ${ }^{i{ }^{P r}} \mathbf{1}-\mathrm{CO}$.

\begin{tabular}{|c|c|c|c|}
\hline Selected bond length & Distance $(\AA)$ & Selected Bond Angles & $(\mathrm{deg})$ \\
\hline $\operatorname{Ir}(1)-\mathrm{P}(1)$ & $2.280(4)$ & $\mathrm{P}(2)-\operatorname{Ir}(1)-\mathrm{P}(1)$ & $163.87(14)$ \\
\hline $\operatorname{Ir}(1)-\mathrm{P}(2)$ & $2.276(4)$ & $\mathrm{C}(3)-\operatorname{Ir}(1)-\mathrm{C}(1)$ & $179.5(7)$ \\
\hline $\operatorname{Ir}(1)-\mathrm{C}(1)$ & $1.817(18)$ & $\mathrm{C}(3)-\operatorname{Ir}(1)-\mathrm{P}(1)$ & $82.0(4)$ \\
\hline $\operatorname{Ir}(1)-\mathrm{C}(3)$ & $2.086(13)$ & $\mathrm{C}(3)-\operatorname{Ir}(1)-\mathrm{P}(2)$ & $82.1(4)$ \\
\hline $\mathrm{P}(1)-\mathrm{C}(11)$ & $1.833(14)$ & & \\
\hline $\mathrm{P}(2)-\mathrm{C}(10)$ & $1.807(17)$ & & \\
\hline
\end{tabular}

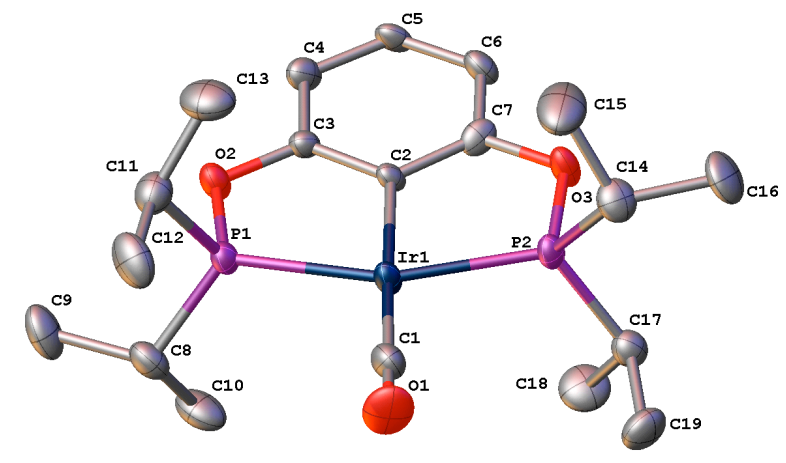

Figure S139. Crystal structure for ${ }^{i P r}-2-C O$.

Table S6. Selected bond length and bond angles for ${ }^{i \mathrm{Pr}-2-\mathrm{CO}}$.

\begin{tabular}{|c|c|c|c|}
\hline Selected bond length & Distance $(\AA)$ & Selected Bond Angles & $(\mathrm{deg})$ \\
\hline $\operatorname{Ir}(1)-\mathrm{P}(1)$ & $2.2700(13)$ & $\mathrm{P}(2)-\operatorname{Ir}(1)-\mathrm{P}(1)$ & $157.82(5)$ \\
\hline $\operatorname{Ir}(1)-\mathrm{P}(2)$ & $2.2563(13)$ & $\mathrm{C}(2)-\operatorname{Ir}(1)-\mathrm{C}(1)$ & $175.7(2)$ \\
\hline $\operatorname{Ir}(1)-\mathrm{C}(1)$ & $1.855(6)$ & $\mathrm{C}(2)-\operatorname{Ir}(1)-\mathrm{P}(1)$ & $79.22(14)$ \\
\hline $\operatorname{Ir}(1)-\mathrm{C}(2)$ & $2.058(5)$ & $\mathrm{C}(2)-\operatorname{Ir}(1)-\mathrm{P}(2)$ & $78.69(14)$ \\
\hline $\mathrm{P}(1)-\mathrm{O}(2)$ & $1.656(4)$ & & \\
\hline $\mathrm{P}(2)-\mathrm{O}(3)$ & $1.650(4)$ & & \\
\hline
\end{tabular}




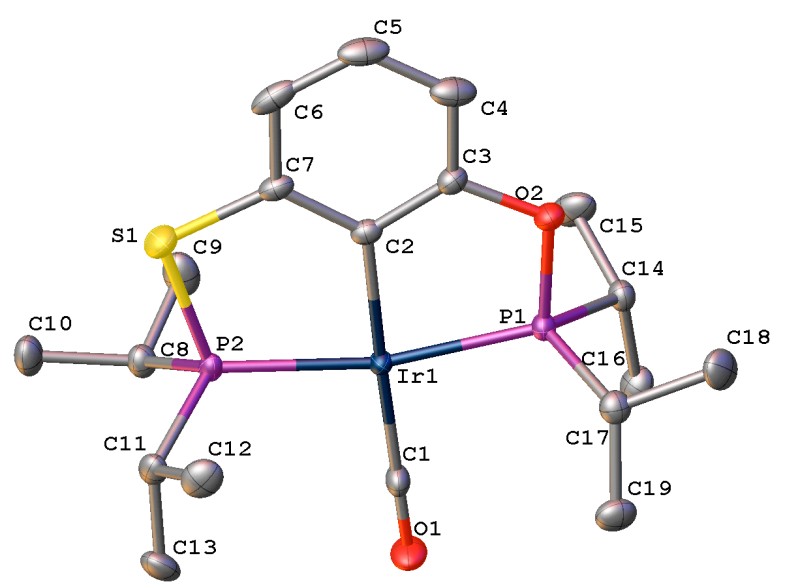

Figure S140. Crystal structure for ${ }^{i \mathrm{Pr}-3-\mathrm{CO} .}$

Table S7. Selected bond length and bond angles for ${ }^{i P r}-3-C O$.

\begin{tabular}{|c|c|c|c|}
\hline Selected bond length & Distance $(\AA)$ & Selected Bond Angles & (deg) \\
\hline $\operatorname{Ir}(1)-\mathrm{P}(1)$ & $2.2556(6)$ & $\mathrm{P}(2)-\operatorname{Ir}(1)-\mathrm{P}(1)$ & $165.52(2)$ \\
\hline $\operatorname{Ir}(1)-\mathrm{P}(2)$ & $2.2792(6)$ & $\mathrm{C}(2)-\operatorname{Ir}(1)-\mathrm{C}(1)$ & $177.8(2)$ \\
\hline $\operatorname{Ir}(1)-\mathrm{C}(1)$ & $1.868(3)$ & $\mathrm{C}(2)-\operatorname{Ir}(1)-\mathrm{P}(1)$ & $80.0(2)$ \\
\hline $\mathrm{Ir}(1)-\mathrm{C}(2)$ & $2.045(8)$ & $\mathrm{C}(2)-\operatorname{Ir}(1)-\mathrm{P}(2)$ & $85.8(2)$ \\
\hline $\mathrm{P}(1)-\mathrm{O}(2)$ & $1.630(3)$ & & \\
\hline $\mathrm{P}(2)-\mathrm{S}(1)$ & $2.1043(12)$ & & \\
\hline
\end{tabular}

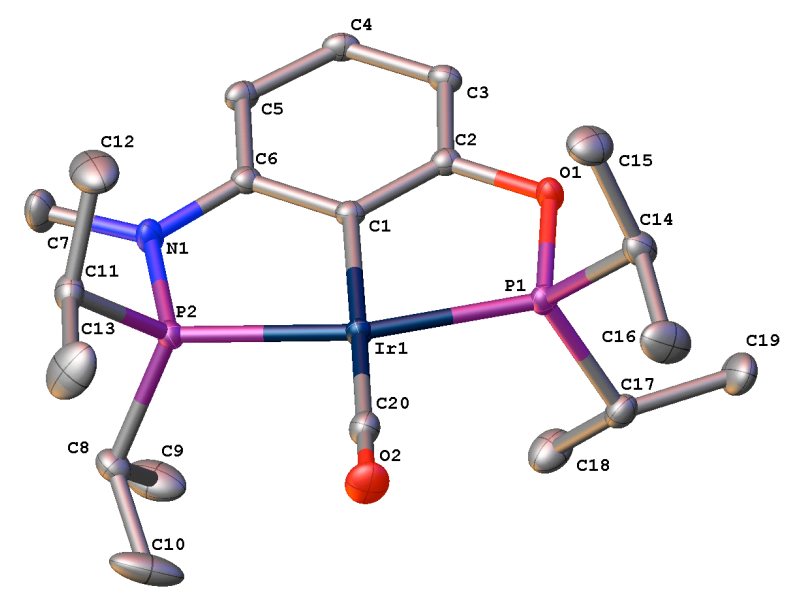

Figure S141. Crystal structure for $4 \mathrm{~b}-\mathrm{CO}$.

Table S8. Selected bond length and bond angles for $\mathbf{4 b}-\mathrm{CO}$.

\begin{tabular}{|c|c|c|c|}
\hline Selected bond length & Distance $(\AA)$ & Selected Bond Angles & $(\mathrm{deg})$ \\
\hline $\operatorname{Ir}(1)-\mathrm{P}(1)$ & $2.2619(6)$ & $\mathrm{P}(2)-\operatorname{Ir}(1)-\mathrm{P}(1)$ & $158.02(2)$ \\
\hline $\operatorname{Ir}(1)-\mathrm{P}(2)$ & $2.2777(6)$ & $\mathrm{C}(1)-\operatorname{Ir}(1)-\mathrm{C}(20)$ & $174.32(10)$ \\
\hline $\operatorname{Ir}(1)-\mathrm{C}(1)$ & $2.060(2)$ & $\mathrm{C}(1)-\operatorname{Ir}(1)-\mathrm{P}(1)$ & $78.95(7)$ \\
\hline $\operatorname{Ir}(1)-\mathrm{C}(20)$ & $1.873(3)$ & $\mathrm{C}(1)-\operatorname{Ir}(1)-\mathrm{P}(2)$ & $80.26(7)$ \\
\hline $\mathrm{P}(1)-\mathrm{O}(1)$ & $1.6499(18)$ & & \\
\hline $\mathrm{P}(2)-\mathrm{N}(1)$ & $1.696(2)$ & & \\
\hline
\end{tabular}




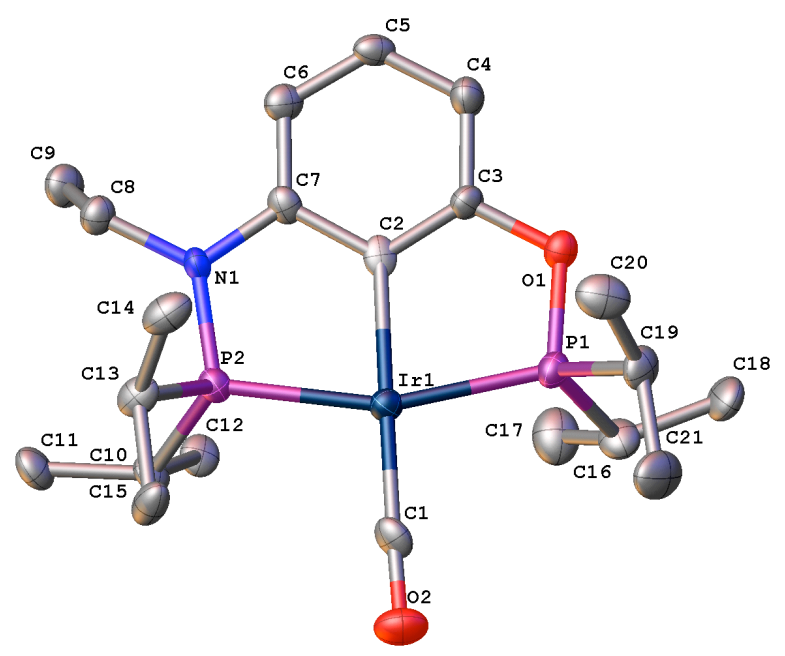

Figure S142. Crystal structure for $4 \mathrm{e}-\mathrm{CO}$.

Table S9. Selected bond length and bond angles for $4 \mathrm{e}-\mathrm{CO}$.

\begin{tabular}{|c|c|c|c|}
\hline Selected bond length & Distance $(\AA)$ & Selected Bond Angles & $(\mathrm{deg})$ \\
\hline $\operatorname{Ir}(1)-\mathrm{P}(1)$ & $2.264(3)$ & $\mathrm{P}(2)-\operatorname{Ir}(1)-\mathrm{P}(1)$ & $159.30(12)$ \\
\hline $\operatorname{Ir}(1)-\mathrm{P}(2)$ & $2.277(3)$ & $\mathrm{C}(2)-\operatorname{Ir}(1)-\mathrm{C}(1)$ & $178.5(6)$ \\
\hline $\operatorname{Ir}(1)-\mathrm{C}(1)$ & $1.823(14)$ & $\mathrm{C}(2)-\operatorname{Ir}(1)-\mathrm{P}(1)$ & $79.0(3)$ \\
\hline $\operatorname{Ir}(1)-\mathrm{C}(2)$ & $2.054(13)$ & $\mathrm{C}(2)-\operatorname{Ir}(1)-\mathrm{P}(2)$ & $80.6(3)$ \\
\hline $\mathrm{P}(1)-\mathrm{O}(1)$ & $1.650(9)$ & & \\
\hline $\mathrm{P}(2)-\mathrm{N}(1)$ & $1.687(10)$ & & \\
\hline
\end{tabular}

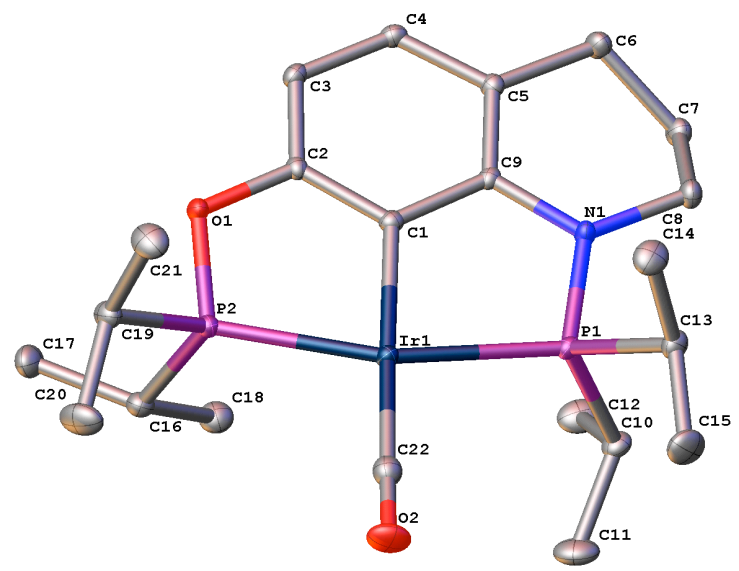

Figure S143. Crystal structure for $\mathbf{4 g - C O}$.

Table S10. Selected bond length and bond angles for 4g-CO.

\begin{tabular}{|c|c|c|c|}
\hline Selected bond length & Distance $(\AA)$ & Selected Bond Angles & $(\mathrm{deg})$ \\
\hline $\operatorname{Ir}(1)-\mathrm{P}(1)$ & $2.2828(6)$ & $\mathrm{P}(2)-\operatorname{Ir}(1)-\mathrm{P}(1)$ & $156.60(2)$ \\
\hline $\operatorname{Ir}(1)-\mathrm{P}(2)$ & $2.2658(6)$ & $\mathrm{C}(1)-\operatorname{Ir}(1)-\mathrm{C}(22)$ & $173.94(10)$ \\
\hline $\operatorname{Ir}(1)-\mathrm{C}(1)$ & $2.065(2)$ & $\mathrm{C}(1)-\operatorname{Ir}(1)-\mathrm{P}(1)$ & $80.00(6)$ \\
\hline $\operatorname{Ir}(1)-\mathrm{C}(22)$ & $1.877(3)$ & $\mathrm{C}(1)-\operatorname{Ir}(1)-\mathrm{P}(2)$ & $78.86(6)$ \\
\hline $\mathrm{P}(2)-\mathrm{O}(1)$ & $1.6522(16)$ & & \\
\hline $\mathrm{P}(1)-\mathrm{N}(1)$ & $1.694(2)$ & & \\
\hline
\end{tabular}




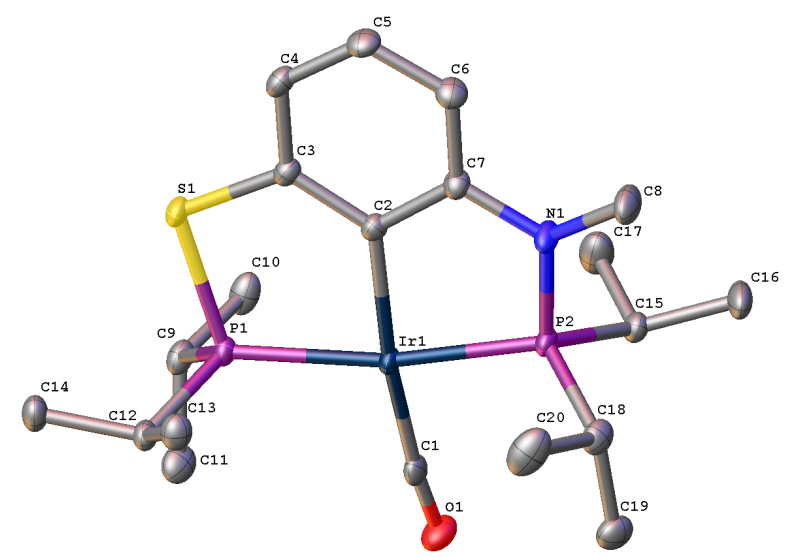

Figure S144. Crystal structure for ${ }^{i \mathrm{Pr}-}$ 5-CO.

Table S11. Selected bond length and bond angles for ${ }^{i{ }^{2}-5}-\mathrm{CO}$.

\begin{tabular}{|c|c|c|c|}
\hline Selected bond length & Distance $(\AA)$ & Selected Bond Angles & $(\mathrm{deg})$ \\
\hline $\operatorname{Ir}(1)-\mathrm{P}(1)$ & $2.2763(15)$ & $\mathrm{P}(2)-\operatorname{Ir}(1)-\mathrm{P}(1)$ & $167.68(6)$ \\
\hline $\operatorname{Ir}(1)-\mathrm{P}(2)$ & $2.2641(15)$ & $\mathrm{C}(2)-\operatorname{Ir}(1)-\mathrm{C}(1)$ & $171.2(3)$ \\
\hline $\operatorname{Ir}(1)-\mathrm{C}(1)$ & $1.858(7)$ & $\mathrm{C}(2)-\operatorname{Ir}(1)-\mathrm{P}(1)$ & $86.51(18)$ \\
\hline $\operatorname{Ir}(1)-\mathrm{C}(2)$ & $2.072(6)$ & $\mathrm{C}(2)-\operatorname{Ir}(1)-\mathrm{P}(2)$ & $81.36(18)$ \\
\hline $\mathrm{P}(2)-\mathrm{N}(1)$ & $1.692(5)$ & & \\
\hline $\mathrm{P}(1)-\mathrm{S}(1)$ & $2.109(2)$ & & \\
\hline
\end{tabular}


3. Crystal structures and crystallographic data for iridium complexes ${ }^{i \mathbf{P r}-\mathbf{2}}$-(perpendicular-COE) and ${ }^{i \mathrm{Pr}-2}-\mathrm{SMe}_{2}$.

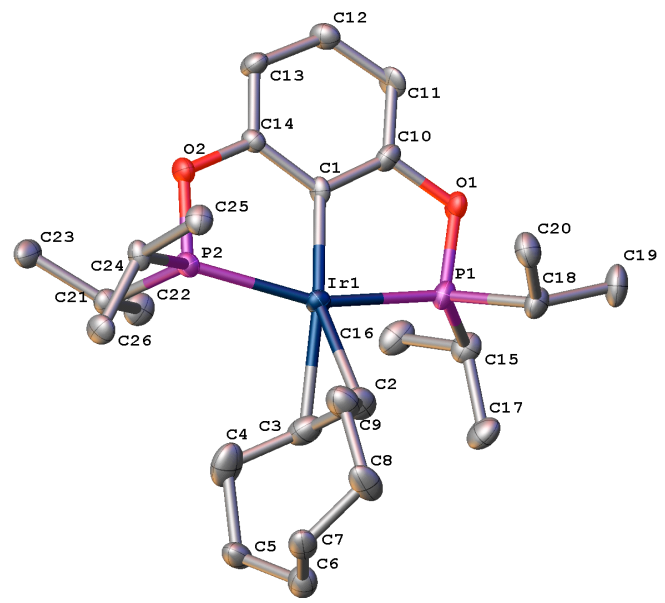

Figure S145. Crystal structure for ${ }^{i P r} \mathbf{2}$-(perpendicular-COE).

Table S12. Selected bond length and bond angles for ${ }^{i \mathrm{Pr}-2}$-(perpendicular-COE).

\begin{tabular}{|c|c|c|c|}
\hline Selected bond length & Distance $(\AA)$ & Selected Bond Angles & $(\mathrm{deg})$ \\
\hline $\mathrm{Ir}(1)-\mathrm{P}(1)$ & $2.256(2)$ & $\mathrm{P}(2)-\operatorname{Ir}(1)-\mathrm{P}(1)$ & $157.43(8)$ \\
\hline $\mathrm{Ir}(1)-\mathrm{P}(2)$ & $2.284(2)$ & $\mathrm{C}(1)-\operatorname{Ir}(1)-\mathrm{C}(2)$ & $156.6(4)$ \\
\hline $\operatorname{Ir}(1)-\mathrm{C}(1)$ & $2.036(8)$ & $\mathrm{C}(1)-\operatorname{Ir}(1)-\mathrm{C}(3)$ & $163.7(4)$ \\
\hline $\mathrm{Ir}(1)-\mathrm{C}(2)$ & $2.186(10)$ & $\mathrm{C}(1)-\operatorname{Ir}(1)-\mathrm{P}(1)$ & $79.0(2)$ \\
\hline $\mathrm{Ir}(1)-\mathrm{C}(3)$ & $2.229(11)$ & $\mathrm{C}(1)-\operatorname{Ir}(1)-\mathrm{P}(2)$ & $79.0(2)$ \\
\hline $\mathrm{P}(1)-\mathrm{O}(1)$ & $1.651(7)$ & & \\
\hline $\mathrm{P}(2)-\mathrm{O}(2)$ & $1.667(6)$ & & \\
\hline
\end{tabular}

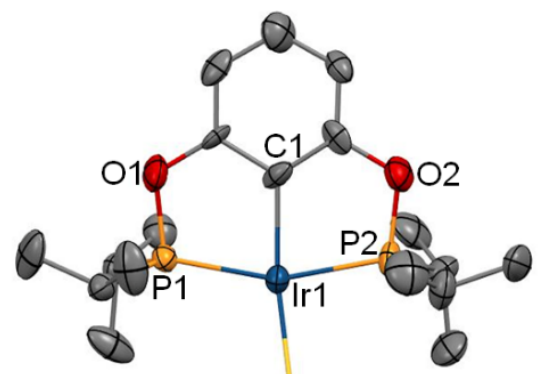

S1

Figure S146. Crystal structure for ${ }^{\mathrm{iPr}-2}-\mathrm{SMe}_{2}$.

Table S13. Selected bond length and bond angles for ${ }^{\mathrm{iPr}-2}-\mathrm{SMe}_{2}$.

\begin{tabular}{|c|c|c|c|}
\hline Selected bond length & Distance $(\AA)$ & Selected Bond Angles & $(\mathrm{deg})$ \\
\hline $\operatorname{Ir}(1)-\mathrm{S}(1)$ & $2.388(7)$ & $\mathrm{P}(2)-\operatorname{Ir}(1)-\mathrm{P}(1)$ & $158.5(2)$ \\
\hline $\operatorname{Ir}(1)-\mathrm{P}(1)$ & $2.263(8)$ & $\mathrm{C}(1)-\operatorname{Ir}(1)-\mathrm{S}(1)$ & $171.4(7)$ \\
\hline $\operatorname{Ir}(1)-\mathrm{P}(2)$ & $2.265(7)$ & $\mathrm{C}(1)-\operatorname{Ir}(1)-\mathrm{P}(1)$ & $78.8(8)$ \\
\hline $\mathrm{Ir}(1)-\mathrm{C}(1)$ & $2.06(2)$ & $\mathrm{C}(1)-\operatorname{Ir}(1)-\mathrm{P}(2)$ & $79.9(9)$ \\
\hline $\mathrm{P}(1)-\mathrm{O}(1)$ & $1.699(17)$ & & \\
\hline $\mathrm{P}(2)-\mathrm{O}(2)$ & $1.678(17)$ & & \\
\hline
\end{tabular}


Table S14. Crystal data and structure refinement for $\mathbf{4 a}-\mathrm{HCl}$.

Identification code

Empirical formula

Formula weight

Temperature

Wavelength

Crystal system

Space group

Unit cell dimensions

Volume

$\mathrm{Z}$

Density (calculated)

Absorption coefficient

$\mathrm{F}(000)$

Crystal size

Theta range for data collection

Index ranges

Reflections collected

Independent reflections

Completeness to theta $=53.594^{\circ}$

Absorption correction

Max. and min. transmission

Refinement method

Data / restraints / parameters

Goodness-of-fit on $\mathrm{F}^{2}$

Final $\mathrm{R}$ indices [I $>2 \operatorname{sigma}(\mathrm{I})]$

$\mathrm{R}$ indices (all data)

Extinction coefficient

Largest diff. peak and hole 4a- $\mathrm{HCl}$

C23 H43 Cl Ir N O P2

639.17

$170.0 \mathrm{~K}$

$1.34139 \AA$

Monoclinic

C $12 / \mathrm{c} 1$

$\mathrm{a}=31.9259(6) \AA$

$\alpha=90^{\circ}$.

$\mathrm{b}=7.9828(2) \AA$

$\beta=100.6140(10)^{\circ}$.

$\mathrm{c}=20.1715(4) \AA$

$\gamma=90^{\circ}$.
8

$1.680 \mathrm{Mg} / \mathrm{m}^{3}$

$8.585 \mathrm{~mm}^{-1}$

2560

$0.08 \times 0.05 \times 0.03 \mathrm{~mm}^{3}$

4.190 to $54.911^{\circ}$.

$-38<=\mathrm{h}<=38,-8<=\mathrm{k}<=9,-24<=1<=24$

26956

$4804[\mathrm{R}(\mathrm{int})=0.0468]$

$99.9 \%$

Semi-empirical from equivalents

0.7508 and 0.3905

Full-matrix least-squares on $\mathrm{F}^{2}$

4804 / 0 / 279

1.107

$\mathrm{R} 1=0.0219, \mathrm{wR} 2=0.0446$

$\mathrm{R} 1=0.0258, \mathrm{wR} 2=0.0460$

$\mathrm{n} / \mathrm{a}$

0.764 and -0.741 e. $\AA^{-3}$ 
Table S15. Crystal data and structure refinement for ${ }^{t \mathrm{Bu}} \mathbf{5}-\mathrm{HCl}$.

Identification code

Empirical formula

Formula weight

Temperature

Wavelength

Crystal system

Space group

Unit cell dimensions

Volume

Z

Density (calculated)

Absorption coefficient

$\mathrm{F}(000)$

Crystal size

Theta range for data collection

Index ranges

Reflections collected

Independent reflections

Completeness to theta $=53.594^{\circ}$

Absorption correction

Max. and min. transmission

Refinement method

Data / restraints / parameters

Goodness-of-fit on $\mathrm{F}^{2}$

Final $\mathrm{R}$ indices [I $>2 \operatorname{sigma}(\mathrm{I})]$

$\mathrm{R}$ indices (all data)

Extinction coefficient

Largest diff. peak and hole
${ }^{t \mathbf{B u}} \mathbf{5}-\mathrm{HCl}$

C23 H43 Cl Ir N P2 S

655.23

$170.0 \mathrm{~K}$

$1.34139 \AA$

Orthorhombic

Pbca

$\begin{array}{ll}\mathrm{a}=12.2672(2) \AA & \alpha=90^{\circ} . \\ \mathrm{b}=15.0400(3) \AA & \beta=90^{\circ} . \\ \mathrm{c}=28.7115(6) \AA & \gamma=90^{\circ} .\end{array}$

$5297.23(18) \AA^{3}$

8

$1.643 \mathrm{Mg} / \mathrm{m}^{3}$

$8.649 \mathrm{~mm}^{-1}$

2624

$0.03 \times 0.02 \times 0.01 \mathrm{~mm}^{3}$

4.124 to $54.997^{\circ}$.

$-12<=\mathrm{h}<=14,-18<=\mathrm{k}<=18,-35<=1<=35$

49248

$4989[\mathrm{R}(\mathrm{int})=0.0656]$

$98.8 \%$

Semi-empirical from equivalents

0.7519 and 0.4985

Full-matrix least-squares on $\mathrm{F}^{2}$

4989 / 13 / 275

1.038

$\mathrm{R} 1=0.0443, \mathrm{wR} 2=0.1205$

$\mathrm{R} 1=0.0504, \mathrm{wR} 2=0.1274$

$\mathrm{n} / \mathrm{a}$

1.914 and -1.942 e. $\AA^{-3}$ 
Table S16. Crystal data and structure refinement for ${ }^{i \mathbf{P r}^{-}} \mathbf{1 - C O}$.

Identification code

Empirical formula

Formula weight

Temperature

Wavelength

Crystal system

Space group

Unit cell dimensions

Volume

Z

Density (calculated)

Absorption coefficient

$\mathrm{F}(000)$

Crystal size

Theta range for data collection

Index ranges

Reflections collected

Independent reflections

Completeness to theta $=25.242^{\circ}$

Absorption correction

Max. and min. transmission

Refinement method

Data / restraints / parameters

Goodness-of-fit on $\mathrm{F}^{2}$

Final $\mathrm{R}$ indices [I $>2 \operatorname{sigma}(\mathrm{I})]$

$\mathrm{R}$ indices (all data)

Extinction coefficient

Largest diff. peak and hole
${ }^{i \text { Pr- }}$ 1-CO.

C21 H35 Ir O P2

557.63

$296.15 \mathrm{~K}$

$0.71073 \AA$

Triclinic

P-1

$\mathrm{a}=11.336(3) \AA$

$\alpha=78.309(5)^{\circ}$.

$\mathrm{b}=14.130(3) \AA$

$\beta=82.053(5)^{\circ}$.

$\mathrm{c}=14.921(4) \AA$

$\gamma=89.309(5)^{\circ}$.

4

$1.598 \mathrm{Mg} / \mathrm{m}^{3}$

$5.906 \mathrm{~mm}^{-1}$

1104

$0.05 \times 0.03 \times 0.02 \mathrm{~mm}^{3}$

1.814 to $25.681^{\circ}$.

$-13<=\mathrm{h}<=13,-17<=\mathrm{k}<=17,-18<=1<=13$

16920

$8797[\mathrm{R}(\mathrm{int})=0.1026]$

$100.0 \%$

Semi-empirical from equivalents

0.7456 and 0.6596

Full-matrix least-squares on $\mathrm{F}^{2}$

8797 / 0 / 467

0.923

$\mathrm{R} 1=0.0602, \mathrm{wR} 2=0.0987$

$\mathrm{R} 1=0.1700, \mathrm{wR} 2=0.1337$

$\mathrm{n} / \mathrm{a}$

1.782 and -1.146 e. $\AA^{-3}$ 
Table S17. Crystal data and structure refinement for ${ }^{i \mathbf{P r}} \mathbf{2}-\mathrm{CO}$.

Identification code

Empirical formula

Formula weight

Temperature

Wavelength

Crystal system

Space group

Unit cell dimensions

Volume

Z

Density (calculated)

Absorption coefficient

$\mathrm{F}(000)$

Crystal size

Theta range for data collection

Index ranges

Reflections collected

Independent reflections

Completeness to theta $=53.594^{\circ}$

Absorption correction

Max. and min. transmission

Refinement method

Data / restraints / parameters

Goodness-of-fit on $\mathrm{F}^{2}$

Final $\mathrm{R}$ indices [I $>2 \operatorname{sigma}(\mathrm{I})]$

$\mathrm{R}$ indices (all data)

Extinction coefficient

Largest diff. peak and hole
${ }^{i P r}-2-\mathrm{CO}$

C19 H31 Ir O3 P2

561.58

$169.99 \mathrm{~K}$

$1.34139 \AA$

Triclinic

P-1

$\mathrm{a}=14.2131(3) \AA \quad \alpha=108.3700(10)^{\circ}$.

$\mathrm{b}=14.3576(3) \AA \quad \beta=97.8940(10)^{\circ}$.

$\mathrm{c}=17.1807(4) \AA \quad \gamma=91.0830(10)^{\circ}$.

$3288.58(13) \AA^{3}$

6

$1.701 \mathrm{Mg} / \mathrm{m}^{3}$

$9.154 \mathrm{~mm}^{-1}$

1656

$0.18 \times 0.15 \times 0.12 \mathrm{~mm}^{3}$

2.828 to $54.965^{\circ}$.

$-17<=\mathrm{h}<=17,-17<=\mathrm{k}<=16,-17<=1<=20$

47601

$12494[\mathrm{R}$ (int) $=0.0612]$

$99.9 \%$

Semi-empirical from equivalents

0.7508 and 0.3981

Full-matrix least-squares on $\mathrm{F}^{2}$

12494 / 0 / 700

1.116

$\mathrm{R} 1=0.0422, \mathrm{wR} 2=0.1093$

$\mathrm{R} 1=0.0460, \mathrm{wR} 2=0.1123$

$\mathrm{n} / \mathrm{a}$

2.194 and -3.808 e. $\AA^{-3}$ 
Table S18. Crystal data and structure refinement for ${ }^{i \mathrm{Pr}} \mathbf{3}-\mathrm{CO}$.

Identification code

Empirical formula

Formula weight

Temperature

Wavelength

Crystal system

Space group

Unit cell dimensions

Volume

Z

Density (calculated)

Absorption coefficient

$\mathrm{F}(000)$

Crystal size

Theta range for data collection

Index ranges

Reflections collected

Independent reflections

Completeness to theta $=53.594^{\circ}$

Absorption correction

Max. and min. transmission

Refinement method

Data / restraints / parameters

Goodness-of-fit on $\mathrm{F}^{2}$

Final $\mathrm{R}$ indices [I $>2 \operatorname{sigma}(\mathrm{I})]$

$\mathrm{R}$ indices (all data)

Extinction coefficient

Largest diff. peak and hole
iPr-3-CO

C19 H31 Ir O2 P2 S

577.64

$170.0 \mathrm{~K}$

$1.34139 \AA$

Monoclinic

C $12 / \mathrm{c} 1$

$\mathrm{a}=29.6785(5) \AA \quad \alpha=90^{\circ}$.

$\mathrm{b}=8.07860(10) \AA \quad \beta=101.2420(10)^{\circ}$.

$\mathrm{c}=18.7571(3) \AA \quad \gamma=90^{\circ}$.

$4410.92(12) \AA^{3}$

8

$1.740 \mathrm{Mg} / \mathrm{m}^{3}$

$9.653 \mathrm{~mm}^{-1}$

2272

$0.05 \times 0.03 \times 0.02 \mathrm{~mm}^{3}$

5.266 to $54.923^{\circ}$.

$-36<=\mathrm{h}<=36,-8<=\mathrm{k}<=9,-22<=1<=22$

23079

$4175[\mathrm{R}($ int $)=0.0351]$

$99.5 \%$

Semi-empirical from equivalents

0.7508 and 0.5650

Full-matrix least-squares on $\mathrm{F}^{2}$

4175 / 6 / 234

1.068

$\mathrm{R} 1=0.0220, \mathrm{wR} 2=0.0494$

$\mathrm{R} 1=0.0232, \mathrm{wR} 2=0.0501$

$\mathrm{n} / \mathrm{a}$

1.658 and -0.866 e. $\AA^{-3}$ 
Table S19. Crystal data and structure refinement for $4 \mathbf{b}-\mathrm{CO}$.

Identification code

Empirical formula

Formula weight

Temperature

Wavelength

Crystal system

Space group

Unit cell dimensions

Volume

$\mathrm{Z}$

Density (calculated)

Absorption coefficient

$\mathrm{F}(000)$

Crystal size

Theta range for data collection

Index ranges

Reflections collected

Independent reflections

Completeness to theta $=53.594^{\circ}$

Absorption correction

Max. and min. transmission

Refinement method

Data / restraints / parameters

Goodness-of-fit on $\mathrm{F}^{2}$

Final $\mathrm{R}$ indices [I $>2 \operatorname{sigma}(\mathrm{I})]$

$\mathrm{R}$ indices (all data)

Extinction coefficient

Largest diff. peak and hole
$4 \mathbf{b}-\mathrm{CO}$

C20 H34 Ir N O2 P2

574.62

$170.01 \mathrm{~K}$

$1.34139 \AA$

Monoclinic

P $121 / \mathrm{c} 1$

$\mathrm{a}=13.2206(3) \AA \quad \alpha=90^{\circ}$.

$\mathrm{b}=11.3239(2) \AA \quad \beta=97.3780(10)^{\circ}$.

$\mathrm{c}=15.3513(3) \AA \quad \gamma=90^{\circ}$.

2279.20(8) $\AA^{3}$

4

$1.675 \mathrm{Mg} / \mathrm{m}^{3}$

$8.801 \mathrm{~mm}^{-1}$

1136

$0.1 \times 0.06 \times 0.05 \mathrm{~mm}^{3}$

2.932 to $54.867^{\circ}$.

$-14<=\mathrm{h}<=16,-13<=\mathrm{k}<=13,-18<=1<=18$

22096

$4178[\mathrm{R}(\mathrm{int})=0.0347]$

$96.5 \%$

Semi-empirical from equivalents

0.7508 and 0.5447

Full-matrix least-squares on $\mathrm{F}^{2}$

4178 / 0 / 244

1.112

$\mathrm{R} 1=0.0196, \mathrm{wR} 2=0.0458$

$\mathrm{R} 1=0.0198, \mathrm{wR} 2=0.0459$

$\mathrm{n} / \mathrm{a}$

0.516 and -0.619 e. $\AA^{-3}$ 
Table S20. Crystal data and structure refinement for $4 \mathbf{e}-\mathrm{CO}$.

Identification code

Empirical formula

Formula weight

Temperature

Wavelength

Crystal system

Space group

Unit cell dimensions

Volume

Z

Density (calculated)

Absorption coefficient

$\mathrm{F}(000)$

Crystal size

Theta range for data collection

Index ranges

Reflections collected

Independent reflections

Completeness to theta $=53.594^{\circ}$

Absorption correction

Max. and min. transmission

Refinement method

Data / restraints / parameters

Goodness-of-fit on $\mathrm{F}^{2}$

Final R indices [I $>2 \operatorname{sigma}(\mathrm{I})]$

$\mathrm{R}$ indices (all data)

Extinction coefficient

Largest diff. peak and hole 2.133 and -1.297 e. $\AA^{-3}$
$4 \mathrm{e}-\mathrm{CO}$

C21 H36 Ir N O2 P2

588.65

$170.01 \mathrm{~K}$

$1.34139 \AA$

Monoclinic

C $12 / \mathrm{c} 1$

$\mathrm{a}=36.270(2) \AA$

$\alpha=90^{\circ}$.

$\mathrm{b}=7.8548(4) \AA$

$\beta=113.602(3)^{\circ}$.

$\mathrm{c}=36.2929(17) \AA$

$\gamma=90^{\circ}$.
9474.6(9) $\AA^{3}$

16

$1.651 \mathrm{Mg} / \mathrm{m}^{3}$

$8.479 \mathrm{~mm}^{-1}$

4672

$0.1 \times 0.03 \times 0.02 \mathrm{~mm}^{3}$

3.872 to $55.119^{\circ}$.

$-44<=\mathrm{h}<=41,-9<=\mathrm{k}<=9,-42<=1<=44$

36642

8847 [R(int) $=0.0977]$

$98.0 \%$

Semi-empirical from equivalents

0.7508 and 0.4572

Full-matrix least-squares on $\mathrm{F}^{2}$

8847 / 0 / 505

1.032

$\mathrm{R} 1=0.0708, \mathrm{wR} 2=0.1439$

$\mathrm{R} 1=0.1108, \mathrm{wR} 2=0.1670$

$\mathrm{n} / \mathrm{a}$ 
Table S21. Crystal data and structure refinement for $4 \mathrm{~g}-\mathrm{CO}$.

Identification code

Empirical formula

Formula weight

Temperature

Wavelength

Crystal system

Space group

Unit cell dimensions

Volume

$\mathrm{Z}$

Density (calculated)

Absorption coefficient

$\mathrm{F}(000)$

Crystal size

Theta range for data collection

Index ranges

Reflections collected

Independent reflections

Completeness to theta $=53.594^{\circ}$

Absorption correction

Max. and min. transmission

Refinement method

Data / restraints / parameters

Goodness-of-fit on $\mathrm{F}^{2}$

Final $\mathrm{R}$ indices [I $>2 \operatorname{sigma}(\mathrm{I})]$

$\mathrm{R}$ indices (all data)

Extinction coefficient

Largest diff. peak and hole
$4 \mathrm{~g}-\mathrm{CO}$

C22 H36 Ir N O2 P2

600.66

$170.01 \mathrm{~K}$

$1.34139 \AA$

Monoclinic

P $121 / \mathrm{c} 1$

$\mathrm{a}=13.6088(2) \AA \quad \alpha=90^{\circ}$.

$\mathrm{b}=11.1953(2) \AA \quad \beta=100.6750(10)^{\circ}$.

$\mathrm{c}=15.5695(3) \AA \quad \gamma=90^{\circ}$.

2331.03(7) $\AA^{3}$

4

$1.712 \mathrm{Mg} / \mathrm{m}^{3}$

$8.626 \mathrm{~mm}^{-1}$

1192

$0.1 \times 0.08 \times 0.02 \mathrm{~mm}^{3}$

6.781 to $56.937^{\circ}$.

$-16<=\mathrm{h}<=17,-13<=\mathrm{k}<=6,-19<=\mathrm{l}<=19$

22542

$4588[\mathrm{R}(\mathrm{int})=0.0320]$

$96.3 \%$

Semi-empirical from equivalents

0.7512 and 0.4777

Full-matrix least-squares on $\mathrm{F}^{2}$

4588 / 0 / 261

1.154

$\mathrm{R} 1=0.0195, \mathrm{wR} 2=0.0470$

$\mathrm{R} 1=0.0196, \mathrm{wR} 2=0.0471$

$\mathrm{n} / \mathrm{a}$

0.941 and -0.812 e. $\AA^{-3}$ 
Table S22. Crystal data and structure refinement for ${ }^{i P r}-2$-(perpendicular-COE).

Identification code

Empirical formula

Formula weight

Temperature

Wavelength

Crystal system

Space group

Unit cell dimensions

Volume

Z

Density (calculated)

Absorption coefficient

$\mathrm{F}(000)$

Crystal size

Theta range for data collection

Index ranges

Reflections collected

Independent reflections

Completeness to theta $=53.594^{\circ}$

Absorption correction

Max. and min. transmission

Refinement method

Data / restraints / parameters

Goodness-of-fit on $\mathrm{F}^{2}$

Final $\mathrm{R}$ indices [I $>2 \operatorname{sigma}(\mathrm{I})]$

$\mathrm{R}$ indices (all data)

Extinction coefficient

Largest diff. peak and hole
iPr-2-(perpendicular-COE)

C26 H45 Ir O2 P2

643.76

$170.01 \mathrm{~K}$

$1.34139 \AA$

Monoclinic

P $121 / \mathrm{c} 1$

$\mathrm{a}=8.6225(2) \AA \quad \alpha=90^{\circ}$.

$\mathrm{b}=18.5843(4) \AA \quad \beta=90.7610(10)^{\circ}$.

$\mathrm{c}=17.0349(4) \AA \quad \gamma=90^{\circ}$.

2729.49(11) $\AA^{3}$

4

$1.567 \mathrm{Mg} / \mathrm{m}^{3}$

$7.385 \mathrm{~mm}^{-1}$

1296

$0.06 \times 0.05 \times 0.05 \mathrm{~mm}^{3}$

3.062 to $54.910^{\circ}$.

$-10<=\mathrm{h}<=9,-22<=\mathrm{k}<=21,-20<=1<=20$

25040

$5166[\mathrm{R}(\mathrm{int})=0.0699]$

$99.6 \%$

Semi-empirical from equivalents

0.7508 and 0.5140

Full-matrix least-squares on $\mathrm{F}^{2}$

$5166 / 0 / 288$

1.144

$\mathrm{R} 1=0.0665, \mathrm{wR} 2=0.1689$

$\mathrm{R} 1=0.0764, \mathrm{wR} 2=0.1767$

$\mathrm{n} / \mathrm{a}$

2.497 and -3.890 e. $\AA^{-3}$ 
Table S23. Crystal data and structure refinement for ${ }^{i \mathrm{Pr}}-\mathbf{2}-\mathrm{SMe}_{2}$.

Identification code

Empirical formula

Formula weight

Temperature

Wavelength

Crystal system

Space group

Unit cell dimensions

Volume

Z

Density (calculated)

Absorption coefficient

$\mathrm{F}(000)$

Crystal size

Theta range for data collection

Index ranges

Reflections collected

Independent reflections

Completeness to theta $=25.049^{\circ}$

Absorption correction

Max. and min. transmission

Refinement method

Data / restraints / parameters

Goodness-of-fit on $\mathrm{F}^{2}$

Final $\mathrm{R}$ indices [I $>2 \operatorname{sigma}(\mathrm{I})]$

$\mathrm{R}$ indices (all data)

Extinction coefficient

Largest diff. peak and hole
${ }^{i P r}-2-\mathrm{SMe}_{2}$

C20 H37 Ir O2 P2 S

595.69

$296.15 \mathrm{~K}$

$0.71073 \AA$

Monoclinic

P $121 / \mathrm{c} 1$

$\begin{array}{ll}\mathrm{a}=19.059(13) \AA & \alpha=90^{\circ} . \\ \mathrm{b}=8.033(5) \AA & \beta=92.063(11)^{\circ} . \\ \mathrm{c}=16.181(11) \AA & \gamma=90^{\circ} .\end{array}$

2476(3) $\AA^{3}$

4

$1.598 \mathrm{Mg} / \mathrm{m}^{3}$

$5.617 \mathrm{~mm}^{-1}$

1184

$0.1 \times 0.06 \times 0.01 \mathrm{~mm}^{3}$

1.069 to $25.049^{\circ}$.

$-20<=\mathrm{h}<=22,-9<=\mathrm{k}<=9,-19<=\mathrm{l}<=19$

16192

$4342[\mathrm{R}(\mathrm{int})=0.1161]$

$99.5 \%$

Semi-empirical from equivalents

0.7456 and 0.4971

Full-matrix least-squares on $\mathrm{F}^{2}$

4342 / 18 / 246

1.157

$\mathrm{R} 1=0.1116, \mathrm{wR} 2=0.2453$

$\mathrm{R} 1=0.1586, \mathrm{wR} 2=0.2694$

$\mathrm{n} / \mathrm{a}$

8.272 and -1.804 e. $\AA^{-3}$ 


\section{Computational details}

We used Gaussian 09 program to carry out all calculations. All geometry optimization calculations in the gas phase were conducted by B3LYP-D3 method. The 6-31G* basis set was used for $\mathrm{C}, \mathrm{H}, \mathrm{O}, \mathrm{P}, \mathrm{S}$, and $\mathrm{N}$ atoms, as well as the Lanl2DZ basis set and ECP were used for Ir atom. Frequency calculations at the same level of theory on the optimized geometries were carried out to verify the stationary points as local minima, and to obtain their Gibbs free energy correction. The images of the optimized geometry were prepared by CYLview.
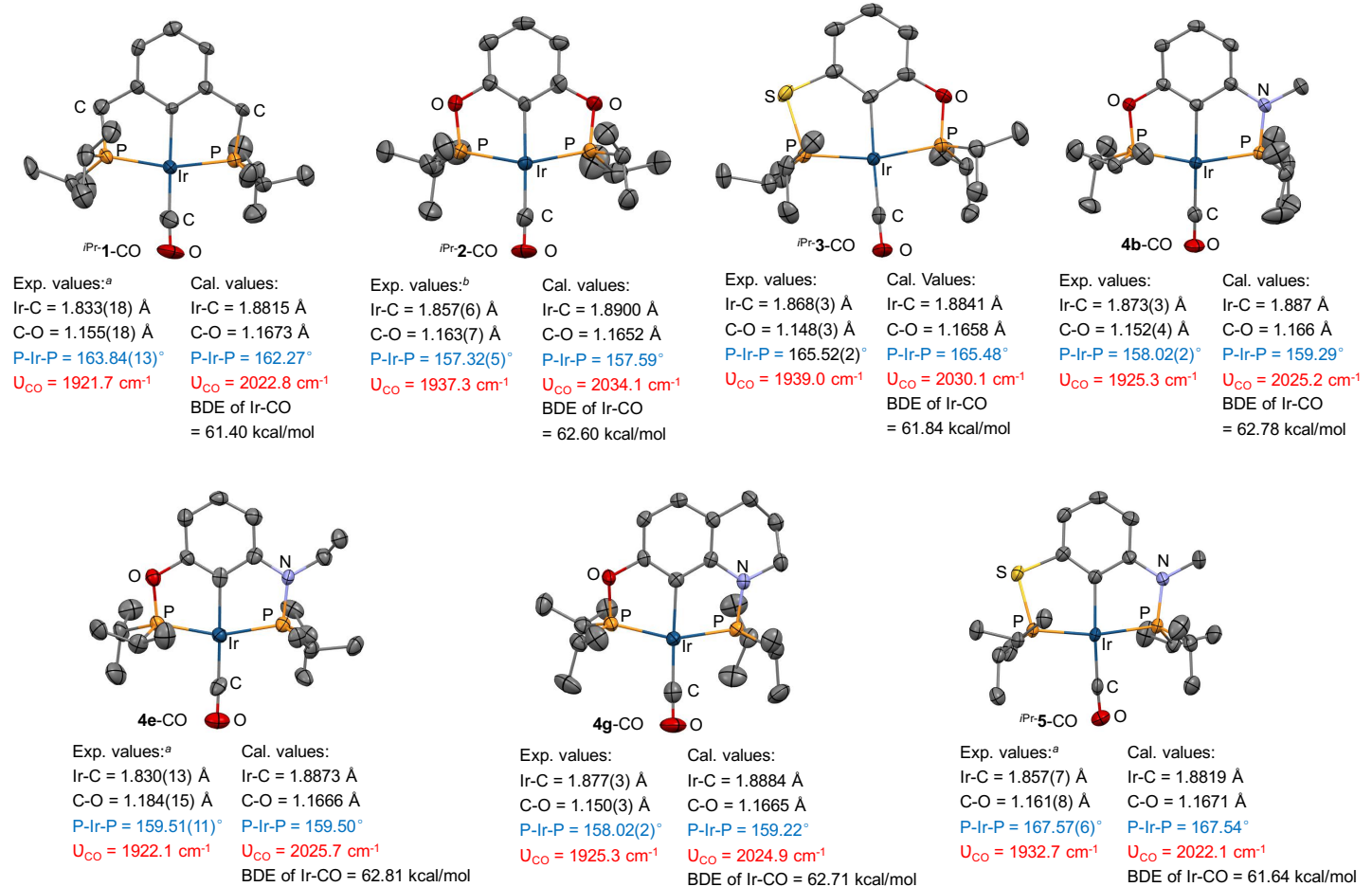

Figure S147. Crystal and computed structures, key bond distances and angles, $v_{\mathrm{CO}}$ values, and Ir-CO BDEs for complexes ${ }^{i \mathrm{Pr}-} \mathbf{1}-\mathrm{CO},{ }^{i \mathrm{Pr}-} \mathbf{2}-\mathrm{CO}$ and ${ }^{i \mathrm{Pr}-} \mathbf{3}-\mathrm{CO}, \mathbf{4 b}-\mathrm{CO}, \mathbf{4 e - C O}, \mathbf{4 g}-\mathrm{CO}$, and ${ }^{i \mathrm{Pr}-\mathbf{5}-}$ CO. Unimportant hydrogen atoms are not shown for clarity. (Data in left came from X-ray; data in right was calculated by DFT)

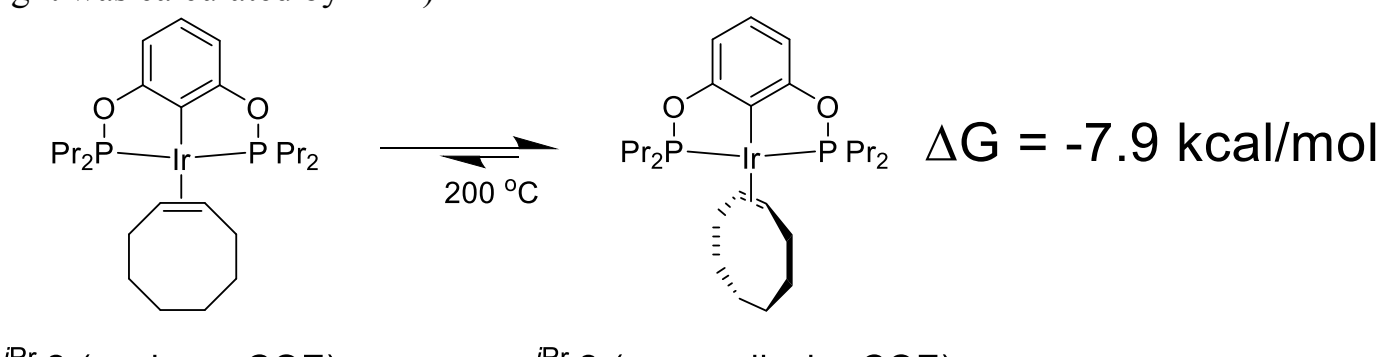

iPr-2-(coplanar-COE)

iPr-2-(perpendicular-COE)
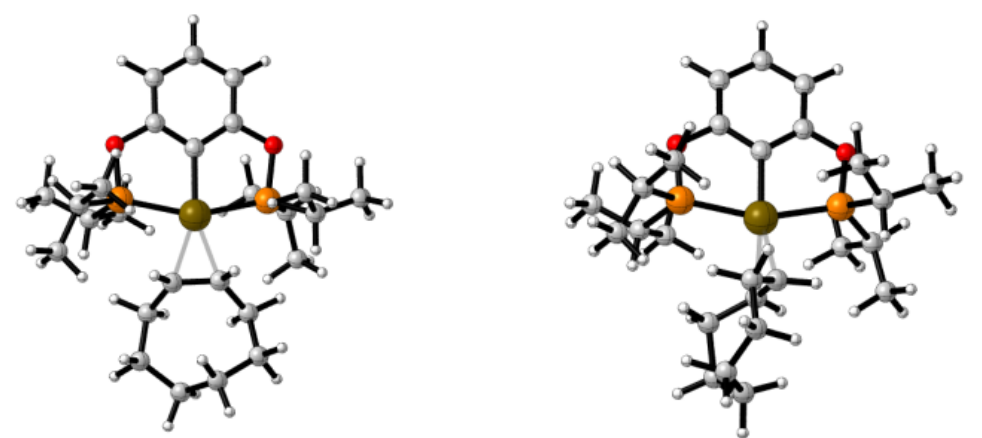

Figure S148. Two conformers of the (pincer)Ir-cyclooctene complex calculated by the B3LYPD3 method. 
XI. Cartesian coordinates of the optimized compounds

\begin{tabular}{|c|c|c|c|}
\hline \multicolumn{4}{|c|}{${ }^{i} \mathrm{Pr}_{-} \mathbf{1}-\mathrm{CO}$} \\
\hline $\mathrm{Ir}$ & 0.078221 & 0.535870 & 0.059546 \\
\hline $\mathrm{P}$ & 2.313887 & 0.049042 & 0.002429 \\
\hline $\mathrm{P}$ & -2.197810 & 0.201913 & 0.042087 \\
\hline $\mathrm{O}$ & 2.427875 & -1.614944 & -0.181602 \\
\hline $\mathrm{O}$ & 0.178691 & 3.586162 & 0.163517 \\
\hline $\mathrm{N}$ & -2.384690 & -1.508889 & -0.038612 \\
\hline $\mathrm{C}$ & 0.022333 & -1.533527 & -0.106242 \\
\hline $\mathrm{C}$ & 1.202261 & -2.278532 & -0.213454 \\
\hline $\mathrm{C}$ & 1.230802 & -3.666478 & -0.358693 \\
\hline $\mathrm{H}$ & 2.177826 & -4.189759 & -0.436685 \\
\hline $\mathrm{C}$ & 0.011815 & -4.339024 & -0.403648 \\
\hline $\mathrm{H}$ & 0.000500 & -5.419724 & -0.520148 \\
\hline $\mathrm{C}$ & -1.202873 & -3.651990 & -0.304673 \\
\hline $\mathrm{H}$ & -2.132386 & -4.208950 & -0.350556 \\
\hline $\mathrm{C}$ & -1.194411 & -2.257899 & -0.150586 \\
\hline $\mathrm{C}$ & -3.677858 & -2.163570 & -0.121941 \\
\hline $\mathrm{H}$ & -4.474593 & -1.436887 & 0.052963 \\
\hline $\mathrm{H}$ & -3.770009 & -2.947499 & 0.641116 \\
\hline $\mathrm{H}$ & -3.840602 & -2.622458 & -1.107860 \\
\hline $\mathrm{C}$ & -3.190146 & 0.727973 & 1.541460 \\
\hline $\mathrm{H}$ & -4.251752 & 0.727868 & 1.254591 \\
\hline $\mathrm{C}$ & -2.969100 & -0.267459 & 2.692467 \\
\hline $\mathrm{H}$ & -3.480523 & 0.090713 & 3.594201 \\
\hline $\mathrm{H}$ & -1.900721 & -0.355968 & 2.920510 \\
\hline $\mathrm{H}$ & -3.345558 & -1.267312 & 2.461946 \\
\hline $\mathrm{C}$ & -2.788413 & 2.144593 & 1.991604 \\
\hline $\mathrm{H}$ & -1.750118 & 2.146836 & 2.338037 \\
\hline $\mathrm{H}$ & -3.430779 & 2.463471 & 2.821444 \\
\hline $\mathrm{H}$ & -2.869971 & 2.891727 & 1.198144 \\
\hline $\mathrm{C}$ & -3.151477 & 0.797759 & -1.450621 \\
\hline $\mathrm{H}$ & -4.169302 & 0.391990 & -1.359504 \\
\hline $\mathrm{C}$ & -2.491984 & 0.218443 & -2.712843 \\
\hline $\mathrm{H}$ & -1.473643 & 0.606738 & -2.823678 \\
\hline $\mathrm{H}$ & -3.071490 & 0.499670 & -3.600691 \\
\hline $\mathrm{H}$ & -2.426983 & -0.873549 & -2.675789 \\
\hline $\mathrm{C}$ & -3.238384 & 2.329379 & -1.520928 \\
\hline $\mathrm{H}$ & -3.837604 & 2.748984 & -0.707230 \\
\hline $\mathrm{H}$ & -3.710275 & 2.629551 & -2.464354 \\
\hline $\mathrm{H}$ & -2.242192 & 2.783631 & -1.484844 \\
\hline $\mathrm{C}$ & 3.321234 & 0.635027 & -1.437776 \\
\hline $\mathrm{H}$ & 4.268558 & 0.082249 & -1.403904 \\
\hline $\mathrm{C}$ & 2.587397 & 0.285229 & -2.742067 \\
\hline $\mathrm{H}$ & 2.391503 & -0.789118 & -2.814156 \\
\hline $\mathrm{H}$ & 3.196262 & 0.583381 & -3.604449 \\
\hline $\mathrm{H}$ & 1.625841 & 0.807639 & -2.795868 \\
\hline $\mathrm{C}$ & 3.597649 & 2.142346 & -1.322921 \\
\hline $\mathrm{H}$ & 2.662571 & 2.712191 & -1.278832 \\
\hline $\mathrm{H}$ & 4.157369 & 2.485694 & -2.200851 \\
\hline $\mathrm{H}$ & 4.189406 & 2.390673 & -0.434678 \\
\hline $\mathrm{C}$ & 3.342708 & 0.313639 & 1.525501 \\
\hline $\mathrm{H}$ & 3.378474 & 1.404751 & 1.651071 \\
\hline
\end{tabular}




\begin{tabular}{|c|c|c|c|}
\hline $\mathrm{C}$ & 2.602406 & -0.295334 & 2.728910 \\
\hline $\mathrm{H}$ & 1.592436 & 0.116233 & 2.823693 \\
\hline $\mathrm{H}$ & 3.157060 & -0.090286 & 3.652425 \\
\hline $\mathrm{H}$ & 2.515048 & -1.382001 & 2.618790 \\
\hline $\mathrm{C}$ & 4.770417 & -0.239083 & 1.399921 \\
\hline $\mathrm{H}$ & 4.749778 & -1.308409 & 1.164392 \\
\hline $\mathrm{H}$ & 5.304024 & -0.111325 & 2.349447 \\
\hline $\mathrm{H}$ & 5.349678 & 0.273096 & 0.624447 \\
\hline $\mathrm{C}$ & 0.138666 & 2.420557 & 0.143035 \\
\hline \multicolumn{4}{|c|}{ iPr-2-CO } \\
\hline Ir & 0.086760 & -0.485204 & -0.009787 \\
\hline S & 2.660454 & 2.008867 & 0.051194 \\
\hline $\mathrm{P}$ & 2.358935 & -0.097963 & 0.057680 \\
\hline $\mathrm{P}$ & -2.199582 & -0.374047 & -0.061826 \\
\hline $\mathrm{O}$ & 0.285456 & -3.527503 & 0.021285 \\
\hline $\mathrm{N}$ & -2.551735 & 1.302666 & -0.047747 \\
\hline $\mathrm{C}$ & 0.217866 & -2.362490 & 0.002124 \\
\hline $\mathrm{C}$ & -0.132188 & 1.603971 & 0.013366 \\
\hline $\mathrm{C}$ & 0.931505 & 2.530350 & 0.050189 \\
\hline $\mathrm{C}$ & 0.747063 & 3.921139 & 0.086473 \\
\hline $\mathrm{H}$ & 1.597898 & 4.595596 & 0.113491 \\
\hline $\mathrm{C}$ & -0.546259 & 4.425779 & 0.090720 \\
\hline $\mathrm{H}$ & -0.708870 & 5.500031 & 0.124890 \\
\hline $\mathrm{C}$ & -1.643268 & 3.564877 & 0.053709 \\
\hline $\mathrm{H}$ & -2.641746 & 3.986118 & 0.067988 \\
\hline $\mathrm{C}$ & -1.438288 & 2.179160 & 0.008857 \\
\hline $\mathrm{C}$ & -3.889863 & 1.846982 & -0.223632 \\
\hline $\mathrm{H}$ & -4.603969 & 1.040669 & -0.390605 \\
\hline $\mathrm{H}$ & -3.929069 & 2.516950 & -1.092996 \\
\hline $\mathrm{H}$ & -4.217383 & 2.410090 & 0.660881 \\
\hline $\mathrm{C}$ & 3.280204 & -0.661644 & 1.586604 \\
\hline $\mathrm{H}$ & 4.262182 & -0.171387 & 1.562673 \\
\hline $\mathrm{C}$ & 2.521410 & -0.197713 & 2.838593 \\
\hline $\mathrm{H}$ & 2.381906 & 0.887689 & 2.846683 \\
\hline $\mathrm{H}$ & 3.082353 & -0.479274 & 3.738375 \\
\hline $\mathrm{H}$ & 1.531943 & -0.665935 & 2.883252 \\
\hline $\mathrm{C}$ & 3.474368 & -2.186200 & 1.582017 \\
\hline $\mathrm{H}$ & 2.513256 & -2.709298 & 1.537160 \\
\hline $\mathrm{H}$ & 3.977788 & -2.493342 & 2.506619 \\
\hline $\mathrm{H}$ & 4.088459 & -2.529113 & 0.742802 \\
\hline $\mathrm{C}$ & 3.356422 & -0.718655 & -1.397544 \\
\hline $\mathrm{H}$ & 3.260066 & -1.810401 & -1.320002 \\
\hline $\mathrm{C}$ & 4.841492 & -0.335693 & -1.348950 \\
\hline $\mathrm{H}$ & 4.965231 & 0.752712 & -1.386754 \\
\hline $\mathrm{H}$ & 5.362489 & -0.758040 & -2.216812 \\
\hline $\mathrm{H}$ & 5.342394 & -0.707834 & -0.449108 \\
\hline $\mathrm{C}$ & 2.692085 & -0.266909 & -2.706471 \\
\hline $\mathrm{H}$ & 1.642861 & -0.577136 & -2.744561 \\
\hline $\mathrm{H}$ & 3.221807 & -0.702864 & -3.562345 \\
\hline $\mathrm{H}$ & 2.726877 & 0.823763 & -2.803459 \\
\hline $\mathrm{C}$ & -3.057721 & -1.146586 & 1.409511 \\
\hline $\mathrm{H}$ & -2.725006 & -2.192722 & 1.357936 \\
\hline $\mathrm{C}$ & -2.493877 & -0.523338 & 2.696964 \\
\hline $\mathrm{H}$ & -1.404173 & -0.617175 & 2.739231 \\
\hline
\end{tabular}




\begin{tabular}{|c|c|c|c|}
\hline $\mathrm{H}$ & -2.925392 & -1.018984 & 3.575070 \\
\hline $\mathrm{H}$ & -2.740778 & 0.543044 & 2.753018 \\
\hline $\mathrm{C}$ & -4.593758 & -1.122349 & 1.403748 \\
\hline $\mathrm{H}$ & -4.976091 & -0.105858 & 1.541984 \\
\hline $\mathrm{H}$ & -4.972166 & -1.726289 & 2.237392 \\
\hline $\mathrm{H}$ & -5.022956 & -1.530316 & 0.482326 \\
\hline $\mathrm{C}$ & -3.062219 & -1.038391 & -1.575290 \\
\hline $\mathrm{H}$ & -4.123543 & -0.766781 & -1.502118 \\
\hline $\mathrm{C}$ & -2.465660 & -0.372506 & -2.824938 \\
\hline $\mathrm{H}$ & -2.547614 & 0.718546 & -2.782649 \\
\hline $\mathrm{H}$ & -2.989354 & -0.722427 & -3.722928 \\
\hline $\mathrm{H}$ & -1.403571 & -0.623013 & -2.920281 \\
\hline $\mathrm{C}$ & -2.955109 & -2.569855 & -1.644783 \\
\hline $\mathrm{H}$ & -1.909665 & -2.889735 & -1.699064 \\
\hline $\mathrm{H}$ & -3.465066 & -2.935260 & -2.544136 \\
\hline $\mathrm{H}$ & -3.415944 & -3.061223 & -0.780969 \\
\hline \multicolumn{4}{|c|}{${ }^{i \mathrm{Pr}-} \mathbf{3}-\mathrm{CO}$} \\
\hline $\mathrm{Ir}$ & -0.301125 & 0.604767 & 0.013173 \\
\hline$P$ & -2.463674 & -0.129263 & 0.104627 \\
\hline$P$ & 1.994396 & 0.535983 & -0.145453 \\
\hline $\mathrm{O}$ & -0.722346 & 3.628970 & 0.066231 \\
\hline $\mathrm{O}$ & -2.381677 & -1.806366 & 0.119376 \\
\hline $\mathrm{N}$ & 2.396122 & -1.141751 & -0.084221 \\
\hline $\mathrm{C}$ & -0.563714 & 2.473525 & 0.038865 \\
\hline $\mathrm{C}$ & -0.001018 & -1.448948 & 0.010439 \\
\hline $\mathrm{C}$ & -1.092138 & -2.326865 & 0.040854 \\
\hline $\mathrm{C}$ & -0.970919 & -3.715561 & -0.012292 \\
\hline $\mathrm{H}$ & -1.854170 & -4.344761 & 0.013583 \\
\hline $\mathrm{C}$ & 0.312077 & -4.247780 & -0.106074 \\
\hline $\mathrm{H}$ & 0.443507 & -5.325637 & -0.156219 \\
\hline $\mathrm{C}$ & 1.442065 & -3.424218 & -0.133383 \\
\hline $\mathrm{H}$ & 2.419779 & -3.885317 & -0.208197 \\
\hline $\mathrm{C}$ & 1.288740 & -2.030160 & -0.064297 \\
\hline $\mathrm{C}$ & 3.755656 & -1.657114 & -0.255006 \\
\hline $\mathrm{H}$ & 4.395219 & -0.837975 & -0.594603 \\
\hline $\mathrm{H}$ & 3.755442 & -2.395373 & -1.068682 \\
\hline $\mathrm{C}$ & 4.352660 & -2.275547 & 1.015392 \\
\hline $\mathrm{H}$ & 4.472393 & -1.523184 & 1.800340 \\
\hline $\mathrm{H}$ & 5.337437 & -2.707549 & 0.800878 \\
\hline $\mathrm{H}$ & 3.708393 & -3.064792 & 1.411024 \\
\hline $\mathrm{C}$ & 2.919645 & 1.419633 & 1.216890 \\
\hline $\mathrm{H}$ & 2.514536 & 2.437335 & 1.127741 \\
\hline $\mathrm{C}$ & 4.448065 & 1.503320 & 1.093421 \\
\hline $\mathrm{H}$ & 4.922327 & 0.526090 & 1.219589 \\
\hline $\mathrm{H}$ & 4.842034 & 2.157409 & 1.880885 \\
\hline $\mathrm{H}$ & 4.770131 & 1.917758 & 0.132406 \\
\hline $\mathrm{C}$ & 2.477182 & 0.857312 & 2.577284 \\
\hline $\mathrm{H}$ & 1.387536 & 0.891383 & 2.678017 \\
\hline $\mathrm{H}$ & 2.924513 & 1.442791 & 3.389630 \\
\hline $\mathrm{H}$ & 2.790957 & -0.185044 & 2.696261 \\
\hline $\mathrm{C}$ & 2.729220 & 1.153617 & -1.746152 \\
\hline $\mathrm{H}$ & 3.804273 & 0.930515 & -1.733211 \\
\hline $\mathrm{C}$ & 2.081880 & 0.402038 & -2.919694 \\
\hline $\mathrm{H}$ & 2.212857 & -0.681273 & -2.830102 \\
\hline
\end{tabular}




$\begin{array}{llll}\mathrm{H} & 2.532014 & 0.725880 & -3.866146 \\ \mathrm{H} & 1.006039 & 0.605534 & -2.957009 \\ \mathrm{C} & 2.543573 & 2.673253 & -1.878675 \\ \mathrm{H} & 1.482243 & 2.940918 & -1.848834 \\ \mathrm{H} & 2.951587 & 3.014581 & -2.837664 \\ \mathrm{H} & 3.055763 & 3.228603 & -1.085456 \\ \mathrm{C} & -3.564362 & 0.164291 & -1.362430 \\ \mathrm{H} & -3.705193 & 1.253876 & -1.387352 \\ \mathrm{C} & -4.929651 & -0.531221 & -1.255405 \\ \mathrm{H} & -4.802665 & -1.611894 & -1.130210 \\ \mathrm{H} & -5.505923 & -0.362632 & -2.173106 \\ \mathrm{H} & -5.526182 & -0.155429 & -0.417452 \\ \mathrm{C} & -2.811460 & -0.262405 & -2.634626 \\ \mathrm{H} & -1.845477 & 0.246541 & -2.714506 \\ \mathrm{H} & -3.411511 & -0.026028 & -3.521544 \\ \mathrm{H} & -2.624060 & -1.341908 & -2.628453 \\ \mathrm{C} & -3.486618 & 0.181552 & 1.616584 \\ \mathrm{H} & -4.354446 & -0.486347 & 1.546587 \\ \mathrm{C} & -2.668390 & -0.192302 & 2.862329 \\ \mathrm{H} & -3.284620 & -0.077373 & 3.762538 \\ \mathrm{H} & -1.790568 & 0.456563 & 2.955513 \\ \mathrm{H} & -2.318249 & -1.228203 & 2.814189 \\ \mathrm{C} & -3.959036 & 1.642987 & 1.659977 \\ \mathrm{H} & -3.106433 & 2.331590 & 1.651443 \\ \mathrm{H} & -4.525150 & 1.824074 & 2.581218 \\ \mathrm{H} & -4.609981 & 1.896373 & 0.815660\end{array}$

\begin{tabular}{llll}
\multicolumn{4}{l}{$\mathbf{4 b}-\mathrm{CO}$} \\
$\mathrm{Ir}$ & -0.416583 & -0.641544 & -0.069526 \\
$\mathrm{P}$ & 1.867281 & -0.929183 & -0.026458 \\
$\mathrm{P}$ & -2.439496 & 0.424240 & -0.005144 \\
$\mathrm{O}$ & -2.107916 & 2.063105 & 0.136066 \\
$\mathrm{O}$ & -1.328553 & -3.552684 & -0.226621 \\
$\mathrm{~N}$ & 2.503355 & 0.668265 & 0.039742 \\
$\mathrm{C}$ & 0.189344 & 1.338522 & 0.087973 \\
$\mathrm{C}$ & -0.748905 & 2.374579 & 0.168225 \\
$\mathrm{C}$ & -0.396809 & 3.718720 & 0.282563 \\
$\mathrm{H}$ & -1.162706 & 4.485205 & 0.335424 \\
$\mathrm{C}$ & 0.960336 & 4.034950 & 0.319245 \\
$\mathrm{H}$ & 1.261972 & 5.077442 & 0.400855 \\
$\mathrm{C}$ & 1.955585 & 3.052753 & 0.253385 \\
$\mathrm{C}$ & 3.426943 & 3.411713 & 0.306522 \\
$\mathrm{H}$ & 3.751410 & 3.541450 & 1.350623 \\
$\mathrm{H}$ & 3.599653 & 4.375408 & -0.188358 \\
$\mathrm{C}$ & 4.282700 & 2.320418 & -0.346520 \\
$\mathrm{H}$ & 4.100539 & 2.302797 & -1.428481 \\
$\mathrm{H}$ & 5.350516 & 2.513832 & -0.191524 \\
$\mathrm{C}$ & 3.922361 & 0.953525 & 0.241003 \\
$\mathrm{H}$ & 4.512895 & 0.165722 & -0.240155 \\
$\mathrm{H}$ & 4.174964 & 0.938825 & 1.314507 \\
$\mathrm{C}$ & 1.551848 & 1.710545 & 0.133547 \\
$\mathrm{C}$ & 2.706753 & -1.724812 & -1.501094 \\
$\mathrm{H}$ & 3.719457 & -2.017340 & -1.188374 \\
$\mathrm{C}$ & 1.935280 & -2.978131 & -1.952248 \\
$\mathrm{H}$ & 1.782860 & -3.705167 & -1.150618 \\
& & & 118
\end{tabular}




\begin{tabular}{llll}
$\mathrm{H}$ & 2.483146 & -3.478116 & -2.760301 \\
$\mathrm{H}$ & 0.946979 & -2.696061 & -2.328884 \\
$\mathrm{C}$ & 2.797529 & -0.718531 & -2.659709 \\
$\mathrm{H}$ & 3.430197 & 0.140085 & -2.420607 \\
$\mathrm{H}$ & 1.801548 & -0.337657 & -2.913653 \\
$\mathrm{H}$ & 3.209735 & -1.212690 & -3.547944 \\
$\mathrm{C}$ & 2.607168 & -1.734937 & 1.487977 \\
$\mathrm{H}$ & 3.694372 & -1.585805 & 1.421896 \\
$\mathrm{C}$ & 2.074555 & -1.008261 & 2.733587 \\
$\mathrm{H}$ & 2.270500 & 0.068156 & 2.695452 \\
$\mathrm{H}$ & 2.548779 & -1.413183 & 3.636057 \\
$\mathrm{H}$ & 0.990490 & -1.142780 & 2.817398 \\
$\mathrm{C}$ & 2.319848 & -3.241664 & 1.556517 \\
$\mathrm{H}$ & 1.244321 & -3.441276 & 1.495482 \\
$\mathrm{H}$ & 2.682092 & -3.644684 & 2.510129 \\
$\mathrm{H}$ & 2.818920 & -3.795872 & 0.755681 \\
$\mathrm{C}$ & -3.539912 & 0.409598 & -1.501980 \\
$\mathrm{H}$ & -3.852748 & -0.638849 & -1.604994 \\
$\mathrm{C}$ & -4.776990 & 1.307535 & -1.353999 \\
$\mathrm{H}$ & -5.446853 & 0.966860 & -0.557401 \\
$\mathrm{H}$ & -5.349883 & 1.310887 & -2.289160 \\
$\mathrm{H}$ & -4.479254 & 2.338682 & -1.135827 \\
$\mathrm{C}$ & -2.701248 & 0.794322 & -2.732671 \\
$\mathrm{H}$ & -2.343127 & 1.826340 & -2.648468 \\
$\mathrm{H}$ & -3.311918 & 0.718883 & -3.640392 \\
$\mathrm{H}$ & -1.829102 & 0.141072 & -2.838441 \\
$\mathrm{C}$ & -3.533903 & 0.157006 & 1.466094 \\
$\mathrm{H}$ & -4.307710 & 0.934047 & 1.425927 \\
$\mathrm{C}$ & -4.189457 & -1.231202 & 1.402955 \\
$\mathrm{H}$ & -4.839696 & -1.346226 & 0.528398 \\
$\mathrm{H}$ & -4.803609 & -1.394030 & 2.296434 \\
$\mathrm{H}$ & -3.430832 & -2.021493 & 1.369417 \\
$\mathrm{C}$ & -2.710067 & 0.341556 & 2.749933 \\
$\mathrm{H}$ & -1.920367 & -0.415329 & 2.813009 \\
$\mathrm{H}$ & -3.360320 & 0.241972 & 3.627839 \\
$\mathrm{H}$ & -2.236111 & 1.327563 & 2.782631 \\
$\mathrm{C}$ & -0.978406 & -2.441012 & -0.179606 \\
& & & \\
\hline
\end{tabular}

\begin{tabular}{|c|c|c|c|}
\hline \multicolumn{4}{|c|}{$\mathbf{4 e - C O}$} \\
\hline Ir & -0.000016 & -0.480703 & 0.000157 \\
\hline $\mathrm{P}$ & 2.277570 & -0.125461 & 0.004470 \\
\hline $\mathrm{P}$ & -2.277598 & -0.125599 & -0.004468 \\
\hline $\mathrm{O}$ & 0.000226 & -3.529490 & -0.000230 \\
\hline $\mathrm{C}$ & 0.000265 & -2.362179 & -0.000134 \\
\hline $\mathrm{C}$ & -0.000013 & 1.627836 & 0.000505 \\
\hline $\mathrm{C}$ & 2.463950 & 1.631496 & 0.583787 \\
\hline $\mathrm{H}$ & 2.634087 & 1.603341 & 1.668079 \\
\hline $\mathrm{H}$ & 3.345814 & 2.109394 & 0.138527 \\
\hline $\mathrm{C}$ & 1.179550 & 2.373661 & 0.264660 \\
\hline $\mathrm{C}$ & 1.177723 & 3.772494 & 0.255214 \\
\hline $\mathrm{H}$ & 2.097899 & 4.317903 & 0.456961 \\
\hline $\mathrm{C}$ & 0.000106 & 4.474551 & 0.000455 \\
\hline $\mathrm{H}$ & 0.000154 & 5.561760 & 0.000406 \\
\hline $\mathrm{C}$ & -1.177565 & 3.772584 & -0.254233 \\
\hline $\mathrm{H}$ & -2.097701 & 4.318056 & -0.455992 \\
\hline
\end{tabular}




\begin{tabular}{|c|c|c|c|}
\hline $\mathrm{C}$ & -1.179523 & 2.373734 & -0.263599 \\
\hline $\mathrm{C}$ & -2.464068 & 1.631767 & -0.582621 \\
\hline $\mathrm{H}$ & -2.634886 & 1.604452 & -1.666824 \\
\hline $\mathrm{H}$ & -3.345654 & 2.109383 & -0.136499 \\
\hline $\mathrm{C}$ & 3.115905 & -0.138976 & -1.665882 \\
\hline $\mathrm{H}$ & 4.127223 & 0.263895 & -1.517115 \\
\hline $\mathrm{C}$ & 2.356578 & 0.778212 & -2.638666 \\
\hline $\mathrm{H}$ & 1.335046 & 0.412491 & -2.788642 \\
\hline $\mathrm{H}$ & 2.869949 & 0.796843 & -3.608282 \\
\hline $\mathrm{H}$ & 2.284111 & 1.806368 & -2.270316 \\
\hline $\mathrm{C}$ & 3.215724 & -1.568213 & -2.219158 \\
\hline $\mathrm{H}$ & 3.826716 & -2.220556 & -1.585462 \\
\hline $\mathrm{H}$ & 3.672720 & -1.553632 & -3.216159 \\
\hline $\mathrm{H}$ & 2.219730 & -2.016461 & -2.309744 \\
\hline $\mathrm{C}$ & 3.367918 & -1.155855 & 1.118724 \\
\hline $\mathrm{H}$ & 3.311900 & -2.164256 & 0.687912 \\
\hline $\mathrm{C}$ & 4.835487 & -0.703599 & 1.141931 \\
\hline $\mathrm{H}$ & 5.302133 & -0.753359 & 0.152628 \\
\hline $\mathrm{H}$ & 5.417347 & -1.345902 & 1.814422 \\
\hline $\mathrm{H}$ & 4.927929 & 0.325670 & 1.508953 \\
\hline $\mathrm{C}$ & 2.768574 & -1.217391 & 2.533089 \\
\hline $\mathrm{H}$ & 2.816540 & -0.241693 & 3.031478 \\
\hline $\mathrm{H}$ & 3.333162 & -1.928338 & 3.148557 \\
\hline $\mathrm{H}$ & 1.720174 & -1.530817 & 2.506868 \\
\hline $\mathrm{C}$ & -3.116579 & -0.140271 & 1.665529 \\
\hline $\mathrm{H}$ & -4.128002 & 0.262262 & 1.516563 \\
\hline C & -3.215977 & -1.569788 & 2.218121 \\
\hline $\mathrm{H}$ & -3.826532 & -2.222082 & 1.583957 \\
\hline $\mathrm{H}$ & -3.673241 & -1.555853 & 3.215007 \\
\hline $\mathrm{H}$ & -2.219813 & -2.017663 & 2.308740 \\
\hline C & -2.357919 & 0.776789 & 2.638947 \\
\hline $\mathrm{H}$ & -1.336430 & 0.411160 & 2.789444 \\
\hline $\mathrm{H}$ & -2.871835 & 0.795178 & 3.608274 \\
\hline $\mathrm{H}$ & -2.285366 & 1.805020 & 2.270816 \\
\hline C & -3.367482 & -1.155303 & -1.119830 \\
\hline $\mathrm{H}$ & -3.311701 & -2.163956 & -0.689580 \\
\hline C & -4.835021 & -0.702966 & -1.143390 \\
\hline $\mathrm{H}$ & -5.302076 & -0.753246 & -0.154302 \\
\hline $\mathrm{H}$ & -5.416637 & -1.344865 & -1.816476 \\
\hline $\mathrm{H}$ & -4.927266 & 0.326512 & -1.509874 \\
\hline C & -2.767534 & -1.216055 & -2.533974 \\
\hline $\mathrm{H}$ & -2.815063 & -0.240034 & -3.031769 \\
\hline $\mathrm{H}$ & -3.332011 & -1.926485 & -3.150144 \\
\hline $\mathrm{H}$ & -1.719214 & -1.529721 & -2.507496 \\
\hline \multicolumn{4}{|c|}{ 4g-CO } \\
\hline Ir & 0.000015 & -0.551938 & -0.000052 \\
\hline $\mathrm{P}$ & -2.250817 & -0.106040 & -0.052997 \\
\hline $\mathrm{P}$ & 2.250801 & -0.105925 & 0.053106 \\
\hline $\mathrm{O}$ & 0.000536 & -3.607166 & 0.000111 \\
\hline $\mathrm{O}$ & 2.400383 & 1.570697 & 0.080553 \\
\hline $\mathrm{O}$ & -2.400517 & 1.570575 & -0.080544 \\
\hline $\mathrm{C}$ & 0.000018 & -2.441977 & -0.000293 \\
\hline $\mathrm{C}$ & -0.000026 & 1.515878 & -0.000158 \\
\hline $\mathrm{C}$ & 1.190654 & 2.256518 & 0.039371 \\
\hline
\end{tabular}




\begin{tabular}{|c|c|c|c|}
\hline $\mathrm{C}$ & 1.217929 & 3.649784 & 0.040179 \\
\hline $\mathrm{H}$ & 2.165095 & 4.177905 & 0.071348 \\
\hline $\mathrm{C}$ & -0.000023 & 4.334882 & -0.000176 \\
\hline $\mathrm{H}$ & -0.000012 & 5.421545 & -0.000206 \\
\hline $\mathrm{C}$ & -1.218058 & 3.649837 & -0.040442 \\
\hline $\mathrm{H}$ & -2.165253 & 4.177977 & -0.071565 \\
\hline $\mathrm{C}$ & -1.190776 & 2.256485 & -0.039602 \\
\hline $\mathrm{C}$ & 3.216573 & -0.573455 & 1.562516 \\
\hline $\mathrm{H}$ & 4.186308 & -0.065315 & 1.487879 \\
\hline $\mathrm{C}$ & 2.479667 & -0.061733 & 2.810081 \\
\hline $\mathrm{H}$ & 2.338528 & 1.022936 & 2.773703 \\
\hline $\mathrm{H}$ & 3.057606 & -0.303900 & 3.710293 \\
\hline $\mathrm{H}$ & 1.491765 & -0.528350 & 2.893290 \\
\hline $\mathrm{C}$ & 3.431123 & -2.094592 & 1.606955 \\
\hline $\mathrm{H}$ & 2.472661 & -2.626204 & 1.617017 \\
\hline $\mathrm{H}$ & 3.974416 & -2.366714 & 2.519362 \\
\hline $\mathrm{H}$ & 4.013646 & -2.458877 & 0.753122 \\
\hline $\mathrm{C}$ & 3.297623 & -0.529205 & -1.420959 \\
\hline $\mathrm{H}$ & 3.296558 & -1.627629 & -1.453660 \\
\hline $\mathrm{C}$ & 2.598957 & -0.000126 & -2.685599 \\
\hline $\mathrm{H}$ & 1.574813 & -0.379367 & -2.762485 \\
\hline $\mathrm{H}$ & 3.157829 & -0.307104 & -3.577591 \\
\hline $\mathrm{H}$ & 2.554005 & 1.094490 & -2.672840 \\
\hline $\mathrm{C}$ & 4.740830 & -0.015900 & -1.312236 \\
\hline $\mathrm{H}$ & 5.285762 & -0.238141 & -2.237525 \\
\hline $\mathrm{H}$ & 5.288216 & -0.482547 & -0.486525 \\
\hline $\mathrm{H}$ & 4.753686 & 1.069168 & -1.164613 \\
\hline $\mathrm{C}$ & -3.297482 & -0.529194 & 1.421100 \\
\hline $\mathrm{H}$ & -3.296359 & -1.627604 & 1.453911 \\
\hline $\mathrm{C}$ & -4.740664 & -0.015908 & 1.312315 \\
\hline $\mathrm{H}$ & -4.753561 & 1.069159 & 1.164602 \\
\hline $\mathrm{H}$ & -5.285589 & -0.238063 & 2.237625 \\
\hline $\mathrm{H}$ & -5.288076 & -0.482608 & 0.486653 \\
\hline C & -2.598762 & 0.000180 & 2.685563 \\
\hline $\mathrm{H}$ & -1.574729 & -0.379218 & 2.762656 \\
\hline $\mathrm{H}$ & -3.157727 & -0.306359 & 3.577644 \\
\hline $\mathrm{H}$ & -2.553593 & 1.094788 & 2.672445 \\
\hline $\mathrm{C}$ & -3.216789 & -0.573725 & -1.562253 \\
\hline $\mathrm{H}$ & -4.186541 & -0.065622 & -1.487523 \\
\hline $\mathrm{C}$ & -3.431257 & -2.094872 & -1.606459 \\
\hline $\mathrm{H}$ & -2.472714 & -2.626376 & -1.616654 \\
\hline $\mathrm{H}$ & -3.974724 & -2.367122 & -2.518729 \\
\hline $\mathrm{H}$ & -4.013558 & -2.459092 & -0.752457 \\
\hline C & -2.480090 & -0.062108 & -2.810006 \\
\hline $\mathrm{H}$ & -2.338916 & 1.022587 & -2.773716 \\
\hline $\mathrm{H}$ & -3.058157 & -0.304345 & -3.710124 \\
\hline $\mathrm{H}$ & -1.492167 & -0.528763 & -2.893297 \\
\hline \multicolumn{4}{|c|}{${ }^{i \mathrm{Pr}-} \mathbf{5}-\mathrm{CO}$} \\
\hline Ir & -0.051637 & 0.421027 & -0.013097 \\
\hline S & 2.761859 & -1.808140 & 0.218753 \\
\hline $\mathrm{P}$ & -2.297338 & 0.011082 & -0.009228 \\
\hline $\mathrm{P}$ & 2.252954 & 0.259086 & 0.069059 \\
\hline $\mathrm{O}$ & -0.169346 & 3.448685 & -0.360419 \\
\hline $\mathrm{O}$ & -2.470081 & -1.653006 & 0.036800 \\
\hline
\end{tabular}




\begin{tabular}{|c|c|c|c|}
\hline $\mathrm{C}$ & -0.117914 & 2.293356 & -0.213052 \\
\hline $\mathrm{C}$ & -0.046892 & -1.668422 & 0.127815 \\
\hline $\mathrm{C}$ & -1.275810 & -2.364339 & 0.125140 \\
\hline $\mathrm{C}$ & -1.394533 & -3.749740 & 0.200675 \\
\hline $\mathrm{H}$ & -2.378265 & -4.207435 & 0.194571 \\
\hline $\mathrm{C}$ & -0.231315 & -4.512918 & 0.281339 \\
\hline $\mathrm{H}$ & -0.297524 & -5.595970 & 0.340510 \\
\hline $\mathrm{C}$ & 1.018461 & -3.894807 & 0.284938 \\
\hline $\mathrm{H}$ & 1.920290 & -4.497160 & 0.345233 \\
\hline $\mathrm{C}$ & 1.096212 & -2.498211 & 0.208604 \\
\hline $\mathrm{C}$ & 3.186982 & 0.865053 & -1.432987 \\
\hline $\mathrm{H}$ & 2.975398 & 1.943384 & -1.437074 \\
\hline $\mathrm{C}$ & 2.579875 & 0.248287 & -2.701964 \\
\hline $\mathrm{H}$ & 2.734089 & -0.836230 & -2.719743 \\
\hline $\mathrm{H}$ & 3.062139 & 0.675361 & -3.589639 \\
\hline $\mathrm{H}$ & 1.503393 & 0.438976 & -2.760089 \\
\hline $\mathrm{C}$ & 4.703490 & 0.644024 & -1.359835 \\
\hline $\mathrm{H}$ & 5.159089 & 1.135365 & -0.493763 \\
\hline $\mathrm{H}$ & 5.181248 & 1.049047 & -2.260113 \\
\hline $\mathrm{H}$ & 4.940134 & -0.425292 & -1.312895 \\
\hline $\mathrm{C}$ & 3.103922 & 1.023841 & 1.549328 \\
\hline $\mathrm{H}$ & 4.130630 & 0.635477 & 1.562771 \\
\hline $\mathrm{C}$ & 2.383390 & 0.584788 & 2.832328 \\
\hline $\mathrm{H}$ & 1.350851 & 0.951476 & 2.834935 \\
\hline $\mathrm{H}$ & 2.902736 & 0.993003 & 3.708040 \\
\hline $\mathrm{H}$ & 2.355659 & -0.505095 & 2.926821 \\
\hline $\mathrm{C}$ & 3.141537 & 2.555367 & 1.425746 \\
\hline $\mathrm{H}$ & 3.723980 & 2.893756 & 0.562540 \\
\hline $\mathrm{H}$ & 3.603036 & 2.983192 & 2.323725 \\
\hline $\mathrm{H}$ & 2.131243 & 2.969897 & 1.341092 \\
\hline $\mathrm{C}$ & -3.290582 & 0.402621 & -1.525316 \\
\hline $\mathrm{H}$ & -4.265767 & -0.081886 & -1.387604 \\
\hline $\mathrm{C}$ & -2.589790 & -0.219836 & -2.743829 \\
\hline $\mathrm{H}$ & -1.602147 & 0.231186 & -2.892254 \\
\hline $\mathrm{H}$ & -3.190545 & -0.048118 & -3.645255 \\
\hline $\mathrm{H}$ & -2.454020 & -1.298575 & -2.621025 \\
\hline $\mathrm{C}$ & -3.487777 & 1.916420 & -1.698239 \\
\hline $\mathrm{H}$ & -4.086385 & 2.354140 & -0.893176 \\
\hline $\mathrm{H}$ & -4.009304 & 2.114141 & -2.642137 \\
\hline $\mathrm{H}$ & -2.526698 & 2.441181 & -1.732472 \\
\hline C & -3.285331 & 0.477923 & 1.496730 \\
\hline $\mathrm{H}$ & -2.827173 & -0.175741 & 2.251664 \\
\hline $\mathrm{C}$ & -4.773295 & 0.120003 & 1.378009 \\
\hline $\mathrm{H}$ & -5.267617 & 0.252803 & 2.347811 \\
\hline $\mathrm{H}$ & -4.911624 & -0.920603 & 1.067409 \\
\hline $\mathrm{H}$ & -5.285053 & 0.768364 & 0.657293 \\
\hline C & -3.054129 & 1.933934 & 1.928293 \\
\hline $\mathrm{H}$ & -1.987790 & 2.145063 & 2.050351 \\
\hline $\mathrm{H}$ & -3.555346 & 2.117746 & 2.886194 \\
\hline $\mathrm{H}$ & -3.460230 & 2.647696 & 1.203878 \\
\hline \multicolumn{4}{|c|}{ iPr-2-(coplanar-COE) } \\
\hline Ir & -0.056489 & -0.000638 & -0.173276 \\
\hline $\mathrm{P}$ & -0.533669 & 2.250834 & -0.019934 \\
\hline $\mathrm{P}$ & -0.594680 & -2.213984 & 0.094407 \\
\hline
\end{tabular}




\begin{tabular}{|c|c|c|c|}
\hline $\mathrm{O}$ & -2.230453 & -2.373073 & -0.258358 \\
\hline $\mathrm{O}$ & -2.197741 & 2.411799 & -0.176660 \\
\hline $\mathrm{C}$ & -2.121917 & 0.017637 & -0.228093 \\
\hline $\mathrm{C}$ & -2.892007 & -1.155763 & -0.306764 \\
\hline $\mathrm{C}$ & -4.281550 & -1.173517 & -0.409345 \\
\hline $\mathrm{H}$ & -4.802885 & -2.123859 & -0.461695 \\
\hline $\mathrm{C}$ & -4.965910 & 0.042793 & -0.438253 \\
\hline $\mathrm{H}$ & -6.049174 & 0.052974 & -0.520246 \\
\hline $\mathrm{C}$ & -4.263140 & 1.245976 & -0.356600 \\
\hline $\mathrm{H}$ & -4.770311 & 2.205281 & -0.373071 \\
\hline $\mathrm{C}$ & -2.873838 & 1.203672 & -0.255181 \\
\hline $\mathrm{C}$ & -0.640754 & -2.944318 & 1.814423 \\
\hline $\mathrm{H}$ & -1.239215 & -3.856089 & 1.691852 \\
\hline $\mathrm{C}$ & -1.400016 & -1.988910 & 2.749094 \\
\hline $\mathrm{H}$ & -2.390613 & -1.739196 & 2.358950 \\
\hline $\mathrm{H}$ & -1.526628 & -2.459416 & 3.732366 \\
\hline $\mathrm{H}$ & -0.847086 & -1.053288 & 2.878651 \\
\hline $\mathrm{C}$ & 0.726277 & -3.316561 & 2.398122 \\
\hline $\mathrm{H}$ & 1.345662 & -2.426612 & 2.545790 \\
\hline $\mathrm{H}$ & 0.588639 & -3.792584 & 3.376685 \\
\hline $\mathrm{H}$ & 1.279592 & -4.018922 & 1.764998 \\
\hline $\mathrm{C}$ & 0.041577 & -3.542803 & -1.048311 \\
\hline $\mathrm{H}$ & 1.129671 & -3.558729 & -0.915800 \\
\hline $\mathrm{C}$ & -0.267539 & -3.113234 & -2.493864 \\
\hline $\mathrm{H}$ & 0.106137 & -2.106391 & -2.705852 \\
\hline $\mathrm{H}$ & 0.193632 & -3.814629 & -3.199603 \\
\hline $\mathrm{H}$ & -1.348037 & -3.110493 & -2.669176 \\
\hline $\mathrm{C}$ & -0.524192 & -4.939371 & -0.748836 \\
\hline $\mathrm{H}$ & -0.179319 & -5.651320 & -1.508705 \\
\hline $\mathrm{H}$ & -0.204381 & -5.318418 & 0.227482 \\
\hline $\mathrm{H}$ & -1.618886 & -4.926226 & -0.771569 \\
\hline $\mathrm{C}$ & -0.284643 & 3.105534 & 1.623090 \\
\hline $\mathrm{H}$ & 0.795273 & 3.267896 & 1.721562 \\
\hline $\mathrm{C}$ & -1.006417 & 4.459754 & 1.698915 \\
\hline $\mathrm{H}$ & -2.078364 & 4.334571 & 1.518556 \\
\hline $\mathrm{H}$ & -0.875552 & 4.893969 & 2.697579 \\
\hline $\mathrm{H}$ & -0.620221 & 5.181549 & 0.971420 \\
\hline $\mathrm{C}$ & -0.736091 & 2.159140 & 2.747261 \\
\hline $\mathrm{H}$ & -0.186633 & 1.213855 & 2.706613 \\
\hline $\mathrm{H}$ & -0.570530 & 2.629536 & 3.724418 \\
\hline $\mathrm{H}$ & -1.803249 & 1.927343 & 2.657449 \\
\hline $\mathrm{C}$ & -0.078885 & 3.514534 & -1.316862 \\
\hline $\mathrm{H}$ & -0.828988 & 4.303363 & -1.175552 \\
\hline $\mathrm{C}$ & 1.315794 & 4.139743 & -1.166122 \\
\hline $\mathrm{H}$ & 2.113510 & 3.409605 & -1.328400 \\
\hline $\mathrm{H}$ & 1.442511 & 4.931226 & -1.914747 \\
\hline $\mathrm{H}$ & 1.467689 & 4.592380 & -0.180486 \\
\hline $\mathrm{C}$ & -0.289750 & 2.896951 & -2.708107 \\
\hline $\mathrm{H}$ & -1.299491 & 2.487885 & -2.811367 \\
\hline $\mathrm{H}$ & -0.146677 & 3.659257 & -3.484099 \\
\hline $\mathrm{H}$ & 0.418477 & 2.081706 & -2.891847 \\
\hline C & 5.241170 & 0.397632 & 0.479101 \\
\hline $\mathrm{H}$ & 5.125030 & -0.110101 & 1.447860 \\
\hline $\mathrm{H}$ & 6.271415 & 0.775988 & 0.466742 \\
\hline $\mathrm{C}$ & 5.071134 & -0.620511 & -0.672577 \\
\hline
\end{tabular}




\begin{tabular}{|c|c|c|c|}
\hline $\mathrm{H}$ & 4.613805 & -0.117997 & -1.534578 \\
\hline $\mathrm{H}$ & 6.060434 & -0.953519 & -1.011777 \\
\hline $\mathrm{C}$ & 4.259056 & -1.876850 & -0.321822 \\
\hline $\mathrm{H}$ & 4.824555 & -2.480479 & 0.402483 \\
\hline $\mathrm{H}$ & 4.163177 & -2.493513 & -1.227311 \\
\hline C & 2.852090 & -1.626532 & 0.258788 \\
\hline $\mathrm{H}$ & 2.369289 & -2.597942 & 0.376301 \\
\hline $\mathrm{H}$ & 2.933332 & -1.209747 & 1.266925 \\
\hline $\mathrm{C}$ & 2.040665 & -0.705393 & -0.632012 \\
\hline $\mathrm{H}$ & 1.951103 & -1.069556 & -1.657457 \\
\hline $\mathrm{C}$ & 2.083522 & 0.693125 & -0.471407 \\
\hline $\mathrm{H}$ & 2.059194 & 1.276940 & -1.390031 \\
\hline $\mathrm{C}$ & 2.805648 & 1.384734 & 0.675065 \\
\hline $\mathrm{H}$ & 2.354606 & 2.366980 & 0.837714 \\
\hline $\mathrm{H}$ & 2.657092 & 0.833765 & 1.610099 \\
\hline $\mathrm{C}$ & 4.311160 & 1.623160 & 0.431679 \\
\hline $\mathrm{H}$ & 4.657430 & 2.341540 & 1.188008 \\
\hline $\mathrm{H}$ & 4.436730 & 2.124299 & -0.540141 \\
\hline \multicolumn{4}{|c|}{ iPr-2-(perpendicular-COE) } \\
\hline $\mathrm{Ir}$ & -0.150815 & -0.028593 & 0.050613 \\
\hline $\mathrm{P}$ & -1.996587 & -1.371317 & 0.097825 \\
\hline $\mathrm{P}$ & 1.075480 & 1.927021 & -0.063055 \\
\hline $\mathrm{O}$ & -0.083606 & 3.162233 & -0.192963 \\
\hline $\mathrm{O}$ & -3.336515 & -0.351357 & 0.049714 \\
\hline $\mathrm{C}$ & -1.654850 & 1.360723 & -0.069646 \\
\hline $\mathrm{C}$ & -1.396500 & 2.737374 & -0.166856 \\
\hline $\mathrm{C}$ & -2.403481 & 3.700278 & -0.237677 \\
\hline $\mathrm{H}$ & -2.145107 & 4.751717 & -0.309877 \\
\hline $\mathrm{C}$ & -3.733361 & 3.273859 & -0.212486 \\
\hline $\mathrm{H}$ & -4.531777 & 4.009150 & -0.267395 \\
\hline $\mathrm{C}$ & -4.054640 & 1.916990 & -0.117232 \\
\hline $\mathrm{H}$ & -5.084595 & 1.576105 & -0.097498 \\
\hline $\mathrm{C}$ & -3.011919 & 0.995439 & -0.045886 \\
\hline $\mathrm{C}$ & 2.091833 & 2.456700 & -1.537582 \\
\hline $\mathrm{H}$ & 2.054499 & 3.552562 & -1.495461 \\
\hline $\mathrm{C}$ & 1.385005 & 1.998742 & -2.822763 \\
\hline $\mathrm{H}$ & 0.358248 & 2.376006 & -2.863372 \\
\hline $\mathrm{H}$ & 1.923110 & 2.372094 & -3.703121 \\
\hline $\mathrm{H}$ & 1.339256 & 0.907006 & -2.879614 \\
\hline $\mathrm{C}$ & 3.563005 & 2.020370 & -1.488567 \\
\hline $\mathrm{H}$ & 3.672822 & 0.932686 & -1.525432 \\
\hline $\mathrm{H}$ & 4.094378 & 2.427923 & -2.357199 \\
\hline $\mathrm{H}$ & 4.074468 & 2.379727 & -0.589560 \\
\hline $\mathrm{C}$ & 1.990674 & 2.577327 & 1.428453 \\
\hline $\mathrm{H}$ & 2.898101 & 1.965314 & 1.504131 \\
\hline $\mathrm{C}$ & 1.124146 & 2.332685 & 2.675713 \\
\hline $\mathrm{H}$ & 0.851989 & 1.277480 & 2.775813 \\
\hline $\mathrm{H}$ & 1.662956 & 2.647952 & 3.577792 \\
\hline $\mathrm{H}$ & 0.194264 & 2.909504 & 2.616933 \\
\hline $\mathrm{C}$ & 2.387494 & 4.057098 & 1.309983 \\
\hline $\mathrm{H}$ & 2.875266 & 4.385201 & 2.236146 \\
\hline $\mathrm{H}$ & 3.085959 & 4.240349 & 0.487008 \\
\hline $\mathrm{H}$ & 1.502808 & 4.681295 & 1.151603 \\
\hline $\mathrm{C}$ & -2.360004 & -2.467679 & -1.362557 \\
\hline
\end{tabular}




$\begin{array}{llll}\mathrm{H} & -1.587286 & -3.248435 & -1.334502 \\ \mathrm{C} & -3.747362 & -3.123719 & -1.307019 \\ \mathrm{H} & -4.530104 & -2.361194 & -1.238087 \\ \mathrm{H} & -3.921524 & -3.706831 & -2.219538 \\ \mathrm{H} & -3.855343 & -3.803564 & -0.455224 \\ \mathrm{C} & -2.173769 & -1.642791 & -2.647653 \\ \mathrm{H} & -1.181552 & -1.181673 & -2.684107 \\ \mathrm{H} & -2.303387 & -2.283221 & -3.528615 \\ \mathrm{H} & -2.916277 & -0.838643 & -2.699992 \\ \mathrm{C} & -2.412823 & -2.369872 & 1.607863 \\ \mathrm{H} & -3.474004 & -2.634645 & 1.518331 \\ \mathrm{C} & -1.572811 & -3.655288 & 1.674068 \\ \mathrm{H} & -0.499937 & -3.433797 & 1.685017 \\ \mathrm{H} & -1.803492 & -4.204850 & 2.594431 \\ \mathrm{H} & -1.771191 & -4.324962 & 0.830264 \\ \mathrm{C} & -2.224150 & -1.492055 & 2.855207 \\ \mathrm{H} & -2.848615 & -0.594363 & 2.806516 \\ \mathrm{H} & -2.499520 & -2.053681 & 3.756543 \\ \mathrm{H} & -1.182036 & -1.166820 & 2.949120 \\ \mathrm{C} & 4.261896 & -2.761776 & -0.749698 \\ \mathrm{H} & 4.757708 & -1.779632 & -0.750755 \\ \mathrm{H} & 5.017078 & -3.471528 & -1.111066 \\ \mathrm{C} & 3.865669 & -3.151622 & 0.696008 \\ \mathrm{H} & 2.920099 & -3.707772 & 0.669882 \\ \mathrm{H} & 4.610985 & -3.849992 & 1.098196 \\ \mathrm{C} & 3.744534 & -1.988722 & 1.696279 \\ \mathrm{H} & 4.740397 & -1.555906 & 1.870060 \\ \mathrm{H} & 3.415556 & -2.397660 & 2.662203 \\ \mathrm{C} & 2.787200 & -0.849006 & 1.283761 \\ \mathrm{H} & 2.693270 & -0.156040 & 2.127634 \\ \mathrm{H} & 3.233391 & -0.281408 & 0.460668 \\ \mathrm{C} & 1.430398 & -1.376100 & 0.878360 \\ \mathrm{H} & 0.940907 & -1.922012 & 1.687338 \\ \mathrm{C} & 1.144112 & -1.791075 & -0.439763 \\ \mathrm{H} & 0.496803 & -2.663051 & -0.547351 \\ \mathrm{C} & 2.070237 & -1.629182 & -1.624210 \\ \mathrm{H} & 1.456184 & -1.591026 & -2.533567 \\ \mathrm{H} & 2.587411 & -0.668522 & -1.574382 \\ \mathrm{C} & 3.116298 & -2.752261 & -1.781187 \\ \mathrm{H} & 3.558657 & -2.662372 & -2.783283 \\ \mathrm{H} & 2.608547 & -3.727995 & -1.758903 \\ & & & \end{array}$

